\title{
Operatieve behandeling van verschillende vormen van kyfose van de wervelkolom
}

Citation for published version (APA):

van Ooij, A. (1985). Operatieve behandeling van verschillende vormen van kyfose van de wervelkolom. [Doctoral Thesis, Maastricht University]. Rijksuniversiteit Limburg.

https://doi.org/10.26481/dis.19850208ao

Document status and date:

Published: 01/01/1985

DOI:

10.26481/dis.19850208ao

Document Version:

Publisher's PDF, also known as Version of record

\section{Please check the document version of this publication:}

- A submitted manuscript is the version of the article upon submission and before peer-review. There can be important differences between the submitted version and the official published version of record.

People interested in the research are advised to contact the author for the final version of the publication, or visit the DOI to the publisher's website.

- The final author version and the galley proof are versions of the publication after peer review.

- The final published version features the final layout of the paper including the volume, issue and page numbers.

Link to publication

\footnotetext{
General rights rights.

- You may freely distribute the URL identifying the publication in the public portal. please follow below link for the End User Agreement:

www.umlib.nl/taverne-license

Take down policy

If you believe that this document breaches copyright please contact us at:

repository@maastrichtuniversity.nl

providing details and we will investigate your claim.
}

Copyright and moral rights for the publications made accessible in the public portal are retained by the authors and/or other copyright owners and it is a condition of accessing publications that users recognise and abide by the legal requirements associated with these

- Users may download and print one copy of any publication from the public portal for the purpose of private study or research.

- You may not further distribute the material or use it for any profit-making activity or commercial gain

If the publication is distributed under the terms of Article $25 \mathrm{fa}$ of the Dutch Copyright Act, indicated by the "Taverne" license above, 
Operatieve behandeling van verschillende vormen van kyfose van de wervelkolom 
Un savant est celui dont

L'ignorance a quelques

lacunes

Pierre Stagnara

2 


\section{OPERATIEVE BEHANDELING VAN VERSCHILLENDE VORMEN VAN KYFOSE VAN DE WERVELKOLOM}

\section{PROEFSCHRIFT}

TER VERKRIJGING VAN DE GRAAD VAN DOCTOR IN DE GENEESKUNDE AAN DE RIJKSUNIVERSITEIT LIMBURG TE MAASTRICHT, OP GEZAG VAN DE RECTOR MAGNIFICUS PROF. DR. F. I. M. BONKE, VOLGENS BESLUIT VAN HET COLLEGE VAN DEKANEN IN HET OPENBAAR TE VERDEDIGEN IN DE AULA VAN DE UNIVERSITEIT OP 8 FEBRUARI 1985 DES NAMIDDAGS TE VIER UUR

door

ANDRE VAN OOIJ

geboren te Leiden in 1948

ROOS EN ROOS

DRUKKERS B. $\mathrm{V}$.

ARNHEM

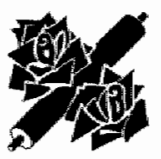


Promotor: Prof. Dr. A. J. van der Linden

Referenten: Prof. Dr. H. A. J. Lemmens

Dr. G. H. Slot

Met dank aan:

Joop Boersma

Coen Eggen

Maarten Roos

Chris Voskamp

Dit proefschrift is mede tot stand gekomen door een financiële bijdrage van Eli Lilly Nederland, Basko CAMP, Ebbink bv, VDL instrumenten bv, Ortomed by, J. van Straten instrumenten cv, West bv, Equip Medical bv en Klees Electronics bv

De illustraties en het omslagontwerp zijn van de hand van Chris Voskamp. 


\section{VOORWOORD}

Gaarne wil ik degenen die mij de mogelijkheid geboden hebben dit proefschrift te schrijven bedanken.

Beste Ton van der Linden, jouw hulp bij het kuisen van de tekst en het relativeren hiervan heb ik ten zeerste op prijs gesteld. Ik denk dat het de leesbaarheid zeer ten goede is gekomen. Bovenal dank ik je voor de goede samenwerking, ook de anderen van onze groep, Ruud Geesink, Geert Walenkamp en de assistenten, waardoor de mogelijkheid bestond dit werk te voltooien.

Beste Gijs Slot, jouw inspirerend werk op het gebied van de wervelkolomchirurgie heeft mij altijd geïmponeerd. Ik dank je voor de geboden mogelijkheid me in dit tot voor kort moeilijk toegankelijk gebied van de orthopaedie te verdiepen en het patiëntenmateriaal te mogen gebruiken, dat in dit proefschrift is verwerkt.

Zeer geachte professor Lemmens, uw deskundige inbreng, met name wat betreft de indeling van het proefschrift, heeft een wezenlijke verbetering tot gevolg gehad, waarvoor ik u hartelijk dank.

Beste Geert Bossers, Fred van der Heyden, Paul Merx en Rinus Kooyman. In jullie kliniek vond mijn orthopaedische opleiding plaats en ik dank jullie voor de gedegen en plezierige wijze waarop dit gebeurde.

Een woord van dank wil ik overbrengen aan mijn andere opleiders die mij in stat hebben gesteld dit doel te bereiken. Dit zijn de orthopaedische chirurgen Prof. Dr. L. II. L. Koekenberg te Hilversum, Dr. Th. W. Beeker te Utrecht, Dr. F. A. A. van de Weyer te Roosendaal, Prof. Dr. Th. J. G. van Rens en Prof. Dr. T. J. J Slooff te Nijmegen, alsmede de algemeen chirurgen Dr. J. Paré, J. Heckman, Dr. F. F. van Haeften, Dr. G. H. Hage te Apeldoorn en Dr. A. R. Koomen, destijds eveneens in Apeldoorn, alwaar ik een zeer plezierige chirurgische vooropleiding heb genoten.

Onze secretaresses en vooral Ien Sondeijker bedank ik voor het geduldig uittypen van het dictaat. Ook Gerda Peters, secretaresse in de St. Maartenskliniek te Nijmegen bedank ik voor haar medewerking bij het doorgeven van de laatste ontwikkelingen bij diverse patiënten. De medische fotograaf van de St. Maartenskliniek te Nijmegen, de heer G. J. van Ballcom, dank ik voor zijn professionele weergave van de medische- en röntgenfoto's.

Tenslotte bedank ik iedereen die daadwerkelijk heeft bijgedragen tot de realisering van dit proefschrift en niet met name in dit voorwoord is genoemd. 



\section{HOOFDSTUK 1}

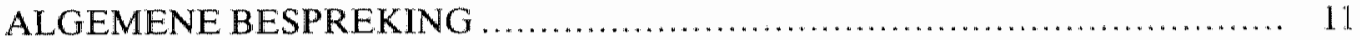

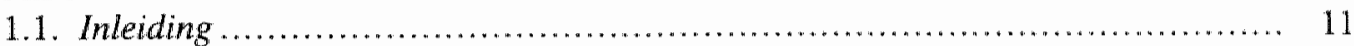

1.2. Symptomatologie ............................................................ 13

1.3. Lichamelijk Onderzoek .................................................... 13

1.4. Aanvullend Onderzoek .......................................................... 14

1.5. Behandeling ................................................................... 14

1.6. Literatuur ................................................................... 15

HOOFDSTUK 2

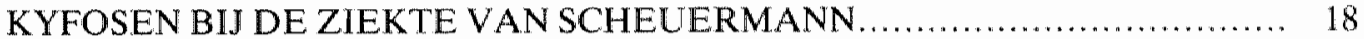

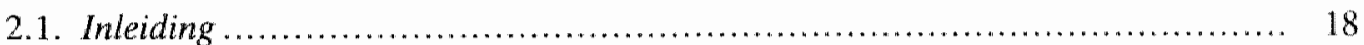

2.2. Symptomatologie ........................................................... 18

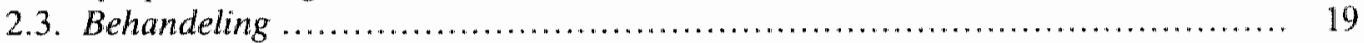

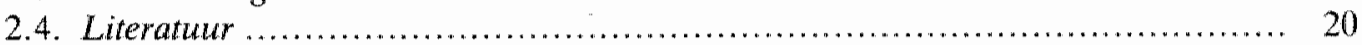

2.5. Patiëntenbeschrijvingen ............................................... 22

HOOFDSTUK 3

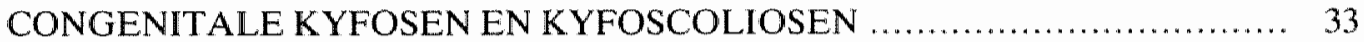

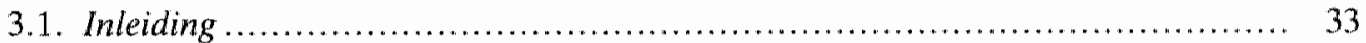

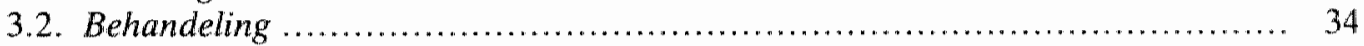

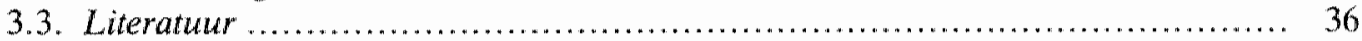

3.4. Patiëntenbeschrijvingen ................................................ 39

HOOFDSTUK 4

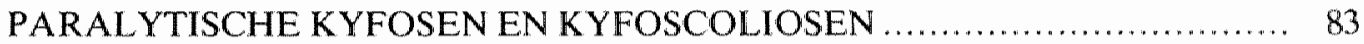

4.1. Inleiding .................................................................... 83

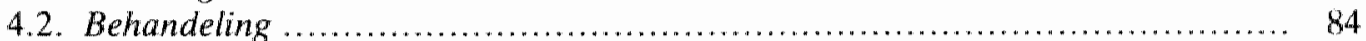

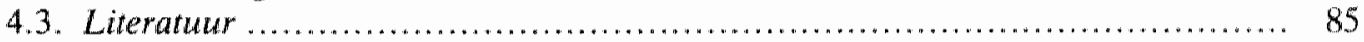

4.4. Patiëntenbeschrijvingen .................................................... 88

HOOFDSTUK 5

KYFOSEN BIJ DE ZIEKTE VAN BECHTEREW ............................... $₫ 16$

5.1. Inleiding ..................................................................... 116

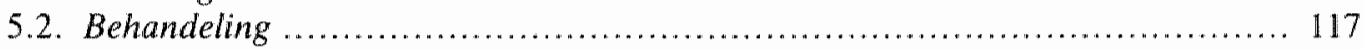

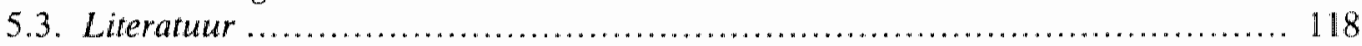

5.4. Patiëntenbeschrijvingen ................................................ 121

HOOFDSTUK 6

KYFOSEN BIJ DE NEUROFIBROMATOSE VAN VON RECKLINGHAUSEN

6.1. Inleiding....

6.2. Behandeling ............................................................ 146 


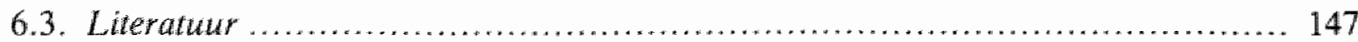

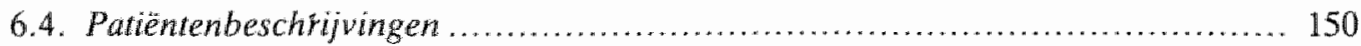

HOOFDSTUK 7

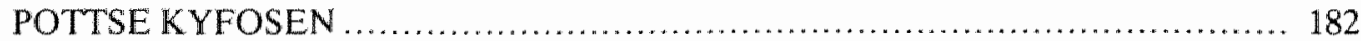

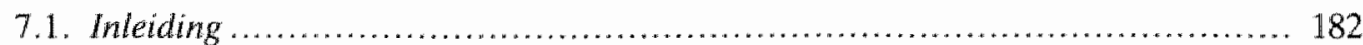

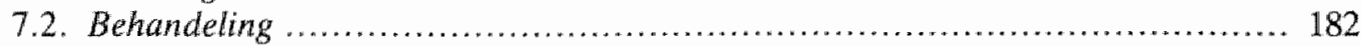

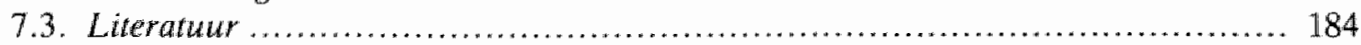

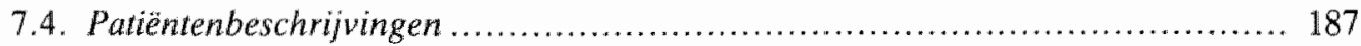

HOOFDSTUK 8

KYFOSEN NA LAMINECTOMIE EN/OF BESTRALING ....................... 202

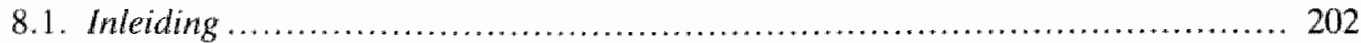

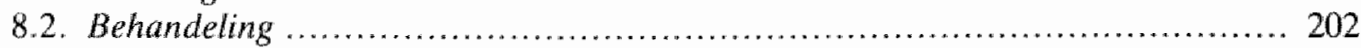

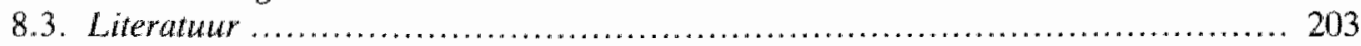

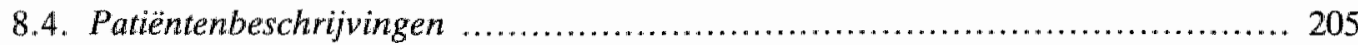

HOOFDSTUK 9

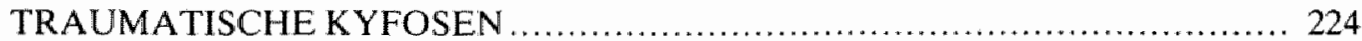

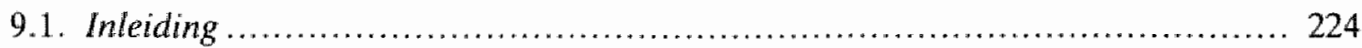

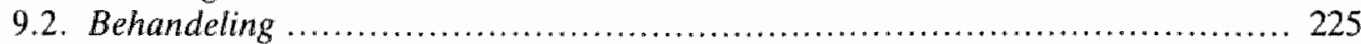

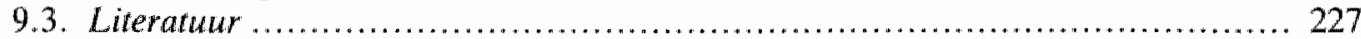

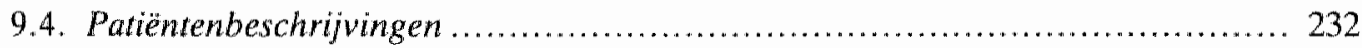

HOOFDSTUK 10

KYFOSEN DOOR PRIMAIRE OF SECUNDAIRE TUMOREN $\ldots \ldots \ldots \ldots \ldots \ldots \ldots . \ldots 240$

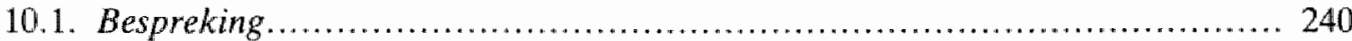

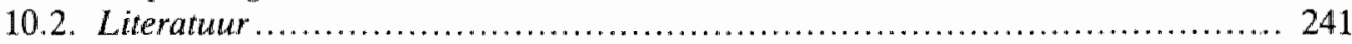

10.3. Patiëntenbeschrijving ..................................................... 243

HOOFDSTUK 11

KYFOSEN DOOR ERNSTIGE ROTATIE BIJ IDIOPATHISCHE SCOLIOSEN

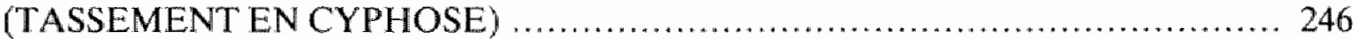

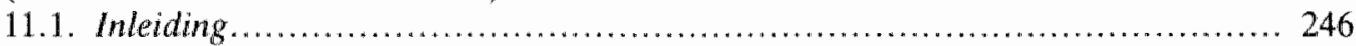

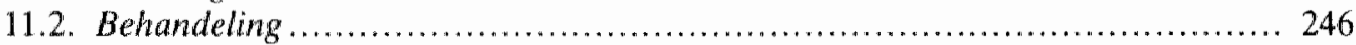

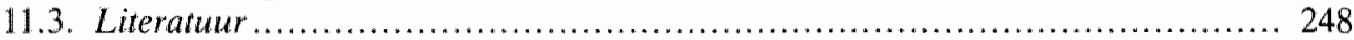

11.4. Patiëntenbeschrijvingen................................................. 250

HOOFDSTUK 12

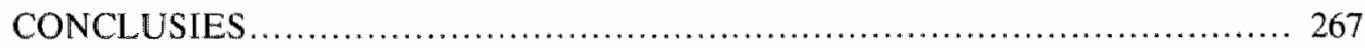

HOOFDSTUK 13

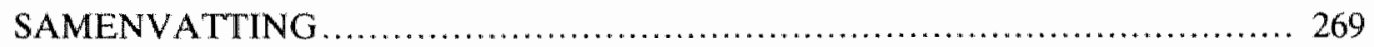

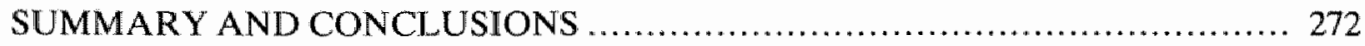

HOOFDSTUK 14

TABELLEN.... 


\section{INLEIDING EN DOELSTELLING}

Van de bestaande wervelkolomdeformaties heeft de laatste decennia vooral de behandeling van scoliosen grote nadruk gekregen en is hierbij grote vooruitgang geboekt. De in- en uitwendige correctie en fixatiemogelijkheden zijn sterk verbeterd. Belangrijke pioniers op dit gebied zijn Blount en Moe (3) met de ontwikkeling van het Milwaukee corset. Harrington (15) ontwikkelde de inwendige correctie en fixatiemogelijkheid aan de achterzijde van de wervelkolom, terwijl Dwyer (9) en later Zielke (38) met de ontwikkeling van inwendige fixatie aan de voorzijde van de wervelkolom kwamen. Hiermee worden goede conservatieve en operatieve resultaten bereikt.

Het beeld van de gebochelde is hierdoor vrijwel verdwenen.

Meer aandacht verdienen nu de kyfotische verkrommingen, vaak samengaand met een scoliose. Door een kyfotische verkromming van de wervelkolom wordt het krachtenspel van de wervelkolom dermate ongunstig beïnvloed, dat falen van conservatieve en operatieve therapie verwacht kan worden als niet de juiste maatregelen genomen worden (35). Het kan ook vooral de kyfotische component in een wervelkolomdeformiteit zijn. die progressief is zowel op jongere als op latere leeftijd (14).

Bekendheid met de conservatieve en operatieve behandelingsmogelijkheden van kyfotische wervelkolomverkrommingen is nodig om een juiste voorlichting te geven en een juiste behandeling aan de patiënt te adviseren. Bij de hier beschreven patiënten was de problematiek in eerste instantie vaak niet onderkend, of bestond onvoldoende kennis over de operatieve mogelijkheden. Doel van dit proefschrift is dan ook meer bekendheid te geven aan de operatieve behandelingsmethoden van kyfotische wervelkolomdeformiteiten, de indicatiestelling tot operatie na te gaan, de resultaten die daarvan verwacht mogen worden te evalueren, alsmede de complicaties die daarbij kunnen optreden.

De kyfosen worden per aetiologie gerangschikt en aan de hand van literatuurstudie en eigen ervaring worden richtlijnen gegeven voor de behandeling van deze verkrommingen. Bij sommige soorten kyfose is, afhankelijk van het stadium, conservatieve behandeling mogelijk. Bij andere soorten is alleen operatief ingrijpen een reëele mogelijkheid. Aan de hand van ziektegeschiedenissen wordt geillustreerd welke de mogelijkheden, problemen en resultaten zijn van de verschillende operatieve behandelingen. Het aantal patiënten per groep is klein, statistische bewerking van dit materiaal wordt daarom niet mogelijk geacht. Door middel van enkele tabellen aan het einde van het proefschrift wordt een overzicht van de resultaten gegeven.

De operatieve behandeling van kyfosen is zonder teamwork ondenkbaar. Naast de orthopaedisch chirurg zijn in een aantal gevallen de algemeen chirurg, revalidatiearts, anaesthesist, röntgenoloog, rheumatoloog, neuroloog en neurochirurg nauw bij de behandeling betrokken. De gipsmeester, instrumentmaker, fysiotherapeut en verpleger zijn onmisbare medewerkers om tot een optimaal resultaat te komen.

De operaties zijn voor het allergrootste deel verricht door $\mathrm{Dr}$. G. H. Slot in de Sint Maartenskliniek te Nijmegen. Bij intensieve postoperatieve verpleging, zoals na thoracotomie, werden de operaties in het Canisius-Wilhelmina Ziekenhuis te Nijmegen uitgevoerd, in samenwerking met de afdeling algemene chirurgie (hoofd Dr. H. J. M. Joosten). De meeste patienten met Bechterew kyfose zijn door $G$. Th. M. Bossers geopereerd. Eén geval (casus 33) is behandeld in het Radboudziekenhuis te Nijmegen door 
Prof. Dr. Th. J. G. v. Rens en B. A. J. Steenaert. 2 patiënten (casus 35 en 51) werden te Maastricht behandeld. 


\section{ALGEMENE BESPREKING}

\subsection{Inleiding}

De pasgeborene heeft een rechte wervelkolom. Onder invloed van zwaartekracht en spierwerking ontstaan curves in de wervelkolom. Zo kennen wij als curves in het sagittale vlak de cervicale lordose, de thoracale kyfose en de lumbale lordose. Deze curves hebben een fysiologische breedte die thoracaal tussen de 20 tot 40 graden ligt (4). Dit word gemeten volgens Cobb en bepaald door de twee uiterste wervels van de kyfotische curve (fig. 1).

De patiënten zijn ingedeeld aan de hand van de classificatie volgens Bradford (4) en aangevuld met het uit de Franse literatuur afkomstige „tassement en cyphose” (30), hetgeen letterlijk verzakking tot kyfose betekent. Men doelt hierbij op de rotatie van een scoliotische curve, waarbij de bocht van het frontale vlak in het sagittale vlak draait en daarom tot een kyfoscoliose wordt. Overigens kan men de kyfosen ook op andere manieren indelen, zoals in angulaire of arcuaire kyfosen (fig. 2), juveniele of seniele kyfosen, kyfosen met of zonder paraplegie, kyfosen sec of kyfoscoliosen.

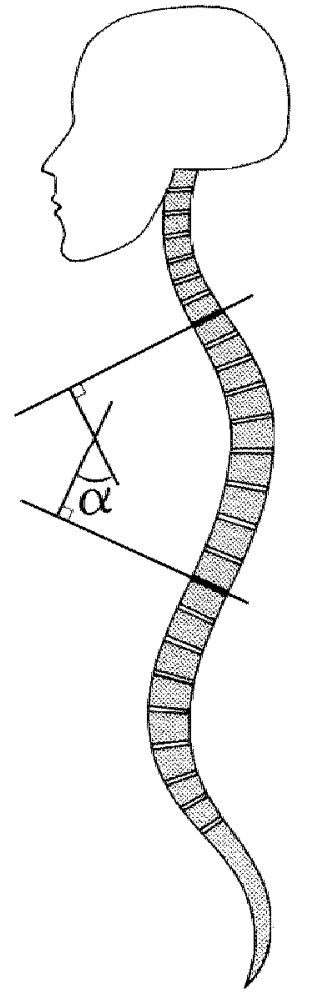

$\alpha=$ kyfosehoek

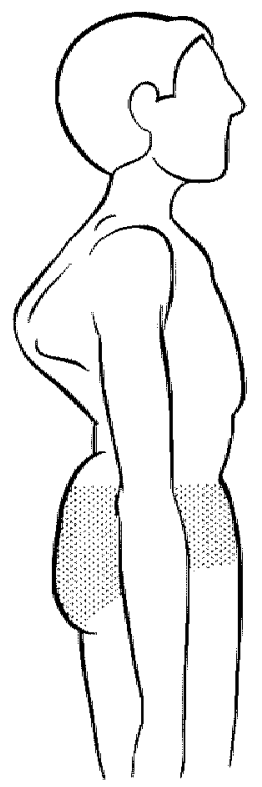

angulaire kyfose

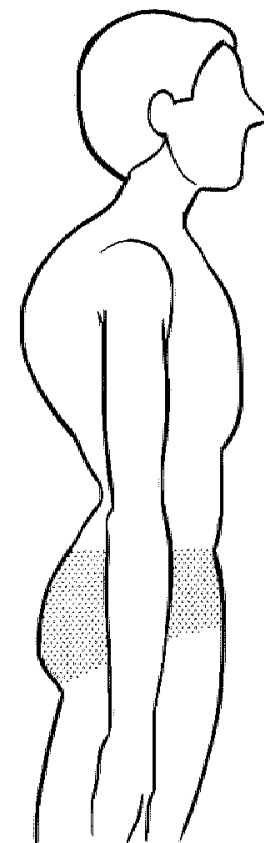

arcuaire kyfose 
Classificatie van kyfosen volgens Bradford:

A. Houdingskyfose.

B. Ziekte van Schetiermann.

C. Congenitale kyfosen. 1. Stoornis in formatie.

2. Stoornis in segmentatie.

3. Gemengd.

D. Paralytische kyfosen (spierziekten, neurogene ziekten).

E. Myelomeningocele kyfosen. 1. Aangeboren kyfosen.

2. In de ontwikkeling ontstaan.

F. Traumatische kyfosen. 1. Zonder neurologische afwijkingen

2. Met neurologische afwijkingen.

G. Inflammatoir. 1. Banaal bacterieel.

2. Tuberculeus.

3. Rheumatoïd (ook ziekte van Bechterew.)

4. Anderszins.

H. Na chirurgisch ingrijpen. 1. Post-laminectomie.

2. Na excisie van wervellichamen.

I. Na bestraling.

J. Metabool. 1. Osteoporose.

2. Osteomalacie.

3. Osteogenesis imperfecta.

4. Anderszins.

K. Skeletdysplasieën. 1. Achondroplasie.

2. Stapelingsziekten.

3. Neurofibromatose.

4. Anderszins.

L. Tumoren. I. Benigne.

2. Maligne. a. Primair.

b. Metastatisch.

M. Tassement en cyphose bij ernstige idiopathische scoliosen.

Van alle groepen worden voorbeelden gegeven, behalve van de groep myelomeningocèle patiënten en de metabole groep. De behandeling van de kyfose bij de spina bifida patiënt verschilt vrij wezenlijk van de behandeling van andere soorten kyfosen, daarom is behandeling van deze groep patiënten achterwege gelaten. Kyfosen van metabole 
origine werden in de betrokken periode niet geopereerd. De verschillende aetiologieèn en de resultaten bereikt met operatieve behandeling van een aantal patienten in de periode 1969-1983 worden besproken.

\subsection{Symptomatologie}

1. De statiek van de wervelkolom wordt door een versterkte kyfose en kyfose op de verkeerde plaats ongunstig beinvloed. De rugmusculatuur moet meervoudige inspanning leveren om de compensatoire curves in stand te houden, waardoor chronische pijnklachten kunnen ontstaan, meestal cervicaal en lumbaal (11). Vervroegde spondylosis behoort tot de mogelijkheden door ongunstige belasting.

2. De cosmetiek speelt een rol. Een ernstige ronde rug is lelijker dan een goed geëquilibreerde scoliose, die staand en zeker met kleding aan nauwelijks zichtbaar is. Dit kan leiden tot psychische problematiek. Deze patiënten worden vaak achter hun rug om gehoond en gaan door het leven als "de kromme" of . de gebochelde".

3. Bij vooral congenitale kyfosen, kyfosen na laminectomie en bestraling, posttraumatische kyfosen en kyfose bij de neurofibromatose kunnen neurologische complicaties optreden door myelum- of caudacompressie (21).

4. Decubitus kan een probleem zijn, vooral bij posttraumatische en spina bifida kyfosen.

5. Door ernstige verkromming van de wervelkolom ontstaat een sterke beperking van het functionerend longvolume (39). Een cor pulmonale kan hiervan het gevolg zijn. Bij de morbus Bechterewkyfose is de ademhalingsfunctie verslechterd door de starre thorax en de verkorte afstand tussen origo en insertie van de buikspieren. Bij paralytische deformaties speelt naast de verkromming zelf natuurlijk ook verlamming van de ademhalingsmusculatuur een rol. Met correctie van de wervelkolom kan een verbetering van de longfunctie tot stand worden gebracht. De patiënt vertelt dan dat hij "meer lucht" heeft. Routinematig is bij praktisch alle patiënten praeoperatief long. functieonderzoek verricht, hier wordt bij de patiëntenbesprekingen op teruggekomen. Voor elke groep patiënten is hiervan een overzicht gegeven. Postoperatief onderzoek naar de longfunctie is helaas zelden verricht. Uitgebreide literatuur over onderzoek hiervan, met name bij scoliosen, is beschikbaar. Meestal treedt na een directe postoperatieve vermindering wan de longfunctie later een verbetering op (20).

6. Onvoldoende blikveld speelt een rol bij patiënten met Bechterewkyfose. Zij kunnen niet vooruit zien behalve als ze achterover leunen in de heupen.

7. Kyfosen die (soms ook op volwassen leeftijd) progressief zijn moeten meestal gestabiliseerd worden. Progressie is te verwachten bij kyfosen van meer dan 60 à 70 graden door de toegenomen compressiekrachten aan de voorzijde van de wervelkolom. Slechte consistentie van het bot, zoals osteoporose en osteolytische haarden bij de ziekte van Bechterew zal het deformerende proces versterken.

Samenvattend zijn er voldoende redenen ingrijpende maatregelen bij deze patiënten te overwegen.

\subsection{Lichamelijk onderzoek}

Een versterkte kyfose is vooral zichtbaar als de patiënt voorover buigt met de armen afhangend, zonder op de knieën te steunen, zijdelings bezien. Hierbij glijden de schou- 
derbladen weg, zodat de wervelkolom volledig à vue komt. Ook inspectie van de rug schuin van achteren geeft een goede indruk van de sagittale curves van de wervelkolom. Nagegaan moet worden of de kyfose redresseerbaar is, bijvoorbeeld door onderzoek in knie-ellebooghouding. Oriënterend neurologisch onderzoek dient altijd te geschieden. Uitgebreider neurologisch onderzoek komt in aanmerking bij verdenking op myelumcompressie of andere neurologische beelden. Gelet moet worden op huidafwijkingen, zoals café au lait vlekken bij neurofibromatosis of abnormale haargroei bij congenitale afwijkingen met diastematomyelie.

\subsection{Aanvullend onderzoek}

Röntgenfoto's van de wervelkolom in 2 richtingen, staande gemaakt zijn onmisbaar om aard en mate van kyfose en de eventueel aanwezige scoliose te beoordelen. De rigiditeit van de kyfose toont men aan met een redressiefoto. Dit kan het best geschieden door de patiënt op zijn rug op een flinke pelotte te leggen, zodat de kyfose zich zoveel mogelijk strekt. Bij zeer ernstige kyfosen zijn vaak geen goede foto's te maken waarop de structurele aard van de kyfose duidelijk wordt. Tomografie is dan noodzakelijk. Myelografie komt in aanmerking bij de operatieve behandeling van congenitale kyfosen om een diastematomyelie uit te sluiten c.q. aan te tonen, alsmede bij alle vormen met myelumcompressie. Om de vaak voorkomende ventilatoire problemen pré-operatief te evalueren is longfunctie onderzoek noodzakelijk, soms zal van operatie moeten worden afgezien als de longfunctie onvoldoende is.

\subsection{Behandeling}

Voor sommige kyfosen, in het bijzonder bij nog groeiende kinderen kan conservatieve therapie in de vorm van bracing ondersteund door oefentherapie goede resultaten geven. In het bijzonder doelen wij hier op de kyfose op basis van de morbus Scheuermann. In de afzonderlijke hoofdstukken wordt hier nog op teruggekomen. Andere kyfosen, zoals de congenitale vorm kunnen alleen operatief behandeld worden, waarbij gestreefd wordt de verdere progressie van de deformiteit te blokkeren, soms zal ook correctie kunnen plaatsvinden.

De chirurgie van de wervelkolom heeft met de inwendige stabilisatie door middel van het Harringtonsysteem aan de achterzijde of het Dwyer, c.q. Zielkesysteem aan de voorzijde grote vorderingen gemaakı. De stabiliteit verbetert, waardoor pseudarthrosen minder gezien worden.

Vooral door het werk van Hodgson in Hongkong, op het terrein van Pottse kyfosen, is de voorste spondylodese sterk in de belangstelling gekomen. Door hem zijn verschillende benaderingen tot de wervellichamen bekend geworden. Juist bij kyfosen is een spondylodese aan de voorzijde vaak superieur aan die aan de wervelbogen, omdat aan de voorzijde van de kyfose een bottransplantaat onder compressie staat en dit werkt ingroeibevorderend. Een spondylodese aan de achterzijde daarentegen, staat onder trekkrachten. Bradford $(4,7)$, White en Panjabi $(35,36)$ hebben gewezen op pseudarthrose vorming bij de spondylodesis posterior bij kyfosen. Het is bekend dat kyfosering progressief kan zijn ondanks een geslaagde achterste spondylodese. Met name geldt dit voor de neurofibromatose van von Recklinghausen. Bot is geen statisch weefsel en er vindt constant afbraak en opbouw plaats, waarbij mechanische krachten een grote rol spelen. Het is dan ook mogelijk dat onder invloed van kyfoserende krachten (lichaamsgewicht, buikmusculatuur) de ombouw van het bot zodanig wordt beïnvloed 
dat een progressieve kyfose het gevolg is. Dit fenomeen wordt bijvoorbeeld gezien bij de ziekte van Bechterew en bij osteoporose. De kwaliteit van het bot speelt een grote rol. Hall (14) meent dat een kyfose van meer dan 60 graden door de veranderde mechanica progressief kan zijn. Alleen operatieve therapie kan bij deze patiënten progressie stoppen en correctie verschaffen. Therapeutische abstinentie lijkt ons minder juist, of er moeten duidelijke contra-indicaties zijn van lichamelijke of psychische aard.

\subsection{Literatuur inleiding en hoofdstuk 1}

1. Bauer R. Die operative behandlung der kyphose. Arch. Orthop. Unf,-Chir. 87, 1977, 85-99.

2. Bjerkreim I. Magnaes B. Semb G. Surgical treatment of severe angular kyphosis. Acta Orthop. Scand. 53, 1982, 913-917.

3. Blount W. P. Moe J. H. the Milwaukee Brace. Second edition. Williams and Wilkins Baltimore 1980.

4. Bradford D. S. Editorial comment. Kyphosis. Clin. Orthop. 128, 1977, 2 -4.

5. Bradford D. S. Anterior vascular pedicle bone grafting for the treatment of kyphosis. Spine 5, 1980, 318-323.

6. Bradford D. S. Ganjavian S. Antonious D. Winter R. B. Lonstein J. E. Moe J. H. Anterior strut-grafting for the treatment of kyphosis. Journ. of Bone and Joint Surg. 64A, 1982, 680-690.

7. Bradford D. S. Winter R. B. Lonstein J. E. Moe J. H. Techniques of anterior spinal surgery for the management of kyphosis. Clin. Orthop. 128, 1977, 129-139.

8. Chou S. N. The treatment of paralysis associated with kyphosis. Role of anterior decompression. Clin. Orthop. 128, 1977, 149-154.

9. Dwyer A. F. Experience of anterior correction of scoliosis. Clin. Orthop. 93, 1973, 191-206.

10. Floman Y. Micheli L. J. Penny J. N. Riseborough E. J. Hall J. E. Combined anterior and posterior fusion in seventy-three spinally deformed patients: indication, results and complications. Clin. Orthop. 164, 1982, 110-122.

11. Fourrier P. Bert G. Evaluation de la compensation lombaire des tassements rachidiens par fracture. Revue de Chir. Orthop. 58, 1972, 131-136.

12. Gonon G. P. de Mauroy J. C. Frankel P. Campo-Paysaa A. Stagnara P. Greffes antérieures en étai dans le traitement des cyphoses et cyphoscolioses. Revue de Chir. Orthop. 67, 1981, 731-745.

13. Hall J. E. The anterior approach to spinal deformities. Orthop. Clin. North. Amer. 3, 1972, 81-98. 
14. Hall J. E. Persoonlijke mededeling. 1979.

15. Harrington P. R. Dickson J. H. An eleven-year clinical investigation of Harrington instrumentation. Clin. Orthop. 93, 1973, 113-130.

16. James J. I. P. Kyphoscoliosis. Journ. of Bone and Joint Surg. 37B, 1955, 414-426.

17. Johnson J. T. H. Robinson R. A. Anterior strut grafts for severe kyphosis. Clin. Orthop. 56, 1968, 25-36.

18. Journees de la scoliose. Exposés. Lyon 8-9-10 Février 1979.

19. Keim H. A. The adolescent spine, Chapter 13. Kyphosis and Lordosis. Springer Verlag New York 1976.

20. Kumano K. Tsuyama N. Pulmonary function before and after surgical correction of scoliosis. Journ. of Bone and Joint Surg. 64A, 1982, 242-248.

21. Lonstein J. E. Winter R. B. Moe J. H. Bradford D. S. Chou S. N. Pinto W. C. Neurologic deficits secondary to spinal deformity. Spine 5, 1980, 331-355.

22. Moe J. H. Winter R. B. Bradford D. S. Lonstein J. E. Scoliosis and other spinal deformities. W. B. Saunders Company. Philadelphia 1978.

23. Morscher E. Dick W. Ruckstuhl J. Schuman L. Wolff G. Operationen an den Wirbelkörpern der Brustwirbelsäulle. Arch. Orthop. Unf.-Chir. 87, 1977, 185-201.

24. Morscher E. Müller W. Operative korrektur fixierter kyphosen. Orthopäde 2, $1973,193-200$.

25. Pinto W. C. Avanzi O. Winter R. B. An anterior distractor for the intraoperative correction of angular kyphosis. Spine 3, 1978, 309-312.

26. Riseborough E. J. Herndon J. H. Scoliosis and other deformities of the axial skeleton. Little, Brown and Company. Boston 1975.

27. Rose G. K. Owen R. Sanderson J. M. Transposition of rib with blood supply for the stabilization of a spinal kyphos. Journ. of Bone and Joint Surg. 57B, 1975, 112.

28. Slot G. H. van Thiel W. Introductie en eerste ervaringen met een nieuw correctiesysteem voor kyfose. Ned. Tijdschr. v. Geneesk. 126, 1982, 1472.

29. Stagnara P. Gounod J. Fauchet R. Jouvinroux P. Les greffes antérieures par voie thoracique dans le traitement des déformations et dislocations vertébrales en cyphose et cyphoscoliose. Revue de Chir. Orthop. 60, 1974, 39-56.

30. Stagnara P. Gounod J. Campo-Paysaa A. Vauzelle C. Fauchet R. Mazoyer D. Biot B. Poncet C. de Mauroy J. C. Villard B. Arthrodèses trans-thoraciques dans le traitement des cyphoses et des cyphoscolioses. Intern. Orthop. 1, 1977, 199-214. 
31. Stagnara P. de Mauroy J. C. Dran G. Gonon G. P. Costanzo G. Dimnet J. Pasquet A. Reciprocal angulation of vertebral bodies in a sagittal plane: Approach to references for the evaluation of kyphosis and lordosis. Spine 7, 1982, 335-342.

32. Streitz W. Brown J. C. Bonnett C. A. Anterior fibular strut grafting in the treatment of kyphosis. Clin. Orthop. 128, 1977, 140-148.

33. Villard $B$. Les arthrodèses vertébrales antérieures par voie thoracique pour le maintien des réductions des cyphoses et cyphoscolioses (A propos de 54 observations du centre des massues). Thèse Lyon 1975.

34. Westgate H. D. Moe J. H. Pulmonary function in kyphoscoliosis before and after correction by the Harrington Instrumentation method. Journ. of Bone and Joint Surg. 51A, 1969, 935-946.

35. White III A. A. Panjabi M. M. Thomas C. L. The clinical biomechanics of kyphotic deformaties. Clin. Orthop. 128, 1977, 8-17.

36. White III A. A. Panjabi M. M. Clinical biomechanics of the spine. J. B. Lippincott Company Philadelphia 1978.

37. Winter R. B. Hall J. E. Kyphosis in childhood and adolescence. Spine 3, 1978, 285308.

38. Zielke K. Skoliose und Kyphose. Operative Behandlung vom vorderen Zugang. Die Wirbelsäule in Forschung und Praxis. Hippocrates Verlag Stuttgart 1976.

39. Zorab P. A. Pulmonary function in spinal deformity. Clin. Orthop. 93. 1973, 33-37. 


\section{KYFOSEN BUJ DE ZIEKTE VAN SCHEUERMANN}

\subsection{Inleiding}

Holger Werfel Scheuermann (1877-1960) beschreef in 1920 (19) het ziektebeeld waarbij een versterkte kyfosering van de thoracale wervelkolom optrad bij groeiende kinderen in de puberteit ten gevolge van een groeistoornis van de ringapofysen van de wervellichamen. Hij beschouwde de afwijking als analoog aan de ziekte van Perthes, dus als een osteochondritis ten gevolge van een avasculaire necrose van deze apofysen.

Schmorl (21) beschouwde de herniatie van de intervertebrale discus in het wervellichaam als een aetiologische factor voor het ontstaan van de kyfose. Bradford (6) acht osteoporose een factor van belang bij het ontstaan van deze adolescentenkyfose. Andere oorzakelijke momenten zouden mechanische factoren zoals zware arbeid en sport zijn, ook ontsteking en genetische factoren worden genoemd. Bij operatieve correctie aan de voorkant van de wervelkolom valt het sterk verdikte ligamentum longitudinale anterius op, dat belangrijke correctie kan tegenhouden als het niet doorgenomen wordt. Mogelijk dat een contractuur van dit ligament, zoals bij de ziekte van Dupuytren, een oorzakelijke factor is, met als gevolg een kyfosering van de wervelkolom (3). Ondanks al deze theorieën is in feite de werkelijke oorzaak van de ziekte niet bekend. Histologisch bestaat een osteochondrose met disruptie en desorganisatie van de vertebrale groeiplaat, waarbij discusmateriaal in het spongieuze bot van het wervellichaam prolabeert. Aseptische necrose van de ringapofyse wordt in de laatste histologische onderzoekingen niet gezien $(1,3,4,15)$. Kenmerkend voor de ziekte is het optreden van een versterkte arcuaire kyfose, in eerste instantie meestal zonder klachten, waarbij röntgenologisch onregelmatige dekplaten van de wervels worden gezien met wigvorming van de aangedane wervels. Om van een echte morbus Scheuermann te mogen spreken zouden mìnstens 4 wervels aangetast moeten zijn met een wigvorming van 5 graden en meer $(3,22)$. Vaak echter zijn slechts enkele segmenten aangetast, mogelijk moeten deze osteochondrosen ook tot de ziekte van Scheuermann gerekend worden. Normal bedraagt de kyfosehoek over het langste traject gemeten $20-40$ graden. Kyfosen boven 40 a 45 graden bij opgroeiende kinderen zijn pathologisch en dienen behandeld te worden (3). Boven 60 à 70 graden kan een operatie indicatie bestaan als er klachten zijn welke niet reageren op conservatieve behandeling, de patiënt uitgegroeid is of er een slechte cosmetiek bestat met eventuele psychologische problemen $(5,1$, $23,24)$.

\subsection{Symptomatologie}

Klachten hebben patiënten met de ziekte van Scheuermann op de jongere leeftijd meestal niet. De voornaamste reden voor het consulteren van een arts is de slechte cosmetiek. Hierdoor kunnen, vaak later in het leven, nogal eens psychische problemen ontstaan.

Bij ernstiger vormen van de ziekte kunnen pijnklachten optreden. Bradford beschrijft de pijn meest thoracaal (3), ook lumbale en cervicale pijn lijkt frequenter te zijn dan in de normale populatie door overbelasting van de lange rug- en nekmusculatuur als gevolg van de compensatoire hyperlordosen $(10,14)$. Bij de meer dysplastische vormen van deze ziekte met slechte botkwaliteit en kyfosen van meer dan 60 graden blijkt ook 
na het beëindigen van de groei progressie te kunnen optreden $(3,12)$. Hoe groter de afstand van de zwaartelijn van het lichaam tot de apex van de kyfose, des te groter de kyfoserende krachten die inwerken op de wervelkolom. Door botombouw onder invloed van deze krachten kan progressieve kyfosering optreden, al gaat dit in het algemeen uiterst langzaam. De longfunctie is als regel niet gestoord. De voor-achterwaartse diameter van de thorax is immers vergroot, waardoor het longvolume niet verminderd is. Slechts bij ernstiger kyfosen treedt vermindering van de longcapaciteit op.

Neurologische problemen worden slechts zelden gezien daar de kyfose arcuair van karakter is. Protrusie van een discus met myelumcompressie, een thoracale hernia dus, is beschreven, evenals myelumcompressie over een scherpere Scheuermann kyfose ( 7 , 18).

\subsection{Behandeling}

Bij het opgroeiende kind is de behandeling praktisch altijd conservatief met als doel de kyfoserende krachten aan de voorzijde van de wervels en disci te verminderen, zodat herstel van het botvormende weefsel kan plaatsvinden. Dat houdingstherapie als enige vorm van therapie bij een morbus Scheuermann met wigvorming van wervels tekort zal schieten is duidelijk als men bedenkt dat de kyfose structureel en rigide is, zodat slechts een continu werkende kracht zodanige ontlasting van de voorzijde van de wervelkolom bewerkstelligt, dat regressie van de groeistoornis optreedt. Een volgens het 3-punts principe werkend corset biedt hiertoe uitstekende mogelijkheden, gecombineerd met oefentherapie om de musculatuur op peil te houden en de rug zo soepel mogelijk te maken $(8,25)$. Is de kyfose niet rigide, dan betreft het meestal een houdingskyfose, welke in het algemeen wel met uitsluitend oefentherapie te beïnvloeden is. Loopt bij de ziekte van Scheuermann de groei van de wervelkolom op zijn eind, dan komt een redresserend gipscorset in anmerking tot volledige uitgroei is opgetreden. Bij deze redressietherapieën is het van het grootste belang de lumbale wervelkolom te delordoseren. De thoracale wervelkolom wordt dan gedwongen zich op te richten om het lichaam niet voorover te doen vallen. Als de kyfose tijdig ontdekt wordt en de behandeling tijdig wordt ingesteld zijn goede resultaten van de conservatieve therapie bij de ziekte van Scheuermann te verwachten (8).

Operatieve behandeling komt in aanmerking bij volwassenen met een versterkte rigide kyfose van meer dan 60 à 70 graden, de meeste auteurs houden 70 graden als grens aan $(5,9,13,16,23,24)$. Belangrijke argumenten om tot operatieve behandeling over te gaan zijn pijnklachten, niet reagerend op conservatieve therapie en progressie van de kyfose, ook al is dit meestal niet objectief aantoonbaar maar wel een door de patiënt geuite klacht. Sommige auteurs stellen de indicatie tot operatie ook bij nog groeiende kinderen, waarbij conservatieve behandeling onvoldoende verbetering te zien geeft. Volstaan kan dan worden met een achterste compressiespondylodese wegens de betere correctiemogelijkheid, die bij operatie op jongere leeftijd nog mogelijk is. Operatie moet dan in ieder geval uitgesteld worden tot de skeletrijping tot risser 3 gevorderd is, dit is de aanleg van de crista apofyse tot halverwege de crista. Bij te vroege operatie bestaat het gevaar van overcorrectie door te sterke doorgroei aan de voorzijde van de wervelkolom $(16,24)$.

$\mathrm{Bij}$ volwassenen moet eerst het ligamentum longitudinale anterius worden doorgenomen, vervolgens worden de disci en dekplaten verwijderd, waarna enige correctie wordt bereikt door inbrengen van crista of ribbot. Bij de achterste Harrington compressie spondylodese twee weken later kan de definitieve correctie bereikt worden. Zonder 
voorste ingreep is minder correctie mogelijk. Bovendien treedt door „elastic recoil" van het contracte ligamentum longitudinale anterius in een aantal gevallen fors verlies aan correctie op $(5,9,16)$. Door het in tweede instantie aanbrengen van correctie wordt het compressie effect van de spondylodese aan de voorzijde teniet gedaan. Pseudarthrose, vooral bij gebruik van ribbot is gemeld (13). Bij gebruik van crista iliaca blokjes zou er een scharnier-effect ter plaatse van de blokjes ontstaan bij het aanbrengen van de compressie, waardoor voldoende botcontact tussen de grafts en de wervellichamen blijft bestaan om consolidatic te waarborgen (23).

Oudere patiënten, in het algemeen boven 40 jaar, komen in de regel niet voor deze grote operaties in aanmerking. De compensatoire lordose is dan voor een grool gedeelte gefixeerd, evenals dat vaak met het klachtenpatroon het geval is. Optimale conservatieve behandeling in de groeiperiode moet voorkomen dat op latere leeftijd operatieve therapie de enige oplossing is.

\subsection{Literatuur hoofdstuk 2}

1. Aufdermaur M. Juvenile kyphosis (Scheuermann's Disease) Clin. Orthop. 154, $1981,166-174$.

2. Bick E. M. Copel J. W. The ring apophysis of the human vertebra. Contribution to human osteogeny II. Journ. of Bone and Joint Surg. 33A, 1951, 783-787.

3. Bradford D. S. Juvenile kyphosis. Clin. Orthop. 128, 1977, 45-55.

4. Bradford D. S. Vertebral osteochondritis (Scheuermann's kyphosis), Clin. Orthop. $158,1981,83-90$.

5. Bradford D. S. Ahmed K. B. Moe J. H. Winter R. B. Lonstein J. E. The surgical management of patients with Scheuermann's disease. Journ. of Bone and Joint surg. 62A, 1980, 705-712.

6. Bradford D. S. Brown D. M. Moe J. H. Winter R. B. Jonsey J. Scheuermann"s kyphosis. A form of osteoporosis? Clin. Orthop. 118, 1976, 10-15.

7. Bradford D. S. Garcia A. Neurological complications in Scheuermann's disease. A case report and review of the literature. Journ. of Bone and Joint Surg. 51 A, 1969, $567-572$.

8. Bradford D. S. Moe J. H. Montalvo F. J. Winter R. B. Scheuermann's kyphosis and roundback deformity. Journ. of Bone and Joint Surg. 56A, 1974, 740-758.

9. Bradford D. S. Moe J. H. Montalvo F. J. Winter R. B. Scheuermann's kyphosis. Results of surgical treatment by posterior spine arthrodesis in twenty-two patients. Journ. of Bone and Joint Surg. 57A, 1975, 439-448.

10. Buchs P. Hyperlordose lombaire et maladie de Scheuermann. Revue de Chir. Orthop. $51,1965,105$. 
11. Ferguson A. B. The etiology of pre-adolescent kyphosis. Journ. of Bone and Joint Surg. 38A, 1956, 149-157.

12. Heine J. Riad C. Steinhausen D. Die prognose der Scheuermannschen Erkrankung. Zeitschr. für Orthopädie 119, 1981, 812-813.

13. Herndon W. A. Emans J. B. Micheli L. J. Hall J. E. Combined anterior and posterior fusion for Scheuermann's kyphosis. Spine 6, 1981, 125-130.

14. Huwyler $\mathrm{J}$. L'apparition des symptômes dégéneratifs à la colonne vertébrale, cervicale et lombaire, après la maladie de Scheuermann thoracique. Revue de Chir. Orthop. 51, 1965, 105.

15. Ippolito E. Ponseti I. V. Juvenile kyphosis. Journ. of Bone and Joint Surg. 63A, $1981,175-182$.

16. Mc Phee J. B. Tuffley D. J. The surgical management of Scheuermann's kyphosis. Journ. of Bone and Joint Surg. 65B, 1983, 97-98.

17. Menge M. Form und Haltung der normalen Wirbelsäule im Röntgenbild. Zeitschr. für Orthopädie 120, 1982, 146-150.

18. Ryan M. D. Taylor T. K. F. Acute spinal cord compression in Scheuermann's disease. Journ. of Bone and Joint Surg. 64B, 1982, 409-412.

19. Scheuermann H. W. Kyphosis dorsalis juvenilis. Ugeskr. Laeger. 82, 1920, 385393.

20. Scheuermann H. W. Kyphosis dorsalis juvenilis. Zeitschr. für Orthopädische Chirurgie $41,1921,305$.

21. Schmorl G. Die Pathogenese der juvenilen Kyphose. Fortschr. Röntgenstr. 41, 1930,359 .

22. Sörenson K. H. Scheuermann's Juvenile Kyphosis. Copenhagen, Munksgaard 1964.

23. Stagnara P. Mauroy J.-C. de. Villard B. Traitement des cyphoses régulières. Annales de médecine physique 18, 1975, 1-16.

24. Taylor T. C. Wenger D. R. Stephen J. Gillespie R. Bobechko W. P. Surgical management of thoracic kyphosis in adolescents. Journ. of Bone and Joint Surg. 61A, $1979,496-503$.

25. Yücel M. Breitenfelder J. Gadiel H. E. Vergleichende untersuchungen des Kor-

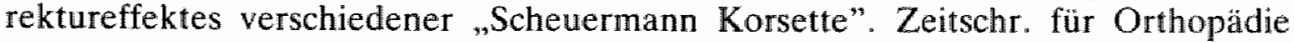
$119,1981,814-819$. 


\subsection{Patiëntenbeschrijvingen bij Scheuermann kyfosen}

Patiènt 1. R. W. mannelijk, geb. dat. 3-12-1960.

Aetiologie:

Vroegere behandeling:

Klachten:

Préoperatieve curves:

Voorbehandeling:

Neurologisch onderzoek:

Operatie:

Complicaties:

Nabehandeling:

Postoperatieve curves:
Ziekte van Scheuermann bij zwak begaafde jongen met flinke wigvorming T6-7-8-9.

Gipsredressie gedurende 1 jaar zonder blijvend succes.

Geen pijnklachten. Cosmetische en profylactische indicatie.

$\mathrm{T} 3 \mathrm{t} / \mathrm{m}$ T10 $70^{\circ}$ kyfose. Risser 4.

2 weken Cotreltractie. Verbetering tot $50^{\circ}$.

Geen afwijkingen.

d.d. 7-12-1977. Achterste Harringtoncompressie spondylodese T4 t/m T10 m.b.v. cristabot.

Geen.

9 maanden gipscorset.

Postoperatief $\quad 47^{\circ}$

Na 6 weken $\quad 53^{\circ}$

$\mathrm{Na} 3$ maanden $\quad 46^{\circ}$

$\mathrm{Na} 9$ maanden $\quad 50^{\circ}$

$\mathrm{Na} 1$ jaar $\quad 47^{\circ}$

Na $1 \frac{1}{2}$ jaar $\quad 47^{\circ}$

Postoperatieve klachten: Geen.

Beschouwing en conclusie:

Veel mensen zullen moeite hebben met het stellen van een cosmetische indicatie. Pijnklachten zijn op de jonge leeftijd nog niet aanwezig en komen in een belangrijk percentage op latere leeftijd. Ook is de kans op progressie van de kyfose aanwezig alls deze aan het eind van de puberteit $70^{\circ}$ meet.

De operatie moet dan ook mede als een profylactische ingreep gezien worden om latere problemen te voorkomen, hoewel natuurlijk niemand kan voorspellen of deze problemen ook daadwerkelijk zullen ontstaan.

Met alleen een achterste compressie spondylodese kan minder correctie bereikt worden dan gecombineerd met een voorste release. Een correctie tot $47^{\circ}$ is goed, al bevindt hiermee de kyfose zich nog niet in het normale traject. Tussen $40^{\circ}$ en $50^{\circ}$ kyfose op de volwassen leeftijd zal echter zelden problemen geven op latere leeftijd. 


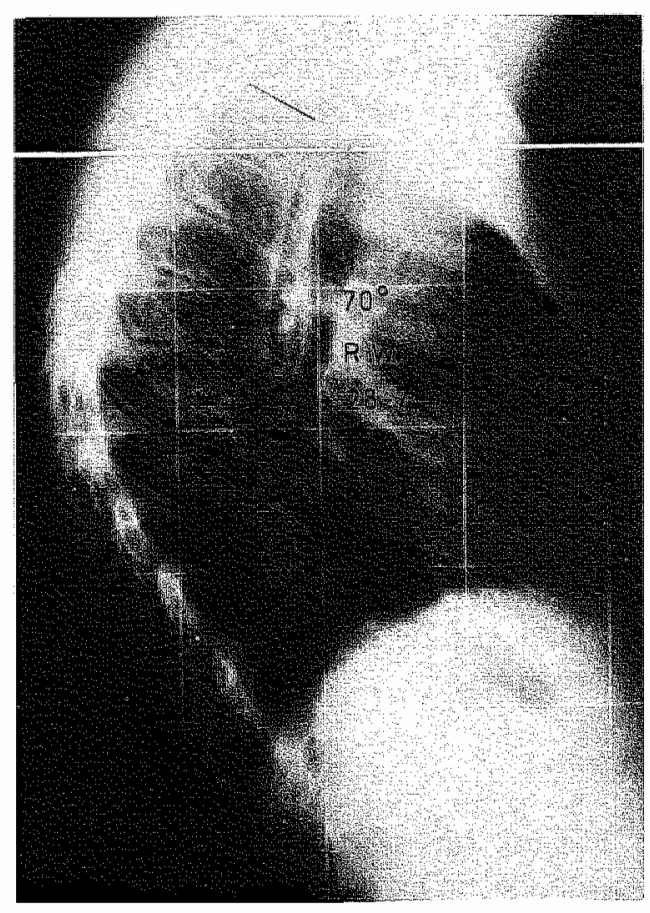

Kyfose préoperatief

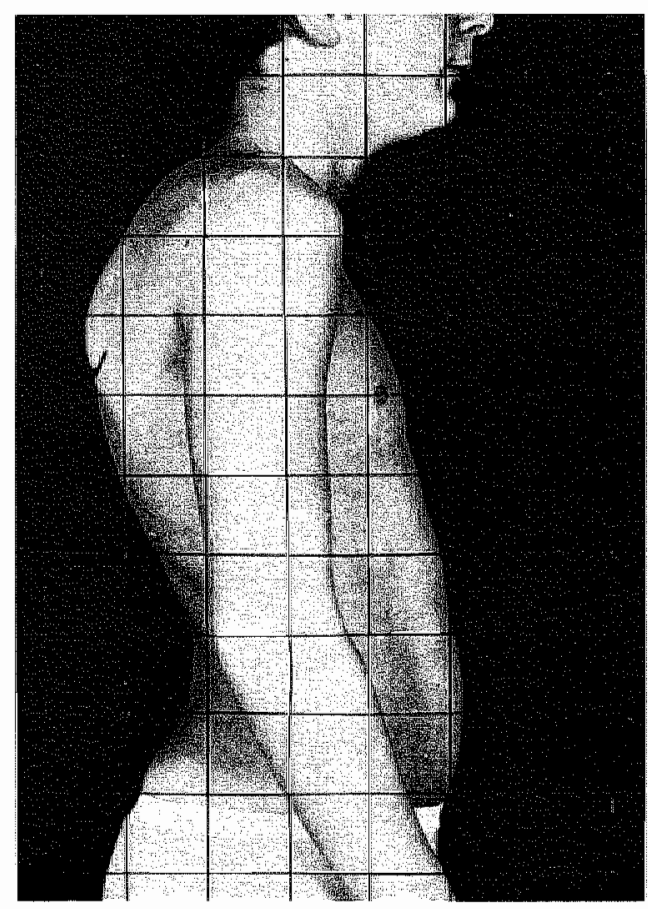

R. W. Kyfose préoperatief

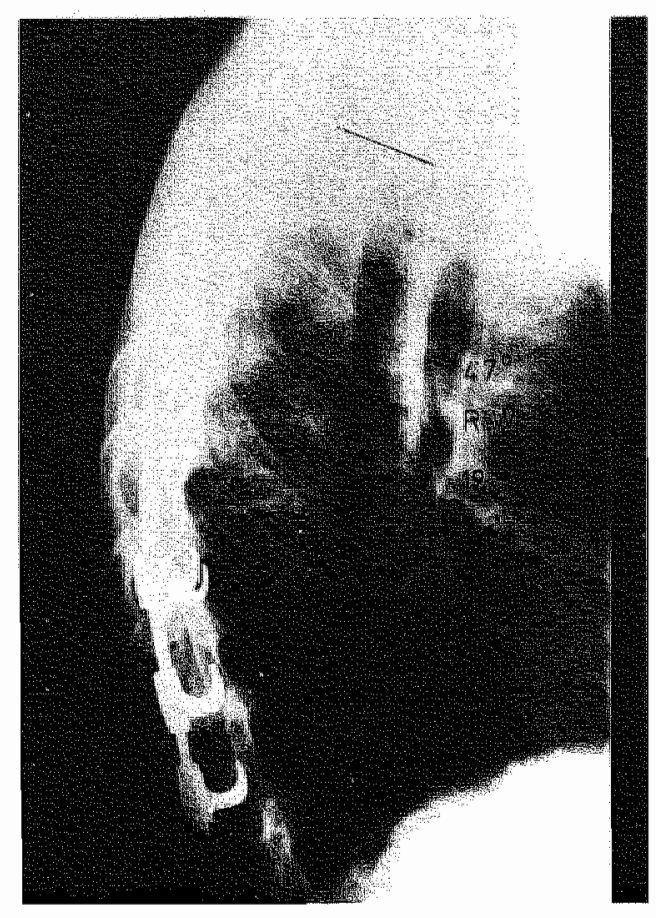

R. W. Kyfose postoperatief

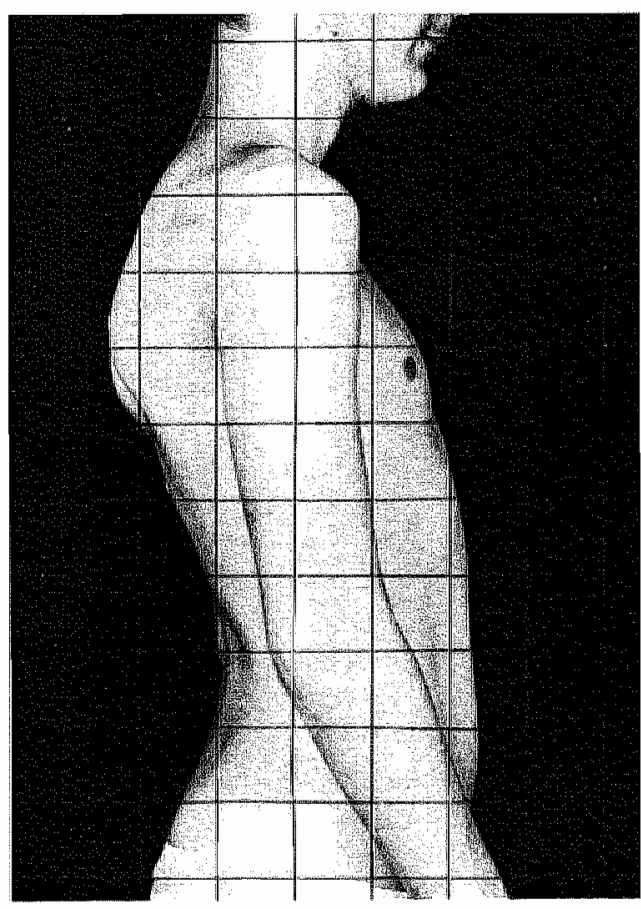

R. W. Kyfose postoperatief 
Patiěnt 2. K.y.T. mannelijk, geb. dat. 16-8-1944.

Aetiologie:

Vroegere behandeling:

Klachten:

Préoperatieve curves:

Voorbehandeling:

Longfunctie:

Conclusie:

Neurologisch onderzoek:

Operaties:

Complicaties:

Nabehandeling:

Postoperatieve curves:

Postoperatieve klachten:
Ziekte wan Scheuermann met ernstige wigvorming T7-8-9.

Alleen fysiotherapie in diverse periodes.

Rugpijn lumbaal, ook cervicaal.

T5 t/m T11 $101^{\circ}$ kyfose. Tractie $90^{\circ}$

Geen.

Vit. capac.: $4025 \mathrm{cc}$ normaal $6050 \mathrm{cc}$. Tot. capac.: $5475 \mathrm{cc}$ normaal $7800 \mathrm{cc}$.

Duidelijke restrictieve functiestoornis met nog ruime ventilatoire reserves.

Geen afwijkingen.

1. 28-2-1977. Release aan de voorzijde via een thoracotomie rechts, 6 niveaus, met spondylodese d.m.v. ribspaan en ribchips. Hierna Halo-Cotrel tractie.

2. 15-3-1977. Harrington compressiespondylodese T5 t/m L2 m.b.v. cristabot.

Uitbreken ribspaan na 2 e operatie, $2 \times$ pneumothorax links, behandeld met zuigdrainage.

Halo-rompgips 6 maanden, waarna 3 maanden gipscorset.

Na le operatie $\quad 84^{\circ}$

Na 2e operatie $\quad 48^{\circ}$

Na 3 maanden $\quad 44^{\circ}$

$\mathrm{Na} 6$ maanden $\quad 58^{\circ}$

$\mathrm{Na} 9$ maanden $\quad 62^{\circ}$

Na 1 jaar $\quad 63^{\circ}$

$\mathrm{Na} 1 \frac{1}{2}$ jaar $\quad 65^{\circ}$

Nog pijnklachten laag lumbaal en hoog thoracaal, maar minder dan préoperatief.

Beschouwing en conclusie:

Door forse correctie bij de achterste compressiespondylodese ontstond uitbreken van de ribspaan. De pneumothorax is waarschijnlijk het gevolg geweest van overrekking van het longweefsel. Bij thoracoscopie na de tweede pneumothorax werd geen laesie 
gevonden. Het verlies aan correctie is fors geweest. Het probleem is dat bij wolwassen patiënten een achterste compressiespondylodese alleén onvoldoende correctie geeft door de rigiditeit aan de voorzijde. De achterste spondylodese met forse correctie na een voorste release en spondylodese makt de voorste spondylodese insufficiënt. Op de postoperatieve röntgenfoto's lijken op de onderste niveaus de ribspaantjes niet goed ingegroeid. Verlies van correctie is dan ook te verwachten door de trekkrachten aan de achterzijde, terwijl het compressiesysteem deze krachten niet altijd kan weerstaan en de voorste afsteuning onvoldoende is. De consequentie zou moeten zijn in $3 e$ tempo een hernieuwde voorste spondylodese te verrichten zodat de correctie gehandhaafd blijft. Dit maakt de operatieve procedure echter wel zeer uitgebreid. Een betere oplossing lijkt het inbrengen van cristablokjes in de tussenwervelruimtes die als scharnierpunt kunnen dienen en ook na de achterste correctie nog voldoende botcontact hebben om vlot te consolideren, zodat minder verlies aan correctie optreedt.

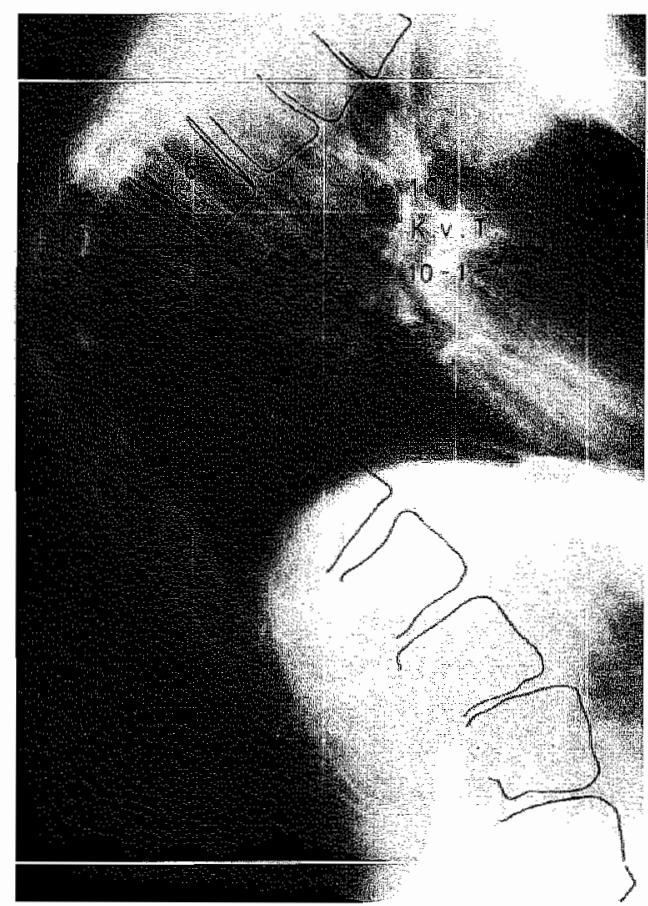

Kyfose préoperatief

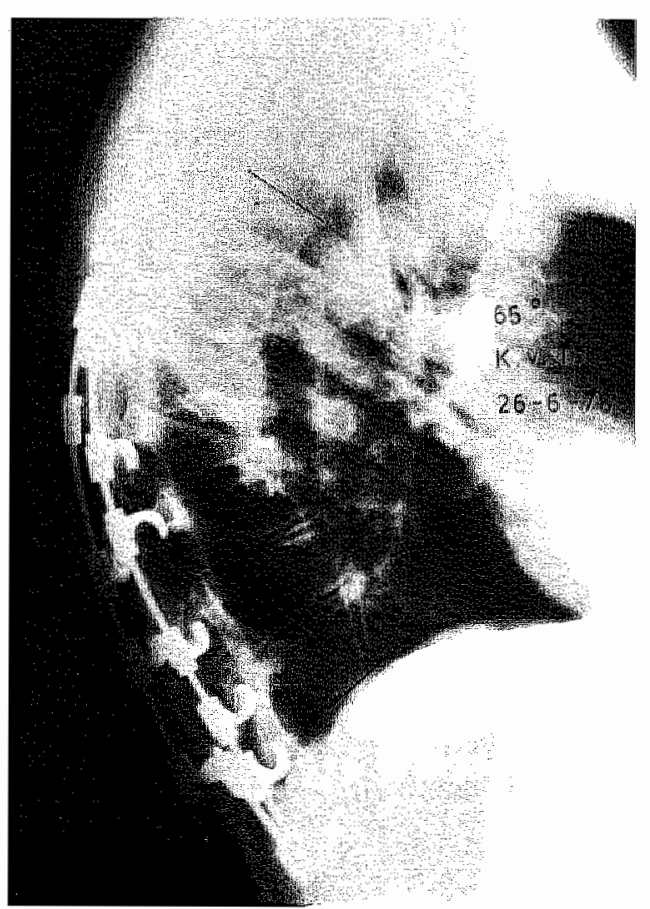

Kyfose postoperatief 


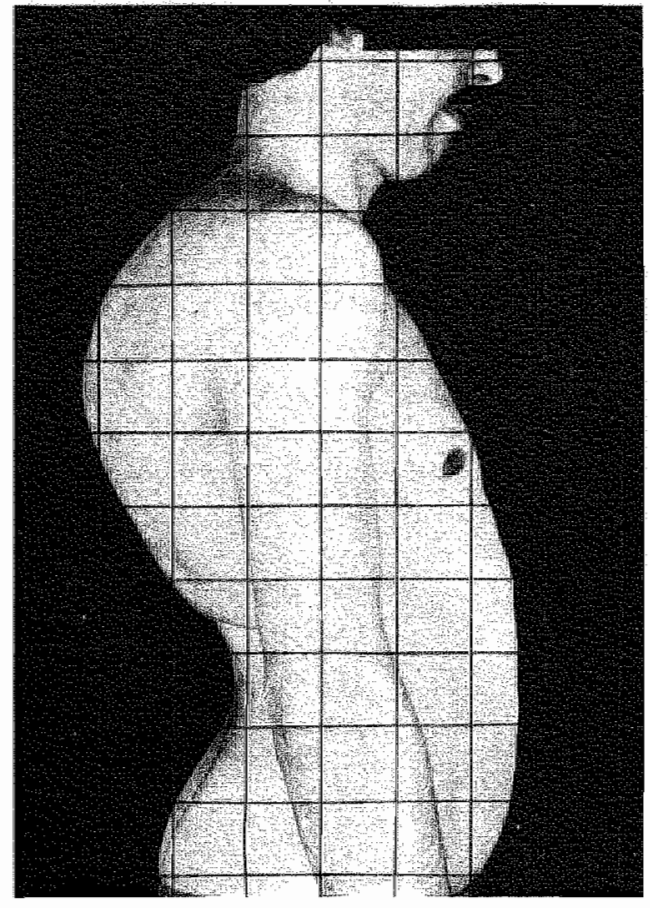

K.v.T. Kyfose préoperatief

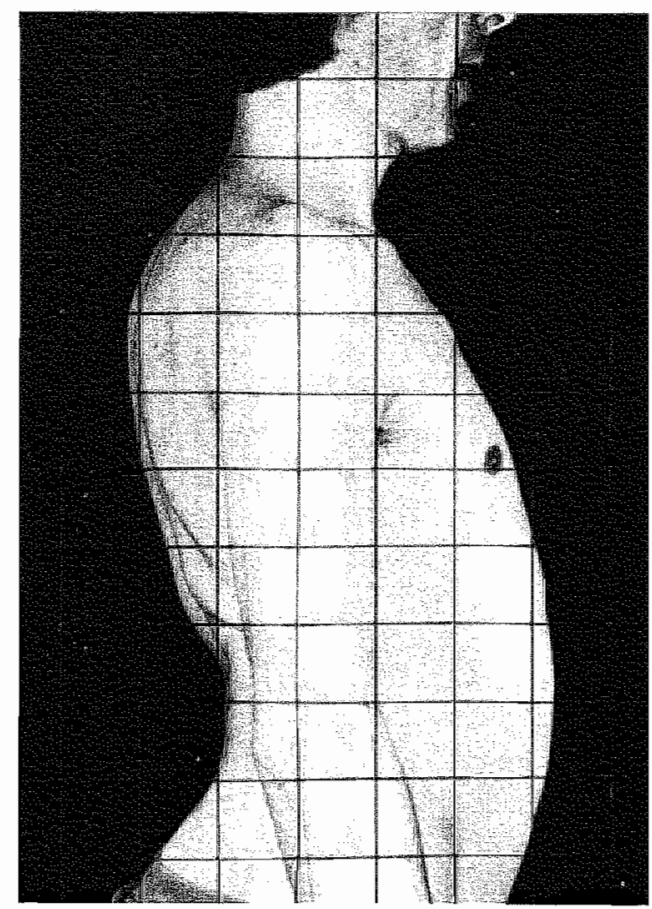

K.v.T. Kyfose postoperatief 
Patiënt 3. J. H. mannelijk, geb. dat. 30-6-1944.

Aetiologie:

Vroegere behandeling:

Klachten:

Préoperatieve curves:

Voorbehandeling:

Longfunctie:

Neurologisch onderzoek:

Operaties:

Complicaties:

Nabehandeling:

Postoperatieve curves:

Postoperatieve klachten:
Ziekte van Scheuermann met forse wigvorming T67-8-9 en verbreding van de wervellichamen.

Niet bekend.

Rugpijn t.p.v. de thoraco-lumbale overgang en laag lumbaal, ook cervicaal sinds het $14 \mathrm{e}$ jaar.

T4 t/m T11 $83^{\circ}$ kyfose. Geen verbetering met tractie.

Geen.

Vitaal capaciteit $5 \frac{1}{2}$ liter, verder onderzoek niet verricht.

Geen afwijkingen.

1. 5-9-1977. Voorste release via thoracotomie rechts op 6 niveaus, spondylodese m.b.v. ribchips. Hierna Halo-Cotreltractie.

2. 20-9-1977. Harrington compressie spondylodese T4 t/m T10 m.b.v. cristabot.

Vertraagde ontplooiing linker long.

Halo-rompgips 6 maanden, waarna 3 maanden gipscorset.

Na 2e operatie $\quad 54^{\circ}$

Na 9 maanden $\quad 57^{\circ}$

Na $1 \frac{1 / 2}{\text { jaar }} \quad 57^{\circ}$

Weinig verandering van het klachtenpatroon, de rug- en nekklachten waren nog aanwezig.

\section{Beschouwing en conclusie:}

Bij deze patiënt werd een behoorlijke correctie van de kyfose bereikt, al is $57^{\circ}$ duidelijk nog meer dan normaal. Het blijkt zeer moeilijk om deze rigide kyfoses op de wat oudere leeftijd binnen het normale gebied te krijgen. Ook is er al vaak teveel gefixeerde lordose opgetreden onder en boven de kyfose, zodat het resultaat van de operatie op de pijnklachten lumbaal en cervicaal moeilijk voorspelbaar is. De pijn welke thoracaal gelocaliseerd is, verdwijnt na operatie bijna altijd. 


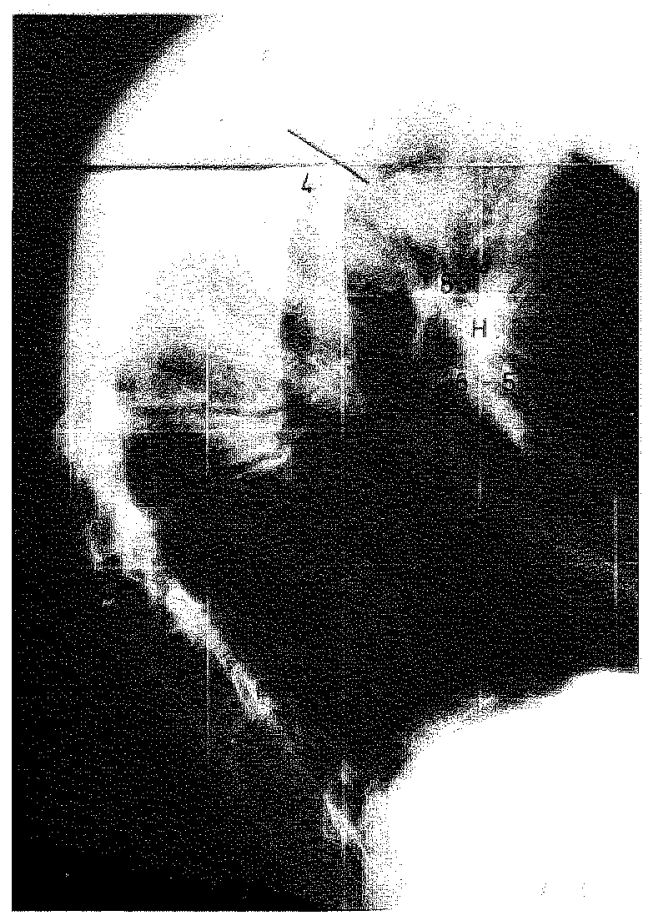

Kyfose préoperatief

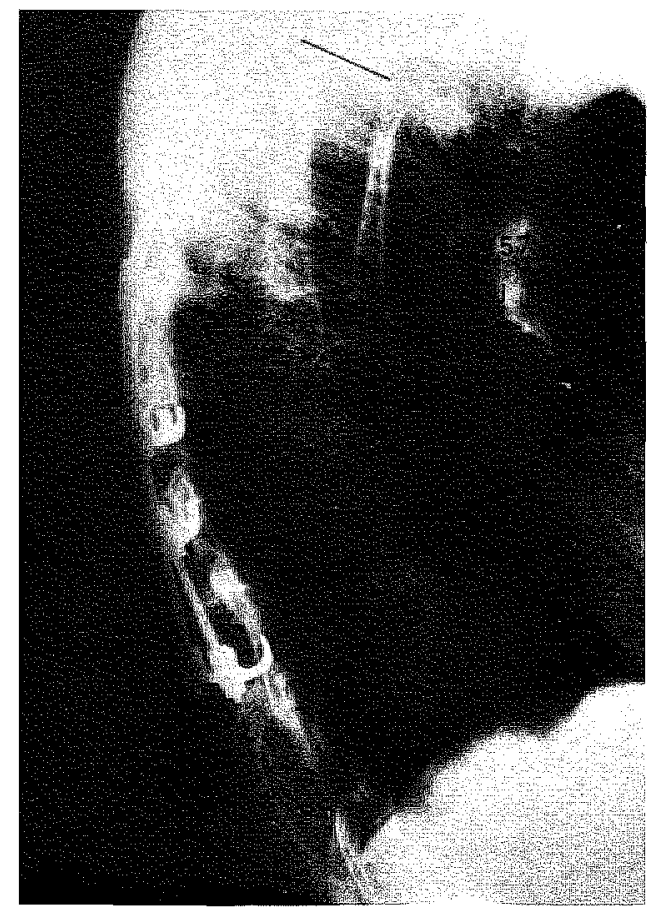

Kyfose postoperatief 
Patiënt 4. S. S. mannelijk, geb. dat. 10-12-1959.

Aetiologie:

Vroegere behandeling:

Klachten:

Préoperatieve curves:

Voorbehandeling:

Longfunctie:

Conclusie:

Neurologisch onderzoek:

Operaties:

Complicaties:

Nabehandeling:

Postoperatieve curves:

Postoperatieve klachten:

Beschouwing en conclusie:

Door Bradford werd onderzocht of osteoporose een rol speelt bij de ziekte van Scheuermann. Dit onderzoek toonde aan dat osteoporose kan voorkomen bij deze af-
Ziekte van Scheuermann met sterke onregelmatigheid en wigvorming van de midthoracale wervels.

Fysiotherapie.

Geen pijnklachten, wel eerder vermoeid in de rug.

Bij le polikliniekbezoek op 14-2-77, $72^{\circ}$ kyfose. Tcen al advies tot operatie gegeven. Op 17-5-1979. $87^{\circ}$ kyfose, dus een progressie van $15^{\circ}$ in ruim 2 jaar tijd.

4 dagen Halo-rolstoeltractie.

Vitaal capac. $5450 \mathrm{cc}$. Normaal $6800 \mathrm{cc}$. Totaal capac. $7325 \mathrm{cc}$. Normaal $8600 \mathrm{cc}$.

Geringe restrictie, overigens uitstekende longfunctie.

Geen afwijkingen.

1. 1-8-1979. Voorste release via thoracotomie rechts op 6 niveaus, spondylodese m.b.v. ribchips en ribspaan in een laterale geul, na zoveel mogelijk strekking d.m.v. een tijdelijke Harrington distractiestaaf. Hierna Halo-Cotreltractie.

2. 15-8-79. Harrington compressiespondylodese T5 $\mathrm{t} / \mathrm{m}$ T12. Bovenste en onderste 2 haakjes om de laminae, andere haakjes om de processi transversi.

Thrombosebeen links. Plexus brachialis parese rechts, van tijdelijke aard, waarschijnlijk t.g.v. ligging op de operatietafel.

8 maanden gipscorset.

Na 2 e operatie $\quad 35^{\circ}$

$\mathrm{Na} 2$ maanden $\quad 43^{\circ}$

Na 8 maanden $\quad 45^{\circ}$

Na 13 maanden $\quad 46^{\circ}$

Geen. De moeheid in de rug.was verdwenen. 
wijking. Bij deze jongeman tonen de midthoracale, wervels een verminderde kalkhoudendheid en lijkt de progressie van de kyfose mede te berusten op de slechte botstructuur ter plaatse. Verder zijn er hier onduidelijke botcontouren en sterke onregelmatigheid van de dekplaten door compressie van discusmateriaal met Schmorlse noduli. Met een gecombineerde voorste en achterste ingreep werd een uitstekende correctie bereikt, afgewacht moet echter worden of in de loop der jaren toch niet weer progressie van de kyfose zal plaatsvinden. 


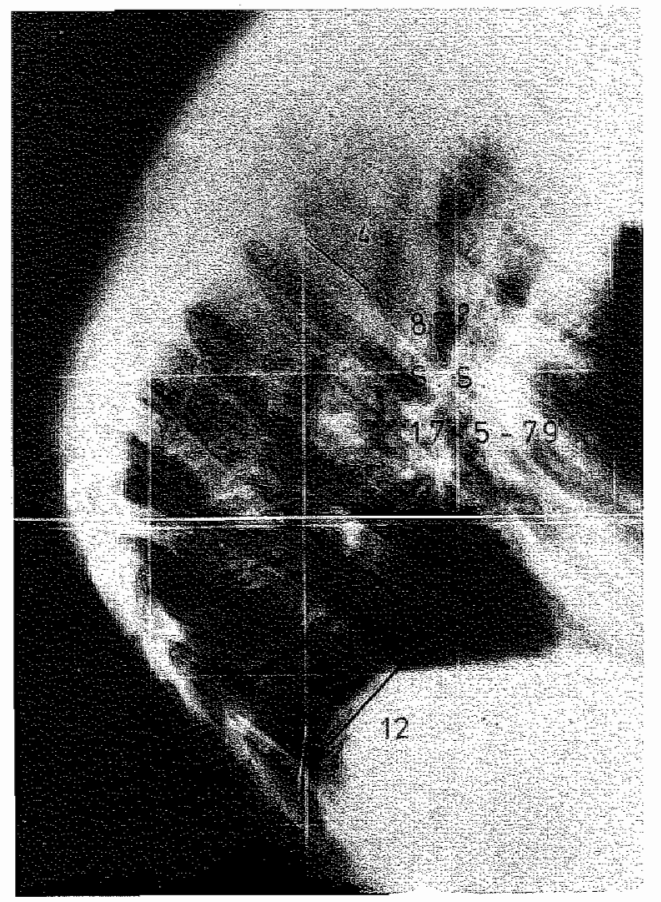

Kyfose préoperatief

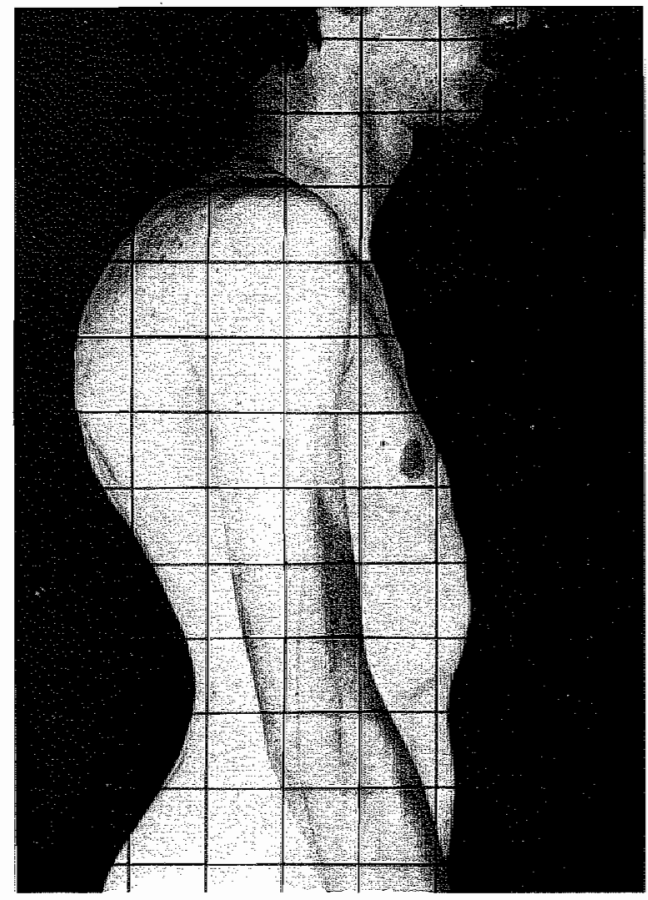

S. S. Kyfose préoperatief

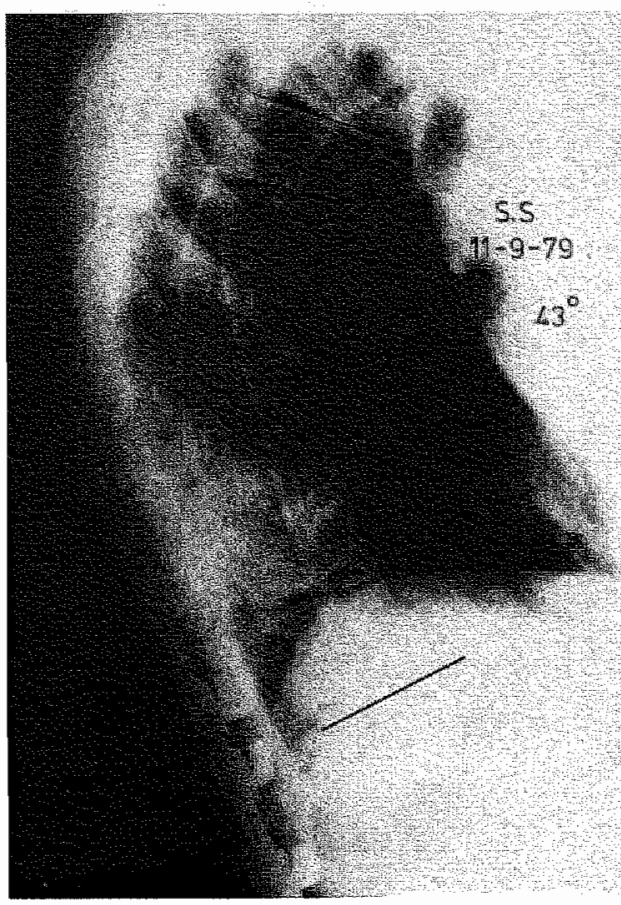

Kyfose postoperatief

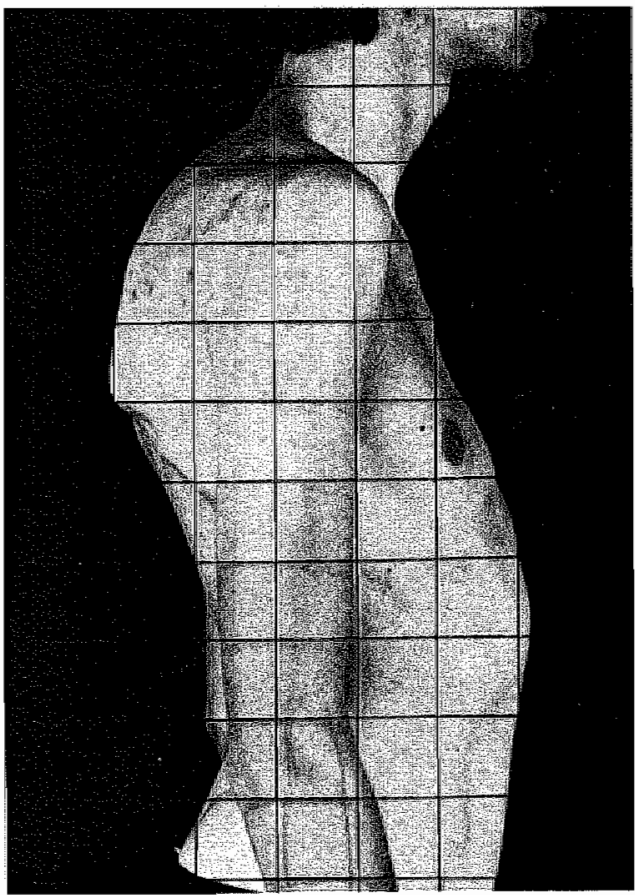

S. S. Kyfose postoperatief 


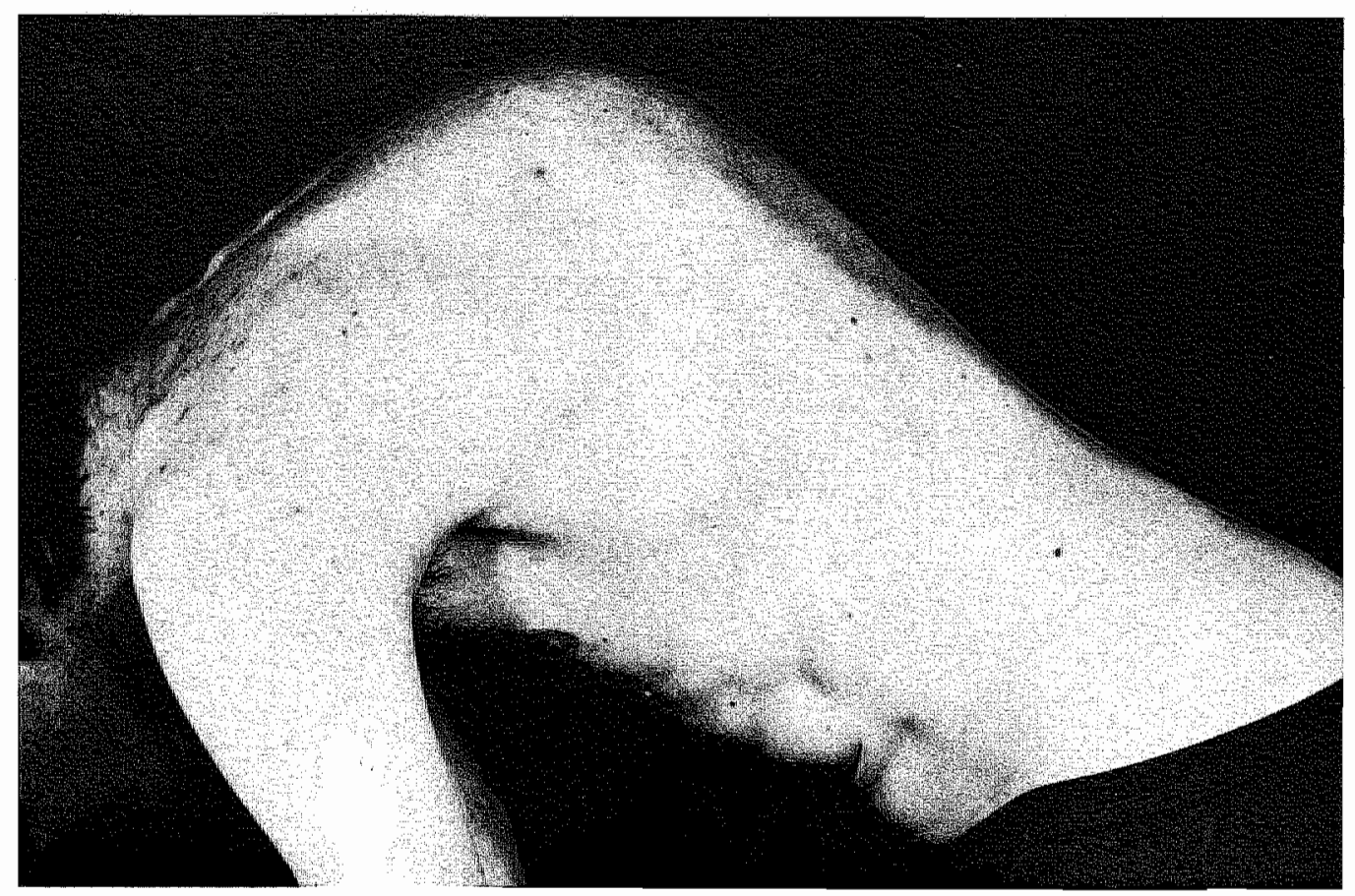

S. S. Kyfose voorovergebogen duidelijk zichtbaar. Préoperatief.

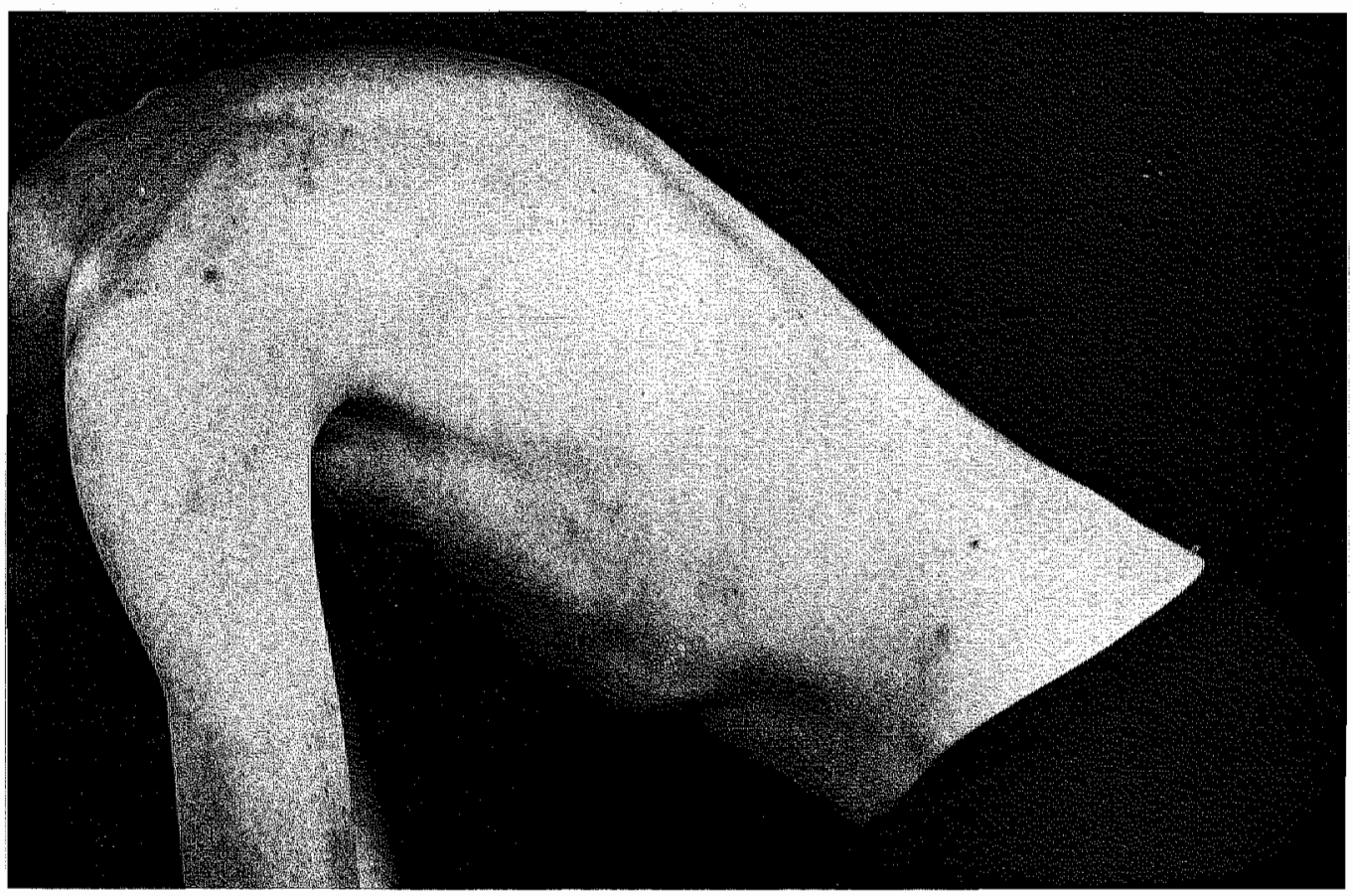

S. S. Kyfose postoperatief. 


\section{CONGENITALE KYFOSEN EN KYFOSCOLIOSEN}

\section{Inleiding}

Kyfosen ten gevolge van ontwikkelingsstoornissen van de wervelkolom kunnen in $3 \mathrm{ca}$ tegorieën worden ingedeeld $(24,25)$.

1. Kyfose door stoornis in de vorm van wervellichamen (aplasie of hypoplasie fig. 3)

2. Kyfose door stoornis in de segmentatie van wervellichamen (anterior bar fig. 3)

3. Kyfose door combinatie van 1 en 2 (gemengd type)

figuur 3

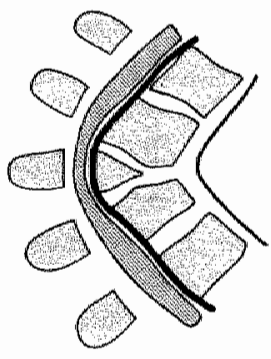

type 1

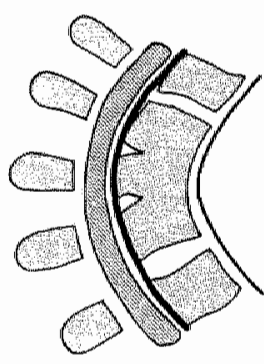

type 2

Bij een stoornis in de vorm van wervellichamen hangt het af van de localisatie van de afwijking of alleen kyfose ontstaat, een scoliose, of beide, dus een kyfoscoliose. Meest frequent is een dorsolaterale half- of kwartwervel, die een angulaire kyfoscoliose tot gevolg kan hebben met gevaar van paraplegie door afknikking van het myelum over de scherpe kyfos $(5,15,25)$. Hetzelfde geldt voor de gecombineerde vorm. Bij de stoornis in segmentatie betreft het meestal meerdere wervels, zodat een arcuaire kyfose optreedt over een groter traject met praktisch geen gevaar voor paraplegie $(10,16)$. Deze congenitale afwijkingen komen het meeste voor op de thoraco-lumbale overgang, minder op hoog thoracaal niveau en weinig op lumbaal niveau. Ook congenitale lordose van de thoracale wervelkolom komt voor als de vergroeiing aan de achterzijde gelocaliseerd is, terwijl de wervellichamen normaal gesegmenteerd zijn (34). De congenitale kyfosen of lordosen zijn progressief als er verschil in groeipotentie bestaat tussen de voor- en achterzijde van de wervelkolom. Een scoliose zal progressief zijn als een hemivertebra niet vergroeid is met de alangrenzende wervels of als er een unilaterale vergroeiing van diverse wervels bestat (de zogenaamde unilaterale ongesegmenteerde bar). Bij het vaststellen van progressie moet men bedenken dat röntgenfoto's altijd met de eerstgenomen foto's moeten worden vergeleken. Bovendien moet altijd hetzelfde traject worden uitgerekend, tenzij de curve verandert. Bij kinderen treedt de meeste progressie op tijdens de puberteitsgroeispurt, doch ook na het beëindigen van de groei is progressie mogelijk. Bij deze afwijkingen ontstaan problemen door pijnklachten ten gevolge van spieroverbelasting, discopathie en ernstige desequilibratie of er is een slechte cosmesis. Bij angulaire kyfosen of kyfoscoliosen dreigt paraplegie of is deze al manifest.

Winter (26) vermeldt 12 patiënten met onbehandelde congenitale kyfose die paralyse 
ontwikkelden op een totale serie van 130 patiénten $(9,2 \%)$. De afwijking was $7 \times$ hoog thoracaal gelocaliseerd, $5 \times$ laag thoracaal of thoracolumbaal. Diverse auteurs hebben beschrijvingen gepubliceerd van patiènten met congenitale kyfose of kyfoscoliose, gecompliceerd door paraplegie $(5,12,15,17,28)$. Men moet bij congenitale kyfosen of scoliosen altijd rekening houden met andere congenitale stigmata, zoals agenesie van een nier of hartgebreken. Een diastematomyelie of filum terminale syndroom, waardoor de opstiging van het myelum is gestoord, moet worden uitgesloten voordat met corrigerende operatieve therapie wordt begonnen. Dit kan het beste geschieden met behulp van een computerscan en myelografie $(2,7,8,15,31)$.

\subsection{Behandeling}

De behandeling dient gericht te zijn op het voorkomen van ernstige deformiteit, waarbij het vroegtijdig opsporen van evident belang is. Nagegaan moet worden of het om een progressieve afwijking gaat, waarbij een vergroeiing aan één zijde van de wervelkolom altijd amleiding geeft tot een progressieve curve door doorgroei aan de andere zijde, vergelijkbaar met een éénzijdige epifysiodese. Een hemivertebra zal progressieve deformatie geven als deze niet met de andere wervels vergroeid is. Bracetherapie heeft in deze gevallen geen zin, omdat de groeikrachten van de wervelkolom de corrigerende krachten van een brace ver overtreffen (26). Niet progressieve afwijkingen behoeven geen behandeling en geven alleen aanleiding tot verkorting van het betreffende wervelkollom gedeelte.

Bij aangetoonde progressie bij een nog geringe curve (minder dan $50^{\circ}$ kyfose) is een achterste spondylodese in situ of met Harrington compressiemateriaal de beste behandeling $(9,16,17,25)$. Als het traject van de achterste spondylodese groter is dan de vergroeiing aan de voorzijde kan tijdens de verdere groei spontane correctie plaatsvinden door doorgroei aan de voorzijde, terwijl aan de achterzijde dit niet het geval is (26). Bij grotere curves voldoet alleen een achterste spondylodese onvoldoende. Er treedt dikwijls een pseudarthrose op, terwijl correctie moeilijk te verkrijgen is. Een voorste oprichtingsspondylodese met strutgrafts, eventueel aangevuld door een achterste spondylodese is dan de aangewezen therapie. Hierbij kan gebruik worden gemaakt van het distractie- en fixatiesysteem volgens Slot en Zielke $(2,17,25)$.

Bij ernstige gedesequilibreerde kyfoscoliosen ten gevolge van een dorsolaterale halfwervel komt wervelresectie in aanmerking $(12,13,19,20,24)$. Dit is de enige manier om een goede statiek van de rug te verkrijgen. Reeds in 1924 werd door von Lackum (11) een wervelresectie verricht, in 1928 berichtte Royle (18) over 1 geval, in 1932 Compere (4) over 2 patiënten. Het probleem was het uitblijven van consolidatie van de tegelijkertijd verrichte achterste spondylodese, waarna door kyfoserende krachten een ernstige kyfose ter plaatse van de pseudarthrose optrad. Met de tegenwoordige fixatiesystemen is dit gevaar nauwelijks meer aanwezig. Vooral Leatherman $(12,13)$ hangt deze methode aan, anderen vinden de techniek te gevaarlijk in verband met het aanwezige risico op paraplegie. De wake-up-test is echter zeer waardevol gebleken om de ruggemergsfunctie te controleren en zo het risico op paraplegie tot een minimum te beperken. Hierbij wordt de patiënt tijdens de narcose zover wakker gemaakt, zonder pijn te voelen, dat hij op verzoek handen en voeten beweegt, waarmee de myelumfunctie gecontroleerd is. De patiënten weten zich later niets meer hiervan te herinneren (23).

Bij paraplegie ten gevolge van druk door de kyfos is laminectomie zinloos. Het myelum is immers over de kyfos uitgespannen en de compressie bevindt zich dus aan de voorzijde van het myelum. Bij de laminectomie worden alleen de structuren aan de achterzijde 
van het myelum verwijderd, hetgeen niet of nauwelijks invloed op de compressie heeft. Bovendien verzwakt de laminectomie de achterstructuren van de wervelkolom, waardoor de kyfose kan toenemen en de neurologische problematiek verergert $(5,17,25,26)$.

Beter is het de druk op het myelum op te heffen door middel van een voorste of posterolaterale decompressie.

De voorste decompressie gebeurt op thoracal niveau via een thoracotomie, lumbaal via een lumbotomie of andere retroperitoneale toegang. De posterolaterale decompressie vindt thoracaal plaats via een costotransversectomie, lumbaal via een transversectomie. Hierbij wordt de achterzijde van de kyfos verwijderd en het myelum naar voren gebracht, waarna ter stabilisatie een strutgrafting kan worden verricht of via de posterolaterale route een spongiosaplastiek $(25,26)$. Bij deze procedure bestaat echter een vrij groot risico op verergering van de paraplegie. Zelfs totale dwarslaesie postoperatief is beschreven (29). Zo is ook préoperatieve tractie bij volledig rigide kyfosen met compressio medullae gevaarlijk, doordat alleen de boven- en onderliggende delen van de wervelkolom worden gestrekt en daarmee het myelum, dat vervolgens nog strakker over de kyfose wordt getrokken. Daarom moet préoperatieve tractie bij deze problemen altijd onder nauwkeurige neurologische controle plaatsvinden $(9,17,26)$. Strekt men echter intra-operatief na verwijderen van de discusresten, eventueel met behulp van osteotomieën, de kyfos zelf, dan zal hierdoor minder druk op het myelum komen en is een decompressie onnodig. Fixatie kan dan geschieden met fibula, tibia of ribspanen met of zonder interne fixatie. Dit lijkt een veiliger methode te zijn om myelumcompressie op te heffen (fig. 4).

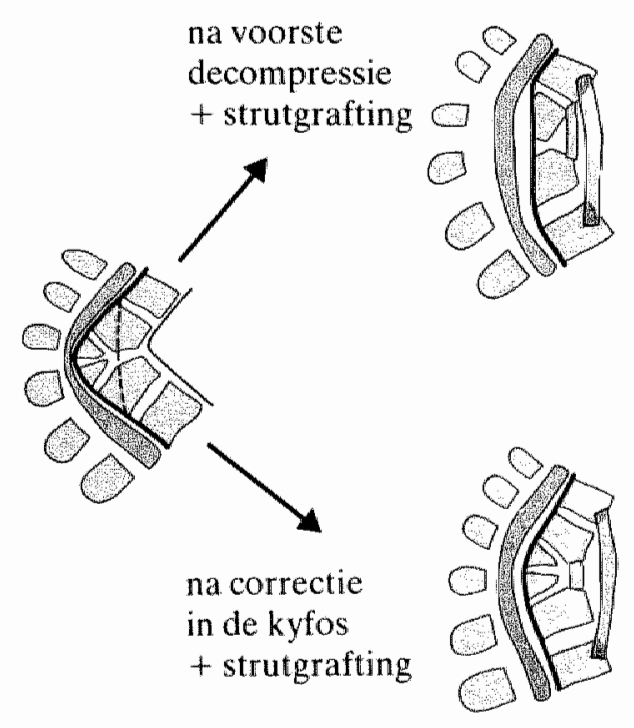

figuur 4

Samenvattend dient de behandeling van congenitale kyfosen of kyfoscoliosen gericht te zijn op het voorkomen van ernstige deformiteit. Behandeling van bestaande ernstige verkrommingen is moeilijk en kan gevaarlijk zijn. Door betere correctie en fixatiemogelijkheden en inzicht in de pathologie zijn de risico's van operatieve behandeling gedaald en is ook op de volwassen leeftijd een bevredigende therapie mogelijk. 
1. Beals R. K. Familial vertebral hypoplasia and kyphosis. Journ. of Bone and Joint Surg. 51A, 1969, 190-196.

2. Been H. D. Slot G. H. Congenitale deformaties van de wervelkolom en hun behandelingswijzen. Referaat 3 april 1981. Afd. Orthopaedie Radboudziekenhuis Nijmegen.

3. Bingold A. C. Congenital kyphosis. Journ. of Bone and Joint Surg. 35B, 1953, 579583.

4. Compere E. L. Excision of hemivertebrae for correction of congenital scoliosis. Report of two cases. Journ. of Bone and Joint Surg. 14, 1932, 555-562.

5. DePalma A. F. McKeen W. B. Congenital kyphoscoliosis with paraplegia. A case report. 39, 1965, 190-1.96.

6. Drehmann F. Die angeborene Kyphose. Bruns Beitr. Klin. Chir. 165, 1937, 595606.

7. Gillespie R. Faithfull D. K. Roth A. Hall J. E. Intraspinal anomalies in congenital scolliosis. Clin. Orthop. 93, 1973, 103-109.

8. Giordiano G. B. Cerisoli M. Diastematomyelia and scoliosis. Usefulness of CT examination. Spine $8,1983,111-112$.

9. Hall J. E. Herndon W. A. Levine C. R. Surgical treatment of congenital scoliosis with or without Harrington instrumentation. Journ. of Bone and Joint Surg. 63A, $1981,608-619$.

10. Kharrat K. Dubousset J. Bloc vertébral antérieur progressif chez l'enfant. Revue de Chir. Orthop. 66, 1980, 485-492.

11. von Lackum H. L.Smith A. de F. Removal of vertebral bodies in the treatment of scoliosis. Surg. Gynaec. and Obstet. 57, 1933, 250-256.

12. Leatherman K. D. The management of rigid spinal curves. Clin. Orthop. 93, 1973, $215-224$.

13. Leatherman K. D. Dickson R. A. Two-stage corrective surgery for congenital deformities of the spine. Journ. of Bone and Joint Surg. 61B, 1979, 324-328.

14. Lénárt G. Köllö K. Ventrale Wirbelsynostosen bei Jugendlichen. Zeitschr. für Orthopädie. $118,1980,927-931$.

15. Lonstein J. E. Developmental abnormalities of spinal cord and vertebral column. In: Spinal deformities and neurological dysfunction. Raven Press New York, 1978, 41-52. 
16. Mayfield J. K. Winter R. B. Bradford D. S. Moe J. H. Congenital kyphosis due to defects of anterior segmentation. Journ. of Bone and Joint Surg. 62A, 1980, 129l. 1301.

17. Montgomery S. P. Hall J. E. Congenital kyphosis. Spine 7, 1982, 360-364.

18. Royle N. D. The operative removal of an accessory vertebra. Medical Journal of Australia 1, 1928, 467.

19. Slabaugh P. B. Winter R. B. Lonstein J. E. Moe J. H. Lumbosacral hemivertebrae. A review of twenty-four patients, with excision in eight. Spine 5, 1980, 234244.

20. Slot G. H. The importance of vertebral resection in correction of spinal deformities. Acta Orthop. Scand. 52, $1981,597$.

21. Tanaka $T$. Uhthoff $H . K$. The pathogenesis of congenital vertebral deformation. Acta Orthop. Scand. 52, 1981, 413-425.

22. Tsou P. M. Embryology of congenital kyphosis. Clin. Orthop. 128, 1977, 18-25.

23. Vauzelle C. Stagnara P. Jouvinroux P. Functional monitoring of spinal cord activity during spinal surgery. Clin. Orthop. 93, 1973, 173-178.

24. Wiles P. Resection of dorsal vertebrae in congenital scoliosis. Journ. of Bone and Joint Surg. 33A, 1951, 151-154.

25. Winter R. B. Congenital kyphosis. Clin. Orthop. 128, 1977, 26-32.

26. Winter R. B. Moe J. H. Wang J. F. Congenital kyphosis. Journ. of Bone and Joint Surg. 55A, 1973, 223-256.

27. Winter R. B. Congenital scoliosis. Clin. Orthop. 93, 1973, 75-94.

28. Winter R. B. Congenital spine deformity. Natural history and treatment. Isr. Journ. Med. Sciences 9, 1973, 719-727.

29. Winter R. B. Congenital kyphoscoliosis with paralysis following hemivertebra excision. Clin. Orthop. 119, 1976, 116-125.

30. Winter R. B. Moe J. H. Lonstein J. E. Bradford D. S. Mayfield J. K. The surgical treatment of congenital scoliosis: analysis of 622 cases. Journ. of Bone and Joint Surg. 64B, 1982, 623 .

31. Winter R. B. Haven J. J. Moe J. H. Lagaard S. M. Diastematomyelia and congenital spine deformities. Journ. of Bone and Joint Surg. 56A, 1974, 27-39.

32. Winter R. B. Moe J. H. Eilers V. E. Congenital scoliosis. A study of 234 patients treated and untreated. Journ. of Bone and Joint Surg. 50A, 1968, 1-47. 
33. Winter R. B. Moe J. H. The results of spinal arthrodesis for congenital spinal deformity in patients younger than five years old. Journ. of Bone and Joint Surg. $64 \mathrm{~A}, 1982,419-432$.

34. Winter R. B. Moe J. H. Bradford D. S. Congenital thoracic lordosis. Journ. of Bone and Joint Surg. 60A, 1978, 806-810.

35. Winter R. B. Congenital deformities of the spine. Thieme-Stratton Inc. New York 1983. 
Patiënt 5. E. v. L. mannelijk, geb. dat. 17-11-1965.

Aetiologie:

Vroegere behandeling:

Klachten:

Préoperatieve curves:

Voorbehandeling:

Longfunctie:

Conclusie:

Neurologisch onderzoek:

Myelografie:

Operatie:

Complicaties:

Nabehandeling:

Postoperatieve curves:

Postoperatief

$\mathrm{Na} 2$ weken

$\mathrm{Na} 2$ maanden

$\mathrm{Na} 4$ maanden

$\mathrm{Na} 9$ maanden

$\mathrm{Na} 13$ maanden

$\mathrm{Na} 20$ maanden
Kyfose

$32^{\circ}$

$25^{\circ}$

$23^{\circ}$

$24^{\circ}$

$25^{\circ}$

$32^{\circ}$

$32^{\circ}$
Scoliose

$10^{\circ}$

$10^{\circ}$

$8^{\circ}$

$8^{\circ}$

$11^{\circ}$

$9^{\circ}$

niet gemeten.

Postoperatieve klachten:

Geen. 
Goede stabilisatie van nog geringe congenitale kyfoscoliose welke waarschijnlijk in de loop van de groei, met name in de puberteitsgroeispurt, sterke progressie getoond zou hebben. Gegevens over progressie tot aan het tijdstip van de operatie waren niet voorhanden, maar dit is wel waarschijnlijk gezien het angulaire karakter van de kyfose en de aard van de afwijking. 


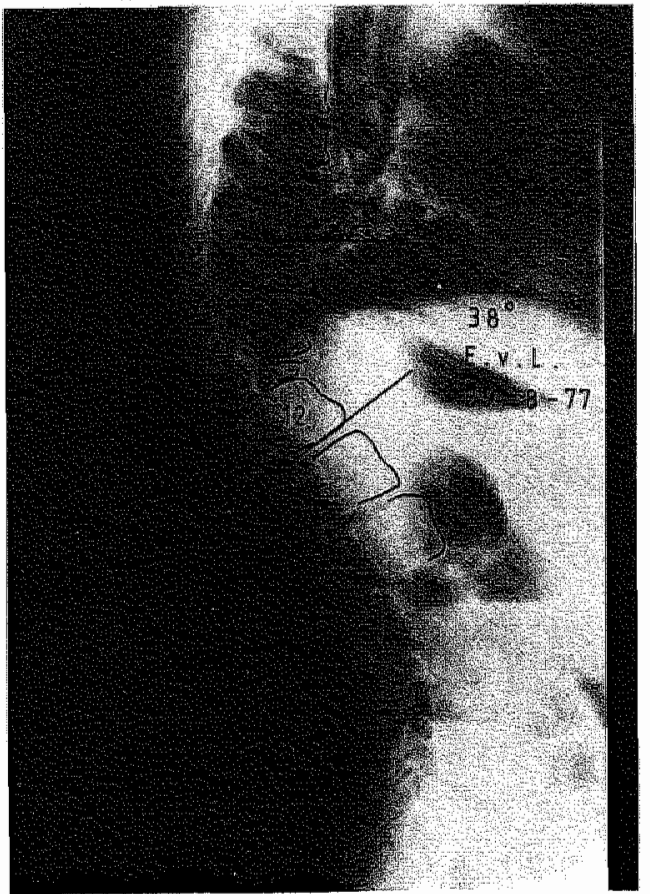

Kyfose préoperatief

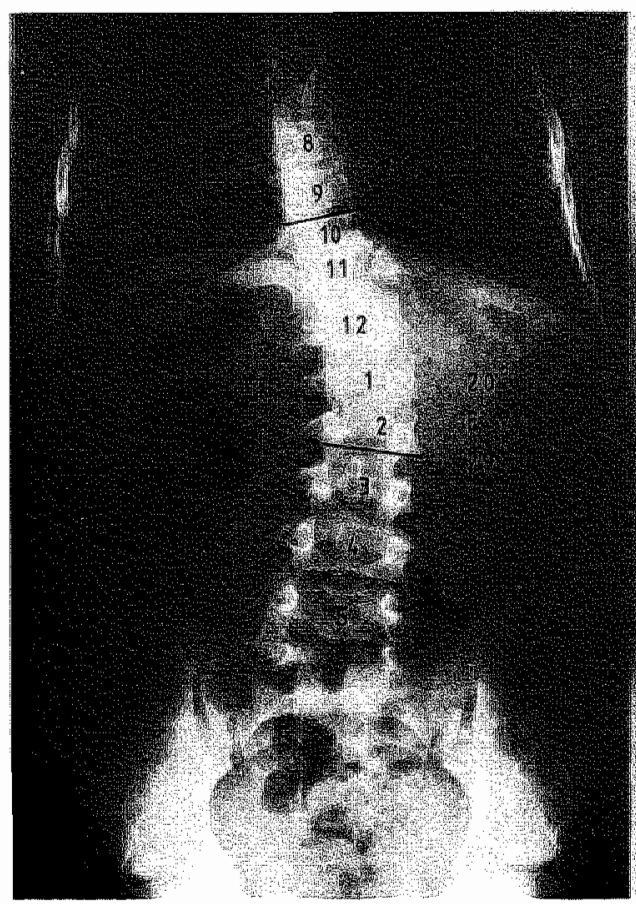

Scoliose préoperatief

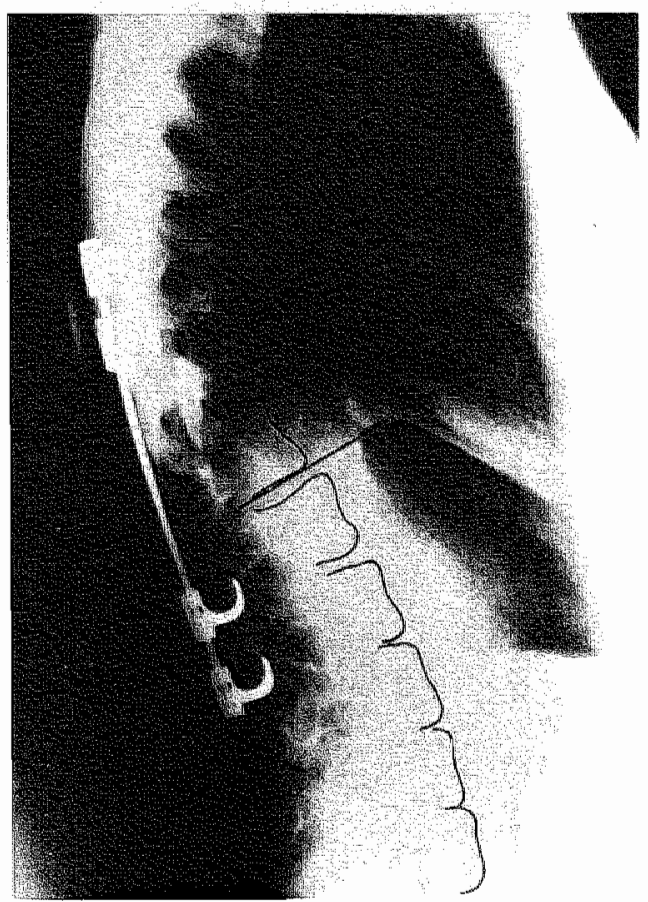

Kyfose postoperatief

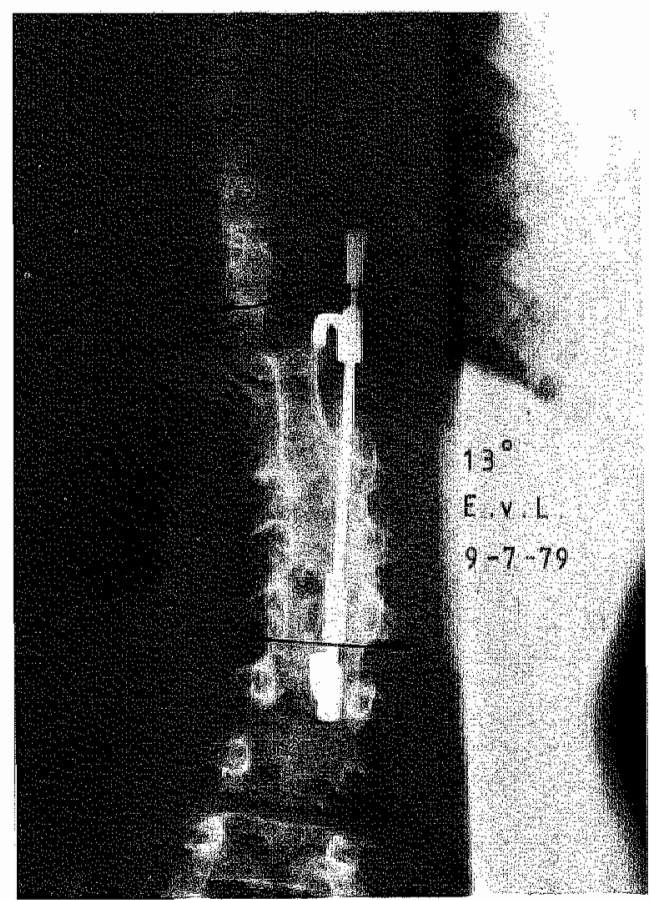

Scoliose postoperatief 


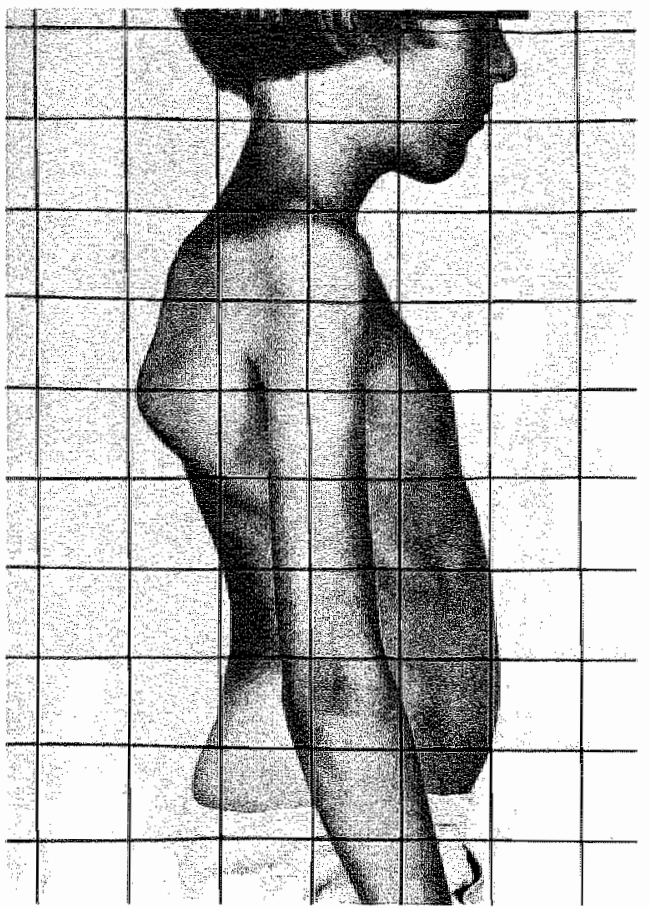

E.v.L. Kyfose préoperatief

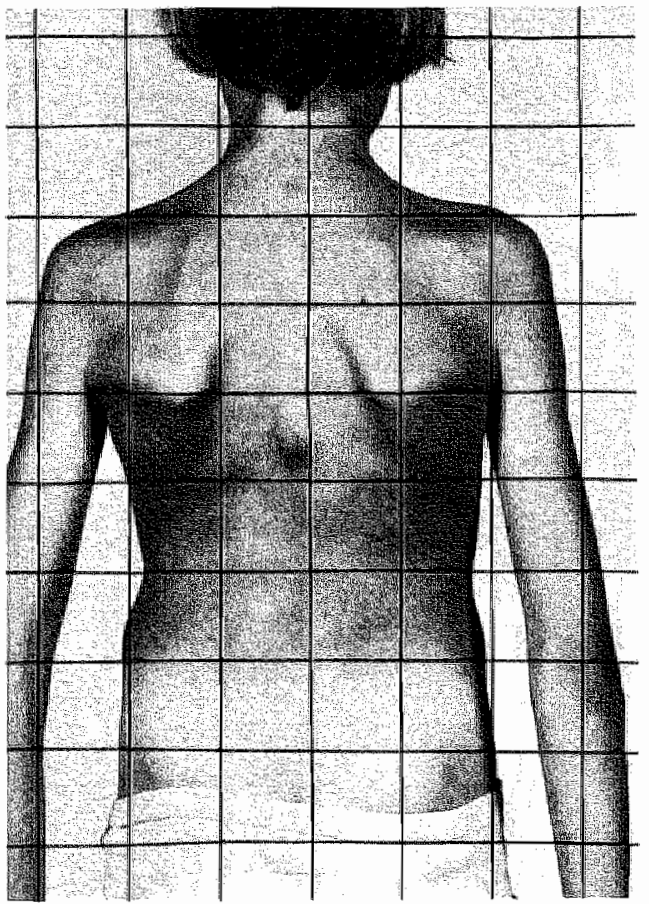

E.v.L. Scoliose préoperatief

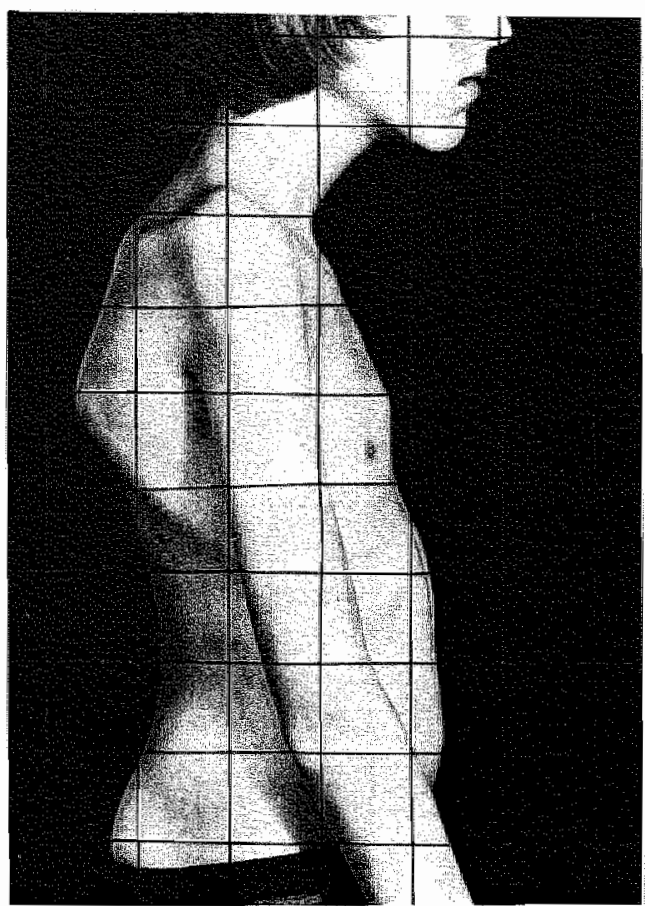

E.v.L. Kyfose postoperatief

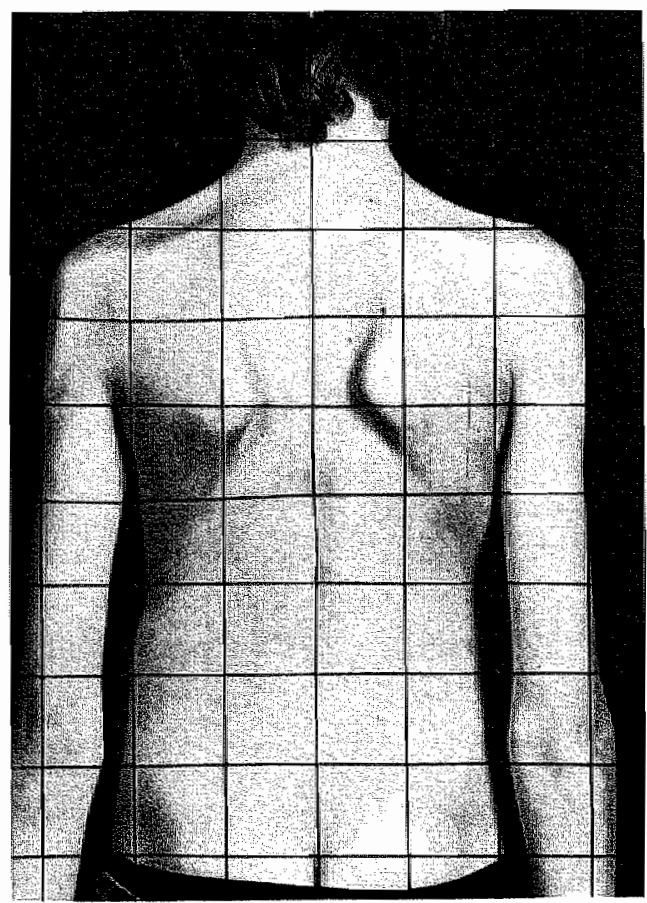

E.v.L. Scoliose postoperatief 
Patiënt 6. F. R. mannelijk, geb dat. 21-3-1961.

Aetiologie:

Vroegere behandeling:

Klachten:

Préoperatieve curves:

Voorbehandeling:

Longfunctie:

Conclusie:

Neurologisch onderzoek:

Myelografie:

Operaties:

Complicaties:

Nabehandeling:

Postoperatieve curves:

Postoperatieve klachten:
Congenitale kyfoscoliose ten gevolge van dorso-laterale halfwervel tussen $\mathrm{T} 9$ en $\mathrm{T} 10$.

Oefentherapie en gipsbed.

Geen.

Kyfose $67^{\circ} \mathrm{T} 3 \mathrm{t} / \mathrm{m}$ T11. Scoliose $25^{\circ} \mathrm{T} 8 \mathrm{t} / \mathrm{m}$ TI1. Sinds puberteit toename van de curves.

Halo-femoraaltractie 4 weken. Redressie van de kyfose tot $36^{\circ}$.

Vit. cap. 4975 cc. Normaal 5800 cc. Tot. cap. 6175 cc. Normaal $7250 \mathrm{cc}$.

Duidelijke restrictieve functiestoornis, dit is een vermindering van het functionerende longvolume.

Groot hoofd en andere stigmata. Waarschijnlijk communicerende hydrocephalus. Verder geen bijzonderheden.

Niet verricht, werd destijds nog niet nodig gevonden.

1. 11-10-1976. Voorste spondylodese via thoracotomie rechts m.b.v. ribspaan en chips, geen wervelresectie, $\mathrm{T} 7 \mathrm{t} / \mathrm{m} \mathrm{T} 12$.

2. 26-10-1976. Achterste spondylodese m.b.v. compressie/distractie systeem $\mathrm{T} 5 \mathrm{t} / \mathrm{m} \mathrm{L1}$.

Geen.

9 maanden gipscorset met kraag.

$\begin{array}{lll} & \text { Kyfose } & \text { Scoliose } \\ \text { Postoperatief } & 34^{\circ} & 25^{\circ} \\ \text { Na 3 maanden } & 35^{\circ} & 24^{\circ} \\ \text { Na 9 maanden } & 30^{\circ} & 24^{\circ} \\ \text { Na } 12 \text { maanden } & 30^{\circ} & 24^{\circ} \\ \text { Na 30 maanden } & 37^{\circ} & 22^{\circ}\end{array}$

Geen. 
Beschouwing en conclusie:

Goede correctic en stabilisatie van matig sterke kyfoscoliose ten gevolge van dorsolaterale halfwervel, welke door progressie ook na de puberteit tot ernstige deformiteit had kunnen leiden. Een voorste spondylodese werd in dit geval noodzakelijk gevonden omdat de kyfose al uitgesproken aanwezig was. 


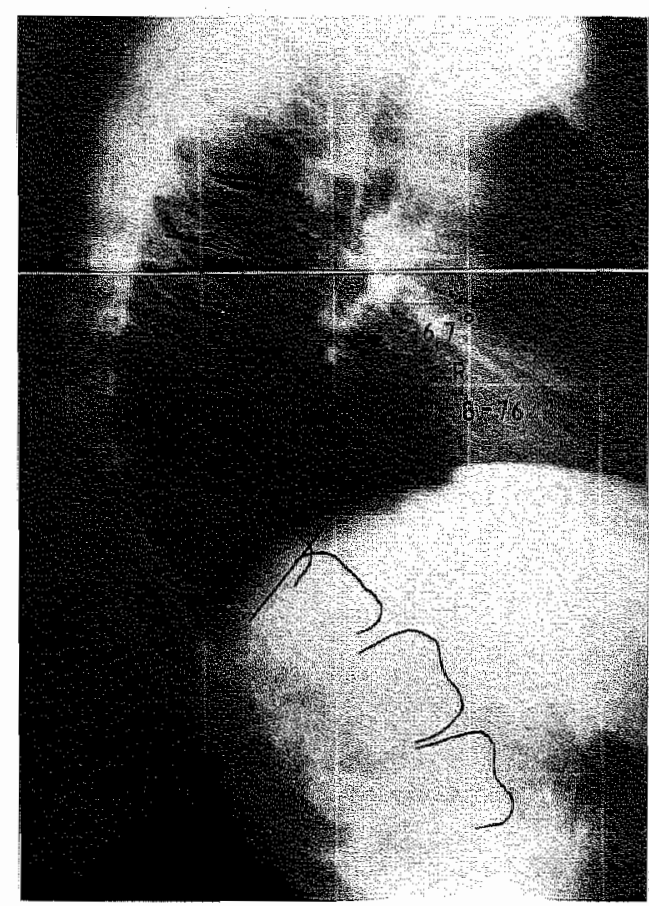

Kyfose préoperatief

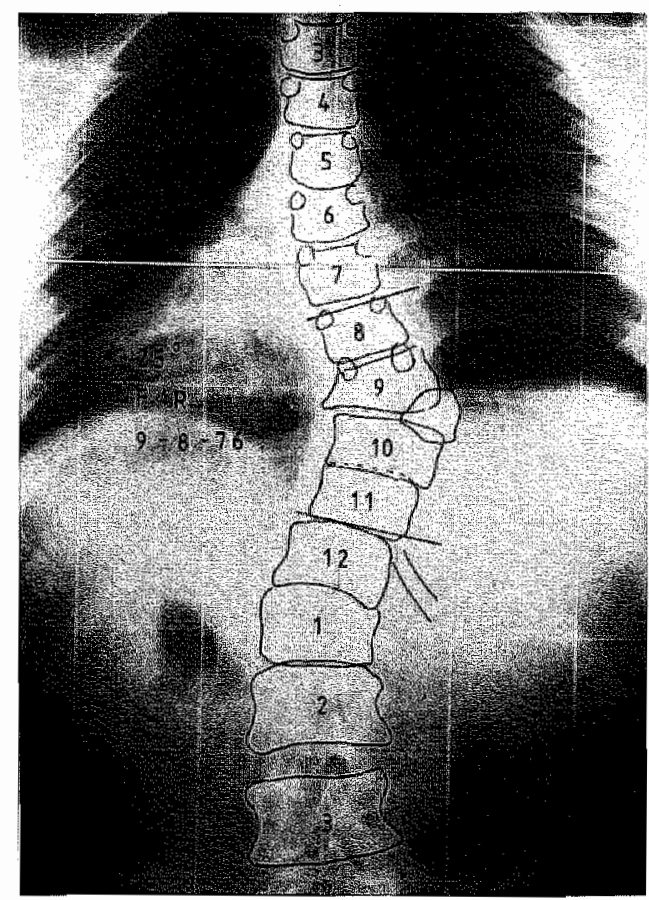

Scoliose préoperatief

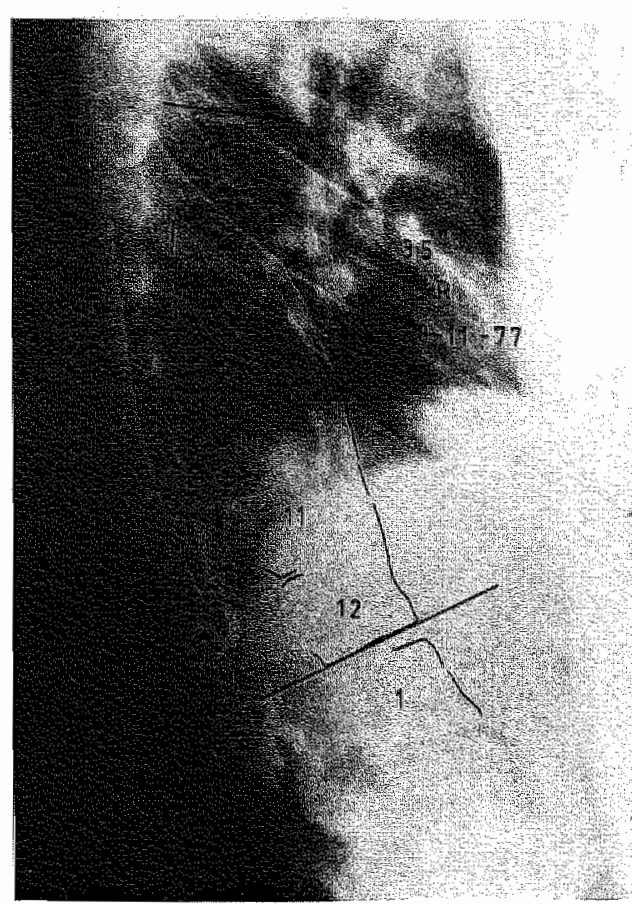

Kyfose postoperatief

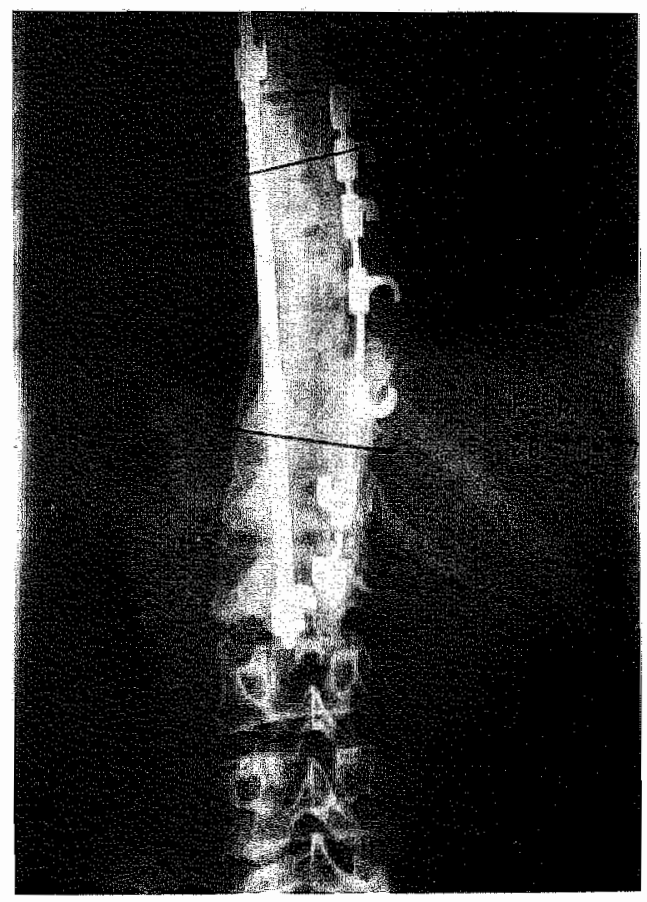

Scoliose postoperatief 


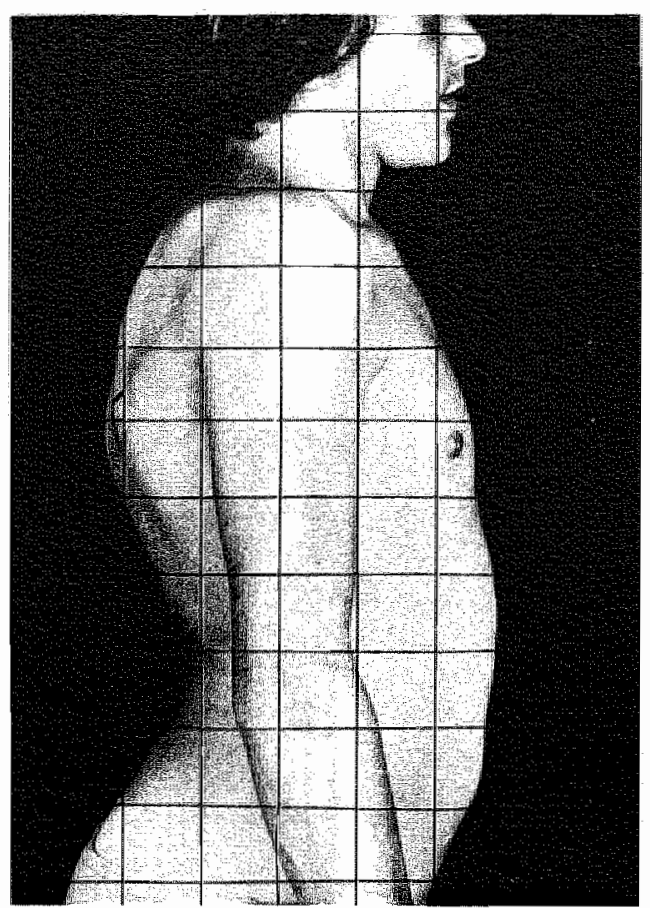

F.R. Kyfose préoperatief

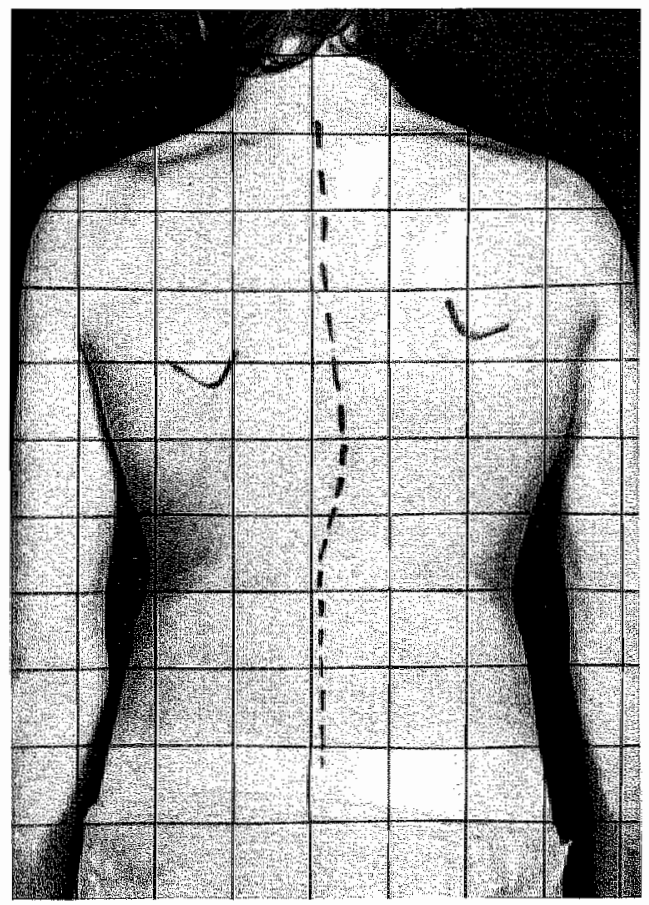

F.R. Scoliose préoperatief

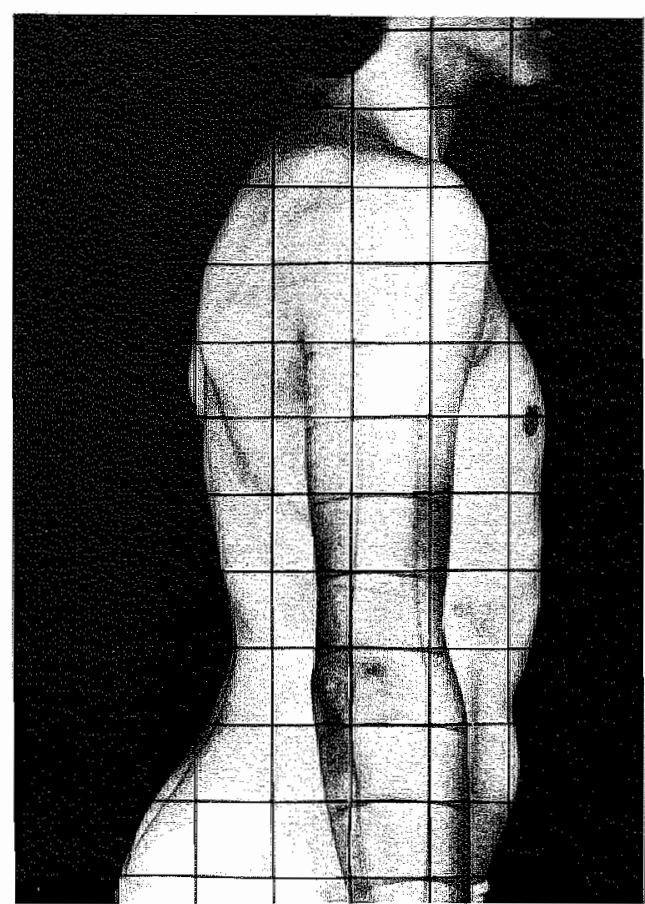

F.R. Kyfose postoperatief

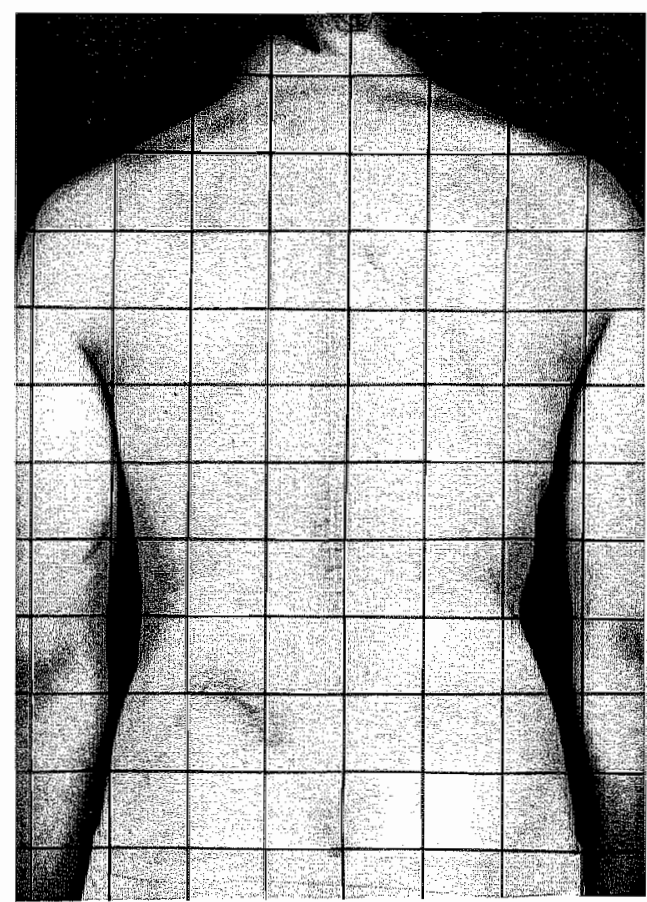

F.R. Scoliose postoperatief 
Patient 7. A. B. vrouwelijk, geb. dat. 10-7-1966.

Aetiologie:

Vroegere behandeling:

Klachten:

Préoperatieve curves:

Voorbehandeling:

Longfunctie:

Conclusie:

Neurologisch onderzoek:

Myelografie:

Operatie:

Complicaties:

Nabehandeling:

Postoperatieve curves:

Postoperatieve klachten:
Congenitale kyfose ten gevolge van stoornis in segmentatie T9-10-11-12 met wigvorming T10 (gecombineerde type) bij geestelijk achtergebleven kind.

Niet bekend.

Geen.

Kyfose T8 t/m T12 in $197338^{\circ}$, in $197543^{\circ}$.

Geen.

Vit. cap. 1075 cc. Normaal 1675 cc. Tot. cap. 1700 cc. Normaal $2100 \mathrm{cc}$.

Geringe restrictieve functiestoornis. Medewerking van de patiënt echter niet optimaal.

Cranio faciale dysmorfie met meerdere stigmata.

Niet verricht. Ook hier kwam het voornamelijk op stabilisatie van de kyfose aan.

4-2-1975. Achterste Harrington compressiespondylodese $\mathrm{T} 7 \mathrm{t} / \mathrm{m} \mathrm{L} 2$ met behulp van cristabot.

Geen.

6 maanden gipscorset, 6 maanden lightcastcorset.

Postoperatieve kyfose $31^{\circ}$

$\mathrm{Na} 2$ weken $\quad 32^{\circ}$

$\mathrm{Na} 3$ maanden $\quad 37^{\circ}$

$\mathrm{Na} 6$ maanden $\quad 35^{\circ}$

$\mathrm{Na} 9$ maanden $\quad 42^{\circ}$

Na 12 maanden $\quad 40^{\circ}$

$\mathrm{Na} 18$ maanden $\quad 37^{\circ}$

Na 24 maanden $\quad 40^{\circ}$

Na 36 maanden $\quad 37^{\circ}$

$\mathrm{Na} 48$ maanden $\quad 35^{\circ}$

Geen. 
Goede stabilisatie van nog betrekkelijk geringe congenitale kyfose door middel van achterste spondylodese. Een woorste ingreep was gezien de matige ernst van de kyfose niet nodig. Had men langer met operatieve therapie gewacht dan was de kyfose verder in ernst toegenomen en had een voorste spondylodese toegevoegd moeten worden. Omdat de spondylodese zich uitbreidt tot enkele segmenten boven en onder de voorste vergroeiing behoort spontane correctie in de loop van de groei tot de mogelijkheden, dit hangt echter ook van de dikte van de spondylodese af. 


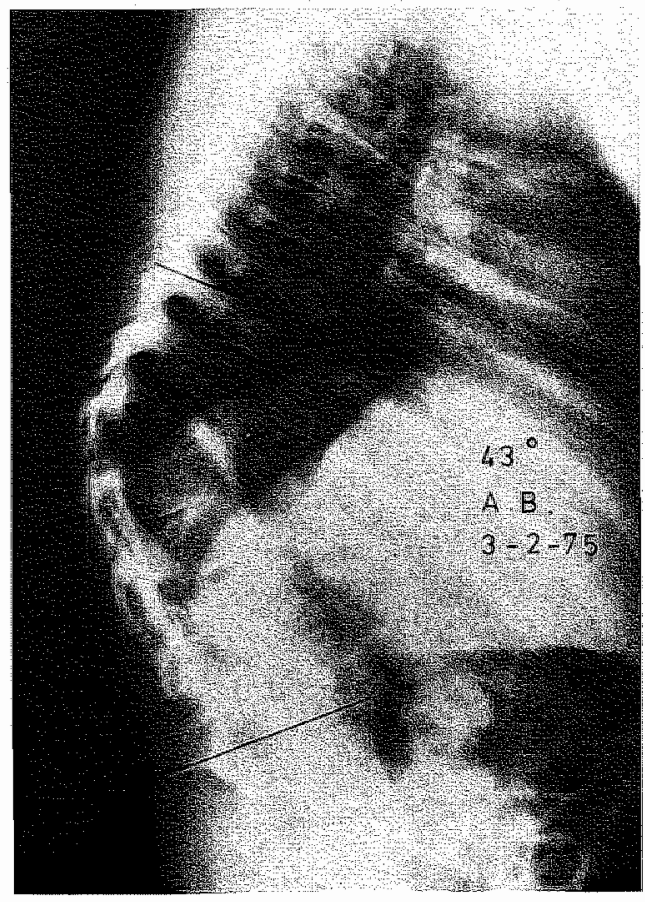

Kyfose préoperatief

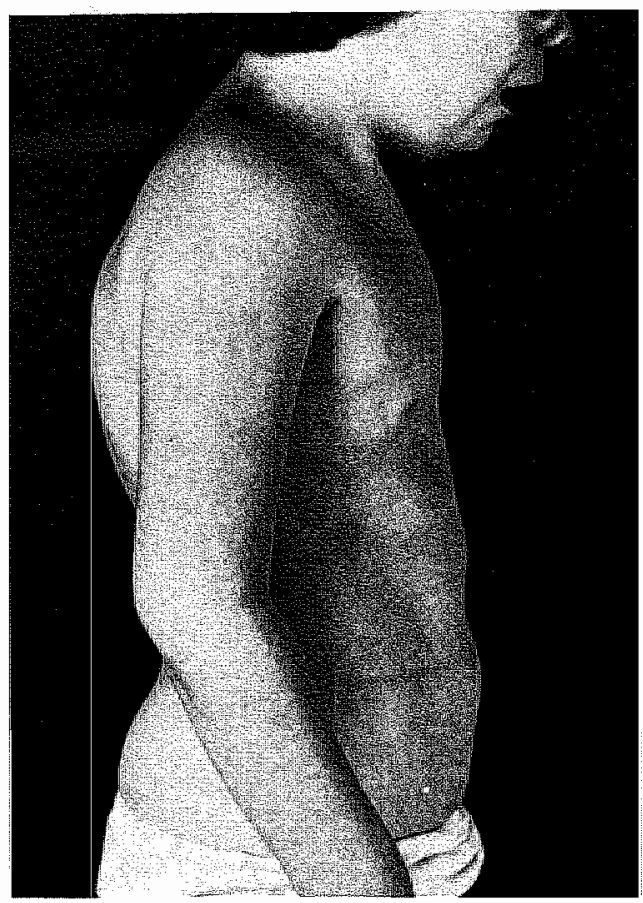

A.B. Kyfose préoperatief

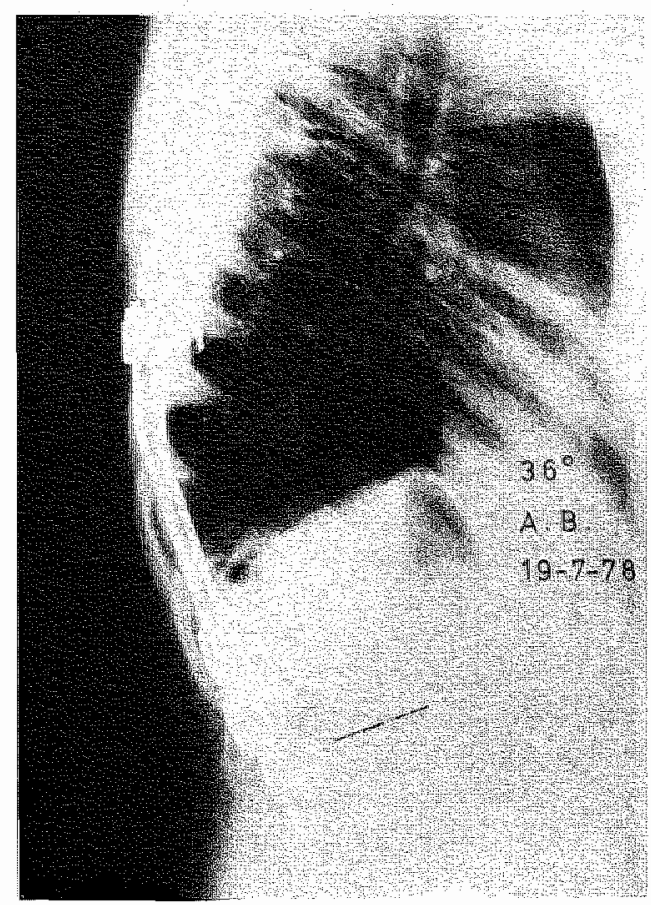

Kyfose postoperatief

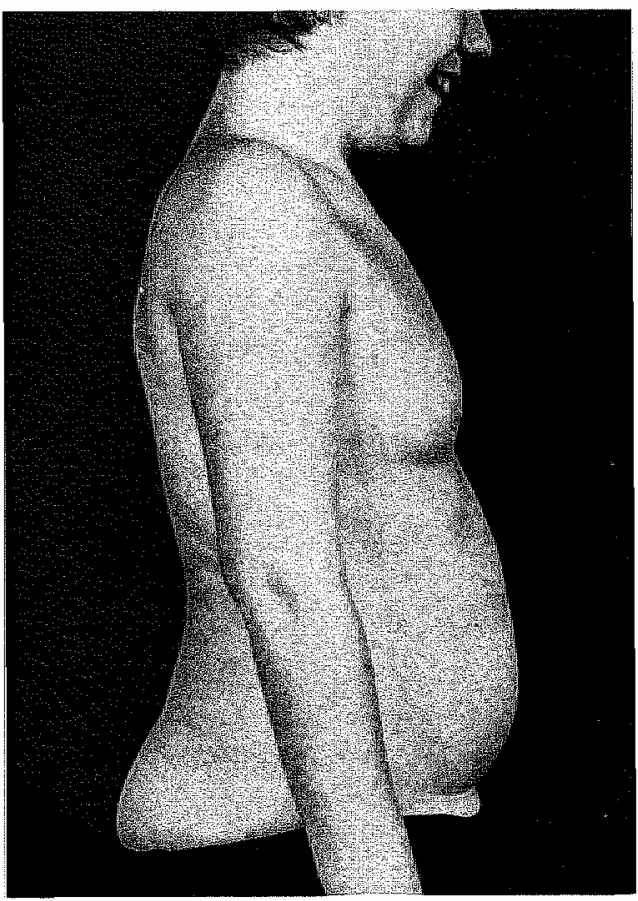

A.B. Kyfose postoperatief 
Patiënt 8. R.v.T. mannelijk, geb. dat. 3-8-1967.

Aetiologie:

Vroegere behandeling:

Klachten:

Préoperatieve curves:

Voorbehandeling:

Longfunctie:

Conclusie:

Neurologisch onderzoek:

Myelografie:

Operatie:

Complicaties:

Nabehandeling:
Congenitale kyfoscoliose ten gevolge van dorsolaterale halfwervel T12 en hypoplasie T11 en T13; tevens agenesie rechter nier, cor vitium en oesophagus atresie.

Geen behandeling voor de rugafwijking gehad. In verband met de oesophagus atresie slokdarmplastieken.

Geen.

Scoliose postnataal $25^{\circ}$. Na 2 jaar $35^{\circ}$ scoliose en $42^{\circ}$ kyfose. Op 7-jarige leeftijd $43^{\circ}$ scoliose en $60^{\circ}$ kyfose. Voor operatie scoliose $\mathrm{T} 10 \mathrm{t} / \mathrm{m} \mathrm{L1} 42^{\circ}$ en kyfose T10 t/m L1 $73^{\circ}$.

6 weken klinische Cotreltractie, waarna 6 maanden nachttractie thuis.

Vit. cap. 1075 cc. Normaal 2325 cc. Tot. cap. 1450 cc. Normaal $2900 \mathrm{cc}$.

Longfunctie vrijwel gehalveerd. Ademreserves klein.

Licht basale encephalopathie. Verder geen afwijkingen.

Niet verricht.

3-12-1975. Laminectomie en verwijderen van de halfwervel via de pedikel met periost en discus T1112 en T12-L1, waarna achterste Harrington compressie spondylodese $\mathrm{T} 10 \mathrm{t} / \mathrm{m} \mathrm{L} 2$.

Geen.

9 maanden gipscorset, waarna Milwaukee brace. 
Postoperatieve curves:

$\begin{array}{lll} & \text { Kyfose } & \text { Scoliose } \\ \text { Postoperatief } & 50^{\circ} & 28^{\circ} \\ \text { Na 2 maanden } & 56^{\circ} & 23^{\circ} \\ \text { Na 4 maanden } & 50^{\circ} & 30^{\circ} \\ \text { Na 6 maanden } & 50^{\circ} & 22^{\circ} \\ \text { Na 9 maanden } & 47^{\circ} & 20^{\circ} \\ \text { Na 12 maanden } & 40^{\circ} & \\ \text { Na 16 maanden } & 46^{\circ} & 22^{\circ} \\ \text { Na 22 maanden } & 44^{\circ} & 24^{\circ} \\ \text { Na 36 maanden } & 54^{\circ} & 28^{\circ} \\ \text { Na 48 maanden } & 38^{\circ} & 24^{\circ}\end{array}$

Postoperatieve klachten:

Geen. Wordt nog nabehandeld met een Milwaukee brace.

Beschouwing en conclusie:

Bij deze jongen met multiple congenitale afwijkingen bestond al een forse kyfosering, reden waarom gekozen werd voor het verwijderen van de halfwervel of liever kwartwervel gezien de grootte van de kyfose. Via de pedikel de kwartwervel verwijderen lijkt niet ideaal te zijn, röntgenologisch zijn de contouren van dit wervelgedeelte nog aanwezig. In ieder geval werd een goede stabilisatie en een redelijke correctie bereikt. Ook hier behoort spontane correctie onder en boven de kwartwervel in de loop van de groei tot de mogelijkheden. Zonder operatie was een ernstige deformiteit ontstaan door vooral toenemende kyfosering, met name in de groeispurt, gezien de al duidelijke progressie préoperatief. Door het angulaire karakter van de kyfose was een grote kans op paraplegie in de toekomst aanwezig. Ook had een afnemende longfunctie extra problemen kunnen geven gezien het bestaande cor vitium. 


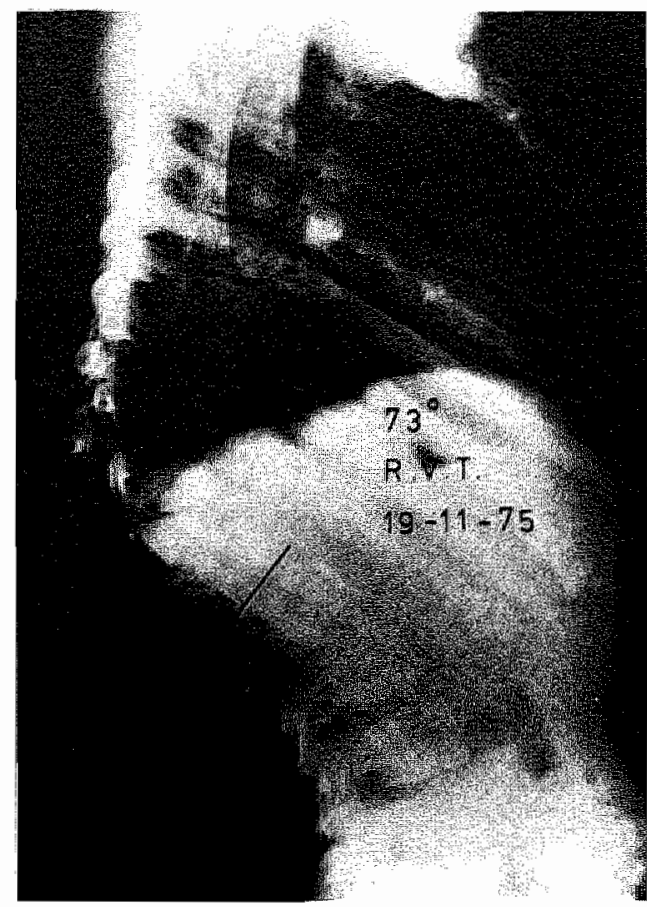

Kyfose préoperatief

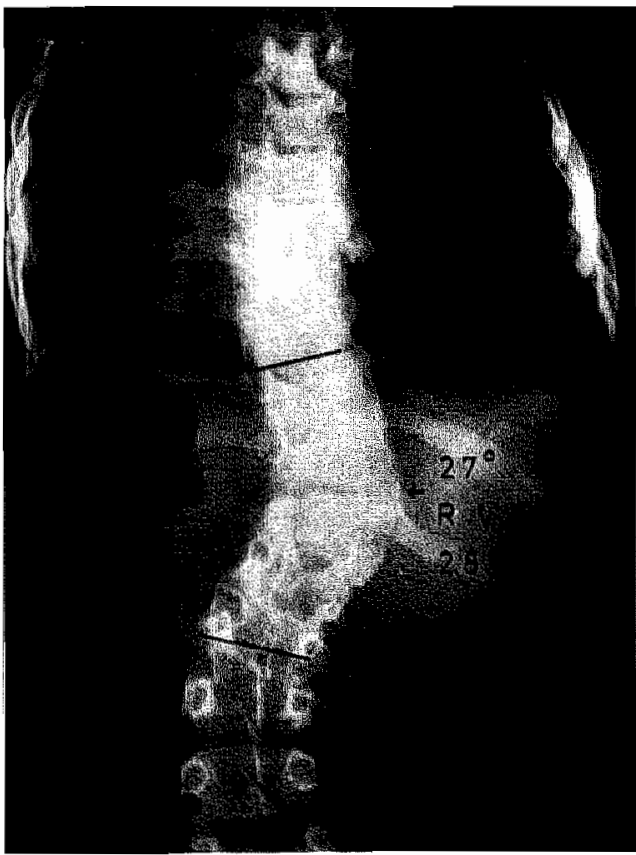

Scoliose préoperatief

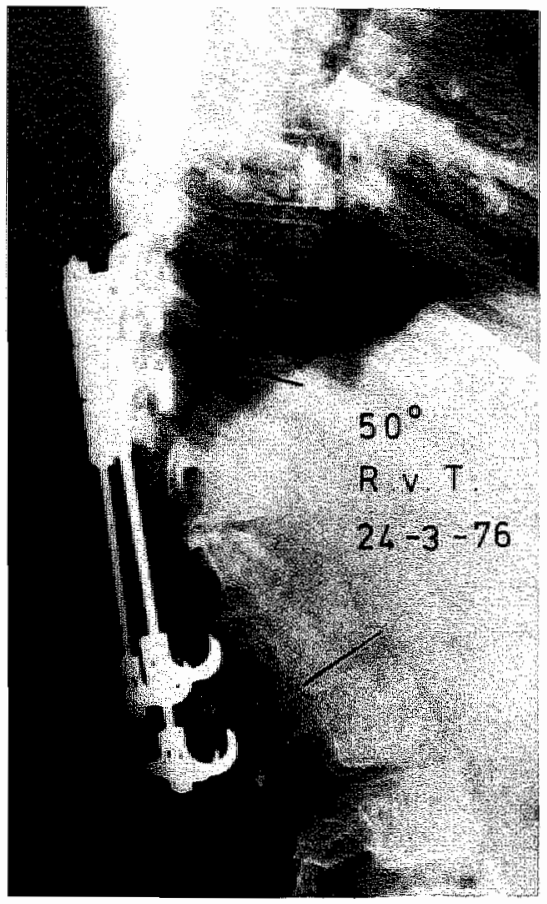

Kyfose postoperatief

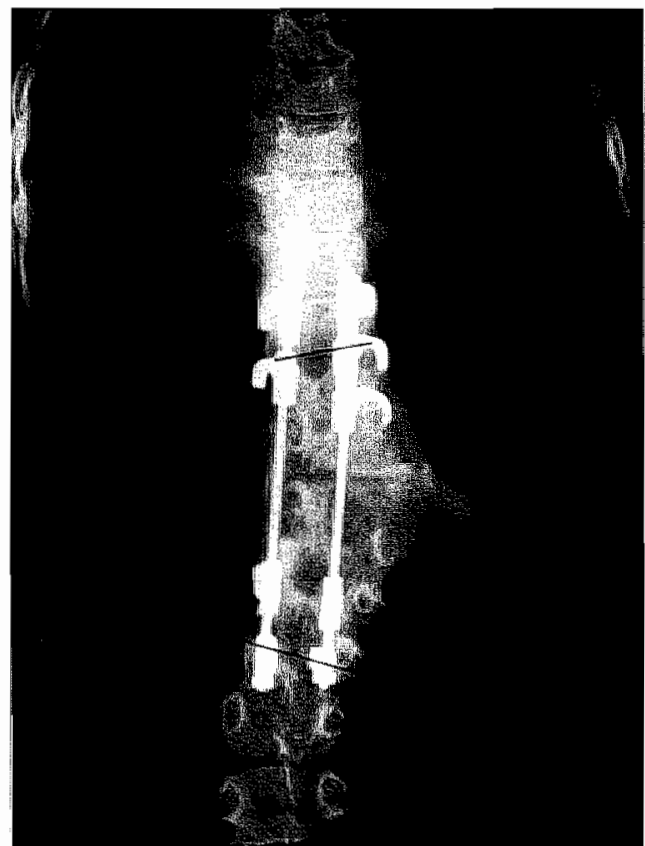

Scoliose postoperatief Pijl wijst naar dorsolaterale half wervel. 


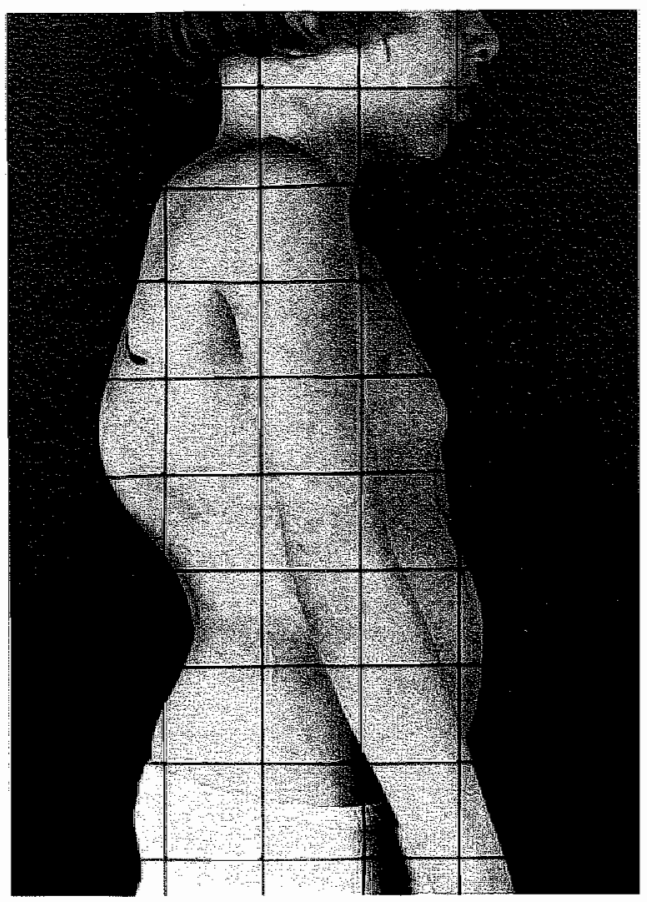

R.v.T. Kyfose préoperatief

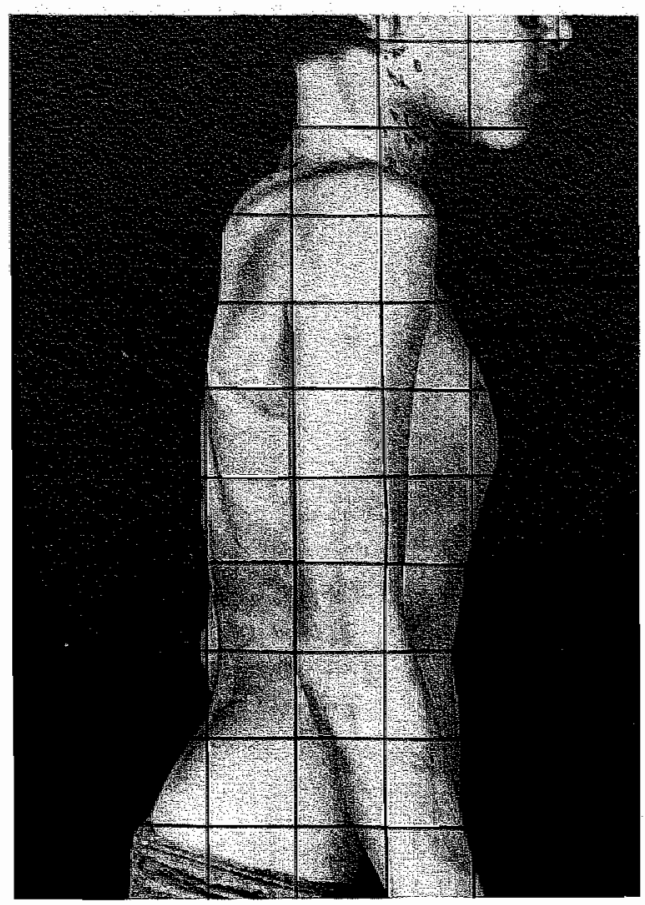

R.v.T. Kyfose postoperatief 
Patient 9. M.R.-W. vrouwelijk, geb. dat. 4-1-1948.

Aetiologie:

Vroegere behandeling:

Klachten:

Préoperatieve curves:

Voorbehandeling:

Longfunctie:

Conclusie:

Neurologisch onderzoek:

Myelografie:

Qperaties:

Complicaties:

Nabehandeling:

Postoperatieve curves:
Congenitale kyfose ten gevolge van stoornis in segmentatie T9-10-11-12-L1.

In 1968 resectie processi spinosi en laminectomie thoracale wervelkolom (operatie in Londen verricht). In 1970 achterste thoracale spondylodese met behulp van tibiaspanen uit beide onderbenen. In 1949 zou er sprake zijn geweest van hilusklier tuberculose.

Rugpijn thoracaal en hoog lumbaal. Dyspnoe d'effort.

Kyfose $\mathrm{T} 7 \mathrm{t} / \mathrm{m} \mathrm{L2} 83^{\circ}$.

T9 $\mathrm{t} / \mathrm{m} \mathrm{L1} 86^{\circ}$.

Geen.

Vit. cap. 3275 cc. Normaal 4150 cc. Tot. cap. 4475 cc. Normaal $5375 \mathrm{cc}$.

Restrictieve functiestoornis met uitstekende ventilatoire reserves.

Geen afwijkingen.

Matige passage over de kyfose. Geen verdere afwijkingen.

1. 9-2-1978. Achterste release met osteotomie van de fusiemassa op 3 niveaus. Verwijderen van oud tibiabot.

2. 1-3-78. Voorste thoracale columnotomie van de bar op 3 niveaus T9-10, T11-12 en T12-L1. Tevens uitruimen en opvullen met ribchips, niveau $T 7-8$, T8-9 en L1-2. Hierna 2 weken Halo-Cotreltractie.

3. 22-3-78. Achterste Harrington compressie spondylodese $\mathrm{T} 7 \mathrm{t} / \mathrm{m} \mathrm{L} 2$ met behulp van cristabot.

Geen.

Halo-rompgips 6 maanden, gipscorset 3 maanden.

Postoperatief $\mathrm{T} 7 \mathrm{t} / \mathrm{m} \mathrm{L} 234^{\circ}, \mathrm{T} 9 \mathrm{t} / \mathrm{m} \mathrm{L1} 47^{\circ}$

$\mathrm{Na} 9$ maanden $\mathrm{T} 7 \mathrm{t} / \mathrm{m} \mathrm{L} 245^{\circ}$

Na 12 maanden $\mathrm{T} 7 \mathrm{t} / \mathrm{m} \mathrm{L} 255^{\circ}$

$\mathrm{Na} 18$ maanden $\mathrm{T} 7 \mathrm{t} / \mathrm{m} \mathrm{L} 255^{\circ}$ 

is patiente zeer tevreden met het bereikte resultaat. met name wat betreft haar rugklachten.

Beschouwing en conclusie:

Deze patiënte vertoonde een ingewikkelde rugproblematiek. Doordat een spondylodese aan de achterzijde was verricht moesten eerst osteotomieën in dit gebied verricht worden, voordat osteotomieën van de voorste bar konden gebeuren. Van te voren stond vast dat hiermee niet al teveel correctie kon worden verkregen, veeleer moest dit gezocht worden boven en onder de vergroeiing, zodat meer compensatie zou plaatsvinden dan correctie zelf. De uiteindelijke correctie moest dan met een achterste compressie spondylodese plaatsvinden. De patiënte was het met deze gang van zaken geheel eens, en is zeer tevreden over het uiteindelijke resultaat. Met name maakte zij ook een belangrijke psychische opbloei door, mede gezien de teleurstellingen van vroegere operaties. 


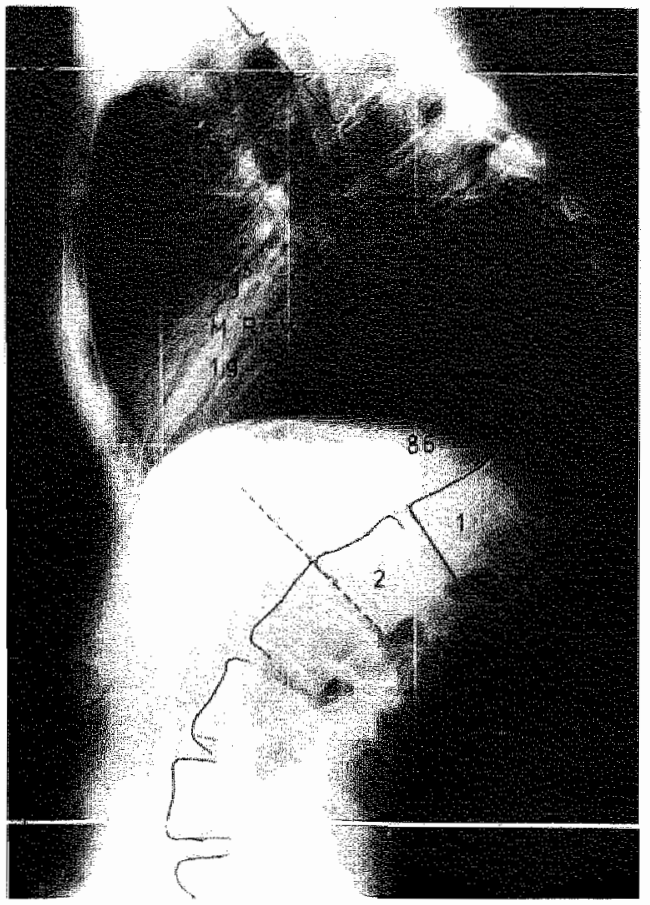

Kyfose préoperatief

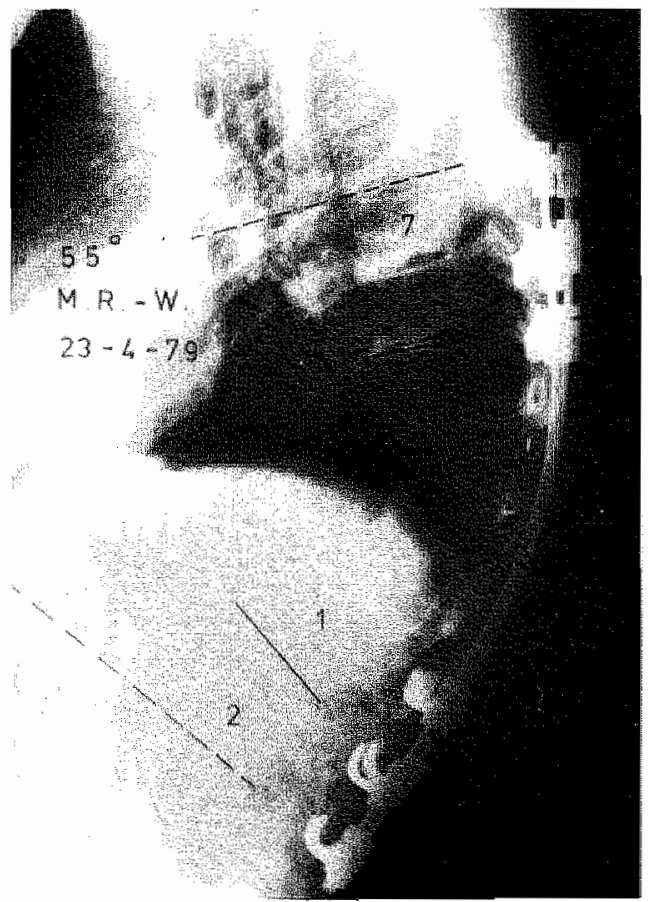

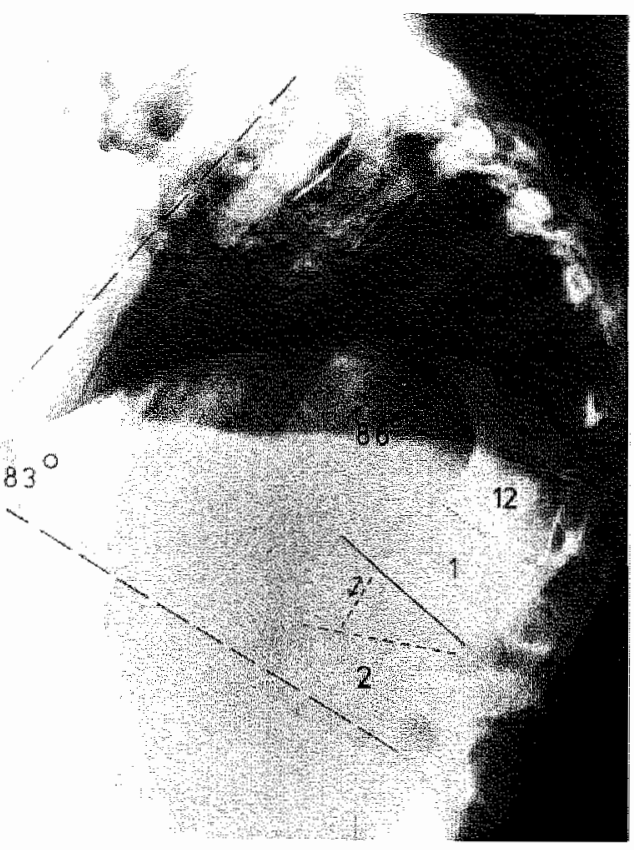

Werkmodel. Osteotomie T9-10, T11-12 en T12-L1. (waar nog resten van discus zijn). Compensatie op niveau T8-9 en L1-2.
Kyfose postoperatief

Correctie in eigenlijke kyfose $T 9 \mathrm{t} / \mathrm{m} \mathrm{Ll}$ van $86^{\circ}$ tot $61^{\circ}$ door osteotomieën en opspouwen. Compensatie op niveau T78 en T8-9 en L1-2, waardoor correctie curve $\mathrm{T} 7 \mathrm{t} / \mathrm{m} \mathrm{L} 2$ van $83^{\circ}$ tot $55^{\circ}$. 


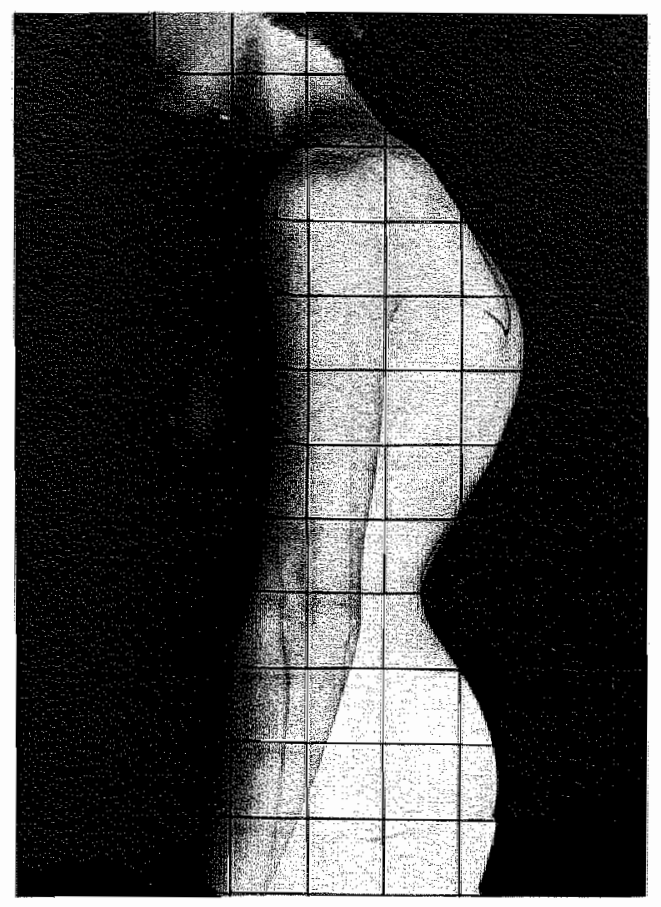

M.R.-W. Kyfose préoperatief

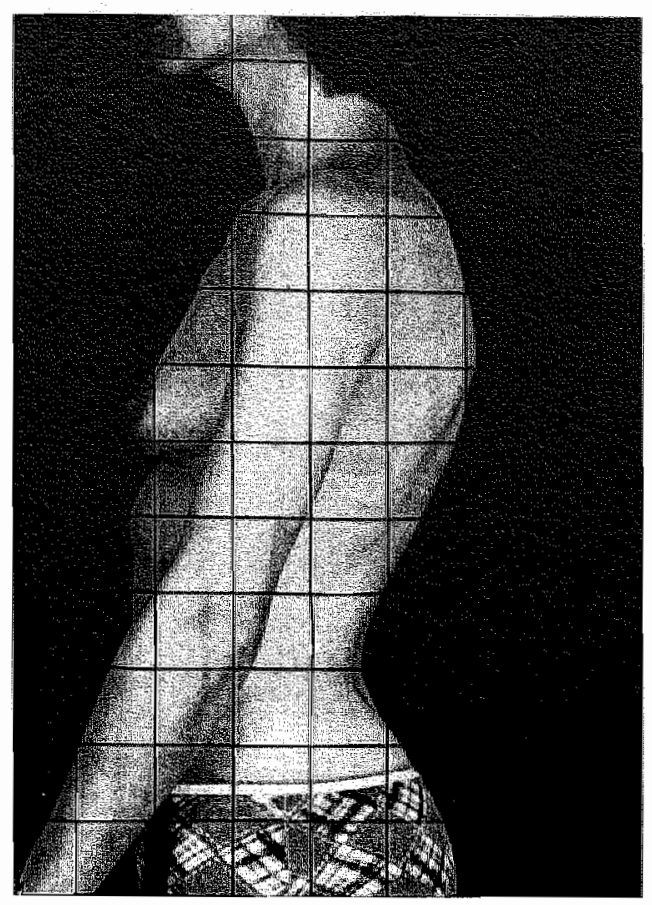

M.R.-W. Kyfose postoperatief 


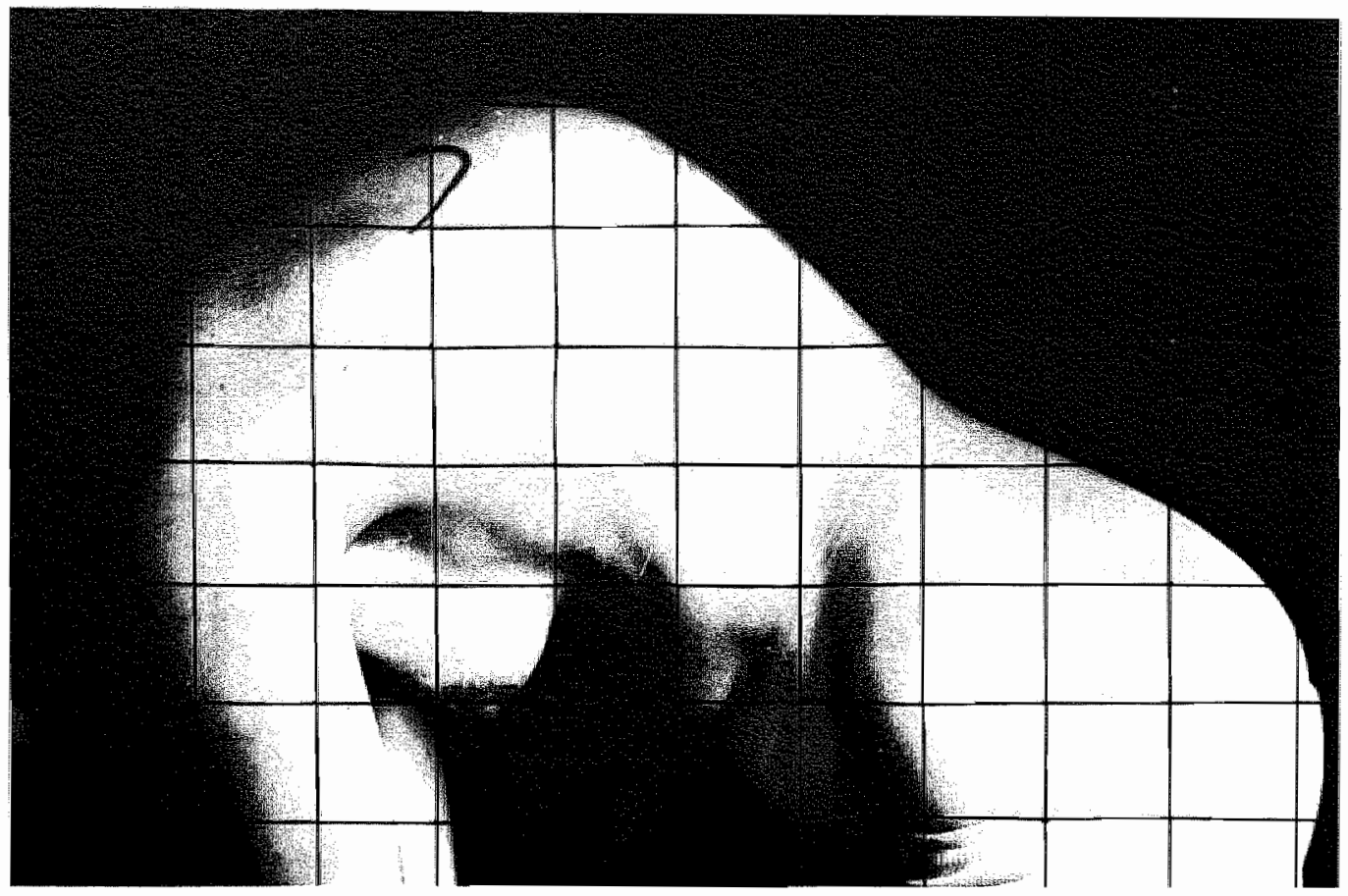

M.R.-W. Bij vooroverbuigen zonder met de handen te steunen kyfose goed te beoordelen.

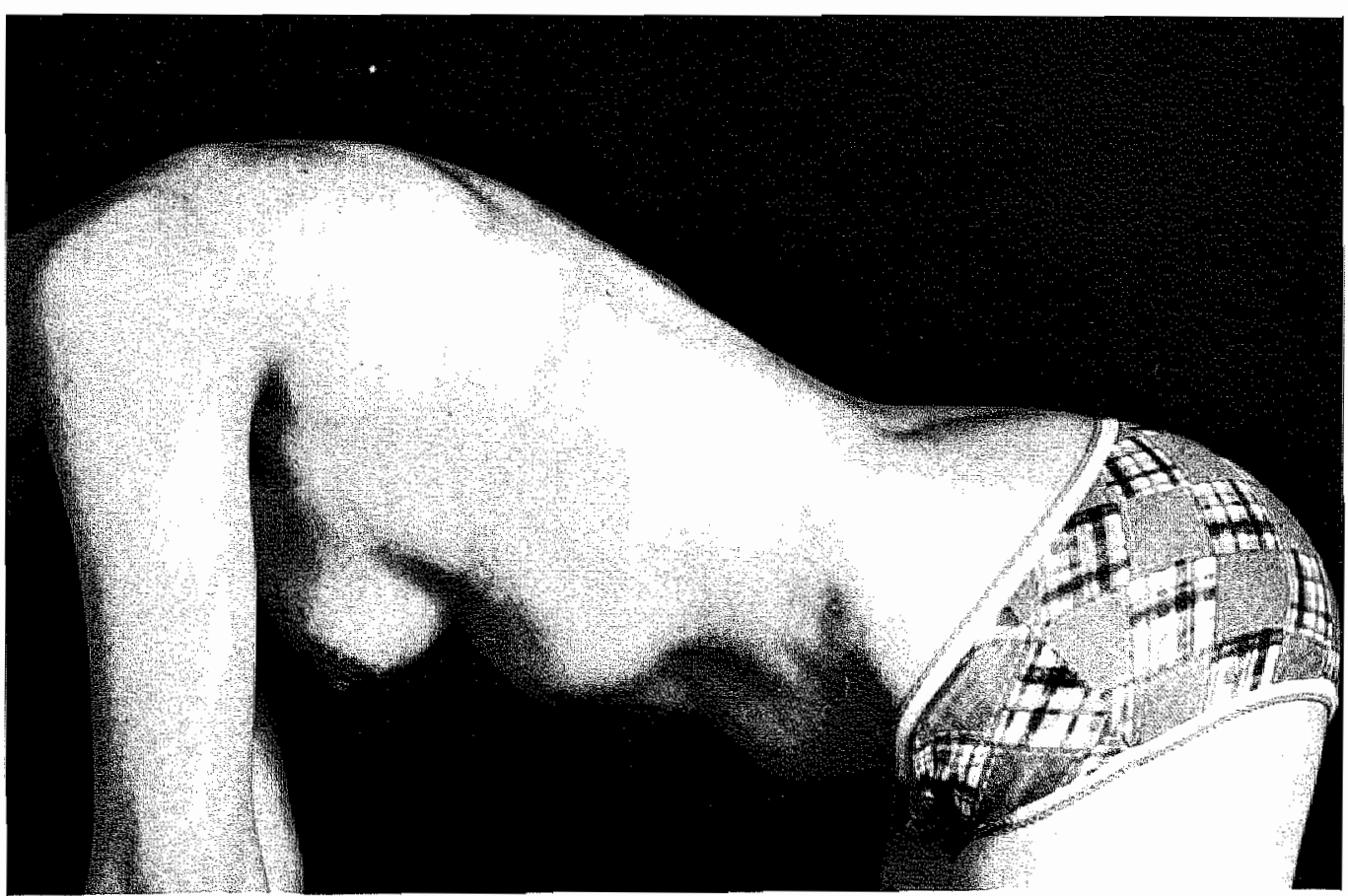

M.R.-W. Correctie kyfose na 3 operaties. 
Patiënt 10. P.N. vrouwelijk, geb. dat. 15-11-1966.

Aetiologie:

Vroegere behandeling:

Klachten:

Préoperatieve curves:

Voorbehandeling:

Longfunctie:

Neurologisch onderzoek:

Myelografie:

Operaties:

Complicaties:

Nabehandeling:

Postoperatieve curves:

Postoperatieve klachten:
Congenitale kyfoscoliose t.g.v. dubbele wigwervel T12-L1 dorsolateraal.

Vanaf le jaar gipsbed. In het $3 e$ jaar half jaar corset. Vanaf $5 \mathrm{e}$ jaar fysiotherapie tot $8 \mathrm{e}$ jaar. Toen 9 weken correctiegips, waarna Milwaukee brace en fysiotherapie tot aan de operatie.

Bij inspanning thoracolumbale pijnklachten en vermoeidheid.

Kyfose $\mathrm{T} 9 \mathrm{t} / \mathrm{m} \mathrm{L} 160^{\circ}$, tractie $44^{\circ}$. Scoliose $\mathrm{T} 10 \mathrm{t} / \mathrm{m}$ L1 $90^{\circ}$.

2 weken Cotreltractie.

Niet verricht.

Geen duidelijke afwijkingen.

Geen diastematomyelie. Iets vernauwing ter plaatse van de kyfose.

1. 14-9-1977. Resectie dubbele wigwervel via bed $12 \mathrm{e}$ rib en lumbotomie, met inlay van de rib en wervelbot in de holte.

2. 30-9-1977. Achterste resectie lamina en pedikel, spondylodese m.b.v. Harrington distractie en compressie-systeem en cristabot onder bewaking van wake-up testen (2x).

Geen.

10 maanden gipscorset.

Postoperatieve scoliose $38^{\circ}$

$\begin{array}{lll} & \text { Kyfose } & \text { Scoliose } \\ \mathrm{Na} 1 \text { maand } & 24^{\circ} & 40^{\circ} \\ \mathrm{Na} 2 \text { maanden } & 24^{\circ} & 40^{\circ} \\ \mathrm{Na} 6 \text { maanden } & 24^{\circ} & 40^{\circ} \\ \mathrm{Na} 10 \text { maanden } & 26^{\circ} & 40^{\circ} \\ \mathrm{Na} 12 \text { maanden } & 26^{\circ} & 45^{\circ} \\ \mathrm{Na} 18 \text { maanden geen laterale foto en } 42^{\circ} \text { scoliose. }\end{array}$

Geen. 
Beschouwing en conclusie:

Ook in dit geval wordt aangetoond dat behandeling van ernstige congenitale kyfoscoliosen door middel van wervelresectie en spondylodese superieure resultaten geeft. Men kan alleen via een wervelresectie de wervelkolom goed aligneren. Het hangt echter van de grootte van de curves af of een wervelresectie noodzakelijk is of dat volstaan kan worden met een spondylodese zonder resectie en met veel minder correctie. 


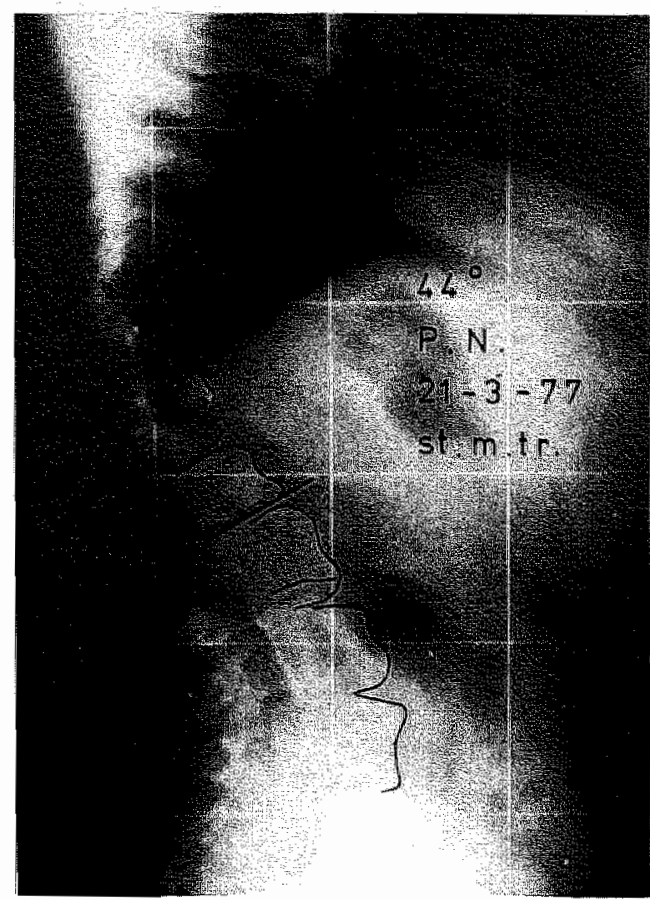

Kyfose préóperatief

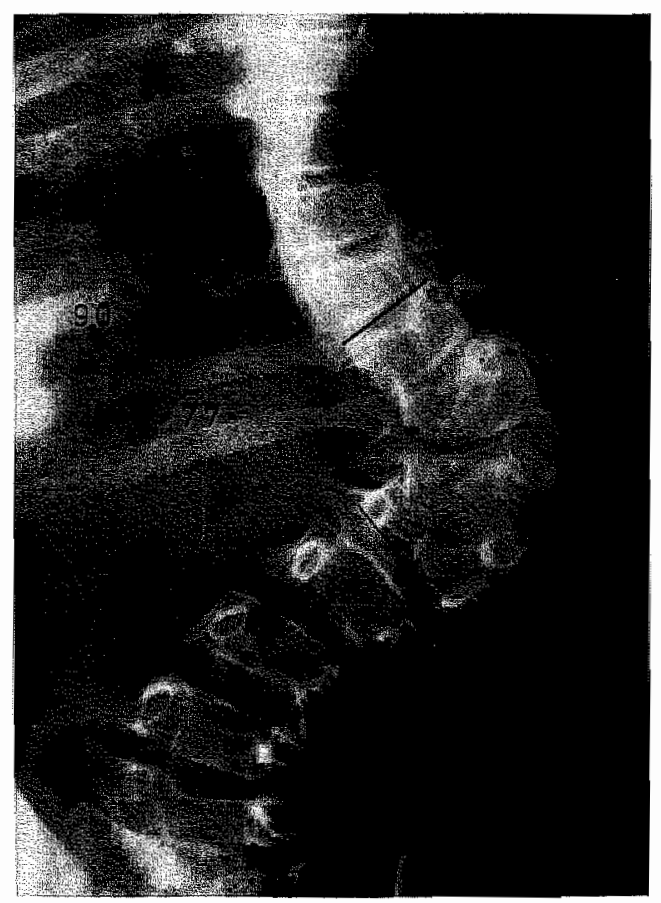

Scoliose préoperatief

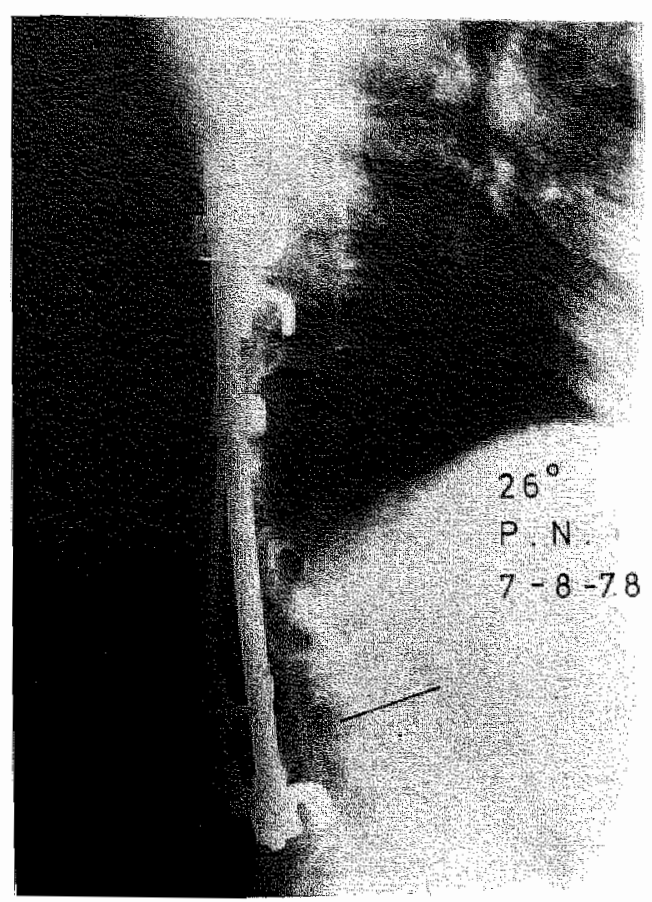

Kyfose postoperatief

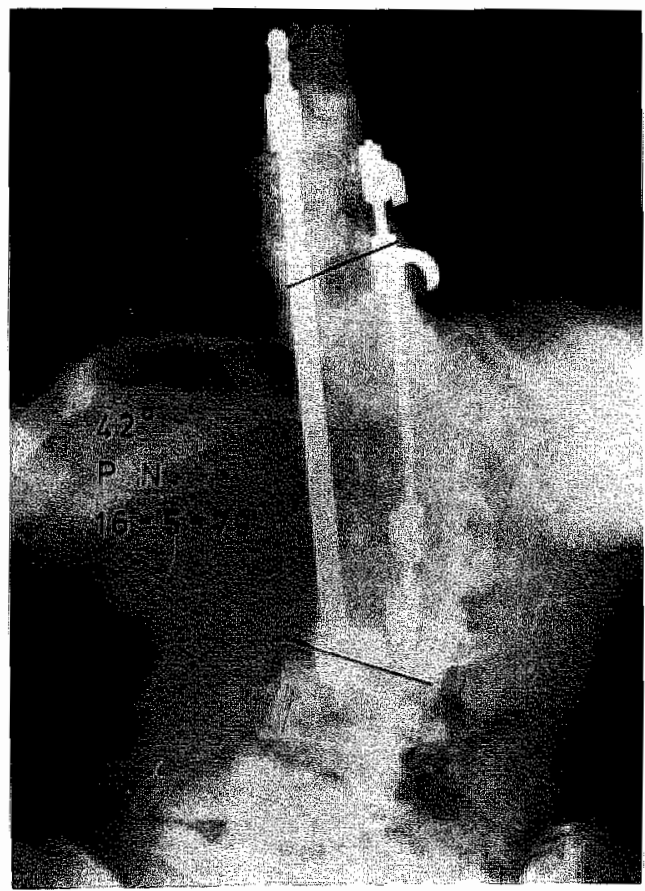

Scoliose postoperatief 


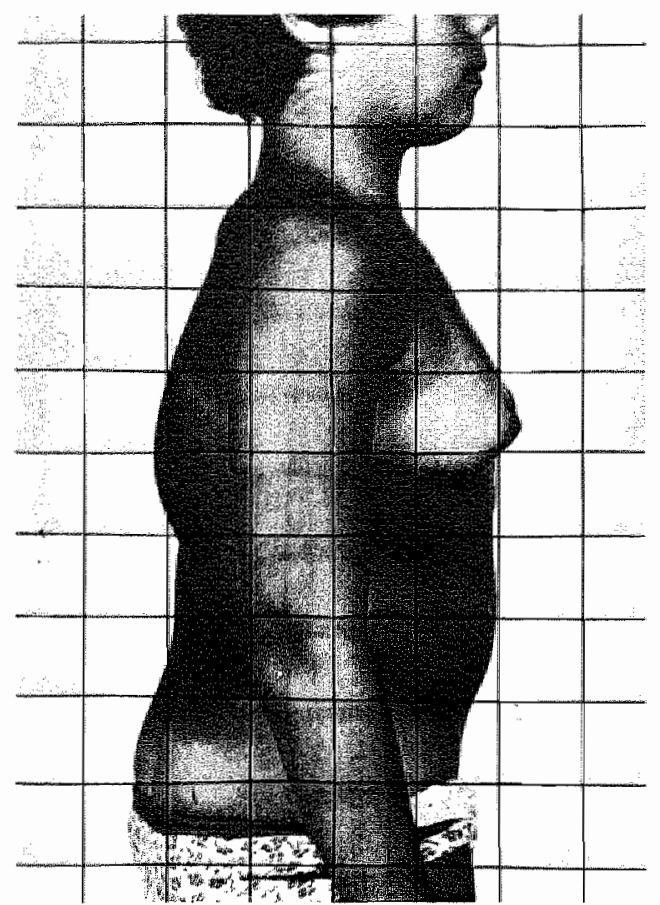

P.N. Kyfose préoperatief

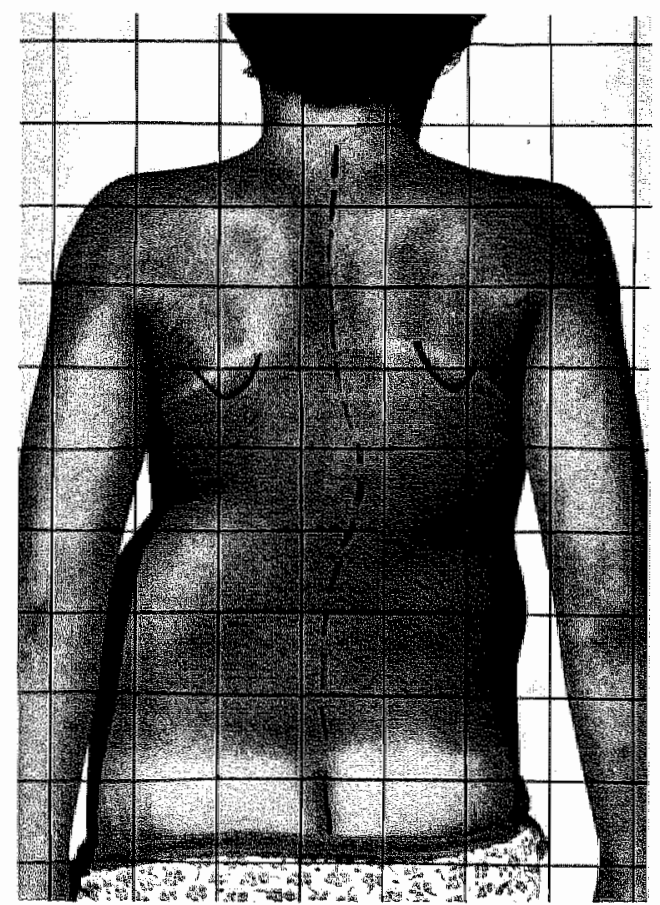

P.N. Scoliose préoperatieft

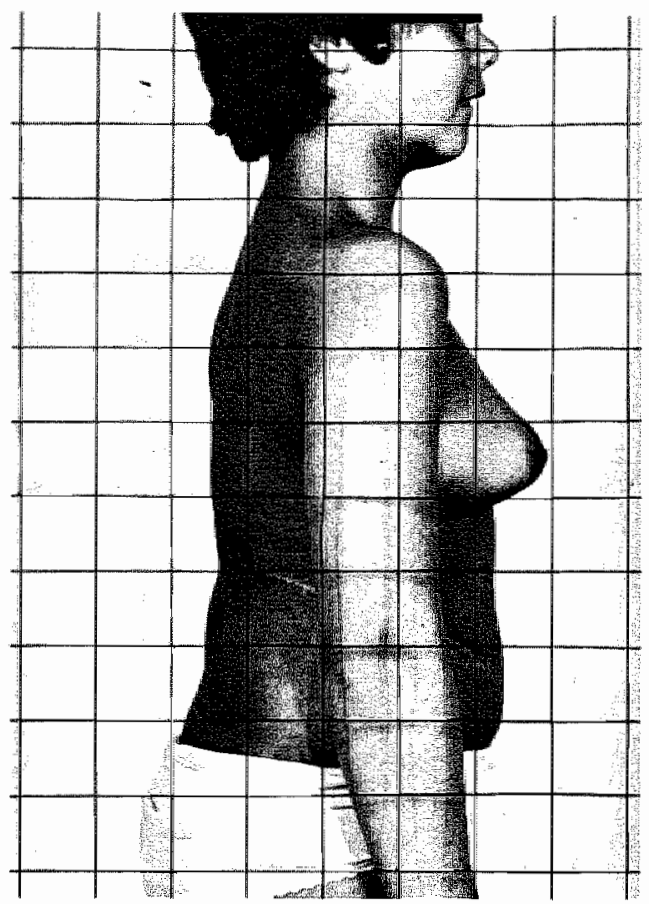

P.N. Kyfose postoperatief

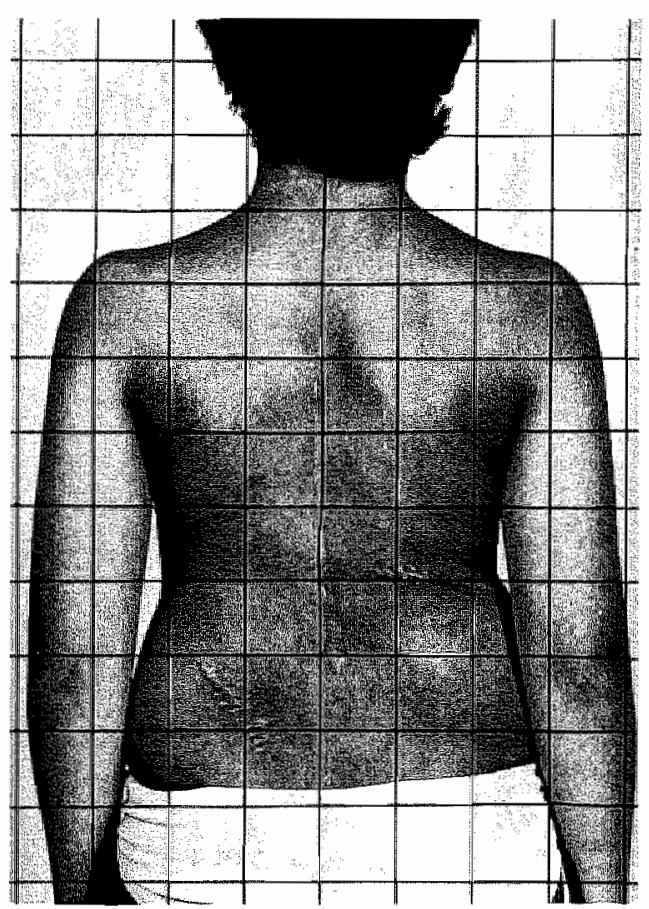

P.N. Scoliose postoperatief 


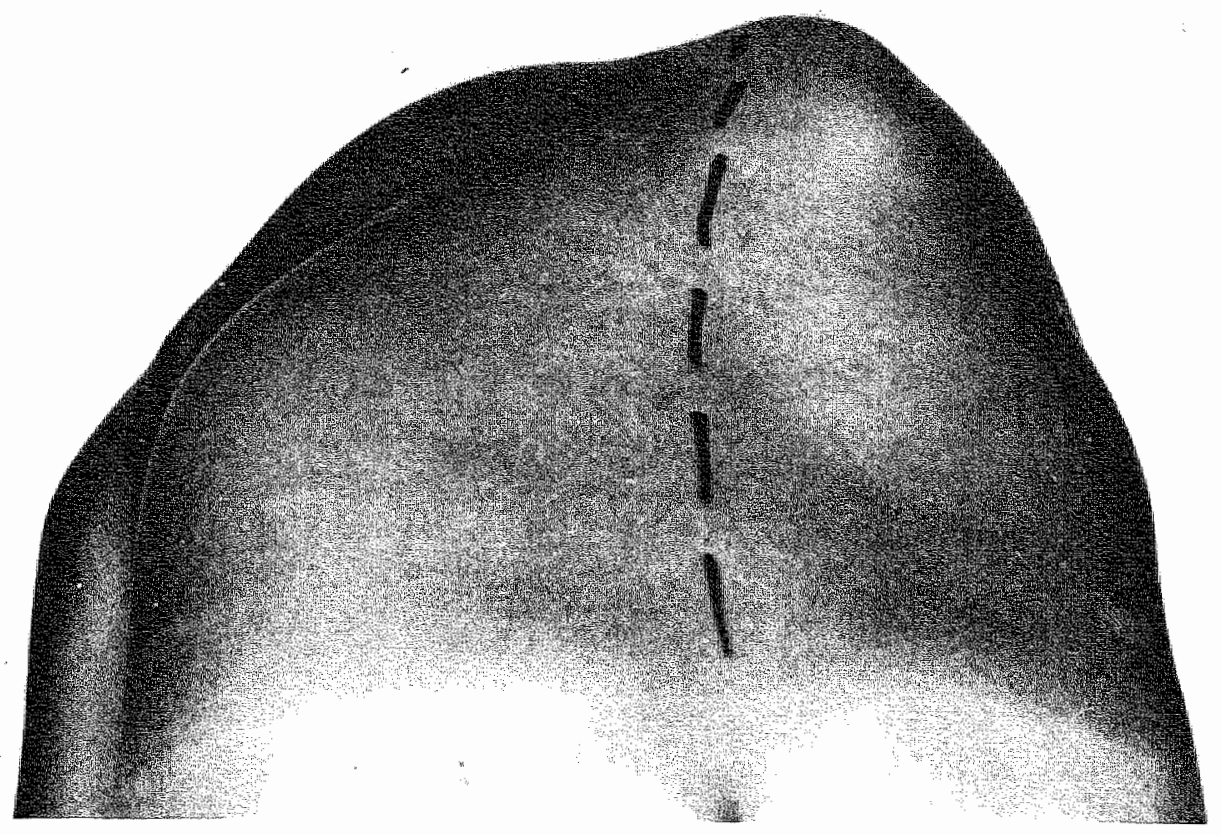

P.N. Gibbus préoperatief laag thoracaal

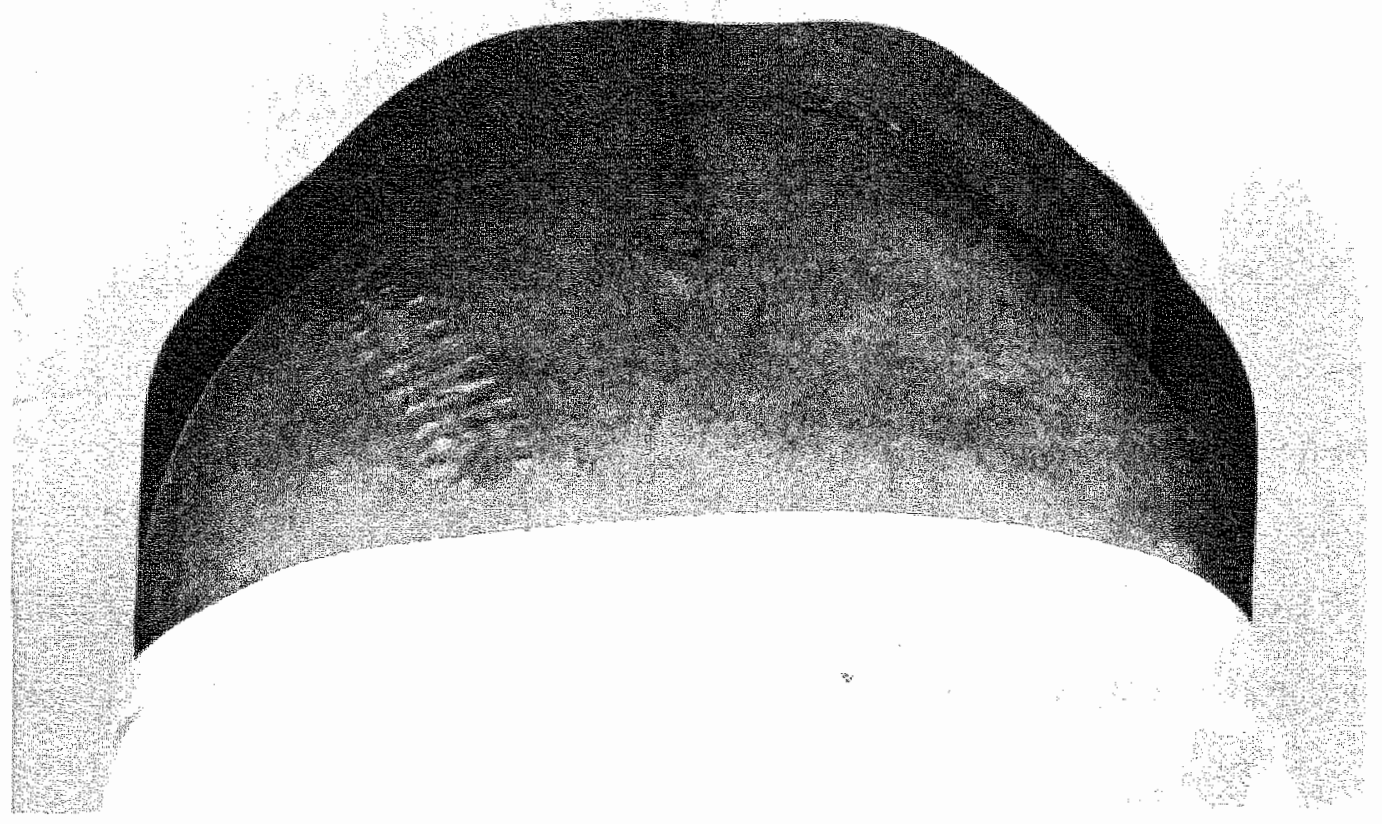

P.N. De gibbus is postoperatief niet meer te ontdekken. 
Patiènt 11. C.D. vrouwelijk, geb. dat 28-2-1939.

Aetiologie:

Vroegere behandeling:

Klachten:

Préoperatieve curves:

Voorbehandeling:

Longfunctie:

Conclusie:

Neurologisch onderzoek:

Myelografie:

Operaties:

Complicaties:

Nabehandeling:

Postoperatieve curves:

Postoperatieve klachten:
Congenitale kyfoscoliose t.g.v. dorsolaterale halfwervel T12.

Gipsbed, orthopaedisch corset, hakverhoging.

Pijn in rug en nek door compensatoire lordose lumbaal en cervicaal. Geen neurologische afwijkingen, geen dyspnoe d'effort.

Scoliose T10 t/m L3 78 . Kyfose T10 t/m L3 100 .

Geen. Wegens moeilijkheid van deze casus vooroverleg met prof. J. Hall uit Boston, USA.

Vit. cap. 3250 cc. Normaal 3900 cc. Tot. cap. 4200 cc. Normaal $5050 \mathrm{cc}$.

Geringe restrictie longfuctie.

Embryopathie e.c.i. Geen neurologische afwijkingen.

Geen passage belemmering.

1. 18-10-1976. Transthoracale columnotomie en wervelresectie. Postoperatief 6 weken zit-Halotractie zonder resultaat.

2. 1-12-1976. Resectie congenitale synostose van laminae en compressie/distractie spondylodese waarbij correctie onder controle van de wake-up test.

3. 21-12-1976. Thoracotomie en voorste spondylodese m.b.v. ribspanen.

Mogelijk uretersteen. Verder geen problemen.

4 maanden Halo-rompgips. 2 maanden gipscorset.

$\begin{array}{lll} & \text { Scoliose } & \text { Kyfose } \\ \text { Postoperatief } & 42^{\circ} & 26^{\circ} \\ \mathrm{Na} 3 \text { maanden } & 41^{\circ} & 45^{\circ} \\ \mathrm{Na} \text { 6 maanden } & 43^{\circ} & 46^{\circ} \\ \mathrm{Na} \text { 15 maanden } & 42^{\circ} & 36^{\circ}\end{array}$

Incidenteel lage rugpijn. Zeer tevreden met het cosmetische resultaat. 
Beschouwing en conclusie:

Zeer fraaie correctie van een ernstig invaliderende kyfoscoliose. Om een aanvaardbaar resultaat te krijgen was men ook hier aangewezen op een wervelresectie. Anders volstaat men met het stoppen van de progressie zonder de slechte statiek te veranderen, indien de spondylodese ten minste slaagt, hetgeen bij deze zeer forse curves al moeilijk genoeg is. Men kan zich in dit geval afvragen of de $3 \mathrm{e}$ ingreep noodzakelijk was. 


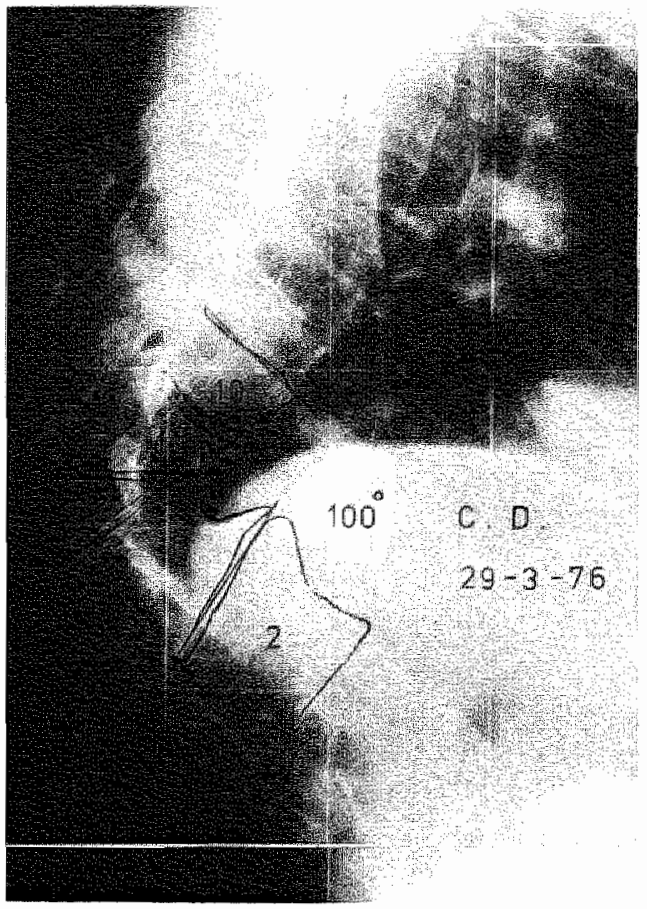

Kyfose préoperatief

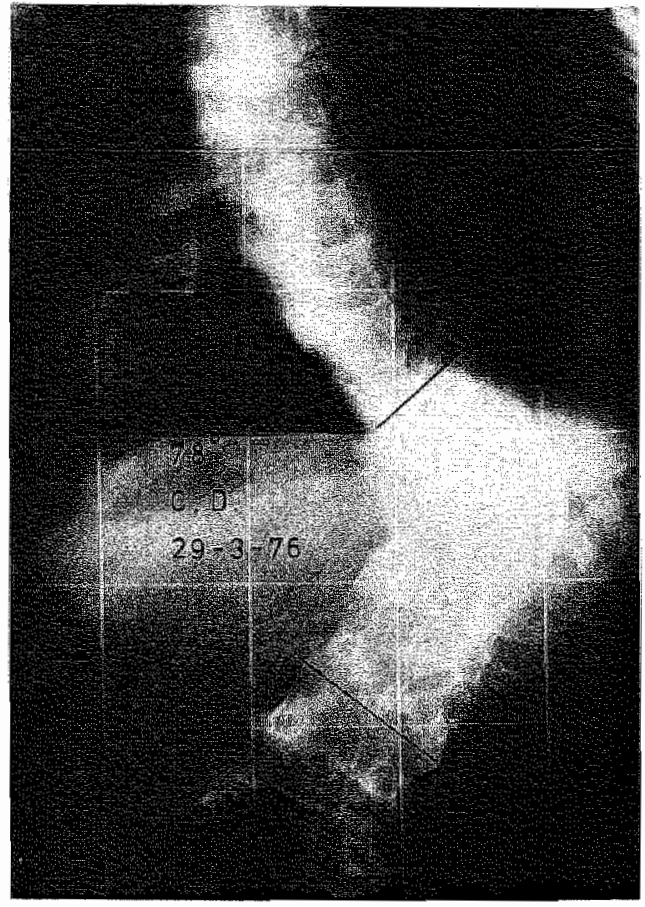

Scoliose préoperatief

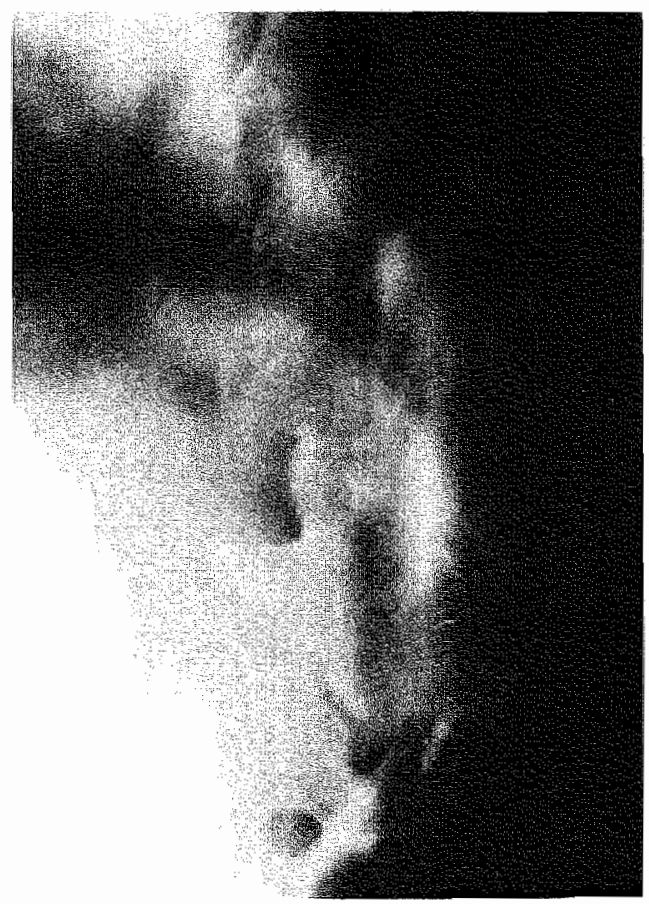

C.D. Tomogram van de kyfose 


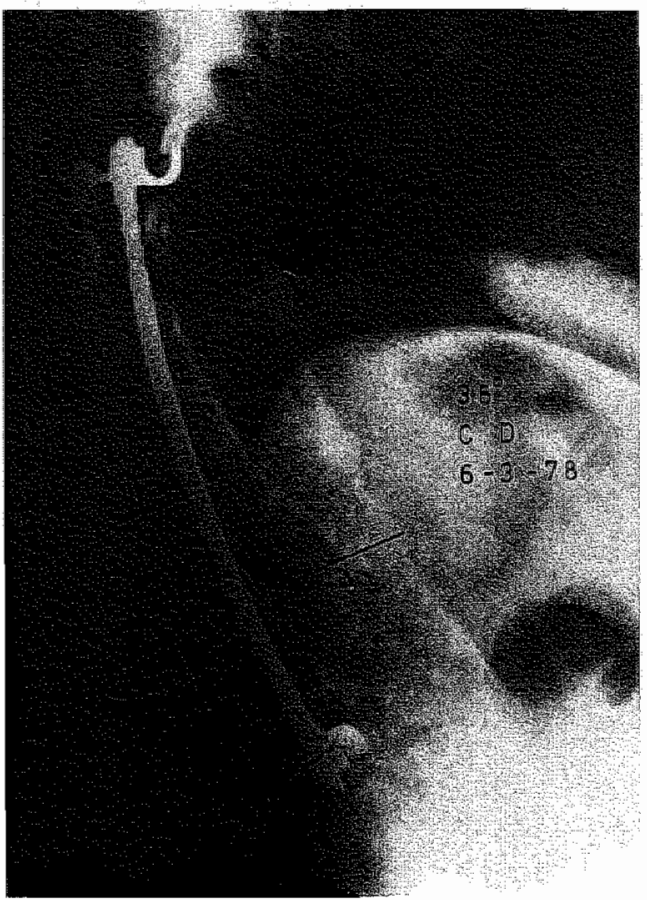

Kyfose postoperatief

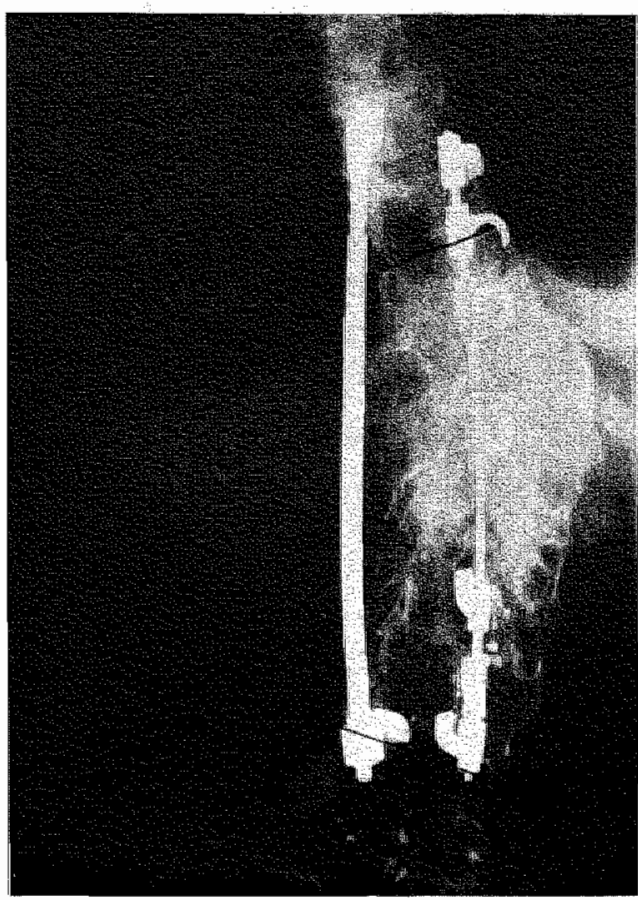

Scoliose postoperatief

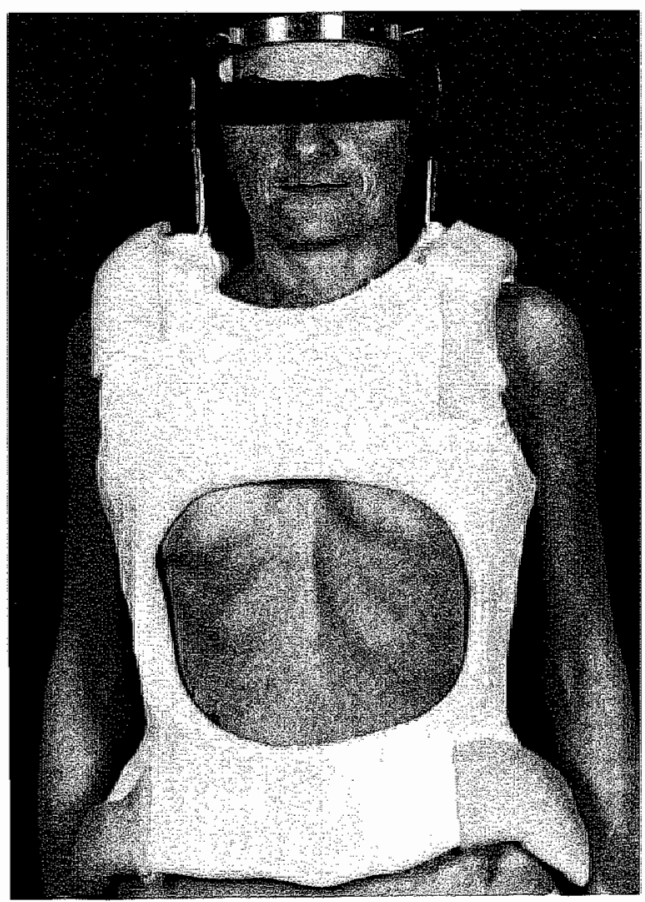

C.D. Patiënte in het Halo-rompgips 

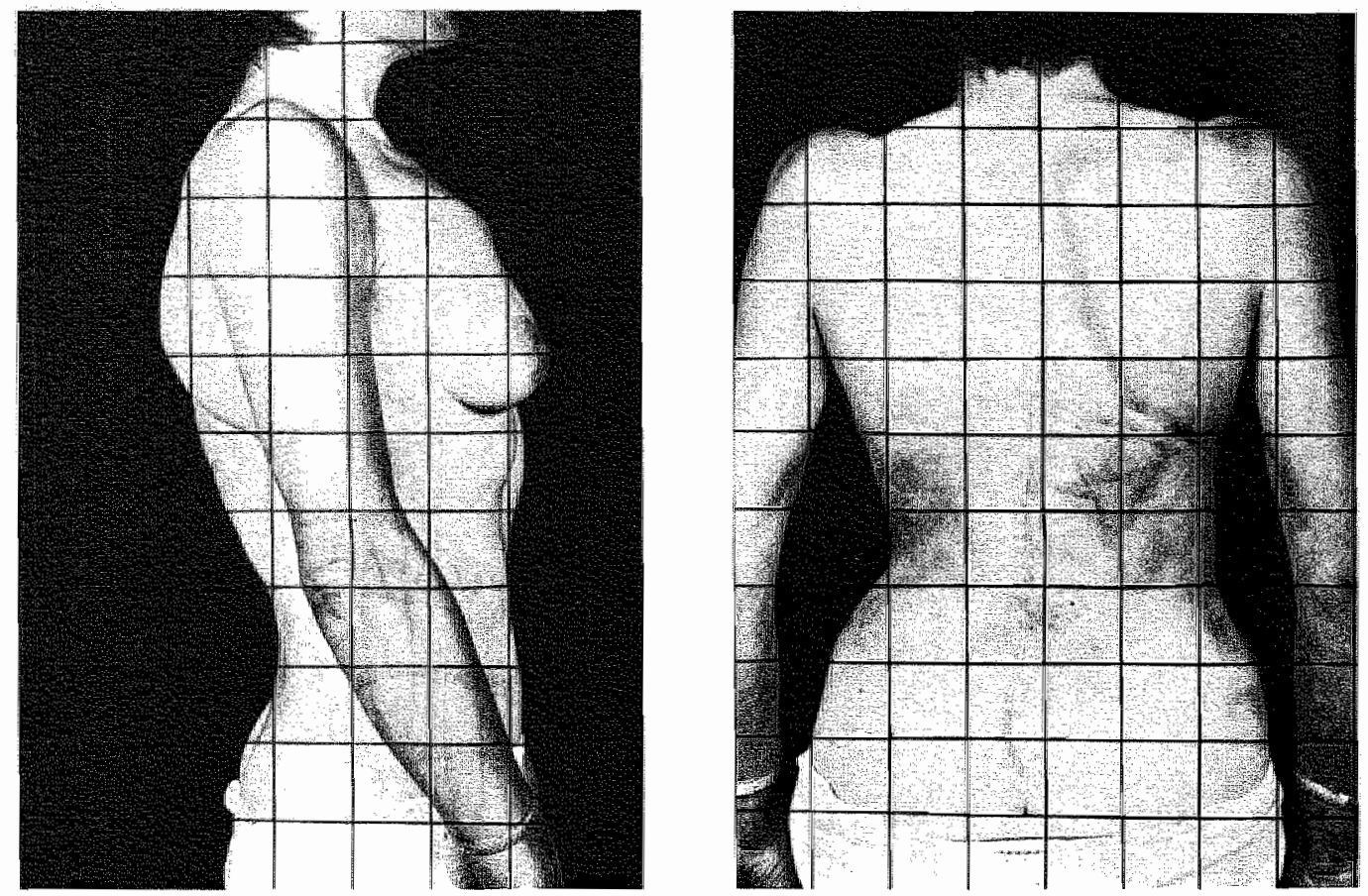

C.D. Uiterlijk van patiënte postoperatief. Fraaie equilibratie. Helaas ontbreken medische foto's préoperatief. 
Patiënt 12. A.R. mannelijk, geb. dat. 23-3-1942.

Aetiologie:

Vroegere behandeling:

Klachten:

Préoperatieve curves:

Voorbehandeling:

Longfunctie:

Conclusie:

Neurologisch onderzoek:

Myelografie:

Operaties:

Complicaties:
Congenitale kyfoscoliose ten gevolge van dubbele dorsolaterale halfwervel T9 en T10.

Tot het $7 \mathrm{e}$ jaar schuine ligplank $3 \mathrm{x}$ per dag een half uur, vervolgens heilgymnastiek. Toen werd geadviseerd een korte spondylodese te verrichten bij prom gressie, hetgeen niet gebeurde. Op $17 \mathrm{e}$ jaar kreeg patiënt een hoog steunend corset, na het $20 \mathrm{e}$ jatar kreeg hij geen enkele therapie.

Pijn en vermoeidheid in de rug, soms in de benen. Periodes van flauwvallen.

Op 7-jarige leeftijd kyfose $8^{\circ}$, scoliose $35^{\circ}$. Op 17-jiarige leeftijd kyfose $77 \mathrm{t} / \mathrm{m} \mathrm{Ll} 64^{\circ}$, scoliose $\mathrm{T} 8 \mathrm{t} / \mathrm{m}$ T11, T12 t/m L3 resp. $73^{\circ}$ en $57^{\circ}$. Op 35 jarige leeftijd kyfose ongeveer $94^{\circ}$, scoliose $83^{\circ} / 77^{\circ}$. Vooral de kyfose is na het 17 e levensjaar flink progressief geworden.

$2^{1 / 2}$ week zit-Halotractie, ook tussen de operaties deze tractie.

Vit. cap. $4600 \mathrm{cc}$. Normaal $6300 \mathrm{cc}$. Tot. cap. 6300 cc. Normaal $8600 \mathrm{cc}$.

Restrictieve functiestoornis met ruime ventilatoire reserves.

Er leek door de stand van de nek vertebrale insufficiëntie te zijn ontstaan, waarvan het flauwvallen het gevolg was. $1 \times$ trad door een black-out een clavicula fractuur op.

Niet verricht.

1. 30-8-1977. Wigwervelresectie T10 tot op de dura met achterlaten van rib-en wervelsnippers, via een thoracotomie. Hiema Halo-rolstoeltractie.

2. 21-9-1977. Dorsale resectie boog en pedikel T9. T10 met graduele correctie m.b.v. Harrington compressie en distractie systeem onder controle van 2 wake-up testen, waarna spondylodese m.b.v. cristabot.

Geen. 
Nabehandelling:

Postoperatieve curves:

Postoperatieve klachten:
Halo-rompgips 6 maanden, waarna 3 maanden gipscorset.

$\begin{array}{lll} & \text { Kyfose } & \text { Scoliose } \\ \text { Postoperatief } & 43^{\circ} & 58 / 54^{\circ} \\ \mathrm{Na} 1 \text { maand } & 59^{\circ} & 44 / 54^{\circ} \\ \mathrm{Na} \mathrm{3} \text { maanden } & 60^{\circ} & 41 / 52^{\circ} \\ \mathrm{Na} \mathrm{6} \text { maanden } & 41^{\circ} & 37 / 54^{\circ} \\ \mathrm{Na} 9 \text { maanden } & 48^{\circ} & 40 / 54^{\circ} \\ \mathrm{Na} 14 \text { maanden } & 45^{\circ} & 40 / 54^{\circ} \\ \mathrm{Na} \text { 26 maanden } & 52^{\circ} & 37 / 54^{\circ}\end{array}$

Geen. Met name waren de black-outs verdwenen, alsook de pijnklachten. Patiënt was zeer tevreden over het cosmetisch resultaat.

Beschouwing en conclusie:

Uitstekend resultaat bij deze man met ernstige klachten ten gevolge van een gesegmenteerde halfwervel. De resectie hiervan met in tweede instantie correctie leverde ook hier een zeer gunstig resultaat op wat betreft de statiek. Het resultaat wat betreft het klachtenpatroon bevestigt dit. Als men bij deze patiënt voor de puberteit een spondylodese had verricht, dan waren deze grote operaties op de volwassen leeftijd niet nodig geweest. 


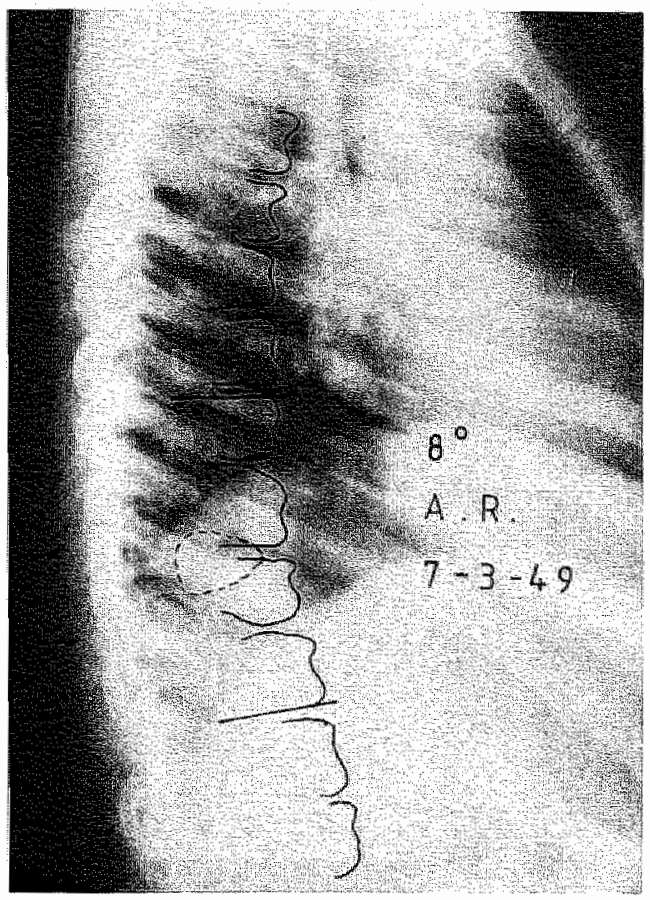

Kyfose op 7-jarige leeftijd

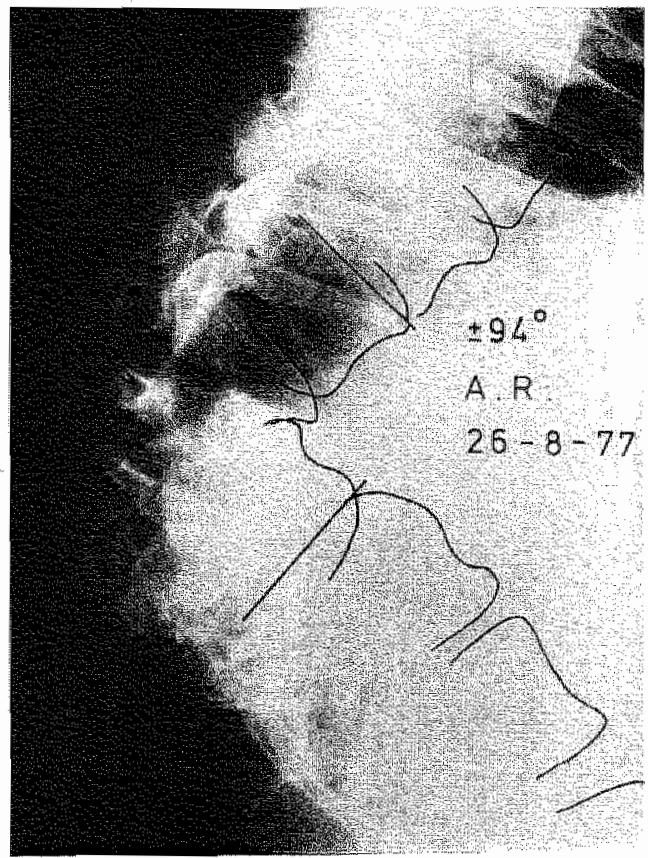

Kyfose op 35-jarige leeftijd (andere curve gemeten)

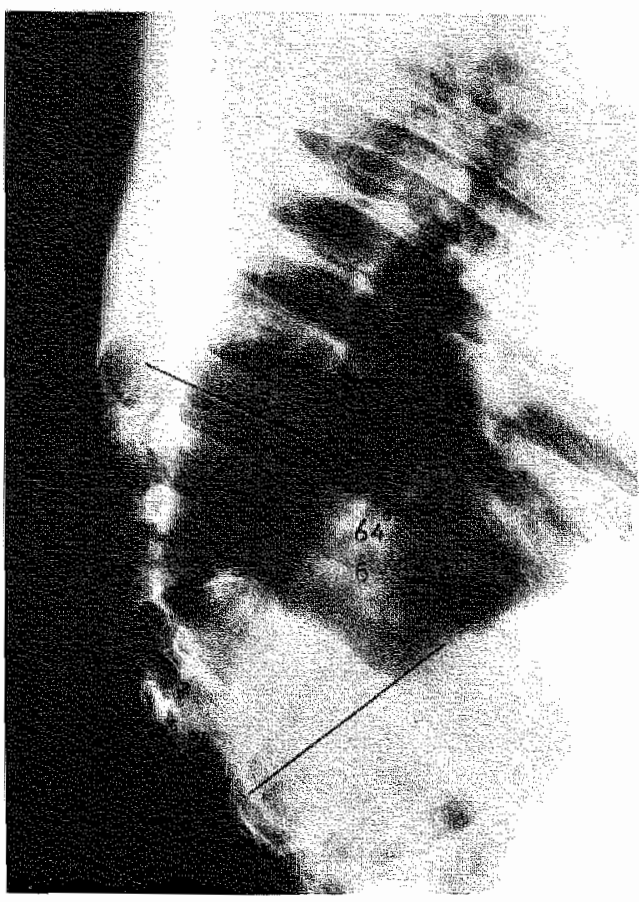

Kyfose op 17-jarige leeftijd

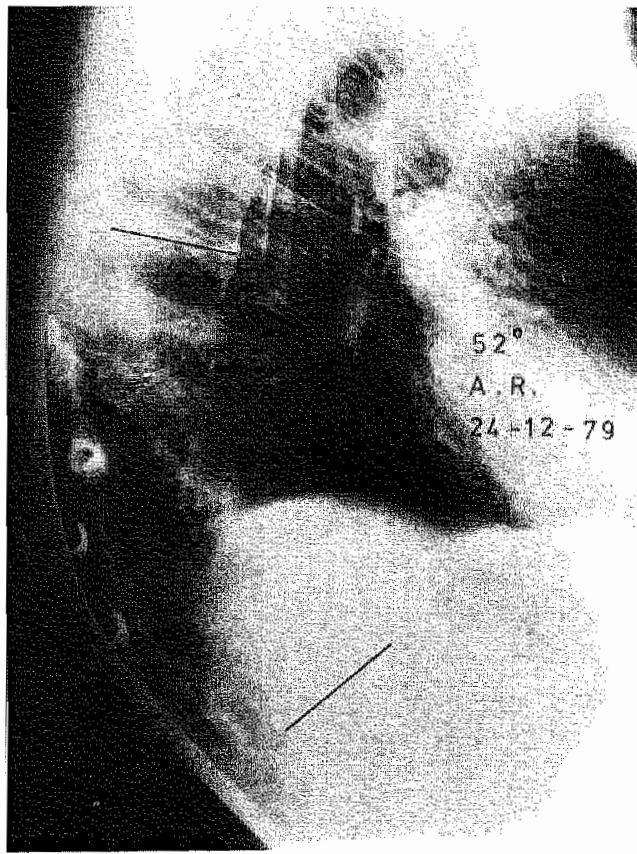

Kyfose cotrectie postoperatief 


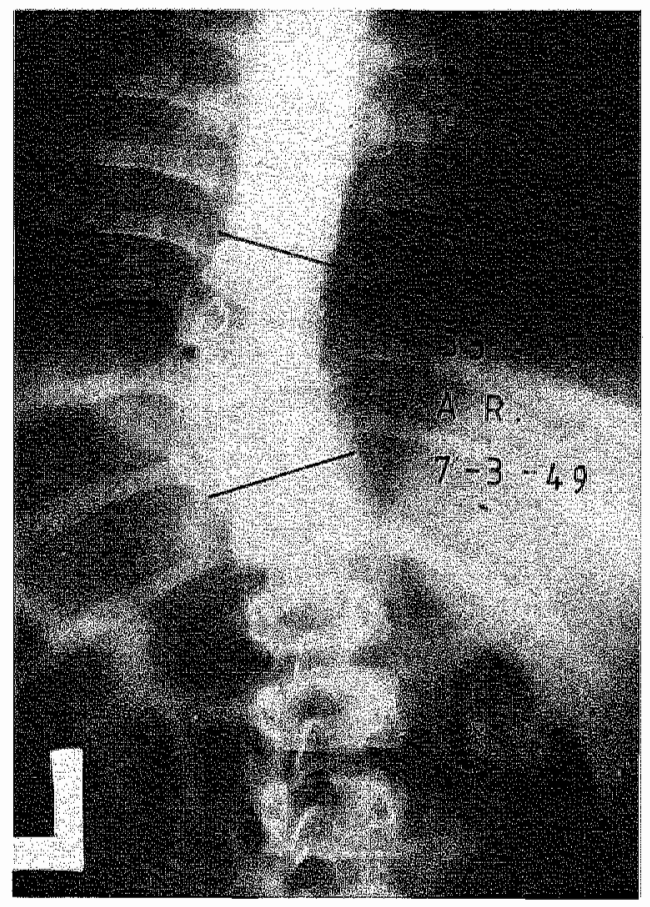

Scoliose op 7-jarige leeftijd

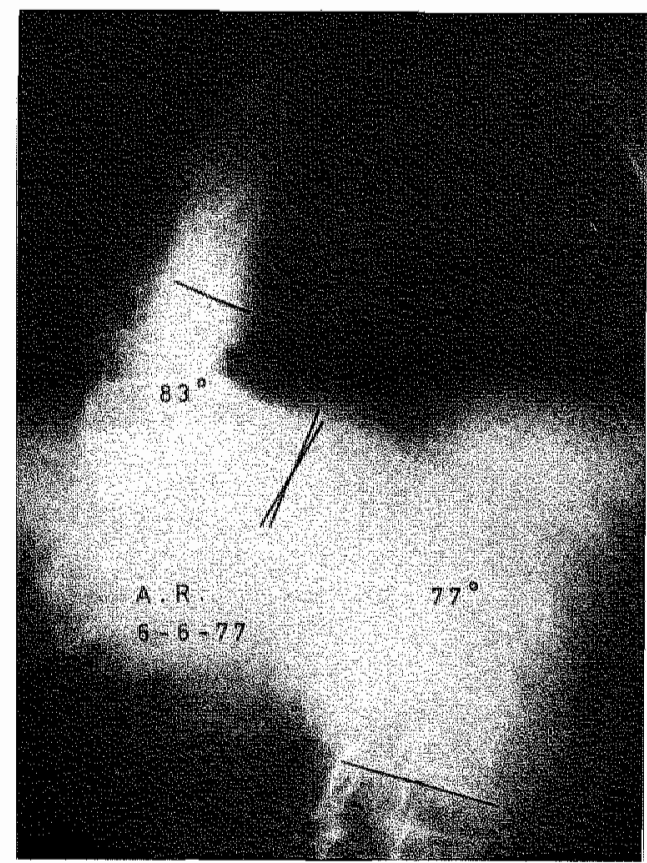

Scoliose op 35-jarige leeftijd Minder progressief dan de kyfose

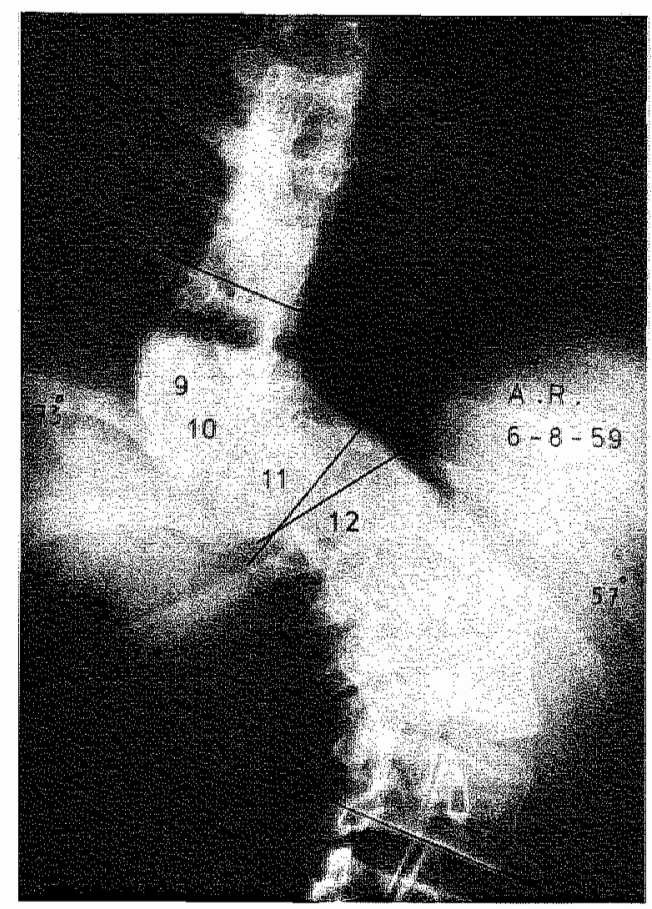

Scoliose op 17-jarige leeftijd

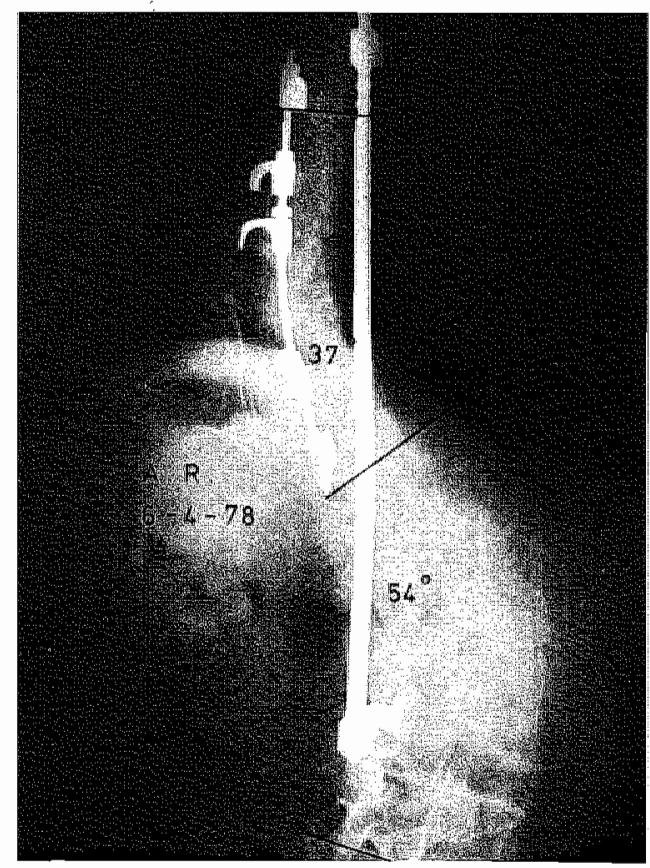

Scoliose postoperatief 


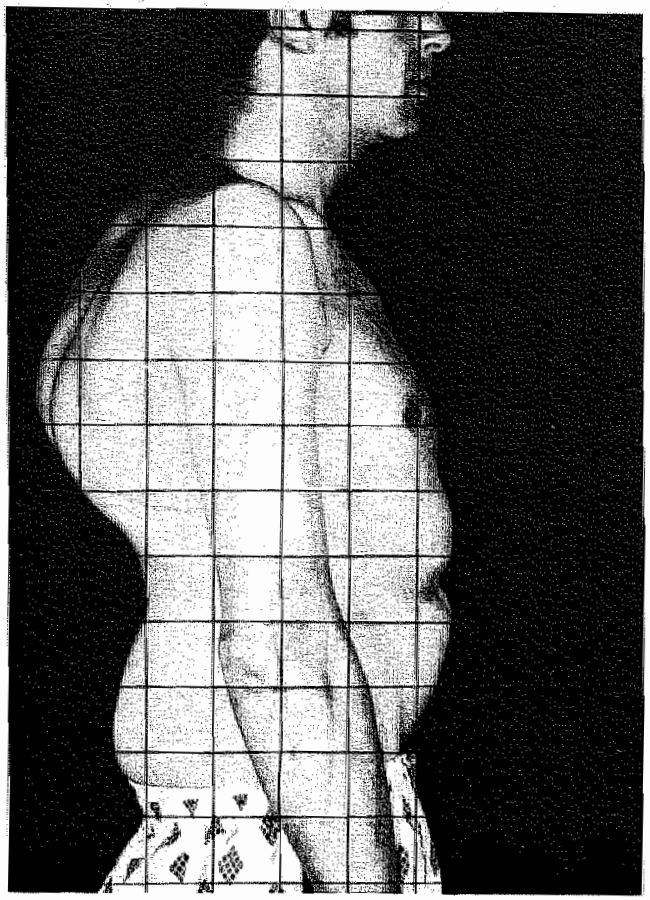

A.R. Kyfose préoperatief

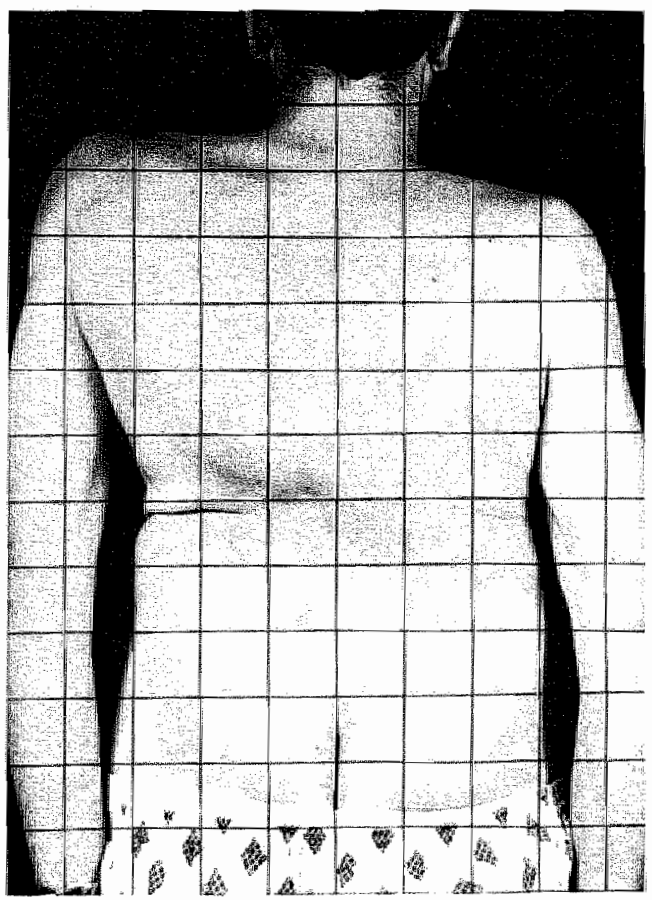

A.R. Scoliose préoperatief

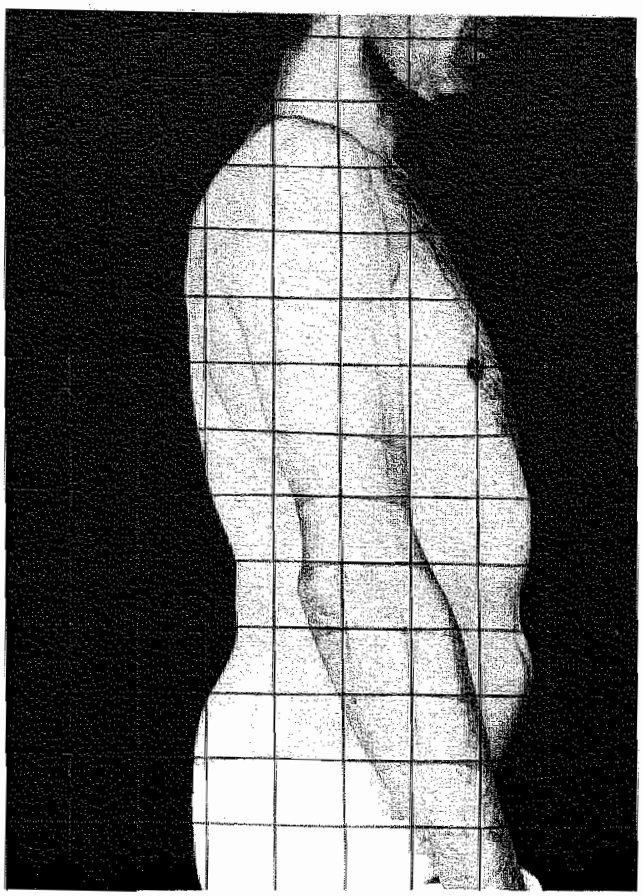

A.R. Kyfose postoperatief Opvallend is de lengtewinst

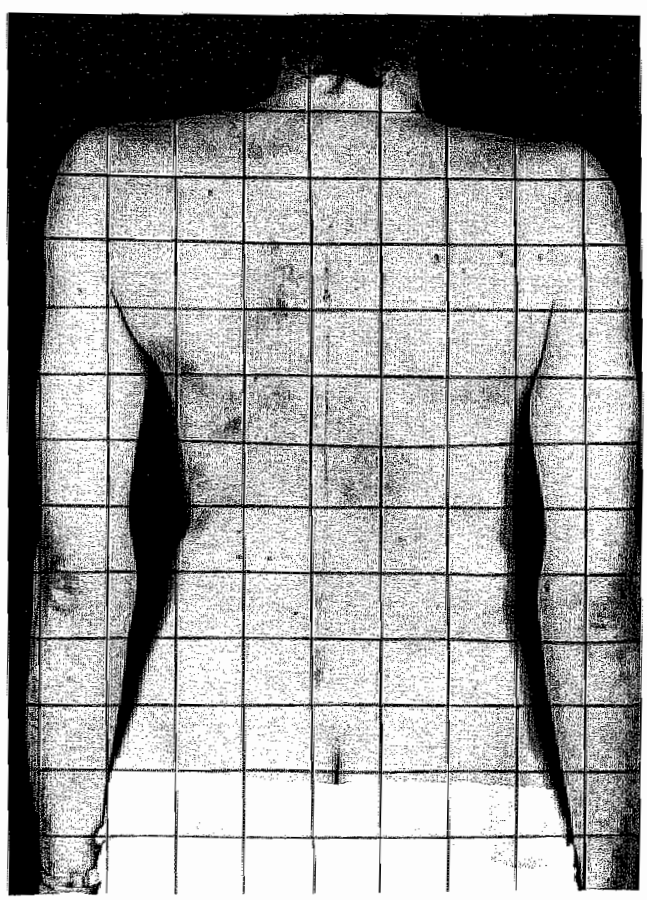

A.R. Scoliose postoperatief 


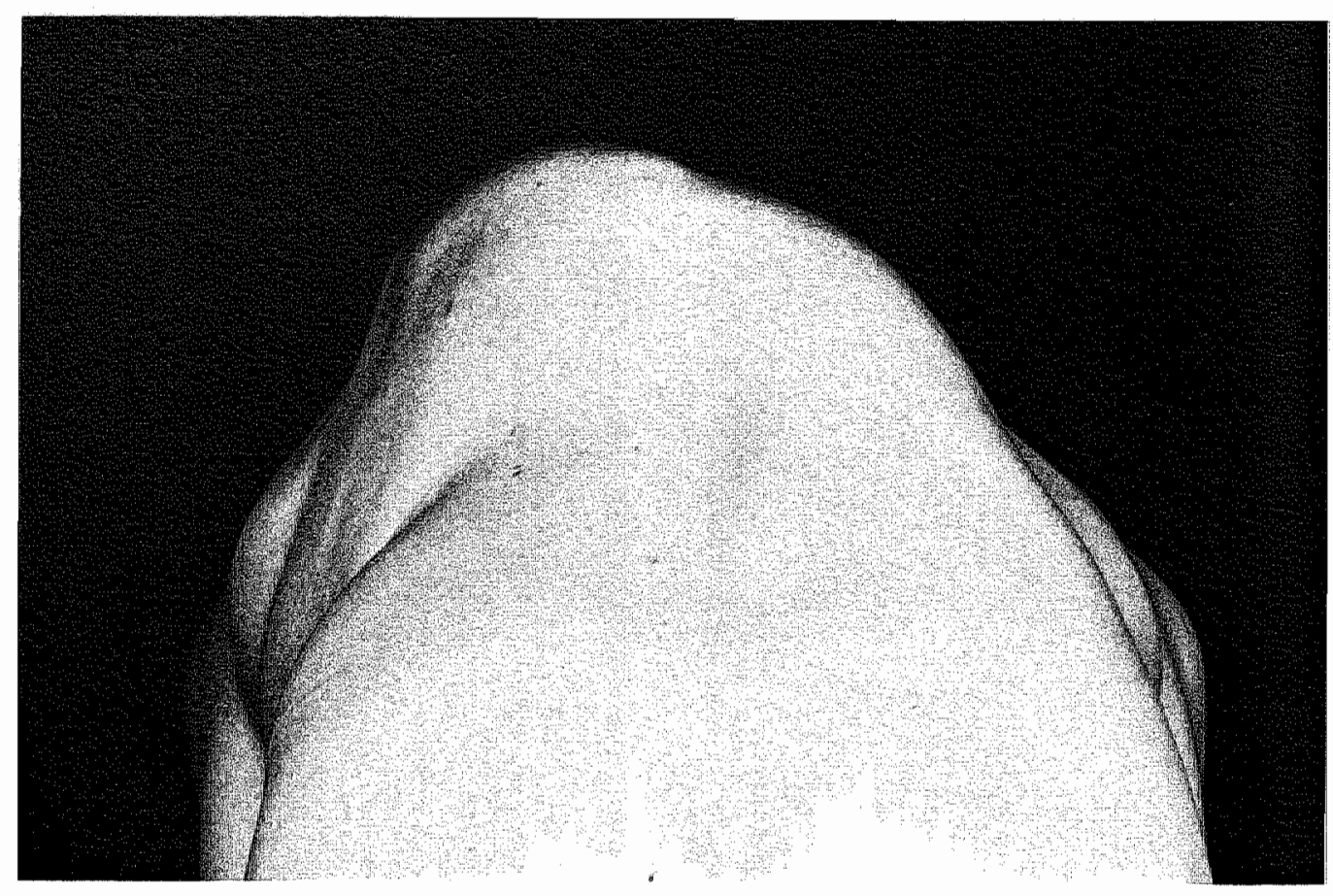

A.R. Ernstige gibbus préoperatief

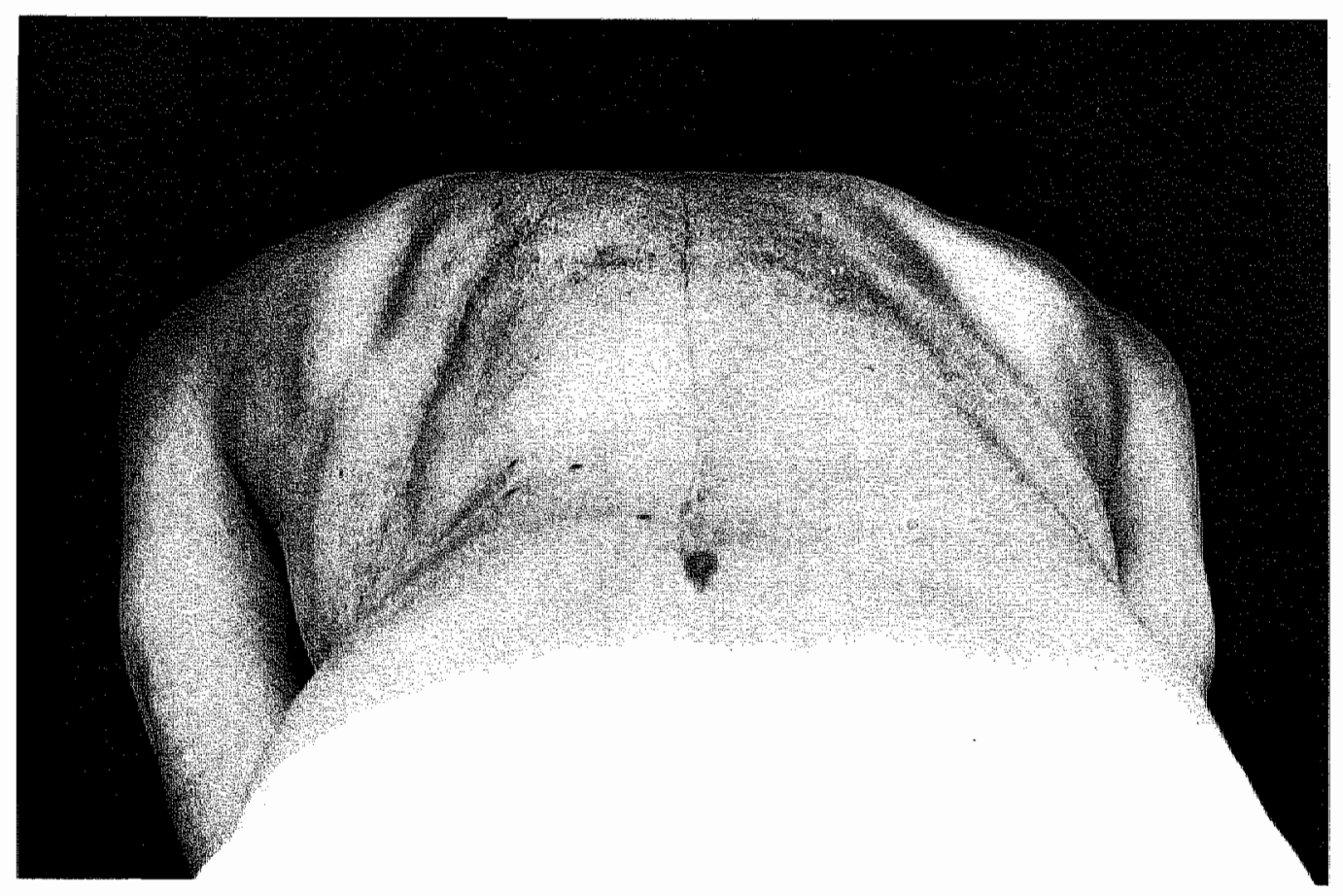

A.R. Verdwijnen van de gibbus postoperatief 
Patiènt 13. R. de W. mannelijk, geboren 28-5-1969.

Aetiologie:

Vroegere behandeling:

Klachten:

Préoperatieve curves:

Voorbehandeling:

Longfunctie:

Conclusie:

Neurologisch onderzoek:

Myelografie:

Operatie:

Complicaties:

Nabehandeling:

Postoperatieve curves:

Postoperatieve klachten:
Congenitale thoracale kyfose met lichte scoliose ten gevolge van anterior bar en dorsale wigwervel T9 (gecombineerde type) bij spina bifida occulta en diastematomyelie.

Geen.

Geen. Kyfose bij toeval gevonden bij orthopaedisch onderzoek in verband met platwoeten. Normale intelligentie.

Kyfose $53^{\circ} \mathrm{T} 4 \mathrm{t} / \mathrm{m}$ T11, redressiefoto $33^{\circ}$. Scoliose $\mathrm{T} 4 \mathrm{t} / \mathrm{m} \mathrm{L} 2$ rechts convex $21^{\circ}$.

Geen.

Vit. cap. 2075 cc. Normaal 2375 cc. Tot. cap. 2525 cc. Normaal $2950 \mathrm{cc}$.

Geringe restrictieve functiestoornis.

Geen abnormale bevindingen.

Diastematomyelie thoracaal.

7-11-1978. Dorsale spondylodese T5 t/m T12 m.b.v. cristabot; geen instrumentatie, geen aviveren van intergewrichten. Er was een blok van 4 wervels.

Geen.

5 maanden gipscorset.

Na 3 maanden kyfose $40^{\circ}$

$\mathrm{Na} 8$ maanden kylose $40^{\circ}$

$\mathrm{Na} 13$ maanden kyfose $55^{\circ}$

curve röntgenologisch moeilijk te meten,

$\mathrm{Na} 30$ maanden kyfose $50^{\circ}$

Geen. 
Bij elke congenitale scoliose c.q. kyfose moet onderzocht worden of er een diastematomyelie bestaat. Dit is het gespleten zijn van het myelum door een soort "schot", dat van de achterzijde van de wervels in het spinaal kanaal uitsteekt. Dit schot kan uit bot, kraakbeen of bindweefsel bestaan. Bestaat dit, dan is tractie zeer gevaarlijk. Het myelum kan door tractie gecomprimeerd worden tegen de "spur" aan met als gevolg neurologische uitval. Bestaat er voor de behandeling al neurologische problematiek, dan komt extirpatie van de spur in aanmerking. In dit geval was dat niet nodig. Wel was een spondylodese geïndiceerd, gezien de groei aar de achterzijde van de disci en ter plaatse van de achterstructuren, welke waarschijnlijk een ernstige kyfose veroorzaakt zou hebben. 


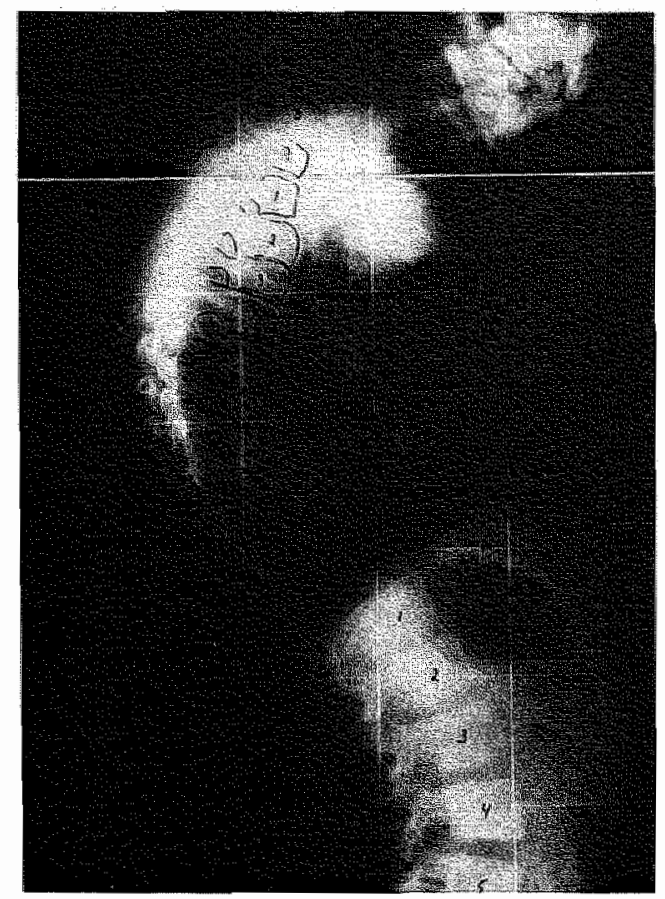

Préoperatieve kyfose $53^{\circ}$
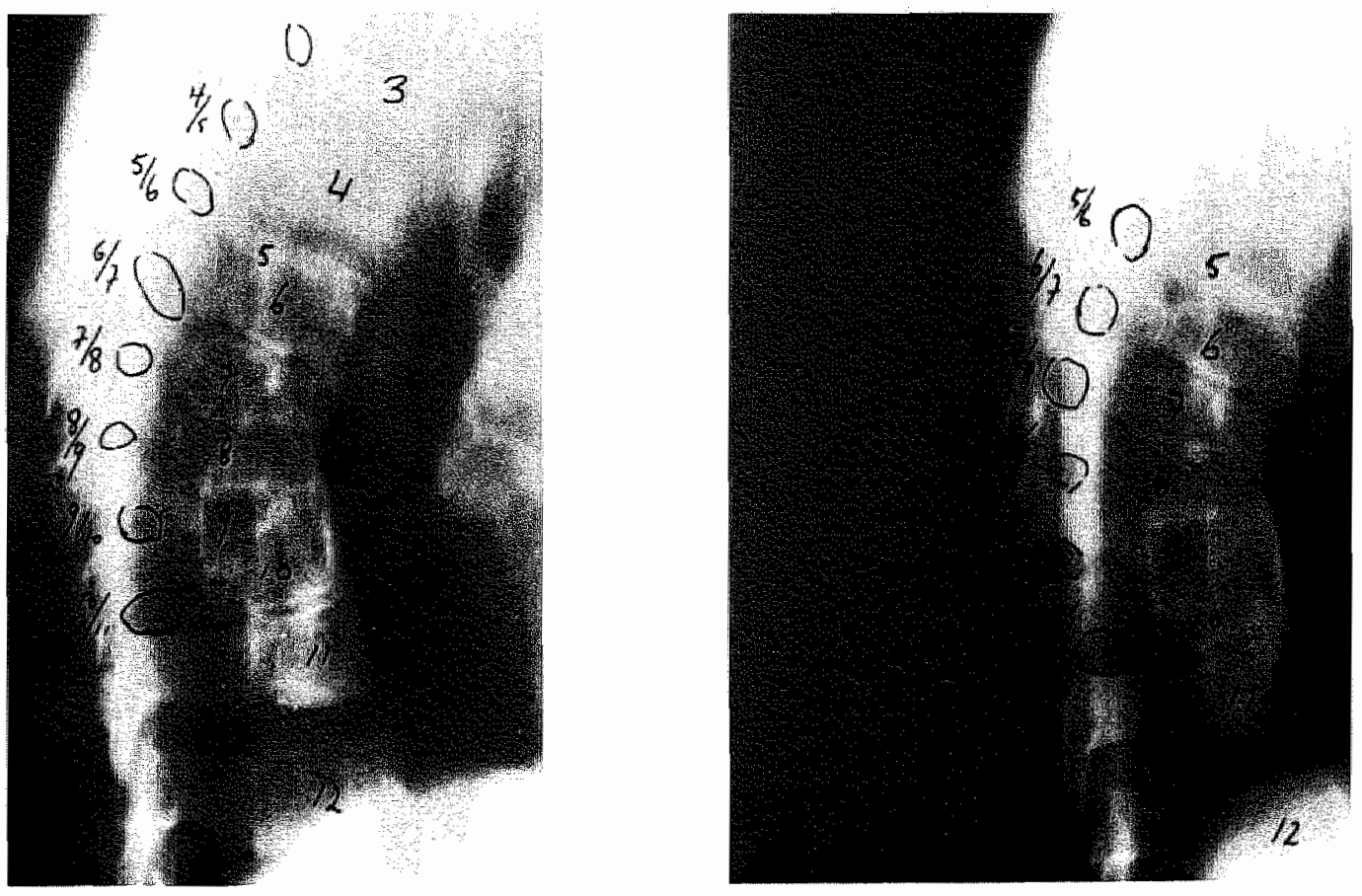

Anterior bar T5-6-7-8-9-10-11 met dorsale wigwervel T9 (gecombineerde type) 


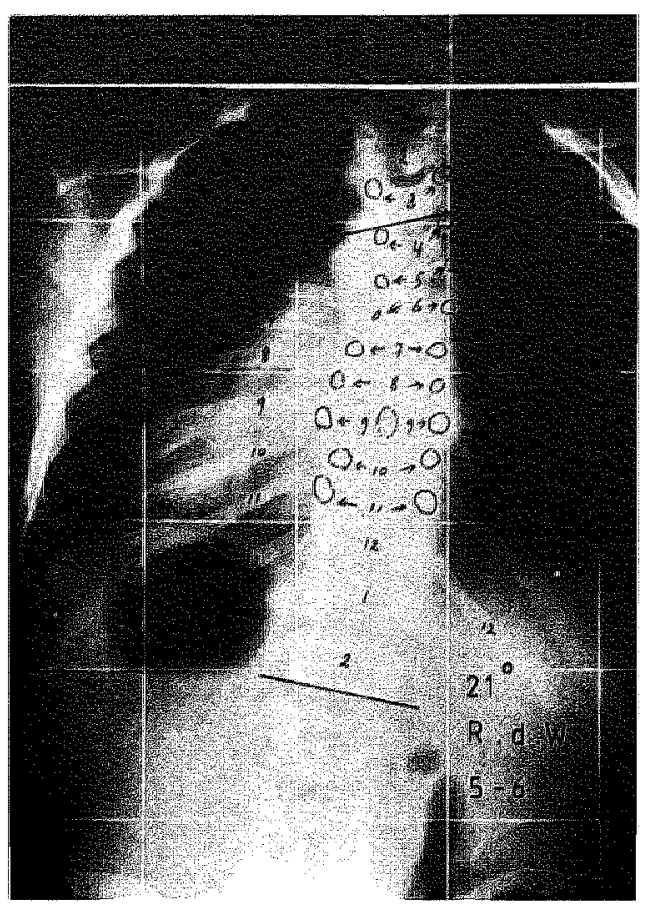

Verwijding van het spinaalkanaal t.p.v. T8-9-10

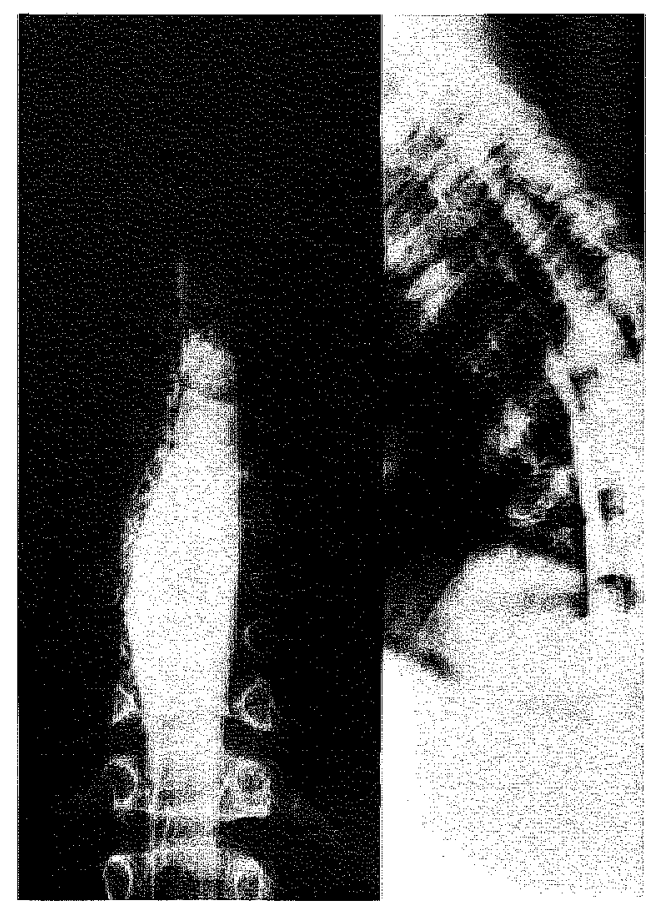

Myelografie diastematomyelie t.p.v. T9

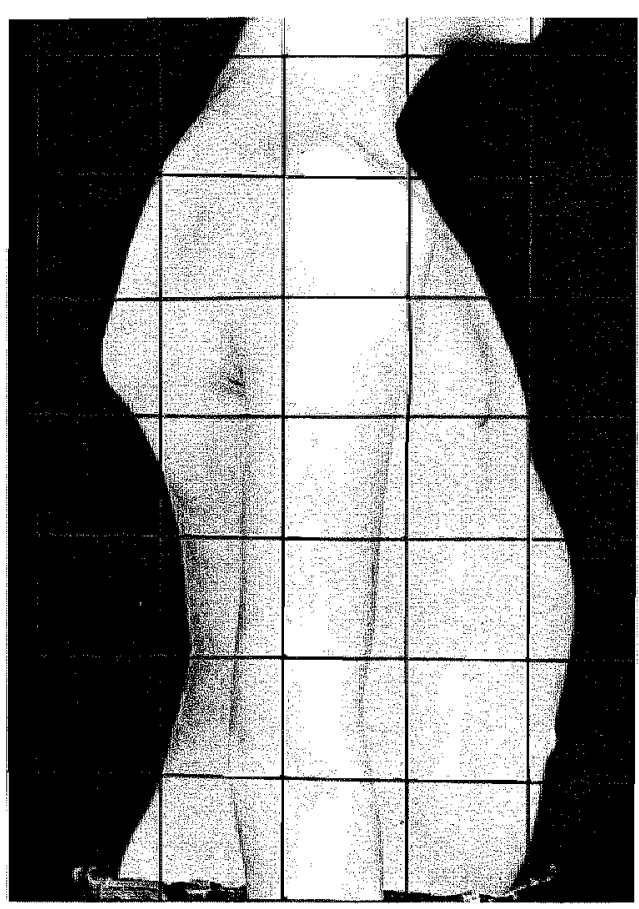

R.d.W. Préoperatieve kyfose 
Patient 14. M.N.-B. vrouwelijk, geb. dat. 3-4-1946.

Aetiologie:

Congenitale kyfoscoliose hoog thoracaal, waarschijnlijk ten gevolge van een halfwervel, met toenemende myelumcompressie. Status na laminectomie $\mathrm{T} 2 \mathrm{t} / \mathrm{m} \mathrm{T}$.

Vroegere behandeling:

Als klein kind een gipsbed. Op 7-jarige leeftijd klompvoetoperatie rechts. Op 11 -jarige leeftijd partiële scapularesectie rechts. Op 12-jarige leeftijd een epifysiodese van de linker knie. Na een val op dezelfde leeftijd trad een dwarslaesiebeeld op, waarvoor laminectomie werd verricht $\mathrm{T} 2 \mathrm{t} / \mathrm{m}$ T6. Hierna trad verbetering op. Tussen het $12 \mathrm{e}$ en $17 \mathrm{e}$ levensjaar werd een Milwaukee brace gedragen "is fysiotherapie gegeven alsmede pijnstillende middelen. Op 21-jarige leeftijd werd een osteotomie van de le straal van de rechter voet verricht.

Klachten:

Toenemende krachtsvermindering van het linker been met paraesthesieën. Bestaat sinds 1 jaar. Ook lage rugpijn en vegetatieve stoornissen, zoals versterkt zweten en hartkloppingen. Dyspnoe d'effort.

Préoperatieve curves:

Scoliose T1 t/m T6 115 . Plan delection $117^{\circ}$ (dit is een uitgedraaide opname). Kyfose $\mathrm{T} 2 \mathrm{t} / \mathrm{m} \mathrm{T} 71.45^{\circ}$.

Voorbehandeling:

Geen tractie. Dit werd in verband met de myelumcompressie te gevaarlijk geacht en er werd weinig correctie van verwacht.

Longfunctie:

Vit. cap. 1625 cc. Normaal 3750 cc. Tot. cap. 2325 cc. Normaal $4875 \mathrm{cc}$.

Conclusie:

Flinke restrictieve functiestoormis met weinig reserves.

Neurologisch onderzoek:

Myelografie:

Pyramidaal syndroom linker been door thoracale myelumdysfunctie.

Geen totale stop, wel afplatting van het myelum.

Operatie:

26-2-1980. Thoracotomie rechts via $3 \mathrm{e}$ rib met omklappen van de scapula naar ventraal. De 2 e rib werd doorgenomen bij de processus transversus om de toegang te vergroten. Discectomie T1-2, T7-8 en T8-9 en columnotomie op de tussenliggende niveaus. Opspouwen en plaatsen van fibulaspanen en Slot/Zielke staafje. 
Complicaties:

Nabehandeling:

Postoperatieve curves:

Postoperatieve klachten:
Mogelijke schroefbreuk.

4 maanden Halo-rompgips, waarna 5 maanden gipscorset.

Plan d'election $90^{\circ}$. Geen kyfose foto gemaakt.

Na de operatie zijn de armen in kracht verminderd. De benen zijn onveranderd, evenals de vegetatieve stoornissen. Neurologisch onderzoek laat geen verandering zien ten opzichte wan de préoperatieve situatie. Ook nu is er geen verklaring voor de vegetatieve stoornissen.

Bij laatste controle d.d. 31-3-1983 waren er meer tintelingen en minder kracht in het linker been. Patiënte kon niet langer dan 10 minuten lopen. Van de rug zelf waren er geen klachten, de kracht in de armen was niet verminderd. Een planigram toonde een mogelijke schroefbreuk, de spondylodese leek vast, de correctie was gehandhaafd. Omdat patiënte zich thuis niet meer goed kon helpen werd ze in juni 1983 in een revalidatiecentrum opgenomen, waaruit ze in februari 1984 naar huis ontslagen werd, nog evenzeer gehandicapt, maar toch zeer tevreden door een beter ziekte-inzicht- en acceptatie, alsmede een positievere levensvisie.

\section{Beschouwing en conclusie:}

Deze ernstige kyfoscoliose bevindt zich op een bijzonder ongunstige plaats. Hoog thoracaal is het spinaalkanaal nauw, zodat myelumcompressie hier eerder zal optreden dan lager in de wervelkolom. Wegens verslechtering van het neurologisch beeld was stabilisatie van de curve noodzakelijk. Een achterste ingreep was niet goed mogelijk door de vroegere laminectomie. Een hoog thoracale voorste spondylodese is technisch zeer moeilijk door de ligging van de scapula, welke de toegang bemoeilijkt en de geringe ruimte welke hoog in de thoraxkoepel aanwezig is. Desondanks lijkt een goede stabilisatie van de deformiteit verkregen. Het neurologisch beeld verbeterde echter niet. Mogelijk dat de versterkte cervicale lordose met degeneratieve veranderingen mede oorzaak van vegetatieve klachten is, bij laatste neurologisch onderzoek in mei $1983 \mathrm{kon}$ echter geen duidelijke verklaring voor deze klachten gevonden worden. 


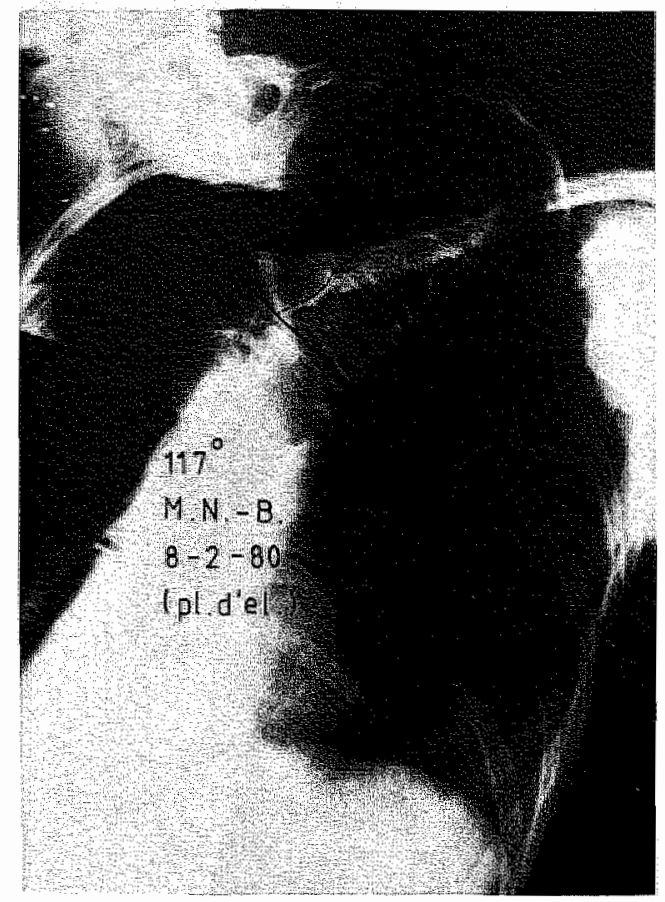

Scoliose en plan d'election préoperatief

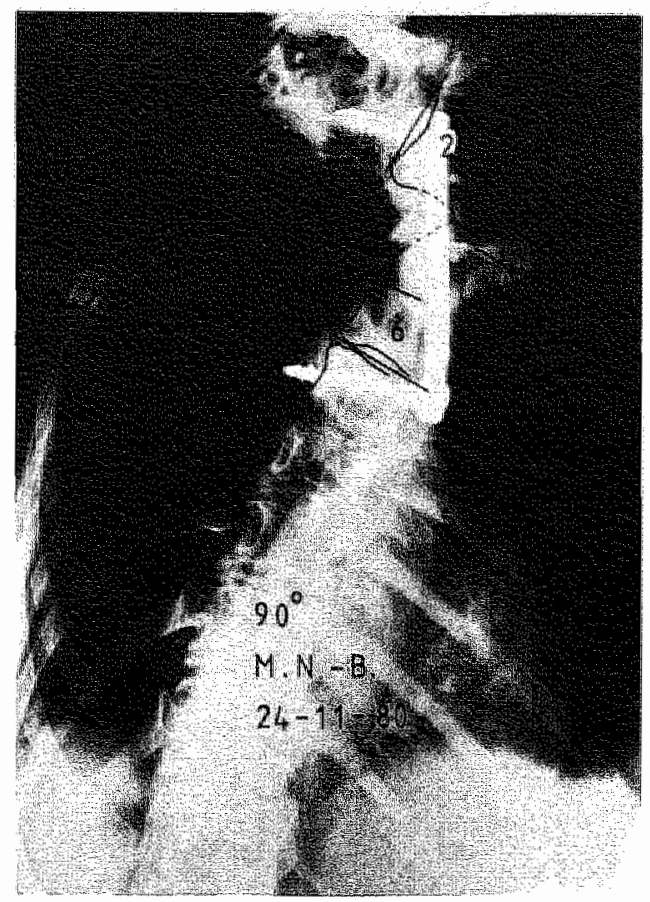

Kyfoscoliose postoperatief

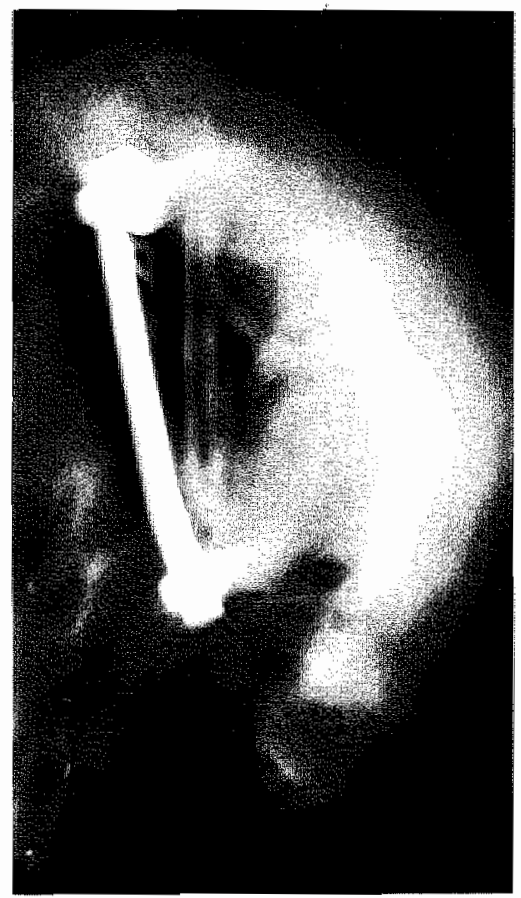

Consolidatie op planigram 


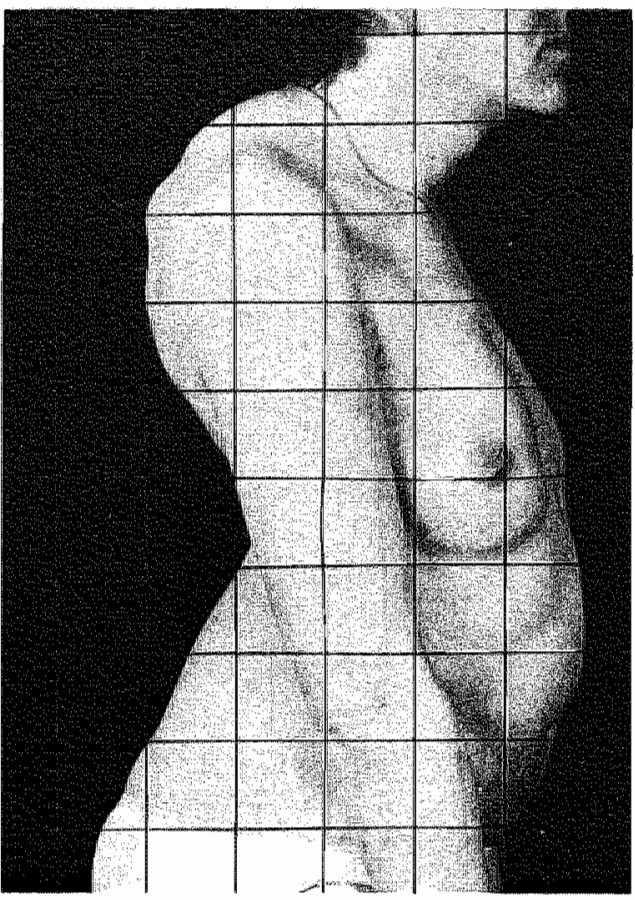

M.N.-B. Kyfose préoperatief

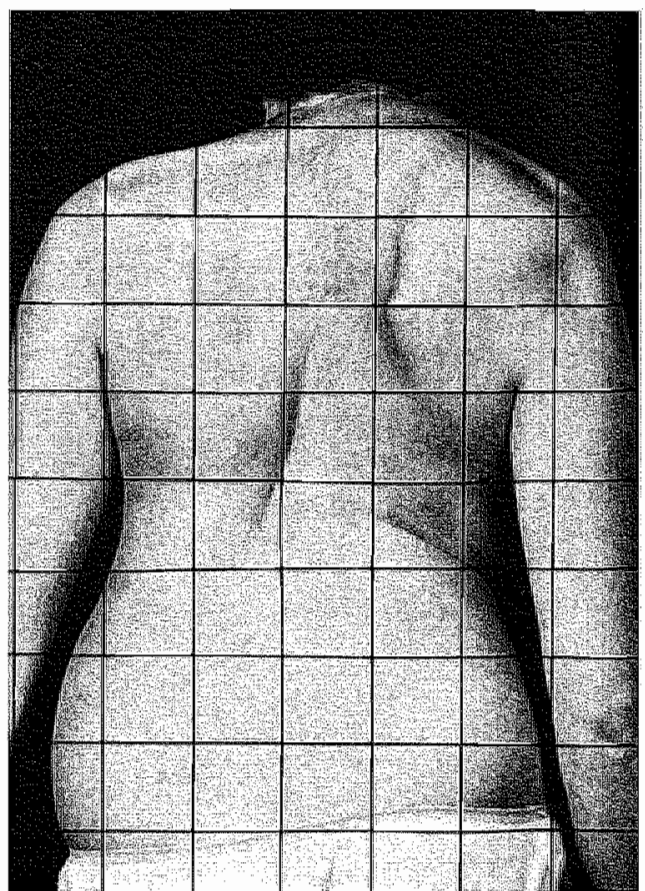

M.N.-B. Scoliose préoperatief

Geen postoperatieve medische foto's 


\section{PARALYTISCHE KYFOSEN EN KYFOSCOLIOSEN}

\subsection{Inleiding}

Door neuro-musculaire aandoeningen kan de wervelkolom een groot gedeelte van zijn stabiliteit verliezen. De musculatuur van de rug is naast de ligamenten en gewrichten immers van evident belang bij het in stand houden van de samenhang van de wervelkolom. $\mathrm{Bij}$ asymmetrische parese van de rugspieren ontstaat meestal een scoliose, vaak gecombineerd met versterkte lordose of kyfose. Bij dubbelzijdige parese kan de wervelkolom kyfoseren, de zogenaamde collapsing spine $(6,9,10,14,25)$. Soms ontstaat juist lordose zoals bij spierdystrofie patiënten $(21,33)$. Bij niet-ambulante patiënten bepaalt de houding in de rolstoel of in bed vaak de richting van de progressieve verkromming. Ook spelen contracturen een rol en eenzijdige heupluxatie (9). Moe geeft de volgende, uitgebreide indeling van neuro-musculaire aandoeningen (17):

\section{A. Neuropathieën}

1. Upper motor neuron aandoeningen
a. Spastische beelden (cerebral palsy)
b. Spino-cerebellaire degeneratie
- Friedreichse ataxie
- z.v. Charcot-Marie-Tooth
- z.v. Roussy-Levy
c. Syringomyelie
d. Myelumtumor
e. Myelumtrauma

2. Lower motor neuron aandoeningen
a. Poliomyelitis
b. Andere virale myelitis
c. Traumatisch
d. Spinale spieratrofie
- z.v. Werdnig-Hoffman
- z.v. Kugelberg-Welander
e. Dysautonomie (Riley-Day)

B. Myopathieën

1. Arthrogryposis

2. Spierdystrofie
a. Duchenne (pseudohypertrofisch)
b. Been-bekkentype
c. Facio-scapulo-humerale type

3. Fibertype disproportion

4. Congenitale hypotonie

5. Myotonia dystrophica 
De deformiteiten welke optreden zijn meestal langgerekt, er ontstaat bij rolstoelpatiënten vaak ernstige bekkenscheefstand en desequilibratie $(8,9,14)$. Door deze bekkenscheefstand verliest de patiënt zijn zitbalans en moet de handen gebruiken om zich rechtop te houden. Door ongelijke krachtenverdeling op de zitbeenderen dreigt decubitus. De longfunctie, welke al precair kan zijn, wordt door de scoliose nog verslechterd met alle gevolgen van dien $(22,23,26)$. De curves zijn in het begin vaak soepel, kunnen goed geredresseerd worden door tractie, maar zakken door de zwaartekracht weer in elkaar. Dit ziet men meest bij slappe verlammingen zoals poliomyelitis of traumatische paraplegie $(15,16,18)$. Bij spastische beelden treden eerder rigide scoliosen op $(5,12$, 14). Kyfosering van een scoliose kan optreden als de apex van de curve $90^{\circ}$ of meer geroteerd is. Thoracaal komen de intergewrichten van het frontale in het sagittale vlak te liggen, waardoor de rotatiekyfose gemakkelijker versterkt kan worden onder invloed van de lichaamskrachten. Lumbaal komen de intergewrichten bij een ernstige scoliose met ongeveer $90^{\circ}$ rotatie juist van het sagittale in het frontale vlak te liggen. De lumbale wervels kunnen dan zijdelings van elkaar afglijden, het zogenaamde drehgleiten (27, $28,34)$. Er zijn hier geen ribben om de zijdelingse krachten te neutraliseren. Bij de rotatie van een lumbale scoliose draait de curve vaak uit zijn lordose weg en het komt tot kyfosering, waarbij de lichaamsas voor de lumbale wervelkolom komt te liggen. Juist de kyfotische component kan hierdoor verergeren. Hetzelfde mechanisme vindt ook bij idiopatische lumbale scolioses plaats. Ook ernstige lordoscolioses kunnen optreden, waarbij de lordose vaak geïnduceerd wordt door contracte heupflexoren (9). Bij paraplegie op de kinderleeftijd treedt bijna altijd een wervelkolomdeformiteit op, vaak in lordose, maar ook kyfosering van de wervelkolom kan optreden $(9,10,16)$.

\subsection{Behandeling}

Bij beginnende paralytische curves kan met brace-therapie getracht worden de progressie te stoppen. Voor thoracale curves wordt het Milwaukee brace of een hoog opgebouwd kunststof brace aanbevolen, voor lagere curves kan een brace gebruikt worden zonder opbouw tot aan het hoofd $(7,8,19,23,24)$. Problemen kunnen ontstaan door anaesthesie van de huid, adipositas of beperkte longfunctie. Vaak zijn paralytische curves progressief ondanks de brace-therapie $(3,22)$ of wordt de patiënt pas gezien als deze al een ernstige deformiteit heeft ontwikkeld, waardoor de vaak al beperkte longfunctie nog meer achteruit is gegaan, zoals bij spierdystrofie aandoeningen (8). Viteindelijk zal vaak operatie aangewezen zijn om de spinale stabiliteit te herstellen. Men kan dit dan beter in een niet al te laat stadium doen omdat bij ernstiger curves de kans op complicaties toeneemt en de correctie minder zal zijn door toegenomen rigiditeit $(7,23$, 24).

Bij thoracale scolioses kan met een Harringtonspondylodese volstaan worden. Is er een ernstige kyfosering bij opgetreden dan zal de staaf voor het kyfotische traject moeten worden gebracht, zodat deze in de belastingslijn loopt. Buigt men de staaf teveel om de kyfose te volgen, dan bestaat meer kans op uitbreken van de haakjes. Stagnara verwijdert enkele ribhalsjes in de concaviteit, de zogenaamde chevalet costal, om de Harringtonstaaf intrathoracaal, maar retropleuraal te laten verlopen, zodat de axiale belastingslijn gevolgd wordt $(28,34)$. Complicaties zoals haematothorax zijn hiermee beschreven, terwijl deze techniek alleen in de meest ernstige gevallen nodig lijkt te zijn. Bij de thoracolumbale en lumbale kyfo- of lordoscoliose komt de voorste derotatiespon- 
dylodese volgens Dwyer of Zielke in aanmerking, waarmee de curve niet alleen beter gecorrigeerd kan worden dan met het Harringtonmateriaal, maar warmee ook een volledig herstel van de bekkenscheefstand en daarmee van de zitbalans vaak mogelijk is $(2,5,11,12,15,18,27,29)$. Een aanvullende achterste Harringtonspondylodese is hierna niet altijd nodig. Voor thoracale curves is de Dwyer of Zielke methode minder geschikt, omdat de wervellichamen hier veel kleiner zijn en het bereikte traject middels een thoracotomie meestal te klein is om de volledige curve te instrumenteren. Fusies tot en met het sacrum zijn geïndiceerd bij curves over de totale lengte van de wervelkolom, zoals bij spierdystrofieën, poliomyelitis of spina bifida.

Een probleem bij de nabehandeling is de postoperatieve immobilisatie. Gips of andere rigide immobilisatie is gevaarlijk bij slechte of afwezige sensibiliteit door de kans op decubitus. Een afneembaar kunststof corset, waardoor dagelijks de huid geïnspecteerd kan worden lijkt een goede oplossing (23). Op het ogenblik maakt de methode van Luque opgang bij paralytische, maar ook wel bij idiopathische curves. Hierbij worden 2 voorgebogen metalen staven tegen alle laminae van het betrokken traject aangebracht middels cerclages, die onder de laminae worden doorgehaald. De kans op neurologische complicaties lijkt bij deze methode echter hoger te zijn dan met de conventionele technieken. De interne stabiliteit is dan echter meestal zodanig dat postoperatieve externe immobilisatie onnodig is $(1,13,32)$.

In het algemeen geldt voor paralytische curves dat ze bijna altijd progressief zijn, vaak ondanks bracebehandeling, en niet te laat operatief gestabiliseerd moeten worden.

\subsection{Literatuur hoofdstuk 4}

1. Aprin H. Bowen J. R. MacEwen G. D. Hall J. E. Spine fusion in patients with spinal muscular atrophy. Journ. of Bone and Joint Surg. 64A, 1982, 1179-1187.

2. Bonnett C. Brown J. C. Brooks H. L. Anterior spine fusion with Dwyer instrumentation for lumbar scoliosis in cerebral palsy. Journ. of Bone and Joint Surg. 55A, 1973, 425.

3. Bonnett C. Brown J. C. Perry J. Nickel V. L. Walinski T. Brooks L. Hoffer M. Stiles C. Brooks R. Evolution of treatment of paralytic scoliosis at Rancho Los Amigos Hospital. Journ. of Bone and Joint Surg. 57A, 1975, 206-215.

4. Brown J. C. Perry J. Thoracic lordosis following long posterior spine fusions for paralytic scoliosis. Journ. of Bone and Joint Surg. 56A, 1974 442.

5. Brown J. C. Swank S. Specht L. Combined anterior and posterior spine fusion in cerebral palsy. Spine 7, 1982, 570-573.

6. Bunch W. H. Smith D. Hakala M. Kyphosis in the paralytic spine. Clin. Orthop. $128,1977,107-112$.

7. Evans G. A. Drennan J. C. Russman B. S. Functional classification and orthopaedic management of spinal muscular atrophy. Journ. of Bone and Joint Surg. 63B, $1981,516-522$. 
8. Hensinger R. N. MacEwen G. D. Spinal deformity associated with heritable neurological conditions: spinal muscular atrophy. Friedreich's ataxia, familial dysautonomia and Charcot-Marie-Tooth disease. Journ. of Bone and Joint Surg. 58A, 1976, $13-24$.

9. Kilfoyle R. M. Foley J. J. Norton P. L. Spine and pelvic deformity in childhood and adolescent paraplegia. Journ. of Bone and Joint Surg. 47 A, 1965, 659-682.

10. Lancourt J. E. Dickson J. H. Carter R. E. Paralytic spinal deformity following traumatic spinal-cord injury in children and adolescents. Journ. of Bone and Joint Surg. 63A, 1981, 47-53.

11. Leong J. C. Y. Wilding K. Mok C. K. Ma A. Chow S. P. Yau A. C. M. C. Surgical treatment of scoliosis following poliomyelitis. Journ. of Bone and Joint Surg. 63A, $1981,726-740$.

12. Lonstein J. E. Akbarnia B. A. Operative treatment of spinal deformities in patients with cerebral palsy or mental retardation. Journ. of Bone and Joint Surg. $65 \mathrm{~A}, 1983,43-55$.

13. Luque E. R. Paralytic scoliosis in growing children. Clin. Orthop. 163, 1982, 202209.

14. Madigan R. R. Wallace J. L. Scoliosis in the institutionalized cerebral palsy population. Spine 6, 1981, 583-590.

15. Mayer P. J. Dove J. Ditmanson M. Shen Y. S. Post-poliomyelitis paralytic scoliosis. Spine 6, 1981, 573-582.

16. Mayfield J. K. Erkkila J. C. Winter R. B. Spine deformity subsequent to acquired childhood spinal cord injury. Journ. of Bone and Joint Surg. 63A, 1981, 1401-1411.

17. Moe J. H. Winter R. B. Bradford D. S. Lonstein J. E. Scoliosis and other spinal deformities. W. B. Saunders Company Philadelphia 1978.

18. O'Brien J. P. Dwyer A. P. Hodgson A. R. Paralytic pelvic obliquity. Its prognosis and management and the development of a technique for full correction of the deformity. Journ. of Bone and Joint Surg. 57A, 1975, 626-631.

19. Riddick M. F. Winter R. B. Lutter L. D. Spinal deformities in patients with spinal muscle atrophy. A review of 36 patients. Spine 7, 1982, 476-483.

20. Robin G. C. Brief L. P. Scoliosis in childhood muscular dystrophy. Journ. of Bone and Joint Surg. 53A, 1.971, 466-476.

21. Sakai D. N. Hsu J. D. Bonnett C. A. Brown J. C. Stabilization of the collapsing spine in Duchenne muscular dystrophy. Clin. Orthop. 128, 1977, 256-260. 
22. Schwentker E. P. Gibson D. A. The orthopaedic aspects of spinal muscular atrophy. Journ. of Bone and Joint Surg. 58A, 1976, 32-38.

23. Shapiro F. Bresnan M. J. Orthopaedic management of childhood neuromuscular disease. Part I: Spinal muscular atrophy. Journ. of Bone and Joint Surg. 64A, 1982. $785-789$.

24. Shapiro F. Bresnan M. J. Orthopaedic management of childhood neuromuscular disease. Part II: Peripheral neuropathies, Friedreich's ataxia and arthrogryposis multiplex congenita. Journ. of Bone and Joint Surg. 64A, 1982, 949-953.

25. Siegel I. M. Scoliosis in muscular dystrophy. Clin. Orthop. 93, 1973, 235-238.

26. Silva W. J. Rucker R. W. Ewald B. A. Preoperative pulmonary assessment in pediatric neuromuscular disease. Anesthesiology Review 9, 1982, 35-42.

27. Slot G. H. Surgical treatment of spinal deformity resulting from neuro-muscular disorders. Acta Orthop. Belgica 42, 1976, 373-386.

28. Stagnara P. Mauroy J. C. de. Gonon G. Campo-Paysaa A. Scolioses cyphosante de l'adulte et greffes antérieures. Int. Orthop. 2, 1978, 149-165.

29. Stanitski C. L. Micheli L. J. Hall J. E. Rosenthal R. K. Surgical correction of spinal deformity in cerebral palsy. Spine 7, 1982, 563-569.

30. Sullivan J. A. Conner S. B. Comparison of Harrington instrumentation and segmental spinal instrumentation in the management of neuromuscular spinal deformity. Spine 7, 1982, 299-304.

31. Swank S. M. Brown J. C. Perry R. E. Spinal fusion in Duchenne's muscular dystrophy. Spine 7, 1982, 484-491.

32. Taddonio R. F. Segmental spinal instrumentation in the management of neuromuscular spinal deformity. Spine 7, 1982, 305-311.

33. Wilkins K. E. Gibson D. A. The patterns of spinal deformity in Duchenne muscular dystrophy. Journ. of Bone and Joint Surg. 58A, 1976, 24-32.

34. Zielke $\mathbb{K}$. Pellin B. Ergebnisse operativer Skoliosen-und Kyphoskoliosen-Behandlung bei Adoleszenten über 18 Jahre und beim Erwachsenen. Zeitschr. Für Orthopädie 113, 1975, 157-174.

35. Zielke K. Ventrale Derotationsspondylodese. Behandlungsergebnisse bei idiopathischen lumbalskoliosen. Zeitschr. für Orthopädie 120, 1982, 320-329. 


\subsection{Patiëntenbeschrijvingen bij paralytische kyfosen}

Patiènt 15. J. B.-I. vrouwelijk, geb. dat. 14-8-1944.

Aetiologie:

Vroegere behandeling:

Klachten:

Préoperatieve curve:

Voorbehandeling:

Longfunctie:

Conclusie:

Neurologisch onderzoek:

Operaties:

Complicaties:

Nabehandeling:
Paralytische kyfoscoliose na wroegere poliomyelitis met tassement en cyphose (doorzakken in kyfose).

Epifysiodese linker knie. Orthopaedisch corset. De mobiliteit is normaal.

Onbalans, voelt zich in elkaar zakken. Dyspnoe d'effort. Rugpijn laag lumbaal.

Scoliose T1 $1 \mathrm{t} / \mathrm{m} \mathrm{L} 3102^{\circ}$. Tractie ongeveer $75^{\circ}$. Kyfose $\mathrm{T} 9 \mathrm{t} / \mathrm{m} \mathrm{L} 280^{\circ}$.

Geen.

Vit. cap. $3200 \mathrm{cc}$, normaal $4250 \mathrm{cc}$. Tot. cap. 4025 $\mathrm{cc}$, normaal $5550 \mathrm{cc}$.

Duidelijke restrictie met nog ruime ventilatoire reserves.

Lichte parese rechter been, met name adductoren- en abductoren-zwakte ten gevolge van de vroegere poliomyelitis.

1. 1-12-1975. Spondylodese volgens Dwyer T11 $\mathrm{t} / \mathrm{m}$ L4.

2. 6-1-1976. Excisie fistelgang van operatiewond.

3. 3-2-1976. Achterste Harrington spondylodese met dwarstractie $\mathrm{T} 8 \mathrm{t} / \mathrm{mL} L$.

4. 10-3-1978. Revisie achterste spondylodese wegens pseudarthrose met staafbreuk.

Fisteling na $1 \mathrm{e}$ operatie genezen na $2 \mathrm{e}$ operatie. Pseudarthrose en staafbreuk.

$\mathrm{Na}$ 1e operaties 9 maanden gipscorset, na de revisie operatie $81 / 2$ maand gipscorset. 


$\begin{array}{lll} & \text { Scoliose } & \text { Kyfose } \\ \mathrm{Na} \text { operatie 1 } & 65^{\circ} & 35^{\circ} \\ \mathrm{Na} \text { operatie 3 } & 49^{\circ} & \text { niet gemeten } \\ \mathrm{Na} 3 \text { maanden } & 49^{\circ} & 48^{\circ} \\ \mathrm{Na} 6 \text { maanden } & 46^{\circ} & 65^{\circ} \\ \mathrm{Na} 9 \text { maanden } & 51^{\circ} & 48^{\circ} \\ \mathrm{Na} 13 \text { maanden } & 62^{\circ} & 58^{\circ} \\ \mathrm{Na} 18 \text { maanden } & 64^{\circ} & 70^{\circ} \\ \mathrm{Na} 24 \text { maanden } & 65^{\circ} & 73^{\circ} \\ \text { Pseudarthrose en staafbreuk. } & \\ \mathrm{Na} \text { operatie 4 } & 43^{\circ} & 36^{\circ} \\ \mathrm{Na} 2 \text { weken } & 50^{\circ} & 44^{\circ} \\ \mathrm{Na} 2 \text { maanden } & 50^{\circ} & \text { niet gemeten } \\ \mathrm{Na} 5 \text { maanden } & 50^{\circ} & \text { niet gemeten } \\ \mathrm{Na} 9 \text { maanden } & 52^{\circ} & 42^{\circ} \\ \mathrm{Na} 14 \text { maanden } & 56^{\circ} & \text { niet gemeten } \\ \mathrm{Na} 21 \text { maanden } & 52^{\circ} & \text { niet gemeten } \\ \mathrm{Na} 34 \text { maanden } & 55^{\circ} & 43^{\circ}\end{array}$

Postoperatieve klachten:

De rugpijn is verdwenen, patiënte voelt zich goed in balans. De dyspnoe is verminderd, maar niet verdwenen. Haar adipositas lijkt hier ook een rol bij te spelen.

Beschouwing en conclusie:

Adequate behandeling van deze adipeuze vrouw met een ernstige thoracolumbale kyfoscoliose bleek zeer moeilijk. De Dwyerprocedure gaf behoorlijke correctie, maar er bleef teveel kyfose, in mindere mate scoliose bestaan. Het Dwyersysteem is de afgelopen jaren ook minder succesvol gebleken in het corrigeren van de kyfotische component van een rugdeformiteit, het Zielkesysteem kan dit beter corrigeren. De Harrington operatie voegde qua correctie weinig aan de eerste operatie toe. De vooral kyfotische krachten induceerden een pseudarthrose, de Dwyer kabel hield terugzakken van de werveikolom in kyfose niet tegen. Na revisie van de pseudarthrose lijkt nu consolidatie verkregen. 


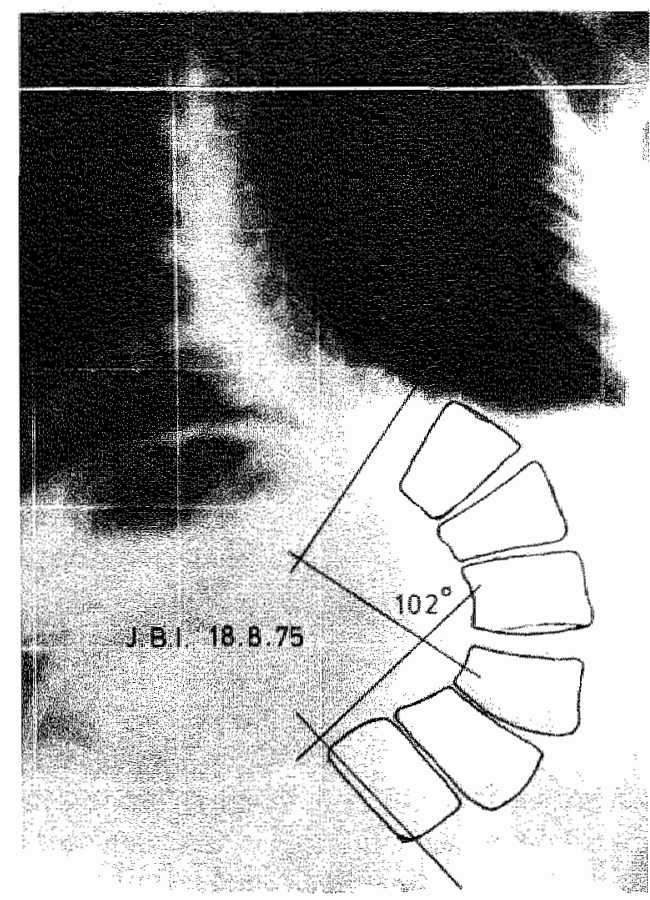

Scoliose préoperatief

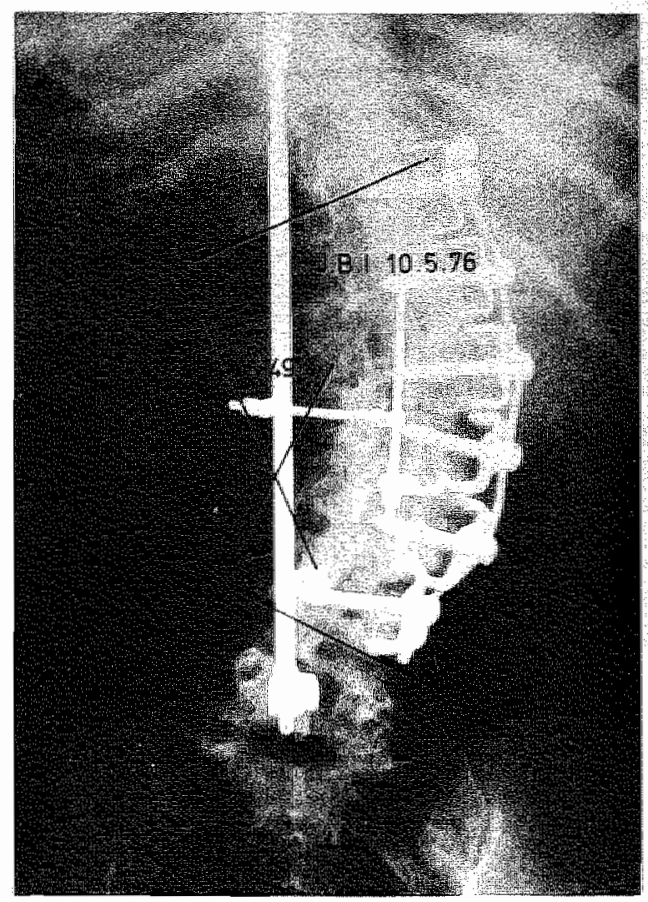

Scoliose postoperatief 3 e operatie

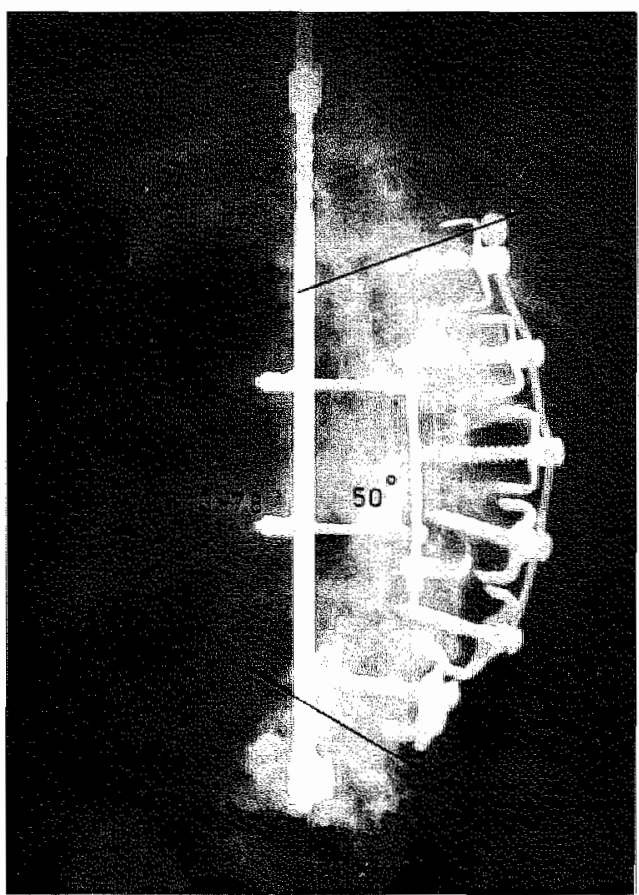

Scoliose na revisie operatie wegens pseudarthrose 


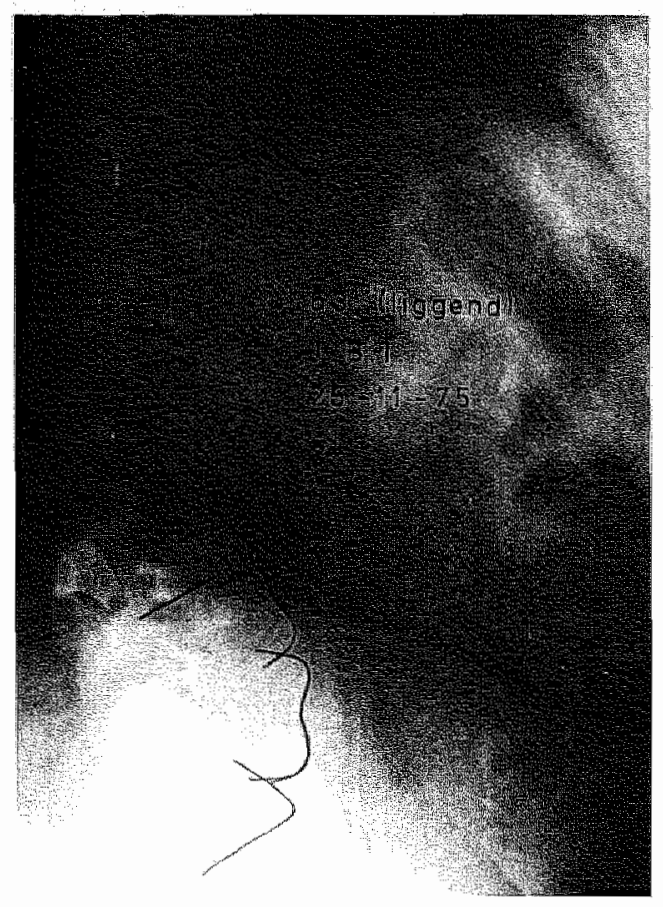

Kyfose préoperatief

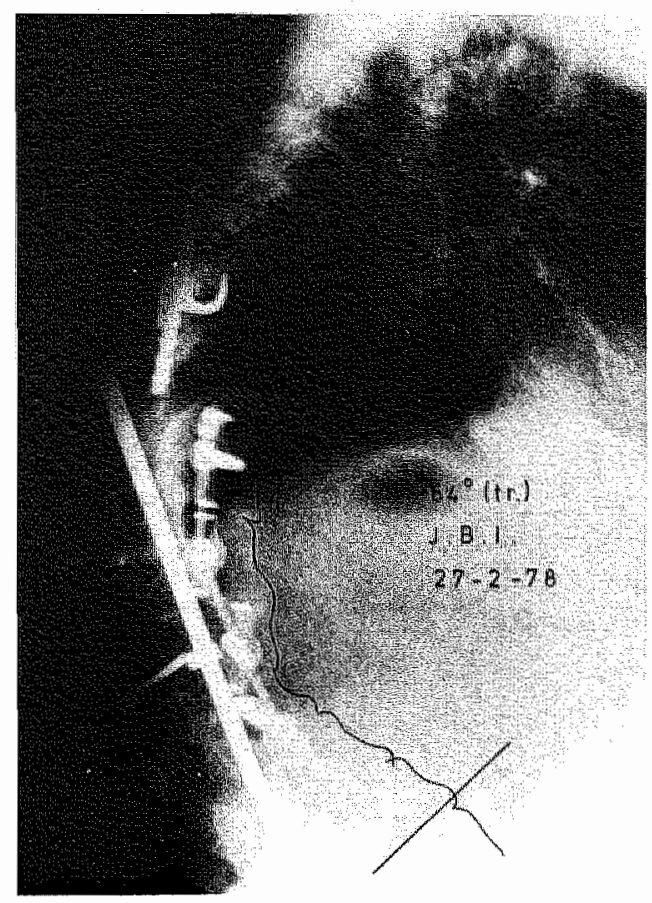

Staafbreuk t.g.v. pseudarthrose Opnieuw tassement en cyphose

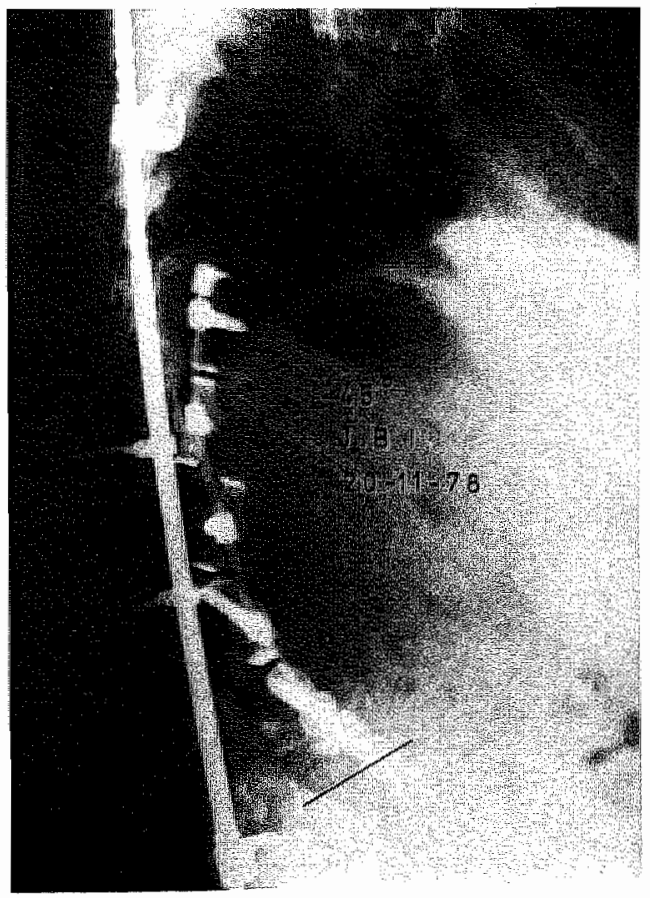

Kyfose na laatste operatie 


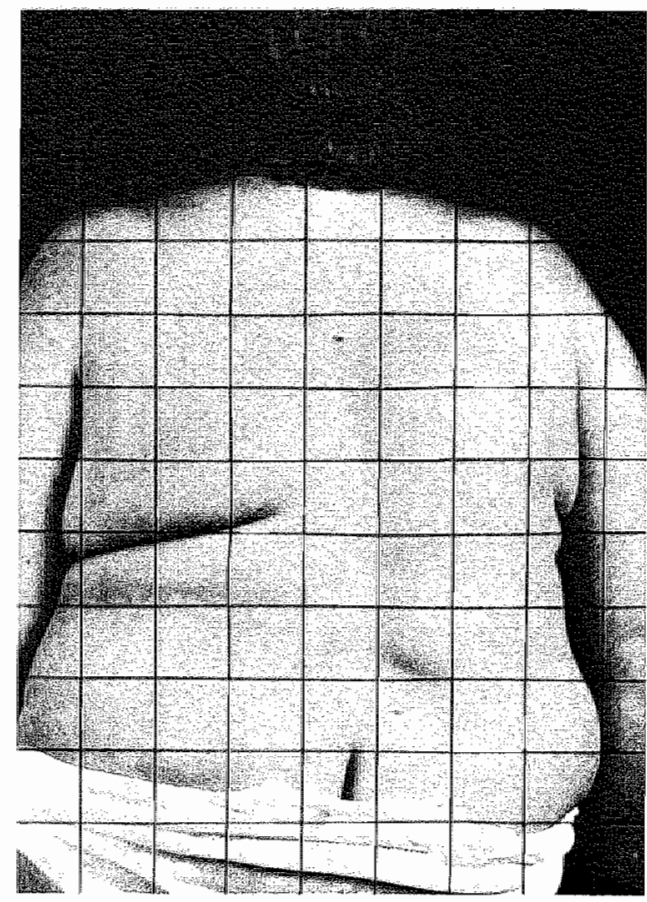

J.B.-I. Scoliose préoperatief

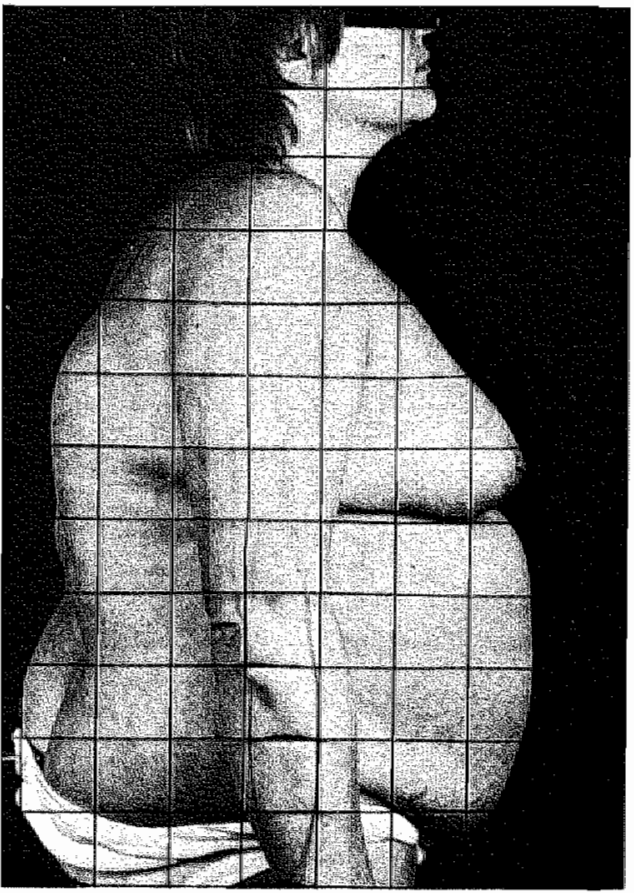

J.B.-I. Kyfose préoperatief

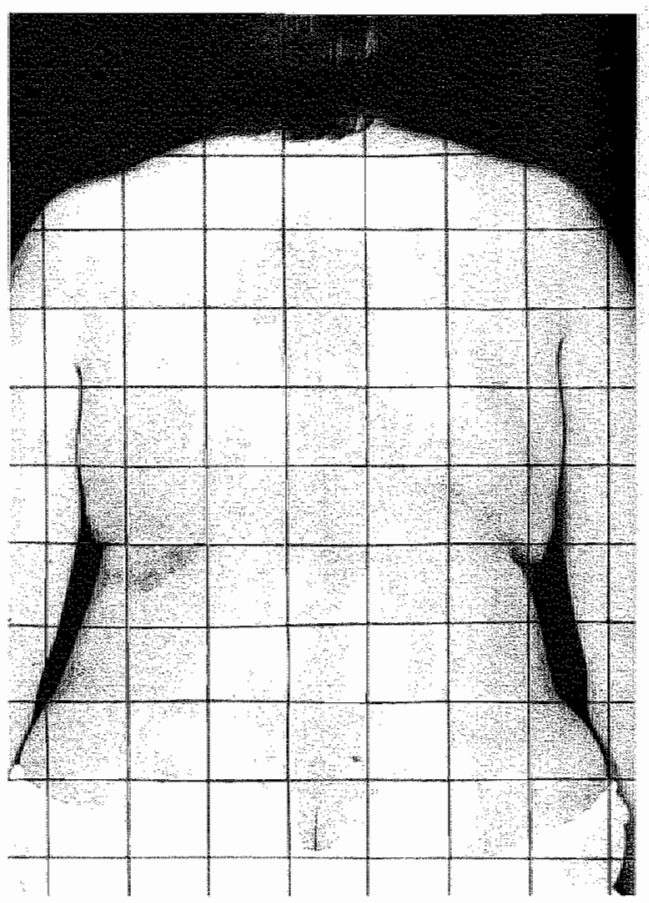

J.B.-I. Scoliose postoperatief

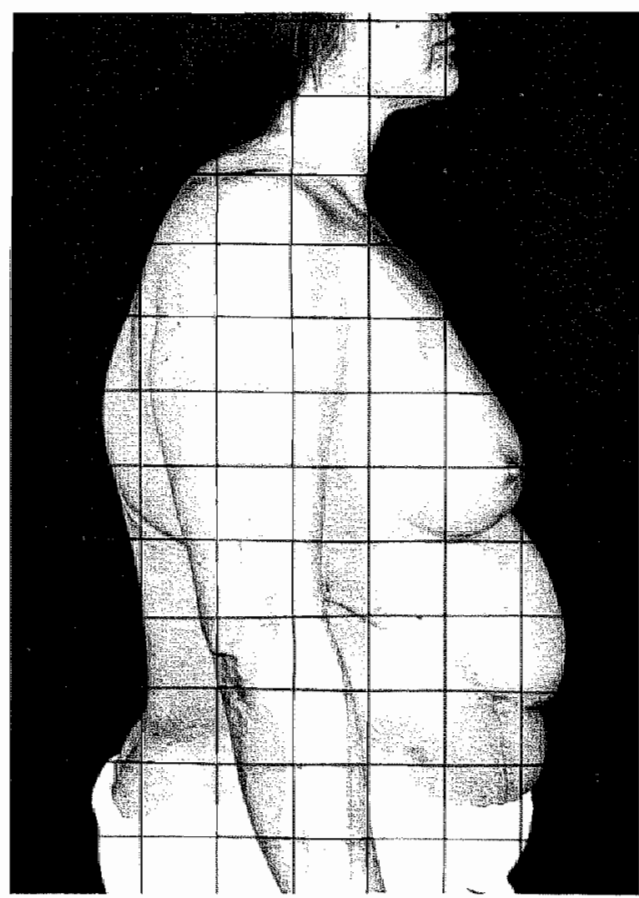

J.B.-I. Kyfose postoperatief 


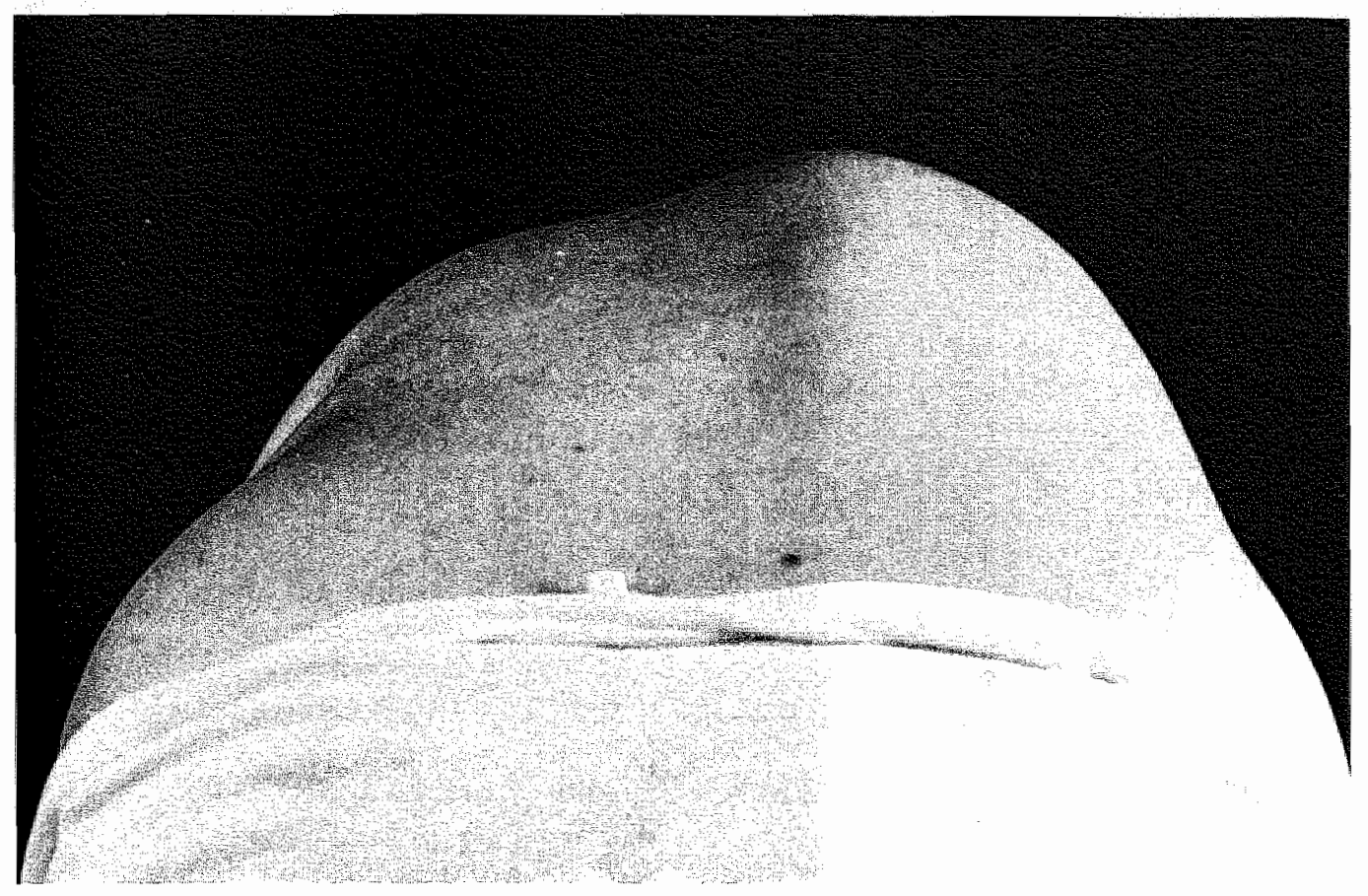

\section{J.B.-I. Gibbus préoperatief}

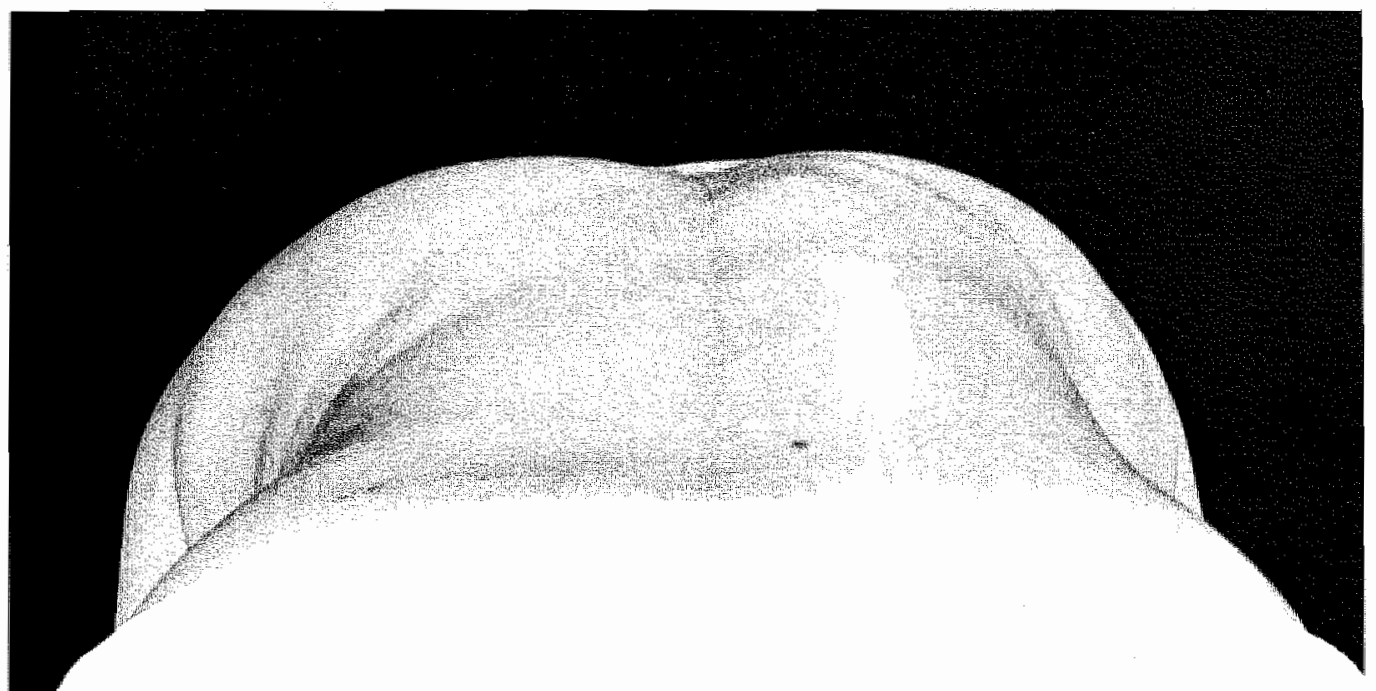

J.B.-I. Gibbus postoperatief 
Patient 16. P. V. mannelijk, geb. dat. 27-09-1950.

Aetiologie:

Vroegere behandeling:

Klachten:

Préoperatieve curves:

Voorbehandeling:

Longfunctie:

Conclusie:

Neurologisch onderzoek:

Operatie:

\section{Complicaties:}

Nabehandeling:

Postoperatieve curves:

Postoperatieve klachten:
Kyfoscoliose na poliomyelitis.

9-1-1959. Spondylodese T12 t/m sacrum met behulp van kalfsbot. 14-12-1959. Spondylodese T5 $\mathrm{t} / \mathrm{m}$ T12 met kalfsbot. 21-2-1966. Columnotomie L1-L2 via costotranswersectomie T12 en respondylodese wegens pseudarthrose en sterke onbalans. Patiënt kon hierna lopen met een bekkenkorf, beugelapparaat en krukken. In 1975 „klapte patiënt in elkaar” bij boogschieten, waarna hij volledig verlamd was en niet meer kon lopen.

Pijnklachten lumbaal. Slechte zitbalans. Druk van de rechter ribbenboog op het bekken.

Scoliose T10 t/m L1 73․ Kyfose T10 t/m L3 $93^{\circ}$.

2 weken Halo-rolstoeltractie.

Vit. cap. $3425 \mathrm{cc}$, normaal $6425 \mathrm{cc}$. Tot. cap. 5150 $\mathrm{cc}$, normaal $8350 \mathrm{cc}$.

Onmiskenbare restrictie met nog ruime ventilatoire reserves.

Resttoestand na poliomyelitis en kyloscoliose. Aan de benen geen functie meer. Volledige atrofie en areflexie. Sensibiliteit intact.

5-8-1977. Achterste respondylodese met behulp van Harrington-distractiestaaf. Kalfsbot niet geconsolideerd. Pseudarthrose ter hoogte van de vroegere columnotomie.

Postoperatieve nabloeding zonder verder gevolg.

9 maanden gipscorset, waarna orthopaedisch corset.

Scoliose $59^{\circ}$, kyfose $52^{\circ}$. Deze waarden zijn constant gebleven tot de laatste controle op 19-3-1979.

Met corset goed in balans. Na meer dan 5 uur zitten sterke vermoeidheid en pijnklachten onder in de rug. Ribbenboogpijn is verdwenen. 
Door de ernstige disbalans en collaps van de wervelkolom in kyfose werd deze jongeman sterk belemmerd in zijn dagelijkse bezigheden en ook in zijn sportbeoefening, met name het handboogschieten. De handen moeten dan gebruikt worden om het lichaam niet te doen omvallen. Ook de pijnklachten waren zeer hinderlijk. Door middel van deze revisieprocedure is hij aanzienlijk verbeterd, al is de balans niet volledig hersteld. Het blijft gezien de resterende kyfose de vraag of het niet beter was geweest een voorste strutgrafting toe te voegen. De toekomst zal dit leren. Deze casus illustreert de problemen die ontstaan bij 2 afzonderlijk gespondylodeseerde trajecten, waarbij op de grens, meestal thoracolumbaal, een pseudarthrose optreedt en vervolgens kyfosering. 


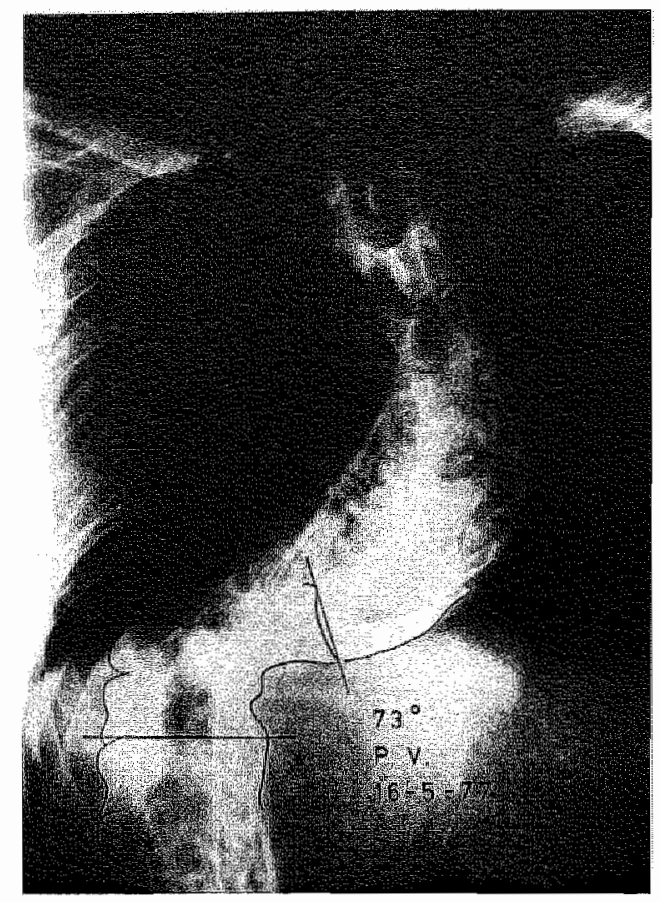

Scoliose préoperatief

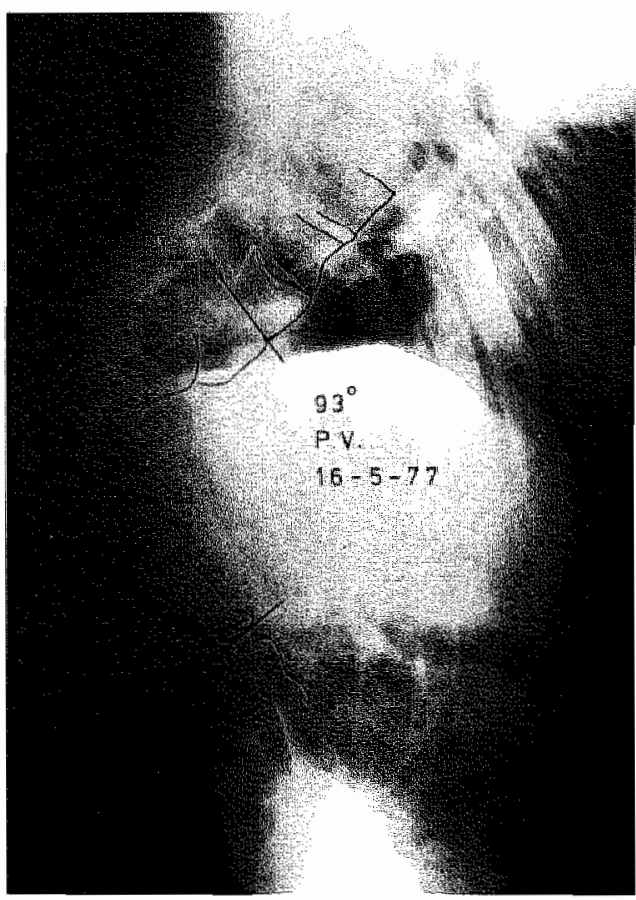

Kyfose préoperatief

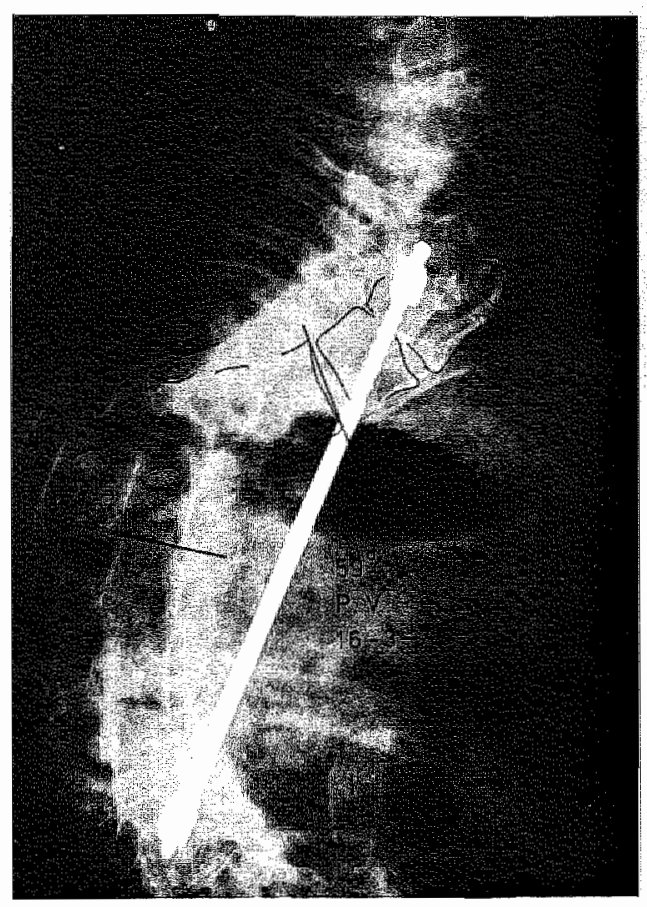

Scoliose postoperatief

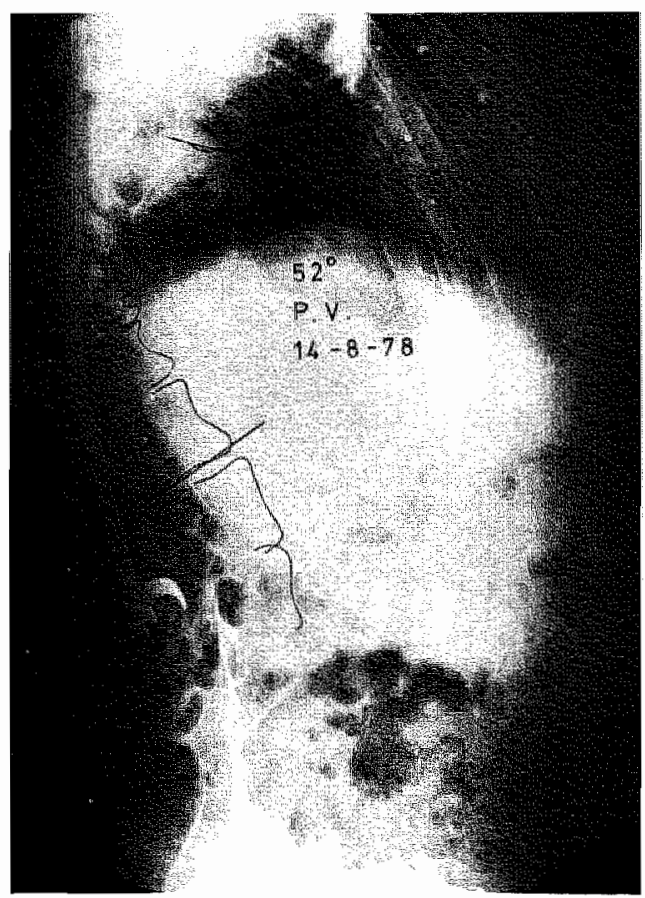

Kyfose postoperatief 


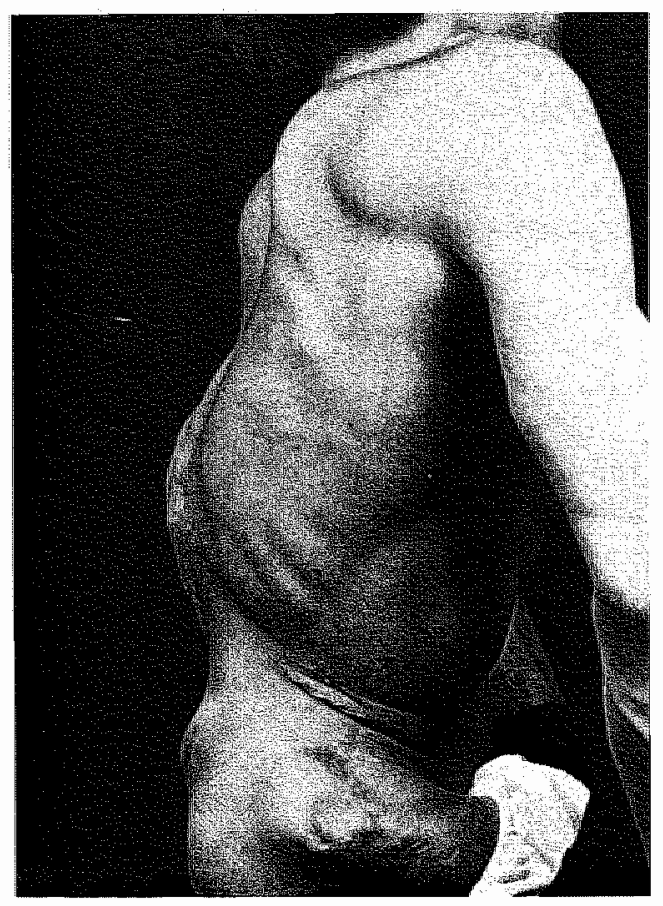

P.V. Medische foto uit 1970

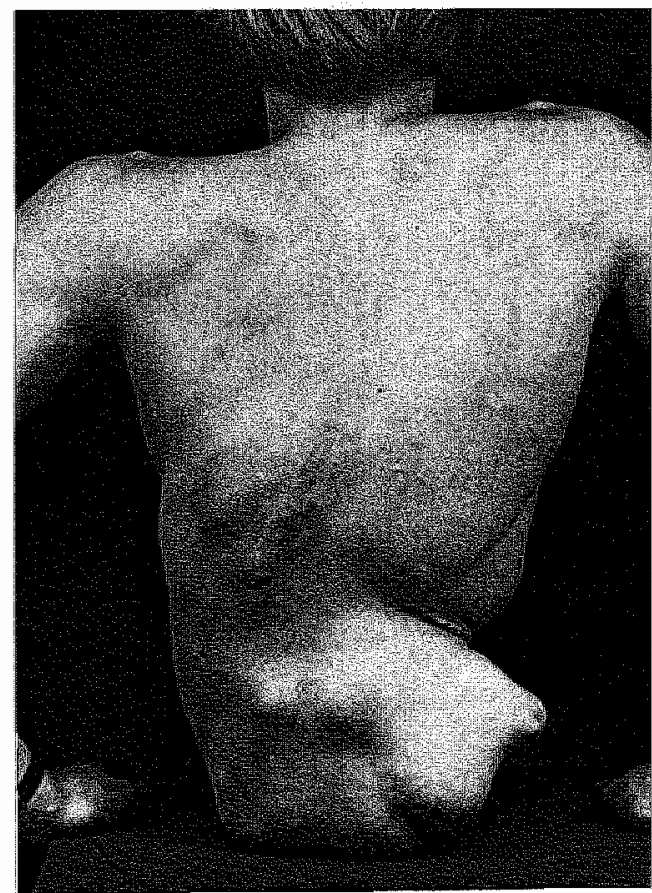

P.V. Scoliose in 1970

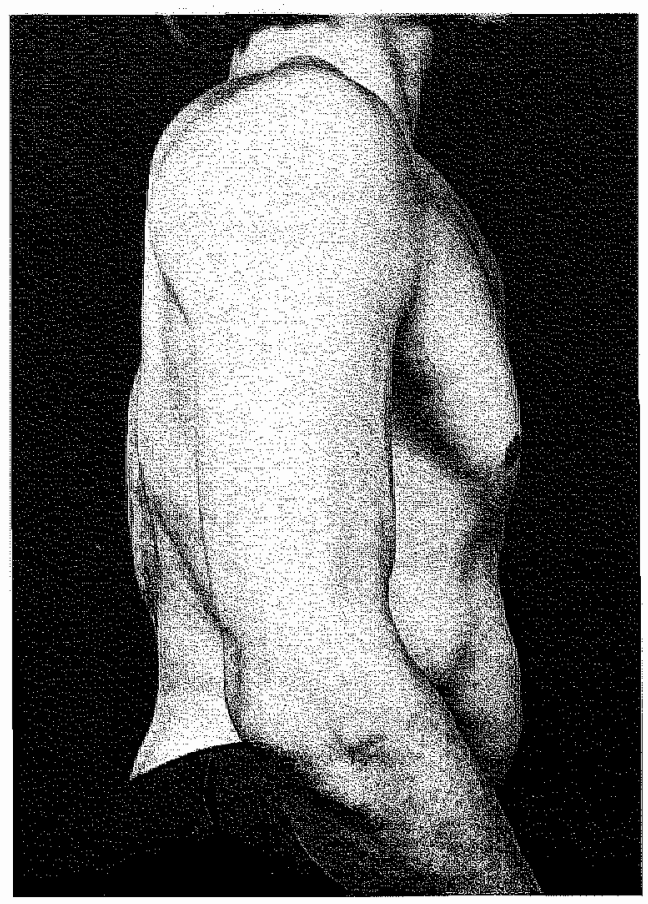

P.V. Kyfose postoperatief

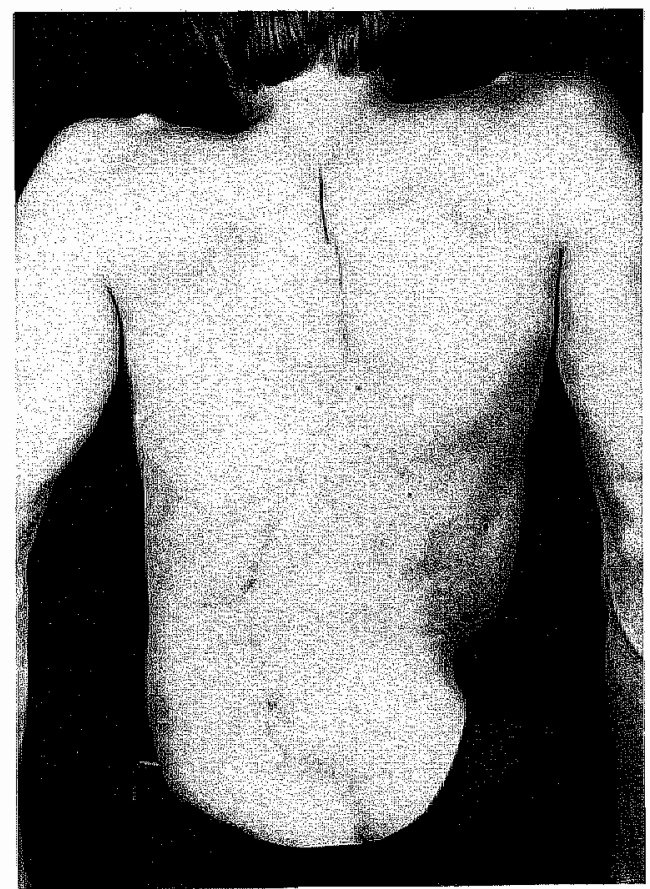

P.V. Scoliose postoperatief 
Patiënt 17. G. v. R. vrouwelijk, geb. dat. 21-08-1961.

Aetiologie:

Vroegere behandeling:

Klachten:

Préoperatieve curves:

Voorbehandeling:

Longfunctie:

Conclusie:

Neurologisch onderzoek:

Operatie:

Complicaties:

Nabehandeling:
Paralytische kyfoscoliose bij congenitalle myopathie.

Milwaukee brace behandeling vanaf het $5 e$ jaar. Achillespeesverlenging beiderzijds. Subtalaire arthrodese beiderzijds. Loopt redelijk met hoge schoenen en beugels.

Soms pijn midden in de rug. Dyspnoe d'effort.

Scoliose T6 t/m L1 $117^{\circ}$. Tractie $98^{\circ}$. Kyfose T5 t/m T12 $148^{\circ}$.

Progressie vanaf

1967 scoliose $69^{\circ}$

in 1969 scoliose $75^{\circ}$

in 1970 scoliose $80^{\circ}$

in 1971 scoliose $80^{\circ}$

in 1973 scoliose $85^{\circ}$

in 1974 scoliose $86^{\circ}$

in 1975 scoliose $105^{\circ}$

in 1977 scoliose $117^{\circ}$

Meeste progressie tussen 5 en 9-jarige leeftijd en tussen 13 en 16-jarige leeftijd.

Halo-rolstoeltractie 5 weken met redelijke correctie.

Vit. cap. $900 \mathrm{cc}$, normaal $3275 \mathrm{cc}$. Tot. cap. $1250 \mathrm{cc}$, normaal $4100 \mathrm{cc}$.

Ernstige restrictieve functiestoornis met uiterst beperkte reserves, die bij verkoudheid aanleiding kan geven tot dyspnoe.

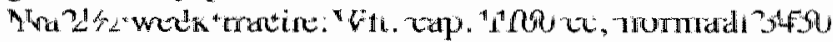
cc. Tot. cap. $1450 \mathrm{cc}$, normaal $4300 \mathrm{cc}$.

Waarschijnlijk congenitale myopathie.

26-9-1977. Achterste Harringtonspondylodese T3 $\mathrm{t} / \mathrm{m} \mathbf{L} 1$ met transversectomie concaaf en transversotomie convex, na dwars klieven van de lange rugspieren.

Arteria mesenterica superior syndroom in liggende houding. In zittende houding geen last.

9 maanden gipscorset. 
Postoperatieve curves:

Postoperatieve klachten:

Longfunctie 2 jaar postoperatief:
Postoperatieve scoliose $78^{\circ}$. Na 9 maanden scoliose $84^{\circ}$ en kyfose ongeveer $98^{\circ}$. Na 12 maanden $84^{\circ}$ scoliose. Na 18 maanden $74^{\circ}$ scoliose. Na 25 maanden $80^{\circ}$, Plan d'election $104^{\circ}$.

Geen. De dyspnoe was aanzienlijk verminderd.

Vit. cap. $1175 \mathrm{cc}$, normaal $3625 \mathrm{cc}$. Tot. cap. 1650 $\mathrm{cc}$, normaal $4525 \mathrm{cc}$.

Beschouwing en conclusie:

Bij deze ernstig gedeformeerde wervelkolom werd een achterste spondylodese verricht om verdere progressie, welke ook na het beëindigen van de groei te verwachten was, te voorkomen. Door verdere progressie zou de longfunctie nog verder afgenomen zijn en een cor pulmonale met uiteindelijk overlijden had tot de mogelijkheden behoord. De scoliose was tot deze ernst gekomen ondanks Milwaukee brace therapie. In een veel eerder stadium had dan ook operatie moeten gebeuren om de progressie te stoppen. Hoe langer men wacht, des te slechter het uiteindelijke resultaat. De correctie in dit geval was bevredigend. Van de winst aan longfunctie moet men bij deze ernstige deformiteiten niet al teveel verwachten, hoewel de winst in dit geval $(30,6 \%$ winst aan vitale capaciteit) aanzienlijk is. De kyfosering, welke zichtbaar is op de zijdelingse röntgenfoto, is het gevolg van de sterke rotatie van de scoliotische thoracale curve. Deze dranit weg uit het frontale vlak en komt in het sagittale vlak te liggen. De apicale wervels komen hierbij $90^{\circ}$ gedraaid te liggen. 


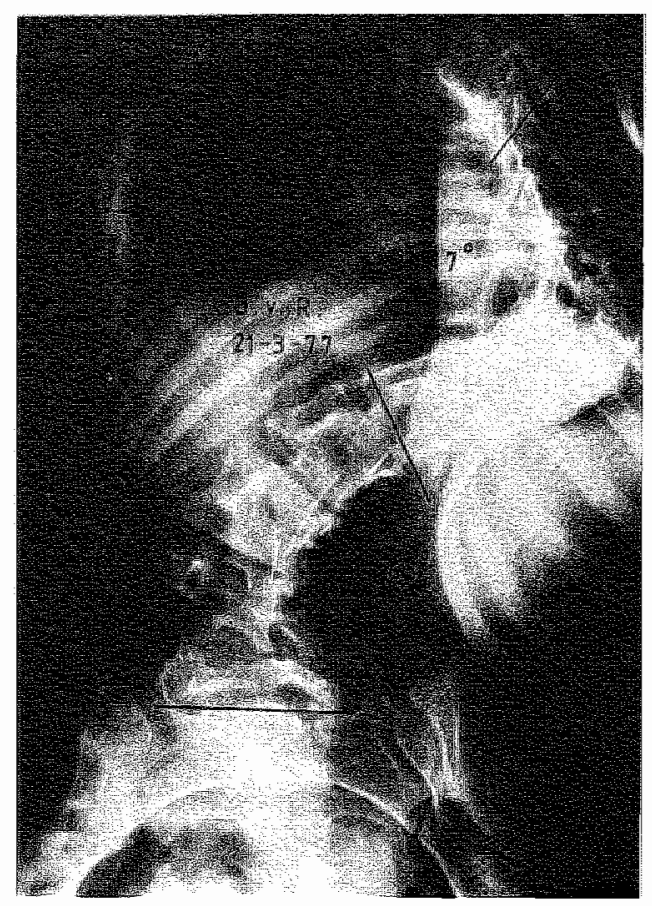

Scoliose préoperatief

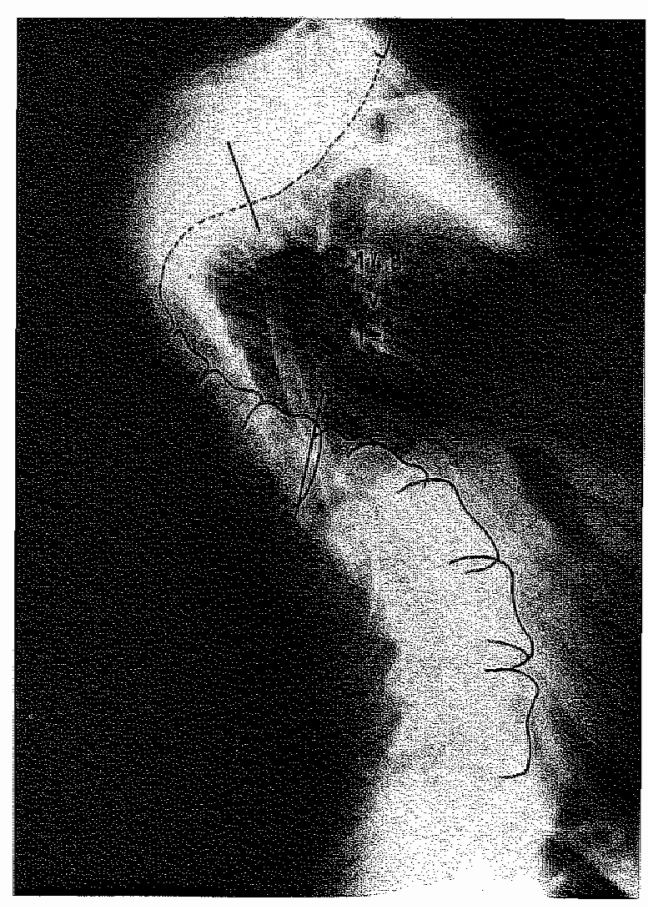

Kyfose préoperatief

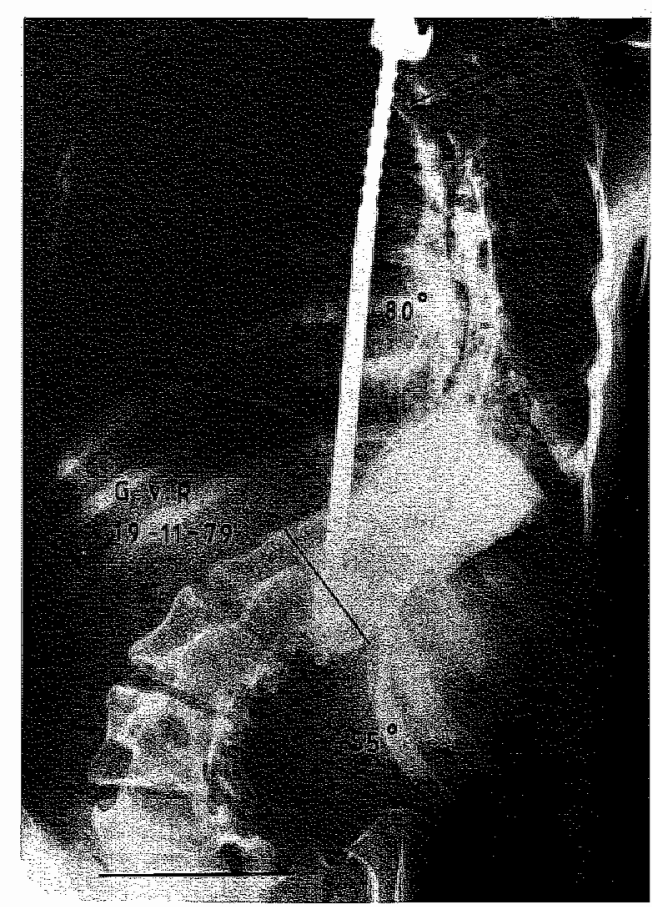

Scoliose postoperatief

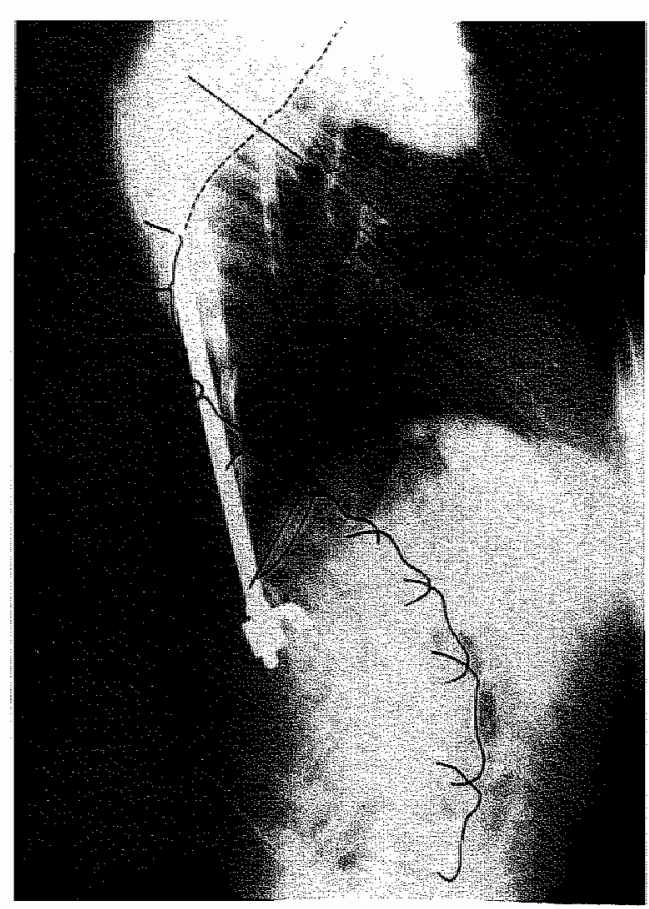

Kyfose postoperatief 


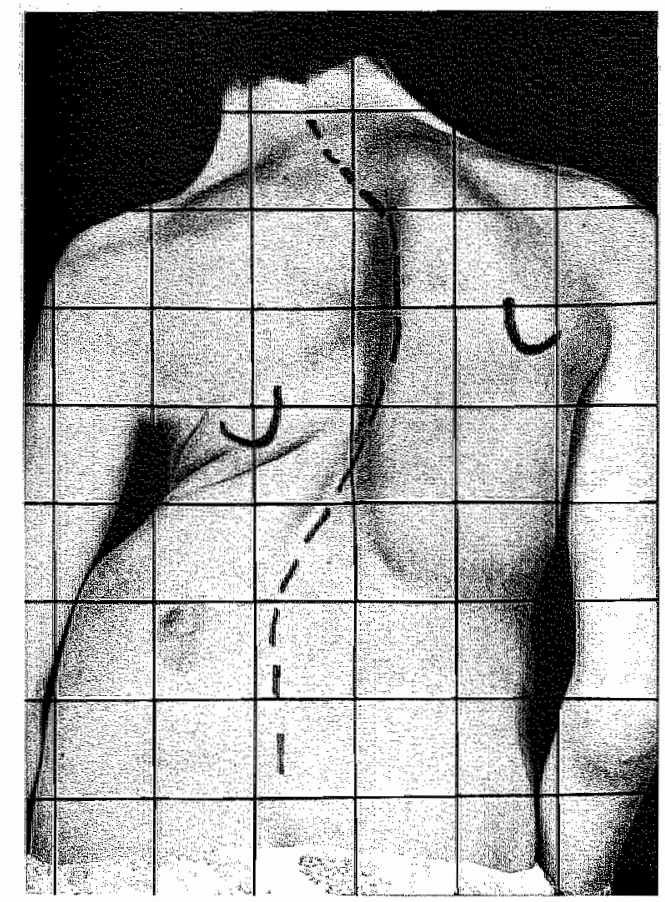

G.v.R. Scoliose préoperatief

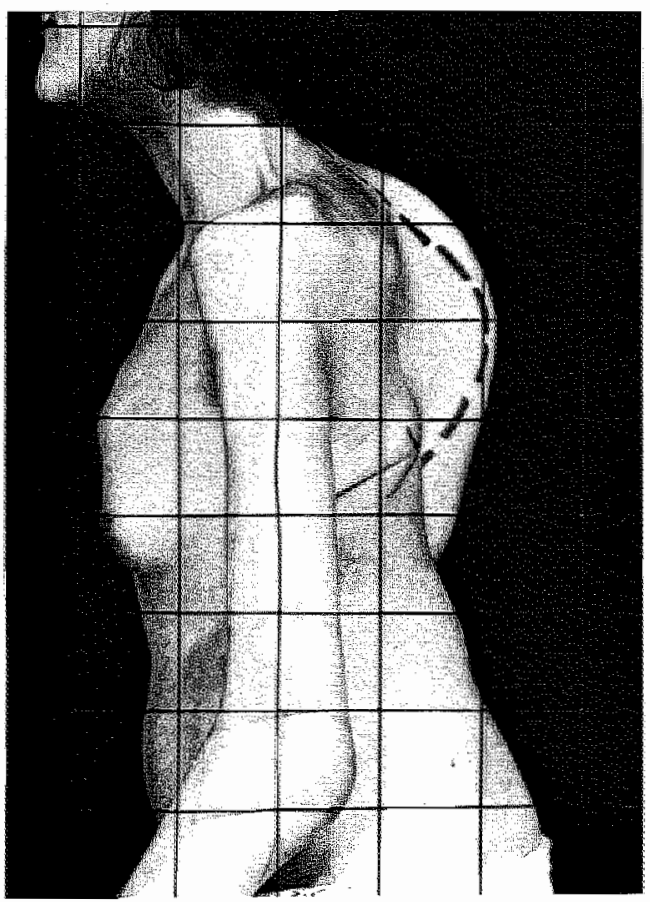

G.v.R. Kyfose préoperatief

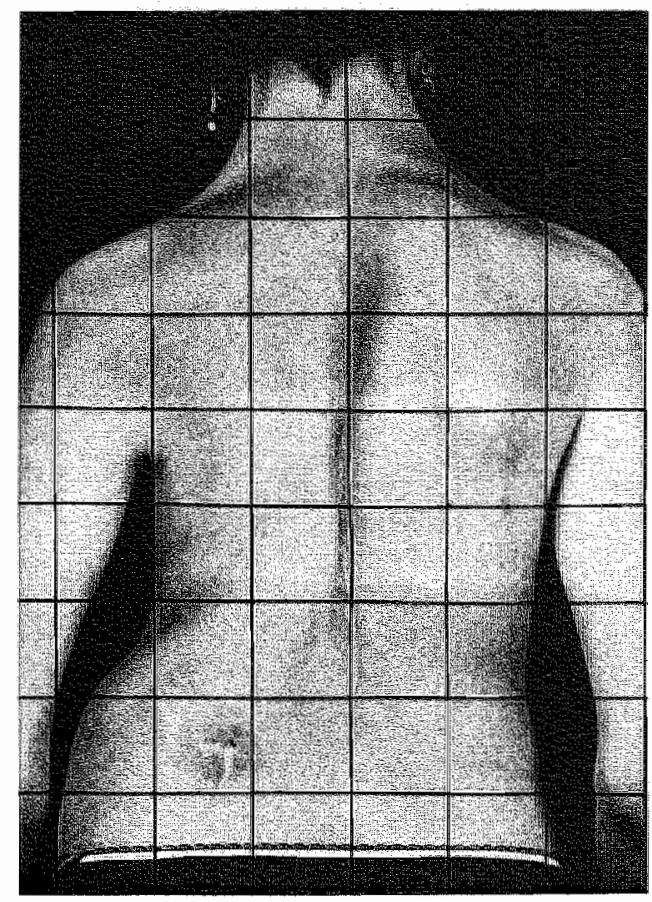

G.v.R. Scoliose postoperatief

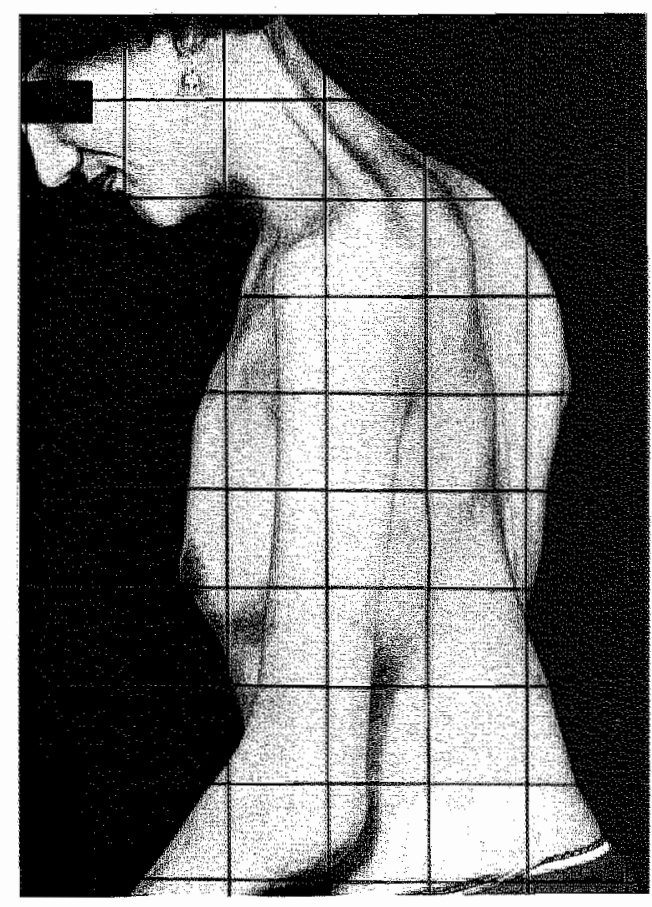

G.V.R. Kyfose postoperatief 


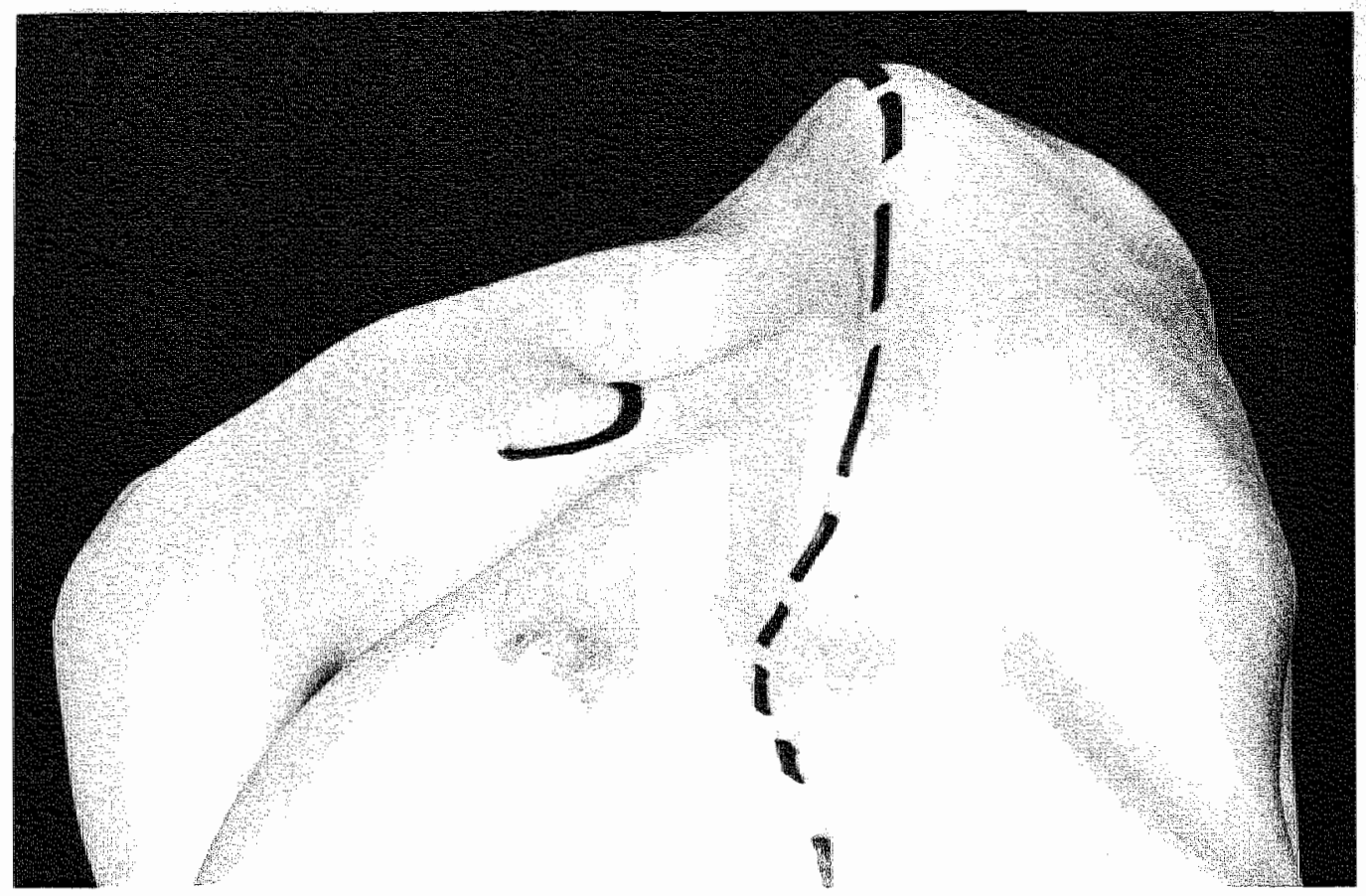

G.v.R. Gibbus préoperatiêt

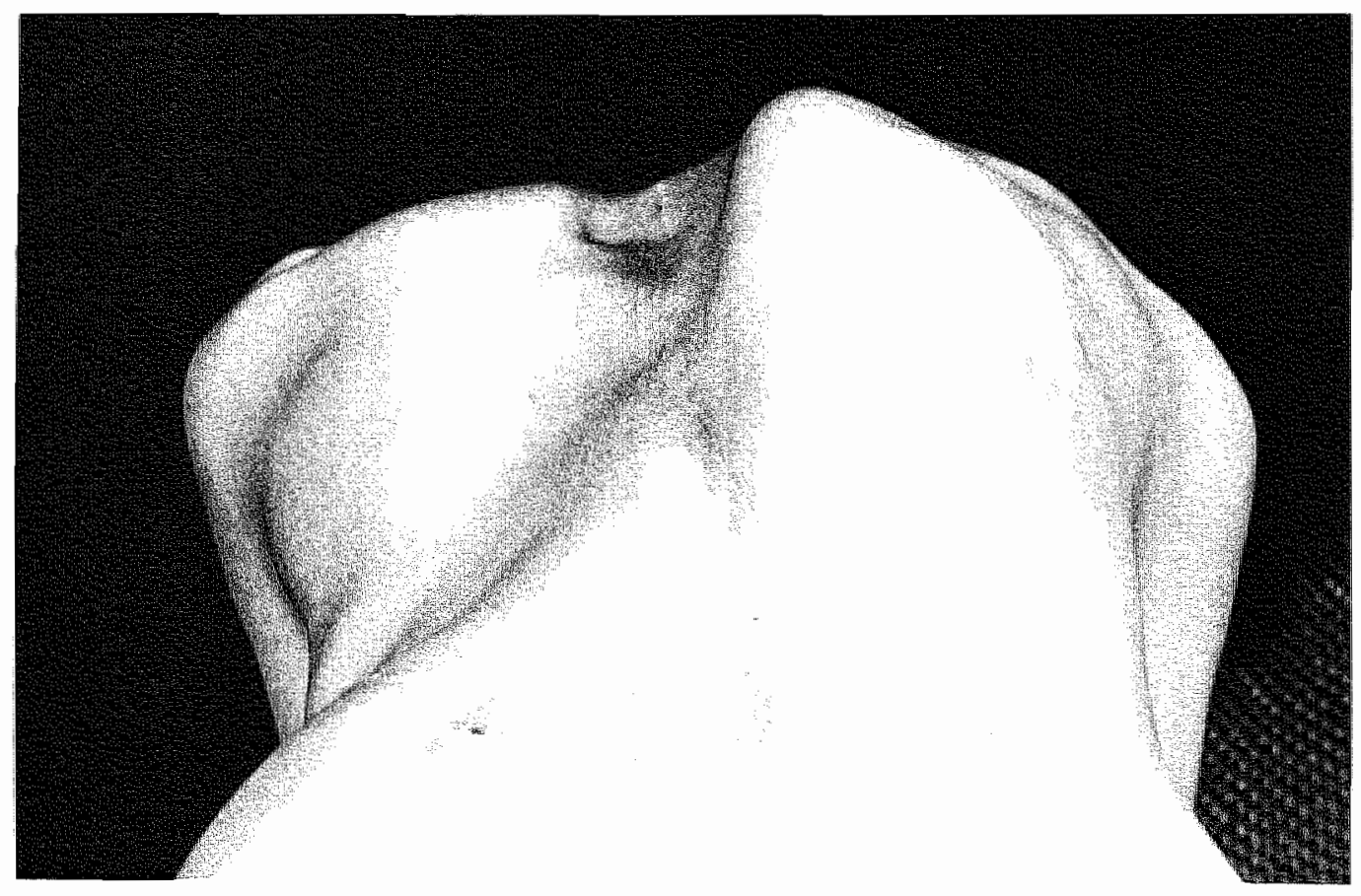

G.v.R. Gibbus postoperatiet 
Patiennt 18. H. R. vrouwelijk, geb. dat. 06-08-1954.

Aetiologie:

Vroegere behandeling:

Klachten:

Préoperatieve curves:

Voorbehandeling:

Longfunctie:

Conclusie:

Neurologisch onderzoek:

E.M.G.:

Operatie:

Complicaties:

Nabehandeling:
Enstige kyfoscoliose bij ziekte van Marie-ToothCharcot-Hoffman, familiair voorkomend.

Geen. In eerste instantie werd aan een op korte termijn lethaal verlopende vorm van spierdystrofie gedacht, zodat geen therapie werd ingesteld. De scoliose werd op het $12 \mathrm{e}$ jaar voor het eerst opgemerkt.

Dyspnoe. Slechte cosmesis. Druk van ribben op het bekken. Zwakte van de distale spiergroepen, van armen en benen, met hol-bal voeten, passend bij het ziektebeeld. Hierdoor gauw vermoeid bij het lopen.

Scoliose T5 t/m T11 $148^{\circ}$. Kyfose plm. T5 t/m T10 $170^{\circ}$.

10 weken Halo-rolstoel tractie. Correctie van de scoliose tot $105^{\circ}$. Lengtewinst van $10 \mathrm{~cm}$.

Vit. cap. $1000 \mathrm{cc}$, normaal $3900 \mathrm{cc}$. Tot. cap. 1700 $\mathrm{cc}$, normaal $5050 \mathrm{cc}$.

Zeer ernstige restrictie zonder ventilatoire reserves. Met eventuele postoperatieve beademing moet rekening worden gehouden. Na tractie vit. cap. 1300 cc en tot. cap. $2025 \mathrm{cc}$.

Familiaire polyneuropathie. Waarschijnlijk van het demyeliniserend karakter met geassocieerde symptomen. Autosomaal dominante overerving.

Duidelijke polyneuropathie zoals bij de ziekte van Marie-Tooth.

11-10-1977. Achterste Harringtonspondylodese T2 $\mathrm{t} / \mathrm{m}$ L1. Er bleek over 3 wervels een spontane fusie in de concavitiet te bestaan. De lange rugspieren moesten op 2 plaatsen dwars gekliefd worden.

Geen.

9 maanden gipscorset. 
Postoperatieve curves:

$\begin{array}{lll} & \text { Scoliose } & \text { Kyfose } \\ \text { Na } 5 \text { maanden } & 121^{\circ} & 120^{\circ} \\ \text { Na } 9 \text { maanden } & 114^{\circ} & 138^{\circ} \\ \text { Na } 12 \text { maanden } & 112^{\circ} & \\ \text { Na } 18 \text { maanden } & 103^{\circ} & \\ \text { Na } 30 \text { maanden } & 127^{\circ} & 140^{\circ} \\ \text { Mogelijk enige progressie bij de laatste controle. }\end{array}$

Postoperatieve klachten:

Geringe rugpijn. De dyspnoe was aanmerkelijk verbeterd, longfunctie werd echter na de operatie niet verricht. Ook het algemene welbevinden was verbeterd, patiënte was minder gauw vermoeid. De ribben drukten niet meer op het bekken. Het gewicht was nog slechts $38 \mathrm{~kg}$, gelijk aan het préoperatieve gewicht.

Beschouwing en conclusie:

Deze patiënte demonstreert de evolutie van een onbehandelde progressieve paralytische scoliose. Een zodanig ernstige deformiteit kan optreden, dat hart en longen in het gedrang komen. De longfunctie was zo slecht, dat van een voorste ingreep moest worden afgezien, welke bij deze patiënte in aanmerking kwam om de kyfose te ondersteunen. Hier moest de Harringtonstaaf gebogen worden om de kyfose te volgen. De kans op uitbreken van de haakjes is hierbij niet denkbeeldig. Stagnara hanteert de techniek, waarbij na verwijderen van enkele ribgedeelten in de concaviteit de niet of nauwelijks gebogen staaf retropleuraal en voor de wervelkolom komt te liggen. Hierdoor vermindert de kans op uitbreken, maar vermeerdert de kans op ernstige complicaties zoals een haematothorax of pneumothorax. 


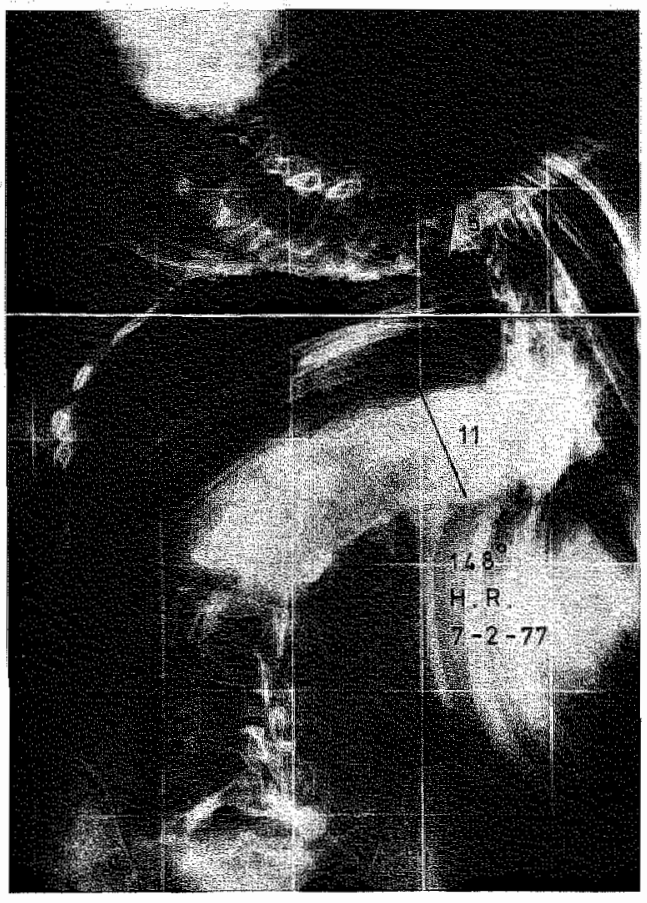

Scoliose préoperatief

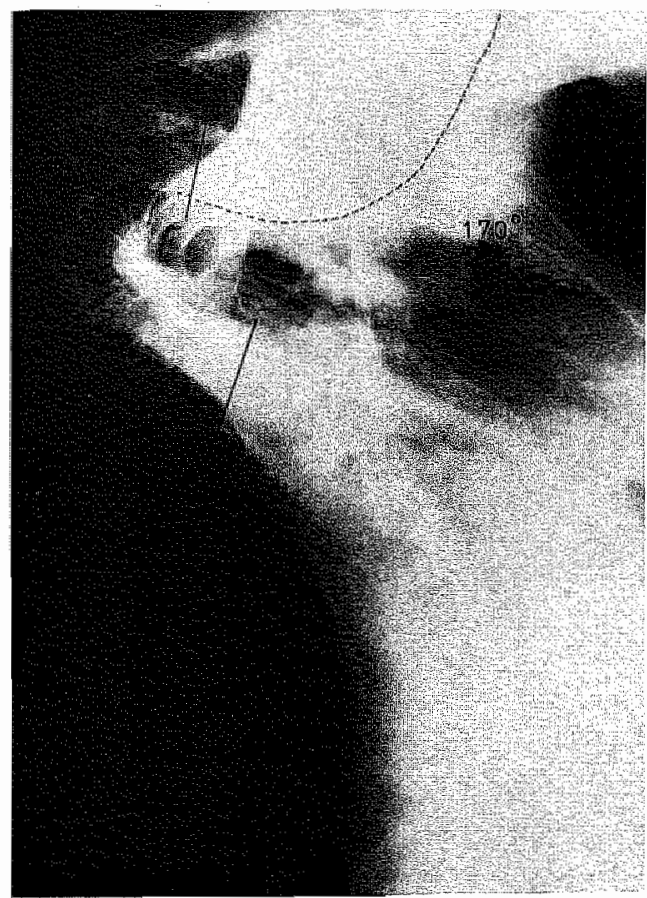

Kyfose préoperatief $170^{\circ}$

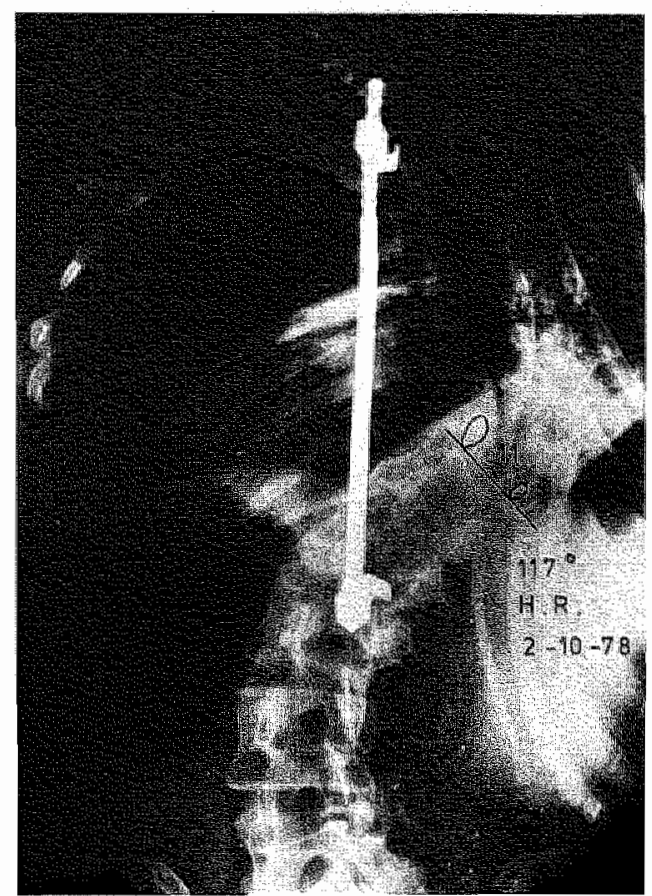

Scoliose postoperatief

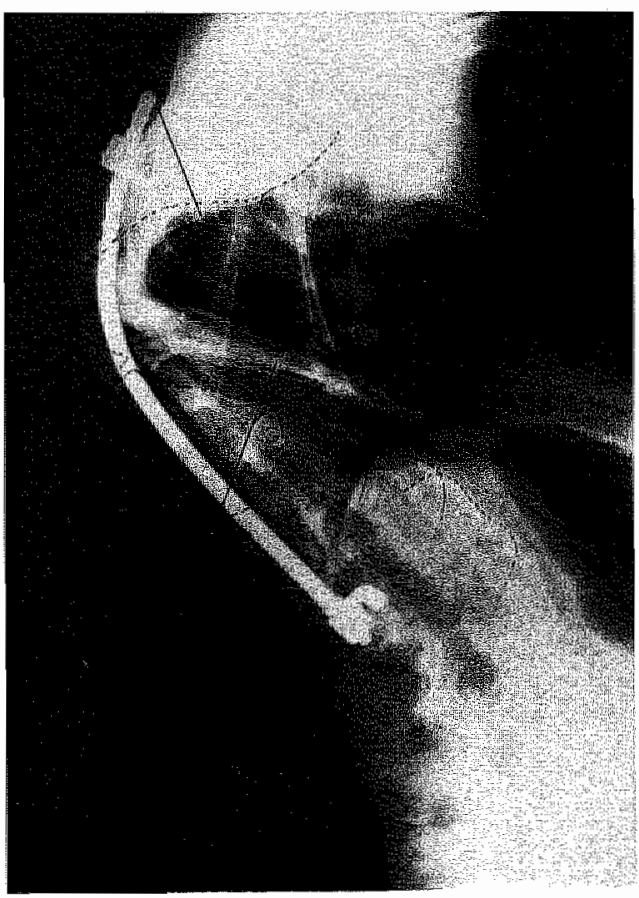

Kyfose postoperatief $138^{\circ}$ 


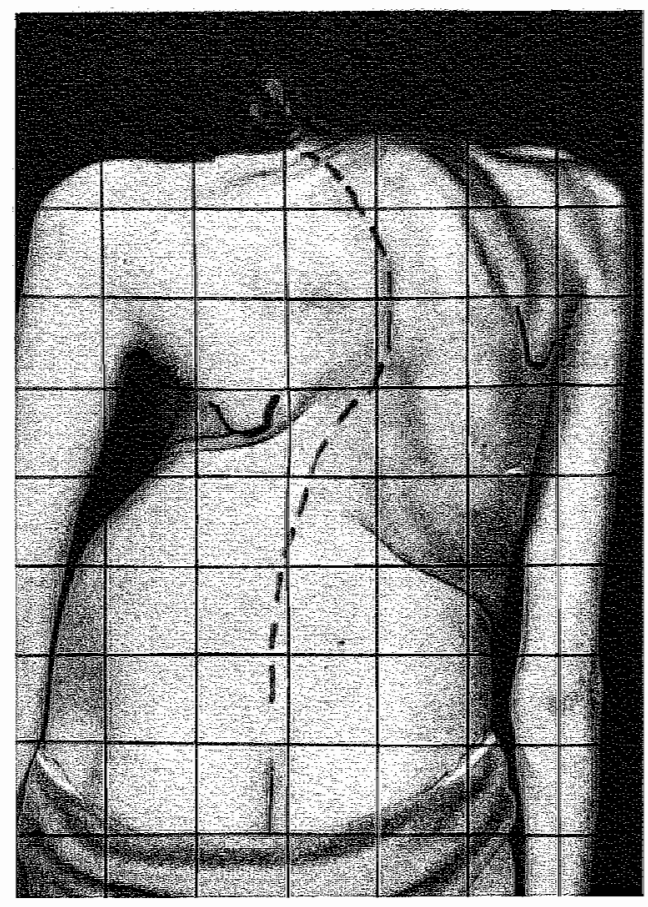

H.R. Scoliose préoperatief

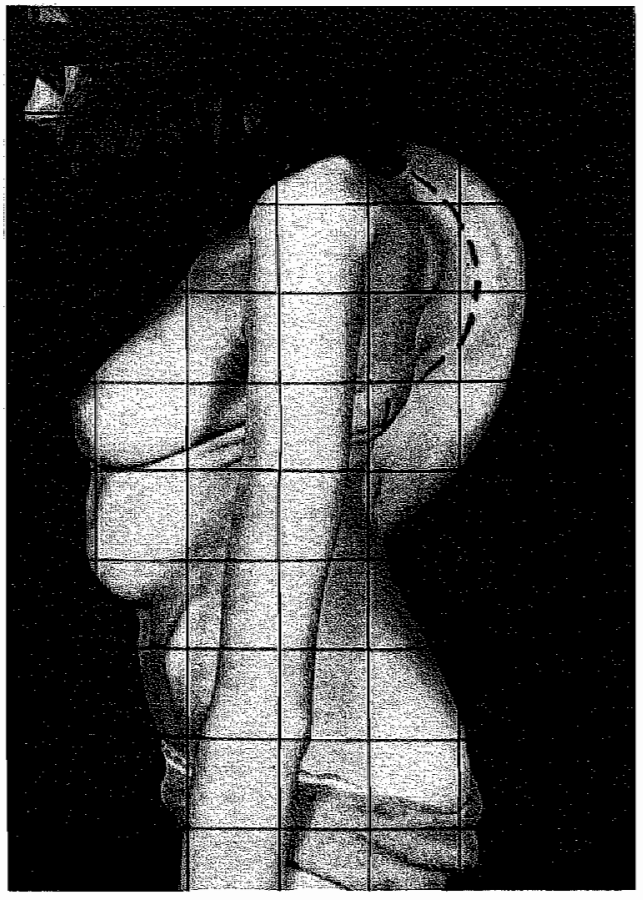

H.R. Kyfose préoperatief

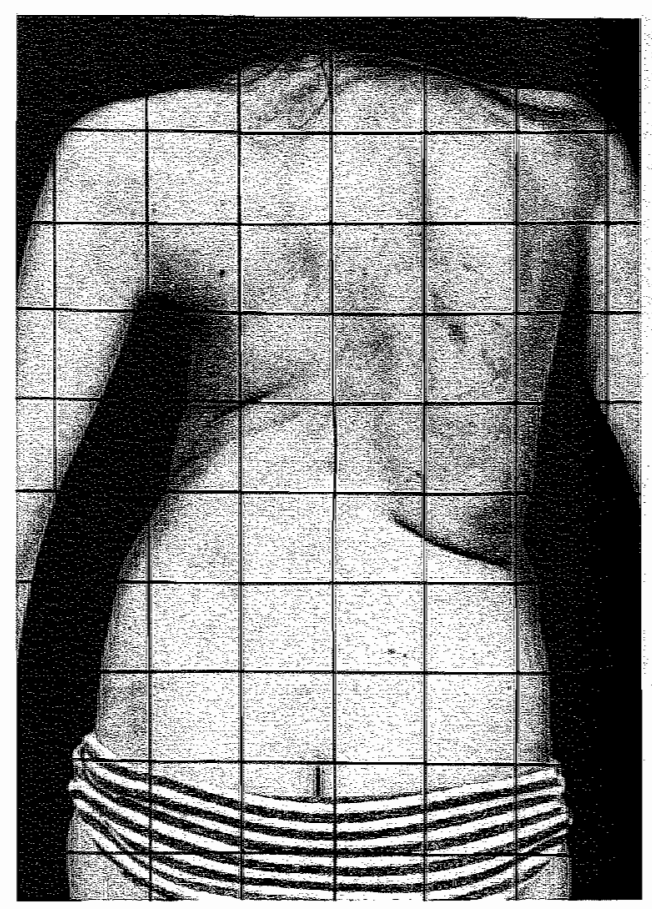

H.R. Scoliose postoperatief. Zie lengteverschil

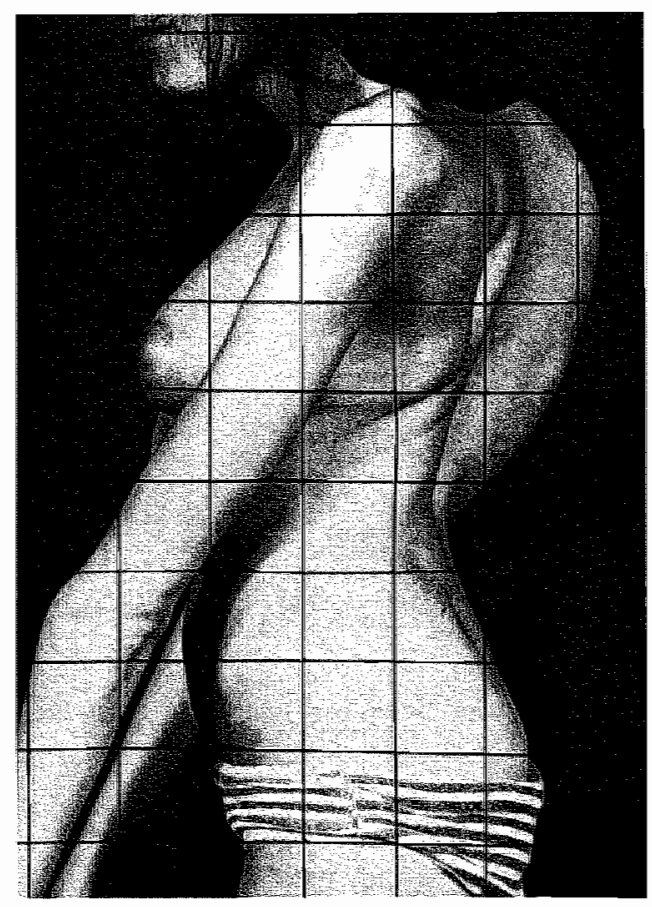

H.R. Kyfose postoperatief 


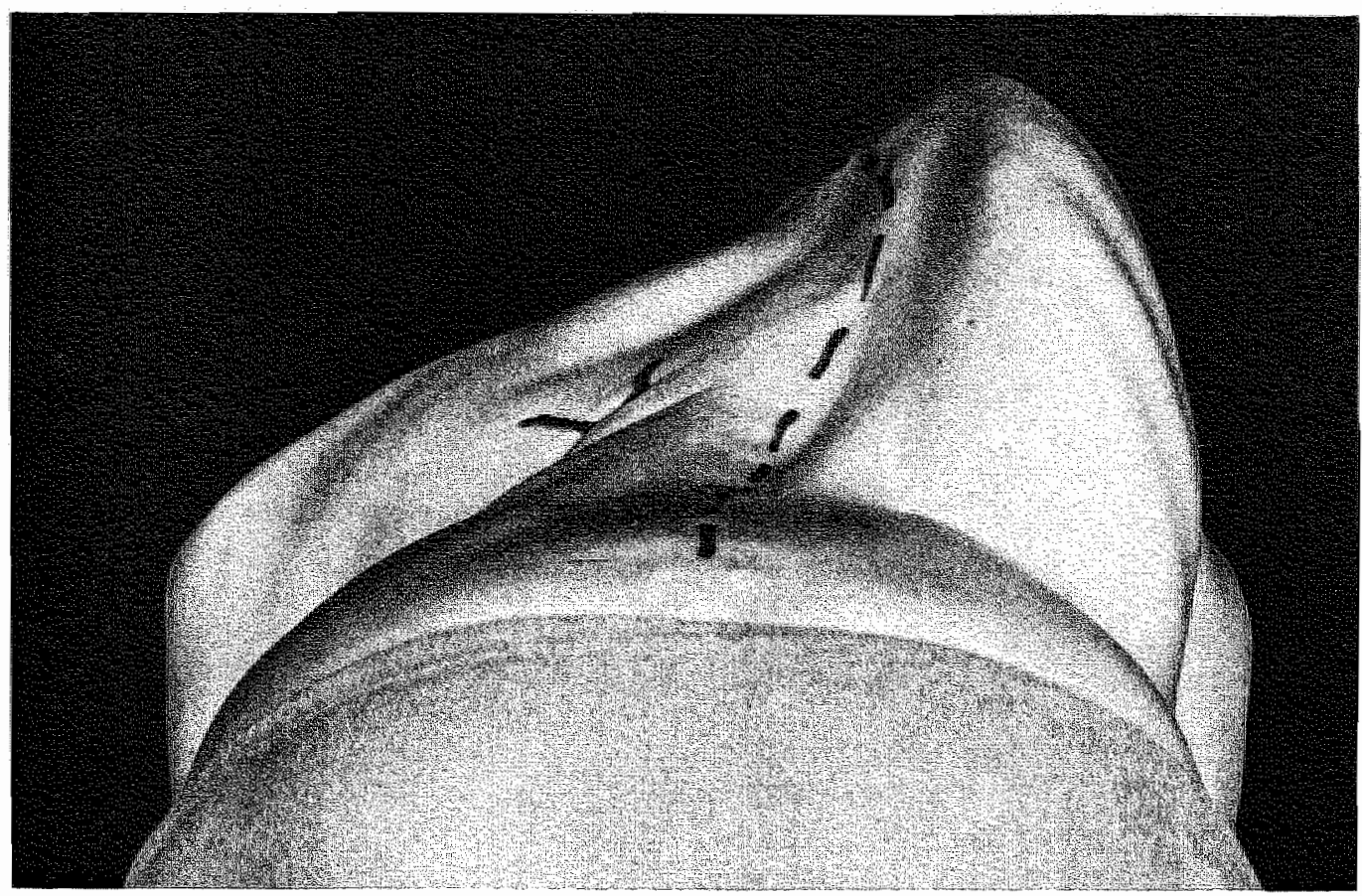

H.R. Gibbus préoperatief

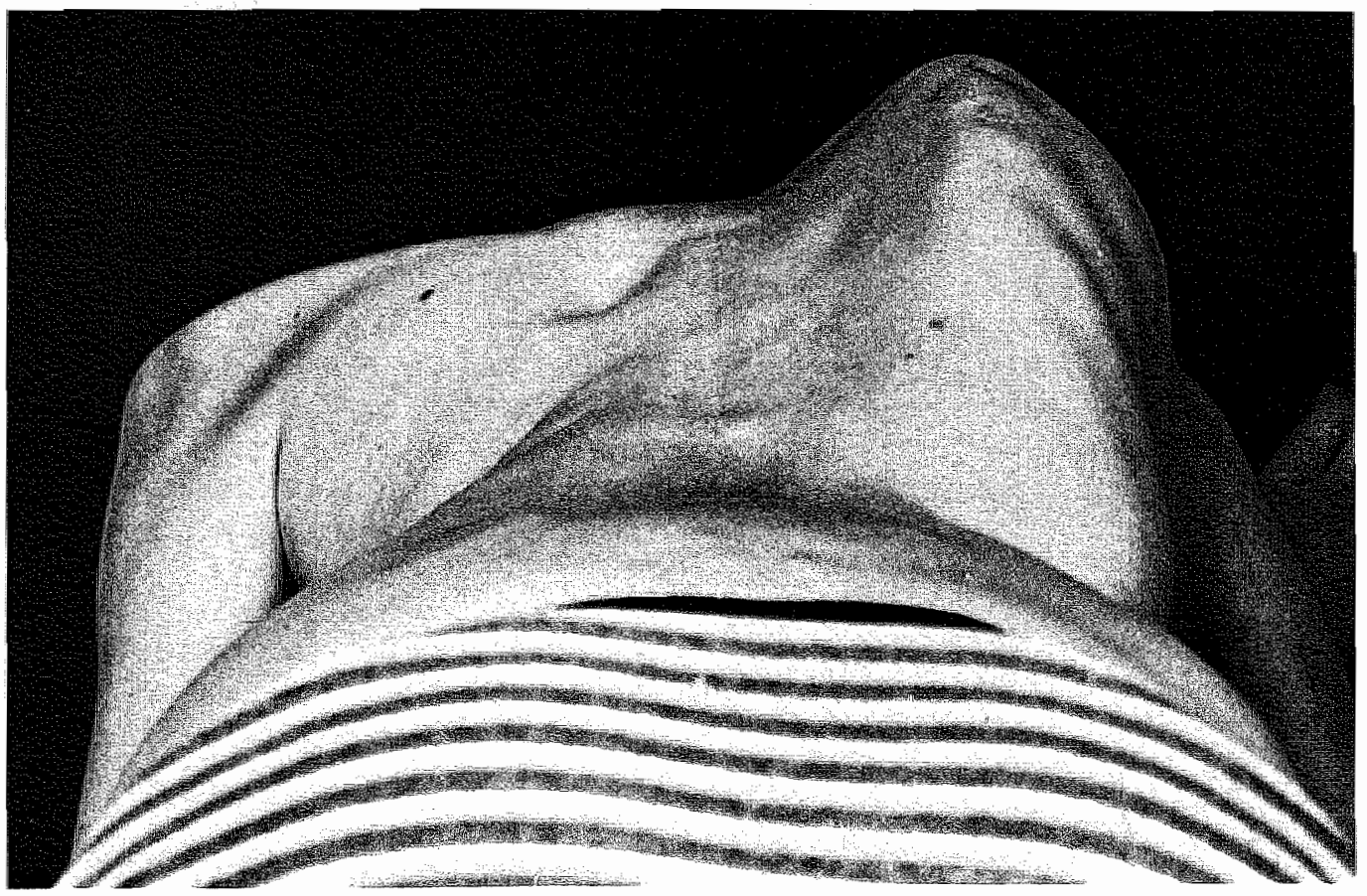

H.R. Gibbus postoperatief 
Patiënt 19. E. v. Z., vrouwelijk, geb. dat. 15-8-1956.

Aetiologie:

Vroegere behandeling:

Klachten:

Préoperatieve curves:

Voorbehandeling:

Longfunctie:

Conclusie:

Na 4 weken Cotreltractie:

Conclusie:

In gipscorset:

Conclusie:

Neurologisch onderzoek:
Paralytische kyfoscoliose ten gevolge van poliomyelitis.

Op 7-jarige leeftijd poliomyelitis doorgemaakt. Van het $9 \mathrm{e}$ tot $13 \mathrm{e}$ jaar met beugels gelopen, na het $13 \mathrm{e}$ jaar rolstoelpatiënte. Ernstige paresen aan de benen. Heeft enkele jaren Milwaukee braces gedragen zonder resultaat.

Dyspnoe d'effort en gauw moe. Vaak verkouden. Slechte zitbalans. Progressieve kyfoscoliose.

$\begin{array}{lcl} & \text { Scoliose } & \text { Correctie } \\ \text { In } 1968 & 32^{\circ} & \text { tot } 9^{\circ} \\ \text { In } 1970 & 75^{\circ} & \text { tot } 56^{\circ} \\ \text { In } 1972 & 122^{\circ} & \\ \text { In } 1973 & 136^{\circ} & \operatorname{tot} 115^{\circ} \\ \text { Scoliose T5 t/m T11. } & & \\ \text { Kyfose 71. T5 t/m T11. } & \end{array}$

Eerst Cotreltractie thuis gedurende 8 weken. Correctie tot $95^{\circ}$ na 4 weken en tot $87^{\circ}$ na 8 weken. Hierna 4 maanden redressiegipscorset, waarna 2 weken klinische Cotreltractie, hierna opnieuw redresserend gips voor 3 maanden met correctie tot $80^{\circ}$. Vervolgens operatie.

d.d. 23-7-1973. Vit. cap. $2100 \mathrm{cc}$, normaal $4050 \mathrm{cc}$. Tot. cap. $2800 \mathrm{cc}$, normaal $5050 \mathrm{cc}$.

Duidelijke restrictieve functiestoornis met nog voldoende reserves.

d.d. 22-8-1973. Vit. cap. $2450 \mathrm{cc}$. Tot. cap. $3100 \mathrm{cc}$. $10 \%$ toename longfunctie.

Vit. cap. $1850 \mathrm{cc}$. Tot. cap. $2500 \mathrm{cc}$.

Toename van de restrictieve functiestoornis in het gips.

Naast de poliomyelitis paresen aan de benen geen bijzonderheden. 
Operatie:

Complicaties:

Nabehandeling:

Postoperatieve curves:

$\mathrm{Na} 1$ jaar

Na 1 t/2 jaar

$\mathrm{Na} 2$ jaar

$\mathrm{Na} 31 / 2 \mathrm{jaar}$

$\mathrm{Na} 4 \frac{1}{2}$ jaar

$\mathrm{Na} 51 / 2$ jaar

$\mathrm{Na} 1$ jaar zijn geen zijdelingse foto's meer gemaakt.

Postoperatieve longfunctie:

Conclusie:

Postoperatieve klachten:

$\begin{array}{ll}\text { Scoliose } & \text { Kyfose } \\ 90^{\circ} & 63^{\circ} \\ 86^{\circ} & \end{array}$

$86^{\circ}$

$87^{\circ}$

$88^{\circ}$

$80^{\circ}$
1 jaar postoperatief d.d. 27-3-1975. Vit. cap. 2600 cc. Tot. cap. $3275 \mathrm{cc}$.

Geringe toename van de longfunctie in vergelijking met het onderzoek op 22-8-1973. Na 1 jaar en 4 maanden d.d. 30-6-1975. Vit. cap. $2750 \mathrm{cc}$. Tot. cap. $3350 \mathrm{cc}$.

Door preoperatieve behandeling en operatie toename van $650 \mathrm{cc}$ vit. cap. $=31 \%$.

Eerste jaren geen klachten, bij laatste controle nekpijn geuit, mogelijk ten gevolge van de hyperlordose. Minder dyspnoe, betere zitballans.

Beschouwing en conclusie:

Goede strekking van een ernstige post-polio kyfoscoliose. Ook in dit geval was eerder ingrijpen beter geweest, aangezien de scoliose steeds meer rigide werd en het resultaat van operatie daardoor is afgenomen. Dat bij deze ernstige deformiteiten operatie wel degelijk zin heeft, niet alleen om de verdere progressie te stoppen, bewijst de $31 \%$ toename van de vitaalcapaciteit en de betere zitbalans. Overigens lijkt het traject van de fusie aan de bovenzijde 1 à 2 wervels te kort te zijn. 


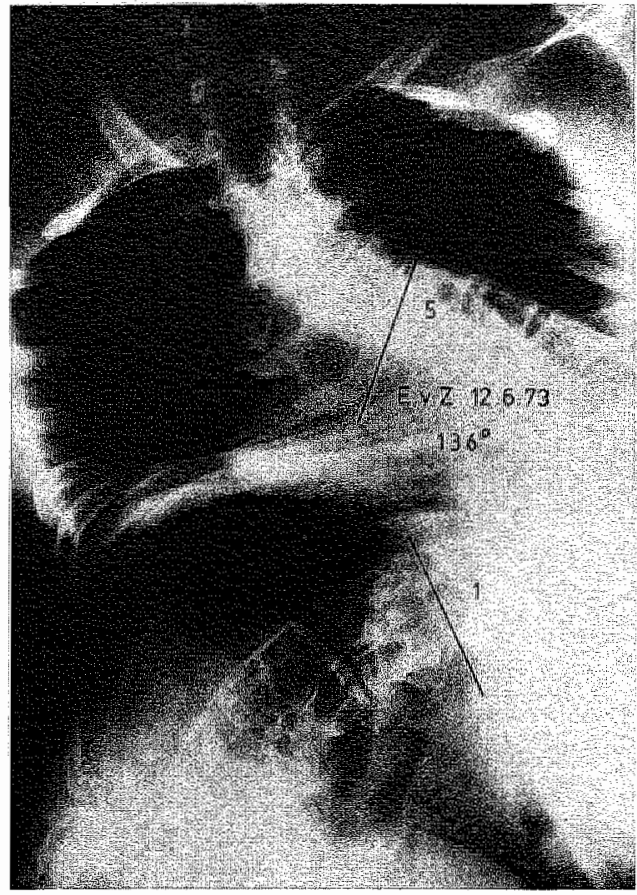

Scolliose préoperatief

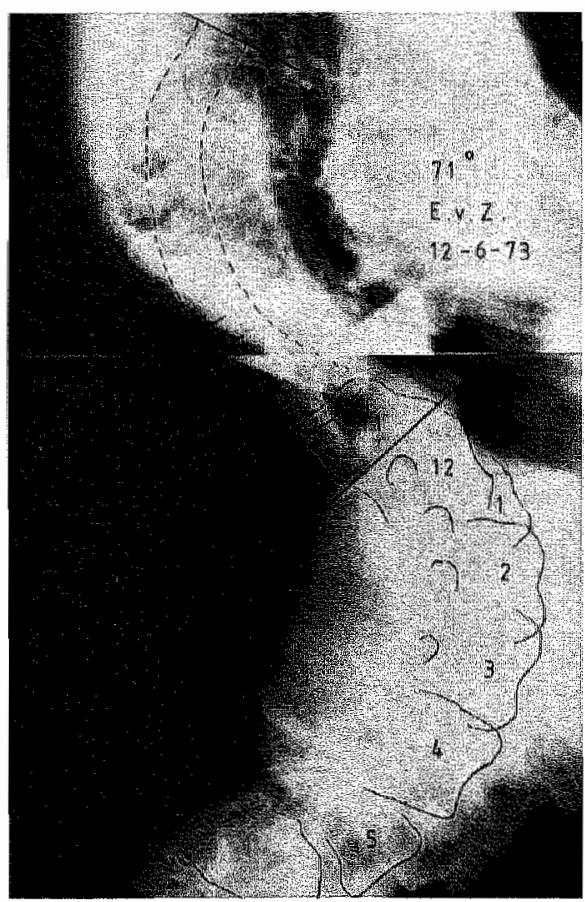

Kyfose préoperatief

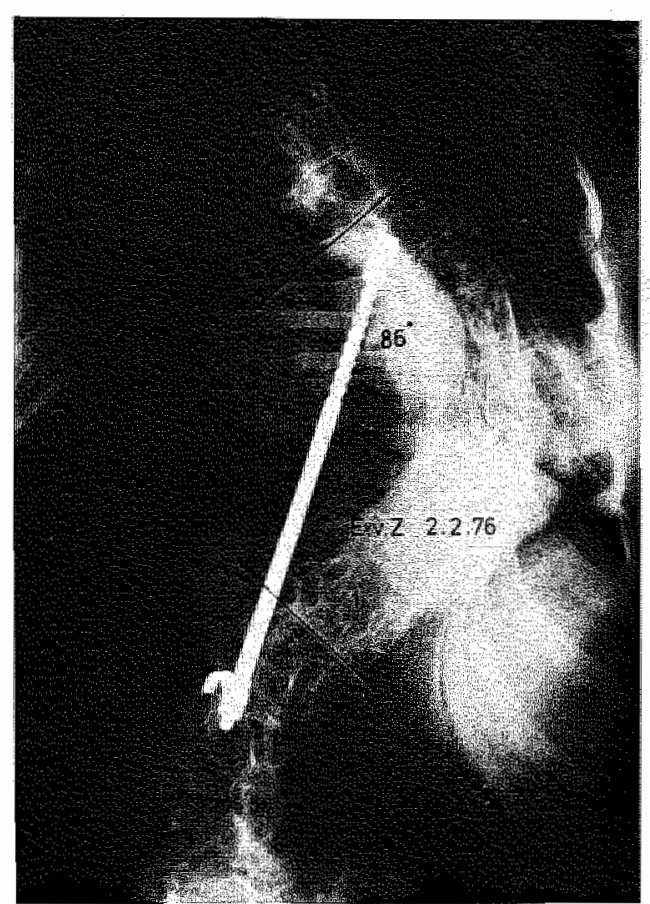

Scoliose postoperatief

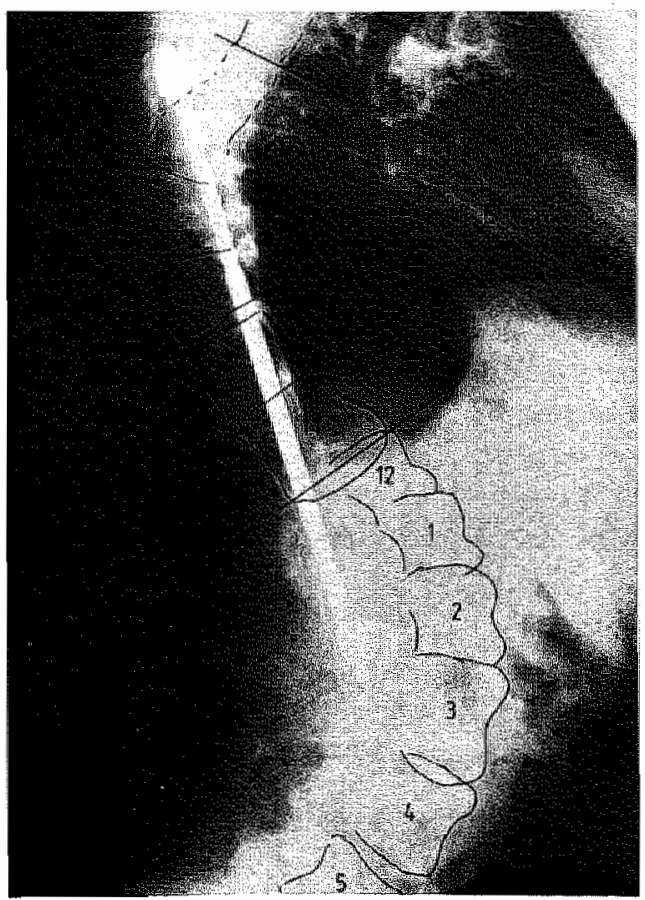

Kyfose postoperatief 


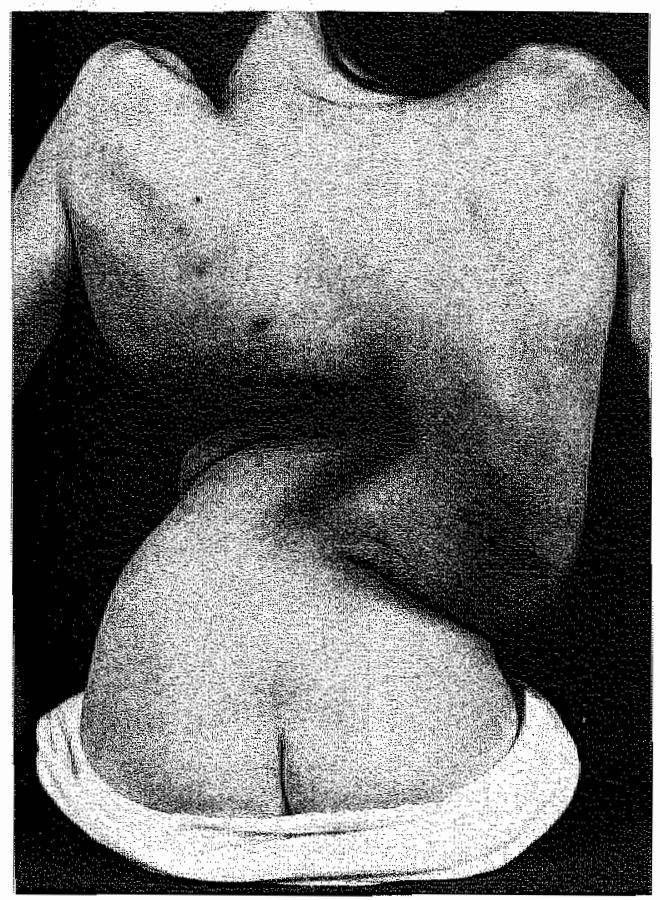

E.v.Z. préoperatief

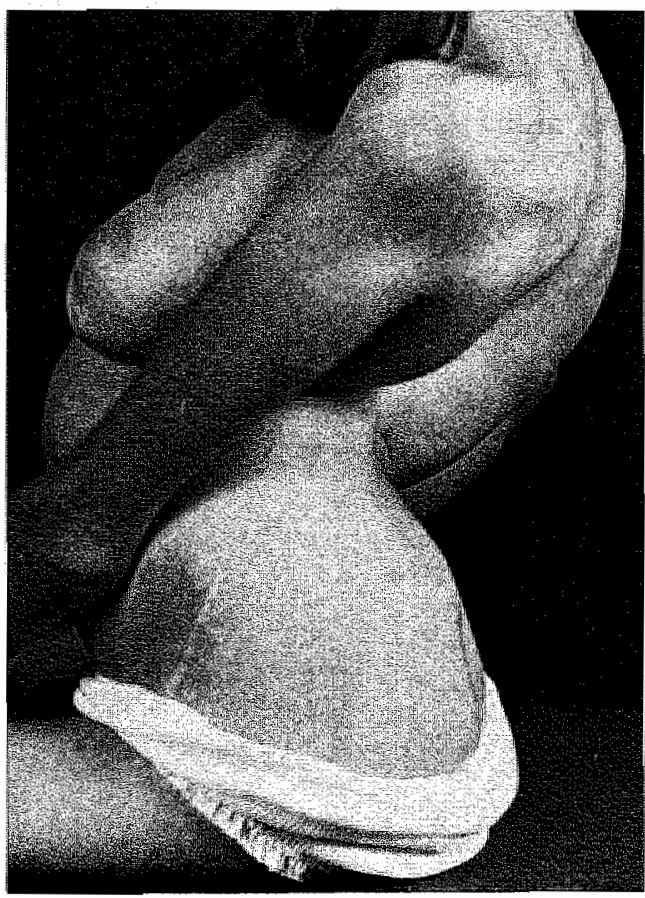

préoperatief

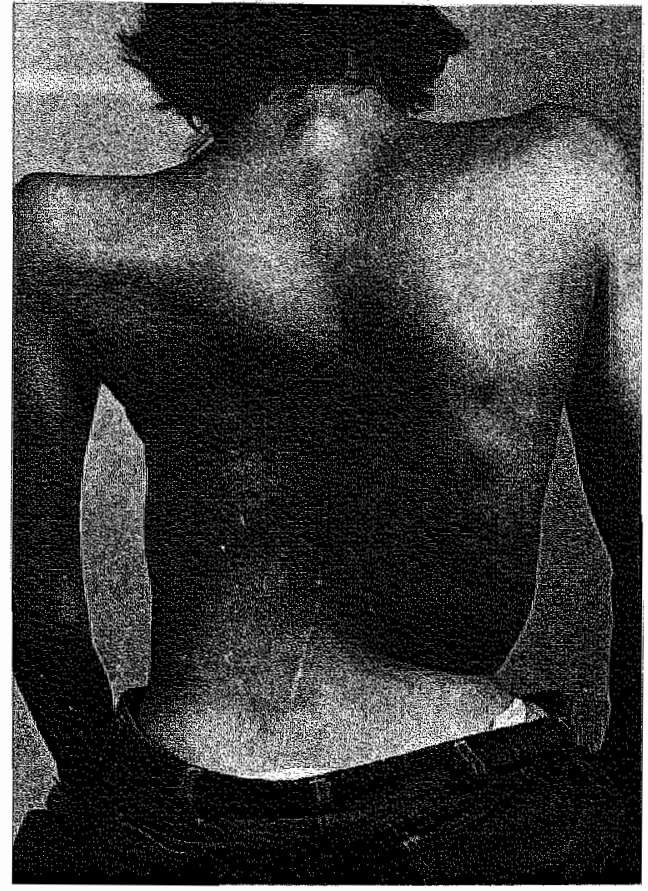

E.v.Z. postoperatief

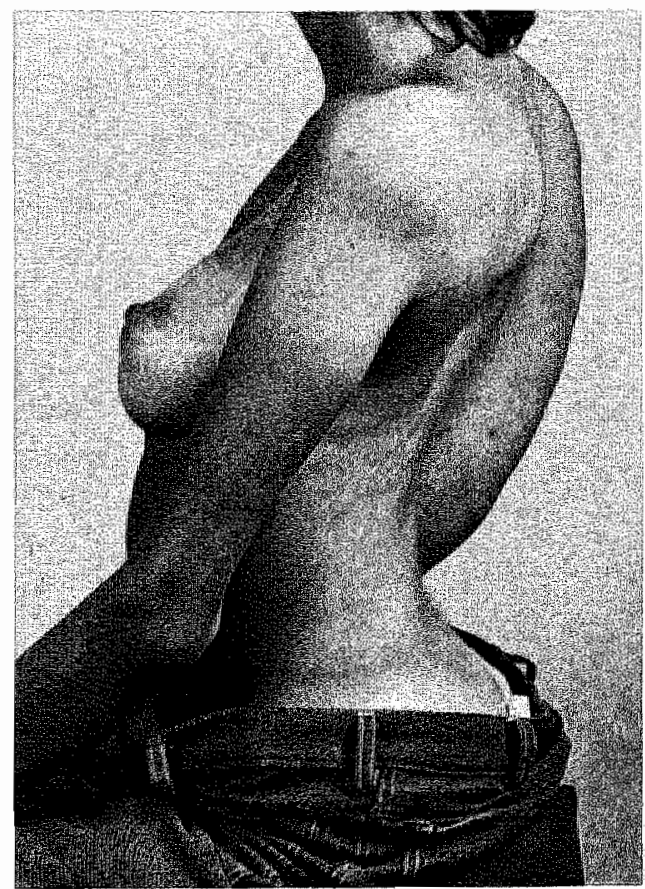

postoperatief 
Patiënt 20. J. V. mannelijk, geb. dat 21-11-1933.

Aetiologie:

Vroegere behandeling:

Klachten:

Préoperatieve curves:

Voorbehandeling:

Longfunctie:

Conclusie:

Neurologisch onderzoek:

Operaties:

Complicaties:

Nabehandeling:

Postoperatieve curves:
Kyfoscoliose ten gevolge van poliomyelitis op 10-jarige leeftijd.

Leren corset. Spondylodese L $3 \mathrm{t} / \mathrm{m}$ L5 met behulp van tibiaspaan op 16 -jarige leefrijd.

Vooral "s middags rugpijn. Sneller vermoeid. Krachtsverlies in het linker been, dit been was het meest door de polio aangedaan.

Scoliose T8 t/m L2 105. Kyfose T9 t/m L1 $68^{\circ}$.

Halo-rolstoeltractie 2 weken. Hiermee weinig verbetering.

Vit. cap. $3900 \mathrm{cc}$, normaal $4700 \mathrm{cc}$. Tot. cap. 5000 $\mathrm{cc}$, normaal $7025 \mathrm{cc}$.

Geringe restrictieve functiestoornis.

Naast de polio parese vooral in het linker been geen bijzonderheden.

1. 29-3-1978. Dorsale release $18 \mathrm{t} / \mathrm{m} \mathrm{L2}$. In de concaviteit spontane fusies van facetgewrichten. Weinig mobiliteit te verkrijgen. De oude spondylodese werd in situ gelaten.

2. 12-4-1978. Spondylodese volgens Dwyer T9 $\mathrm{t} / \mathrm{m}$ L2 via thoraco-phreno-lumbotomie links met verwijderen 9 e rib.

3. 26-4-1978. Achterste Harringtonspondylodese T7 $\mathrm{t} / \mathrm{m} \mathrm{L}$. 3 met behulp van cristabot onder controle van een wake-up test.

Geen.

9 maanden gipscorset.

Na 1 maand
Na 4 maanden
Na 8 maanden
Na 9 maanden
Na 13 maanden
Na 19 maanden
Na 29 maanden

$\begin{array}{ll}\text { Scoliose } & \text { Kyfose } \\ 68^{\circ} & 27^{\circ} \\ 64^{\circ} & 25^{\circ} \\ 64^{\circ} & 22^{\circ} \\ 64^{\circ} & 31^{\circ} \\ 62^{\circ} & 38^{\circ} \\ 72^{\circ} & 40^{\circ} \\ 72^{\circ} & 40^{\circ}\end{array}$


Postoperatieve klachten:

Zelden laag lumbale rugpijn. Zeer tevreden over het resultaat, kan met name weer goed tennissen. wat voor de operatie nauwelijks meer lukte.

Beschouwing en conclusie:

Op de volwassen leeftijd zijn soms spontane fusies in de concaviteit van een scoliose aanwezig. Ook na losmaken hiervan blijkt de bereikte correctie vaak matig te zijn, hoewel met het Zielke systeem waarschijnlijk een beter resultaat was verkregen. Dit was in 1978 echter nog niet in gebruik. Met name is de kyfotische component slecht te corrigeren met het Dwyer systeem en beter met het Zielke materiaal. Bij deze patiënt is het resultaat desondanks zeer bevredigend en is verdere progressie voorkomen. 


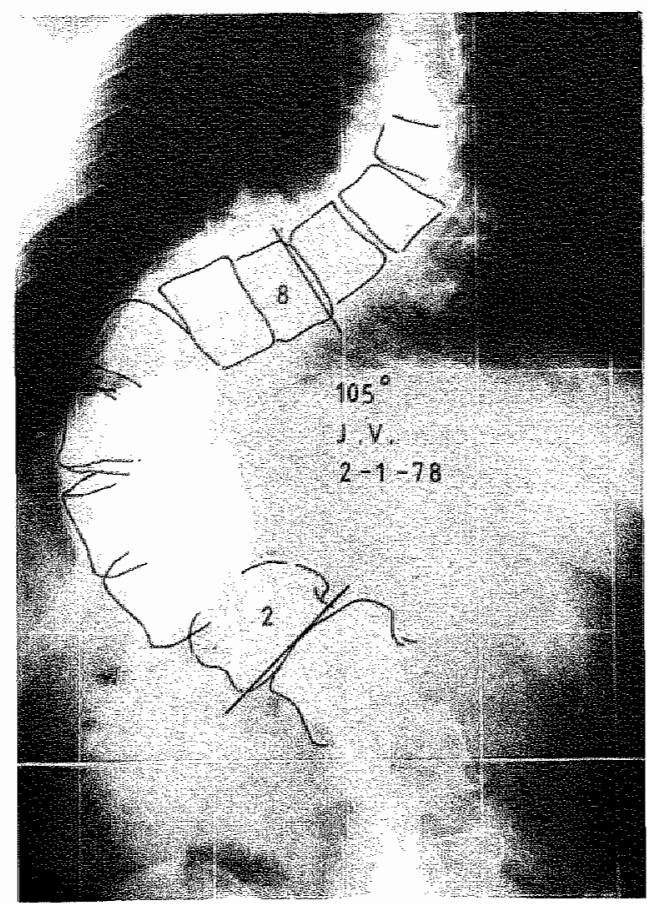

Scoliose préoperatief

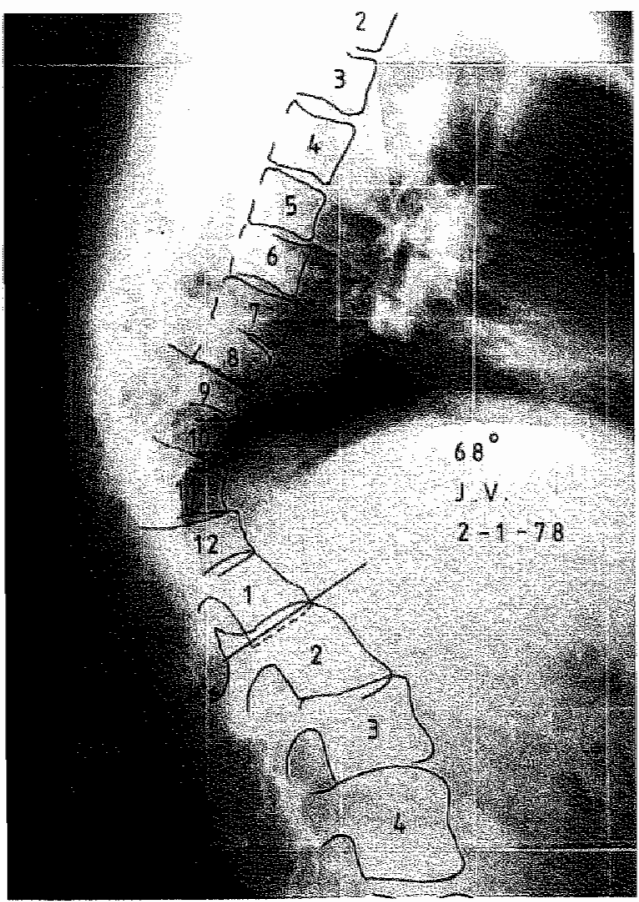

Rotatie kyfose préoperatief

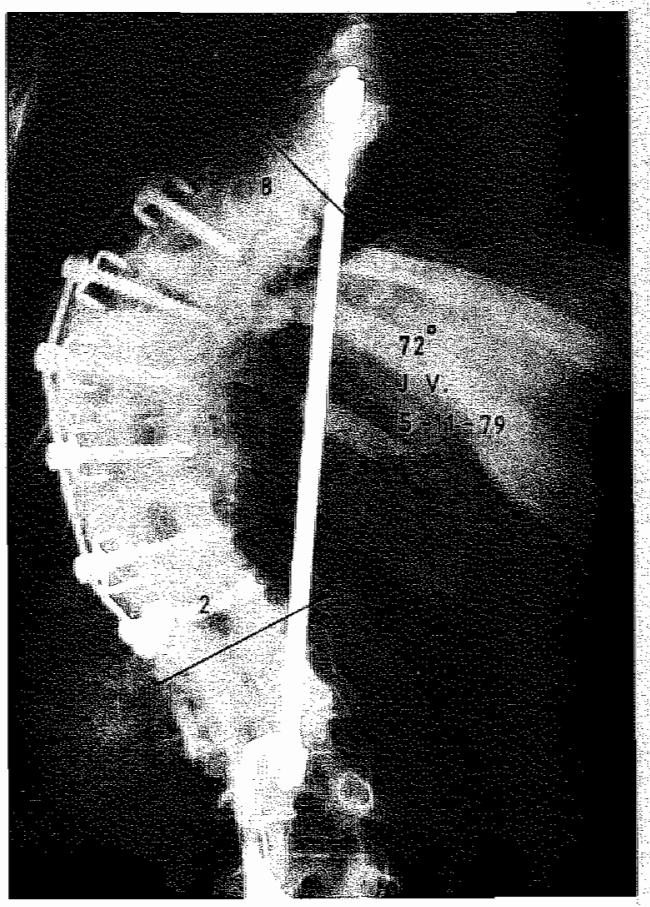

Scoliose postoperatief

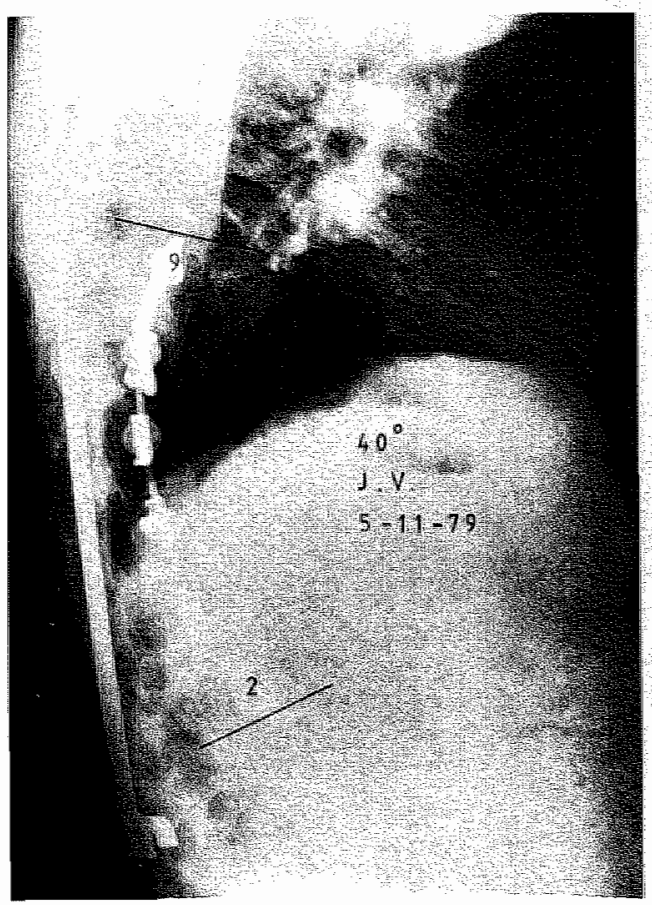

Kylose postoperatief 


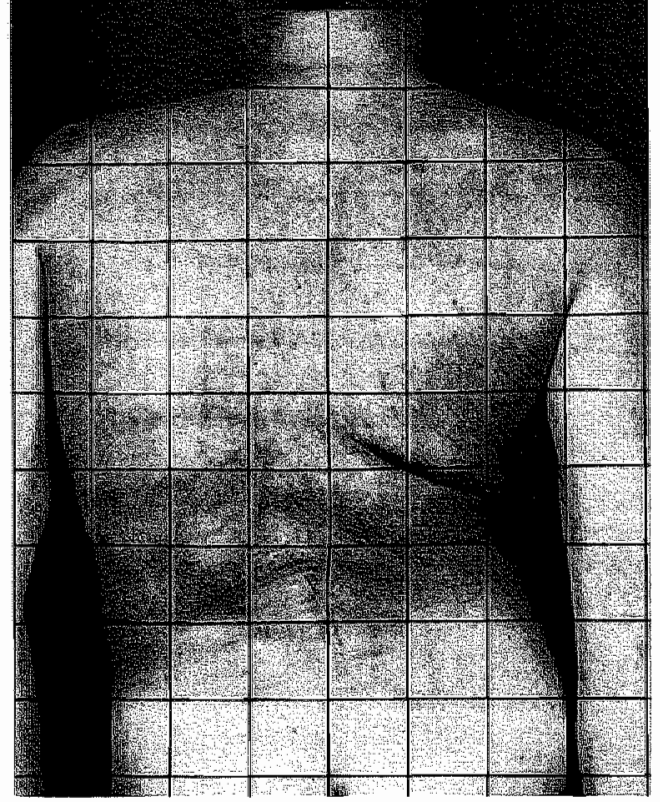

J. V. Scoliose préoperatief

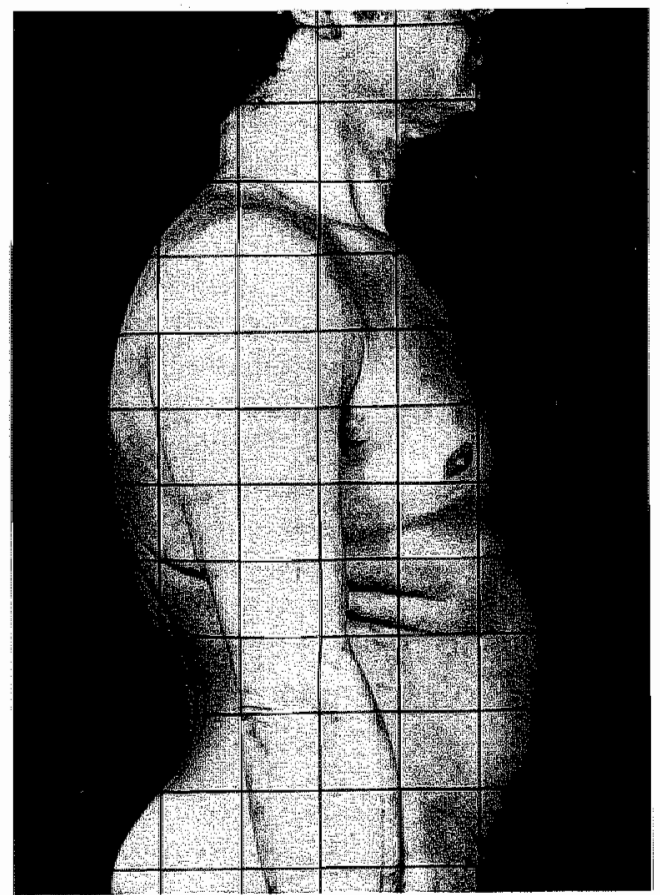

J. V. Kyfose préoperatief

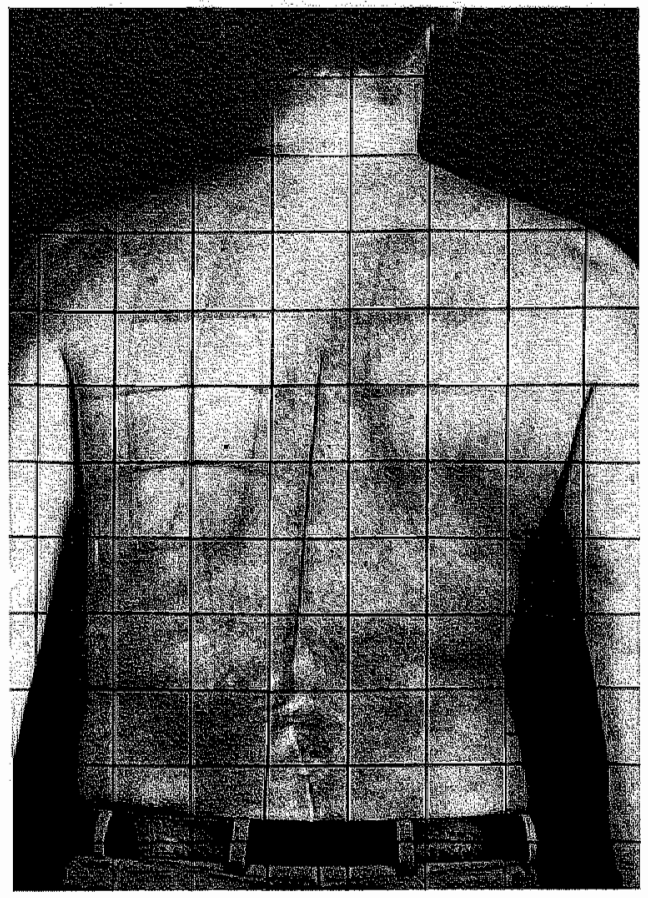

J.V. Scoliose postoperatief

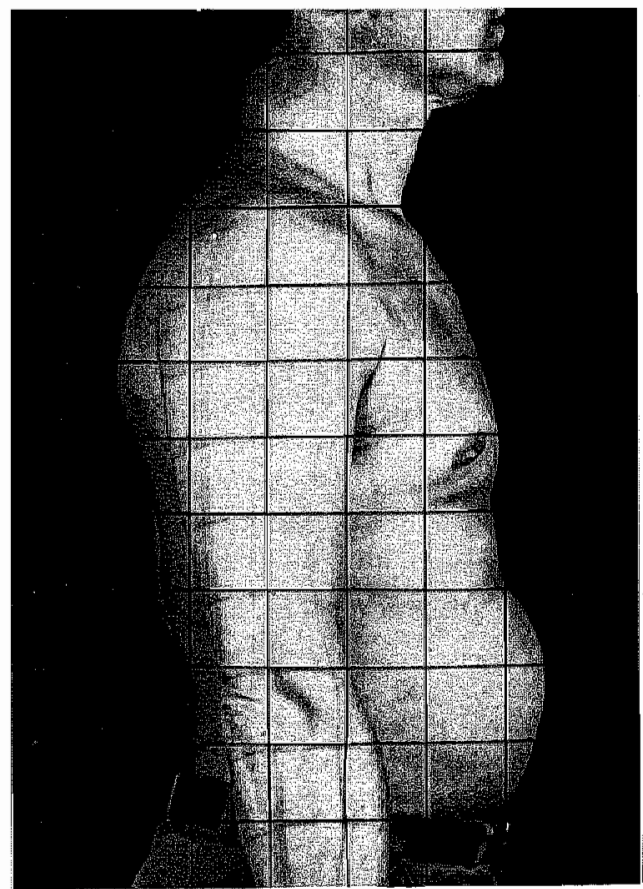

J.V. Kyfose postoperatief 


\section{HOOFDSTUK 5}

\section{KYFOSEN BIJ DE ZIEKTE VAN BECHTEREW}

\subsection{Inleiding}

De spondylitis ankylopoëtica of ziekte van Bechterew wordt in de onbehandelde vorm gekenmerkt door een zich vaak uitbreidende verstijving van de sacro-iliacale en wervelgewrichten, waarbij ook de costovertebrale gewrichten zijn aangedaan. Dit is de algemeen bekende vorm, zich uitend in een niet of nauwelijks bewegende wervelkolom, terwijl ook de ademexcursie van de thorax meestal sterk verminderd is. In een deel van de gevallen kunnen de proximale gewrichten van de ledematen door het ziekteproces worden aangedaan. Daarnaast kan, soms in de beginfase, een perifere arthritis optreden, bijvoorbeeld van de knie of van een voetgewricht, of een tendoperiostitis van de aanhechting van de achillespees aan de calcaneus (25). Ook rib en sternumpijnen zijn bekende vroegsymptomen. Vaak wordt niet aan de ziekte gedacht totdat forse verstijving is opgetreden. De klachten van de patiënt kunnen dan jarenlang niet goed begrepen zijn (23). Haematologisch onderzoek kan een verhoogde bezinking en een leucocytose opleveren. Bij onderzoek van de weefselantigenen wordt in een hoog percentage (ongeveer $90 \%$ ) de factor HLA-B27 gevonden. Het belang van de kwantitatieve sacroiliacale botscan moet nog nader uitgewerkt worden $(12,23)$. Voor het stellen van de diagnose zijn anamnese, lichamelijk onderzoek en röntgenonderzoek echter het belangrijkste (23).

In het laatste stadium van de ziekte is de wervelkolom volledig rigide met verbening van de intervertebraalgewrichten, laterale discusgedeelten en ligamenten, waardoor het karakteristieke beeld van de Bamboo-spine ontstaat. Het is belangrijk als verstijving optreedt deze in een zo gunstig mogelijke stand te doen plaatsvinden. Door ongunstige houding van de wervelkolom tijdens het slapen of zitten of onvoldoende oefentherapie kan deze verbening plaatsvinden in een kyfotische stand, waarbij voorall het verlies van de lumbale lordose de kyfose van de wervelkolom accentueert. De indruk bestaat dat ondanks een volledig verstijfd zijn van de rug de kyfose toch progressief kan zijn door ongelijke opbouw en afbraak van het botweefsel aan de voor- en achterzijde van de wervels onder invloed van kyfoserende krachten. Hierbij speelt de kwaliteit van het bot een belangrijke rol. Bij Bechterew patiënten komen osteolytische haardvormige gebieden in de wervellichamen woor en lijkt het bot zachter en meer porotisch dan bij gezonde personen, zodat de uitwerking van het krachtenspel op de wervelkolom groter is en veranderingen van de sagittale rugcurves het gevolg kunnen zijn $(19,22)$. Bij toename van de kyfose kan de patient problemen krijgen met het voor zich uitkijken. Bij het lopen moet de patiënt na enkele stappen stilstaan en achterover leunen in de heupen om te kunnen zien wat voor hem is, waarna hetzelfde ritueel zich nat enkele stappen herhaalt. Dat één en ander zeer vermoeiend is, maar ook frustrerend moet zijn, behoeft geen betoog. Een ander gevolg van de opgeheven lumbale lordose is de verkorte afstand tussen de origo en insertie van de buikmusculatuur, waardoor de diafragmale ademhaling bemoeilijkt wordt, terwijl de thoraxademhaling al volledig is weggevallen door verstijving van de costo-vertebrale gewrichten. Dyspnoe d'effort behoort dan ook tot één van de kenmerkende symptomen bij deze afwijking $(2,6)$. Bij de ernstiger vormen van de ziekte van Bechterew kunnen de heupen worden aangetast. Dit kan aanleiding geven tot flexiecontracturen, waardoor de patiënt zijn wervelkolomkyfose niet goed meer kan compenseren door achterover te leunen in de heupen. Doet hij dit, dan 
dreigt hij om te vallen (28). Kyfosering van de cervicale wervelkolom geeft aanleiding tot verdere inkrimping van het gezichtsveld. In extreme vormen komt het hoofd bijna op het sternum te rusten, zodat de mond niet goed meer geopend kan worden en de (meestal mannelijke) patiënt zich niet meer kan scheren $(27,29,32)$.

\subsection{Behandeling}

Naast de conservatieve behandelingsmogelijkheden van de ziekte van Bechterew (6) komt bij invaliderende kyfosering van de wervelkolom een columnotomie in aanmerking. Dit is een osteotomie van de wervelzuil. Smith-Petersen (31) beschreef in 1945 als eerste deze operatie. Kort hierop volgde La Chapelle (1946) die deze operatie in de oorlogsjaren eveneens had verricht zonder te weten dat Smith-Petersen deze operatie ook ontwikkeld had (13). Pas na het einde wan de tweede wereldoorlog volgde La Cha. pelles publicatie. Later verschenen nog vele artikelen over dit onderwerp $(2,3,4,5,7$, $9,10,15,20,24,26,28,30$ ).

De meest gebruikelijke plaats voor de ingreep is de hoog lumbale wervelkolom, waar het myelum zich heeft voortgezet in de cauda equina. De overgang tussen myelum en cauda is bijna altijd ter hoogte van L1. Aan de achterzijde wordt een wigvormige resectie verricht van processi spinosi, laminae, intergewrichten en pedikels met vrijleggen van de duraalzak en uittredende wortels, waarna de wig door manuele druk gesloten wordt zodat aan de voorzijde een spouwing plaatsvindt, waarbij de wervelkolom alls het ware gebroken wordt bij verbening van het voorste ligament. Een spondylodese ter plaatse van de osteotomie met behulp van het uitgenomen bot wordt vrijwel altijd toegevoegd. De op deze manier verkregen lumbale lordose kan gehandhaafd worden met interne fixatie door een dubbelzijdig Harringtoncompressie systeem of door cerclage, vaak wordt alleen uitwendige stabilisatie door een gipsbed of gipscorset gebruikt. Als de wig niet ruim genoeg genomen is kan compressie van uittredende zenuwwortels plaatsvinden met als gevolg paresen. Ook is een enkele keer een volledige dwarslaesie beschreven door excessieve voorachterwaartse verplaatsing ter plaatse van de osteotomie $(15,24)$. Een ander gevaar is ruptuur van de aorta, met name als door sterke arteriosclerose en aneurysmavorming de aorta adherent is geworden aan de wervelkolom. dit is echter slechts zelden beschreven en dan nog na voorafgaande bestraling $(5,18)$.

Sommige auteurs prefereren de operatie zowel aan de voor- als achterzijde te verrichten, waardoor meer controle over de situatie ter plaatse van de columnotomie wordt verkregen $(10,14)$.

Bij thoraco-cervicale kyfose bestaat de mogelijkheid de operatie cervicaal te verrichten, ter hoogte van C7-T1, waarbij een veel ruimere laminectomie moet geschieden om myelum en wortels zoveel mogelijk ruimte te geven. Dezc operatie geeft meer kans op neuropraxie, reden waarom de operatie veelal onder locaal anaesthesie gebeurt of onder een lichte narcose, waarbij de patiënt na de correctie wakker wordt gemaakt om de myelumfunctie te controleren. Intubatie kan door de sterke cervicale kyfose zeer moeilijk zijn, ook dit is een reden om de operatie onder locale anaesthesie te verrichten ( 16 , $27,29,32)$.

Thoracale operatie is mogelijk via een release aan de voorzijde van de wervelkolom via thoracotomie, waarna in $2 \mathrm{e}$ tempo achterste compressiespondylodese. Bestaat er geen volledige ankylose en is er een redelijke correctiemogelijkheid, dan kan worden volstaan met alleen een compressiespondylodese (28). Meestal zal gekozen worden voor een hoog lumbale collumnotomie, waarmee de thoracale kyfose gecompenseerd wordt door de gecreëerde hoog lumbale lordose. Een laatste mogelijkheid is correctie te ge- 
wen in het bekken door middel van een dubbelzijdige iliumosteotomie boven het acetabulum met spouwen en inbrengen van wigvormige botstukken aan de voorzijde, zodat de gehele wervelkolom achterover wordt gekanteld (33). Soms is het bot van de patiënten met deze ziekte zo zacht, dat met conservatief-redresserende maatregelen zoals gipsredressie of Halo-tractie al correctie kan worden verkregen (8). Ook bij de laatst beschreven Bechterewpatiënte werd door postoperatieve gipsredressie een lordosering onder de laminectomie verkregen, welke echter na het verwijderen van het gips weer snel verloren ging. Hier was sprake van meebuigen van het zachte bot van de verbeende wervelzuil.

Samenvattend is de correctie van een invaliderende Bechterewkyfose door middel van een columnotomie een goede ingreep met betrekkelijk weinig morbiditeit, al zijn in de literatuur ernstige complicaties beschreven.

\subsection{Literatuut hoofdstuk 5}

1. Boersma J. W. Retardation of ossification of the lumbar vertebral column in ankylosing spondylitis by means of phenylbutazone. Scand. J. Rheumatology 5, 1976, $60-64$.

2. Bossers G. Th. M. Columnotomy in severe Bechterew kyphosis. Acta Orthop. Belg. 38, 1.972, 47-54.

3. Briggs $\mathrm{H}$. Keats $\mathrm{S}$. Schlesinger $\mathbb{P}$. T. Wedge osteotomy of the spine with bilateral intervertebral foraminotomy. Journ. of Bone and Joint Surg. 29, 1947, 1075-1082.

4. Chapchal G. Operative treatment of severe kyphosis as the result of Bechterew's disease. Arch. Chir. Neerl. 1, $194957-63$.

5. Crawford Adams J. Technique, dangers and safeguards in osteotomy of the spine. Journ. of Bone and Joint Surg. 34B, 1952, 226-232.

6. Dudley Hart F. Ankylosing spondylitis. Chapter 8 in: Modern trends in diseases of the vertebral column. Butterworths Medical Publications London 1959.

7. Emneus H. Wedge osteotomy of spine in ankylosing spondylitis. Acta Orthop. Scand. $39,1968,321-326$.

8. Freeman G. E. Correction of severe deformity of the cervical spine in ankylosing spondylitis with the Halo device. Journ. of Bone and Joint Surg. 43A, 1961, 547552.

9. Goel M. K. Vertebral osteotomy for correction of fixed flexion deformity of the spine. Journ. of Bone and Joint Surg. 50A, 1968, 287-294.

10. Herbert J. J. Vertebral osteotomy, technique, indications and results. Journ. of Bone and Joint Surg. 30A, 1948, 680-689.

11. Herbert J. I. Vertebral osteotomy for kyphosis, especially in Marie-Strümpell arthritis. A report on fifty cases. Journ. of Bone and Joint Surg. 41A, 1959, 291-320. 
12. Ho G. J. Sadownikoff N. Malhotra C. M. Claunch B. C. Quantitative sacroiliatic joint scintigraphy. A critical assessment. Arthr. and Reumatism 22, 1979, 837-844.

13. La Chapelle E. H. Osteotomy of the lumbar spine for correction of kyphosis in a case of ankylosing spondylarthritis. Journ. of Bone and Joint Surg. 28, 1946, 851858 .

14. La Chapelle E. H. Columnotomia lumbalis. Ned. Tijdschr. Geneesk. 91, 1947. 1504-1511.

15. Law W. A. Lumbar spinal osteotomy. Joum. of Bone and Joint Surg. 41B, 1959. $270-278$.

16. Law W. A. Osteotomy of the spine. Journ. of Bone and Joint Surg. 44A. 1962. 1199-1206.

17. Law W. A. Osteotomy of the spine. Clin. Orthop. 66, 1969.70-76.

18. Lichtblau P. O. Wilson P. D. Possible mechanism of aortic rupture in orthopaedic correction of rheumatoid spondylitis. Journ. of Bone and Joint Surg. 38A, 1956, 123-127.

19. Van der Linden A. J. Osteolytische defecten by spondylitis ankylopoetica. Ned. Tijdschr. Geneesk. 112, 1968, 1696-1698.

20. McMaster P. E. Osteotomy of the spine for fixed flexion deformity. Journ. of Bone and Joint Surg. 44A, 1962, 1207-1216.

21. Nanninga K. J. Grepen uit de geschiedenis van de ziekte van Bechterew. Reuma Wereldwijd 2, 1978, 13-16.

22. Oepen G. Clarenbach P. Gilsbach J. Destruierende Wirbelkörperosteolysen mit tetraparese bei morbus Bechterew. Zeitschr. für Orthopädie 120, 1982, 73-75.

23. Van Oijen P. L. M. Boersma J. W. Vertraagde diagnosestelling bij de ziekte van Bechterew. Ned. Tijdschr. Geneesk. 126, 1982, 1761-1764.

24. Püschel J. Korrekturoperationen beim morbus Bechterew. Technik-Ergebnisse. Zeitschr. für Orthopädie 119, 1981, 823-824.

25. Schatler J. G. Ankylosing spondylitis of childhood onset. Arthr. and Rheumatism $20,1977,398-401$.

26. Scudese V. A. Calabro J. J. Vertebral wedge osteotomy. Correction of rheumatoid (ankylosing) spondylitis. J. A. M. A. 186, 1963, 105-109.

27. Simmons E. H. The surgical correction of flexion deformity of the cervical spine in ankylosing spondylitis. Clin. Orthop. 86, 1972, 132-143. 
28. Simmons E. H. Kyphotic deformity of the spine in ankylosing spondylitis. Clin. Orthop. $128,1977,65-76$.

29. Simmons E. H. Osteotomy of the cervical spine in ankylosing spondylitis: a 15 year experience. Journ, of Bone and Joint Surg. 64B, 1982, 635.

30. Slot G. H. Bossers G. Th. M. Osteotomy of the vertebral column (columnotomy) in 15 patients with kyphosis due to Bechterew's disease. Acta Orthop. Scand. 54, 1983,674 .

31. Smith-Petersen M. N. Larson C. B. Aufranc D. E. Osteotomy of the spine for correction of flexion deformity in rheumatoid arthritis. Journ. of Bone and Joint Surg. $27,1945,1-11$.

32. Urist M. R. Osteotomy of the cervical spine. Report of a case of ankylosing theumatoid spondylitis. Journ. of Bone and Joint Surg. 40A, 1958, 833-843.

33. Wilson P. D. Levine D. B. Compensatory pelvic osteotomy for ankylosing spondylitis. A case report. Journ. of Bone and Joint Surg. 51 A, 1969, 142-148. 
Patient 21. W. S. mannelijk, geb. dat. 30-5-1940.

Aetiologie:

Vroegere behandeling:

Klachten:

Préoperatieve curves:

Voorbehandeling:

Longfunctie:

Conclusie:

Neurologisch onderzoek:

Operatie:

Complicaties:

Nabehandeling:

Postoperatieve curves:

Postoperatieve klachten:

Beschouwing en conclusie:
Totaalkyfose bij de ziekte van Bechterew.

Medicijnen en fysiotherapie.

Dyspnoe d'effort. Geen pijnklachten van betekenis. Problemen bij het vooruit zien.

Totaalkyfose van $70^{\circ}$. De lendenlordose is verstreken.

Geen.

Vit.cap. $4525 \mathrm{cc}$. Normaal $6100 \mathrm{cc}$. Tot.cap. $6100 \mathrm{cc}$. Normaal $8350 \mathrm{cc}$.

Matige restrictie van de longfunctie. Zeer ruime ventilatoire reserves. De dyspnoe kan dan ook niet uit dit onderzoek verklaard worden.

Geen afwijkingen.

31-3-1976. Columnotomie op het niveau L1-2.

In de $2 \mathrm{e}$ postoperatieve nacht is de patiënt met gipsschelp en al uit bed gevallen door sterke onrust en desoriëntatie. De correctie in de columnotomie was hierna röntgenologisch verminderd. Op 5-4-1976 werd patiënt onder narcose opnieuw ingegipst met goede correctie tot gevolg. Geen verdere complicaties.

3 Maanden liggipscorset met pijpen, vervolgens 2 maanden ortholane loopcorset.

$24^{\circ}$ Lordosering ter plaatse van niveau $\mathrm{L} 1-2$. Dit is constant gebleven in het postoperatieve beloop.

Geen. De dyspnoe is verdwenen.

Bij deze patiënt stond de dyspnoe op de voorgrond. Dit is niet te wijten aan een beperkte longcapaciteit, doch aan de starre thorax en aan de insufficiente diafragma ademhaling door de verkorting van de afstand origo-insertie van de buikmusculatuur. Door de buikmusculatuur te strekken door middel van een columnotomie kan de dyspnoe verdwijnen, zoals bij deze patiënt. Ook het blikveld wordt met de operatie flink verruimd. terwijl het psychisch welbevinden na de operatie meestal sterk verbetert. 


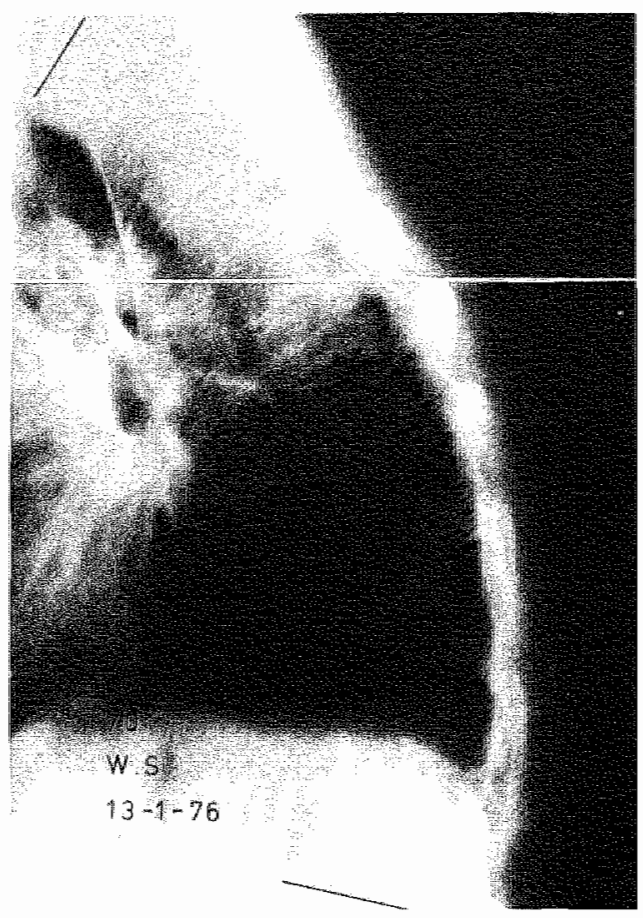

Totaalkyfose préoperatief

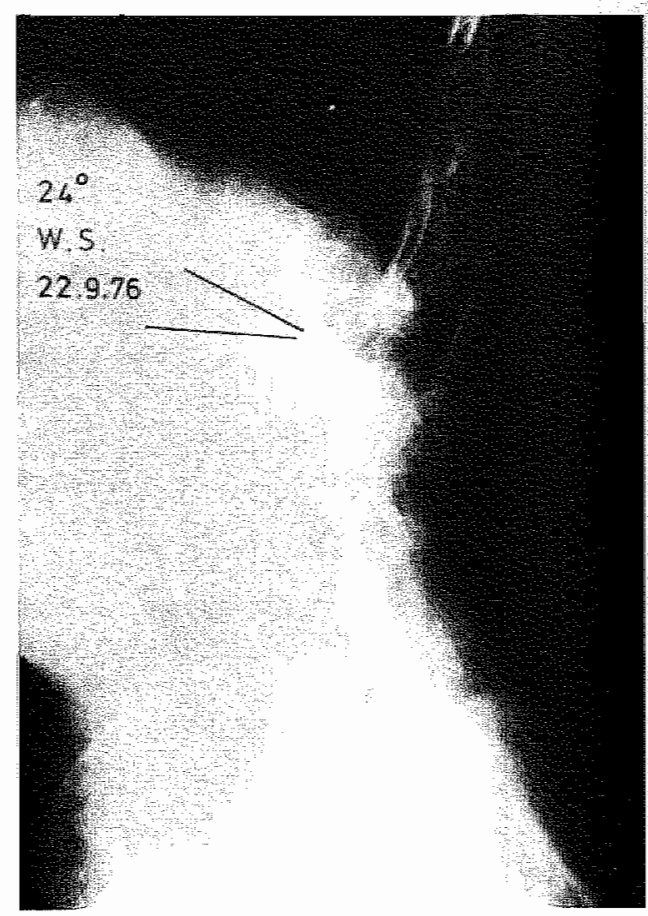

Compensatoire lordose ter plaatse van L $1-2$ van $24^{\circ}$ 


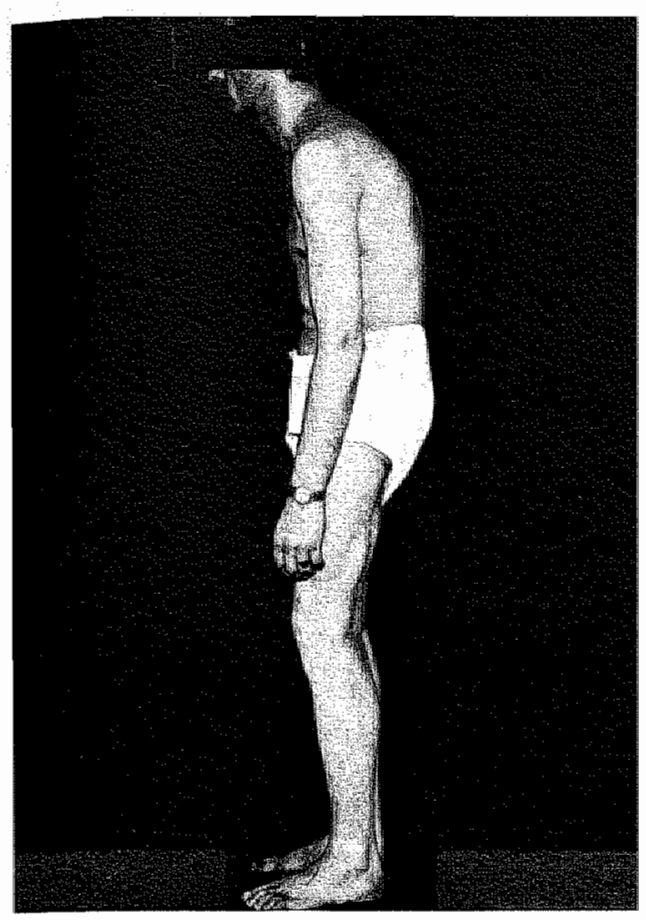

W. S. kyfose préoperatief

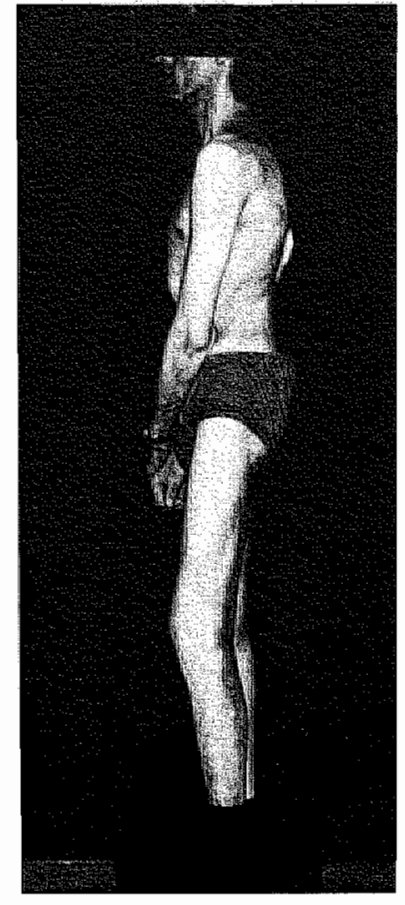

W. S. goede strekking van de rug postoperatief. Let op het weer promineren van de thorax
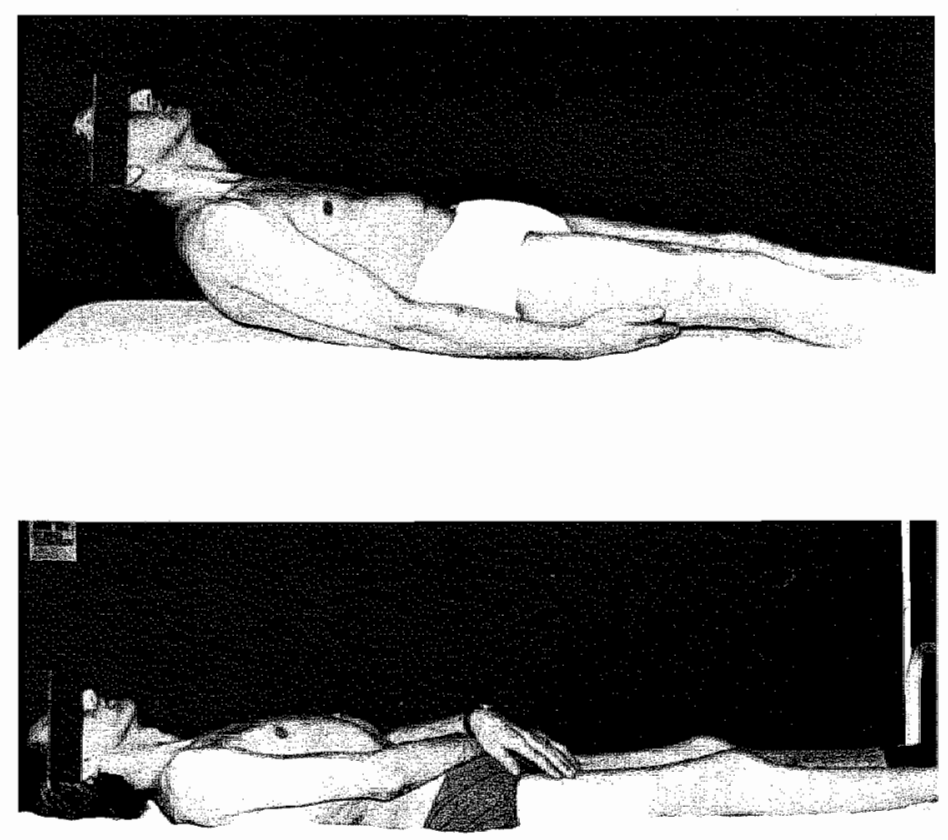

W. S. patiënt kan na de operatie weer met het hoofd op de onderlaag liggen. Let ook op de forse atrofie van de beenmusculatuur na 3 maanden liggipscorset. 
Patiënt 22. M. B. vrouwelijk, geb. dat. 24-5-1923.

Actiologie:

Vroegere behandeling:

Klachten:

Préoperatieve curves:

Voorbehandeling:

Longfunctie:

Conclusie:

Neurologisch onderzoek:

Operatie:

Complicaties:

Nabehandeling:

Postoperatieve curves:

Postoperatieve klachten:
Totaalkyfose bij de ziekte van Bechterew.

Medicamenten en fysische therapie.

Cervicale en lumbale pijn. Algehele vermoeidheid en depressiviteit. Dyspnoe d'effort. Matige eetlust; status na Billroth I maagresectie.

Totaalkyfose $71^{\circ}$ met opgeheven zijn van de lumbale lordose.

Geen.

Vit.cap. 2700 cc. Normaal 3625 cc. Tot.cap. 3825 ce, Normaal $5125 \mathrm{cc}$.

Matige restrictie met nog ruime ventilatoire reserves.

Geen afwijkingen.

4-11-1977. Columnotomie ter hoogte van L2 met spondylodese L1-2-3.

Decubitus op de rug. Maagklachten. Urineweginfectie. Vermagering.

3 Maanden romp-been liggips.

$47^{\circ}$ Lordosering ter plaatse van de columnotomie.

I Jaar postoperatief (laatste controle) zeer tevreden met de verbeterde houding. Geen dyspnoe klachten meer, geen pijnklachten.

Beschouwing en conchusie:

Ook bij deze vrouw met veel klachten, waaronder psychische problemen trad een goede verbetering op van het algehele welbevinden na de operatie. Deze patiënten lijden vaak onder hun kromme rug. Na het verkrijgen van een min of meer rechte rug verbetert deze problematiek meestal.

Naar mijn mening mogen psychische factoren een rol spelen in de indicatiestelling. Soms zal dit negatief zijn, soms positief. 


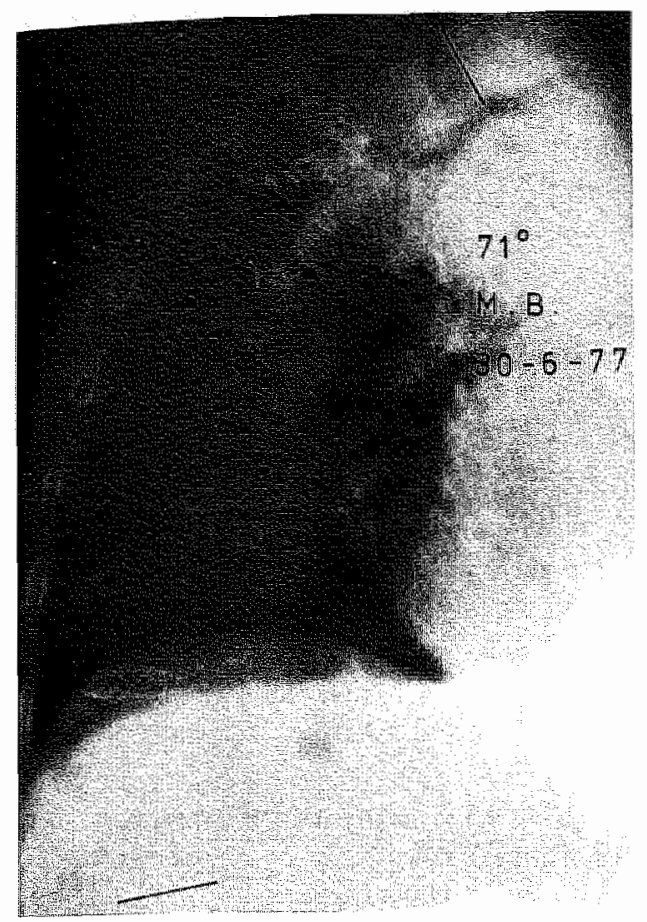

Totaalkyfose préoperatief

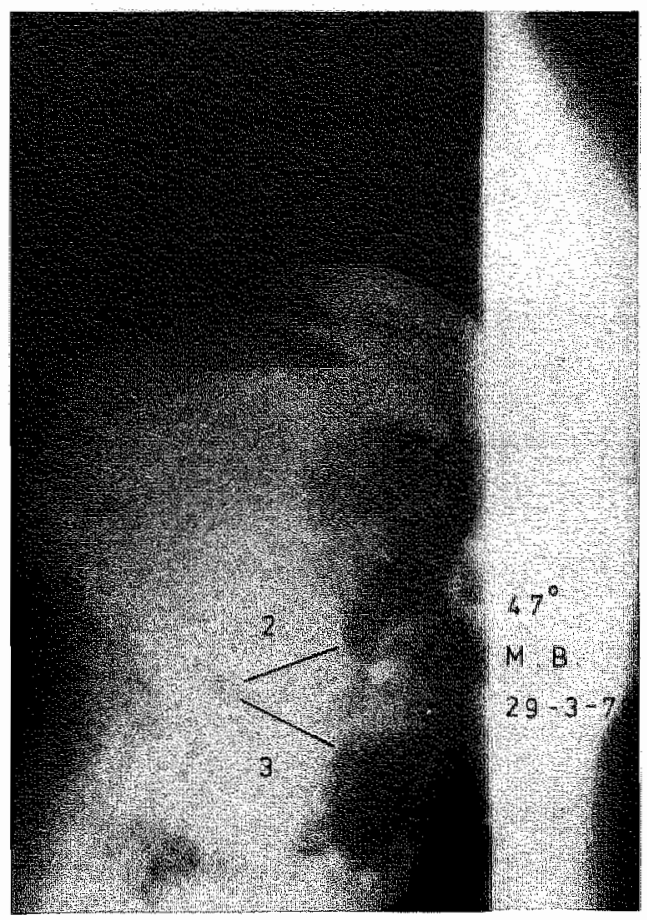

Goede correctie postoperatief. $47^{\circ}$ lordosering

Helaas geen medische foto's beschikbaar 
Patiènt 23. C. w. K. mannelijk, geb. dat. 19-6-1947.

Aetiologie:

Vroegere behandeling:

Klachten:

Préoperatieve curves:

Voorbehandeling:

Longfunctie:

Conclusie:

Neurologisch onderzoek:

Operatie:

Complicaties:

Nabehandeling:

Postoperatieve curves:

Postoperatieve klachten:
Totaalkyfose bij de ziekte van Bechterew. Tevens diabetes mellitus en een totale heupprothese links na arthrose van dit heupgewricht door de ziekte van Bechterew.

Medicamenten. Fysiotherapie. Totale heupprothese links.

Dyspnoe d'effort. Onmogelijkheid om de horizon te zien.

Ongeveer $72^{\circ}$ totaalkyfose zonder lumbale lordose.

Geen.

Vit.cap. 3900 cc. Normaal 6425 cc. Tot.cap. $5650 \mathrm{cc}$. Normaal $8350 \mathrm{cc}$.

Duidelijke restrictieve functiestoornis met toch nog ruime ventilatoire reserves.

Geen afwijkingen.

8-3-1978. Columnotomie ter plaatse van L2-3.

Geen.

Ongeveer 10 dagen gipsbed waarna gipscorset met 2 pijpen. Patiënt is toen elders verder behandeld.

Er werd een lordosering van $55^{\circ}$ bereikt. Patiënt is toen elders nabehandeld en werd op 15-2-1980 gezien voor nacontrole. Er bleek toen jammer genoeg nog slechts $19^{\circ}$ lordosering aanwezig te zijn. Blijkbaar is in de latere postoperatieve fase de correctie voor het grootste gedeelte verloren gegaan.

Patiënt is tevreden over het effect van de operatie. De houding is verbeterd, ook de ademhaling is makkelijker. Hij heeft tot 1 jaar na de operatie last van de nek gehad. Nu waren er klachten van de rechter heup, er bestond hier een flexie contractuur, waardoor de houding weer verslechterd was. 
Beschouming en conclusie:

Bij deze patiënt werd op goede indicatie een geslaagde columnotomie verricht. Helaas bleef er van de fraaie correctie niet weel over, waarschijnlijk door insufficięnte nabehandeling, mogelijk dat de consolidatie ten tijde van de gipsverwijdering ( 3 maanden) onvoldoende was. Niettemin is patiënt over het effect tevreden. 


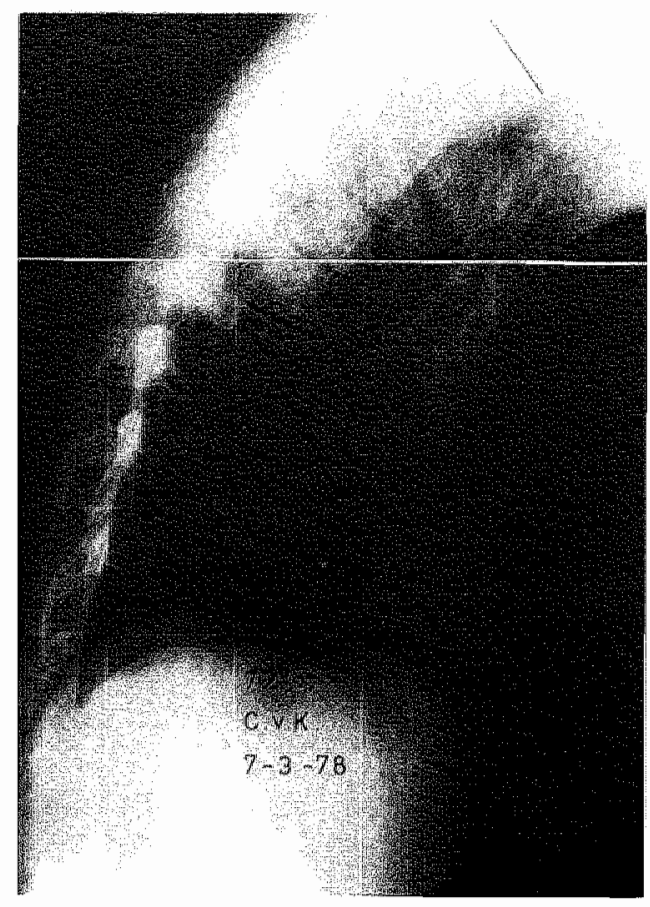

Totaalkyfose préoperatief

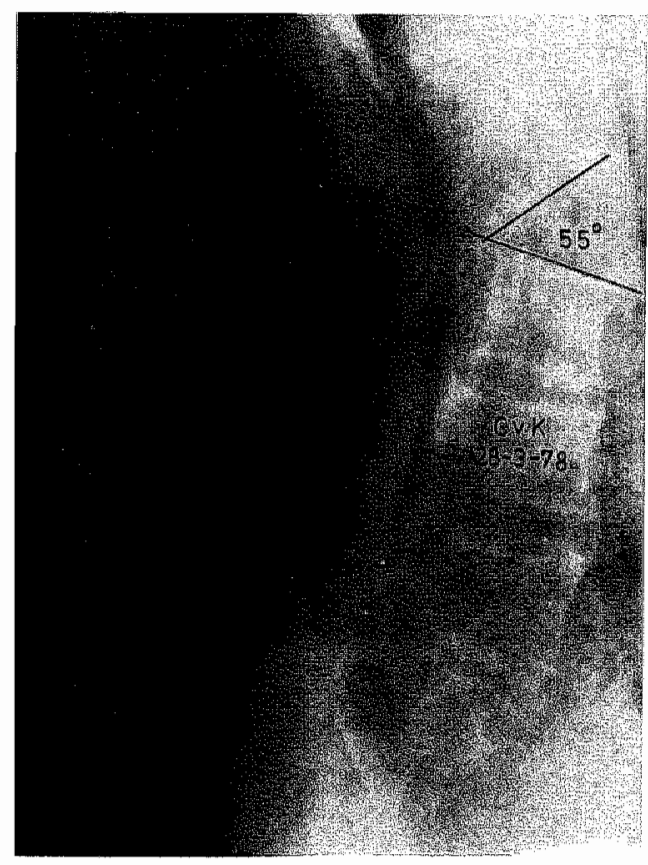

20 dagen postoperatief $55^{\circ}$ lordosering

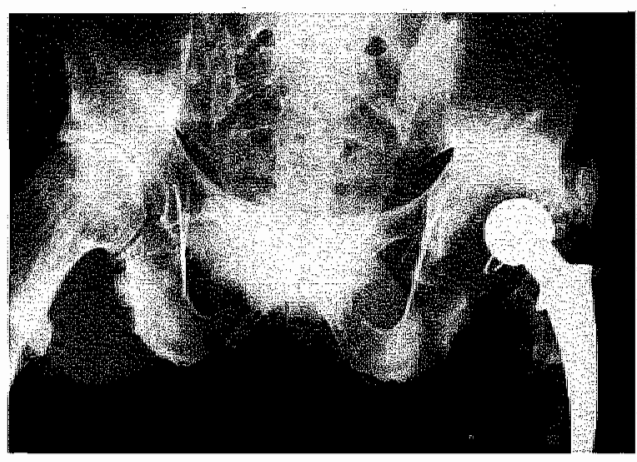

Totaalprothese. Let op de peri-articulaire verkalkingen. Rechts nog goede gewrichtsspleet, desondanks flexiecontractuur

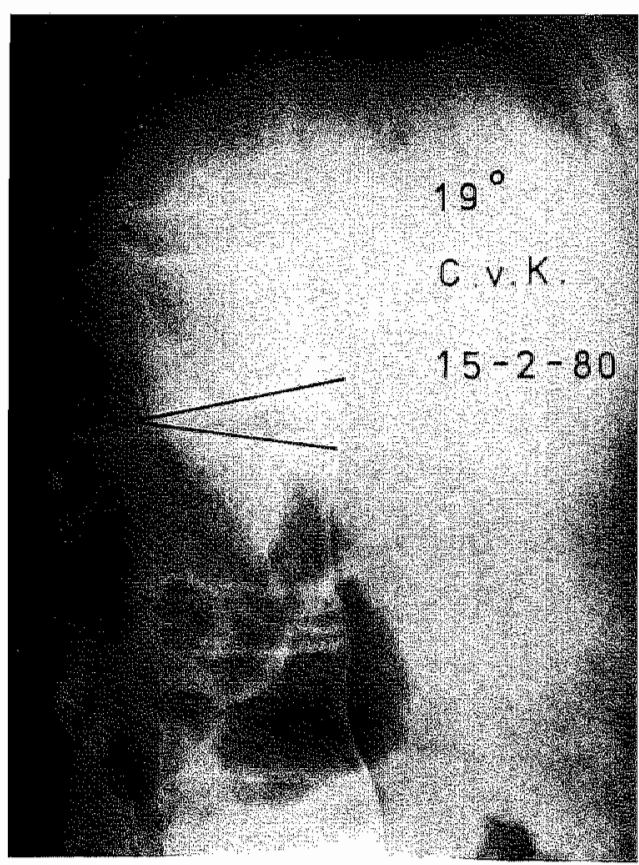

2 jaar postoperatief slechts $19^{\circ}$ lordosering 


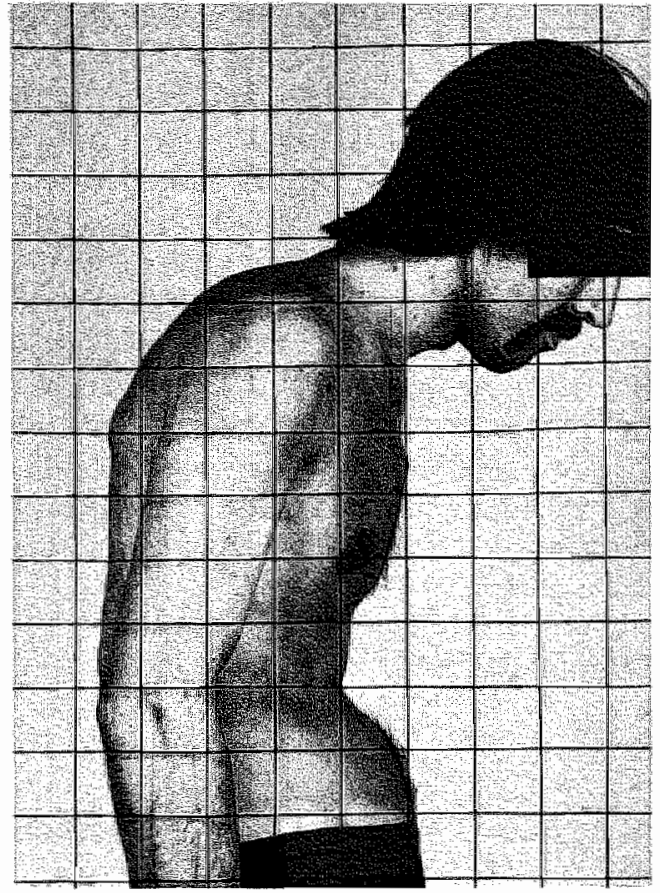

C. v. K. kyfose préoperatief

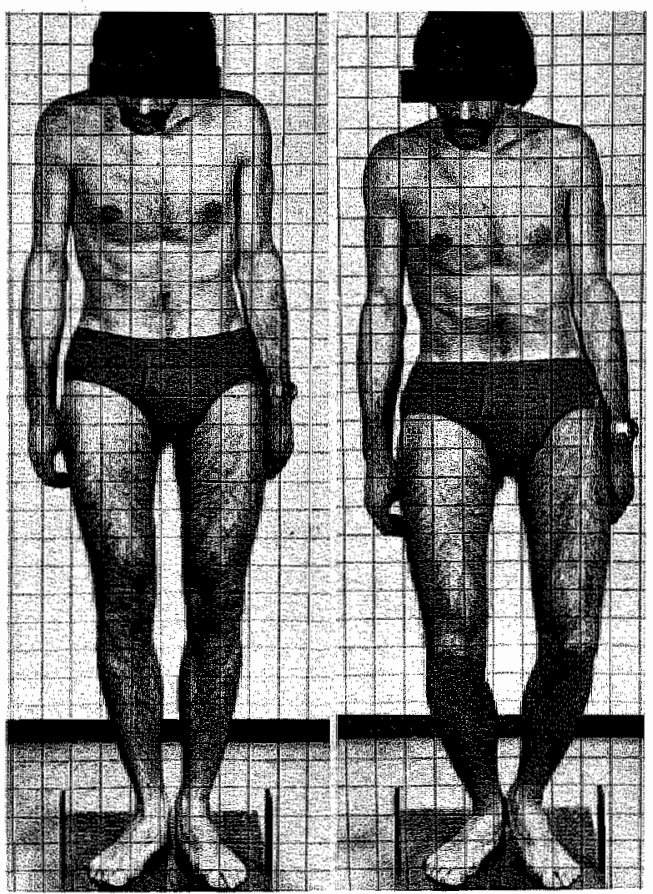

C. v. K. vooraanzicht préoperatief

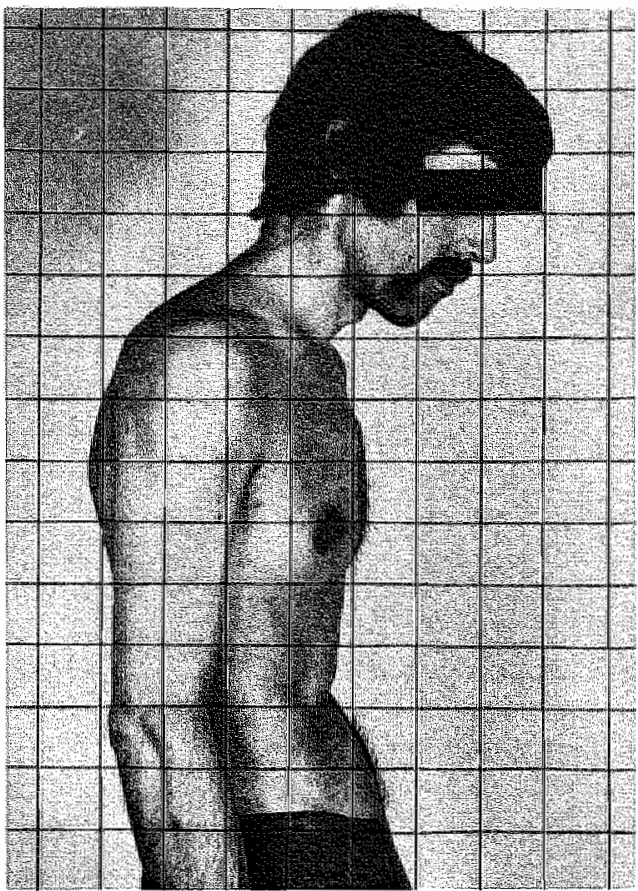

C. v. K. kyfose postoperatief

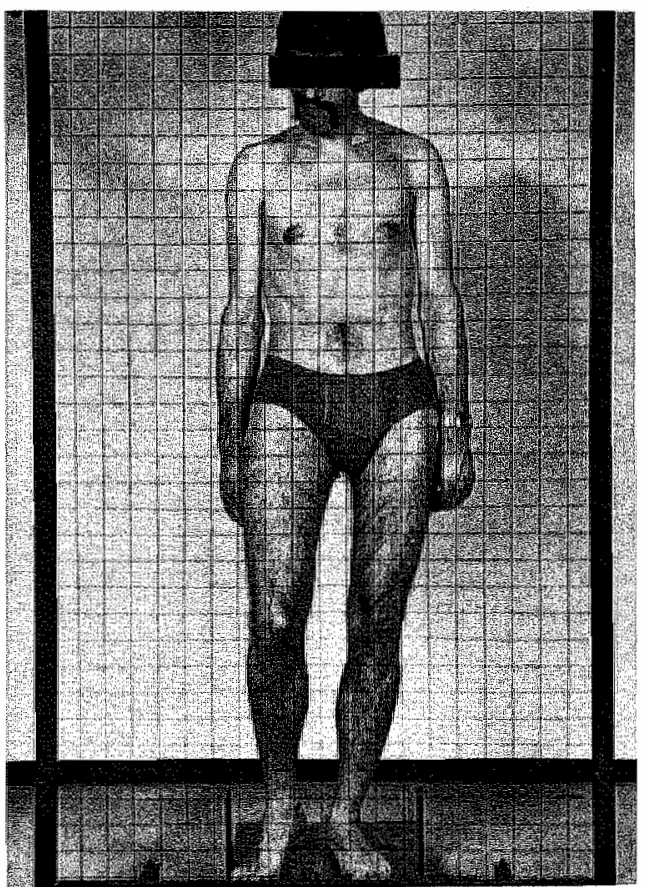

C. v. K. vooraanzicht postoperatief 
Patiënt 24. M. P. mannelijk, geb. dat. 14-12-1925.

Aetiologie:

Vroegere behandeling:

Klachten:

Préoperatieve curves:

Voorbehandeling:

Longfunctie:

Conclusie:

Neurologisch onderzoek:

Operatie:

Complicaties:

Nabehandeling:

Postoperatieve curves:

Postoperatieve klachten:
Versterkte rigide kyfose hoog thoracaal en cervicaal bij de ziekte van Bechterew.

Medicamenten. Fysiotherapie.

Pijnaanvallen rechts in de zij. Onmogelijkheid de horizon te zien. Patiënt kon niet meer autorijden, omdat hij niet meer in de achteruitkijkspiegel kon kijken. Bij het scheren kon hij niet meer onder zijn kin komen. Ook problemen met de rechterheup, door auto-ongeval in 1971 was er een luxatie-fractuur van deze heup opgetreden, met coxarthrosis tot gevolg. Geen dyspnoe.

Ongeveer $115^{\circ}$ totaalkyfose.

Aanleggen Halo.

Vit.cap. $3100 \mathrm{cc}$. Normaal $4975 \mathrm{cc}$. Tot.cap. $4850 \mathrm{cc}$. Normaal $7025 \mathrm{cc}$.

Duidelijke restrictieve functiestoornis met nog redelijke reserves.

Geen duidelijk aantoonbare neurologische afwijkingen.

2-3-1977. Cervicale columnotomie C7-T1. Operatie onder locale anaesthesie met lichte respiratie narcose via de neus met wake-up-test tijdens de operatie.

Passagère partiële n. radialis uitval links.

3 maanden Halo rompgips.

$26^{\circ}$ lordosering t.p.v. C7-T1.

Patiënt is zeer tevreden met het resultaat. Kan weer rechtuit kijken, waardoor beter lopen en beter fietsen. Ook het eten en scheren is makkelijker. 
In dit geval zat het probleem hoog thoracaal en cervicaal. Door een lumbale columnotomie was well het blikveld verbeterd, doch waren de specifieke klachten van de korte kin-borstafstand niet verbeterd. Een cervicale columnotomie is riskanter voor het myelum. Men moet daarom een ruime laminectomie verrichten en ook de uittredende wortels ter plaatse vrijleggen, zodat deze bij het sluiten van de dorsale wig niet gecomprimeerd worden. De passagère radialis uitval bij deze patiënt is waarschijnlijk te wijten geweest aan oedeemvorming rond de zenuwwortel. 


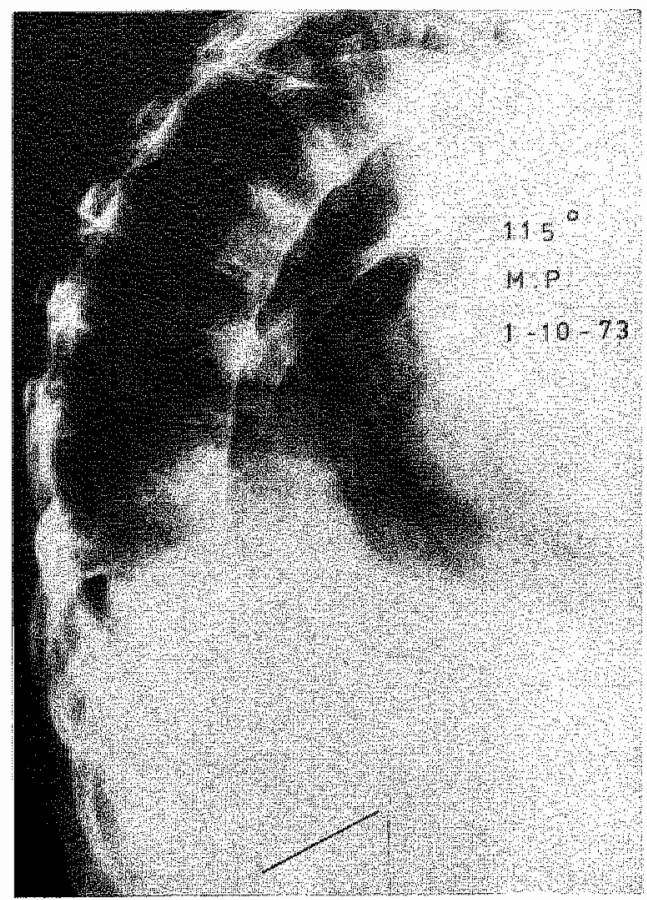

Totaalkytose préoperatief

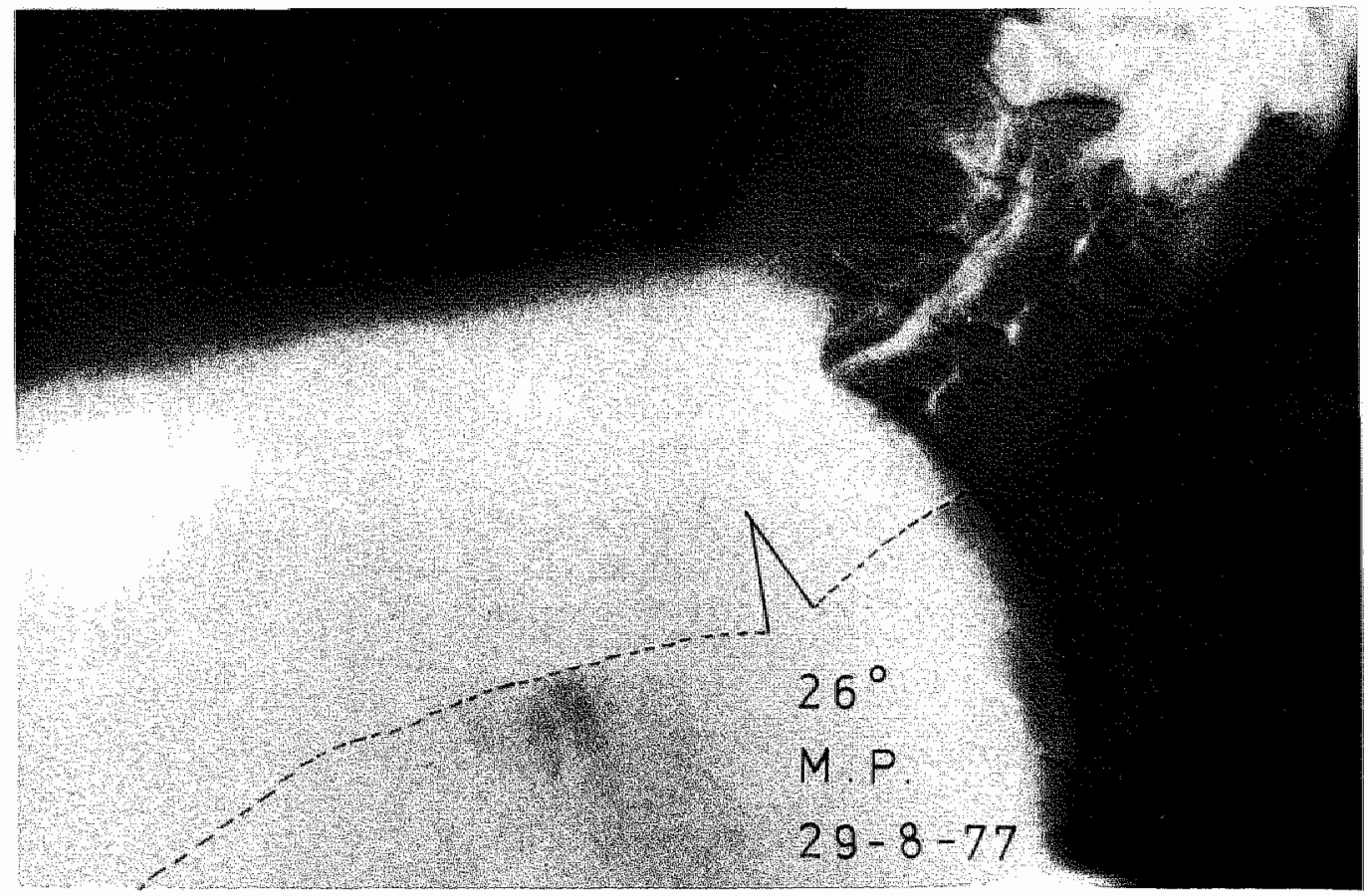

$26^{\circ}$ lordosering cervico-thoracaal 


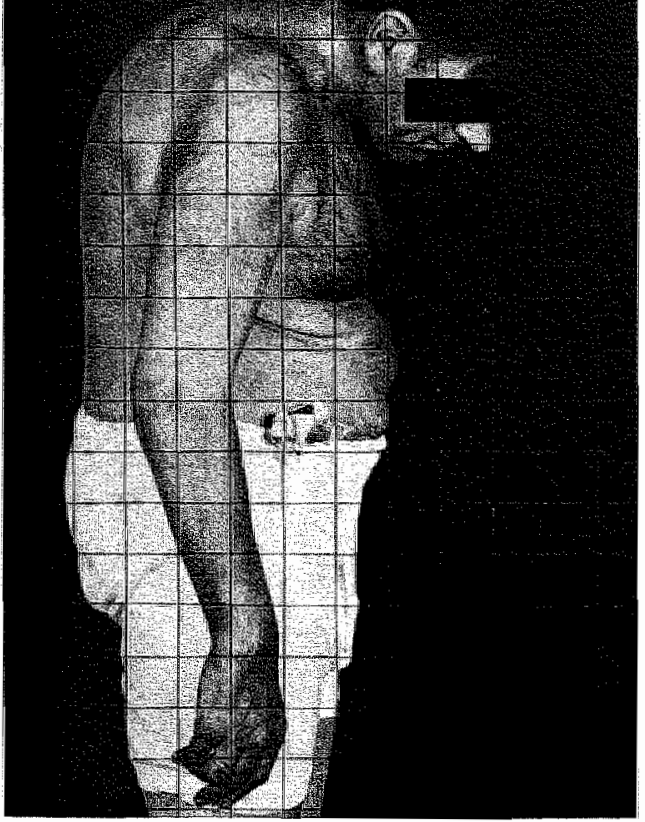

M. P. kyfose préoperatief

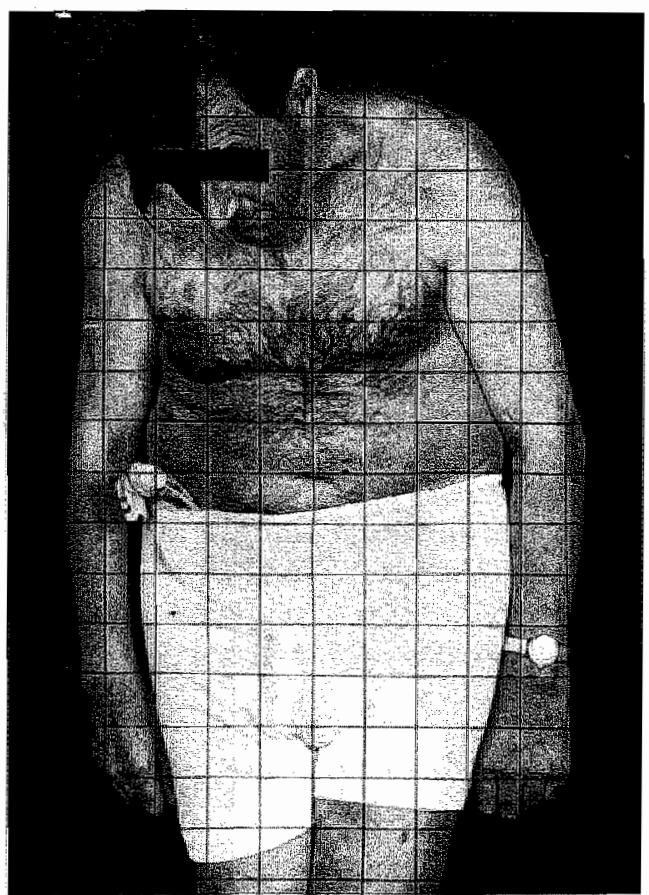

M. P. vooraanzicht préoperatief

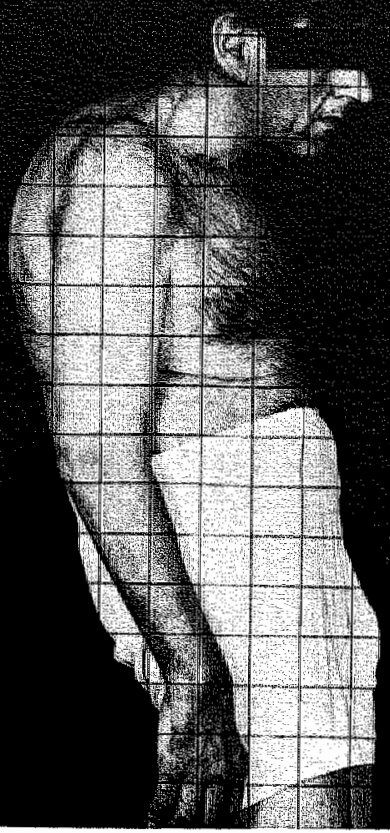

M. P. kyfose postoperatief. Let op de grotere kin-borstafstand

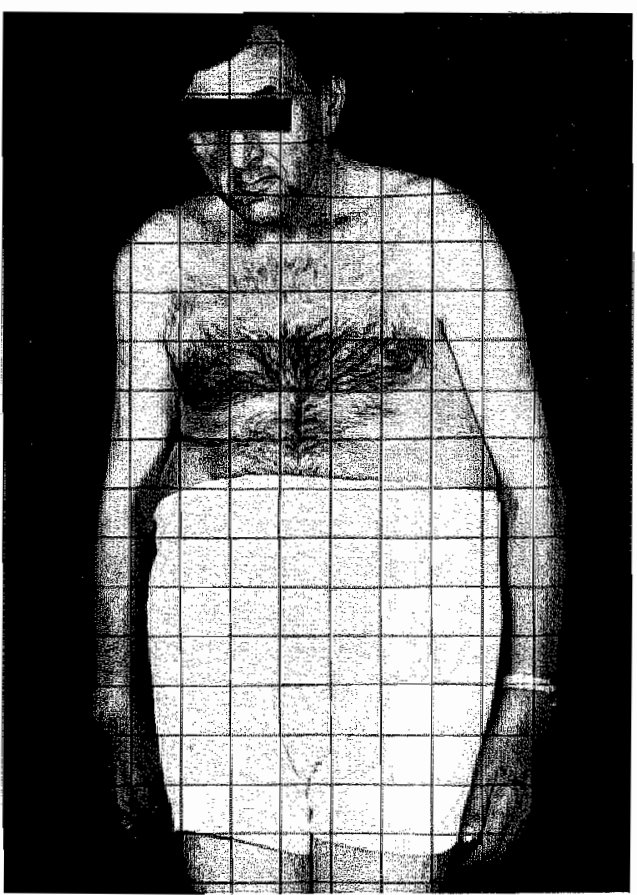

M. P. postoperatief 
Patiënt 25. P. S. mannelijk, geb. dat. 11-3-51.

Aetiologie:

Vroegere behandeling:

Klachten:

Préoperatieve curves:

Voorbehandeling:

Longfunctie:

Neurologisch onderzoek:

Operatie:

Complicaties:

Nabehandeling:

Postoperatieve curves:

Postoperatieve klachten:
Kyfose bij de ziekte van Bechterew.

Brufen, burgodin en indocid.

Gauw moe bij het lopen. Sporten niet meer mogelijk. Schaamt zich voor zijn rug, durft niet meer onder de mensen te komen. Komt alleen 's avonds buiten. Volgens de patiënt is de verkromming progressief.

Kyfose T2 t/m T12 $74^{\circ}$. Lordose L1 t/m L5 $23^{\circ}$.

Geen.

Niet verricht.

Geen afwijkingen.

1-9-1982. Columnotomie L3-L4 met behulp van Harrington compressiesysteem en cerclage.

Hypertensie postoperatief, behandeld met moduretic, selokeen en zoutarm dieet.

2 weken gipsschelp, 10 weken loopgipscorset met pijp, 3 maanden loopgipscorset zonder pijp.

Postop. $38^{\circ}$ lordosering L.3-4. Na 3 maanden $37^{\circ}$. Na 6 maanden $37^{\circ}$.

Geen. De diafragmale ademhaling is verbeterd, patiënt heeft "meer lucht". Hij kan langer lopen dan voorheen. Patiënt durft nu de deur weer uit.

\section{Beschouwing en conchusie:}

De kyfosering bij de ziekte van Bechterew kan sterk invaliderend werken. Niet alleen dat er lichamelijke klachten bestaan, ook de psychische problemen zijn soms indrukwekkend, zoals bij deze jonge man. De columnotomie met interne fixatie biedt een goede mogelijkheid om veel van de lichamelijke en psychische klachten te verbeteren. 


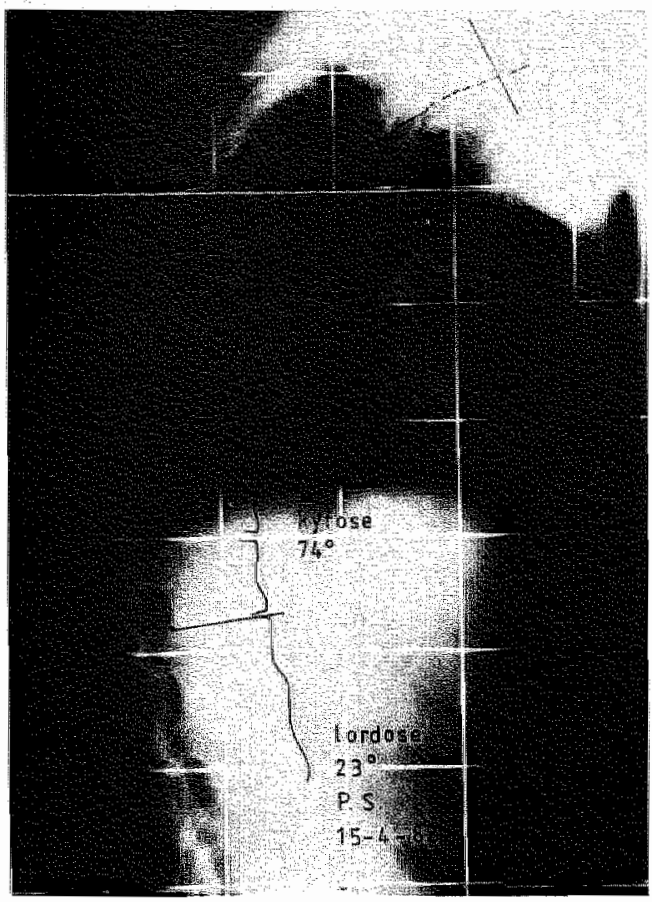

Kyfosering préoperatief

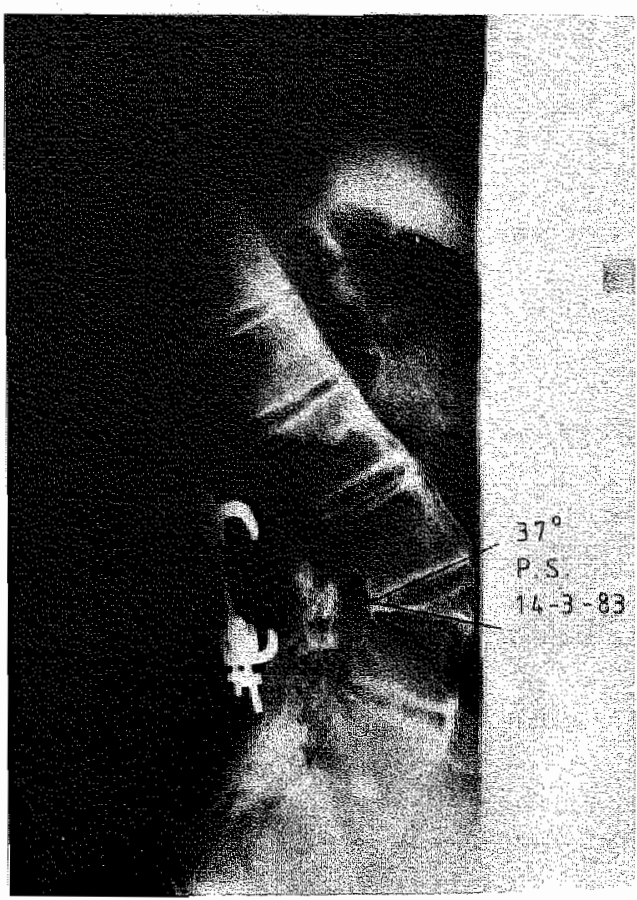

Goede lordosering in de columnotomie 
Patiént 26. G. K. mannelijk, geb dat. 7-3-39.

Aetiologie:

Vroegere bethandeling:

Klachten:

Préoperatieve curves:

Voorbehandeling:

Longfunctie:

Conclusie:

Neurologisch onderzoek:

Operatie:

Complicaties:

Nabehandeling:

Postoperatieve curves:

Postoperatieve klachten:
Totaalkyfose bij de ziekte van Bechterew, sinds 20 jaar bekend.

Fysiotherapie, indocid.

Vermoeidheid in de rug. Wisselend pijn in de rechter lies en rechter bovenbeen.

Kyfose T4-S1 $60^{\circ}$ bij verstreken lendenlordose. Ook arthrose rechter heup, minder links.

Geen.

Vit.cap. $3100 \mathrm{cc}$. Normaal $4900 \mathrm{cc}$. Tot.cap. $5700 \mathrm{cc}$. Normaal $6900 \mathrm{cc}$.

Duidelijke restrictieve functiestoornis, de ventilatoire reserves zijn redelijk.

Geen afwijkingen.

19-6-81. Columnotomie L2-3 met behulp van dubbelzijdig compressiesysteem volgens Harrington.

Geen.

2 weken gipsschelp, waarna mobilisatie. 4 weken gipscorset met pijp, $3 \frac{1}{2}$ maand gipscorset zonder pijp.

Postop. $44^{\circ}$ lordosering L2-3. Na 3 maanden $44^{\circ}$. na 5 maanden $39^{\circ}$, na 7 maanden $38^{\circ}$.

Iets diffuse pijn rechter heup. Stijfheid in de nek. Over het resultaat van de operatie zeer tevreden.

Beschouwing en conchusie:

De toevoeging van interne fixatie bij de columnotomie lijkt een beter in stand houden van de bereikte correctie te waarborgen. Ook kan de patiënt veiliger met een gips of ander corset gemobiliseerd worden, hetgeen een groot voordeel is voor het bot-spierstelsel en het psychisch welbevinden van de patient. 


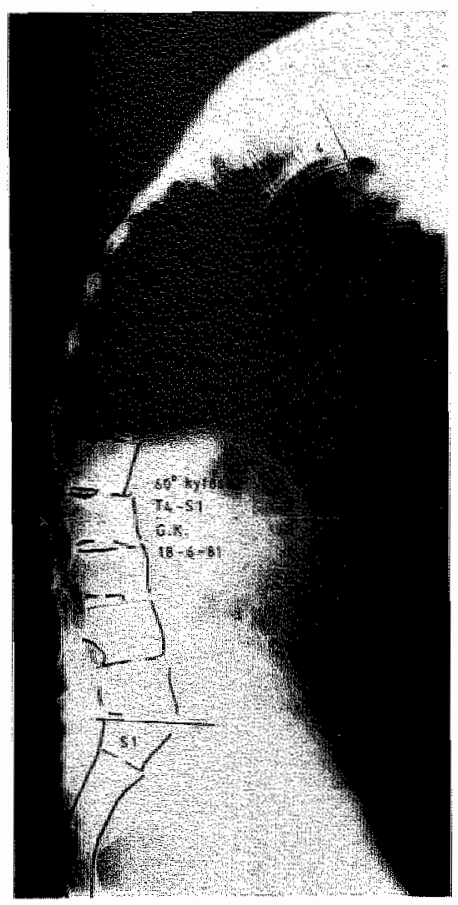

Kyfose préoperatief

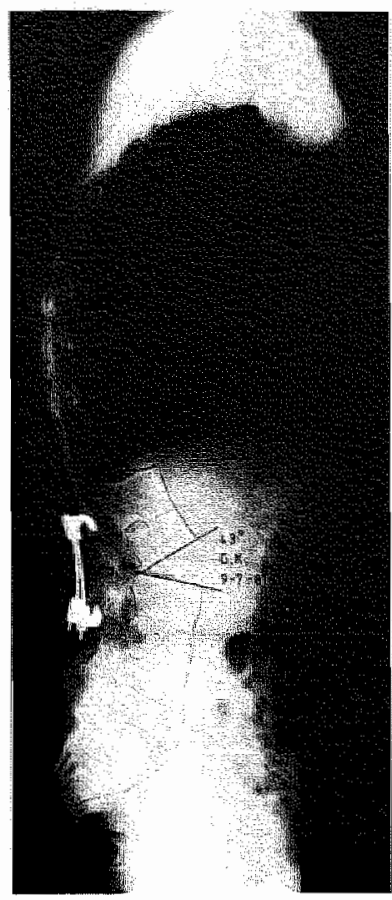

Goede lordosering in de columnotomie 


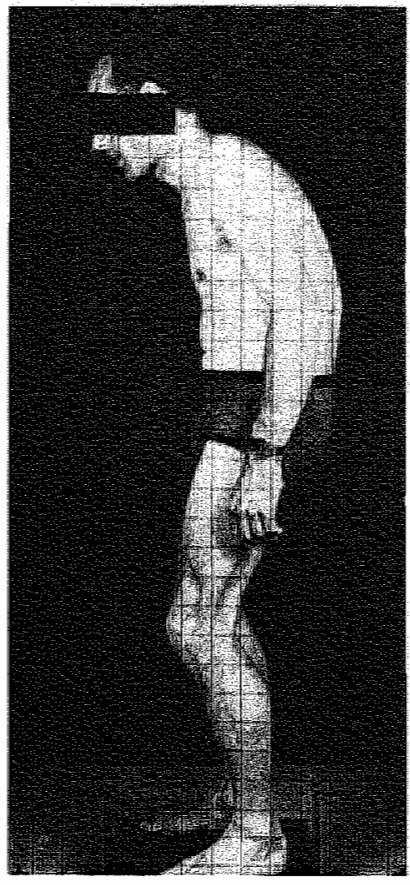

G. K. kyfose préoperatief

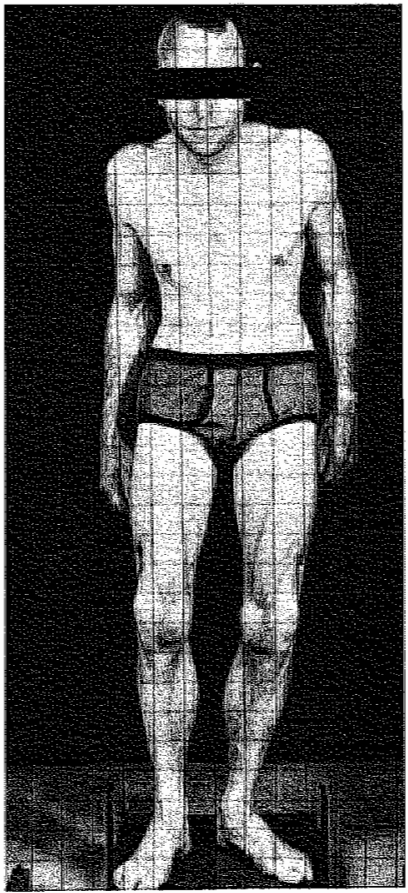

G. K. vooraanzicht préoperatief

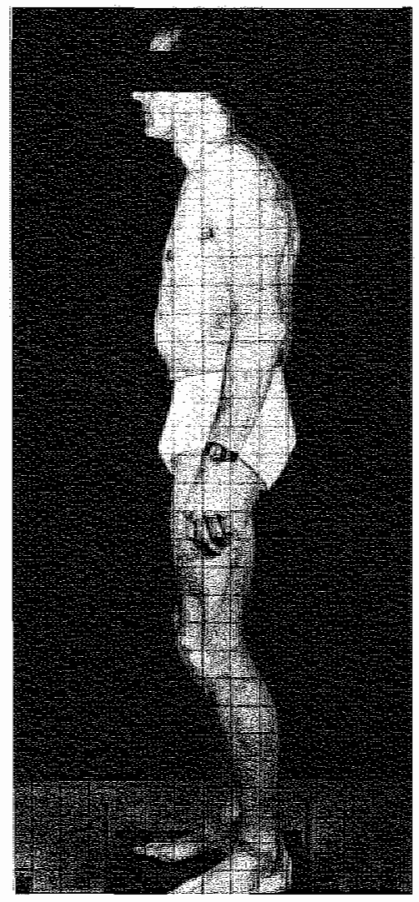

G. K. kyfose postoperatief

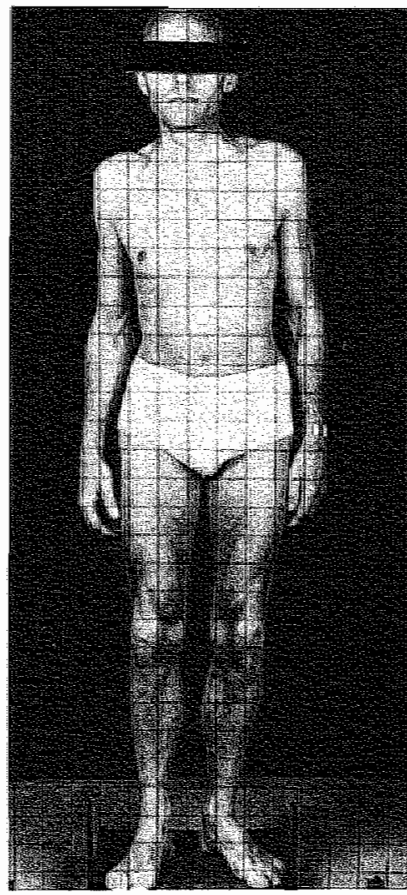

G. K. vooraanzicht postoperatief 
Patiënt 27. G. v. W. vrouwelijk, geb. dat. 20-11-1947.

Aetiologie:

Vroegere behandeling:

Klachten:

Préoperatieve curves:

Voorbehandeling:

Longfunctie:

Conclusie:

Neurologisch onderzoek:

EMG:

Operatie I:

Complicaties:

Nabehandeling:
Totaalkyfose bij de ziekte van Bechterew.

Vanaf het $12 \mathrm{e}$ jaar anorexia nervosa, het gewicht is slechts $431 / 2 \mathrm{~kg}$. Chronische iridocyclitis. Lichte colitis. Vanaf jonge leeftijd al iets krom gelopen. echter in enkele jaren tijds zeer sterke verergering. Afwijking eerst geduid als ziekte van Scheuermann. H.L.A. B27 positief. Kreeg intensieve fysiotherapie, later gipsschaal. Prismabril om recht vooruit te kunnen kijken. Ook tentamen suïcidi.

Pijn in nek en schouders, liezen en bovenbenen. Dyspnoe d'effort. Onmogelijkheid om recht vooruit te kijken.

Kyfose T3 t/m T10 $108^{\circ}$ met opgeheven lumbale lordose. Alleen verbening van de achterstructuren. De röntgenfoto's uit 1972 en 1973 laten slechts een geringe kyfose zien, van die tijd af enorme progressie.

Geen.

Vit.cap. $1325 \mathrm{cc}$. Normal $3700 \mathrm{cc}$. Tot.cap. $3100 \mathrm{cc}$. Normal $4825 \mathrm{cc}$.

Restrictieve stoornis. Buikademhaling niet optimaal door verkorting buikspieren en bovendien een starre thorax. Extra risico bij de operatie.

Geen afwijkingen.

Geen affwijkingen.

18-9-1979. Patiente in zijligging. Harrintoncompressiespondylodese $T 7 / \mathrm{m}$ T12 en columnotomie $11.1-2$ zonder instrumentatie met behulp van wake-up-test.

Geringe wondrandnecrose.

Onder narcose gipsredressie van de onderste columnotomie op 4-10-1979 en op 26-10-1979. Hierbij werd ook in de onderste lumbale segmenten lordosering bereikt. Hierna 6 maanden hoog gipscorset. Bij ontgipsing bleek de $7^{\circ}$ lordosering niveau $\mathrm{L} 1-2$ weer verloren te zijn gegaan. 2 maanden na ontgipsing was er op dit niveau kyfosering van $16^{\text {ip }}$. 
Operatie II:

Complicaties:

Nabehandeling:

Postoperatieve curves:

Conclusie:

Operatie III:

Complicaties:
21-5-1980. Respondylodese met uitbreiden naar boven en onder T6 t/m L4 met behulp van Harringtoncompressiesysteem.

Uitbreken haakje T10. Dit werd poliklinisch verwijderd.

Baycastcorset.

15-9-1980. Lordose L1-2 $8^{\circ}$ (was direkt na operatie 2 $15^{\circ}$ ). Lordose L2-sacrum $46^{\circ}$. Kyfose T7-L1 $57^{\circ}$ (was direkt na operatie $248^{\circ}$ ). Kyfose T3-T6 $38^{\circ}$. 4-111981. Niveau LI-2 lordose $3^{\circ}$. T7 t/m L1 kyfose $63^{\circ}$. T3 t/m T6 kyfose $43^{\circ}$.

Ondanks uitgebreide instumentatie en achterste spondylodese, progressie van de kyfosering.

9-2-1983. Columnotomie L4-5 met behulp van Harringtoncompressiesysteem met verwijderen van het oude compressiemateriaal.

Geen.

Beschouwing en conclusie:

Er bestaan bij de ziekte van Bechterew vormen, waarbij zeer snelle kyfosering van de wervelkolom kan optreden door ernstige osteoporose of osteolyse. Bij deze patiënte speelde mogelijk ook het zeer slechte voedingspatroon een rol. Het bot bleek zo zacht te zijn dat onder narcose een manuele relordosering van de lumbale wervelkolom kon worden bereikt ondanks verbening van de meeste intergewrichten. Deze lordose ging na ontgipsing echter weer snel verloren, terwijl ook later na uitbreiding van de spondylodese toch rekyfosering optrad. De botkwaliteit is bij deze patiënte blijkbaar zo slecht, dat de kyfoserende krachten de spondylodesemassa doen meebuigen. Na de columnotomie is een bevredigende equilibratie verkregen. Inmiddels werd patiënte nog $3 \times$ geopereerd. Op 2-11-1983 werd al het osteosynthesemateriaal uit de rug verwijderd, terwijl op 17-11-1983 en 20-3-1984 totalprotheses van beide heupen werden geplaatst wegens coxarthrosis ten gevolge van de ziekte van Bechterew, één en ander zonder complicaties. 


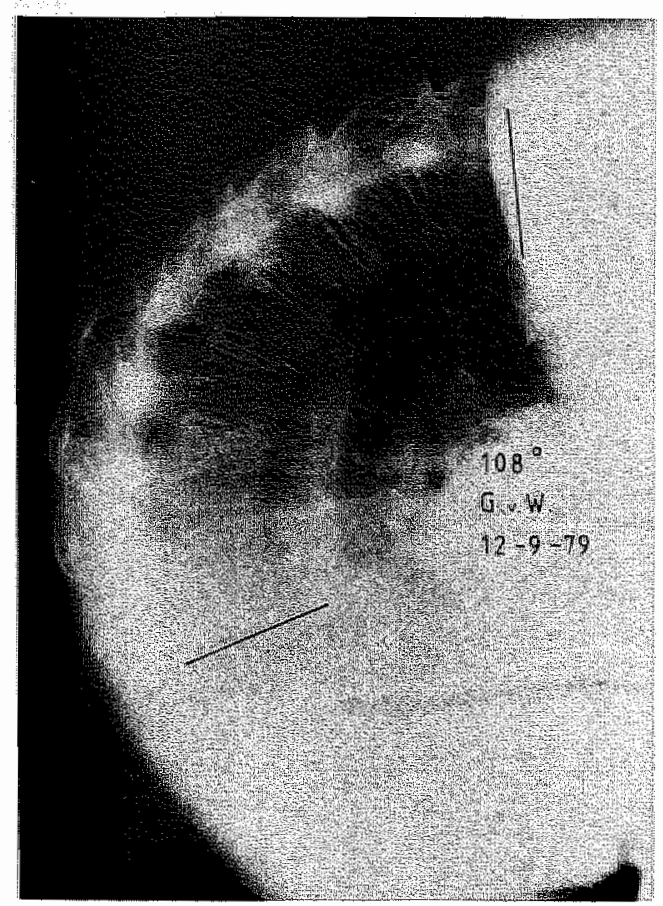

Thoracale kyfose préoperatief

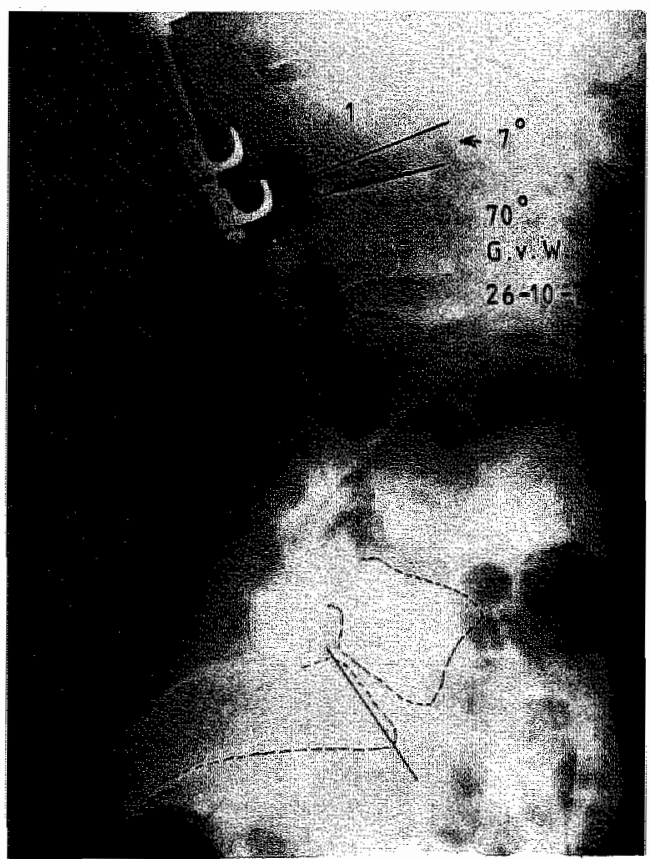

$\mathrm{Na} 2 \mathrm{e}$ gipsredressie fraaie lordosering alle lumbale niveau's

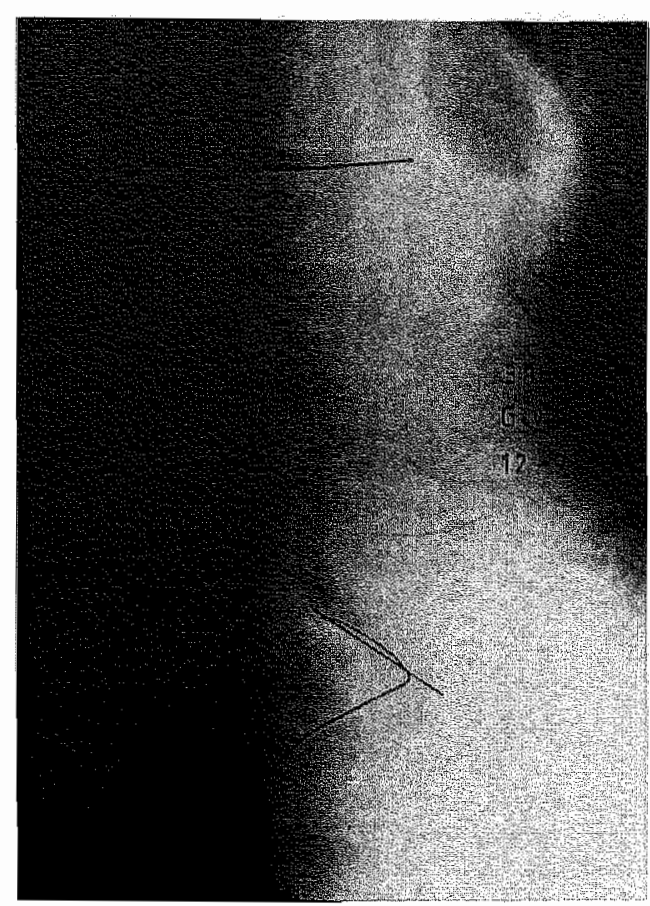

Opgeheven lumbale lordose préoperatief hoek L2-sacrum $38^{\circ}$

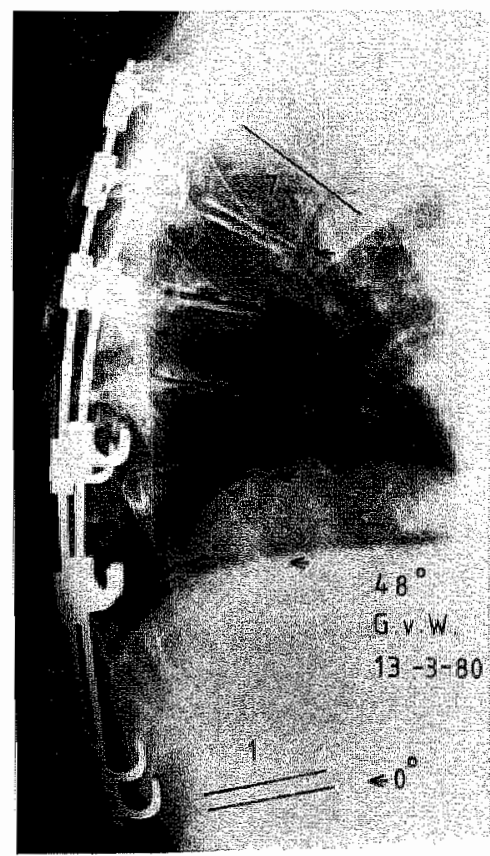

Bij ontgipsing goede correctie kyfose T7-L1 


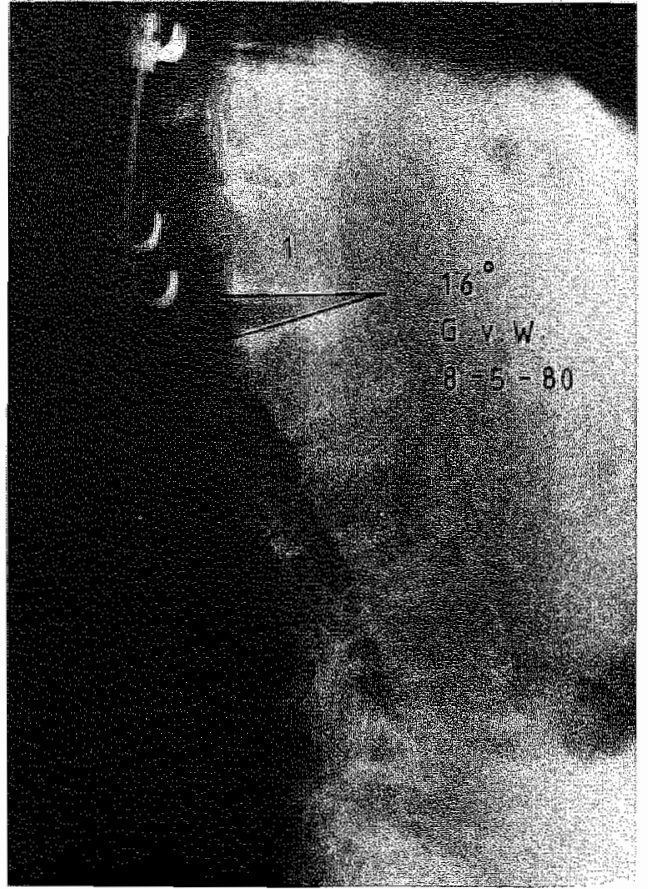

2 maanden na ontgipsing na le operatie rekytosering $\mathbf{L} \mathbf{1}-2$

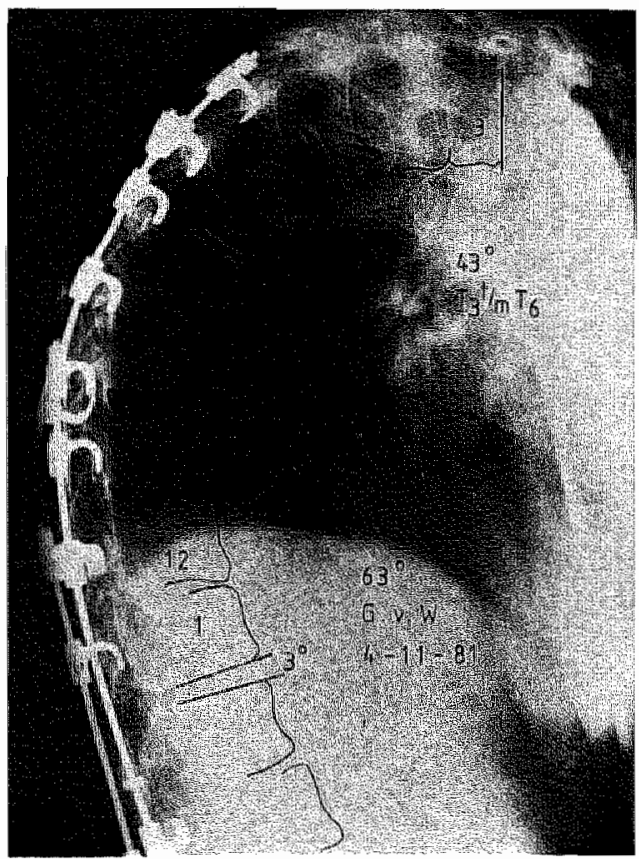

Progressieve kyfosering ook boven de spondylodese

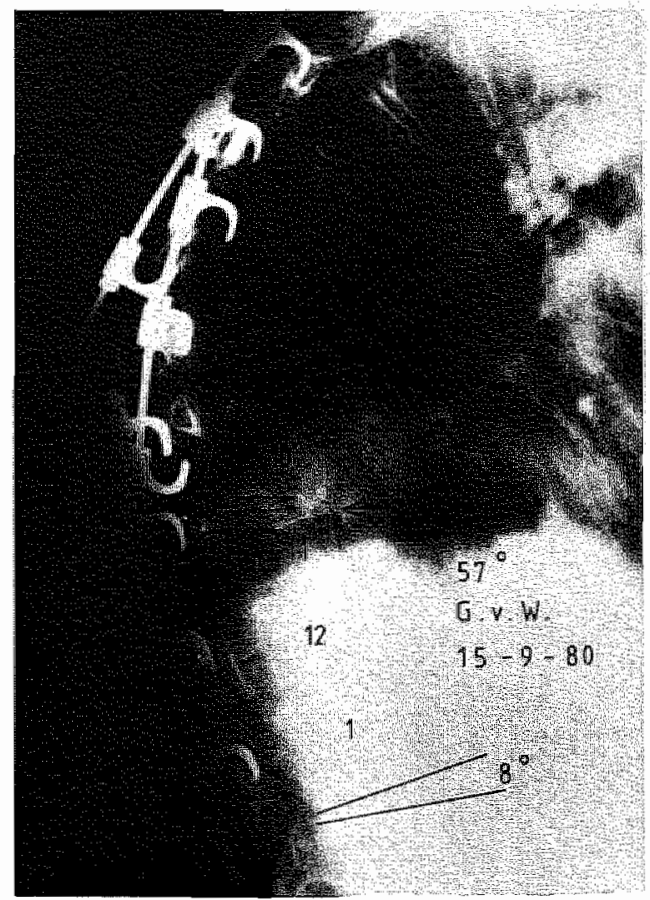

Na uitbreiding instrumentatie $8^{\circ}$ lordosering
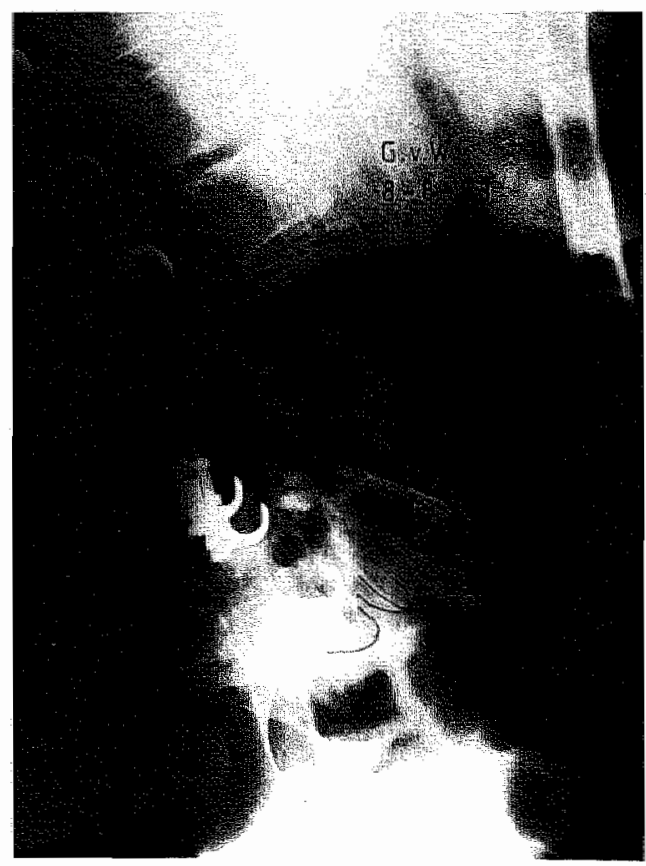

Na columnotomie L4-5 


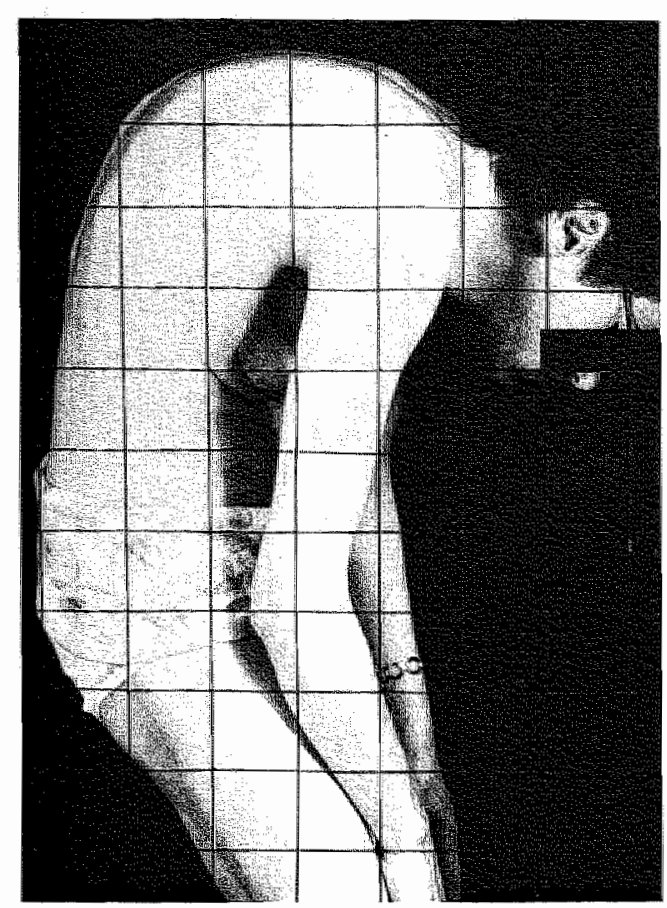

G.v. W. kyfose préoperatief

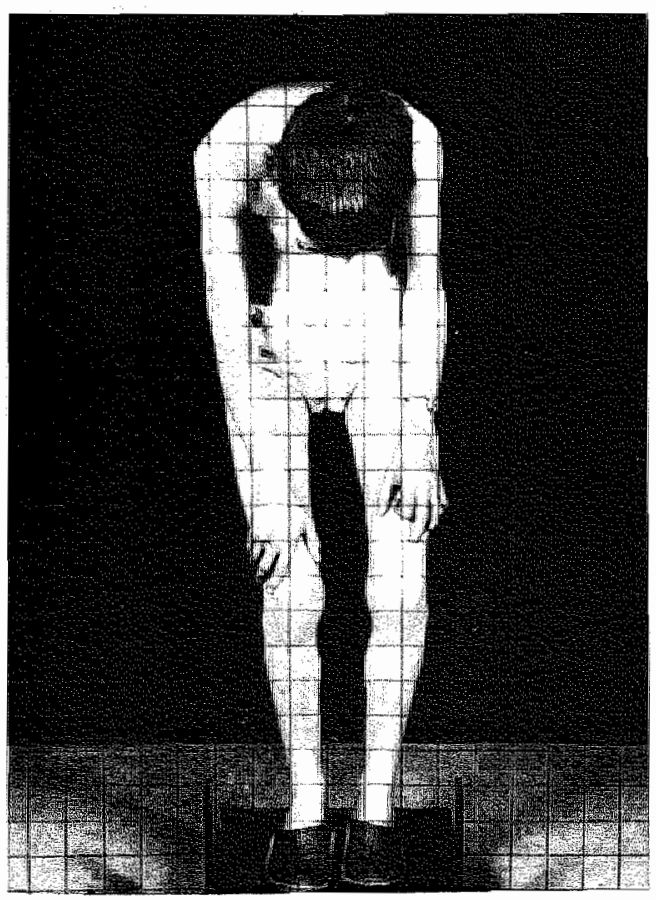

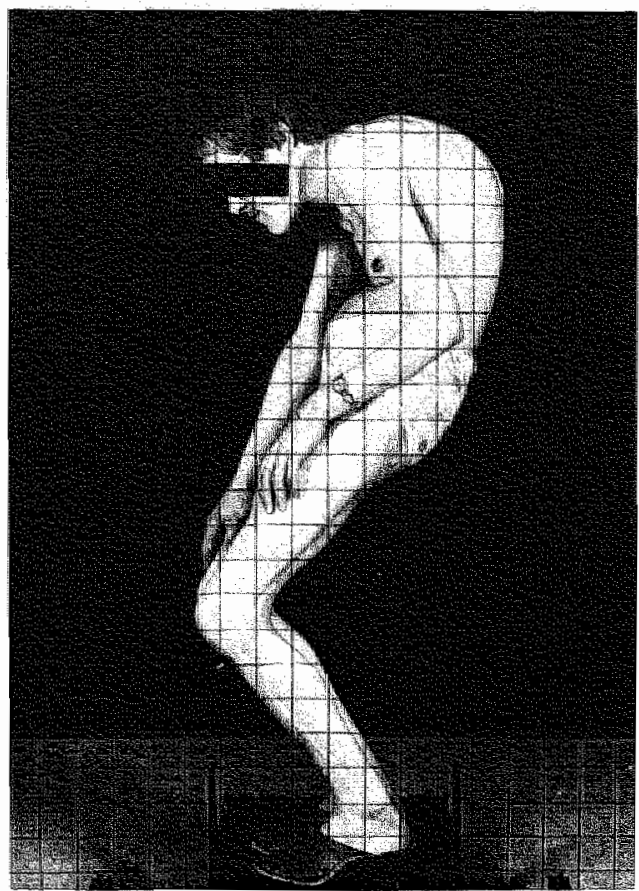

G. v. W. let op flexie van de knieen

G. v. W. recht vooruit kijken is niet meer mogelijk 

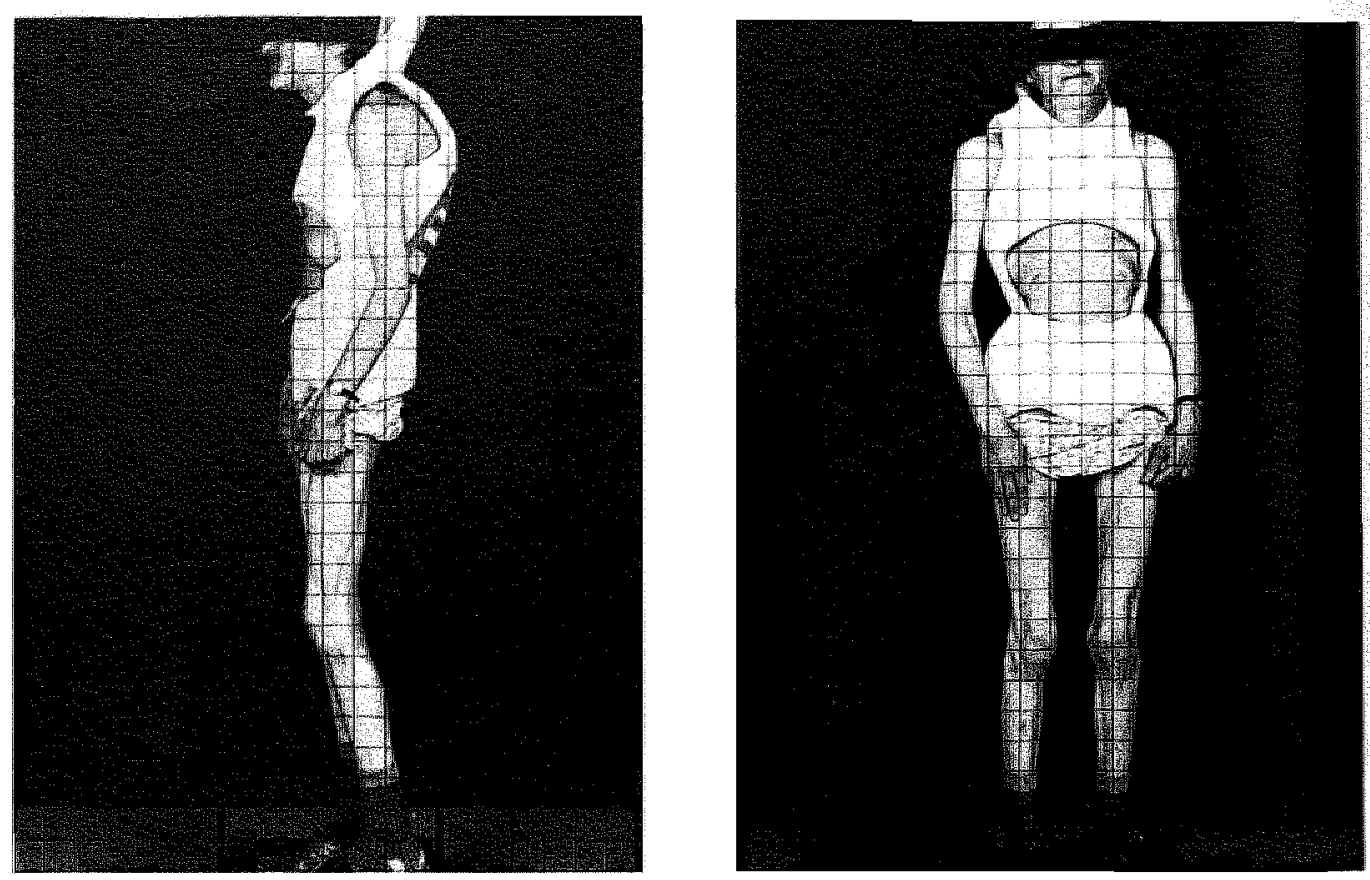

G. v. W. fraaie verbetering van de kyfose postoperatief in het gips
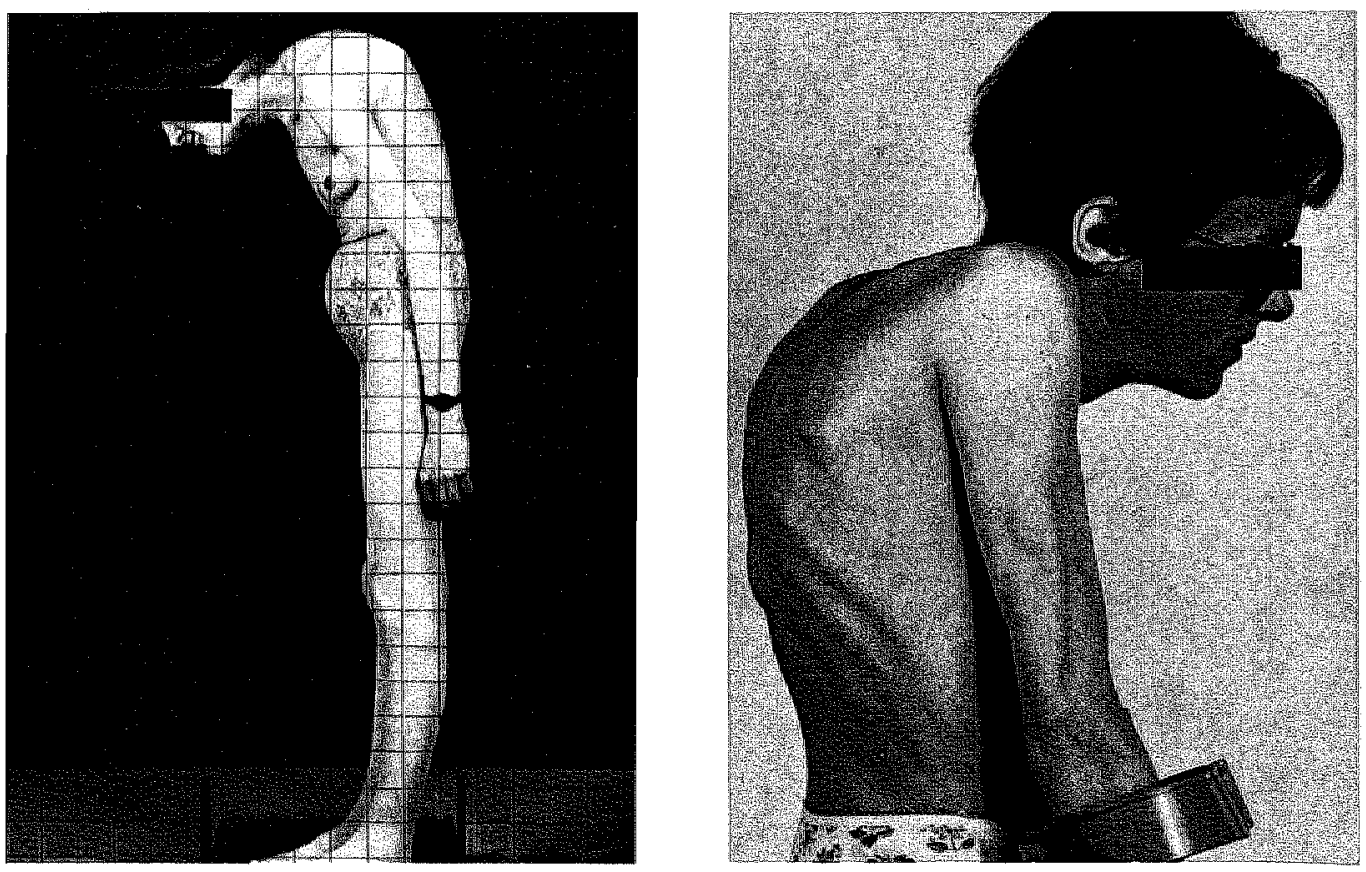

G. v. W. de wereld kan weer gezien worden

Ernstige rekyfosering 18 maanden na operatie II 


\section{KYFOSEN BIJ DE NEUROFIBROMATOSE VAN VON RECKLINGHAUSEN}

\subsection{Inleiding}

De ziekte van Von Recklinghausen of neurofibromatosis (in het vervolg N.F. te noemen) behoort tot de groep van phacomatosen, wartoe verder de tubereuze sclerose van Bourneville, de ziekte van von Hippel-Lindau en de ziekte van Sturge-Weber behoren $(24,26)$.

Het gaat om een autosomaal dominante erfelijke ziekte. De N.F. wordt gekenmerkt door het optreden van café au lait vlekken van de huid en de vorming van neurofibromen in de perifere zenuwen van de huid en soms ook van de uittredende spinale zenuwwortels. Andere afwijkingen zijn hypertrofie van een extremiteit, oog- en botafwijkingen $(1,7,11,19,22,24,27,30)$. Bekend is de moeilijk te genezen tibia-pseudarthrose. welke bij de geboorte aanwezig kan zijn of op de kinderleeftijd ontstaat. Adrian (1) en Weiss (31) wezen als eersten op het frequent voorkomen van scoliose bij N.F.

3 scoliosevormen kunnen onderscheiden worden.

De eerste is de idiopathische vorm, welke niet afwijkt van de scoliose zoals bij adolescenten voorkomt.

De tweede is de karakteristieke vorm met de korte angulaire scoliose, al of niet met kyfosering. De kyfose is soms de voornaamste component en kan aanleiding geven tot een zeer moeilijk te behandelen progressieve deformiteit.

De derde vorm is de congenitale scoliose met wervelmalformaties, welke bij de N.F. frequenter zou voorkomen dan in de normale populatie $(4,5,25,32)$.

De idiopathische vorm kan op elk moment overgaan in de karakteristieke vorm en zal daarom goed gecontroleerd moeten worden. Ook na het beëindigen van de groei kan bij de N.F, een ernstige scoliose ontstaan (4).

De localisatie van de karakteristieke N.F.-curve is meestal hoog of mid-thoracaal. Er treedt wigvorming van slechts enkele wervels op, waardoor een scherpe bocht ontstaat. In het sagittale vlak treedt een z.g. „scalloping” van het wervellichaam op, dit is een concave verandering van de achterzijde van de wervel. Het is waarschijnlijk dat dit het gevolg is van de constant pulserende duraalzak, terwijl de botstructuur van de wervels abnormaal is. Ook treedt een verwijding van de duraalzak en daardoor van het wervelkanaal op, waardoor een intraspinale meningocèle ontstaat. Uitbreiding van de meningocèle door het foramen intervertebrale tot in de thorax is beschreven, doch dit werd door ons nooit opgemerkt $(13,16,17)$.

De meest ernstige afwijking van de wervels is het soms praktisch geheel verdwijnen van het corpus vertebrae. In de Franse literatuur staat dit bekend als de . dysplasie osseuse vertébrale" $(5,28)$. De structuur van het bot vervaagt geleidelijk, ook de dekplaten kunnen onzichtbaar worden, zodat alleen de concave achterzijde van het wervellichaam blijft bestaan. Een ernstige kyfosering met soms luxatie van de wervelkolom kan hiervan het gevolg zijn (23). De kyfose is bijna altijd angulair van karakter, waardoor kans op afknikking van het myelum bestaat met gevaar van paraplegie. Dat de paraplegie eerst optreedt bij vergevorderde kyfosering vindt zijn oorzaak in de verwijding van het wervelkanaal, waardoor het myelum ruimte heeft zich aan te passen aan de toenemende kyfosering $(4,8,10,14,34)$.

Over de oorzaak van het verdwijnen van de wervelstructuur bestaat in de literatuur veel onduidelijkheid. Neurofibroomweefsel ter plaatse is zelden aangetroffen. Het bot- 
weefsel bleek meestal vervangen door vaatrijk bindweefsel zonder specifieke kenmerken. Sommige auteurs zoals Heard (13) en Swann (29) zien een relatie met een gegeneraliseerde osteomalacie, anderen denken meer aan een gestoorde innervatie van de betrokken wervels ten gevolge van het neurofibrotisch proces, ook al zijn de neurofibromen zelden ter plaatse aangetroffen $(11,18)$. Philippart (21) noemt dit een neurotrofische stoornis. Wat voor deze laatste hypothese pleit is het frequent optreden van dysplasie van de ribben ter plaatse van de kyfose, het zogenaamde penciling.

Een duidelijke en algemeen geaccepteerde oorzaak voor het optreden van deze ernstige wervel kolomdeformaties is tot nu toe echter niet gevonden.

\subsection{Behandeling}

Een achterste spondylodese heeft bij deformiteiten met kyfosen groter dan $50^{\circ}$ meestal geen effect. Ook als de spondylodese slaagt treedt in een groot aantal gevallen rekyfosering op door het ontbreken van botstructuur aan de voorzijde van de wervelkollom. De spondylodese buigt gewoon mee onder invloed van de kyfoserende krachten $(6,10$, 28,32 ). Moe (20) zag geen enkele keer consolidatie van uitsluitend achterste spondylodese bij ernstige N.F. kyfoscoliosen. Een voorste spondylodese is bij deze kyfotische verkrommingen aangewezen om de deficiënte voorste wervelkolompijler weer op te bouwen. Het meest geschikt hiervoor is de fibula, terwijl de ruimte tussen deze strutgraft en de resten van de wervellichamen opgevuld moet worden met andere corticospongieuze grafts, bijvoorbeeld van de rib.

Correctie van de kyfose kan plaatsvinden door préoperatief enkele weken tractie toe te passen, bijwoorbeeld Halo-rolstoel tractie. Tijdens de operatie kan lengtetractie toegepast worden gecombineerd met manuele druk op de gibbus, waardoor ruimte verkregen wordt voor het plaatsen van de spanen. Met speciaal ontworpen correctieapparatuur (systeem volgens Pinto of volgens Slot) kan intra-operatief meer correctie verkregen worden dan met de manuele methode. Ook kan blijvende osteosynthese gebruikt worden om een ongestoorde ingroei van de spanen te waarborgen. Zelfs dan ziet men in een aantal gevallen een resorptie van het in eerste instantie goed ingegroeide materiaal ontstaan, zoals ook bij de tibiapseudarthrose wordt gezien (33). Een aanvullende achterste spondylodese met behulp van het Harringtoncompressiesysteem is meestal aangewezen om de kyfotische krachten zoveel mogelijk te neutraliseren $(6,28,32)$.

Bestaat er neurologische uitval, dan mag in geen geval een laminectomie verricht worden, tenzij myelografie het bestaan van een neurofibroom aannemelijk maakt $(6,8,20$, 32). Door het wegnemen van de achterstructuren en het deficiënt zijn van de voorste pijler zal de wervelkolom toenemend in kyfose collaberen en de paraplegie verergeren. Is laminectomie toch noodzakelijk, dan kan het beste tegelijkertijd een fusie verricht worden.

Conservatieve behandeling, bijvoorbeeld bracetherapie, heeft bij de karakteristieke kyfoscoliose geen zin, behalve het misschien vertragen van de progressie.

Het beste is in een vroeg stadium, dat wil zeggen bij nog geringe kyfose een achterste Harringtonspondylodese te doen omdat dan nog de kans bestaat dat hiermee volstaan kan worden. Bij ernstiger deformiteit is het goed de patiënt en zijn familie voor te bereiden op een moeilijke behandeling, waarbij soms operaties herhaald moeten worden om een stabiele wervelkolom te verkrijgen zonder kans op dwarslaesie. Aan de hand van de patiëntenbesprekingen zal dit duidelijk blijken. 


\subsection{Literatuur hoofdstuk 6}

1. Adrian C. Ueber Neurofibromatose und ihre Komplikationen. Beitr. z. Klin. Chir. $31,1901,1-98$.

2. Allibone E. C. Illingworth R. S. Wright T. Neurofibromatosis (von Recklinghausen's disease) of the vertebral column. Arch. of Dis. in Childh. 35, 1960, 153-158.

3. Bernheim M. Francois R. Normand Mme. Loaec Y. La maladie de Recklinghausen chez l'enfant. Pediatrie 9, 1954, 717-728.

4. Biot $\mathrm{B}$. Les déviations du rachis de la neurofibromatose de von Recklinghausen ( 35 observations du centre des massues). Thèse Lyon 1971.

5. Biot B. Fauchet R. Stagnara P. Les lésions vertébrales de la neurofibromatose. Rev. de Chir. Orthop. 60, 1974, 607-621.

6. Chaglassian J. H. Riseborough E. J. Hall J. E. Neurofibromatous scoliosis. Natural history and results of treatment in thirty-seven cases. Journ. of Bone and Joint Surg. 58A, 1976, 695-702.

7. Crowe F. W. Schull W. J. Diagnostic importance of café au lait spots in neurofibromatosis. A.M.A. Archives of Internal Medicine 91, 1953, 758-766.

8. Curtis B. H. Fisher R. L. Butterfield W. L. Saunders F. P. Neurofibromatosis with paraplegia. Journ. of Bone and Joint Surg. 51A, 1969, 843-861.

9. Enklaar J. E. Scoliose bij neurofibromatosis (Recklinghausen); demonstratie van twee patiënten. Ned. Tijdschr. Geneesk. 106, 1962, 2019-2020.

10. Fauchet R. Gounot J. du Peloux J. Gouyet C. Fouletier J-P. Stagnara P. Scolioses par neurofibromatose. Ann. Med. Phys. 11, 1968, 385-394.

11. Friedman M. M. Neurofibromatosis of bone. Am. Journ. Roentgen. Rad.ther. Nucl. Med. 51, 1944, 623-630.

12. Hagelstam L. On the deformities of the spine in multiple neurofibromatosis (von Recklinghausen). Acta Chir. Scand. 93, 1946, 169-193.

13. Heard G. Payne E. E. Scolloping of the vertebral bodies in von Recklinghausen's disease of the nervous system (neurofibromatosis). J. Neurol. Neurosurg. Psychiat. $25,1962,345-351$.

14. Kerr J. G. Scoliosis with paraplegia. Journ. of Bone and Joint Surg. 35A, 1953, $769-773$.

15. Laws J. W. Pallis C. Spinal deformities in neurofibromatosis. Journ. of Bone and Joint Surg. 45B, 1963, 674-682. 
16. Lipmann Kessel A. W. Intrathoracic meningocele, spinal deformity, and multiple neurofibromatosis. Journ. of Bone and Joint Surg. 33B, 1951, 87-93.

17. Loop J. W. Akeson W. H. Clawson D. K. Acquired thoracic abnormalities in neurofibromatosis. Am. Journ. Roentgen. 93, 1965, 416-424.

18. MacKenzie J. A case of neurofibromatosis (von Recklinghausen's disease) illustrating most of the characteristic bone lesions. Brit. Journ. Radiol. 23, 1950, 667-671.

19. Miller G. Die Knochenverändlerungen bei der Neurofibromatosis Recklinghausen. Förtschr. a. d. Gebiete d. Röntgenstr. u. d. Nukl. Med. 78, 1953, 669-689.

20. Moe J. H. Neurofibromatosis. Chapter $10 \mathrm{in:} \mathrm{Spinal} \mathrm{deformity} \mathrm{in} \mathrm{neurological} \mathrm{and}$ muscular disorders. C. V. Mosby St. Louis 1974.

21. Philippart M. Scoliose grave et neurofibromatose infantile sous l'angle d'une pathologie constitutionnelle. Acta Neurol. Psych. Belg. 62, 1961, 384-431.

22. Von Recklinghausen F. D. Ueber die multiplen Fibrome der Haut und ihre Beziehung zu den multiplen Neuromen. Berlin, August Hirschwald 1882.

23. Rockower S. McKay D. Nason S. Dislocation of the spine in neurofibromatose. A report of two cases. Journ. of Bone and Joint Surg. 64A, 1982, 1240-1242.

24. Rijckewaert $\mathrm{Ph}$. Farriaux J. P. Dubois O. Fontaine G. La neurofibromatose de Von Recklinghausen chez l'enfant (A propos de 6 observations). Pediatrie 22, 1967, 301-317.

25. Scott J. C. Scoliosis and neurofibromatosis. Journ. of Bone and Joint Surg. 47B, $1965,240-246$.

26. Sillevis Smitt W. G. Vaandrager W. A. Over phakomatosen bij kinderen en het syndroom van Klippel-Trénaunay. Maandschr. Kindergen. 18, 1950, 389-401.

27. Smith R. W. in: Robert W. Smith's description of generalized neurofibromatosis (1849) door Fulton J. F. New England Journ. Medic. 200, 1929, 1315-1317.

28. Stagnara P. Biot B. Fauchet R. Evaluation critique du traitement chirurgical des lésions vertébrales de la neurofibromatose. 31 cas. (1954-1973). Revue de Chir. Orthop. 61, 1975, 17-38.

29. Swann G. F. Pathogenesis of bone lesions in neurofibromatosis. Brit. Journ. Radiol. 27, 1954, 623-629.

30. Thannhauser S. J. Neurofibromatosis (Von Recklinghausen) and osteitis fibrosa cystica localisata and disseminata (Von Recklinghausen). Medicine 23, 1944, 105149. 
31. Weiss R. S. Curvature of the spine in Von Recklinghausen's disease. Arch. Dermat. Syphil. 3, 1921, 150-151.

32. Winter R. B. Moe J. H. Bradford D. S. Lonstein J. E. Pedras C. V. Weber A. H. Spine deformity in neurofibromatosis. Journ. of Bone and Joint Surg. 61A. 1979, 677-694.

33. Winter R. B. Swayze C. Severe neurofibromatosis kyphoscoliosis in a Jehovah's Witness. Anterior and posterior fusion without blood transfusion. Spine 8, 1983. $39-42$.

34. Van Wulftten Palthe P. M. Neurofibromatosis en wervelafwijkingen. Ned. Tijdschr. Geneesk. 75, 1931, 4239-4247. 
Patiěnt 28. P. L. Mannelijk, geb. dat. 24-2-1956.

Aetiologie:

Vroegere behandeling:

Klachten:

Préoperatieve curves:

$07-04-1972$

$02-10-1972$

Voorbehandeling:

Longfunctie:

Conclusie:

Neurologisch onderzoek:

Myelografie:

Operatie I:

Operatie III:

Operatie III:

Operatie IV:
Thoracale kyfoscoliose bij de ziekte van Von Recklinghausen.

Fysiotherapie en een corset.

Rugpijn sinds enige jaren, vooral bij inspanning.

$\begin{array}{lll} & \text { scoliose } & \text { kyfose } \\ 13-10-1971 & 23^{\circ} & 50^{\circ} \\ 07-04-1972 & 52^{\circ} & 63^{\circ} \\ 02-10-1972 & 62^{\circ} & 93^{\circ}\end{array}$

Halo-femorale tractie 4 weken. Correctie scoliose tot $53^{\circ}$, kyfose tot $36^{\circ}$.

Vit.cap. $2700 \mathrm{cc}$. Normaal $5275 \mathrm{cc}$

Tot.cap. $3350 \mathrm{cc}$. Normaal $6600 \mathrm{cc}$

Duidelijke restrictieve functiestoornis met voldoende respiratoire reserves.

Geen afwijkingen.

Niet verricht.

6-12-1972. Achterste spondylodese m.b.v. Harrington distractie staaf en cristabot $\mathrm{T} 3 \mathrm{t} / \mathrm{m}$ T12. Postoperatieve kyfose $44^{\circ}$ en scoliose $38^{\circ}$.

29-12-1972. Verwijderen losliggende Harrington staaf en aanleggen gipscorset. Postoperatieve kyfose $50^{\circ}$ en scoliose $46^{\circ}$. In gips 10 maanden later kyfose $60^{\circ}$ en scoliose $48^{\circ}$. Pseudarthrose.

19-10-1973. Aviveren pseudarthrose met aanbieden chips, plaatsen 2 compressiestaafjes, Postoperatieve kyfose $34^{\circ}$. Hierna progressie tot $76^{\circ}$ kyfose in april 1974 en meer in augustus 1974. Pseudarthrose.

8-10-1974. Losmaken van de spondylodese aan de achterzijde op meerdere niveaus, verwijderen compressiestaafjes. Aanleggen Halotractie. Correctie tot $55^{\circ}$ kyfose en $48^{\circ}$ scoliose. 
Operatie V:

Operatie VI:

Complicaties:

Nabehandeling:

Postoperatieve curves:

Postoperatieve klachten:
6-12-1974. Transthoracale spondylodese T5 t/m T8 m.b.v. ribspanen. Ter plaatse van de knik waren de wervellichamen volledig samengevallen. Postoperatief gipscorset. Postoperatief kyfose $55^{\circ}$ en scoliose $49^{\circ}$. Hierna progressie tot kyfose $100^{\circ}$ en scoliose $62^{\circ}$ in augustus 1975, de ribspanen resorbeerden aan de onderzijde.

8-9-1975. Re-thoracotomie, voorste spondylodese $\mathrm{m}$. b.v. fibulaspaan en Harringtonstaaf $\mathrm{T} 4 \mathrm{t} / \mathrm{m} \mathrm{T} 12$.

Geen.

9 maanden Halo-rompgips, waarna 6 maanden Milwaukee brace.

(na operatie VI)

$\begin{array}{lll} & k y f o s e & \text { scoliose } \\ \text { Postoperatief } & 67^{\circ} & 57^{\circ} \\ \text { Na } 5 \text { maanden } & 76^{\circ} & \\ \text { Na } 7 \text { maanden } & 78^{\circ} & 38^{\circ} \\ \text { Na 9 maanden } & 66^{\circ} & \\ \text { Na } 10 \text { maanden in } & & \\ \text { Millwaukee brace } & 80^{\circ} & \\ \text { Na } 11 \text { maanden } & 80^{\circ} & \\ \text { Na } 16 \text { manden } & 72^{\circ} & 42^{\circ}\end{array}$

Consolidatie van de spondylodese; na 3 jaar kyfose $87^{\circ}$ en scoliose $45^{\circ}$.

Iets eerder vermoeid. Lichte dyspnoe d'effort. Verder geen klachten.

\section{Beschouwing en conclusie:}

Deze casus laat zien dat de kyfose bij de ziekte van Von Recklinghausen één van de meest ernstige is die er bestaat. De curve begint meestal als een korte scherpe scoliose, waarna door resorptie wan de wervellichamen kyfose optreedt, welke zeer snel progressief kan zijn. Om dwarslaesie te voorkomen moet men de wervelkolom stabiliseren, hetgeen zeer moeilijk is door de agressieve eigenschappen van het botresorptieproces aan de voorzijde. In dit geval was zelfs het in situ laten van een Harringtonstaaf aan de voorzijde noodzakelijk om de fibulaspaan in alle rust te laten ingroejen. Een achterste spondylodese alleen voldoet niet. Ook als de spondylodese consolideert buigt deze onder invloed van de kyfotische krachten gewoon door. Men moet een nieuwe dragende wervelkolom aan de voorzijde zien te maken. 


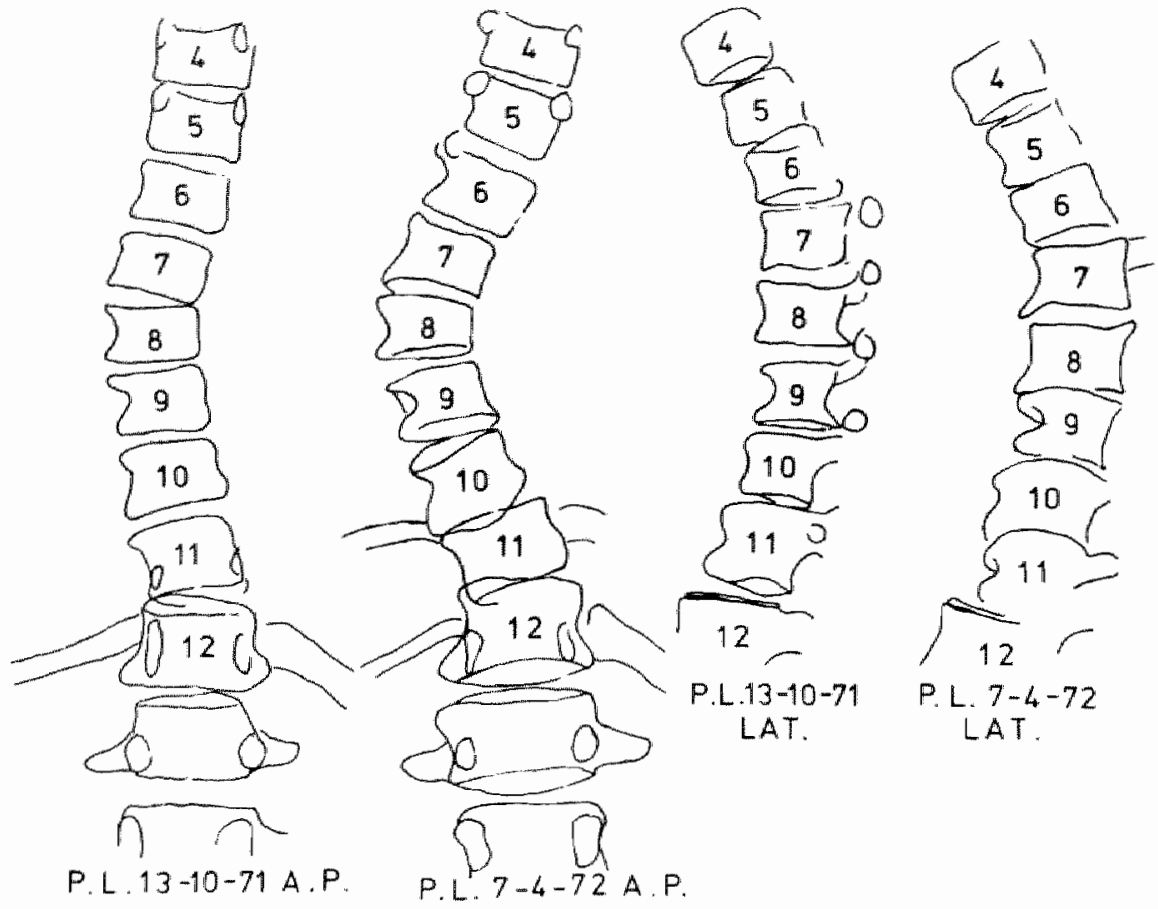

Progressie van scoliose en kyfose met wervellichaam veranderingen in 6 maanden tijd

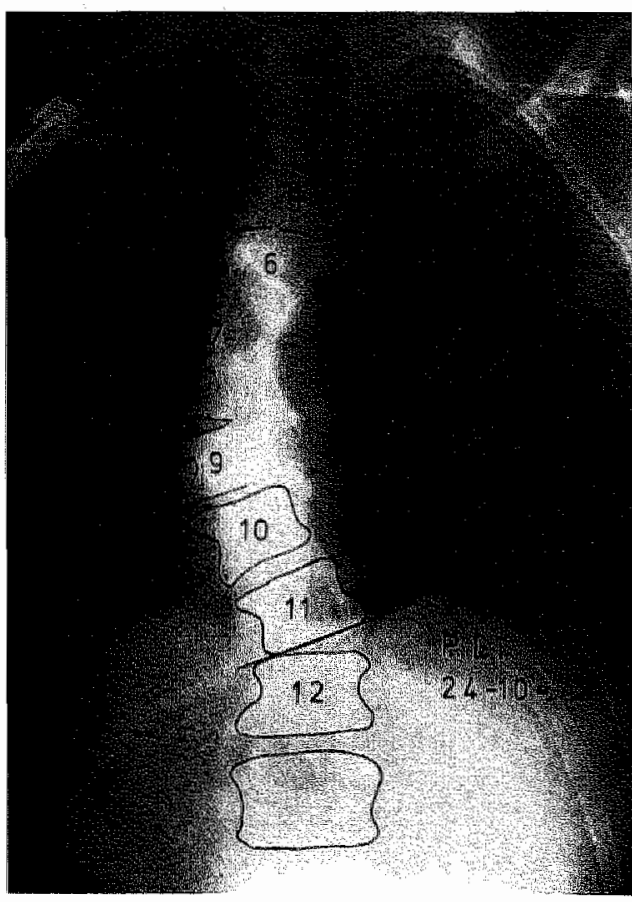

$35^{\circ}$ scoliose préoperatief onder tractie

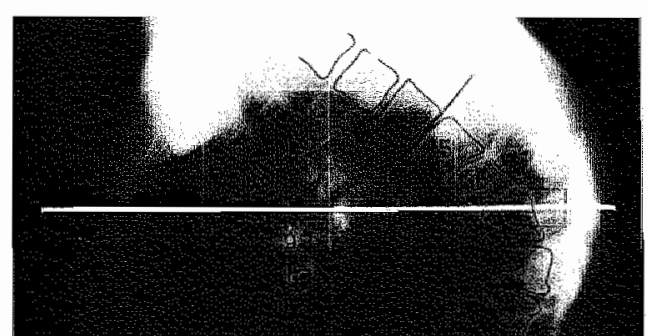




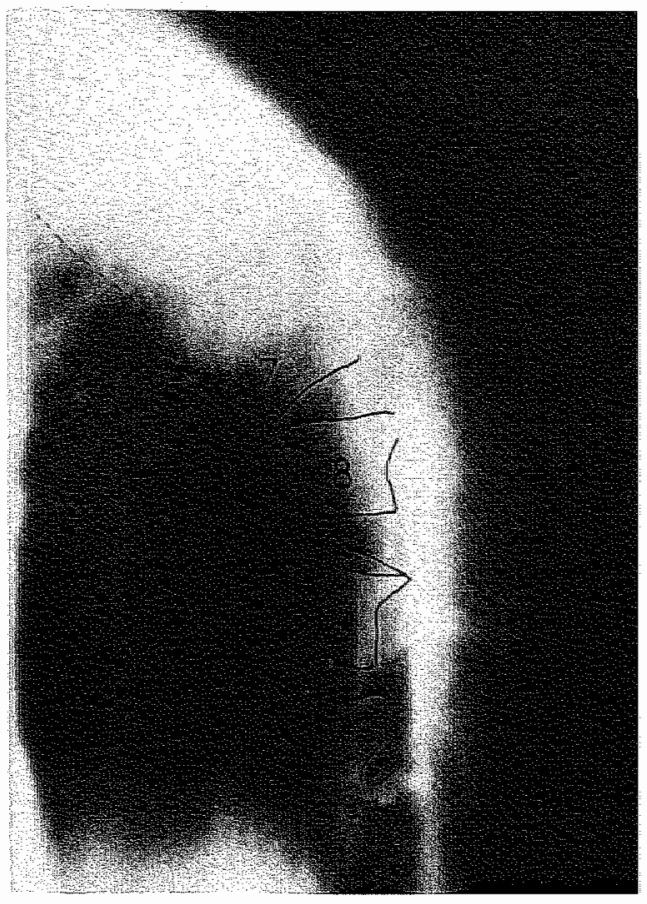

Préoperatief subluxatie T7 op T8

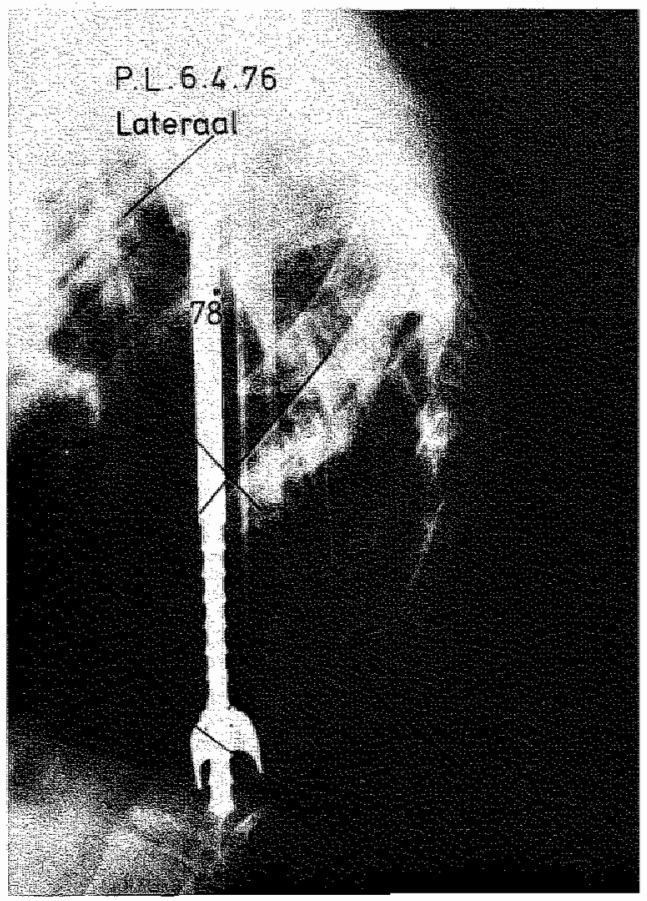

Uiteindelijke spondylodese

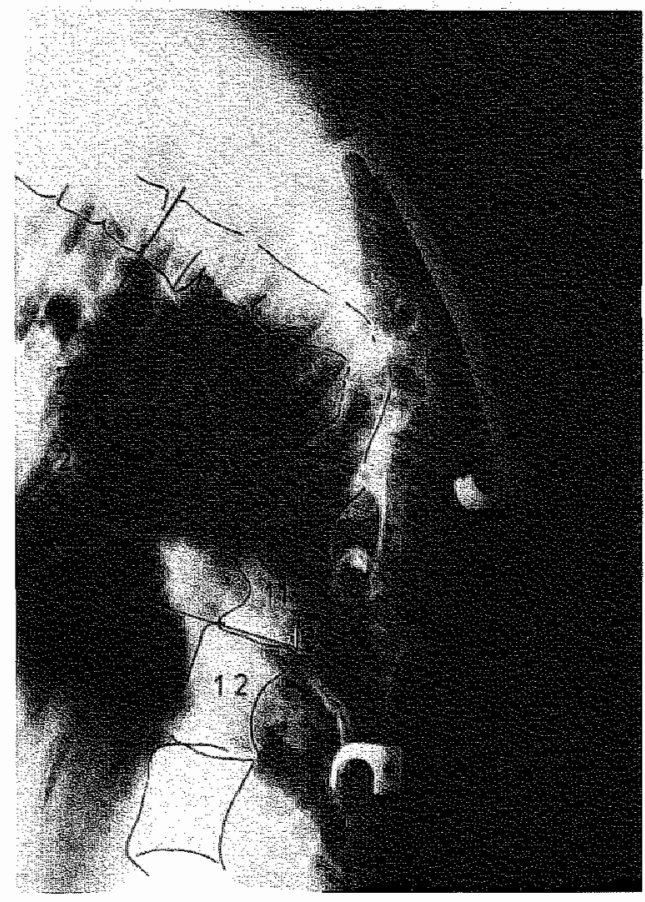

Na operatie 3

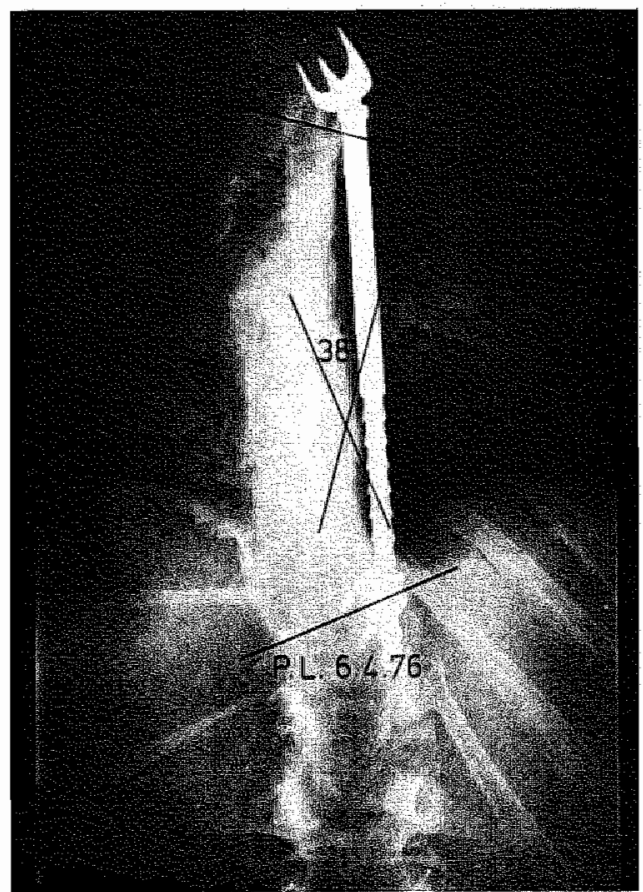

Scoliose postoperatief 


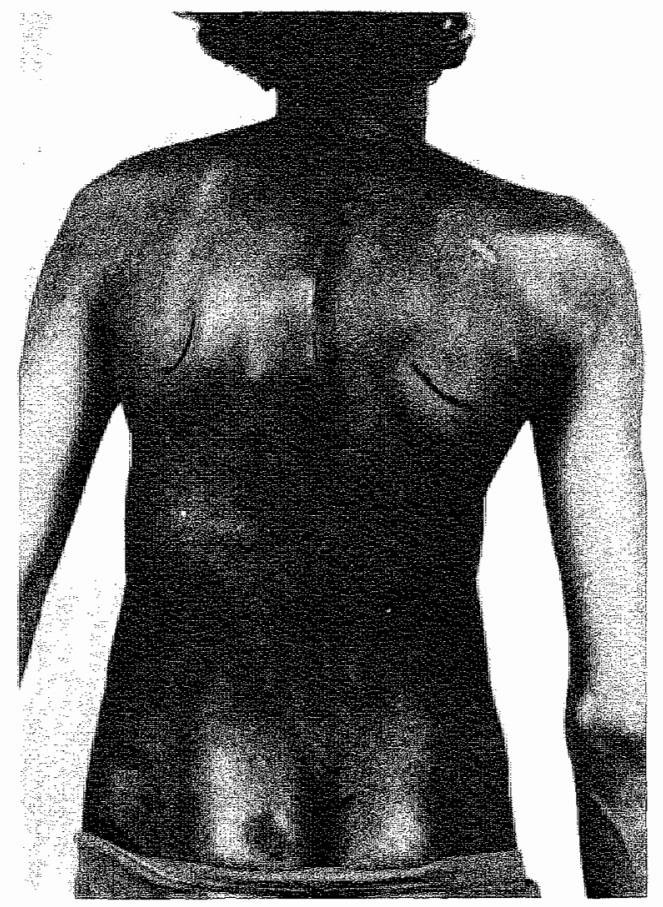

P.L. scoliose préoperatief

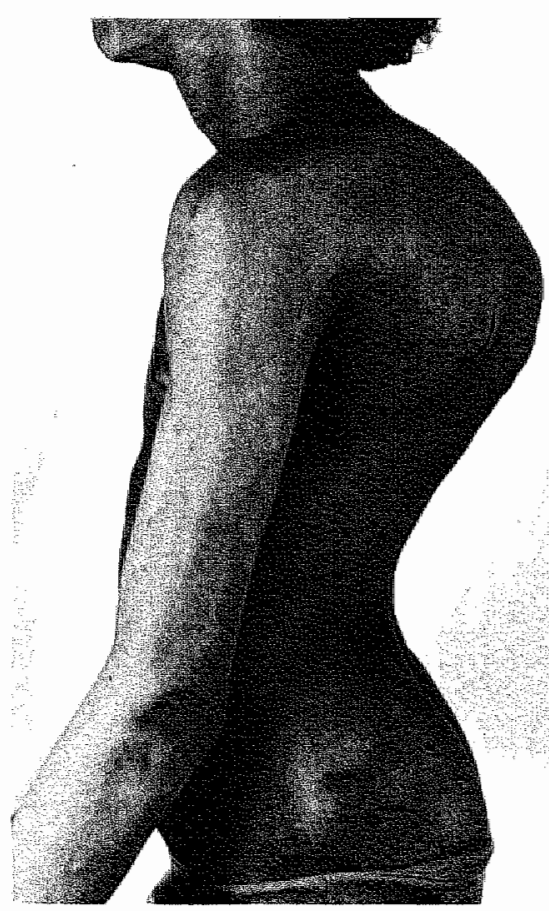

P.L. kyfose préoperaticf

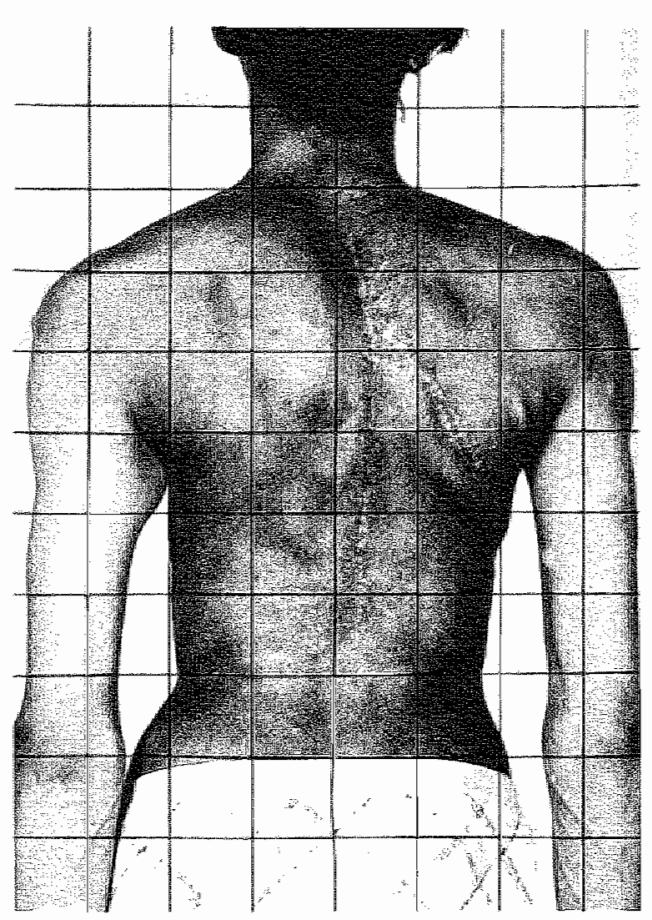

P.L. scoliose postoperatief

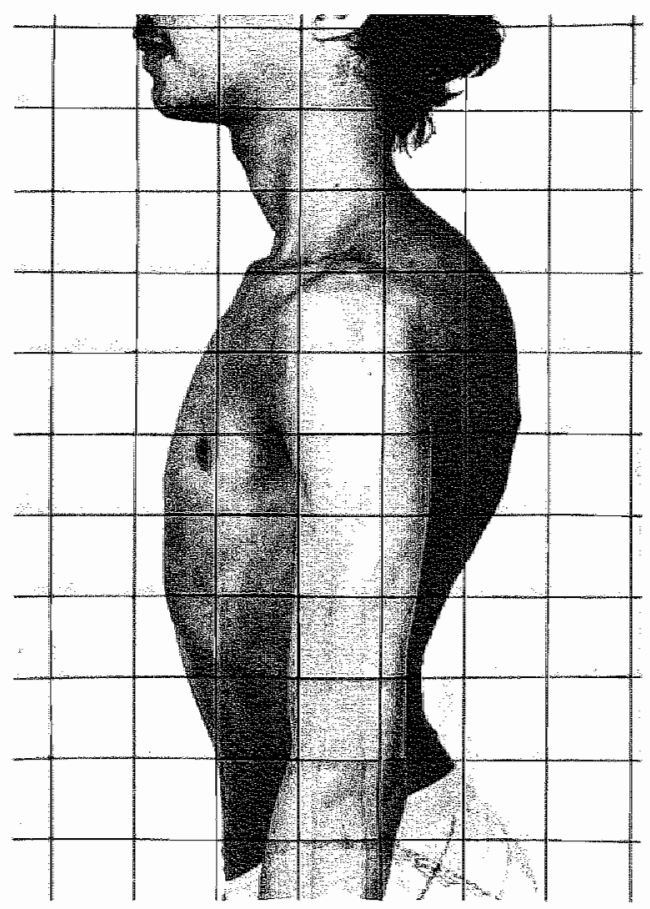

P.L. kytose na 6 operaties 


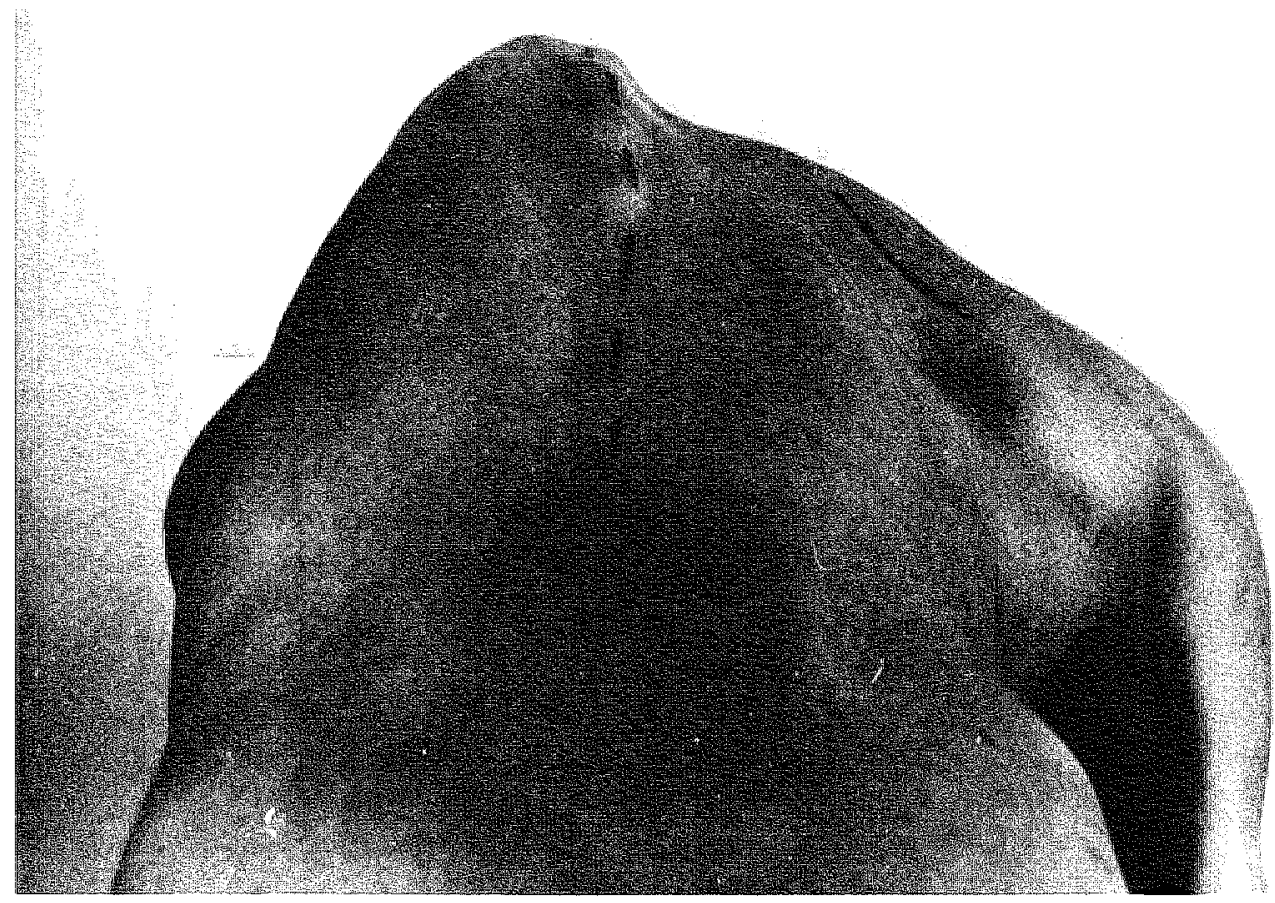

\section{P.L. gibbus préoperatief}

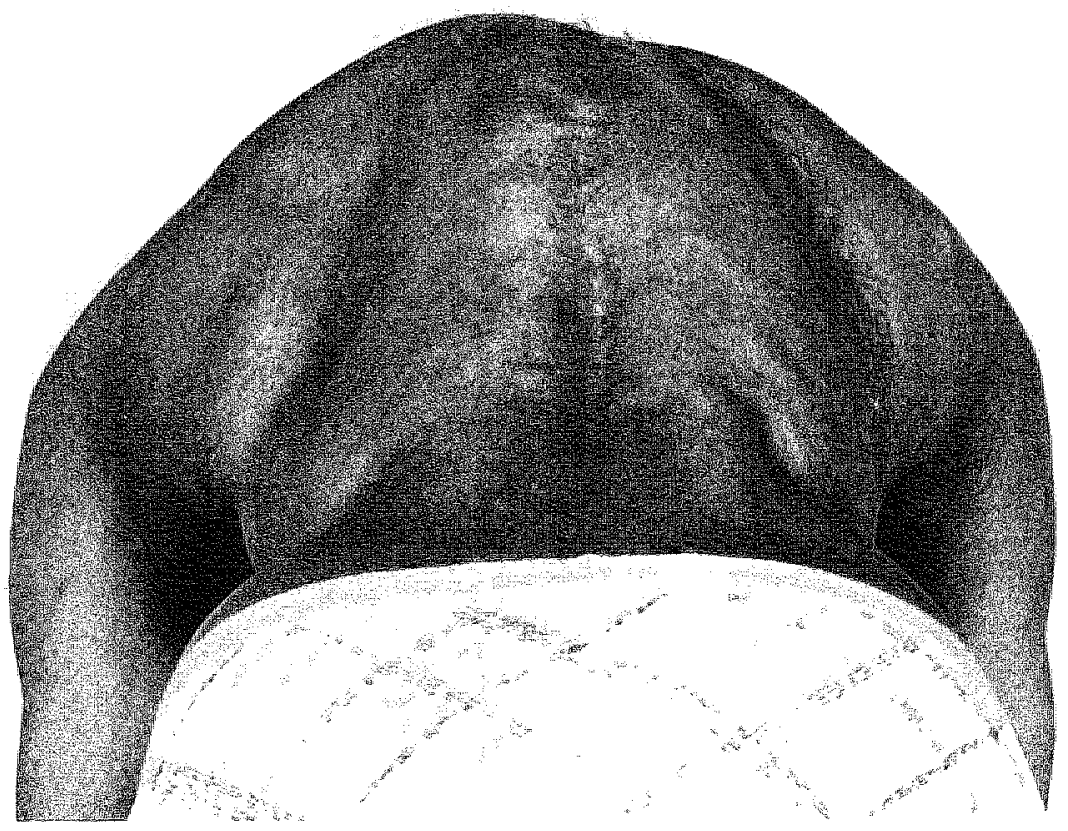

P.L. gibbus postoperatief 
Patiënt 29. M.S. vrouwelijk, geb. dat. 30-5-1963.

Aetiologie:

Vroegere behandelling:

Klachten:

Préoperatieve curves:

Voorbehandeling:

Longfunctie:

Conclusie:

Neurologisch onderzoek:

Myelografie:

Operatie I:

Operatie II:

Operatie III:

Complicaties:

Nabehandeling:
Kyfoscoliose bij de neurofibromatose van von Recklinghausen. Niet familiair voorkomend.

1e levensjaar darmstoornissen. Psychische alsook fysieke onderontwikkeling. Slecht gebit met verkleuring. Multipele café au lait vllekken. Juli 1977 behandeld met klinische bedrust, tractie en Milwaukee brace, later Risser gips, vervolgens weer een brace.

Perioden met buik en rugpijn. Indicatie tot operatie progressieve kyfoscoliose.

Scoliose links convex $82^{\circ} \mathrm{T} 6 \mathrm{t} / \mathrm{m}$ T9. Kyfose $102^{\circ} \mathrm{T} 4$ $\mathrm{t} / \mathrm{m} \mathrm{T} 10$.

4 weken Halo-rolstoeltractie. Correctie scoliose tot $66^{\circ}$, kyfose tot $52^{\circ}$.

Vit.cap. $1975 \mathrm{cc}$. Normaal $3275 \mathrm{cc}$. Tot.cap. $2550 \mathrm{cc}$. Normaal $4100 \mathrm{cc}$.

Duidelijke restrictieve stoornis.

Geen afwijkingen.

Duidelijke insnoering t.p.v. de gibbus. Hoge liquordruk.

9-5-1978. Thoracotomie rechts (6e rib), voorste spondylodese $m . b . v$. fibula en ribspanen.

30-5-1978. Achterste spondylodese m.b.v. Harrington compressie en distractie systeem en cristabot.

27-7-1979. Verwijderen distale Harringtonmateriaal (prominerend onder de huid en was losgeraakt).

Geen, behalve losraken Harringtonmateriaal.

5 maanden Halo-rompgips, waarna 5 maanden gipscorset met kraag. 
Postoperatieve curves:

$\mathrm{Na} 3$ maanden

$\mathrm{Na} 5$ maanden

Voldoende doorbouw, ontgipst.

Spondylodese mooi doorgebouwd

Toename gibbus.

Progressie.

Stilstand progressie.

Spondylodese lijkt goed.

Postoperatieve klachten:
Postoperatief

Na 10 maanden

$\mathrm{Na} 14$ maanden

Na 15 maanden

Na 16 maanden

$\mathrm{Na} 17$ maanden

$\mathrm{Na} 21$ maanden

$\mathrm{Na} 23$ maanden

$\mathrm{Na} 25$ maanden

Na 28 maanden

Na 32 maanden

Na 57 maanden

Na 63 maanden kyfose

$31^{\circ}$

$31^{\circ}$

scoliose

$48^{\circ}$

$48^{\circ}$

$35^{\circ}$

$45^{\circ}$

$49^{\circ}$

$49^{\circ}$

$53^{\circ}$

$55^{\circ}$

$58^{\circ}$

$61^{\circ}$

$60^{\circ}$

$61^{\circ}$

$61^{\circ}$

$61^{\circ}$

$59^{\circ}$

$33^{\circ}$

$34^{\circ}$

$37^{\circ}$
Bij laatste controle d.d. 19-9-1983 waren er geen klachten.

Beschouwing en conclusie:

Ook bij dit meisje leek het moeilijk tot een solide wervelkolom te komen. De juiste procedure werd gevolgd: Voorste strut-grafting en achterste Harringtonspondylodese. Na consolidatie trad toch progressie op door resorptie van het ingebrachte bot. Uiteindelijk is toch een stabiele wervelkolom verkregen, zoals bij de laatste controles gebleken is. 


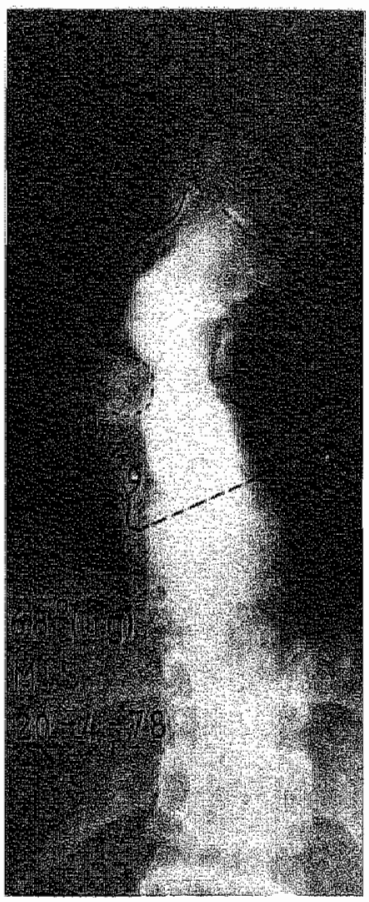

Myelografie. AP préoperatief

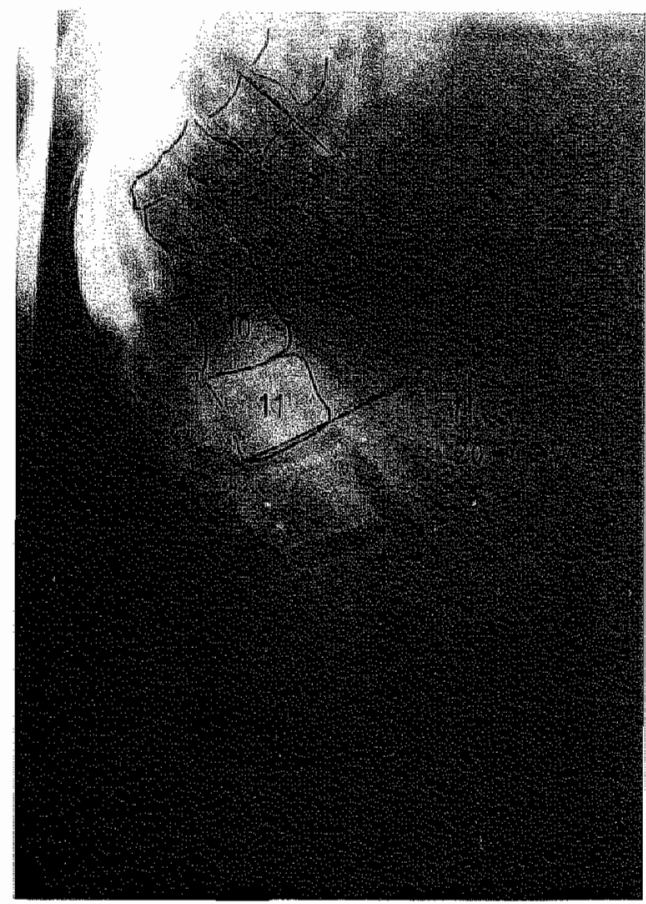

Myelografie zijdelings

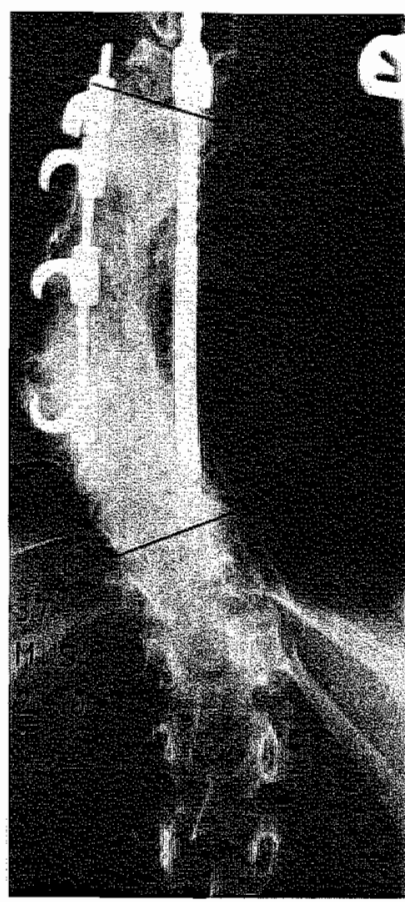

Na operatie 3

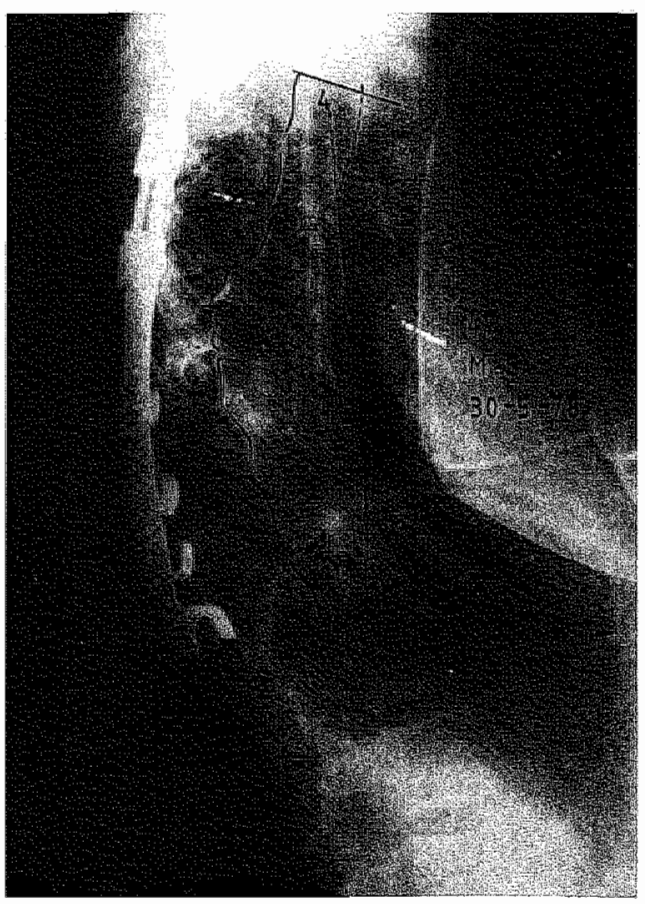

Kyfose na operatie 2 


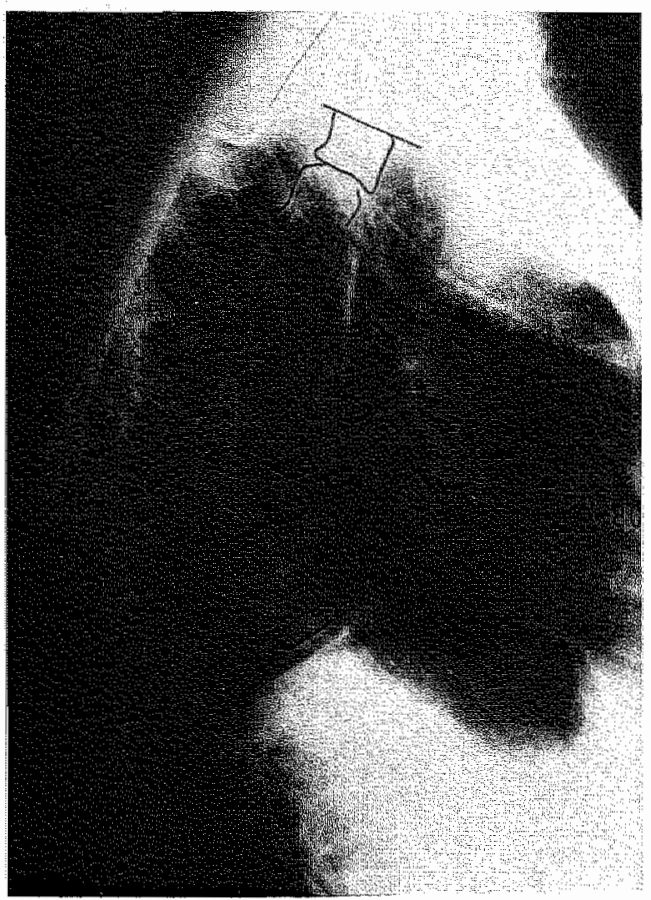

Terugzakken in kyfose $\left(58^{\circ}\right) 2$ jaar postoperatief

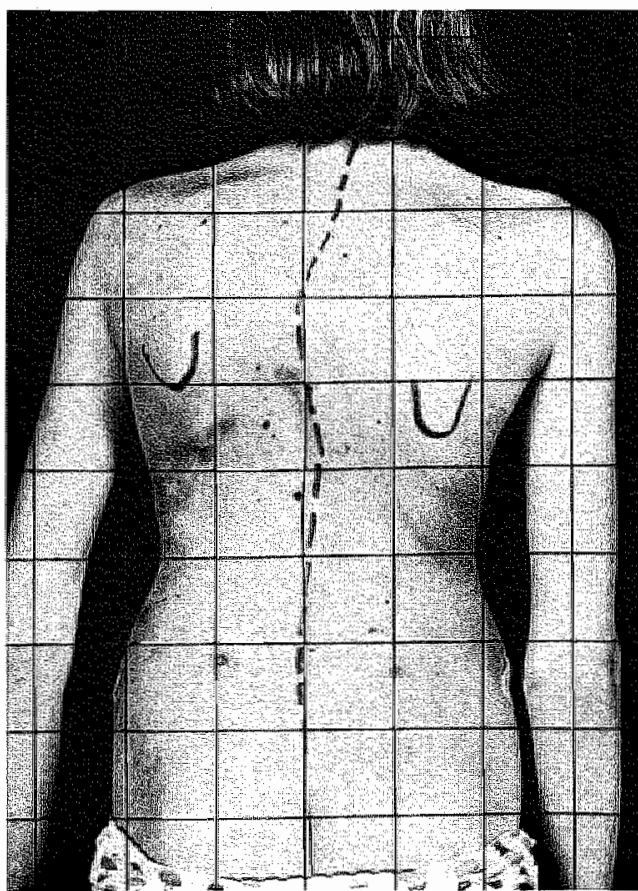

M.S. scoliose préoperatief

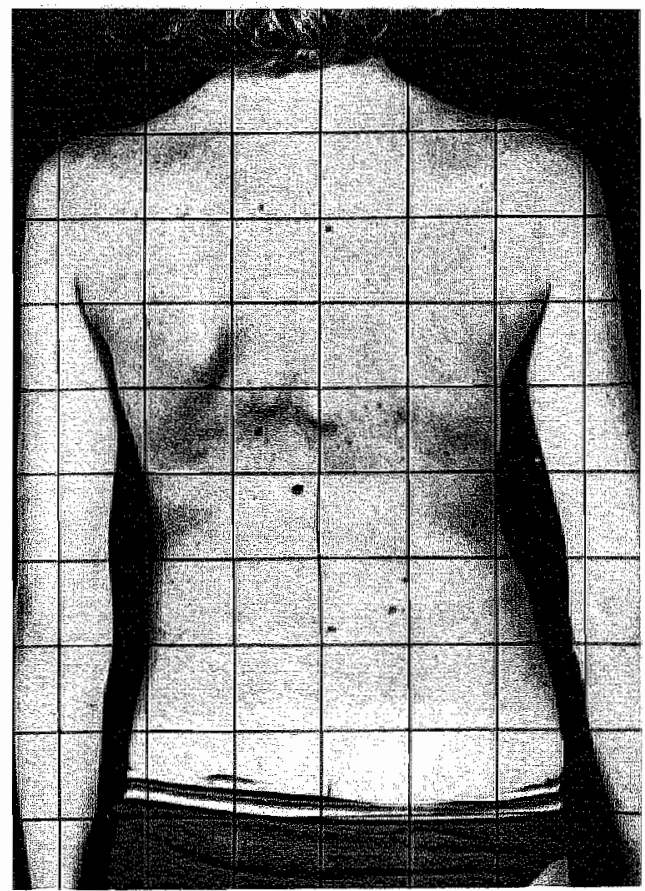

M.S. scoliose postoperatief 


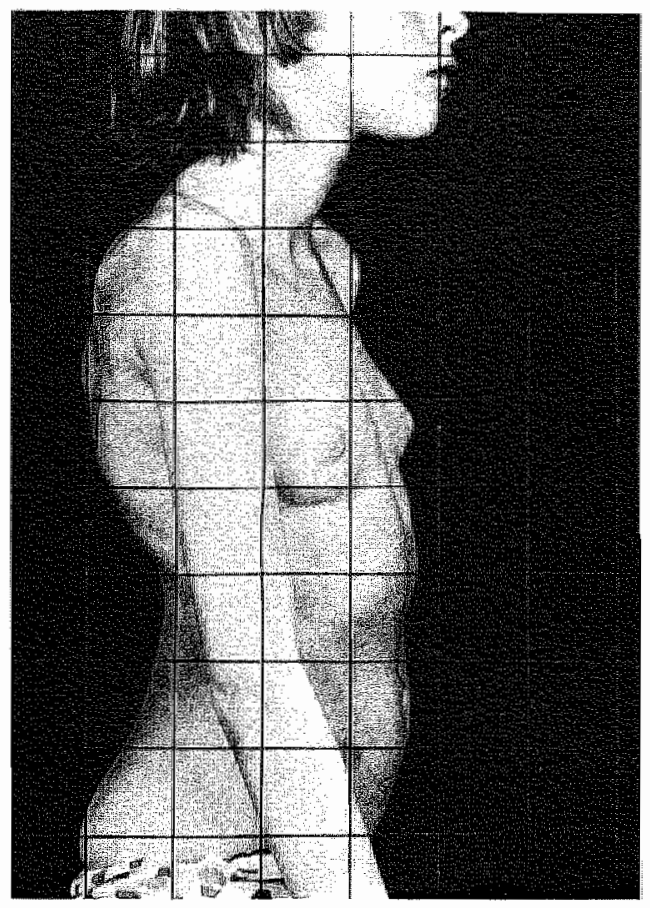

M.S. kyfose préoperatief

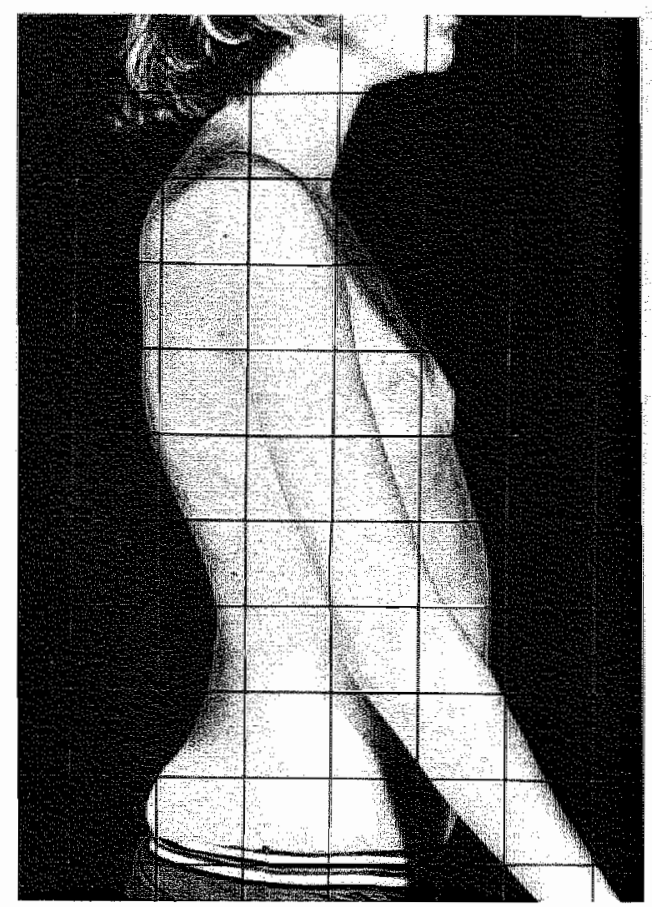

M.S. kyfose postoperatief

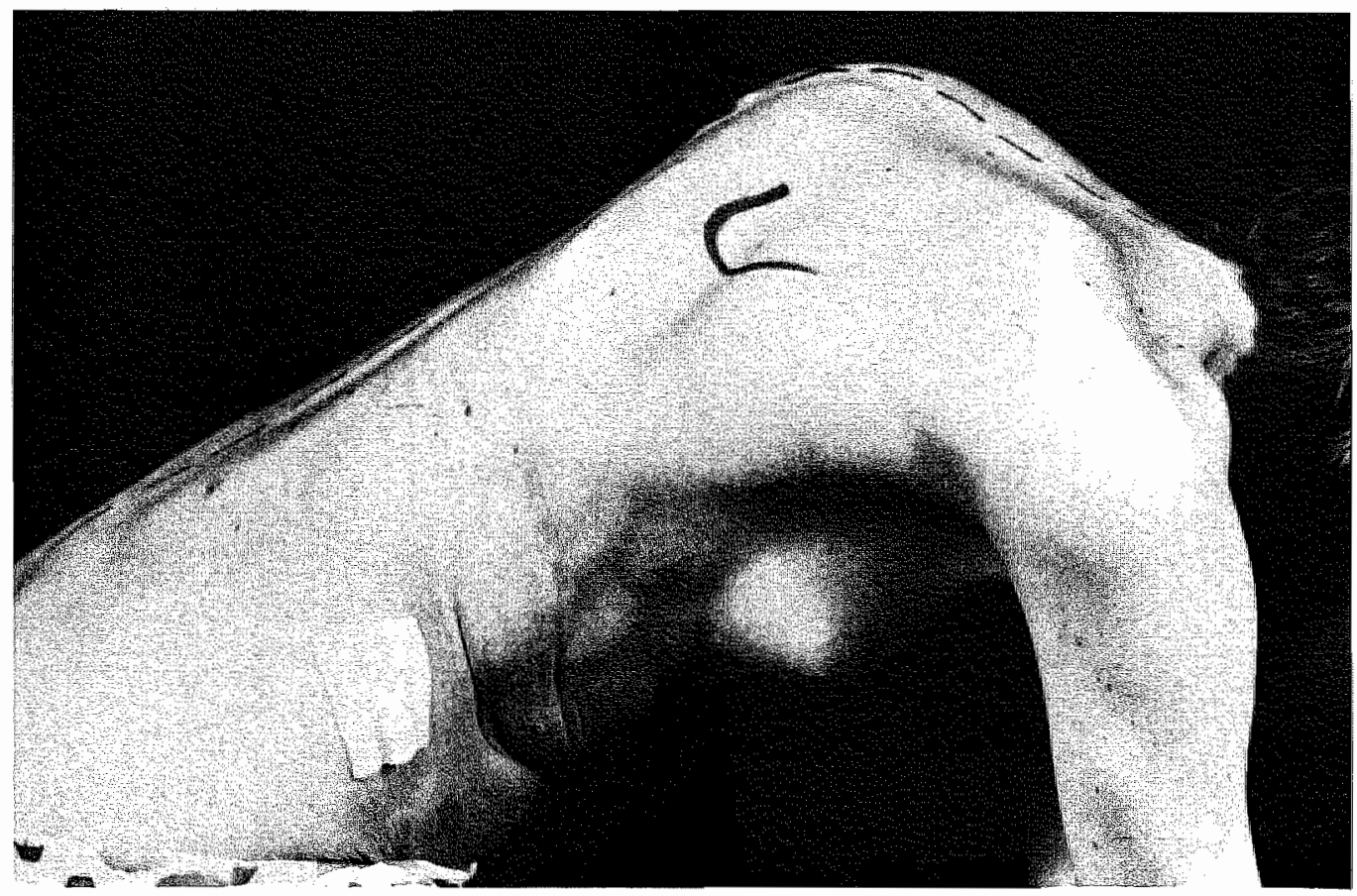

M.S. flinke kyfose préoperatief 
Patiènt 30. M.D. mannelijk, geb. dat. 6-1-1965.

Aetiologie:

Vroegere behandeling:

Klachten:

Préoperatieve curves:

Voorbehandeling:

Longfunctie:

Neurologisch onderzoek:

Myelografie:

Operatie I:

Complicaties:

Nabehandeling:

Postoperatieve curves:
Kyfoscoliose bij de neurofibromatose van Von Recklinghausen (familiair voorkomend).

Milwaukee brace.

Geen. Kyfoscoliose was progressief met resorptie van de wervellichamen aan de voorzijde (dysplasie osseuse).

$\begin{array}{lll} & & \text { kyfose } \\ \text { Januari 1975 } & \text { T5 t/m T9 } & 35^{\circ} \\ \text { April 1976 } & \text { T5 t/m T9 } & 40^{\circ} \\ \text { Augustus 1978 } & \text { T5 t/m T9 } & 54^{\circ} \\ & \text { scoliose } & 47^{\circ}\end{array}$

Geen.

Niet verricht.

Geen afwijkingen.

Niet verricht.

5-9-1978. Achterste compressiespondylodese (2 staafjes) volgens Harrington $T 3 \mathrm{t} / \mathrm{m}$ T10 en cristabot, geen aviveren intergewrichten.

Na 1 week beeld wan een lymfadenitis mesenterialis. Vlot hersteld.

3 maanden gipscorset (slechts!)

$\begin{array}{lll} & \text { kyfose } & \text { scoliose } \\ \text { Postoperatief } & 36^{\circ} & 37^{\circ} \\ \text { Na 3 maanden } & 41^{\circ} & 42^{\circ} \\ \text { Na 5 maanden } & 51^{\circ} & 42^{\circ} \\ \text { Na 11 maanden } & 68^{\circ} & 42^{\circ} \\ \text { Na 17 maanden } & 64^{\circ} & 45^{\circ} \\ \text { Na 27 maanden } & 67^{\circ} & \end{array}$

Röntgenologisch compressiesysteem los met volledig collaberen T6 en T7.

In verband met progressie en wervellichaamcollaps tot voorste strutgrafting besloten, na 2 weken Halozittractie. 
Operatie:

Complicaties:

Nabehandeling:

Postoperatieve curves:

Postoperatieve klachten:
29-4-1981. Voorste spondylodese T4 t/m T10 met behulp van Slot-Zielke systeem via thoracotomie rechts, met fibula en ribgrafts. Tevens verwijderen van het Harringtonmateriaal, de spondylodese leek intact.

Geen.

3 maanden Halo-rompgips, hierna 6 maanden gipscorset.

$\begin{array}{lll} & \text { kyfose } & \text { scoliose } \\ \text { Postoperatief } & 55^{\circ} & 50^{\circ} \\ \mathrm{Na} \mathrm{2} \text { maanden } & 46^{\circ} & 50^{\circ} \\ \mathrm{Na} \mathrm{3} \text { maanden } & 49^{\circ} & 66^{\circ} \\ \mathrm{Na} \mathrm{6} \text { maanden } & 45^{\circ} & 63^{\circ} \\ \mathrm{Na} 8 \text { maanden } & 49^{\circ} & 60^{\circ} \\ \mathrm{Na} \text { 17 maanden } & 48^{\circ} & 57^{\circ} \\ \mathrm{Na} 23 \text { maanden } & 51^{\circ} & 58^{\circ}\end{array}$

Bij laatste controle op 28-3-83 was er pijn rechts naast de scapula sinds 1 maand. Er was een drukpijnlijke plek, mogelijk op een nog losliggend moertje van het compressiesysteem. Röntgenologisch was er volledige consolidatie.

Beschouwing en conclusie:

Bij deze jongen werd in eerste instantie een insufficiënte behandeling ingesteld. Alléén een achterste spondylodese voldoet niet, als de voorste pijler van de wervelkolom door het neurofibrotische proces is aangetast. Een voorste spondylodese is dan aangewezen, ook al garandeert deze geen absoluut succes, omdat zelfs met een sufficiënte voorste strutgrafting de spaan weer geresorbeerd kan worden. Waarschijnlijk draagt het interne fixatiemateriaal bij tot een snellere en betere ingroei van de spanen met minder kans op collaberen en resorptie van het graft-materiaal, bij deze jongen lijkt in ieder geval een goede voorste spondylodese verkregen. 


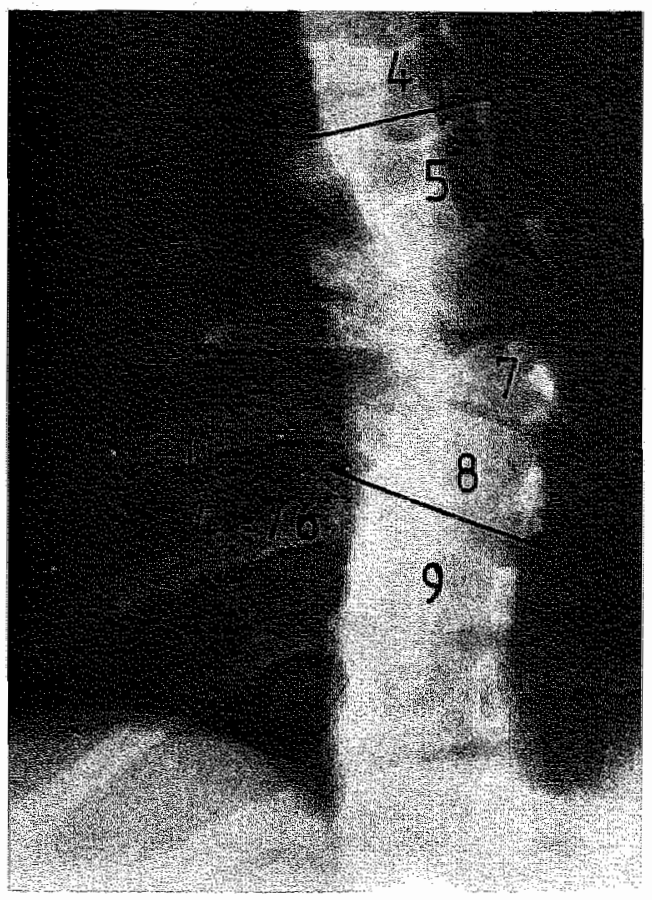

Scoliose in 1976

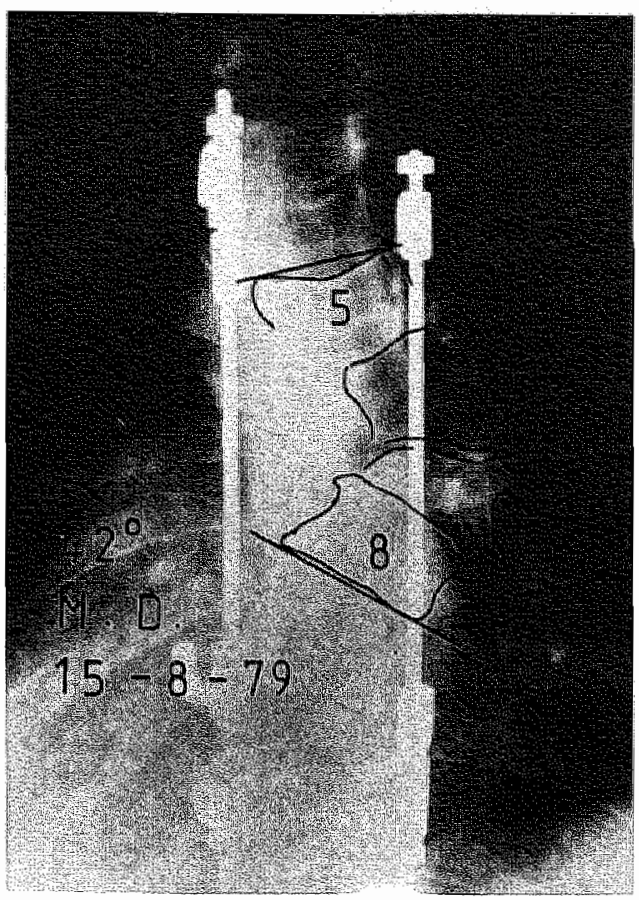

Scoliose in 1979

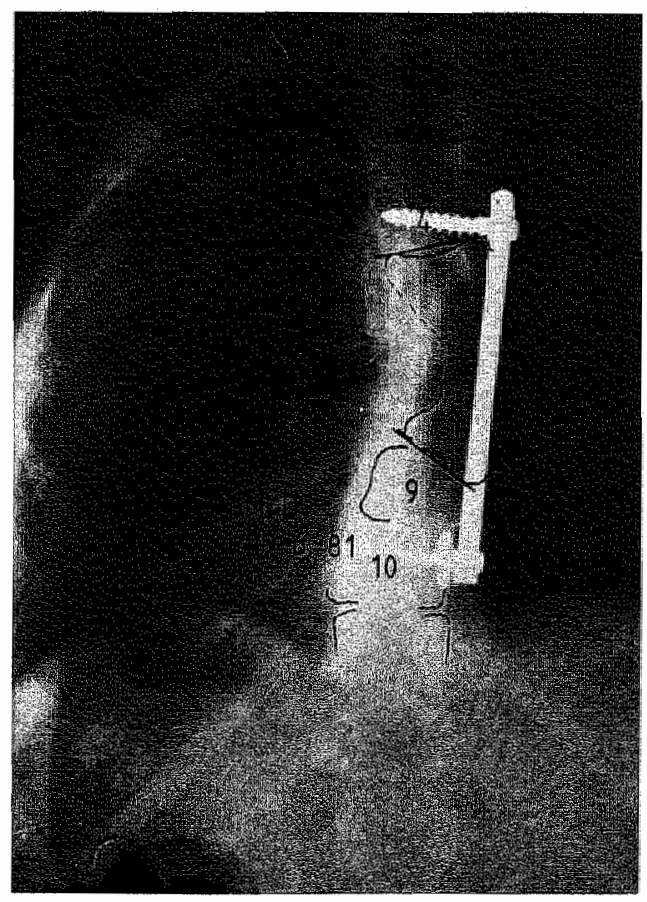

Scoliose na laatste operatie 


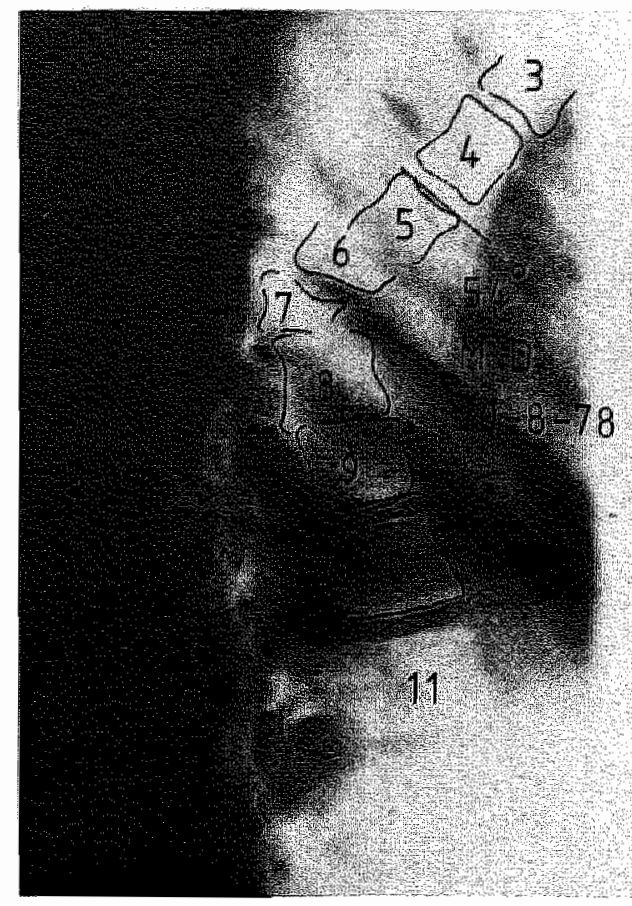

Kyfose préoperatief

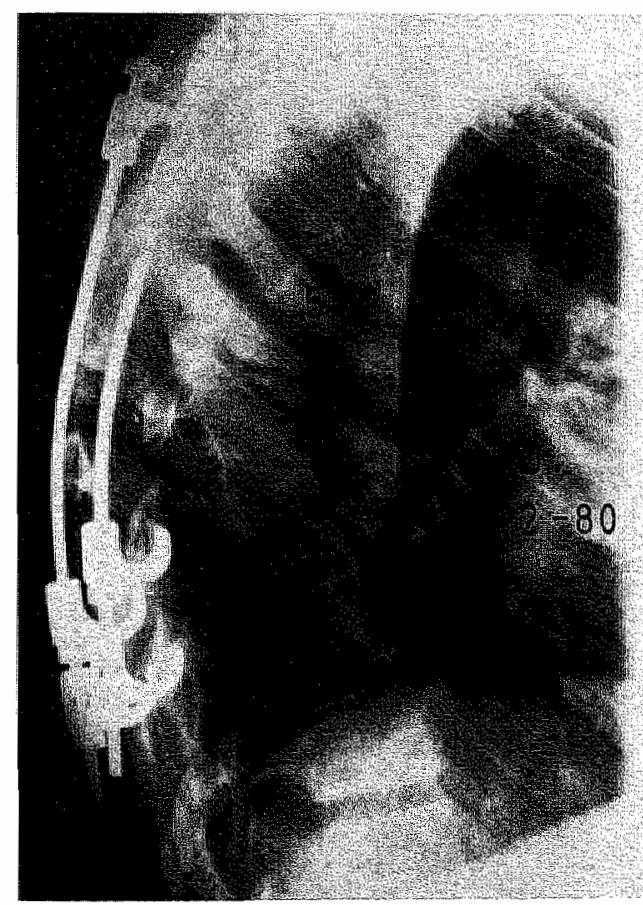

Kyfose $64^{\circ} 11 / 2$ jaar na operatie

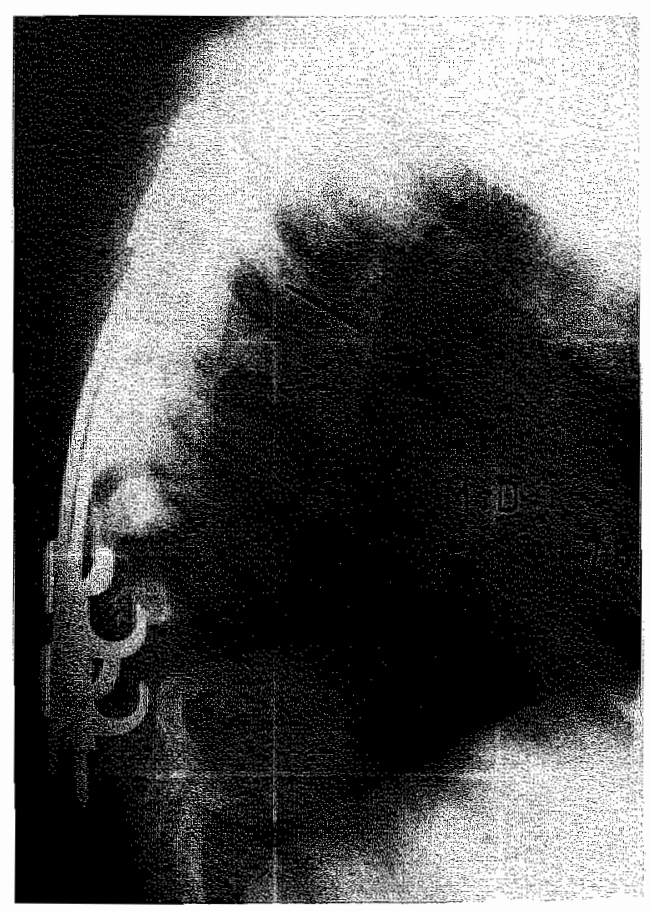

Postoperatief goede correctie

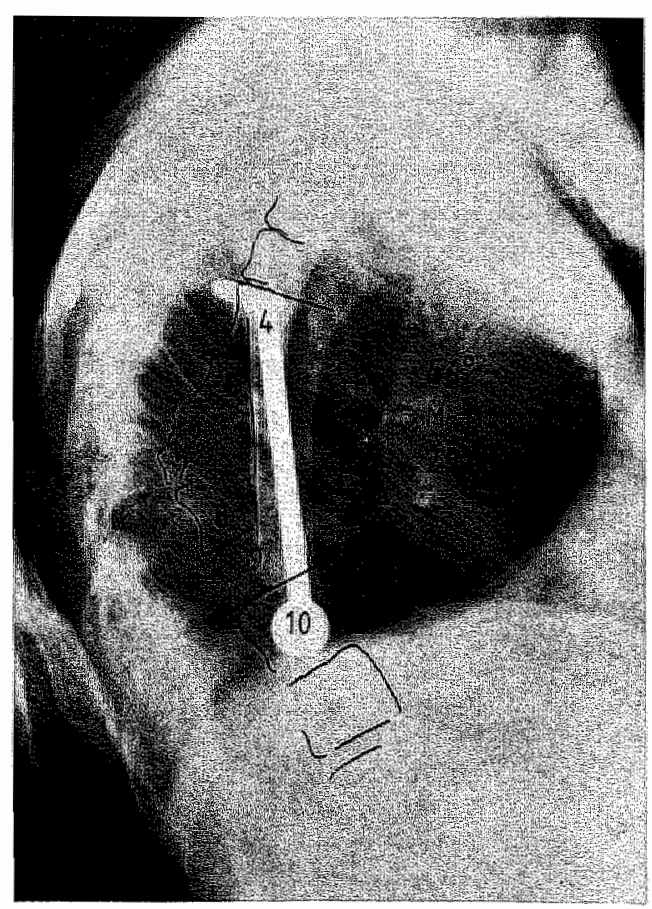

Na laatste operatie 


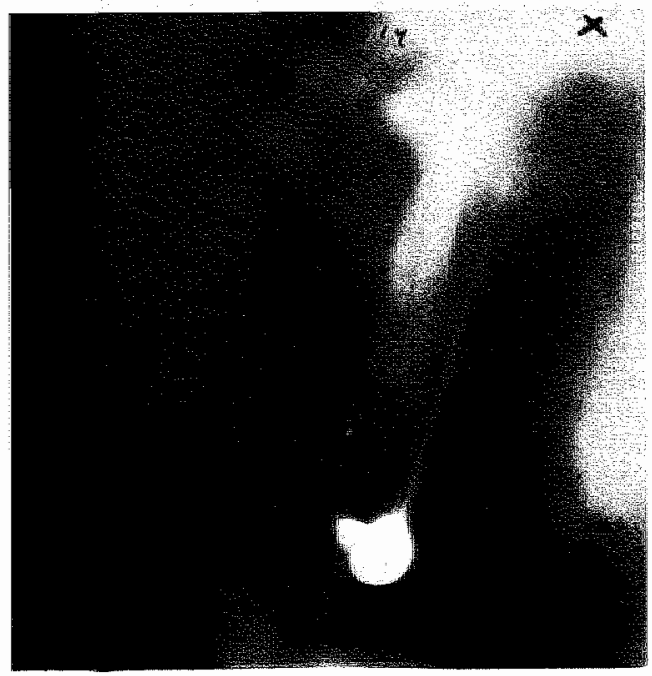

M.D. planigram. Goede ingroei fibulaspaan

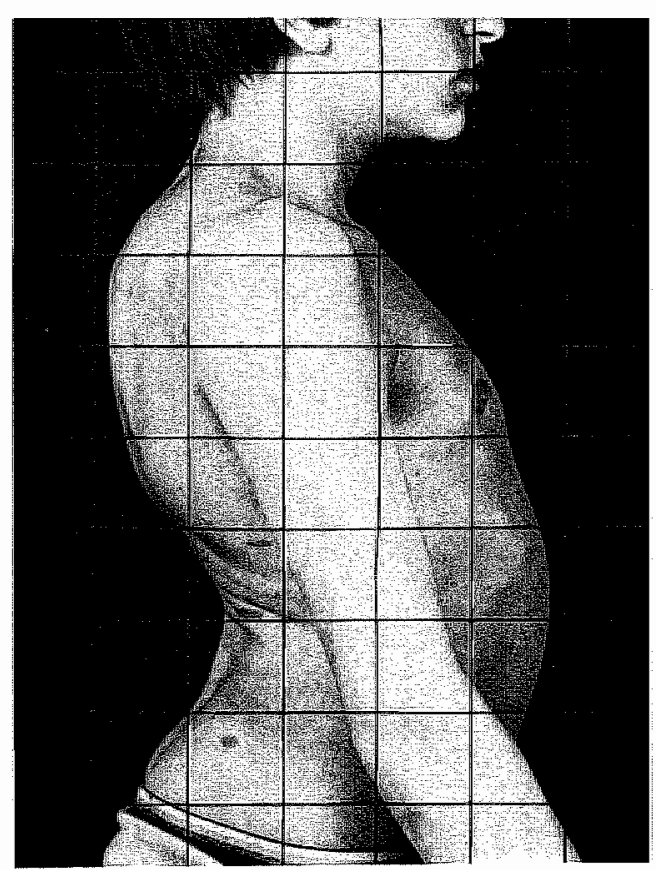

M.D. kyfose préoperatief voor laatste ingreep

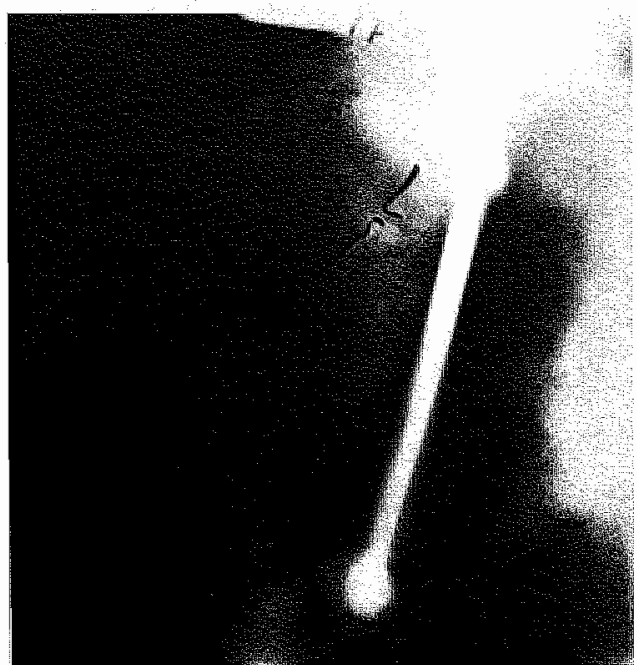

M.D. planigram. Let op het sterk verwijde spinaalkanaal

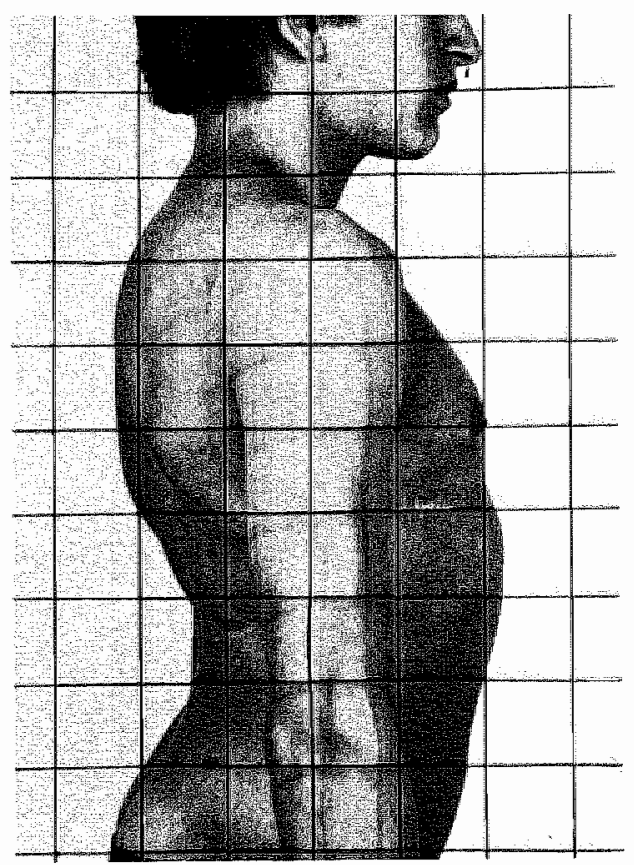

M.D. kyfose postoperatief 


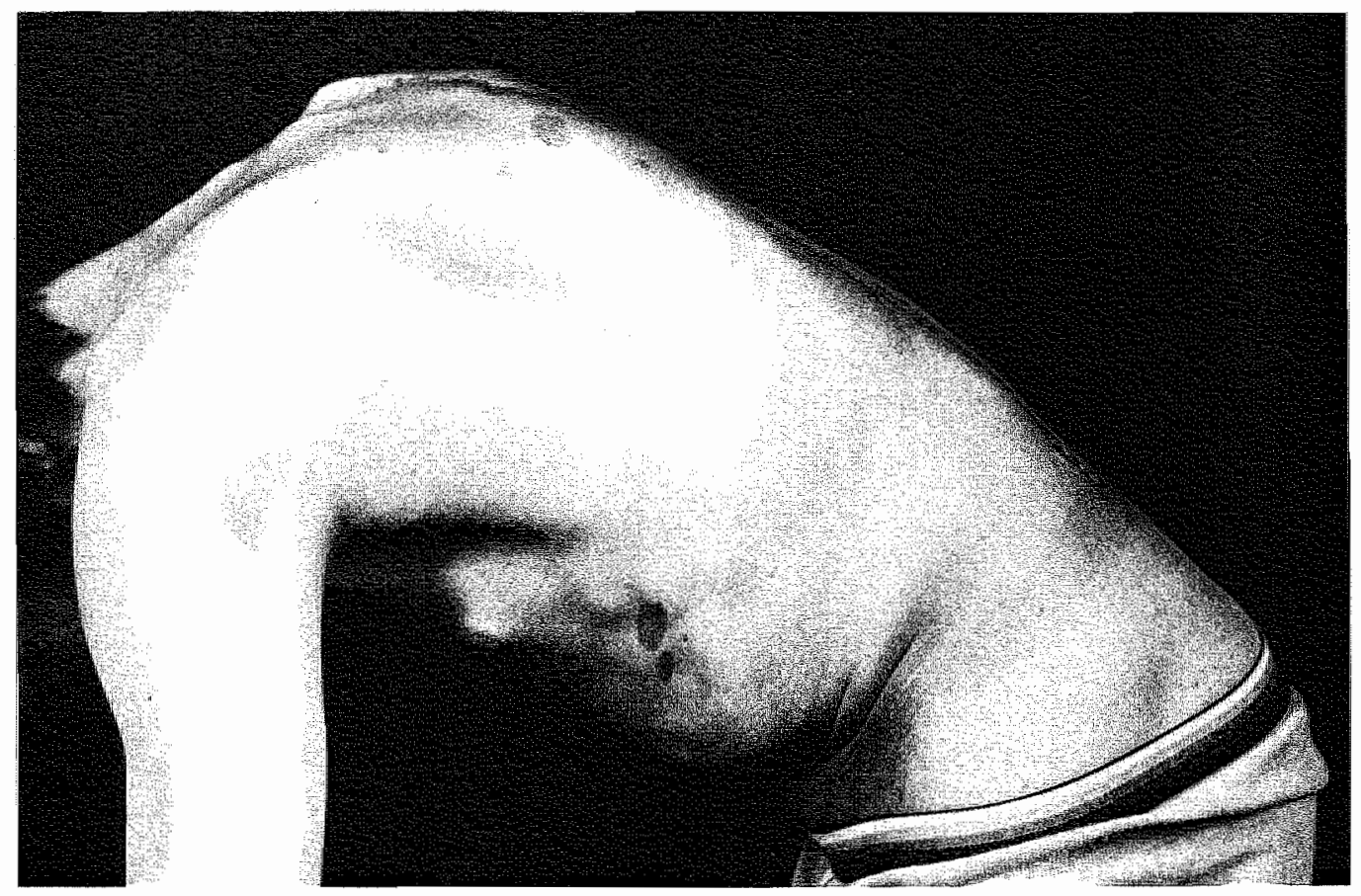

M.D. kyfose voorovergebogen woor laatste operatie (de haakjes steken uit)

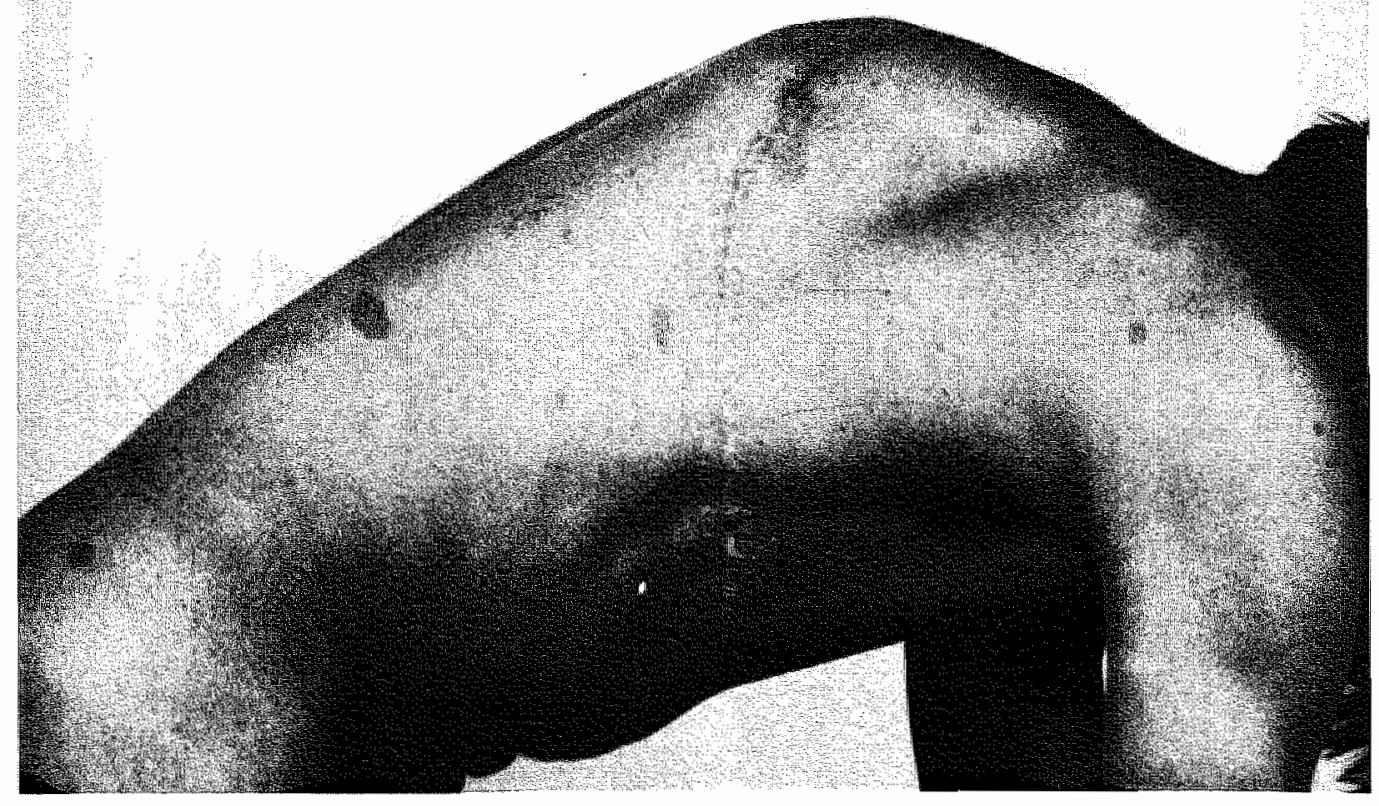

M.D. kyfose postoperatief 
Patiënt 31. B. A. vrouwelijk, geb. dat. 4-3-1952.

Aetiologie:

Vroegere behandeling:

Klachten:

Préoperatieve curves:

Voorbehandeling:

Longfunctie:

Conclusie:

Neurologisch onderzoek:

Myelografie:

Operatie I:

Operatie II:

Complicaties:

Nabehandeling:

Postoperatieve curves:

Postoperatieve klachten:
Lumbale kyfoscoliose bij de neurofibromatose van Von Recklinghausen (niet familiair voorkomend).

Jarenlang leren corset.

Regelmatig rugpijn met uitstraling in rechter been en algehele vermoeidheidsklachten. Geen neurologische uitval.

Scoliose $\mathrm{T} 11 \mathrm{t} / \mathrm{m} \mathrm{L3} 95^{\circ}$, kyfose $55^{\circ}$. Sterke rotaties met "drehgleiten".

3 weken Cotreltractie, enkele dagen Halo-tractie, waarna dorsale release, waarna Halo-rolstoeltractie.

Vit. cap. 3750 cc. Normaal 4150 cc. Tot. cap. 4925 cc. Normaal $5375 \mathrm{cc}$.

Geringe restrictieve functiestoornis.

Lichte pyramidebaanprikkeling linker been.

Niet geslaagd, contrast kwam epiduraal.

8-1-1980. Dorsale release T12 t/m L3 met uitruimen van de intergewrichten. Vervolgens Halo-rolstoeltractie.

23-1-1980. Voorste spondylodese volgens Zielke T11 t/m L4 via thoracophrenolumbotomie via bed 10e rib. Zeer fragiele lumbale venen. Uiterste schroeven m.b.v. palacos gefixeerd.

Irritatie achterste Halo-pen.

9 maanden gipscorset.

$\begin{array}{lll} & \text { scoliose } & \text { kyfose } \\ \text { Postoperatief } & 20^{\circ} & 6^{\circ} \\ \mathrm{Na} 2 \text { maanden } & 26^{\circ} & 6^{\circ} \\ \mathrm{Na} 6 \text { maanden } & 26^{\circ} & \\ \mathrm{Na} 9 \text { maanden } & 24^{\circ} & \\ \mathrm{Na} 24 \text { maanden } & 20^{\circ} & 17^{\circ}\end{array}$

Paraesthesieèn in het gebied van de nervus cutaneus femoris lateralis. Verder geen klachten. 
Bijzonder fraaie correctie van deze ernstige lumbale scoliose met drehgleiten in kyfose bij de ziekte van Von Recklinghausen. Het Zielke instrumentarium blijkt bij de thoracolumbale curve met kyfose een verbetering ten opzichte van het Dwyer systeem te zijn. Met name het deroterende en daardoor dekyfoserende effect is de belangrijkste aanwinst. Let ook op de versmalling van de wervellichamen in voor-achterwaartse richting met "scalloping". Helaas mislukte bij deze patiënte de myelografie zodat de vermoede verwijding van de duraalzak niet zichtbaar kon worden gemaakt. 


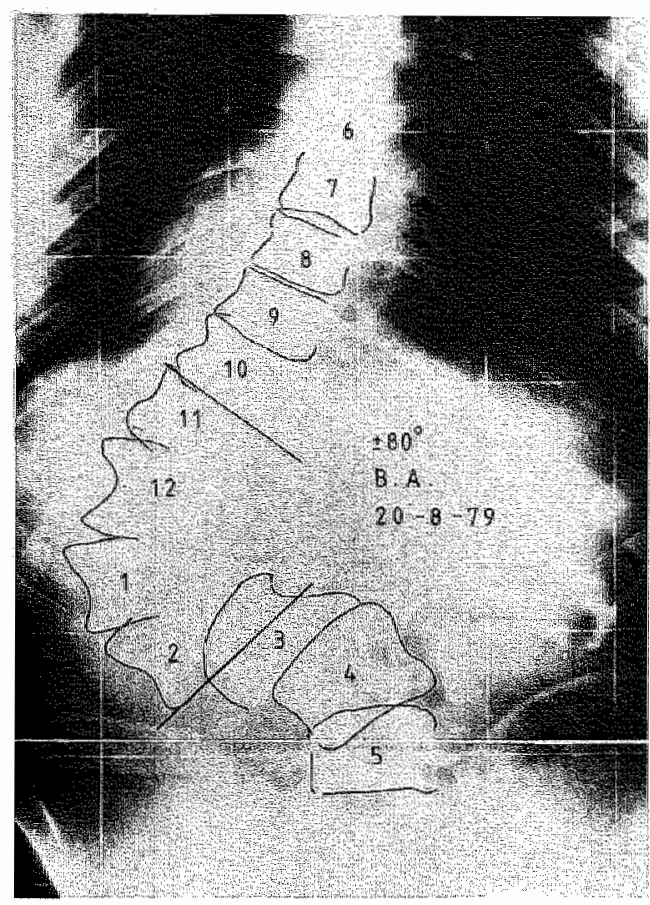

Scoliose préoperatief

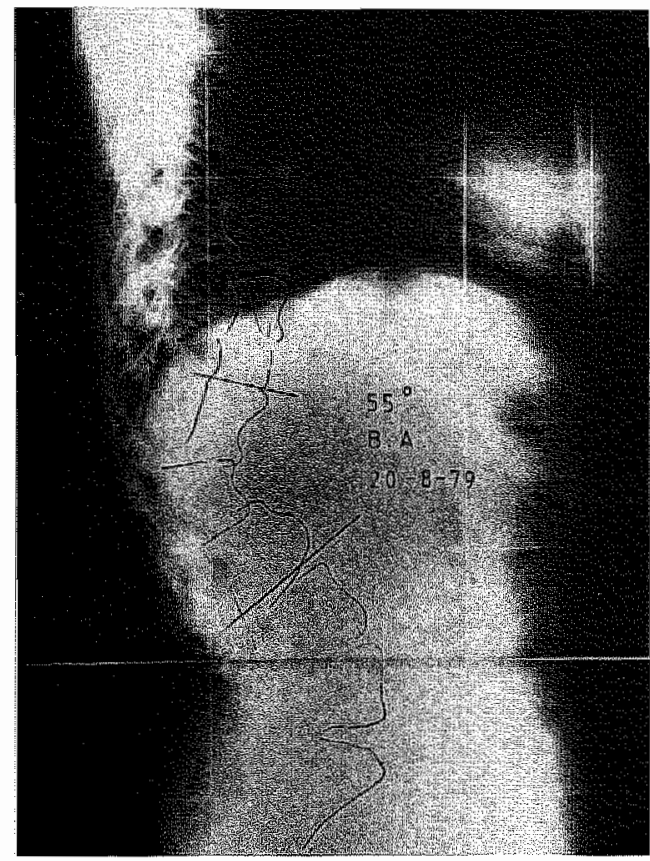

Kyfose door drehgleiten préoperatief

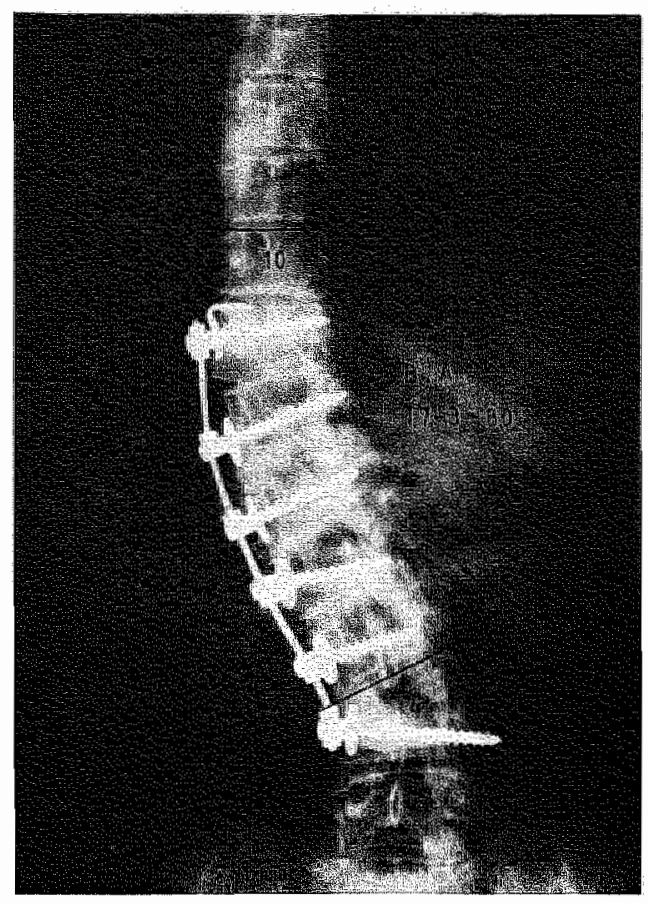

Scoliose postoperatief

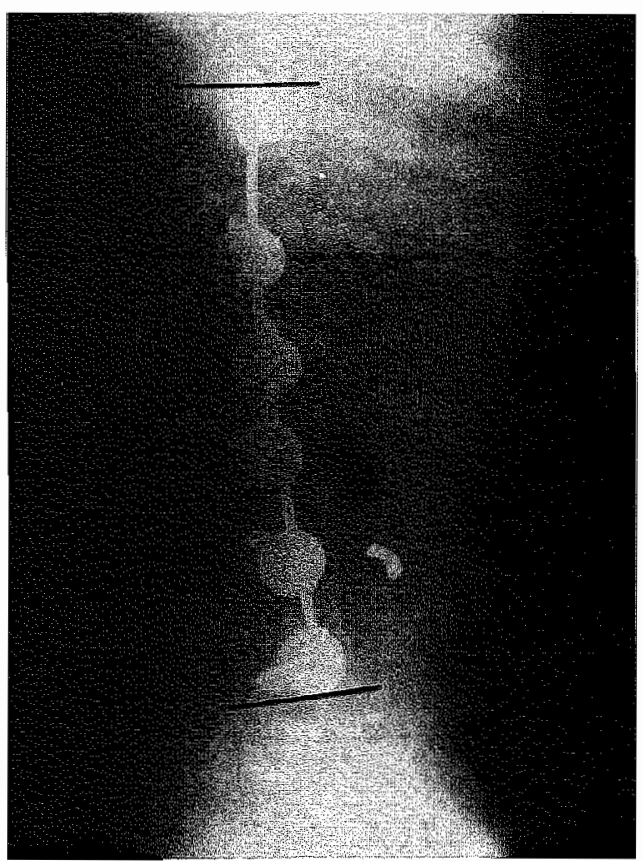

Fraaie strekking door derotatie postoperatief 


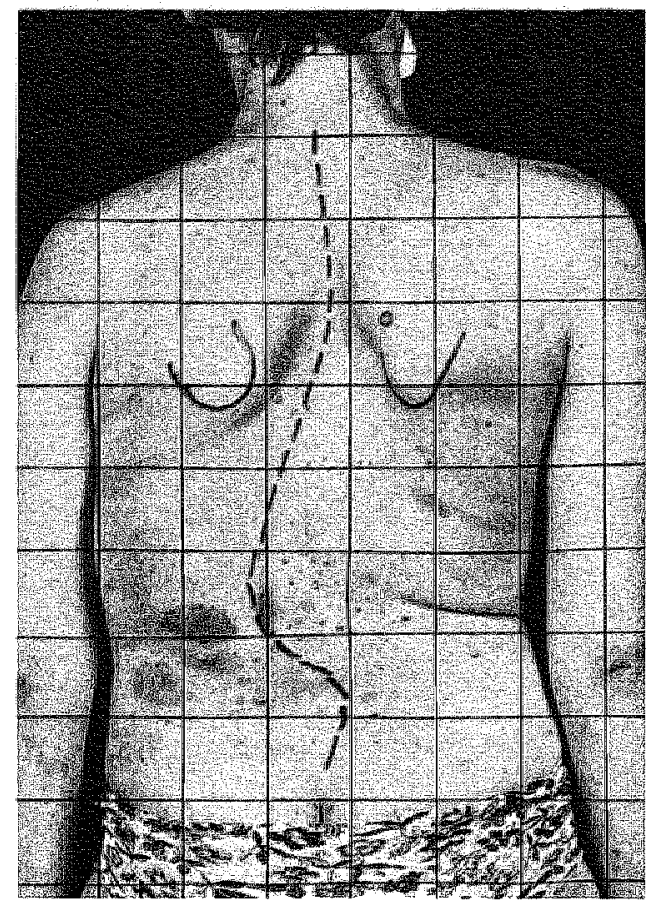

B.A. scoliose préoperatief

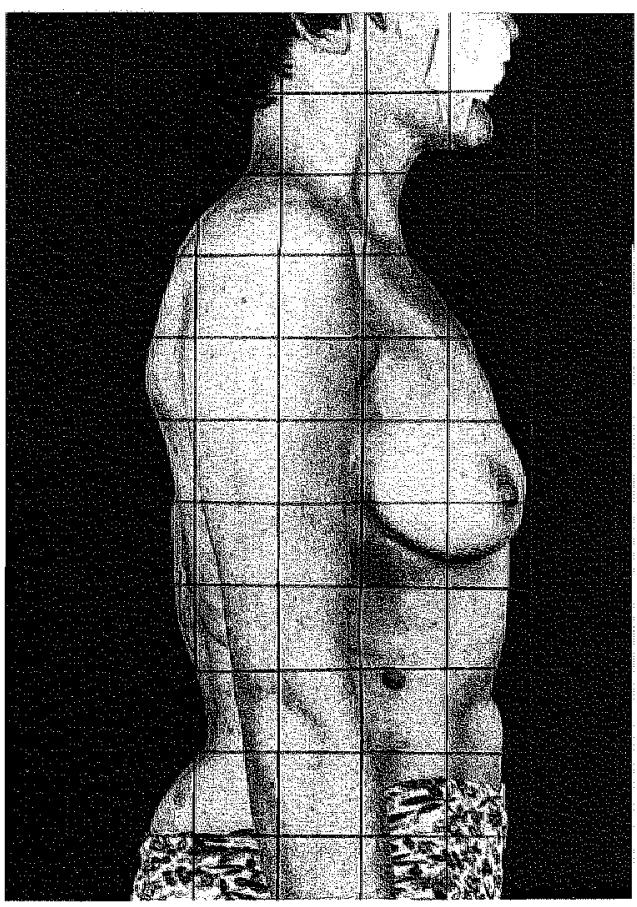

B.A. kyfose préopetatief

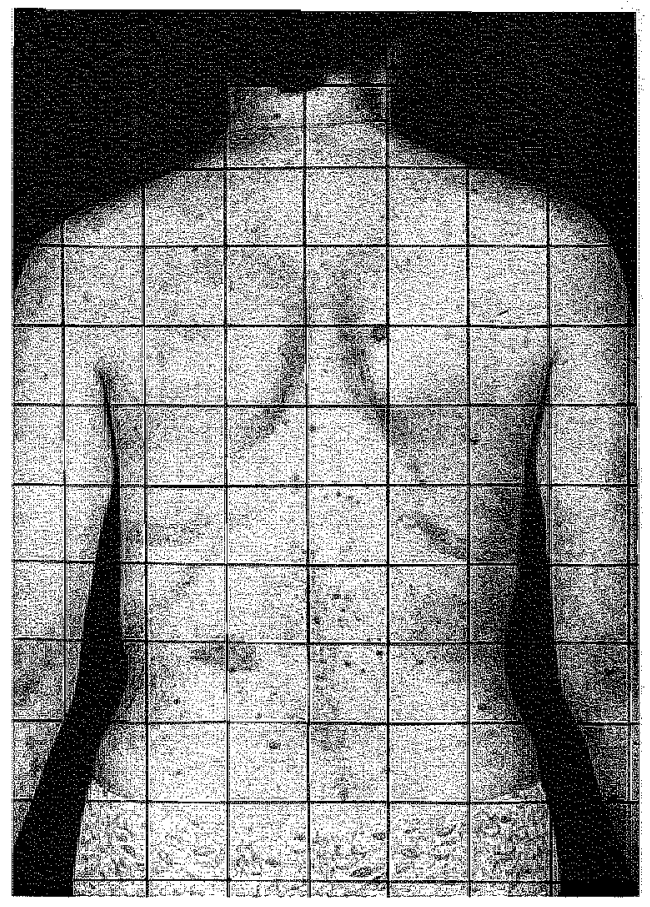

B.A. scoliose postoperatief

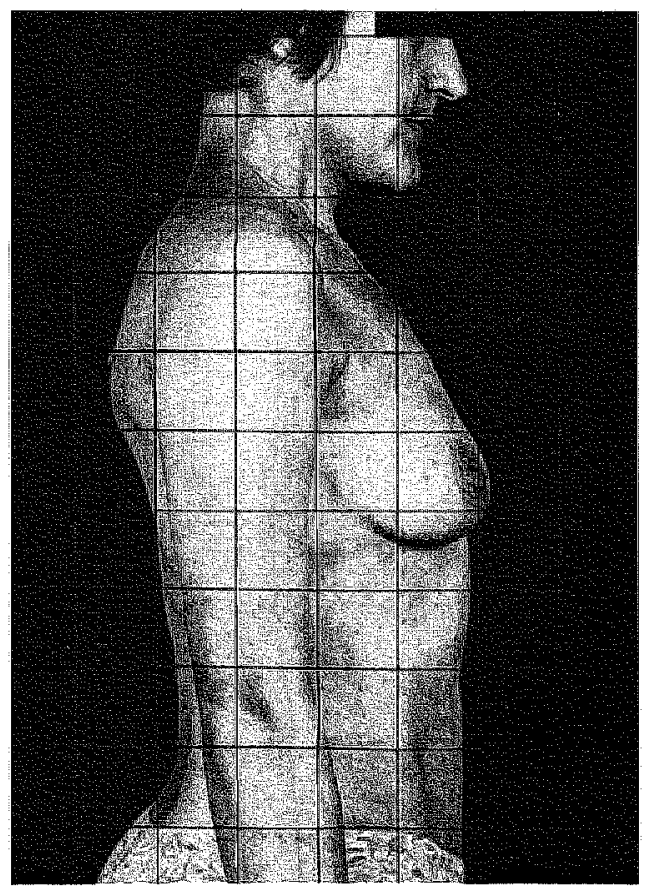

B.A. Kyfose postoperatief 


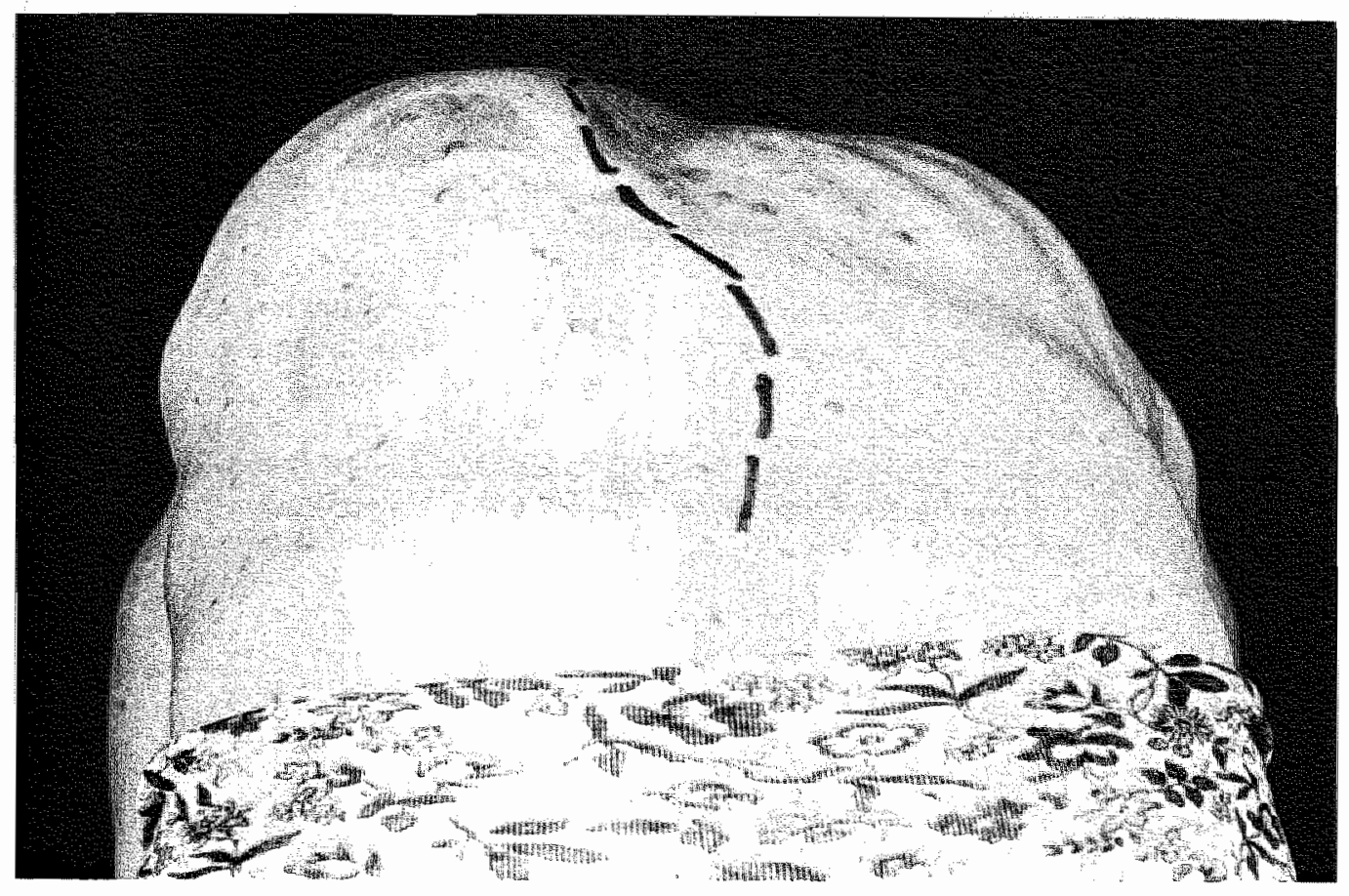

B.A. gibbus préoperatief

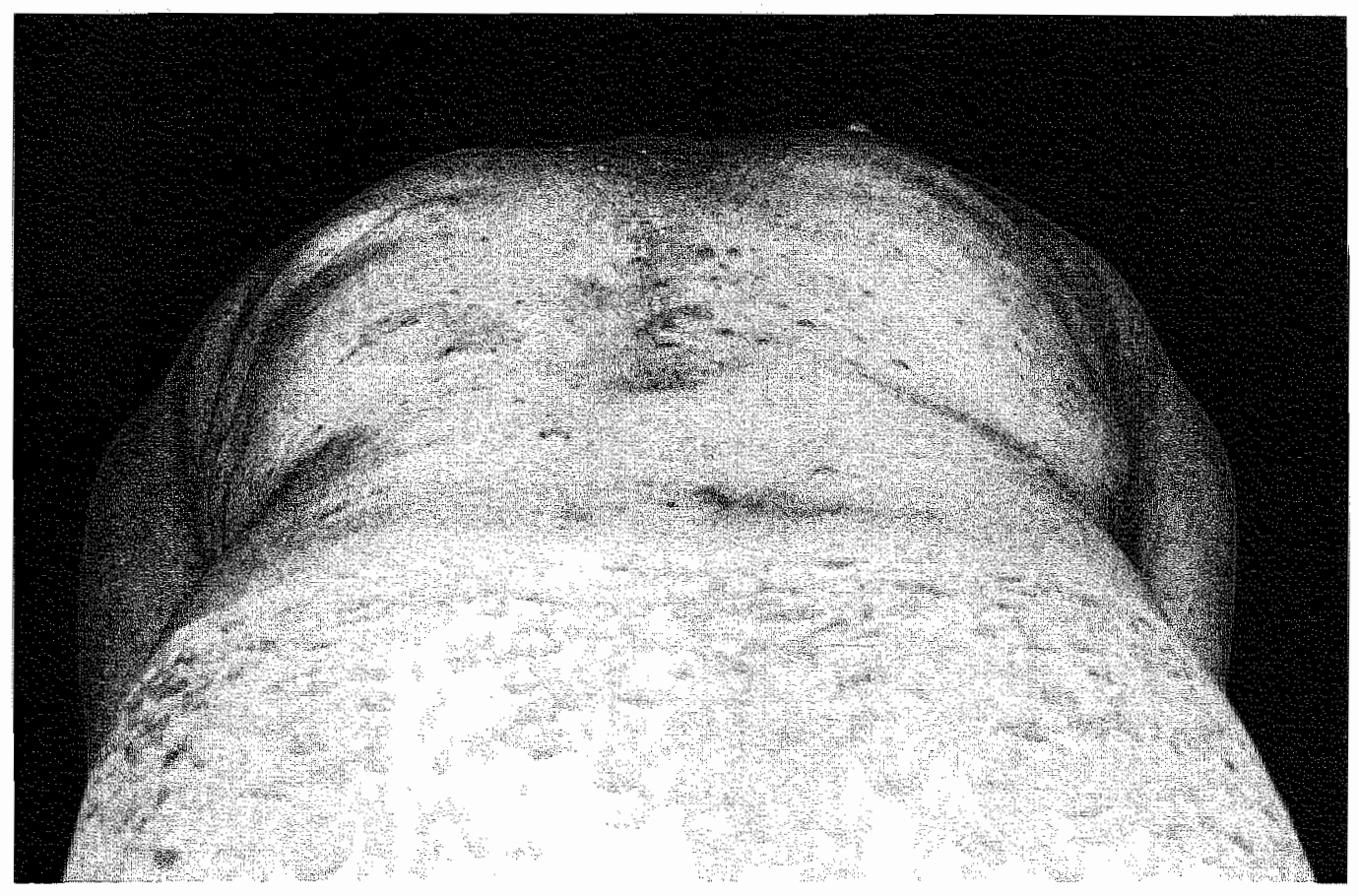

B.A. ..gibbus" postoperatief 
Patiēnt 32. S.B. vrouwelijk, geb. dat. 9-6-44.

Aetiologie:

Vroegere behandeling:

Klachten:

Préoperatieve curves:

Voorbehandeling:

Longfunctie:

Conclusie:

Neurologisch onderzoek:

Myelografie:

Operatie I:

Operatie II:

Complicaties:

Nabehandeling:

Postoperatieve curves:

Postoperatieve klachten:
Lumbale kyfoscoliose bij de neurofibromatose van Von Recklinghausen.

Als kind ,stalen" corset.

Vanaf 1 le jaar vage lumbale rugklachten, langzaam progressief. Sinds kort ook thoracale rugpijn. Soms uitstraling naar benen en voeten.

Scoliose T12 t/m L3 $125^{\circ}$, L4 t/m L5 $96^{\circ}$. Kyfose T11 $\mathrm{t} / \mathrm{m} \mathrm{L} 2106^{\circ}$.

Halo-Cotrel tractie 4 weken.

Vit. cap. 3825 cc. Normaal 4150 cc. Tot. cap. 5250 cc. Normaal $5625 \mathrm{cc}$.

Zeer geringe restrictie.

Geen afwijkingen.

Niet gelukt.

21-4-1982. Spondylodese anterior T10 $\mathrm{t} / \mathrm{m} \mathrm{L5}$ met behulp van Slot-Zielke systeem, fibulaspaan en rib. Hierbij aanprikken van de dura door wervellichaam L4 heen.

11-5-1982. Harrington spondylodese $\mathrm{T} 9 \mathrm{t} / \mathrm{m}$ sacrum met behulp van cristabot.

Geen.

Gipscorset 8 maanden.

Postoperatief scoliose $68^{\circ}$ resp. $37^{\circ}$. Kyfose $79^{\circ}$. Langzame progressie scoliose tot $74^{\circ}$ resp. $56^{\circ}$ en kyfose $93^{\circ}$ met breuk van de Slot-Staaf na 1 jaar. Het sacrumhaakje is naar distaal gemigreerd. Hierna 2 maanden een neofractcorset, waarna een ortholeencorset.

Af en toe uitstralende pijn in de benen, vooral bij liggen. 
Deze patiënte had een extreme vorm van een kyfoscoliose bij de neurofibromatose, nog zonder dwarslaesieverschijnselen. Van de normale wervelstructuur was weinig meer terug te vinden en het dragende karakter van de lumbale wervels leek nauwelijks meer aanwezig en min of meer overgenomen door het contact van de ribben met het bekken. Uiteindelijke dwarslaesie verschijnselen zijn bij deze ernstige neurofibromatose curves te verwachten, terwijl de klachten van patiënte progressief waren. Gekozen werd daarom voor operatie met zo goed mogelijke correctie en stabilisatie. Zelfs met een gecombineerde voorste en achterste instrumentatie en fusie is de curve niet stabiel gebleken. Wegens de toenemende klachten en toenemend verlies aan correctie vond reoperatie plaats op 14-9-1983, waarbij een pseudarthrose lumbosacraal werd aangetroffen. Deze werd gerepareerd en er werd een staaf geplaatst tussen de bekkenkam en de wervelkolom. Nabehandeling vond plaats met het al bestaande kunststofcorset. Er lijkt inmiddels een goede spondylodese verkregen te zijn. 


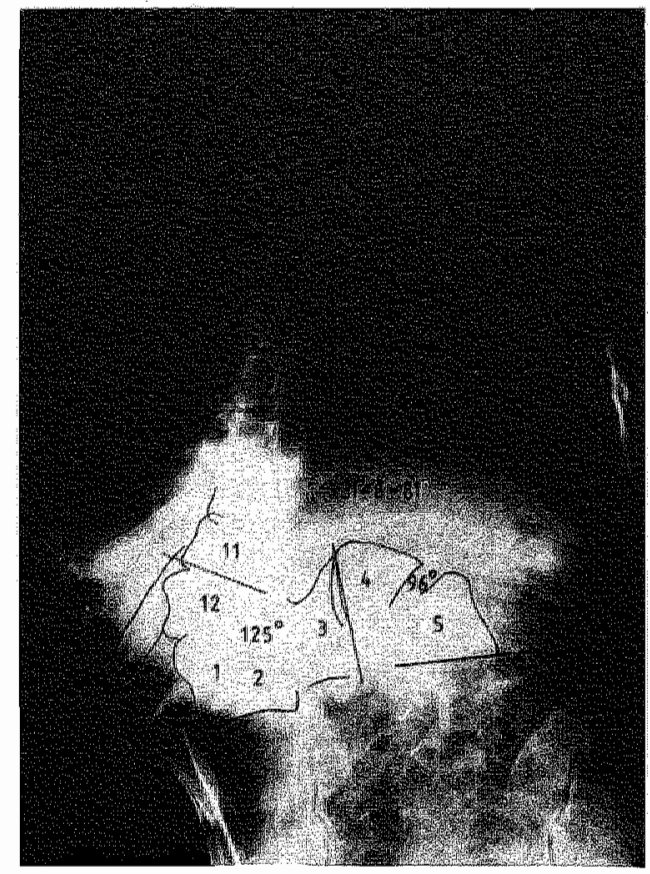

Scoliose préoperatief

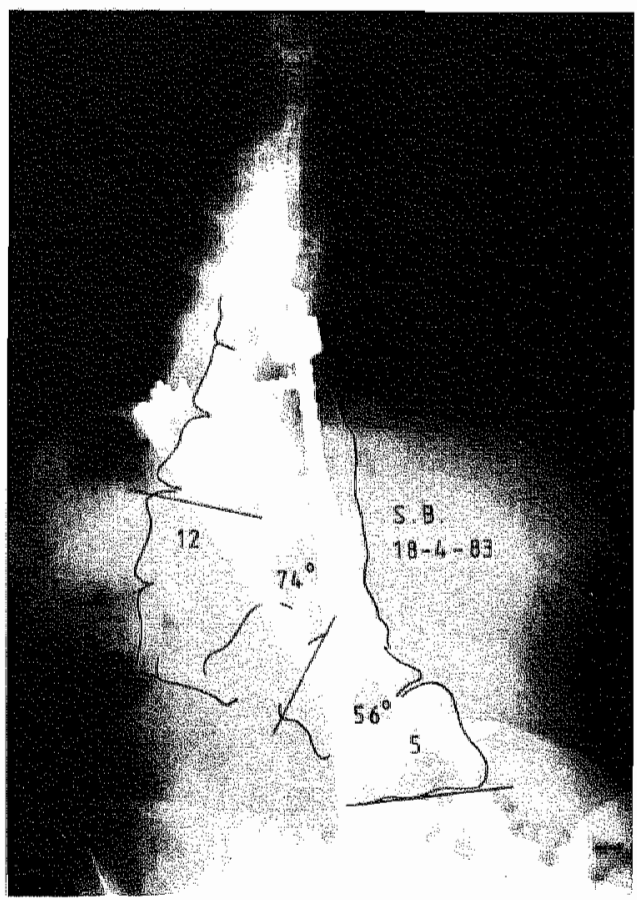

Scoliose 1 jaar postoperatief

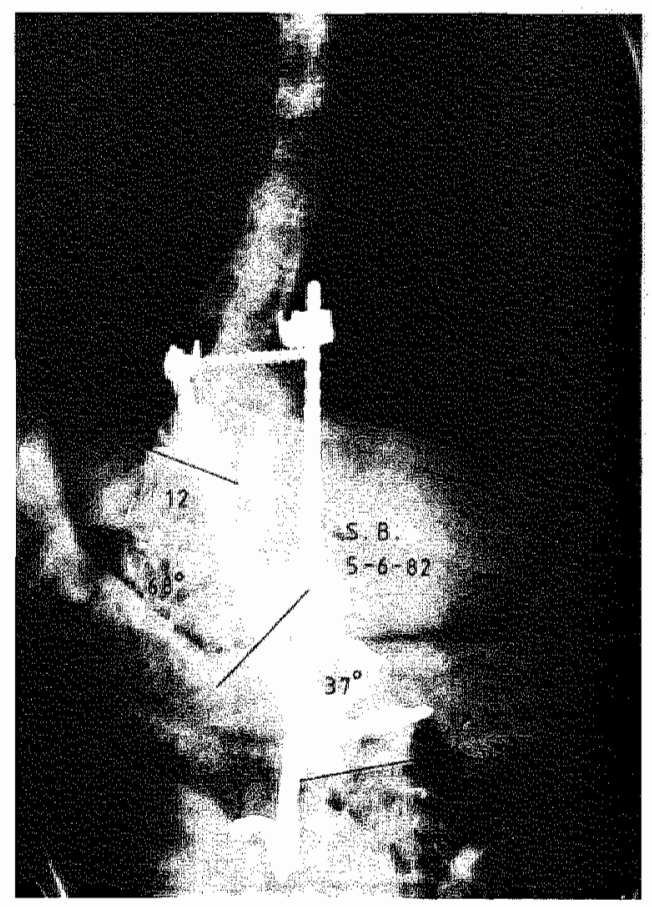

Scoliose na 2 operaties

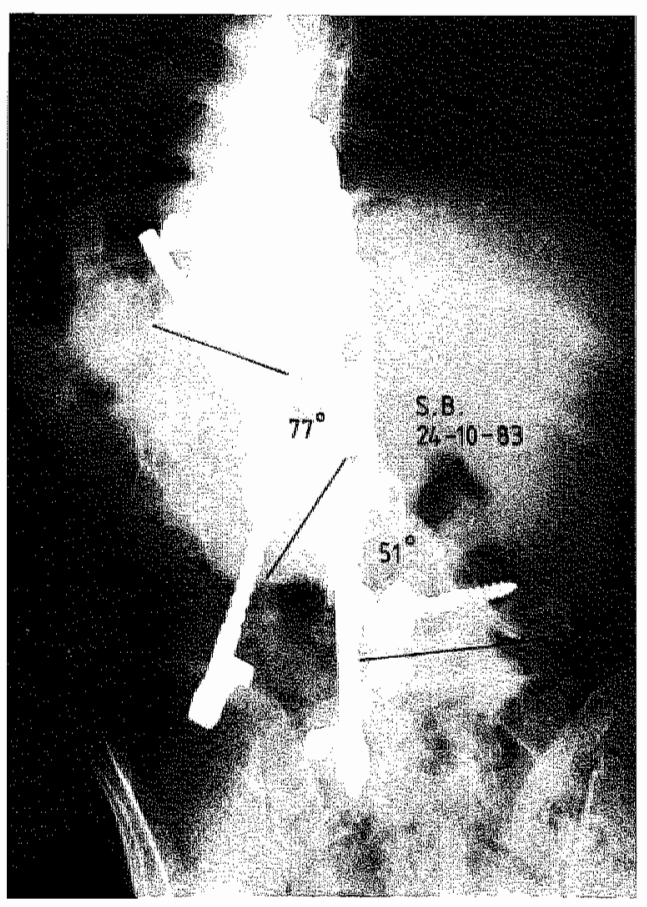

Scoliose na 3 operaties 


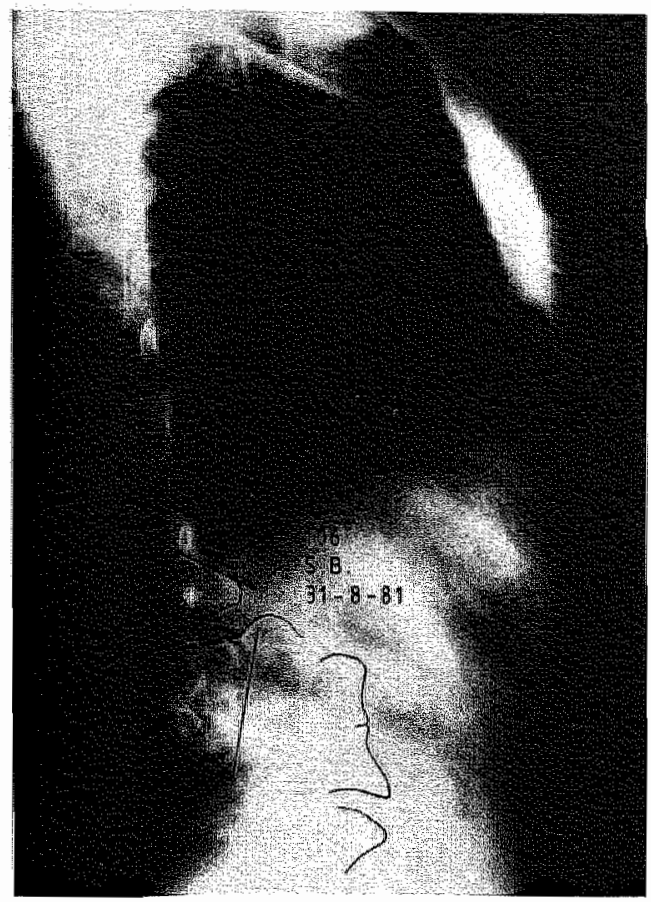

Kyfose préoperatief

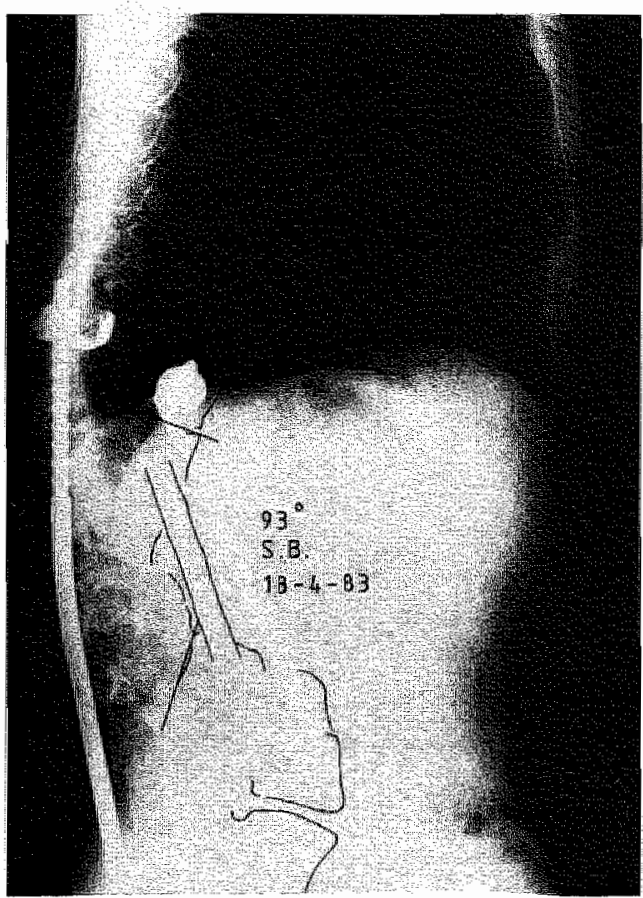

Kyfose 1 jaar postoperatief

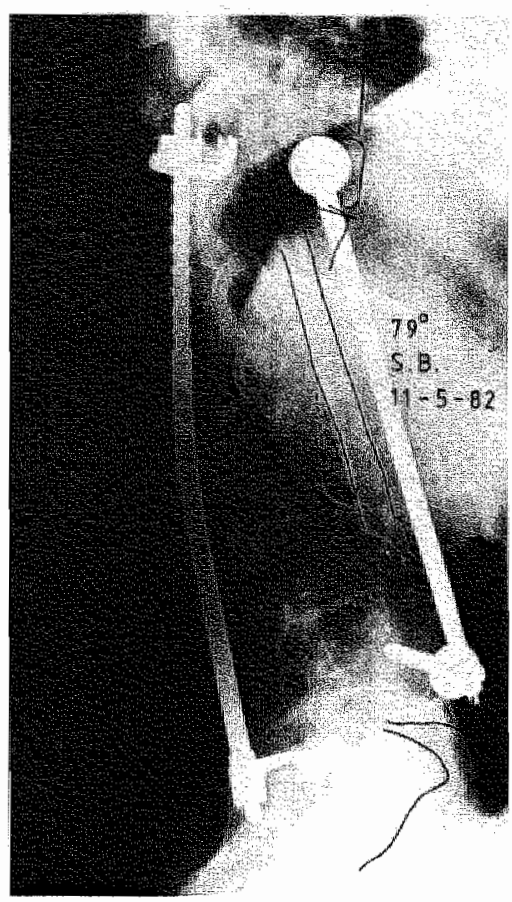

Kyfose postoperatief

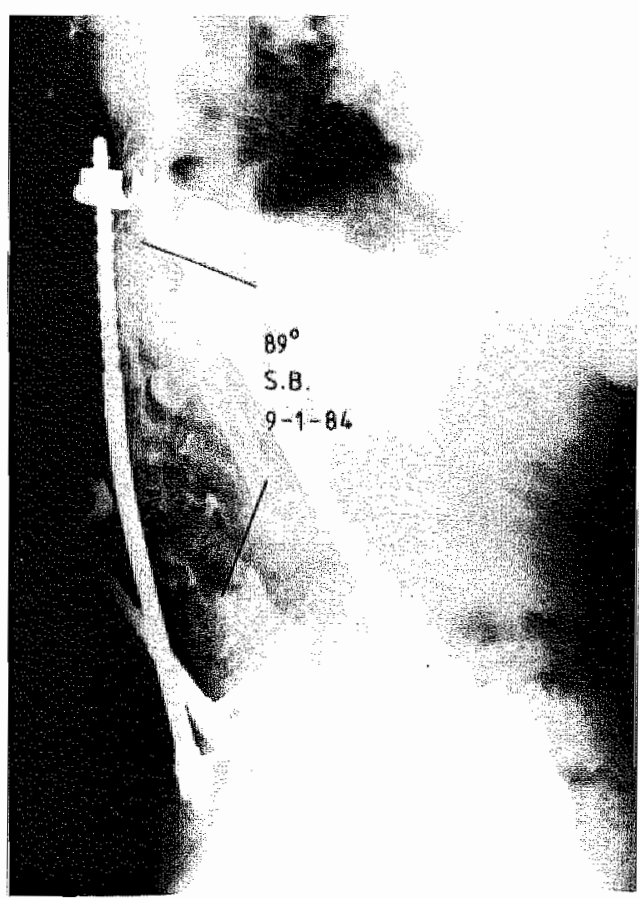

Kylose na 3 operaties 


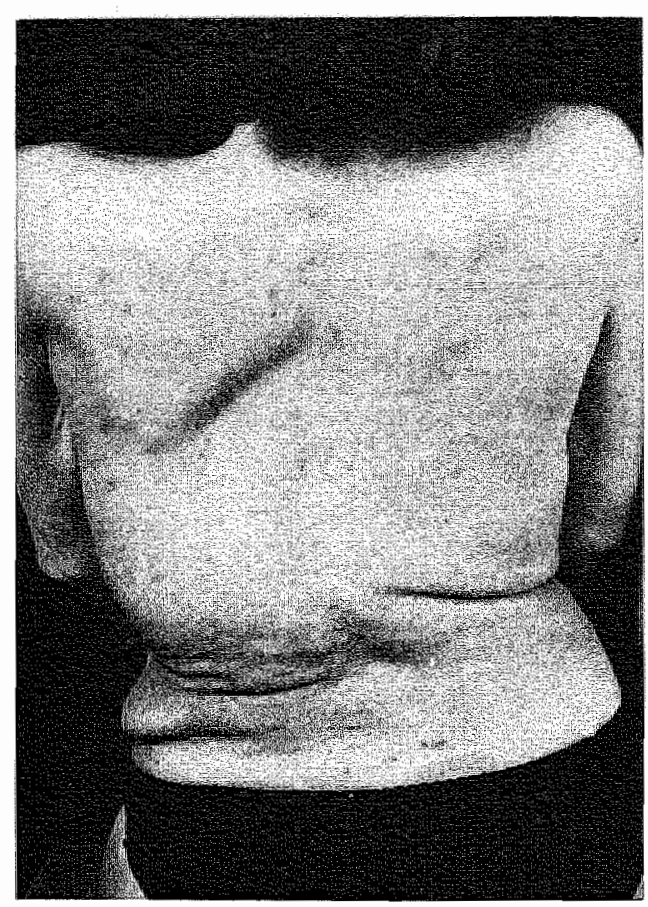

S.B. scoliose préoperatief

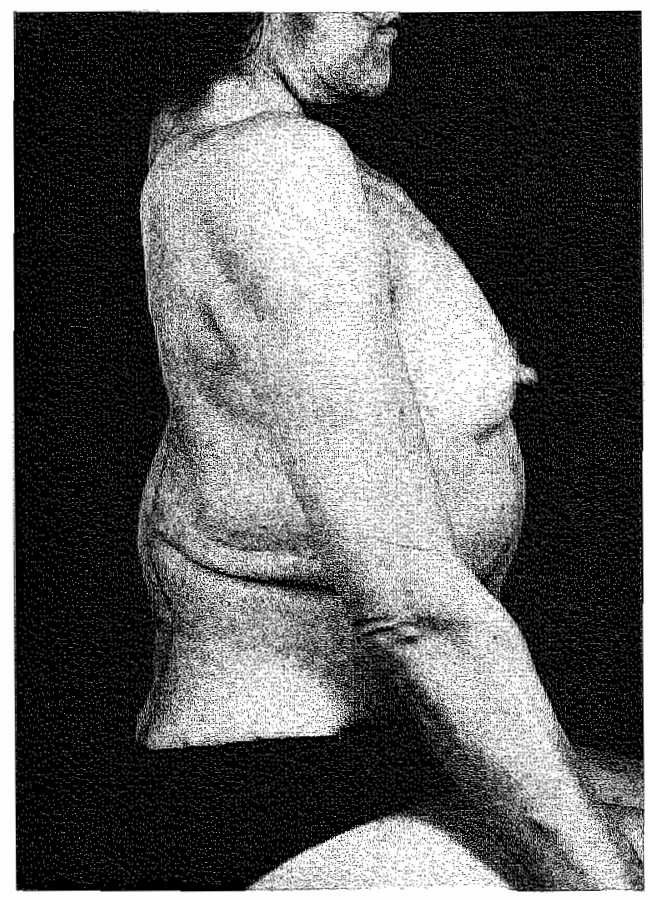

S.B. kyfose préoperatief

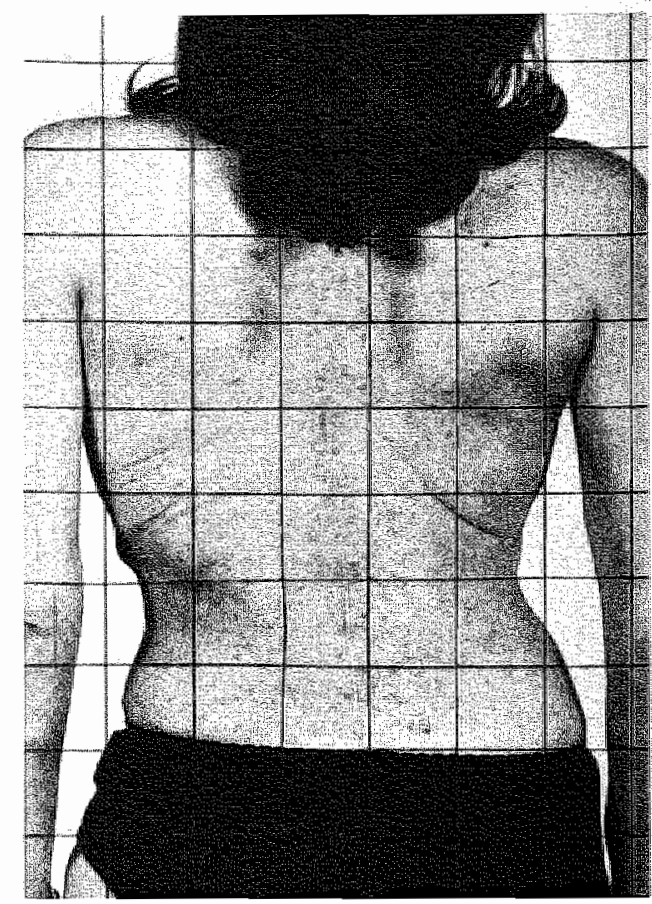

S.B. scoliose postoperatief

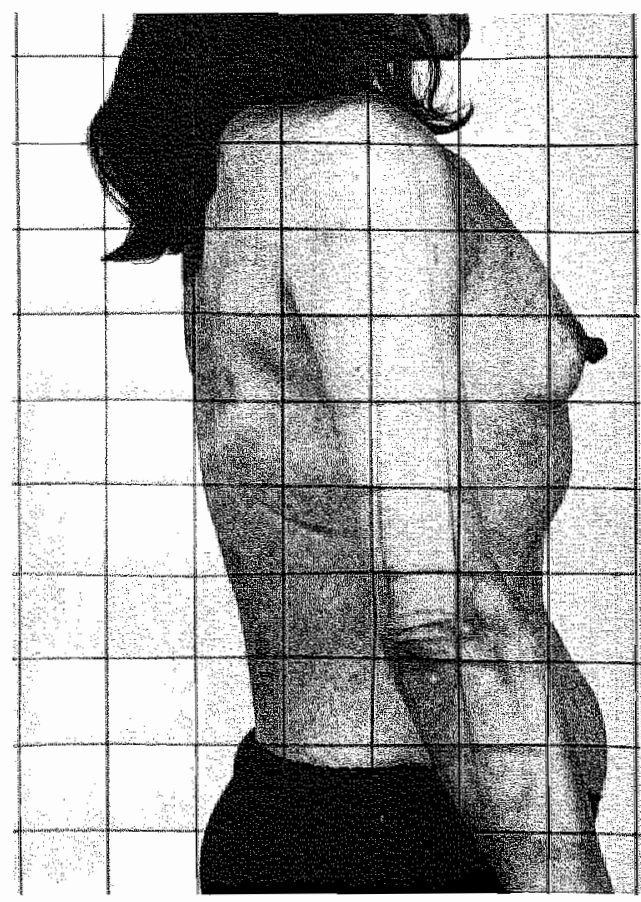

S.B. kytose postoperatief 
Patiènt 33. J.K. mannelijk, geb. dat. 17-10-1971.

Aetiologie:

Vroegere behandeling:

Voorbehandeling:

Operatie:

Complicaties:

Nabehandeling:

Postoperatieve curves:

Postoperatieve klachten:
Kyfoscoliose na laminectomie bij de neurofibromatose van Von Recklinghausen, familiair voorkomend.

In maart 1973 cervicale laminectomie C6-7-T1, met verwijderen van neurofibromen $\mathrm{C} 6-7$ wortels met doorsnijding van 2 achterwortels. In april 1973 verwijderen intrathoracaal neurofibroom met okseltoilet. Hierna parese van rechter arm en het syndroom van Horner rechts. In 1978 ontstond een spondyloptosis $\mathrm{C} 6$ ten opzichte van $\mathrm{C} 7$ met scoliose.

Halotractie tot $2 \frac{1}{2} \mathrm{~kg}$ gedurende 2 weken.

3-7-1978. Voorste spondylodese C6-7 met behulp van cristabot. Er werd enig weefsel gelijkend op neurofibroom ter plaatse aangetroffen, er bestond een forse instabiliteit.

Geen.

3 maanden Halo-rompgips.

Er ontwikkelde zich na de spondylodese een kyfoscoliose, met de apex op C7-T1. Dit werd behandeld met een Milwaukee brace en fysiotherapie. De scoliose was $\mathrm{T} 1 \mathrm{t} / \mathrm{m} \mathrm{T} 750^{\circ}$, kyfose $\mathrm{C} 7 \mathrm{t} / \mathrm{m} \mathrm{T} 590^{\circ}$ in december 1979. In mei 1981 was de scoliose $52^{\circ}$ en de kyfose praktisch gelijk. In mei 1983 was er geen progressie van de kyfoscoliose.

Er waren naast de afunctionele rechter arm geen klachten.

\section{Beschouwing en conclusie:}

Bij de neurofibromatose zal een laminectomie soms noodzakelijk zijn om neurofibromen van de zenuwwortels te verwijderen. Indien geen spondylodese bij de laminectomie wordt aangesloten treedt frequent kyfosering op, waardoor paraplegie kan optreden. Een spondylodese zal dan noodzakelijk zijn, in dit geval werd gekozen voor een voorste fusie op de plaats van de afglijding tussen C6 en C7. De laminectomie vond echter ook op het niveau C7-T1 plaats, zodat het niet verwonderlijk was dat op dit niveau kyfosering optrad. Deze blijkt met brace behandeling en fysiotherapie stabiel te zijn. zodat hernieuwde operatie vooralsnog niet nodig blijkt. 


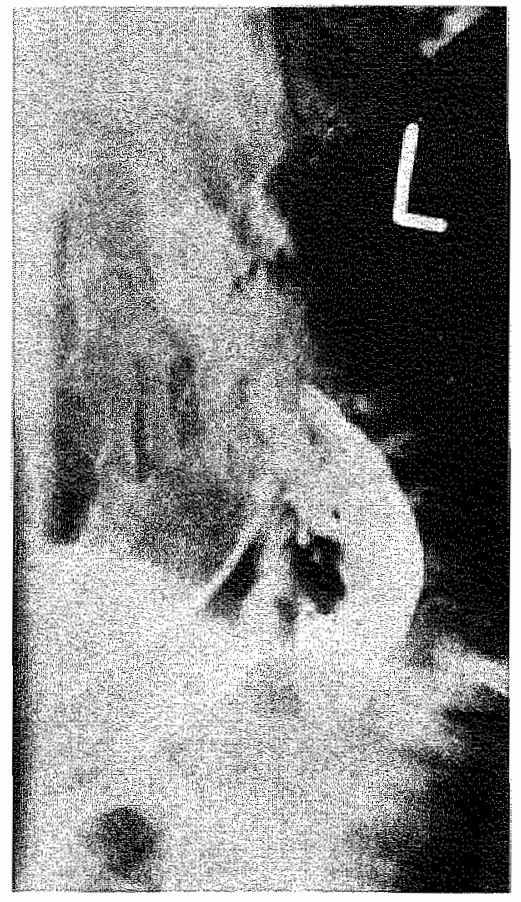

Neurofibroom t.h.v. C6-7

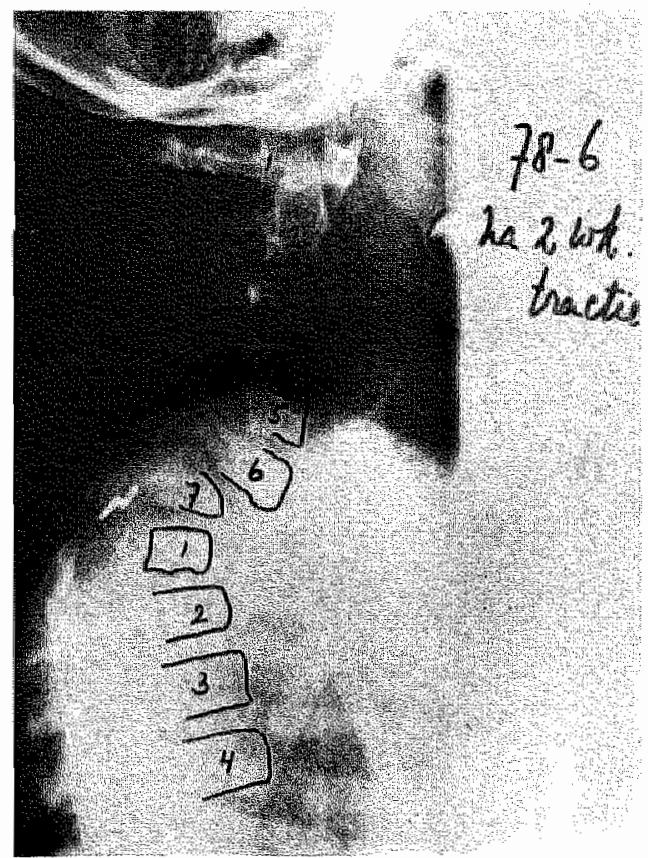

Spondyloptosis C6 t.o.v. C7 2 weken na halotractie

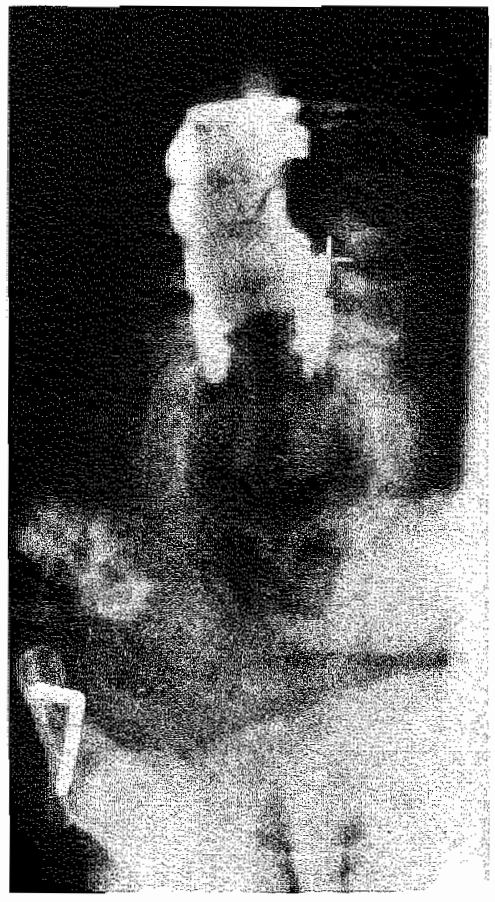

AP. opname myelografie met uitsparing t.p.v. C6-7

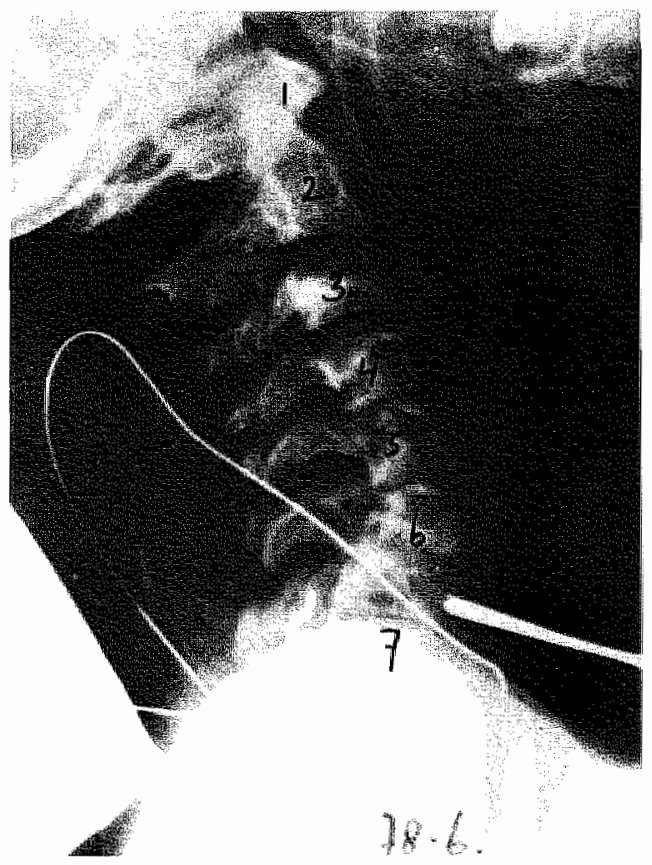

Cervicale spondylodese $\mathrm{C} 6-7$ met volledige repositie 


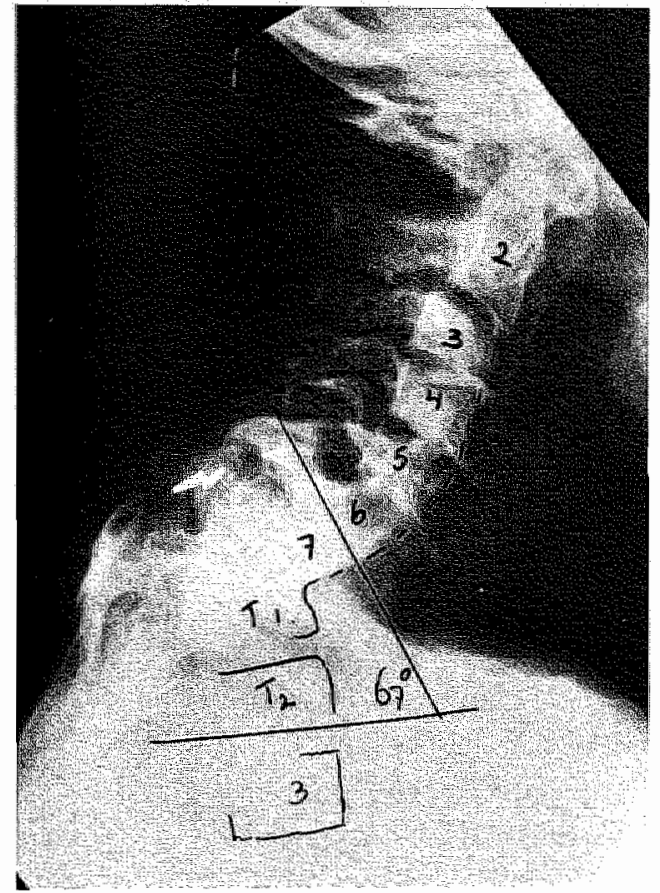

Progressieve kyfosering C7-T2 $67^{\circ}$

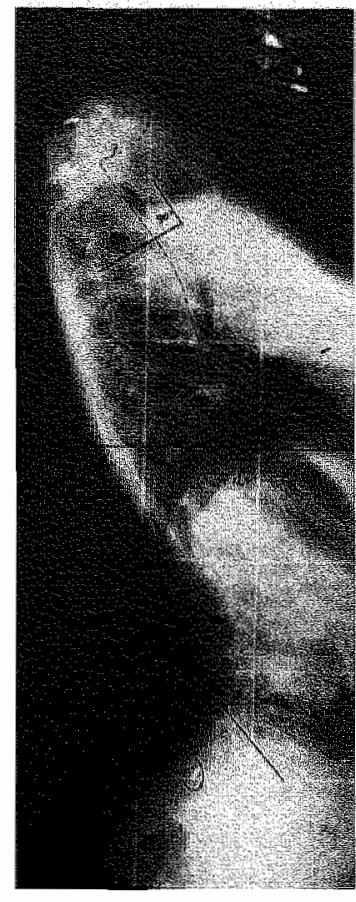

Kyfosering $90^{\circ}$ in 1979

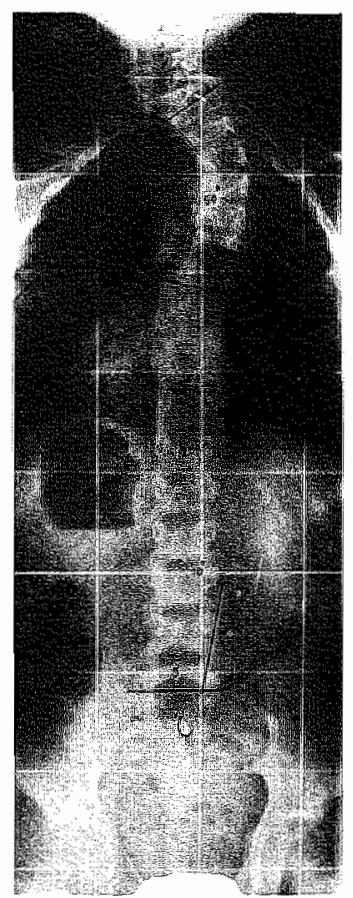

Scoliose $50^{\circ}$ onder de kyfose in 1979 
Patiënt 34. J.E. vrouwelijk, geb. dat. 21-3-1924.

Aetiologie:

Vroegere behandeling:
Kyfoscoliose bij de neurofibromatose van Von Recklinghausen met volledige dwarslaesie.

Op 3-jarige leeftijd toenemende scoliose. Op 6-en 7-jarige leeftijd heeft patiente een behandeling met gipsschelp gehad. Hierna droeg ze 3 corsetten. Op 14-jarige leeftijd ontstonden dwarslaesieverschijnselen, op 15-jarige leeftijd was ze totaal verlamd vanaf het midthoracale niveau.

Sinds die tijd is ze incontinent voor faeces en urine, met frequent urineweginfecties. Ze heeft geen pijnklachten, beweegt zich vlot voort in een rolstoel en kan normale hoeveelheden voedsel tot zich nemen. De intelligentie is normaal.

Beschouwing en conclusie:

Deze patiënte illustreert wat er kan gebeuren indien de wervelkolom niet gestabiliseerd kan worden bij een maligne curve bij de ziekte van Von Recklinghausen. Er kan een alfa kyfoscoliose optreden welke meer dan $180^{\circ}$ bedraagt. Volledige dwarslaesie is hiervan het gevolg. Tot elke prijs moet getracht worden deze ontwikkeling te voorkomen, ook al kan dit soms vele operaties betekenen. 


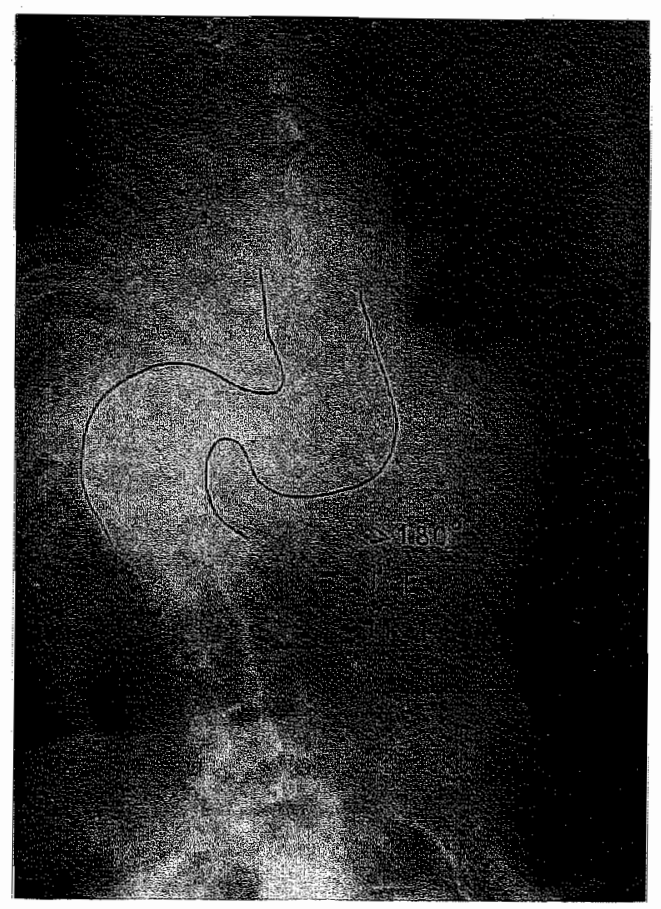

Scoliose meer dan $180^{\circ}$

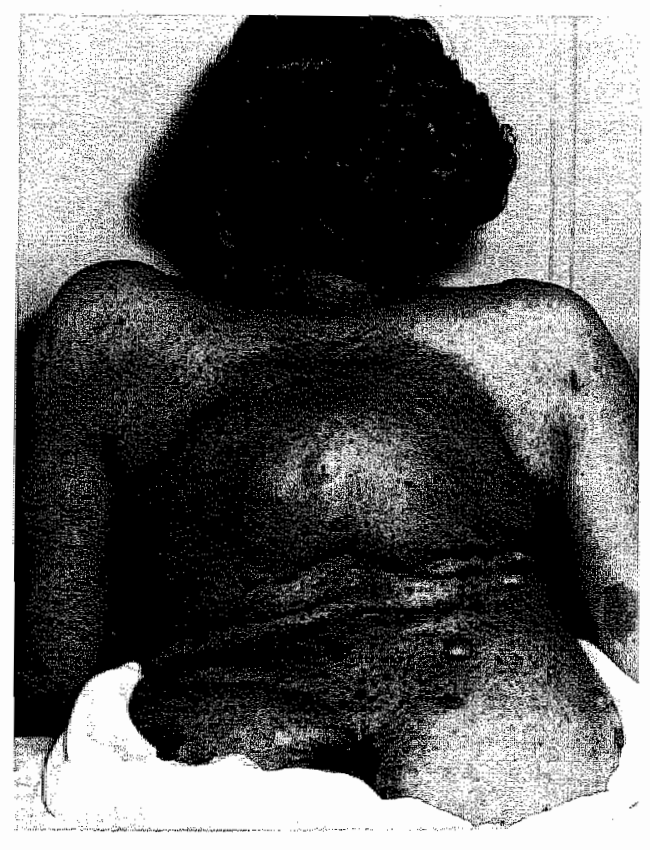

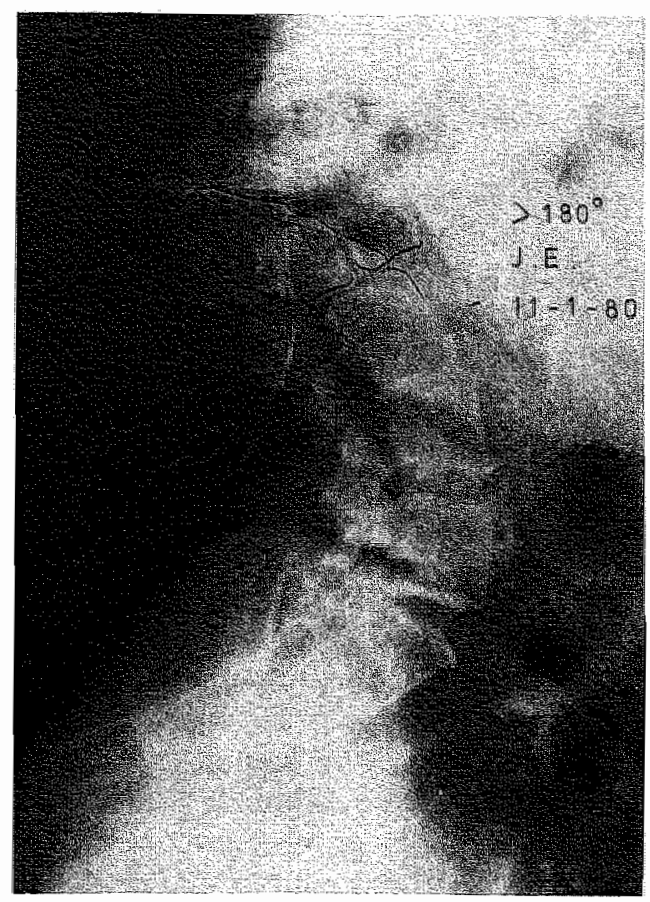

Kyfose meer dan $180^{\circ}$

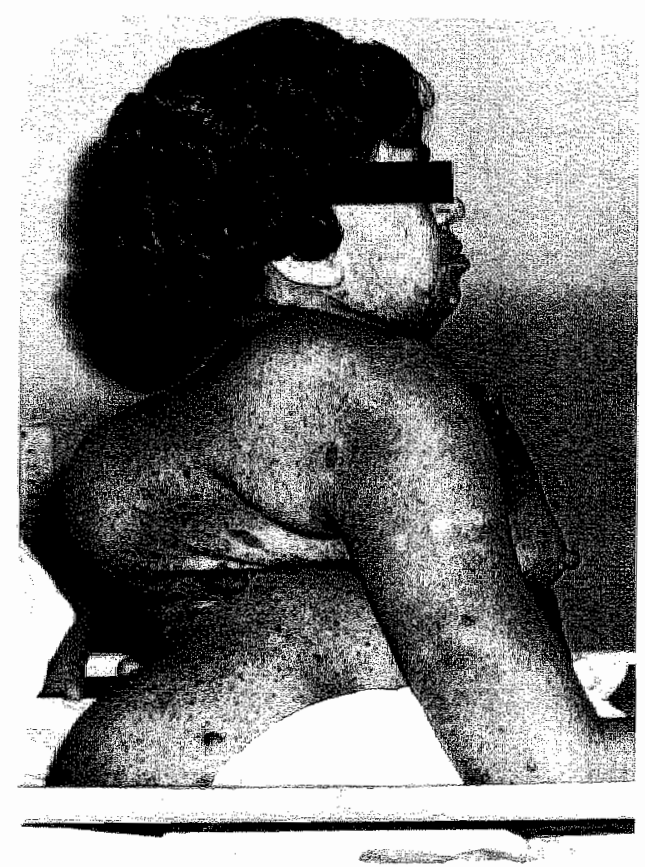

J. E. klinisch beeld van een alfa kyfoscoliose bij de ziekte van Von Recklinghausen 


\section{POTTSE KYFOSEN}

\subsection{Inleiding}

De spondylitis tuberculosa is in Nederland welhaast vergeten, maar komt toch nog geregeld voor, waarbij vertraagde diagnosestelling door onbekendheid met het ziektebeeld niet zeldzaam is. De moderne behandeling van de tuberculeuze spondylitis is dan ook vooral bekend door artikelen uit het verre Oosten en Afrika, met name Hongkong, Korea en Rhodesië $(3,8,12,15,16,17,19,23,24,25,26,27,28,36)$.

De spondylitis ontstaat waarschijnlijk doordat de tuberkelbacil vanuit andere foci, zoals de longen of de nier via de Batsonse venenplexus de wervel bereikt. De Batsonse plexus is een belangrijke bypass voor de afvoer van het veneuze bloed van de benen, pelvis en abdomen als de vena cava inferior wordt dichtgedrukt bij hoesten, niezen, zwaar tillen of de Valsalva manoeuvre (4).

Er treedt een spondylitis op met destructie van botweefsel, waarbij de avasculaire discus grotendeels gespaard blijft, maar wel gesequestreerd wordt. Kenmerkend is het ontstaan van een paraspinaal meestal spoelvormig absces met oplichting van het periost, waardoor de ziekte zich naar onder en naar boven kan uitbreiden $(3,5,15,18,29$, 32). Als het absces in contact komt mett de dura mater kan zich een pachymeningitis ontwikkelen. Zelfs aantasting van het myelum door het tuberculeuze proces is beschreven $(18,36)$. Ook door druk van het absces op het myelum kan paraplegie ontstaan. Tijdens de genezingsfase wordt de abscesinhoud pasteuzer en verandert in fibreus en gedeeltelijk gecalcificeerd weefsel. De wervelkolom collabeert door destructie van de wervellichamen in kyfose. Bij onbehandelde patiënten kunnen deze kyfosen groteske vormen aannemen en treden neurologische symptomen door myelumcompressie niet zelden op $(1,5,9,11,34,36)$. Ook als het proces rustig is kan kyfosering progressief zijn, vooral bij het kind, waarbij de achterstructuren doorgroeien, terwijl de groei aan de voorzijde gestoord is $(12,31)$.

Op volwassen leeftijd kan de kyfose eveneens verergeren, zij het veel langzamer, door doorzakken van de wervelkolom onder en boven de eigenlijke rigide kyfos, waarbij het myelum over de kyfos wordt uitgespannen en tekenen van compressie kan gaan vertonen. Ook langdurig bestaande ischaemie van het myelum zou kunnen bijdragen aan het ontstaan van een late paraplegie $(5,34,36)$.

Mechanische rugklachten ten gevolge van de compensatoire lordose en cosmetische bezwaren spelen een rol bij de indicatiestelling tot behandeling.

\subsection{Behandeling}

Het doel van de behandeling bij de spondylitis tuberculosa is het verkrijgen van een stabiele wervelkolom met de minste kans op paraplegie. Dit houdt ook in dat kyfosering zoveel mogelijk voorkomen moet worden of indien al aanwezig zoveel mogelijk gecorrigeerd moet worden omdat dit een reëel gevaar inhoudt voor het myelum.

Bij verse tuberculeuze spondylitiden bestond vroeger de behandeling uit bedrust, frisse lucht en zonneschijn. Daartoe werden de patiënten langdurig opgenomen in sanatoria. Met de ontdekking van de tuberculostatica nam de genezingskans toe, deze nam echter soms wel enkele jaren in beslag, terwijl de wervelkolom practisch altijd kyfotisch werd. $\mathrm{Om}$ snellere genezing te krijgen kan het proces via een costotransversectomie geëx- 
cochleëerd worden, al of niet gecombineerd met voorste of achterste fusie $6,9,11,25$. $26,33,35$ ). Een strutgrafting met zo mogelijk oprichten van de kyfose is via deze techniek niet mogelijk, daarvoor moet, zoals Hodgson aangaf, een voorste toegang worden gebruikt, waarbij het absces met al het necrotische bot en discusmateriaal verwijderd moet worden. Er moeten bloedende, gezonde botoppervlaktes geformeerd worden, waarna strutgrafting met rib-, fibula- of cristabot kan worden verricht, eén en ander onder een paraplu van tuberculostatica. Met de antibacteriële therapie wordt 3 weken préoperatief begonnen en gewoonlijk een jaar postoperatief doorgegaan. Kyfosering kan op deze wijze tot een minimum worden beperkt $(1,3,8,10,11,15,16,17,19,20$. $28,29,30,31,36$ ). Andere methoden zoals de ambulante therapie met alleen tuberculostatica en de drainage van het absces via een costotransversectomie werden met deze uitgebreide operatie vergeleken. Er bleek een duidelijke gunstige uitkomst te zijn wat betreft de stabiliteit van de kyfose en de kans op paraplegie bij de via de voorzijde geopereerde groep met gebruikmaking van bottransplantaten $(23,24,25,26,27,28)$.

Bij beginnende tuberculose van de wervelkolom met geringe destructie en weinig kyfose kan volstaan worden met tuberculostatica gedurende 1 à $1 \frac{1 / 2}{j a a r}(21,22,23,24)$. Bij aantasting van meerdere wervellichamen en ernstiger kyfose lijkt operatie de betere keus. Bij paraplegie in de acute fase is directe decompressie geindiceerd, ook dit kan het beste via de voorzijde geschieden, waarbij tegelijkertijd een fusie kan worden nagestreefd. De kans op herstel van de paraplegie is groot als deze het gevolg is van druk van het absces alleen. Als er tuberculeuze ontsteking van de meningen of zelfs ontsteking van het myelum zelf bestaat is de kans op herstel veel kleiner $(11,17,18)$.

Bij verouderde Pottse kyfosen is het moeilijk correctie te verkrijgen. De kyfose is meestal zeer rigide door fusie van wervellichamen. Preoperatieve tractie geeft dan meestall weinig resultaat en kan aanwezige neurologische symptomen verergeren, reden waarom nauwkeurige neurologische controle tijdens tractie nodig is.

Een voorste ingreep, waarbij discusresten worden verwijderd en waarbij soms een osteotomie van het gefuseerde gedeelte moet worden gedaan alvorens correctie te verkrijgen, is aangewezen. Stabilisatie geschiedt door strutgrafting, eventueel met interne fixatie. Soms is het beter in $2 \mathrm{e}$ instantie een achterste compressicspondylodese toe te voegen om optimale correctie en stabilisatie te verkrijgen $(15,19,31,36)$.

Bij myelumcompressie zal men moeten kiezen tussen een decompressie van het myelum of een correctie in de kyfose, waarbij door strekking de compressie verminderd wordt (zie het hoofdstuk over congenitale kyfosen). Meestal is de myelumcompressie het gevolg van directe druk, soms kan echter door vroegere meningitis en fibrosis vernauwing van dura en myelum zelf ontstaan zijn, zodat ter plaatse het myelum geïnspecteerd zal moeten worden. Yau e.a. (36) uit Hongkong vinden ondanks hun grote ervaring op dit gebied de voorste decompressie nog steeds gevaarlijk, maar soms zal dit toch nodig zijn om herstel van de paraplegie te verkrijgen. Met name geldt dit als de kyfose sterk rigide is, zodat correctie nauwellijks tot de mogelijkheden behoort.

In Hongkong wordt het volgende gefaseerde schema gehanteerd bij verouderde Pottse kyfosen.

1. Préoperatieve beoordeling met tomografie en neurologisch onderzoek en myelografie, longfunctie en I.V.P.

2. Aanbrengen van het Halo-Pelvic apparaat (zonder distraheren).

3. Voorste osteotomie eventueel met decompressie van het myelum.

4. Spinale distractie.

5. Achnterste osteotomie (vaak is er een spontane achterste fusie). Soms moeten meerdere osteotomieën worden verricht. Een spondylodese wordt soms toegevoegd, is 
echter gevaarlijk omdat de wervelkolom na de voorste en achterste osteotomie volledig doorgenomen is en elke stabiliteit mist, zodat elke klap met guts of beitel direkt op het myelum inwerkt, ondanks het Halo-Pelvic apparaat.

6. Spinale distractie.

7. Voorste spinale fusie met behulp van strutgrafts met maximale correctie.

8. Achterste fusic indien nodig.

9. Postoperatieve immobilisatie in het Halo-Pelvic apparaat en gipscorsetten gedurende 12 maanden.

Deze uitgebreide behandeling van de verouderde Pottse kyfose, zoals deze in Hongkong plaatswindt, wordt beschreven om te illustreren hoe moeilijk het is om deze kyfosen te corrigeren. Zelfs met deze procedure bleken de correcties slechts gemiddeld 20$30 \%$ te zijn. Het lijkt dan ook voor de hand te liggen de eenvoudiger procedure te kiezen, waardoor het risico op complicaties geringer is en de mate van correctie toch bevredigend kan zijn.

\subsection{Literatuur hoofdstuk 7}

1. Ahn B. H. Treatment for Pott's paraplegia. Acta Orthop. Scand. 39, 1968, 145160 .

2. Arct W. Operative treatment of tuberculosis of the spine in old people. Journ. of Bone and Joint Surg. 50A, 1968, 255-267.

3. Bailey H. L. Gabriel M. Hodgson A. R. Shin J. S. Tuberculosis of the spine in children. Journ. of Bone and Joint Surg. 54A, 1972, 1633-1657.

4. Batson O.V. The vertebral vein system. Caldwell Lecture 1956. Am. Journ. of Roentgen. 78, 1957, 195-212.

5. Butler R. W. Paraplegia in Pott's disease with special reference to the pathology and etiology. Brit. Journ. of Surg. 22, 1935, 738-768.

6. Capener N, The evolution of lateral rachotomy. Journ. of Bone and Joint Surg. $36 \mathrm{~B}, 1954,173-178$.

7. Cauchoix J. Tersen G. Callilar N. Abord direct dans le mal de Pott lombaire. Rev. de Chir. Orthop. 43, 1957, 305-3110.

8. Chu C. B. Treatment of spinal tuberculosis in Korea. Using focal débridement and interbody fusion. Clin. Orthop. 50, 1967, 235-253.

9. Dott N. M. Skeletal traction and anterior decompression in the management of Pott's paraplegia. Edinburgh Medic. Journ. 54, 1947, 620-627.

10. Editorial. Tuberculosis of the spine. Brit. Medic. Journ. 4, 1974, 613-614.

11. Felländer M. Paraplegia in spondylitis: results of operative treatment. Paraplegia $13,1975,75-88$. 
12. Fountain S. S. Hsu L. C. S. Yau A. C. M. C. Hodgson A. R. Progressive kyphosis following solid anterior spine fusion in children with tuberculosis of the spine. Journ. of Bone and Joint Surg. 57 A, 1975, 1104-1107.

13. Hallock H. Francis K. C. Jones J. B. Spine fusion in young children. A long-term end-result study with particular reference to growth effects. Journ. of Bone and Joint Surg. 39A, 1957, 481-491.

14. Hibbs R. A. An operation for progressive spinal deformities. A preliminary report of three cases from the service of the Orthopaedic Hospital. New York Med. Journ. 93, 1911, 1013 .

15. Hodgson A. R. Stock F. E. Anterior spinal fusion. A preliminary communication on the radical treatment of Pott's disease and Pott's paraplegia. Brit. Journ. of Surg. $44,1956,266-275$.

16. Hodgson A. R. Stock F. E. Anterior spine fusion for the treatment of tuberculosis of the spine. The operative findings and results of treatment in the first one hundred cases. Journ. of Bone and Joint Surg. 42A, 1960, 295-310.

17. Hodgson A. R. Stock F. E. Fang H. S. Y. Ong G. B. Anterior spinal fusion. The operative approach and pathological findings in 412 patients with Pott's disease of the spine. Brit. Journ. of Surg. 48, 1960, 172-178.

18. Hodgson A. R. Skinsnes O. K. Leong C. Y. The pathogenesis of Pott's paraplegia. Journ. of Bone and Joint Surg. 49A, 1967, 1147-1156.

19. Hodgson A. R. Yau A. C. M. C. Management of spinal deformity. Recent advances in orthopedics. Churchill Livingstone. 2, 1975, 76-92.

20. Ito H. Tsuchiya J. Asami G. A new radical operation for Pott's disease. Report of ten cases. Journ. of Bone and Joint Surg. 16, 1934, 499-515.

21. Konstam P. G. Blesovsky A. The ambulant treatment of spinal tuberculosis. Brit. Journ. of Surg. 50, 1962, 26-38.

22. Konstam P. G. Konstam S. T. Spinal tuberculosis in Southern Nigeria. With special reference to ambulant treatment of thoraco-lumbar disease. Journ. of Bone and Joint Surg. 40B, 1958, 26-32.

23. Medical research council working party on tuberculosis of the spine. First report. A controlled trial of ambulant out-patient treatment and in-patient rest in bed in the management of tuberculosis of the spine in young Korean patients on standard chemotherapy. A study in Masan, Korea. Journ. of Bone and Joint Surg. 55B. 1973. 678-697.

24. Medical research council. Second report. A controlled trial of Plaster-of-Paris jackets in the management of ambulant outpatient treatment of tuberculosis of the spine in children on standard chemotherapy: A study in Pusan, Korea. Tubercle 54, $1973,261-282$. 
25. Medical research council. Third report. A controlled trial of débridement and ambulatory treatment in the management of tuberculosis of the spine in patients on standard chemotherapy. A study in Bulawayo Rhodesia. Tropical Medicine and Hygiene 77, 1974, 72-92.

26. Medical research council. Fourth report. A controlled trial of anterior spinal fusion and débridement in the surgical management of tuberculosis of the spine in patients on standard chemotherapy. A study in Hongkong. Brit. Journ. of Surg. 61. 1974, 853-866.

27. Medical research council. Fifth report. A five-year assessment of controlled trials of in-patient and out-patient treatment and of Plaster-of-Paris jackets for tuberculosis of the spine in children on standard chemotherapy. Studies in Masan and Pusan Korea. Journ. of Bone and Joint Surg. 58B, 1976, 399-411.

28. Medical research council. Eighth report. A 10-year assessment of a controlled trial comparing débridement and anterior spinal fusion in the management of tuberculosis of the spine in patients on standard chemotherapy in Hongkong. Journ. of Bone and Joint Surg. 64B, 1982, 393-398.

29. Moula T. Fowles J. V. Kassab M. T. Sliman N. Pott's paraplegia. A clinical review of operative and conservative treatment in 63 adults and children. Intern. Orthop. $5,1981,23-29$.

30. Müller W. Transperitoneale Freilegung der Wirbelsäule bei tuberkulöser Spondylitis. Deutsche Zeitschrift für Chirurgie 85, 1906, 128-135.

31. O'Brien J. P. Kyphosis secondary to infectious disease. Clin. Orthop. 128, 1977. 56-64.

32. Pott P. Remarks on that kind of palsy of the lower limbs, which is frequently found to accompany a curvature of the spine and is supposed to be caused by it. London, Miscellanea Medica V. 1779.

33. Risko T. Novoszel T. Experiences with radical operations in tuberculosis of the spine. Journ. of Bone and Joint Surg. 45A. 1963, 53-68.

34. Seddon H. J. Pott's paraplegia: Prognosis and treatment. Brit. Journ. of Surg. 22, 1935, 769-799.

35. Wilkinson M. C. The treatment of tuberculosis of the spine by evacuation of the paravertebral abscess and curettage of the vertebral bodies. Journ. of Bone and Joint Surg. 37B, 1955, 382-391.

36. Yau A. C. M. C. Hsu L. C. S. O'Brien J. P. Hodgson A. R. Tuberculous kyphosis. Correction with spinal osteotomy. Halo-pelvic distraction, and anterior and posterior fusion. Journ. of Bone and Joint Surg. 56A, 1974, 1419-1434. 


\subsection{Patiëntenbeschrijvingen bij Potrse kyfosen}

Patiënt 35. C.V. vrouwelijk, geb. dat. 26-7-1957.

Aetiologie:

Vroegere behandeling:

Klachten:

Préoperatieve curves:

Voorbehandeling:

Longfunctie:

Neurologisch onderzoek:

Myelografie:

CT scan:

Operatie:
Spondylitis tuberculosa T4-5-6.

Sinds 9 maanden onder behandeling van de longarts in verband met een pleuritis zonder duidelijke oorzaak met hoogstand rechter diafragma, met spontane verbetering. Mantoux bij herhaling negatief, BSE normaal. Later pijnklachten thoracaal met toenemende prominentie processus spinosus T4. BSE nu $10 \mathrm{~mm}$. Mantoux $6 \mathrm{~mm}$.

Pijn ter plaatse van prominentie T4-5 en laag thoracaal. Algemene malaise. Verergering van de pijn bij lachen, lopen en hoesten.

Kyfose T4-5-6 $45^{\circ}$ met practisch volledige destructie van wervellichaam $\mathrm{T} 5$ en gedeeltelijke destructie T6. Op AP planigram uitgebreid spoelvorming absces.

Punctie van het absces op 16-3-1983. Evacuatie van $20 \mathrm{cc}$. pus onder grote spanning. Ziehl-Neelsen negatief. Positieve Löwensteinkweek voor mycobacterium tuberculosis. Starten van tuberculostatica I.N.H., myambutol, rifampicine en pyridoxine op 19-3-1983.

Niet verricht.

Geen neurologische afwijkingen, met name geen aanwijzingen voor meningitis of ruggemergscompressie. De locale pijn bij lachen en lopen moet door locale drukverandering veroorzaakt worden.

Niet verricht.

19-4-1983. Ernstige destructie T5 en T6 met matig groot restabsces rondom.

20-4-1983. Thoracotomie 5e rib rechts. Uitruimen absces en verwijderen fragmenten T5 en T6 tot in het gezonde bot. Spondylodese T4-5-6 met cristaspaan met manuele correctie kyfose. Wake-up test na inbrengen cristaspaan. Opvullen cristadefect met ribspaan. 
Complicaties:

Nabehandeling:

Postoperatieve curves:

Postoperatieve klachten:

\section{Geen.}

Halo-rompgips 3 maanden, gipscorset 3 maanden. Mobilisatie 2 weken postoperatief.

$\begin{array}{lc} & \text { Kyfose } \\ \text { Postoperatief } & 25^{\circ} \\ \text { Na 3 maanden } & 34^{\circ} \\ \text { Na } 6 \text { maanden } & 32^{\circ} \\ \text { Klinisch en röntgenologisch consollidatie. }\end{array}$

Geen. Patiënte voelt zich herboren na zich enkele jaren slecht te hebben gevoeld. De wervelkolom en de crista zijn pijnloos.

Beschouwing en conclusie:

Het nu zeldzame beeld van de spondylitis tuberculosa houdt meestal een destructie van enkele wervellichamen in. Bij beginnende destructie kan met tuberculostatica alleen worden volstaan. Bij ernstiger destructie en kyfosering, soms met myelumcompressie, lijkt operatieve uitruiming en zo mogelijk correctie van de kyfose de beste behandeling. Dit kan het beste geschieden via een voorste benadering. Bij costo-transversectomie ontstaat een meestal onvoldoende operatieveld om alle sequesters en debris te verwijderen, terwijl ook een oprichting van de kyfose met een solide spaan onmogelijk is. Bovendien is de botgenezing bij voorste strutgraftspondylodese sneller en beter dan na alleen uitruiming van het absces via costotransversectomie. 


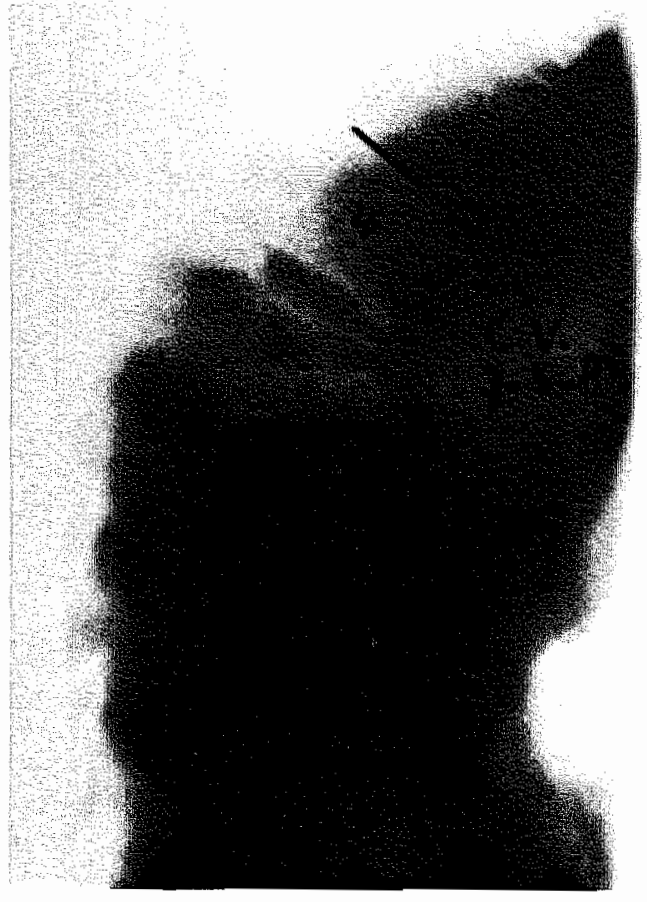

Préoperatieve kyfose

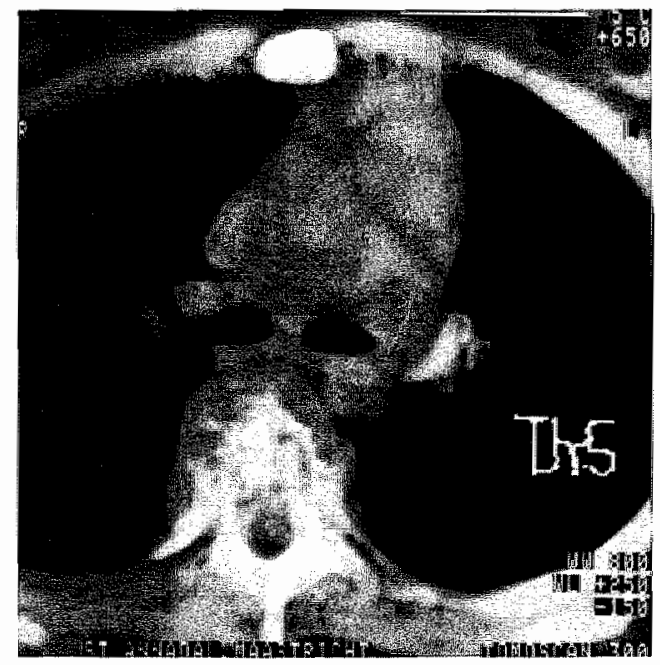

CT Scan préoperatief

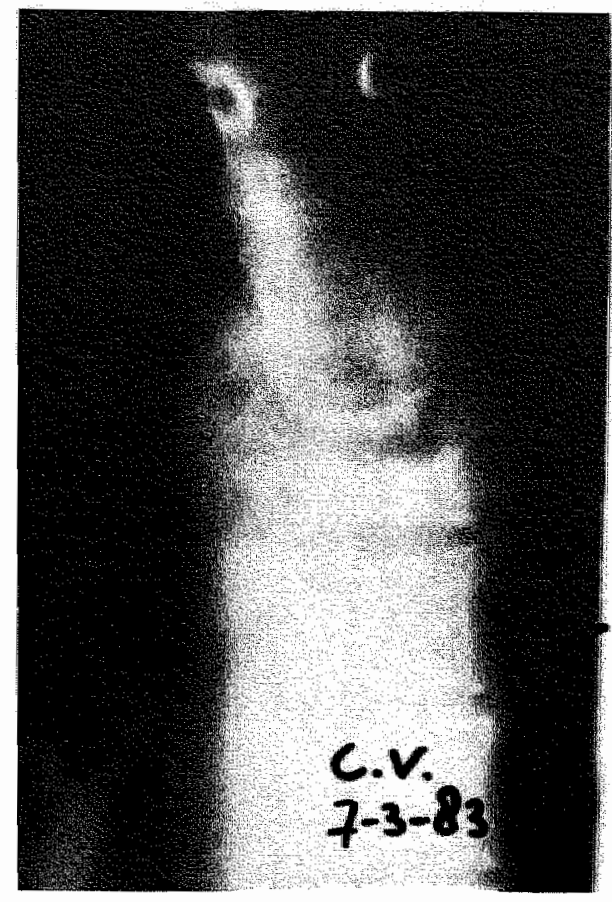

Spoelvormig absces

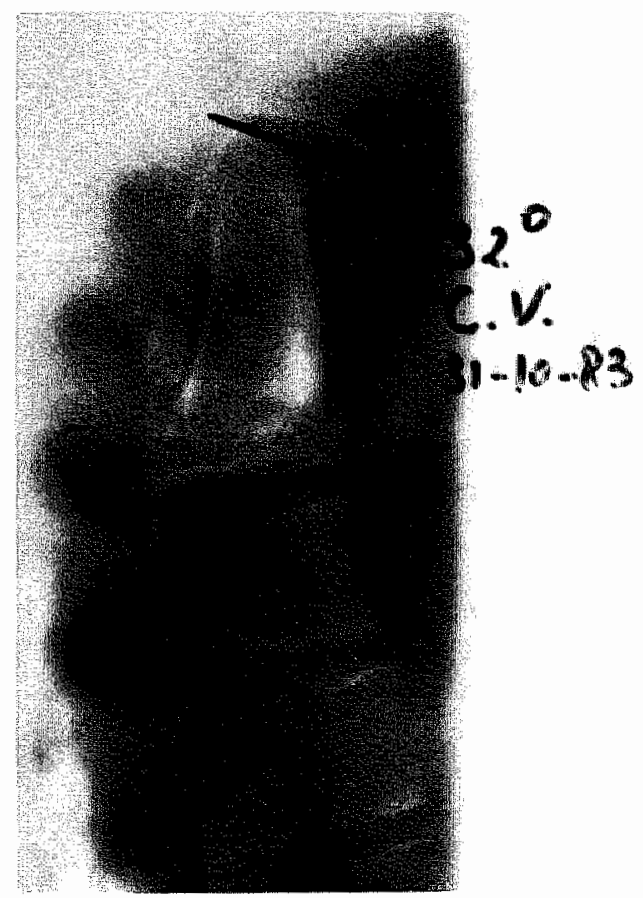

Postoperatieve kyfose 
Patiènt 36. N.Z. vrouwelijk, geb. dat. 14-11-61.

Aetiologie:

Vroegere behandeling:

Klachten:

Préoperatieve curves:

Voorbehandeling:

Longfunctie:

Conclusie:

Neurologisch onderzoek:

Myelografie:

Operatie:

Complicaties:

Nabehandeling:

Postoperatieve curves:

Postoperatieve klachten:

\section{Spondylitis tuberculosa T7-T9.}

Gips en kunststof corset in Turkije. In 1965 streptomycine en nydracine. In 1966 in Nederland een reclinerend gipsbed en corset. Proces leek rustig, in 1973 wegens progressieve kyfose tot operatie besloten.

Vage klachten lumbaal, gauwer vermoeid zijn.

Kyfose $\mathrm{T} 7 \mathrm{t} / \mathrm{m}$ T9 in $196637^{\circ}$, in 1972 progressie tot $52^{\circ}$.

1/2 jaar gipsredressie.

Vit. cap. $2300 \mathrm{cc}$. Normaal $3325 \mathrm{cc}$. Tot. cap. 2800 cc. Normaal $4175 \mathrm{cc}$.

Duidelijke restrictieve functiestoornis met voldoende respiratoire reserves.

Geen bijzonderheden.

Niet verricht.

29-4-1974. Intercorporele spondylodese met spouwing T7-8-9 met behulp van cristablok. Operatie onder paraplu van tuberculostatica.

Geen.

3 maanden liggips, waarna 2 maanden loopgipscorset.

$40^{\circ} \mathrm{kyfose}$, hetgeen constant is gebleven.

Pijn ter hoogte van de thoracale kyfose en op de lumbo-sacrale overgang. Eerder vermoeid zijn.

\section{Beschouwing en conclusie:}

In geval van progressieve kyfosering bij Pottse kyfosen, ook al lijkt het proces rustig, komt een spondylodese in aanmerking. Omdat met een voorste spondylodese ook enige correctie kan worden verkregen werd voor deze procedure gekozen. Indien er nog veel groei te verwachten was geweest kwam een complementaire achterste spondylodese in aanmerking om rekyfosering door resterende groei aan de achterzijde van de wervelkolom te voorkomen. 


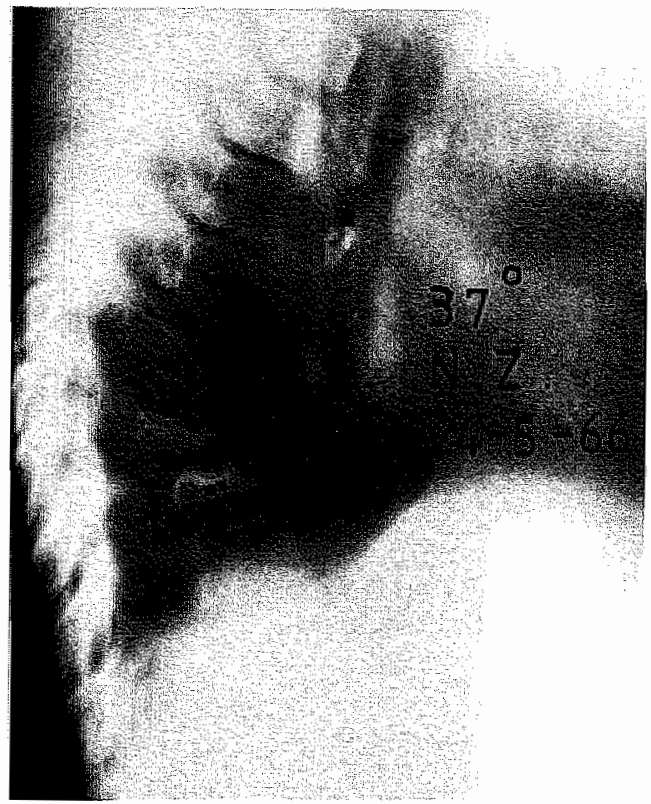

Pottse kyfose in $196637^{\circ}$

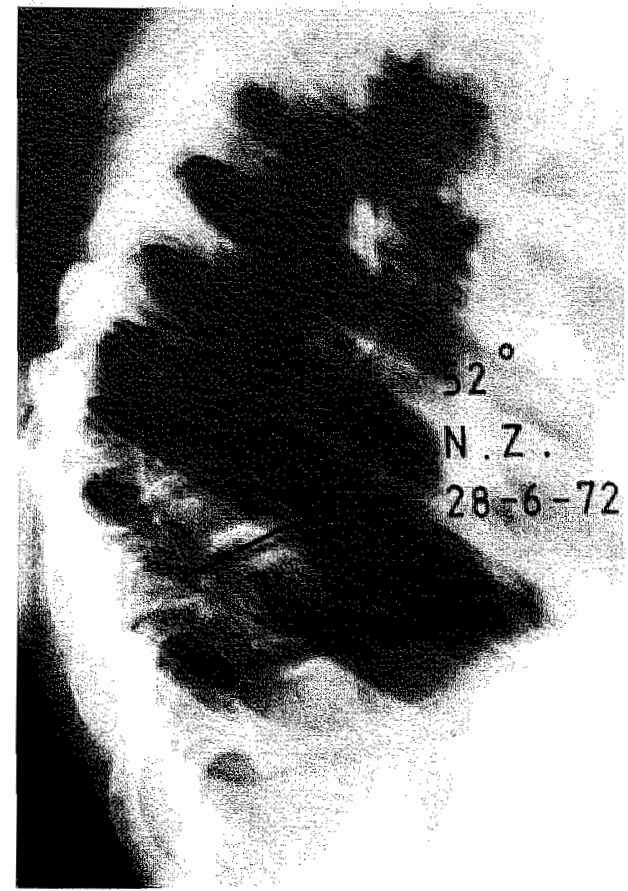

In 1972 progressie tot $52^{\circ}$

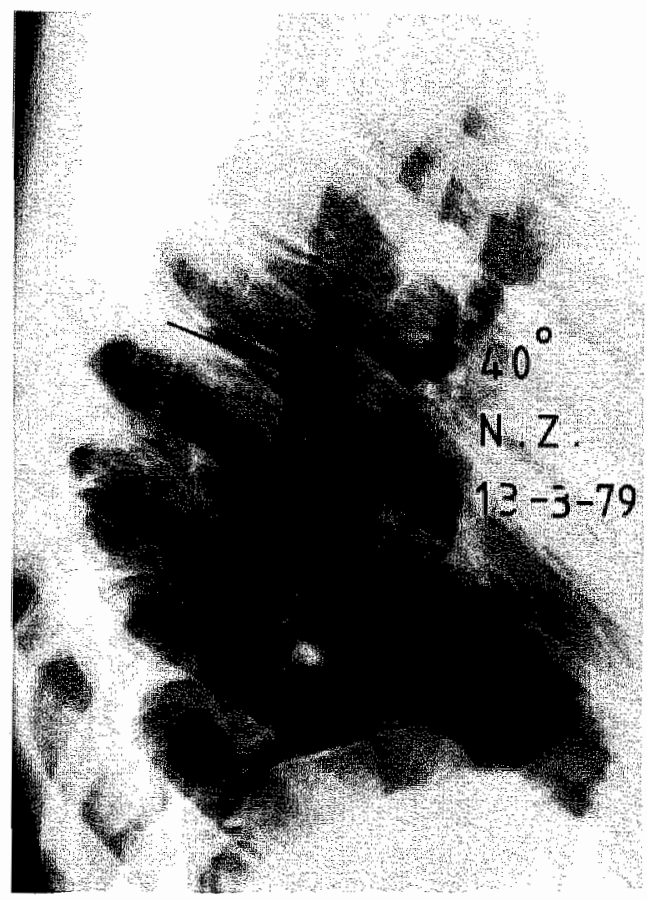

Na operatie in 1974 constante kyfose van $40^{\circ}$ 
Patiẻnt 37. A.J. mannelijk, geb. dat. 31-12-1942.

Aetiologie:

Vroegere behandeling:

Klachten:

Préoperatieve curves:

Voorbehandeling:

Longfunctie:

Conclusie:

Neurologisch onderzoek:

Myelografie:

Operatie:

Complicaties:

Nabehandeling:

Postoperatieve curves:
Kyfose ten gevolge van spondylitis tuberculosa, T10-11-12.

Van $1948 \mathrm{t} / \mathrm{m} 1953$ gekuurd te Katwijk wegens longtbc en spondylitis. Op 9-jarige leeftijd achterste spondylodese. Nooit een corset gehad.

Geen pijnklachten. Patiënt vond de rug lellijk en wilde deze graag recht hebben. Dus cosmetische (en psychologische) indicatie.

Kyfose $112^{\circ} \mathrm{T} 7 \mathrm{t} / \mathrm{m} \mathrm{L1}$. Redressiefoto: correctie tot $100^{\circ}$.

Halo-rolstoeltractie gedurende 2 weken. Correctie tot $90^{\circ}$. Paraplu van tuberculostatica. Myambutol, INH en rifadin.

Vit. cap. 4400 cc. Normaal 6200 cc. Tot. cap. 5300 cc. Normaal $7950 \mathrm{cc}$.

Duidelijke restrictieve functiestoornis met uitstekende ventilatoire reserves.

Geen afwijkingen.

Niet verricht.

I. 25-4-1978. Release aan de voorzijde via thoracotomie 9e rib rechts, osteotomieën tussen $\mathrm{T} 8 \mathrm{t} / \mathrm{m} \mathrm{L}$, spondylodese met cristabot en ribgrafts na spouwen met Harrington distractiestaafje.

JI. 16-5-1978. Achterste compressie spondylodese volgens Harrington $\mathrm{T} 7 \mathrm{t} / \mathrm{m} \mathrm{Lll} \mathrm{m.b.v.} \mathrm{cristabot.}$ Oude fibulaspaan was nog aanwezig.

Na operatie I longinfect. Verder geen problemen.

6 maanden Halo-rompgips, waarna nog 3 maanden gipscorset.

Postoperatief kyfose

$67^{\circ}$

$\mathrm{Na} 2$ maanden kyfose

$67^{\circ}$

$\mathrm{Na} 4$ maanden kyfose

$67^{\circ}$

$\mathrm{Na} 7$ maanden kyfose

$67^{\circ}$

$\mathrm{Na} 9$ maanden kyfose

$68^{\circ}$

$\mathrm{Na} 14$ maanden kyfose

$\mathrm{Na} 27$ maanden kyfose 
Postoperatieve klachten:

Geen, behalve hoofdpijn na een epileptisch insult. wat patient preoperatief nooit gehad had. Over hat cosmetische resultaat is patiënt tevreden.

Beschouwing en conclusie:

De vraag is gewettigd of dergelijke grote ingrepen alleen op cosmetische indicatie mogen gebeuren, terwijl het resultaat niet altijd voorspelbaar is. Men moet ons inziens echter bedenken dat een cosmetisch lelijke rug vaak ernstige psychische problemen met zich meebrengt, ook al zal de patiënt zelf deze niet altijd uitdragen. Indien de patiënt aandringt, een evenwichtige indruk makt en de risico's van deze grote ingrepen wil dragen, dan is het ons inziens gewettigd te trachten de wervelkolomdeformiteit zo veel mogelijk op te heffen, hetgeen bij deze man voortreffelijk gelukt is. 


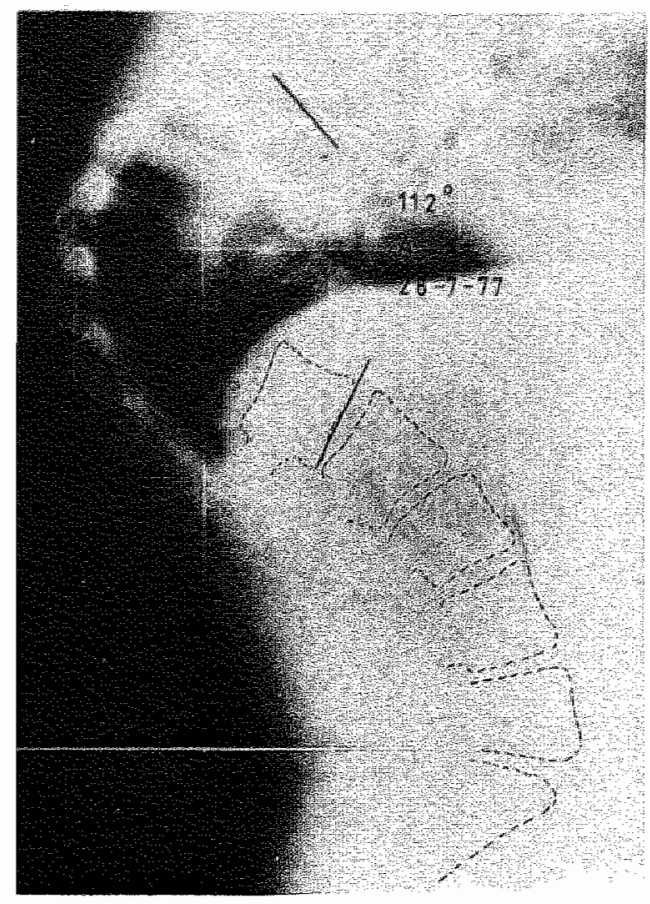

Pottse kyfose préoperatief

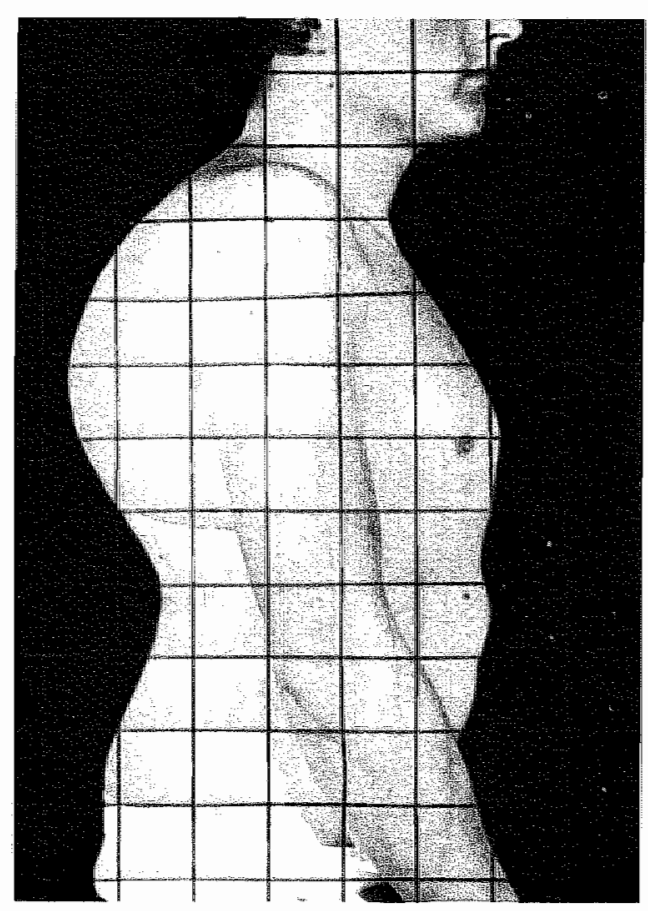

A.J. kyfose préperatief

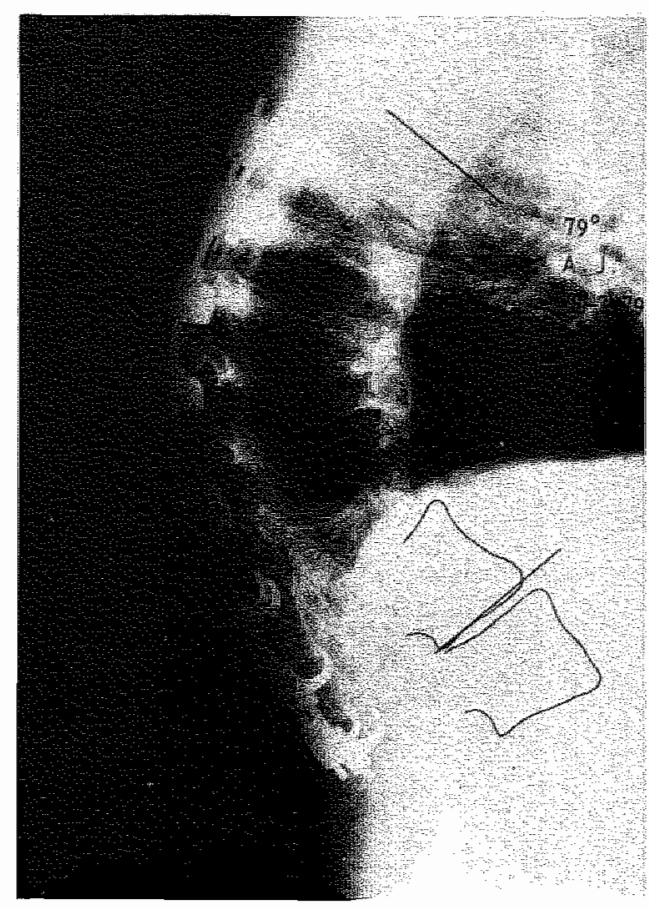

Kyfose postoperatief

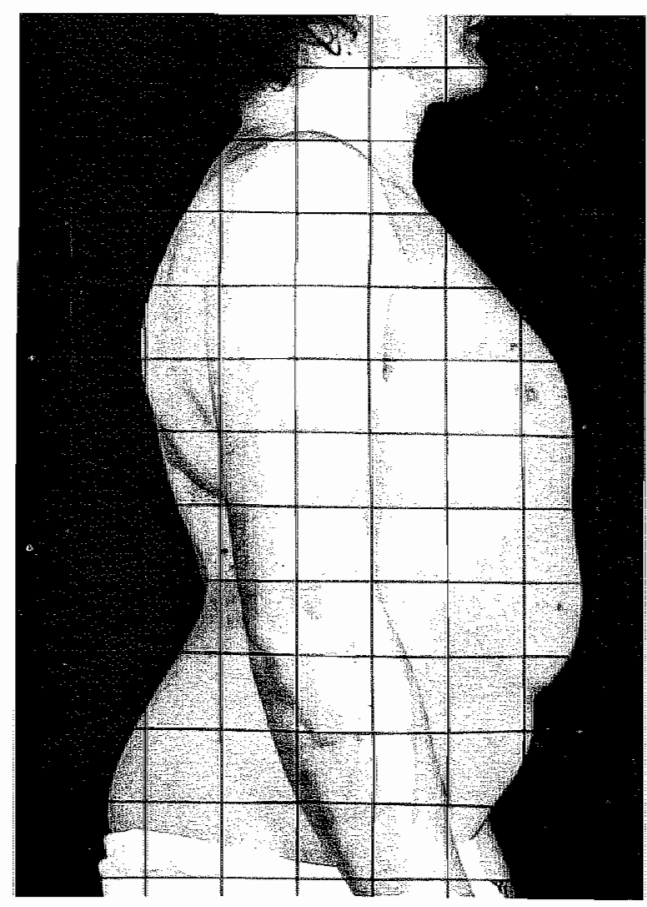

A.J. kyfose postoperatief 


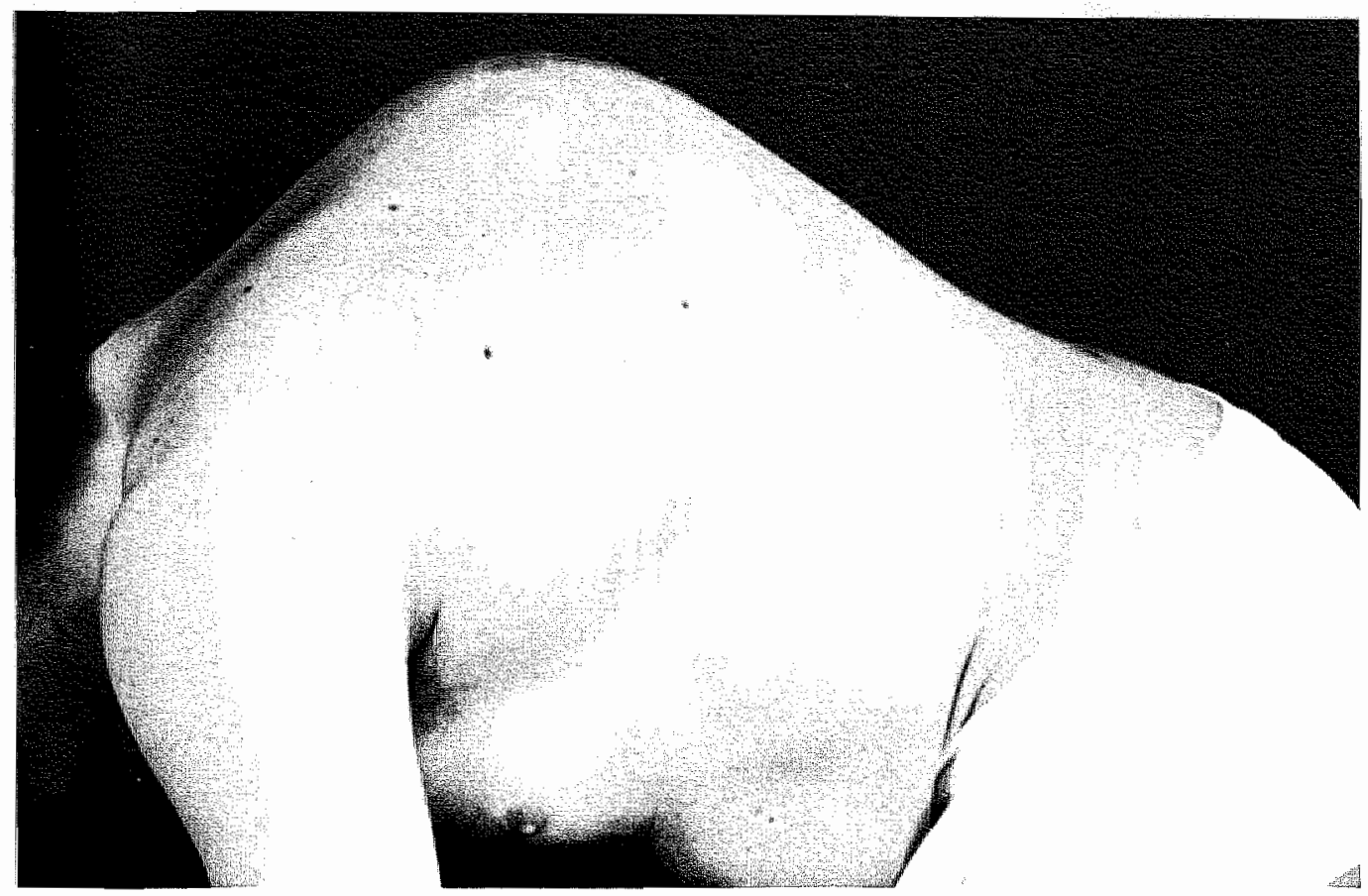

A.J. bij vooroverbuigen wordt de ernstige kyfose duidelijker zichtbaar

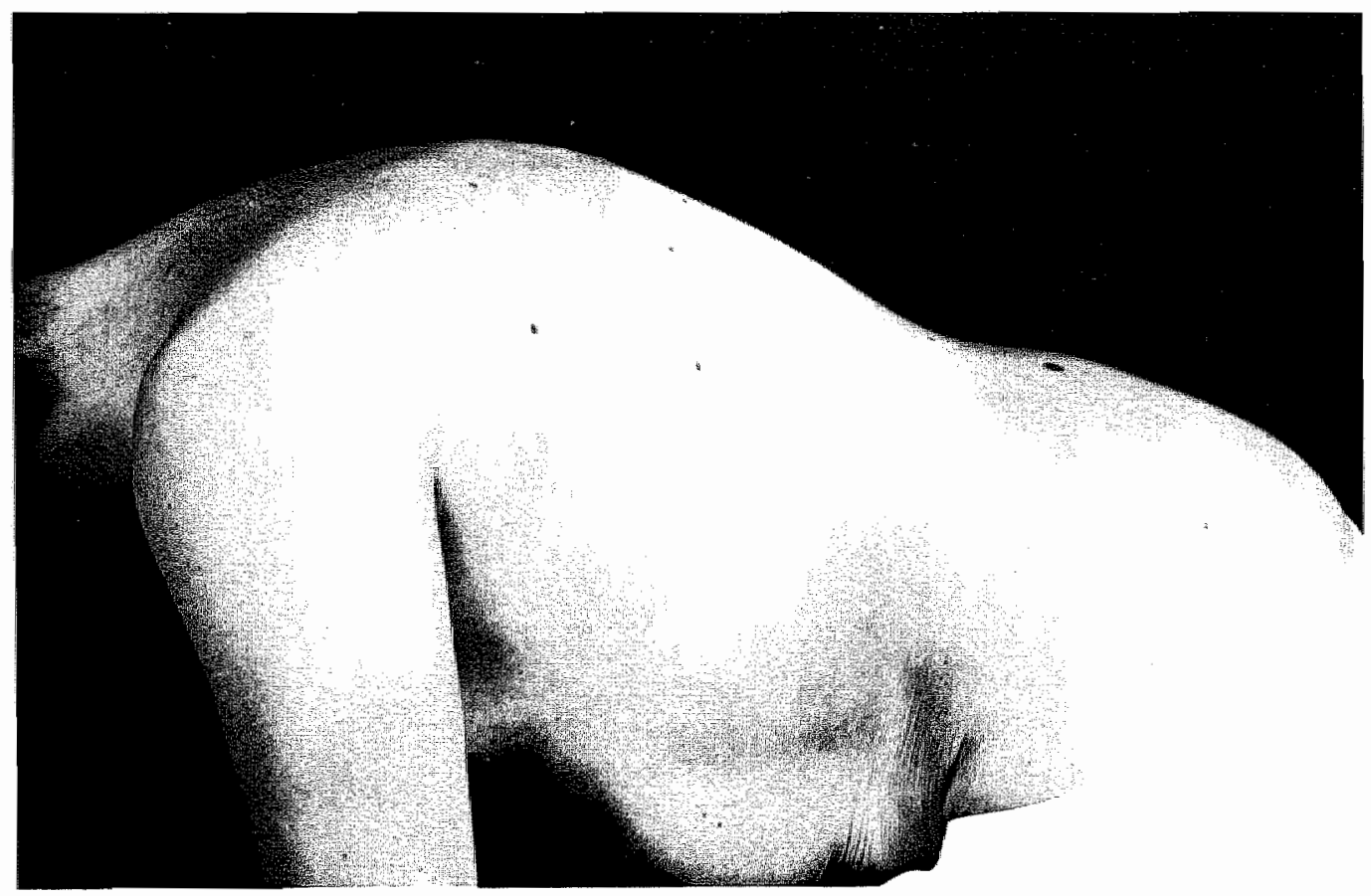

A.J. postoperatief fraaie verbetering van de kyfose 
Patiént 38. M.D. mannelijk, geb. dat. 12-5-1938.

Aetiologie:

Vroegere behandeling:

Klachten:

Préoperatieve curves:

Voorbehandeling:

Longfunctie:

Conclusie:

Neurologisch onderzoek:

Myelografie:

Operatie:

Complicaties:

Nabehandeling:

Postoperatieve curves:
Kyfose door spondylitis tuberculosa met dreigende dwarslaesie.

In 1947 spondylitis tuberculosa waarvoor patiënt heeft gekuurd. Hij heeft toen een achterste spondylodese ondergaan. In $195621 / 2$ jaar verlammingsverschijnselen in de benen, $\mathrm{kreeg}$ toen behandeling met P.A.S. In mei 1979 weer hypaesthesie en minder kracht in de benen met midthoracale rugpijn. Myelografie toonde een stop ter plaatse van T11. De neurochirurg zag geen heil in een laminectomie en stuurde patiënt door naar de orthopaedische chirurg.

Rugpijn, zwaktegevoel in de benen, verminderde sensibiliteit.

Kyfose T5 t/m L1 $108^{\circ}$. Kyfose T7 $t / \mathrm{m}$ T12 $134^{\circ}$ (de eigenlijke kyfose $\mathrm{T} 7 \mathrm{t} / \mathrm{m}$ T12 is postoperatief niet meer na te meten).

3 weken Halo-rolstoeltractie met weinig verbetering. Scherm tuberculostatica: INH, myambutol en rifampicine.

Vit. cap. 2600 cc. Normaal 4925 cc. Tot. cap. 3175 cc. Normaal $6925 \mathrm{cc}$.

Duidelijke restrictieve functiestoornis met nog redelijke ventilatoire reserves.

Incomplete dwarslaesie op T11.

Stop op T11.

8-8-1979. Thoracotomie rechts. Opspouwen van de kyfose met behulp van het Slot-distractiestaafje, spondylodese $\mathrm{T} 5 \mathrm{t} / \mathrm{m} \mathrm{L1}$ met fibulla en ribspanen.

Urineweginfectie.

5 maanden Halo-rompgips, waarna gipscorset tot aan het overlijden.

Correctie van de kyfose tot $99^{\circ}$ TS t/m L1 op 3-11980. 
Postoperatieve klachten:

2 maanden postoperatief was de kracht in het linker been sterk verbeterd, rechts was dit iets minder het geval. Ook de sensibiliteit was verbeterd. 6 maanden postoperatief overleed patiënt echter plotseling ten gevolge van een massale bloeding uit een oude longcaverne.

Beschouwing en conclusie:

Helaas overleed deze patiënt ten gevolge van een massale longbloeding. Indien hij was blijven leven had hij waarschijnlijk veel baat van deze operatie gehad, gezien de verbetering van de neurologische uitval postoperatief. Ook al was de correctie matig, ieder strekken van de kyfose met stabilisatie kan het myelum al zoveel ruimte geven dat functionele verbetering resulteert.

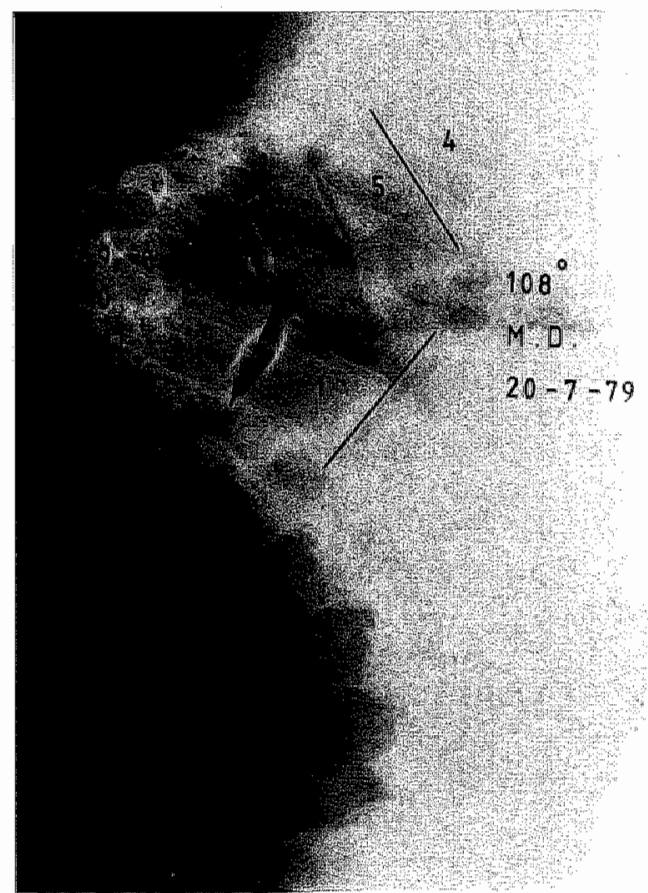

Kyfose préoperatief

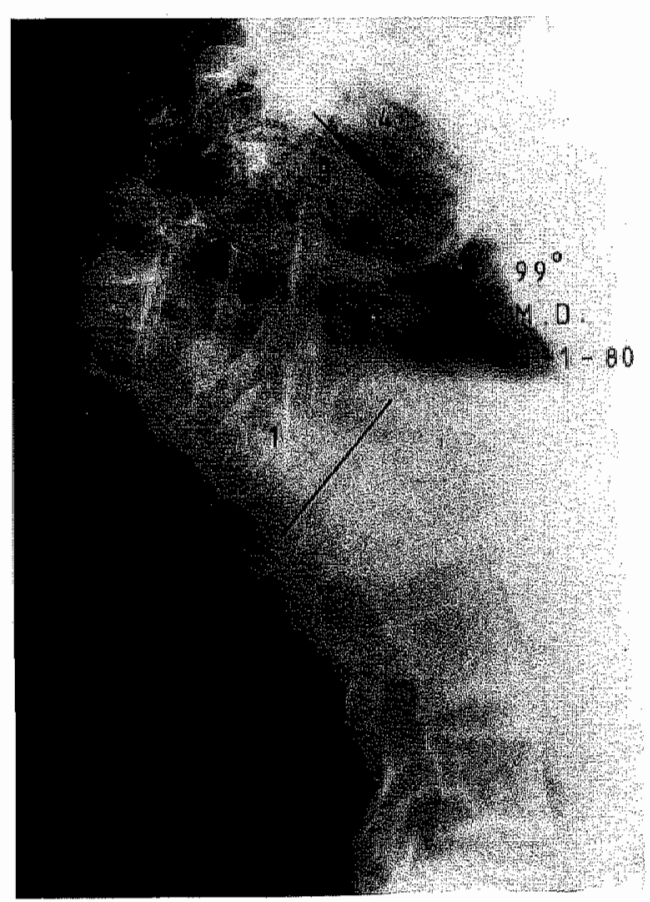

Kyfose postoperatief 
Patiènt 39. J.G. mannelijk, geb. dat. 28-1-1950.

Aetiologie:

Vroegere behandeling:

Klachten:

Préoperatieve curves:

Voorbehandeling:

Longfunctie:

Conclusie:

Neurologisch onderzoek:

Myelografie:

Operatie:

Complicaties:

Nabehandeling:
Kyfose door spondylitis tuberculosa $\mathrm{T} 7 \mathrm{t} / \mathrm{m} \mathrm{T} 12$.

Long tbc op 2-jarige leeftijd in Indonesië. Op 3-jarige leeftijd spondylitis tuberculosa. Tot 8-jarige leeftijd in een gipsschelp gelegen. Patiënt zou ook een paraplegie hebben gehad.

Uitstralende pijn in de linker thoraxhelft met paraesthesieën sinds een jaar. Sinds $1 \frac{1 / 2}{2}$ jaar dyspnoe, mogelijk ten gevolge van een stofallergie.

Kyfose T5 t/m L1 $96^{\circ}$.

2 weken Halo-rolstoeltractie met gering resultaat. Profylactisch INH en floxapen.

Vit. cap. $2550 \mathrm{cc}$. Normaal $5150 \mathrm{cc}$. Tot. cap. 3800 cc. Normaal $6700 \mathrm{cc}$.

Restrictieve en destructieve functiestoornis met redelijke reactie op bricanyl. De reserves zijn beperkt.

Quadrant-hypaesthesie linker thorax en linker arm. Conclusie vooral tractus spino-thalamicus aangedaan op cervicaal niveau, de lange banen zijn goed. Postoperatief was de quadrant-hypaesthesie verdwenen. Waarschijnlijk is dit conversief geweest.

Spoelvormige vernauwing ter plaatse van de kyfose, hieronder verwijding.

5-10-1979. Thoracotomie 6e rib rechts. Columnotomie aan de voorzijde, redressie met behulp van de Slot-distractor, fixatie met behulp van het Slot-staafje en Zielke schroeven, fibula en ribspanen. Spondylodese T4 t/m L2. Eén en ander onder een paraplu van tuberculostatica.

Tot aan de $4 \mathrm{e}$ week temperatuursverhoging zonder duidelijke oorzaak.

3 maanden Halo-rompgips, waarna 6 maanden gipscorset met kraag. 
Postoperatieve curves:

$\begin{array}{ll}\text { Postoperatief } & 81^{\circ} \\ \text { Na } 3 \text { maanden } & 81^{\circ} \\ \text { Na 6 maanden } & 87^{\circ} \\ \text { Na } 9 \text { maanden } & 84^{\circ} \\ \text { Na } 16 \text { maanden } & 81^{\circ}\end{array}$

Longfunctie:

1 jaar postoperatief. Vit. cap. $2375 \mathrm{cc}$. Normaal $5400 \mathrm{cc}$. Tot. cap. $3900 \mathrm{cc}$. Normaal $7025 \mathrm{cc}$.

Conclusie: Geen verandering van betekenis ten opzichte van de waarden preoperatief.

Postoperatieve klachten:

Eerst nog vreemde gevoelens in de linker arm met tintelingen, ook in de benen. Later geen klachten meer.

Beschouwing en conclusie:

Bij deze patiënt bestond een zeer rigide kyfose met fusie van de aangedane wervellichamen ter plaatse van de apex. Ruime correctie was hierdoor niet te verwachten, belangrijk was vooral de stabilisatie ter voorkoming van latere progressie, welke vooral boven en onder de apex te verwachten was. Een voorste strut-grafting met interne lixatie, zoals bij deze patiënt gebeurde maakt een achterste compressiespondylodese in 2e tempo overbodig, aangezien ongestoorde ingroei van de ingebrachte botspanen hiermee mogelijk is. 


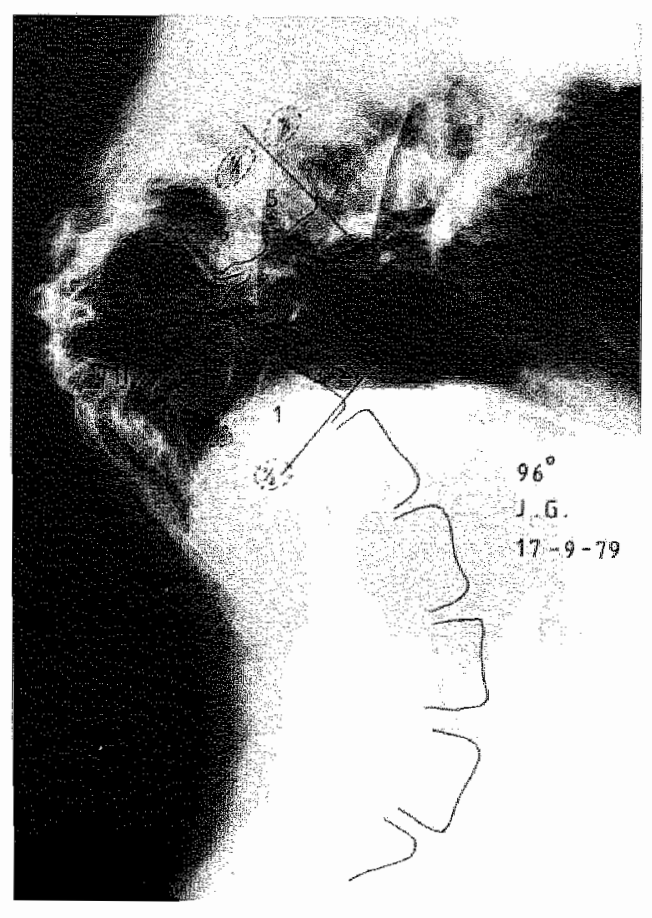

Kyfose préoperatief

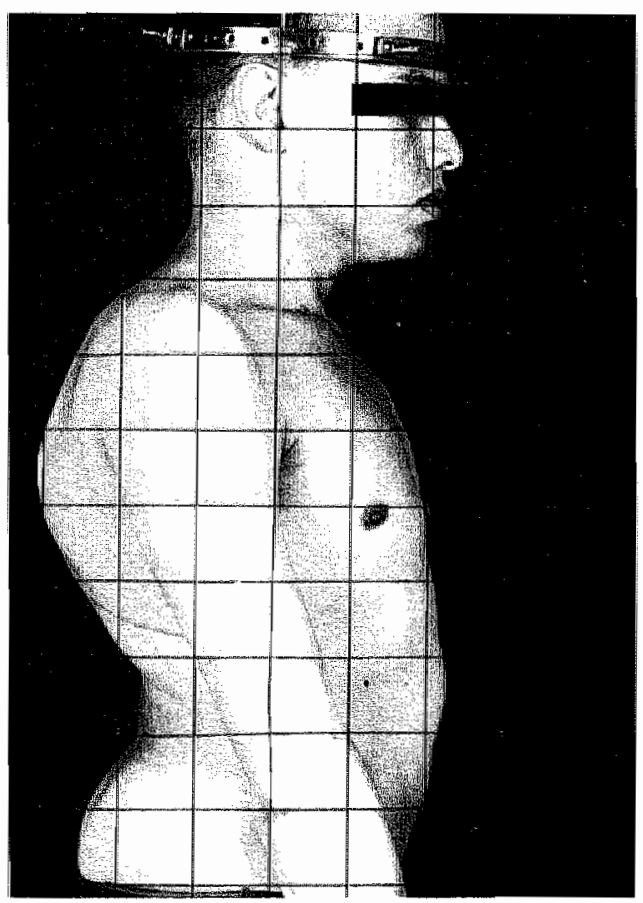

J.G. kyfose préoperatief

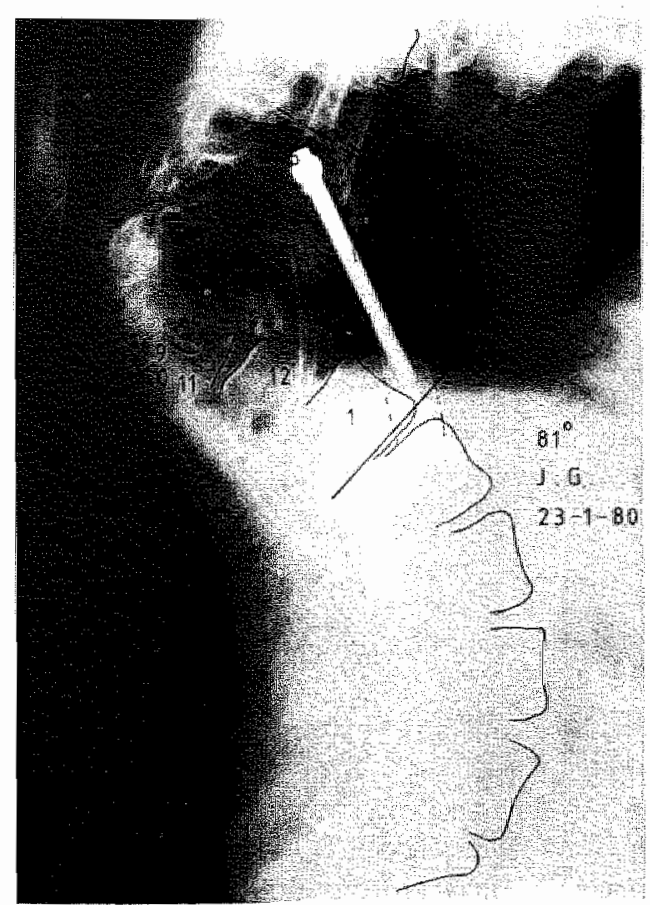

Kyfose postoperatief

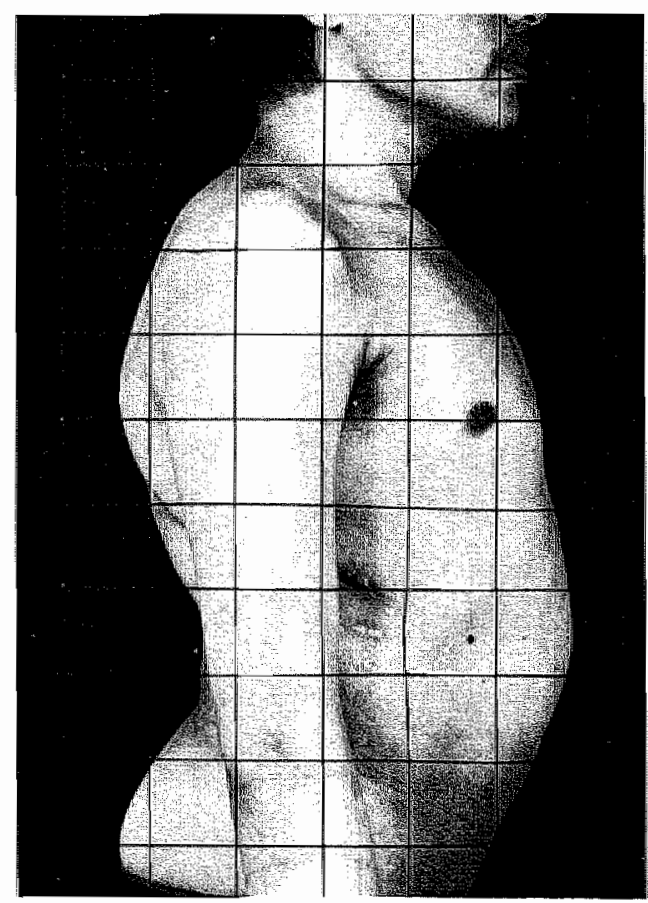

J.G. kyfose postoperatief 


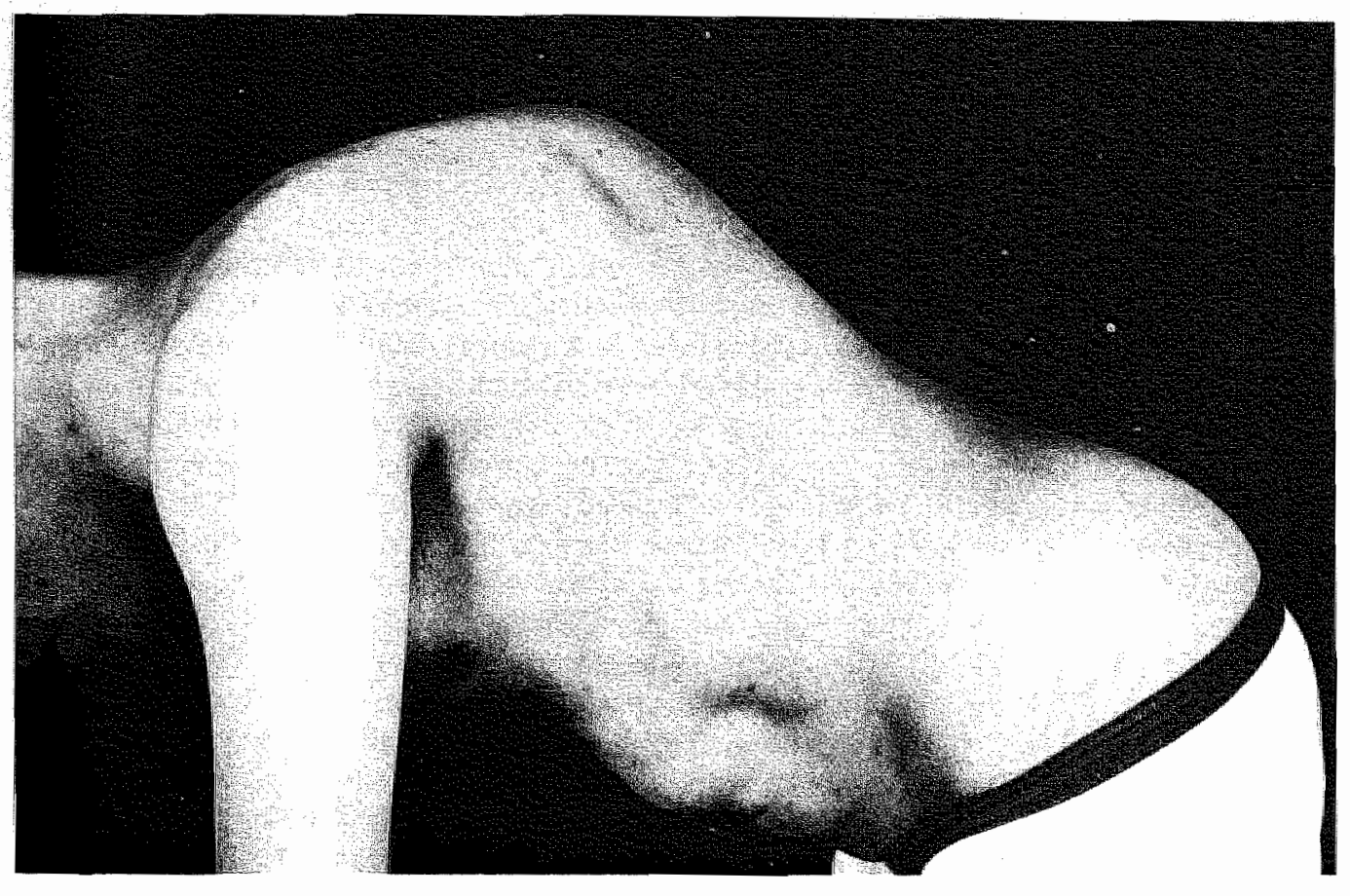

J.G. kyfose préoperatief

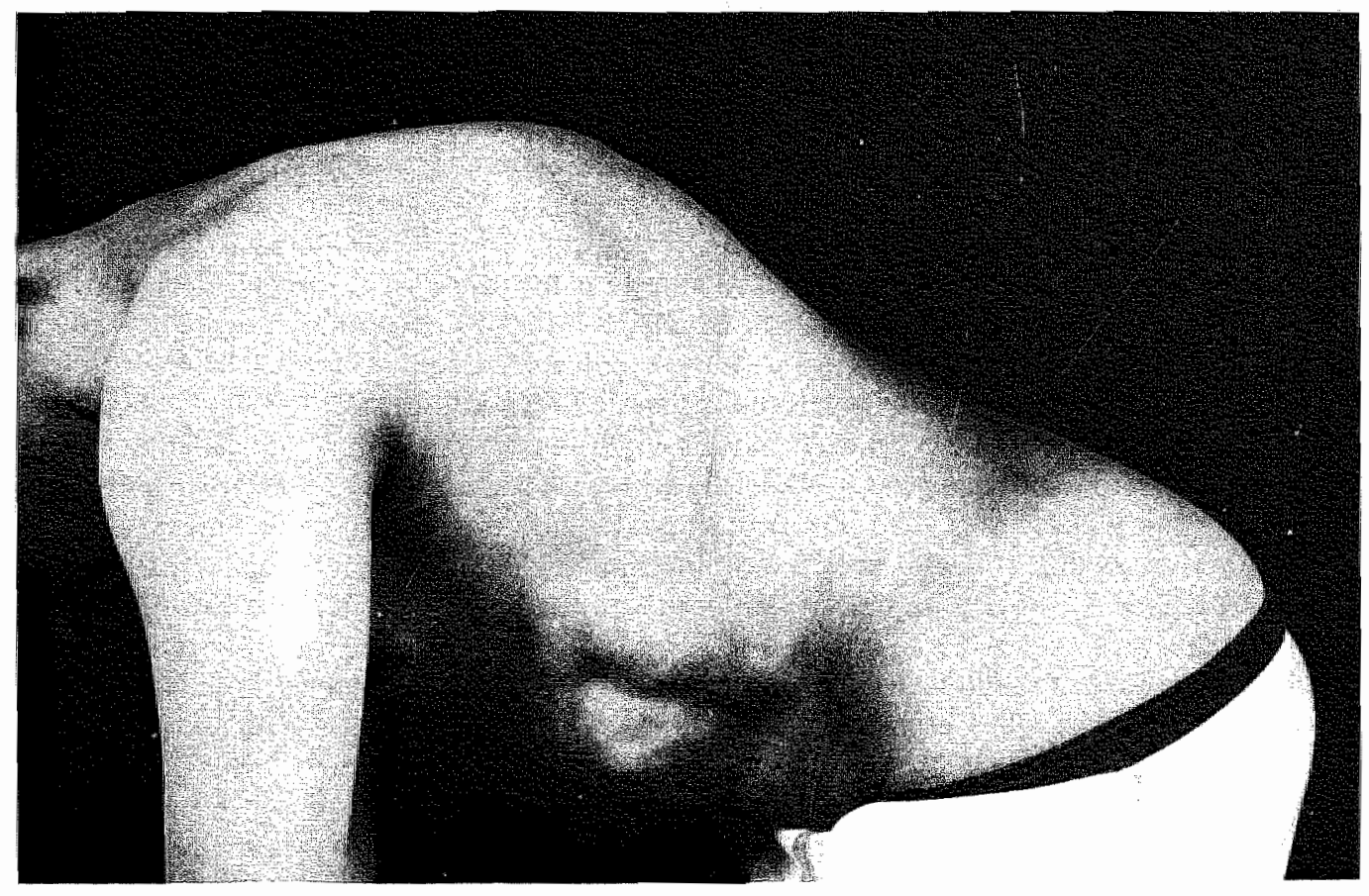

J.G. kyfose postoperatief 


\section{KYFOSEN NA LAMINECTOMIE EN/OF BESTRALING}

\subsection{Inleiding}

Na laminectomie op de kinderleeftijd, vaak gecombineerd met bestraling kan ernstige kyfose of kyfoscoliose ontstaan $(1,3,4,9)$. Laminectomie geschiedt in de meeste gevallen op grond van myelumtumoren, waaronder astrocytoma, neuroblastoma en ependymoma. In ongeveer $49 \%$ treedt bij kinderen met laminectomie wervelkolomdeformiteit op (1). De uitgebreidheid van de laminectomie en de leeftijd van de patiënt bepalen de prognose. Als de facetgewrichten op één of meerdere niveaus zijn verwijderd wordt het achterste ligamentcomplex zodanig verzwakt dat angulaire kyfosering kan optreden. Bij unilaterale facetverwijdering kan scherpe scoliose het gevolg zijn. Bij incomplete facetverwijdering op meerdere niveaus zien we een veel regelmatiger kyfose ontstaan (3). Als andere factoren die in het ontstaansmechanisme van belang zijn kunnen denervatie van de lange rugspieren en bestraling genoemd worden.

Door parese c.q. paralyse van de lange rugspieren wordt het achterste wervelkolomcomplex (wervelbogen, facetgewrichten, ligamenten, rugspieren) nog verder verzwakt (3). Zelfs zonder laminectomie ziet men bij dwarslaesies op kinderleeftijd praktisch altijd wervelkolomdeformiteit optreden. Ook kan door operatief optreden de lange rugmusculatuur beschadigd of gedenerveerd worden.

Door bestraling met meer dan 2000 Rad. op de wervelkolom treedt zodanige schade aan de groeikernen van de wervelkolom op, dat deformiteit in de loop van de ontwikkeling te verwachten is. De zich delende chondroblasten verliezen hun onderlinge samenhang en raken ongeorganiseerd. Tevens vermindert het aantal celdelingen. Een gestoorde lengtegroei van het aangetaste wervelkolomgedeelte is hiervan het gevolg. Ook de botstructuur van de wervels zelf wordt door de bestraling slechter van kwaliteit. Het meest bekende voorbeeld van bestralingskyfose en scoliose is na bestraling bij extirpatie van een Wilmstumor. Bij asymmetrische bestraling van de wervels is scoliose te verwachten. Bij symmetrische bestraling kyfose. Vooral de groeischijven van de wervellichamen worden beschadigd, zodat aan de voorzijde van de wervelkolom een verminderde lengtegroei platatsvindt ten opzichte van de achterzijde. Kyfosering is hiervan het gevolg. Eventuele hypoplasie van het os ilium door de bestraling kan eveneens een rol spelen bij het optreden van deformiteit.

$\mathrm{Na}$ laminectomie en/of bestraling van meer dan 2000 Rad op de wervelkolom bij kinderen moet altijd gelet worden op een zich ontwikkelende deformiteit van de rug. Wordt een deformiteit ontdekt dan zal nauwlettend moeten worden nagegaan of het om een stationaire dan wel progressieve deformiteit gaat. Ook al is de prognose van de primaire ziekte soms slecht, meestal is behandeling aangewezen als progressie wordt vastgesteld. Dit hangt af van het stadium en de aard van de ziekte, de snelheid van progressie en de nog te verwachten groeiperiode. Men moet tevens rekening houden met de mogelijkheid dat de deformiteit een gevolg is van invasie van tumorweefsel in het bot $(2,5$, 7.8).

\subsection{Behandeling}

Het belangrijkste element bij deze vormen van wervelkolomdeformiteit is het voorkomen van zodanig ernstige curves, dat behandeling extreem moeilijk wordt. Bij begin- 
nende curves kan met een brace getracht worden de progressie te stoppen. De resultaten worden in de literatuur als teleurstellend opgegeven $(3,8)$. Als de deformiteit progressief blijkt te zijn ondanks conservatieve behandeling of als de curve al te groot is voor conservatieve therapie komt operatie in aanmerking. Hierbij speelt, zoals al eerder gememoreerd, de levensverwachting een cruciale rol, echter bij vele kindertumoren is deze door gecombineerde therapie beter dan voorheen (3). Bij geringe kyfosering zal een Harringtonspondylodese verricht kunnen worden, waarbij de overgebleven processi transversi en intergewrichten bepalend zijn voor de kwaliteit van de spondylodese. Eventueel kan een overbruggende spaan worden ingebracht, die tussen de processi spinosi boven en onder de laminectomie kan worden ingeklemd.

$\mathrm{Bij}$ gevorderde kyfosen (meer dan 50 à $70^{\circ}$, afhankelijk van de rigiditeit) heeft een achterste spondylodese na laminectomie een vrij grote kans op pseudarthrose. Het is dan beter primair een voorste spondylodese te verrichten met inlay-ribgrafts of strutgrafts. Indien nodig voor de stabiliteit of verdere correctie kan een achterste spondylodese worden toegevoegd. Dit is vooral aan te bevelen bij collapsing spine na laminectomie en paralyse van lange rugspieren $(2,3,4,7,10)$.

Een andere reden om de voorkeur te geven aan een voorste spondylodese is een slechte huidbedekking van de rug na vroegere bestraling. Het gevaar op wondstoornis bij achterste spondylodese is dan groot (2). In uitzonderingsgevallen kan bij volledige dwarslaesie een spondylodese in het mergkanaal worden verricht, waarbij het afunctionele myelum wordt verwijderd.

Samenvattend moet men na laminectomie op de kinderleeftijd altijd rekening houden met kyfose c.q. scolioseontwikkeling vooral indien bestraling is toegevoegd. Als een uitgebreide laminectomie noodzakelijk is geweest met verwijdering van facetgewrichten lijkt het beter gelijktijdig een spondylodese toe te voegen, zodat latere wervelkolomdeformiteit wordt voorkomen $(1,9)$. Een achterste spondylodese heeft dan ook meer kans van slagen dan wanneer zich reeds een ernstige kyfose ontwikkeld heeft. Bestraling behoort ook na spondylodese met intern fixatiemateriaal tot de mogelijkheden. Préoperatief overleg tussen neurochirurg en orthopaedisch chirurg is bij deze patiënten aan te bevelen om tot een uitgebalanceerd behandelingsplan te komen.

\subsection{Literatuur hoofdstuk 8}

1. Boersma G. Verkrommingen van de wervelkolom na laminectomieën bij kinderen. Een klinisch onderzoek en een literatuurstudie over normale en mechanisch verstoorde wervelgroei. Proefschrift. Amsterdam-Assen. 1969.

2. King J. Stowe S. Results of spinal fusion for radiation scoliosis. Spine 7, 1982, 574585 .

3. Lonstein J. E. Post-laminectomy kyphosis. Clin. Orthop. 128, 1977, 93-100.

4. Lonstein J. E. Winter R. B. Moe J. H. Bradford D. S. Bianco A. J. Post-laminectomy spine deformity. Journ. of Bone and Joint Surg. 58A, 1976, 727.

5. Mayfield J. K. Riseborough E. J. Jaffe N. Nehme M. E. Spinal deformity in children treated for neuroblastoma. The effect of radiation and other forms of treatment. Journ. of Bone and Joint Surg. 63A, 1981, 183-193. 
6. Van Nes C. P. Groeistoornissen van het skelet na röntgen- of radiumbestraling op jeugdige leeftijd. Ned. Tijdschr. Geneesk. 110, 1966, 1904-1911.

7. Riseborough E. J. Irradiation induced kyphosis. Clin. Orthop. 128, 1977, 101-106.

8. Riseborough E. J. Grabias S. L. Burton R. I. Jaffe N. Skeletal alterations following irradiation for Wilm's tumor. With particular reference to scoliosis and $\mathrm{ky}$ phosis. Journ. of Bone and Joint Surg. 58A, 1976, 526-536.

9. Tachdjian M. O. Matson D. D. Orthopaedic aspects of intraspinal tumors in infants and children. Journ. of Bone and Joint Surg. 47 A, 1965, 223-248.

10. Wirth C. R. Jacobs R. L. Rolander S. D. Neuropathic spinal arthropathy. A review of the Charcot spine. Spine 5, 1980, 558-567. 


\subsection{Paiëntenbeschrijvingen bij laminectomiebestralingskyfosen}

Patiënt 40. F. B. mannelijk, geb. dat. 9-6-1964.

Aetiologie:

Vroegere behandeling:

Klachten:

Préoperatieve curves:

Voorbehandeling:

Longfunctie:

Conclusie:

Neurologisch onderzoek:

Myelografie:

Operatie:

Nabehandeling:

Operatie:

Complicaties:
Kyfoscoliose hoog thoracaal na laminectomie en bestraling wegens neuro-epithelioom op de leefijd van 7 maanden met dwarslaesie verschijnselen.

Geen behandeling meer gehad na de chirurgische en radiotherapeutische therapie in het le levensjaar.

Geen. De operatie indicatie is de toenemende kytoscoliose. De spastische verschijnselen van de benen zouden altijd al bestaan hebben.

Scoliose T1 t/m T6 $50^{\circ}$. Kyfose T2 t/m T9 75".

Halo-rolstoeltractie 2 weken. Correctie scoliose tot $36^{\circ}$, kyfose tot $50^{\circ}$.

Vit. cap. $1725 \mathrm{cc}$. Normaal $2500 \mathrm{cc}$. Tot. cap. 2075 cc. Normaal $3125 \mathrm{cc}$.

Duidelijke restrictieve functiestoornis met toch nog redelijke ventilatoire reserves.

Dubbelzijdig pyramidaal syndroom aan de benen. Links meer dan rechts. Mogelijk ten gevolge van bestralings neuropathie.

Geen duidelijke compressio medullae, wel versmalling en iets onregelmatigheid van de contrastkolom ter plaatse, waarschijnlijk ten gevolge van fibrosis.

1. 27-6-1978. Spondylodese volgens Harrington $C 7$ $\mathrm{t} / \mathrm{m}$ T9 met behulp van compressie- en distractiesysteem. Tijdens de operatie wordt een wake-up-test verricht. De zijstructuren van de wervelbogen zijn nog redelijk aanwezig.

Halo-rompgips 3 maanden, gipscorset 6 maanden, waarna manifest worden van infectie.

II. 27-3-1979. Verwijderen compressiesysteen wegens fisteling.

Fisteling na 1e operatie, na 2e operatie genezen. 
Postoperatieve curves:

$\begin{array}{lll} & \text { Scoliose } & \text { Kyfose } \\ \text { Na 11 maanden } & 42^{\circ} & 50^{\circ} \\ \text { Na 1.7 maanden } & 45^{\circ} & 50^{\circ} \\ \text { Na.24 maanden } & 37^{\circ} & 52^{\circ}\end{array}$

Postoperatieve klachten:

Geen.

Beschouwing en conclusie:

De combinatie laminectomie en bestraling heeft hier aanleiding gegeven tot een sterk progressieve kyfoscoliose. Door ontbreken van een gedeelte van de achterstructuren en destructie van groeikernen door bestraling is de wervellkolom geleidelijk aan gecollabeerd. Bij progressie moet men in een vroeg stadium de wervelkolom stabiliseren. Hier kon volstaan worden met een achterste spondylodese, in veel gevallen is operatie aan de voorzijde noodzakelijk wegens de deficiëntie van achterstructuren. 


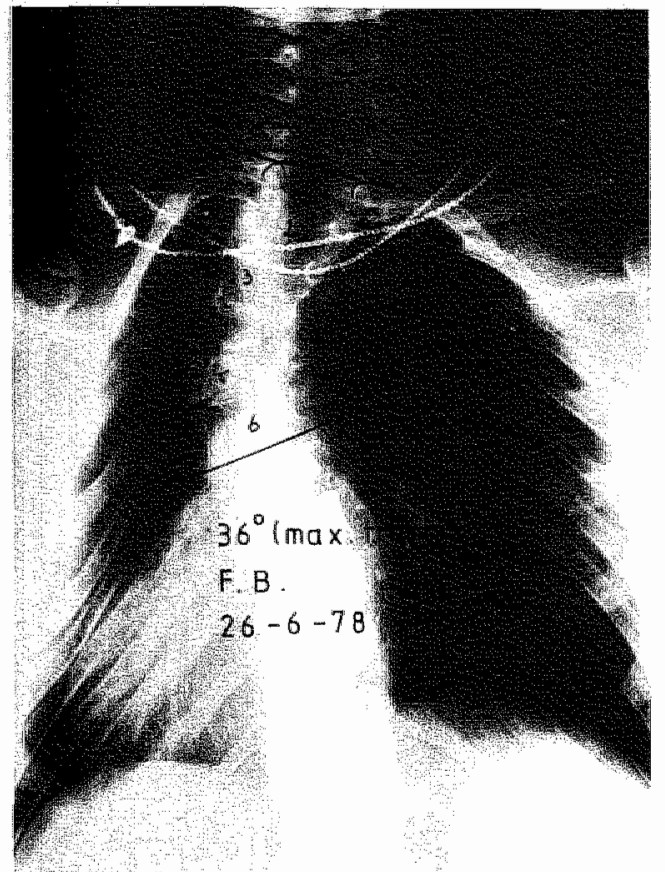

Scoliose préoperatief

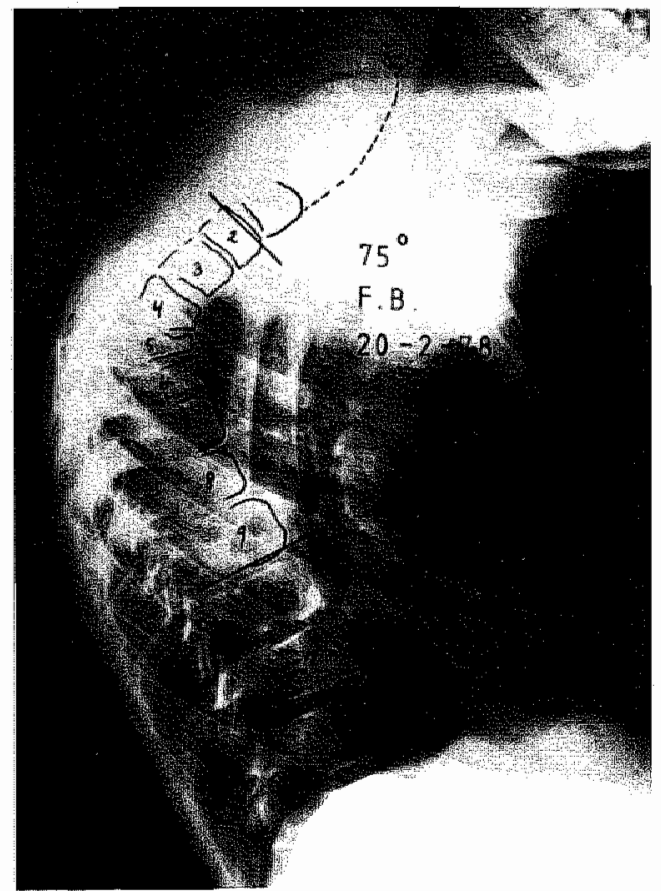

Kyfose préoperatief

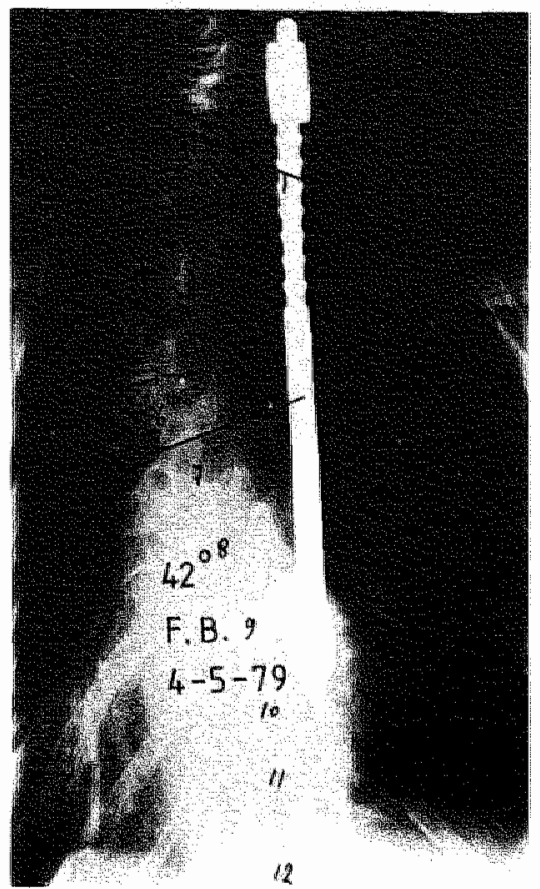

Scoliose postoperatief na verwijderen compressieset links

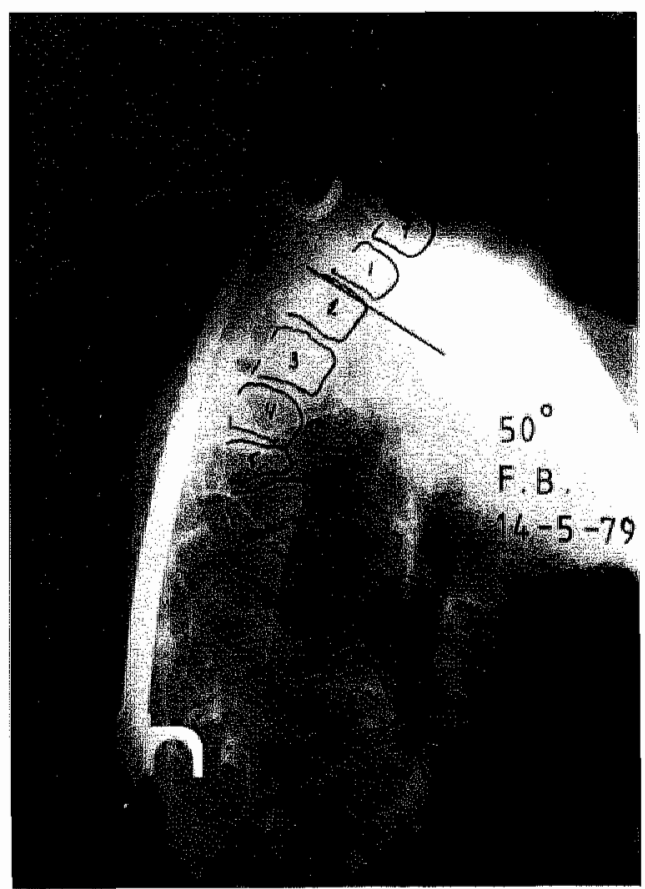

Kyfose postoperatief 


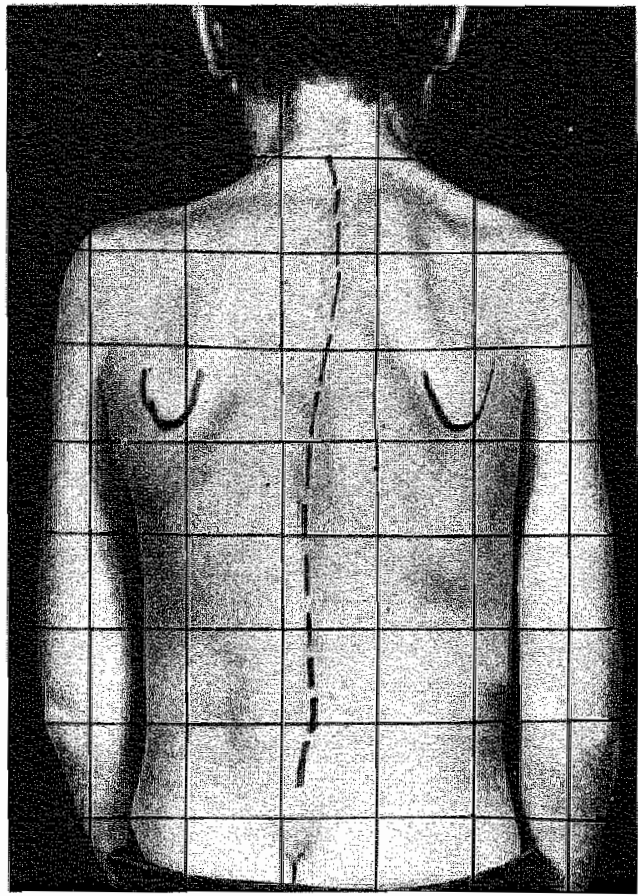

F. B. scoliose préoperatief ffoto in spiegellbeeld)

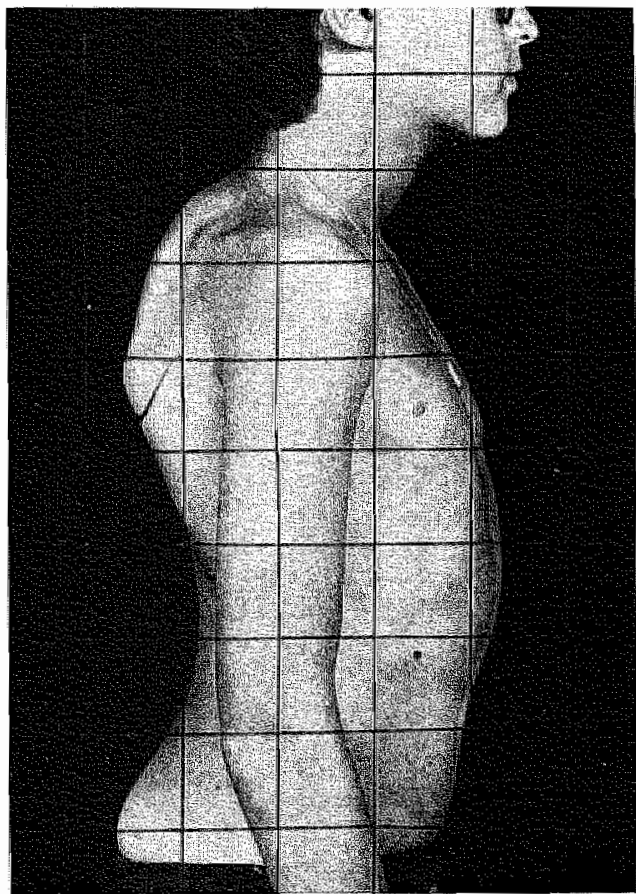

F. B. hoog thoracale kytose préoperatief

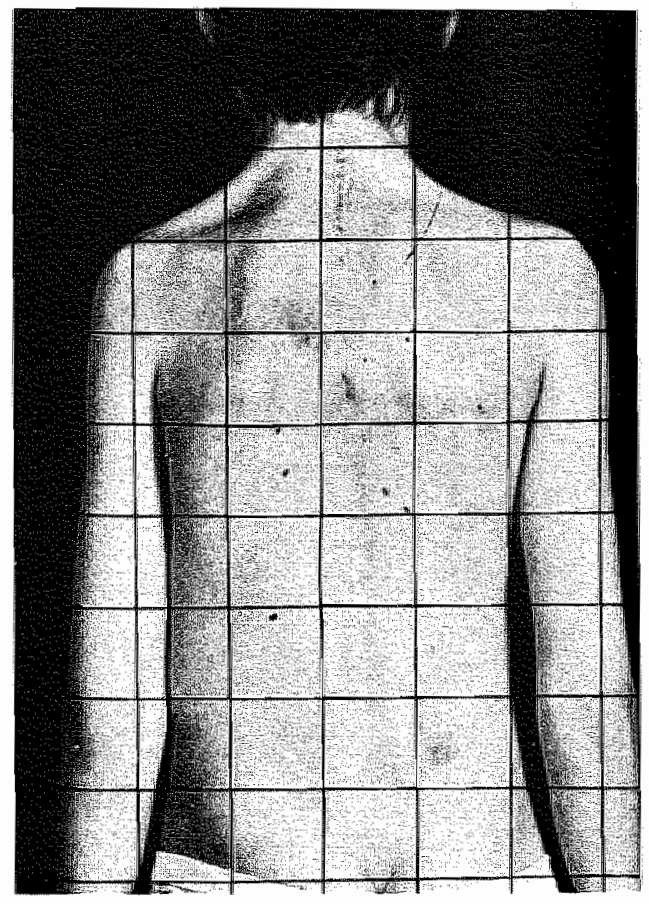

F. B. scoliose postoperatief

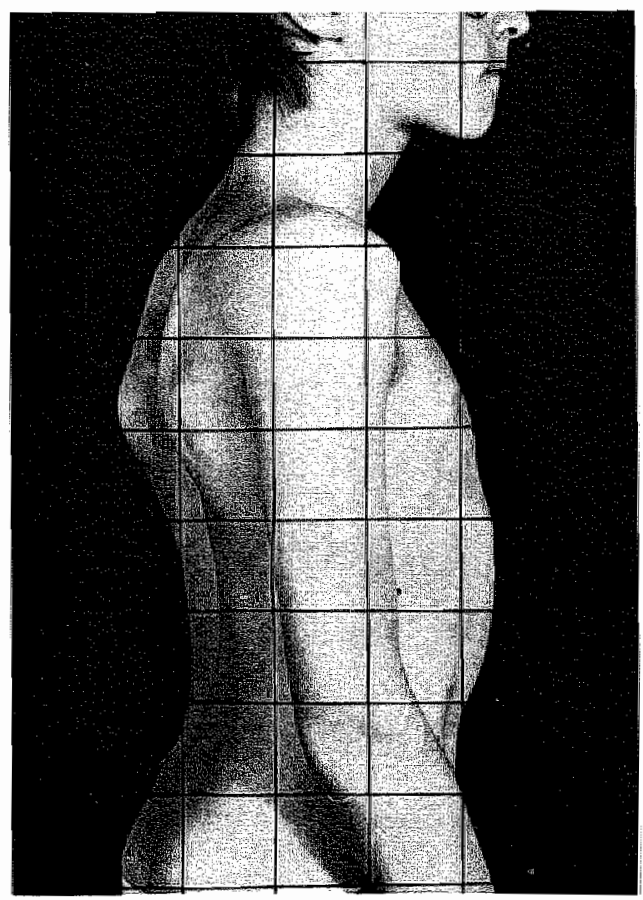

F. B. kyfose postoperatief 
Patiënt 41. M. L. mannelijk, geb. dat. 18-2-1960.

Aetiologie:

Vroegere behandeling:

Klachten:

Préoperatieve curves:

Voorbehandeling:

Longfunctie:

Neurologisch onderzoek:

Myelografie:

Operatie:

Operatie:

Complicaties:

Nabehandeling:

Postoperatieve curves:

Conclusie:

Postoperatieve klachten:
Kyfoscoliose na $2 \times$ laminectomie en bestraling wegens een astrocytoom laag thoracal in $1969 . \mathrm{Er}$ is toen een dwarslaesiebeeld geweest, dat is opgeklaard.

Gipscorsetten, Milwaukee Brace, oefentherapia. Desondanks progressie.

Geen.

Scoliose $48^{\circ} \mathrm{T} 11 \mathrm{t} / \mathrm{m}$ L4 links convex. Kyfose $51^{\circ} \mathrm{TP}$ $\mathrm{u} / \mathrm{m} \mathrm{L1}$.

Geen.

Niet verricht.

Lichte spasticiteit rechter voet.

Niet verricht.

I. 29-10-1974. Spondylodese laterodorsaal volgens Harrington T8 t/m L4 met behulp van distractiestaaf, cristachips en inklemming van tibiaspaan tussen processi spinosi.

II. 26-11-1974. Opnieuw plaatsen van onderste haakje op L5, wegens uitbreken van dit haakje.

Behalve uitbreken van het onderste haakje geen complicaties.

10 maanden toopgipscorset.

$\begin{array}{lll} & \text { Scoliose } & \text { Kyfose } \\ \text { Postoperatief } & 18^{\circ} & 30^{\circ} \\ \text { Na3 maanden } & 24^{\circ} & 31^{\circ} \\ \text { Na } 6 \text { maanden } & 30^{\circ} & 32^{\circ} \\ \text { Na } 9 \text { maanden } & 34^{\circ} & 40^{\circ} \\ \text { Na } 1 / 2 \text { jaar } & 37^{\circ} & 40^{\circ} \\ \text { Na } 2 \text { jaar } & 35^{\circ} & 40^{\circ} \\ \text { Na } 51 / 2 \text { jaar } & 37^{\circ} & 37^{\circ}\end{array}$

Vrij veel verlies in het eerste jaar postoperatief. Daarna een stabiele situatie.

Geen. 
Bij deze groep afwijkingen kan volstaan worden met een achterste ingreep als de kyfotische component nog niet al te sterk is en de achterstructuren nog redelijk aanwezig zijn. Dat deze kyfotische krachten toch al aanzienlijk zijn blijkt uit het uitbreken van het onderste haakje. De slechte botkwaliteit, die men ziet na bestraling kan hierbij ook een rol hebben gespeeld. De spondylodese is uiteindelijk goed geslaagd met een vrijwel normaal belastbare wervel kolom tot gevolg. 


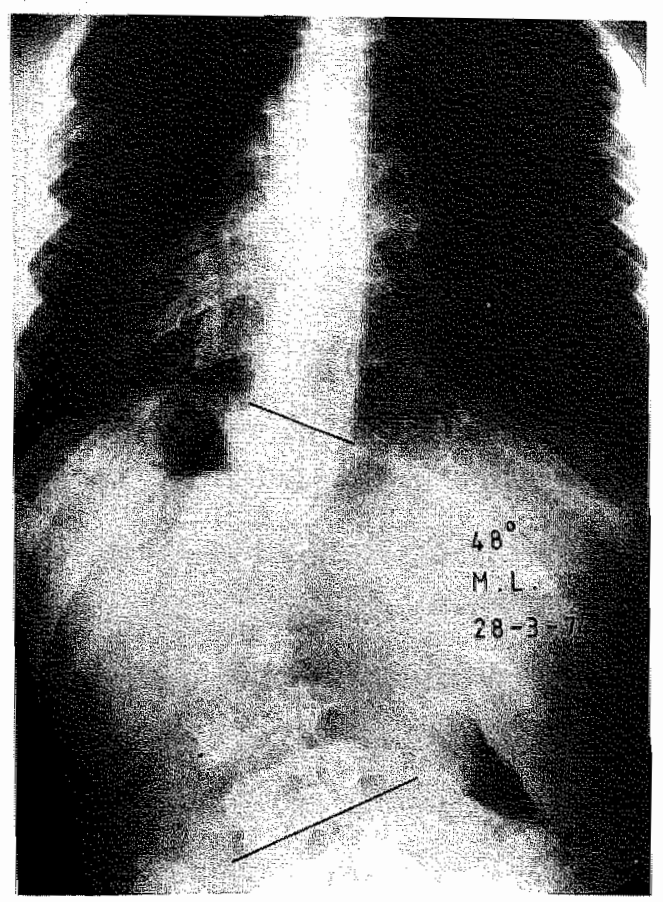

Scoliose préoperatief

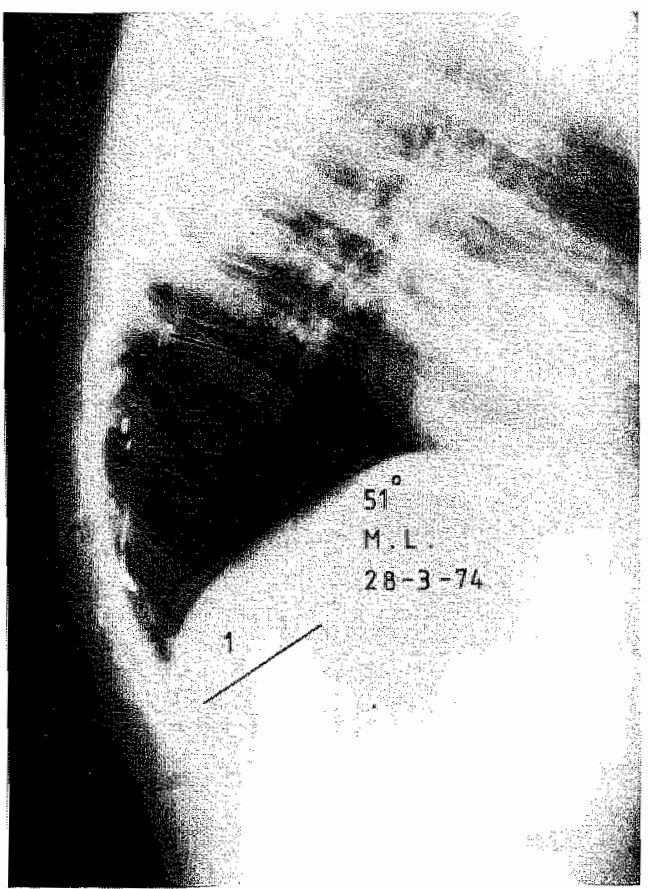

Kyfose préoperatief

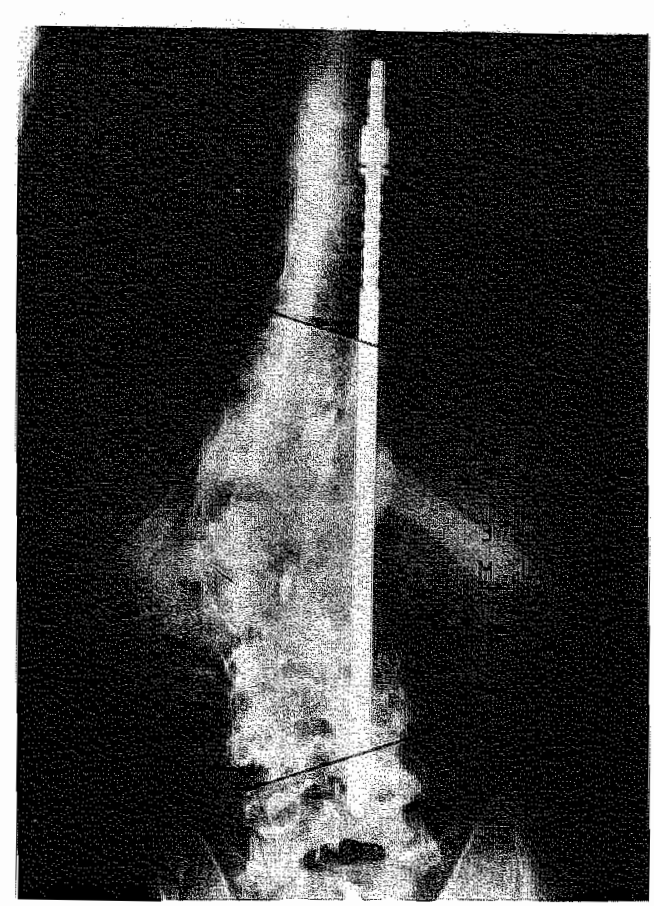

Scoliose $51 / 2$ jaar postoperatief

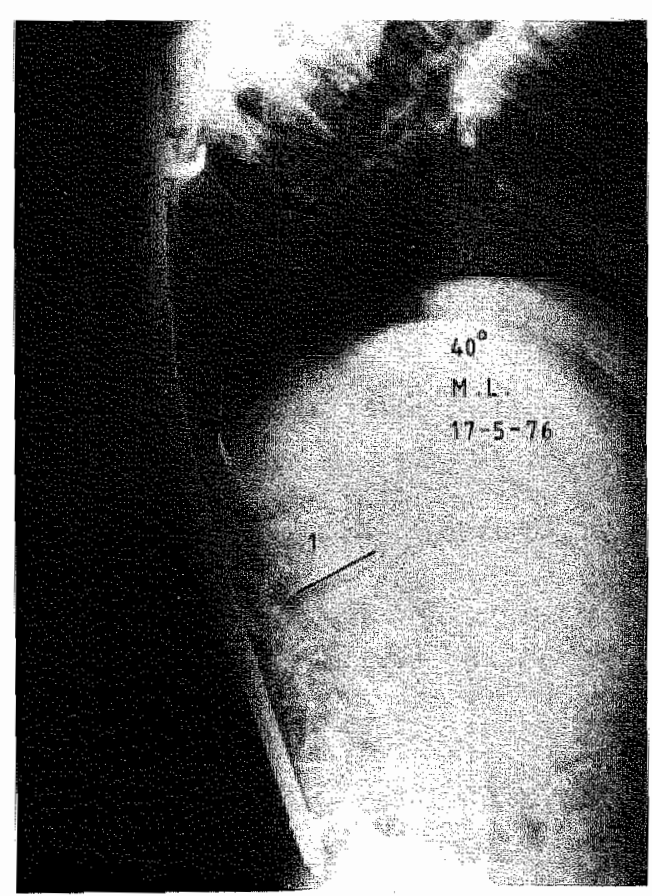

Kyfose $1 \frac{1 / 2}{2}$ jar postoperatief 
Patiẻnt 42. J. K. vrouwelijk, geb. dat. 27-3-1952.

Aetiologie:

Vroegere behandeling:

Klachten:

Préoperatieve curves:

Voorbehandeling:

Longfunctie:

Conclusie:

Neurologisch onderzoek:

Myelografie:

Urologisch onderzoek:

Operatie:
Kyfoscoliose na laminectomie en bestraling wegens sarcoom wervellichaam T9 of congenitale valanomalie op 5 maanden oude leeftijd. Een en ander blijkt niet duidelijk uit de beschikbare papieren. Op grond van de bestraling is een maligne tumor het meest waarschijnlijk.

Op 5 maanden oude leeftijd geopereerd en bestraald. Op 2-jarige leeftijd kan patiente lopen met behulp van corset en beugels. Vanaf het $8 \mathrm{e}$ jaar alleen met een corset. Op 15-jarige leeftijd ontstaat plotseling een verlamming van beide benen met incontinentie voor urine en faeces. Het rechter been herstelt praktisch volledig binnen 3 weken, het linker been blijft licht paretisch. In mei 1976 bestaat er een conus cauda beeld met partiële dwarslaesie op niveau T6. Epifysiodese knie 1967. De huid over de gibbus is zeer slecht.

Pijn ter plaatse van de thoraco-lumbale overgang, partiële dwarslaesie ter hoogte van T6.

Scoliose T5 t/m T10 $113^{\circ}$, T11 t/m L3 $124^{\circ}$, kyfose $\mathrm{T} 7 \mathrm{t} / \mathrm{m} \mathrm{L} 2120^{\circ}$.

Geen. Halo-tractie werd in verband met de neurologische afwijkingen te gevaarlijk geacht.

25-5-1976. Vit. cap. $1400 \mathrm{cc}$. Normal $4075 \mathrm{cc}$. Tot. cap. $2225 \mathrm{cc}$. Normaal $5275 \mathrm{cc}$.

Ernstige restrictieve functiestoornis met een spastische component.

Conus-cauda syndroom links meer dan rechts, gedeeltelijk van het Brown-Sequard type.

Vernauwing van het wervelkanaal ter plaatse van de gibbus.

Twee hypoplastische nieren.

1. 21-6-1976. Thoracotomie rechts. Release van het myelum met resectie wervellichamen T10 $\mathrm{t} / \mathrm{m}$ T12. achterlaten van ribgrafts. 
Complicaties:

Operatie:

Complicaties:

Nabehandeling:

Operatie:

Complicaties:

Nabehandeling:

Postoperatieve curves:

Postoperatieve klachten:
Volledige dwarslaesie, welke langzaam opklaart in verloop van enkele maanden met persisteren van ernstige restverschijnselen. Neurologisch onderzoek d.d. 9-11-1976: Pyramidaal syndroom nu meer uitgesproken, tevens rechts. Automatisme medullaire. Verdere complicaties: haematothorax, urinewegsepsis, decubitus op de gibbus. Na de eerste operatie langdurige Halo-rolstoeltractie in verband met de decubitus.

II. 10-1-1977. Voorste spondylodese met behulp van ribspanen via thoracotomie rechts.

Decubitus op de crista iliaca.

6 maanden Halo-rompgips, 3 maanden gipscorset. Echter geen consolidatie van de spondylodese. progressief verlies van correctie.

III. 14-11-1977. Voorste respondylodese $77 \mathrm{t} / \mathrm{m} \mathrm{L3}$ met behulp van fibulaspaan.

Geen.

3 weken Halo-Pelvic apparaat, 6 maanden Halorompgips, 3 maanden gipscorset.

Na operatie III.

$\mathrm{Na} 3$ weken

Scoliose

Kyfose

$\mathrm{Na} 3$ maanden

$58 / 60^{\circ}$

$67^{\circ}$

$65 / 65^{\circ}$

$83^{\circ}$

Na 9 maanden

$60 / 40^{\circ}$

$93^{\circ}$

Na 21 maanden

$76 / 62^{\circ}$

$92^{\circ}$

Geen pijnklachten. Persisterende rijksdalaldergrote decubitusplek op de gibbus. Geen dyspnoe. Loopt binnenshuis met 2 krukken en met bovenbeensbeugel links en onderbeensbeugel rechts. Builenshuis doet patiente alles met de rolstoed. Zij heeft een aangepast huis, een aangepaste auto en doet hatr vroegere kantoorwerk. Er is een goed stabiele wervelkolom, een praktisch geheel verlamd linker been. rechts een behoorlijke functie van de bovenbeenspieren en voetheffers. 
Bij deze patiënte is, gezien de partiële dwarslaesie, gekozen voor een decompressie van het myelum. Dat deze procedure riskant kan zijn is bekend. Tractie kan gevaarlijk zijn doordat de kyfose zelf hierbij niet altijd gestrekt wordt, maar wel de wervelkolom erboven en eronder. Hierdoor wordt het myelum over de kyfotische knik uitgerekt met progressie van de dwarslaesic. Na operatieve release van de kyfose kan deze wel gestrekt worden zonder dat een decompressie van het myelum hoeft te worden gedaan. Hierbij wordt het uitspannen van het myelum over de kyfose zelf verminderd. Niettemin heeft deze patiënte na de le operatie een ernstiger dwarslaesie dan tevoren. Later wordt gelukkig in twee instanties een goede spondylodese bereikt, waarbij opgemerkt moet worden dat een complementaire achterste spondylodese niet mogelijk is in verband met de slechte huid over de gibbus en de vroegere laminectomie. Het geweldige psychische incasseringsvermogen van de patiënte heeft er belangrijk toe bijgedragen dat het uiteindelijk resultaat bevredigend is, mede in het licht van de slechte prognose bij abstineren van operatie. 


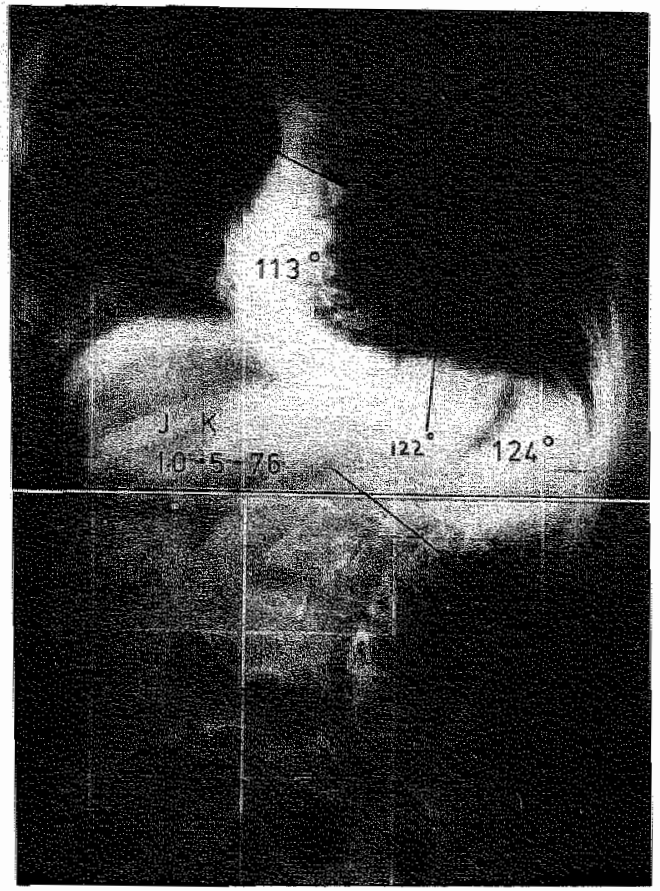

Préoperatieve scoliose

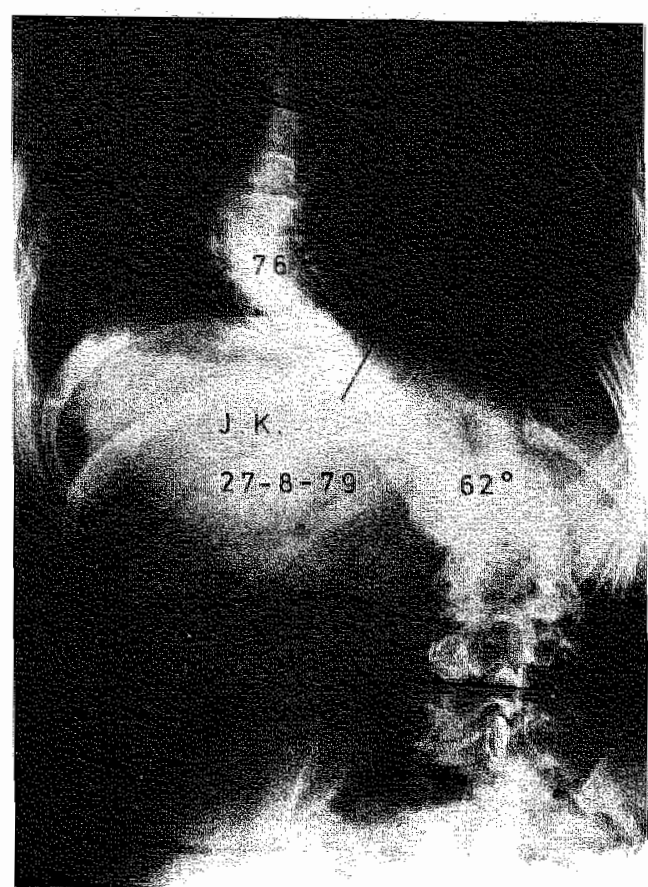

Resultaat na 3 jaar 


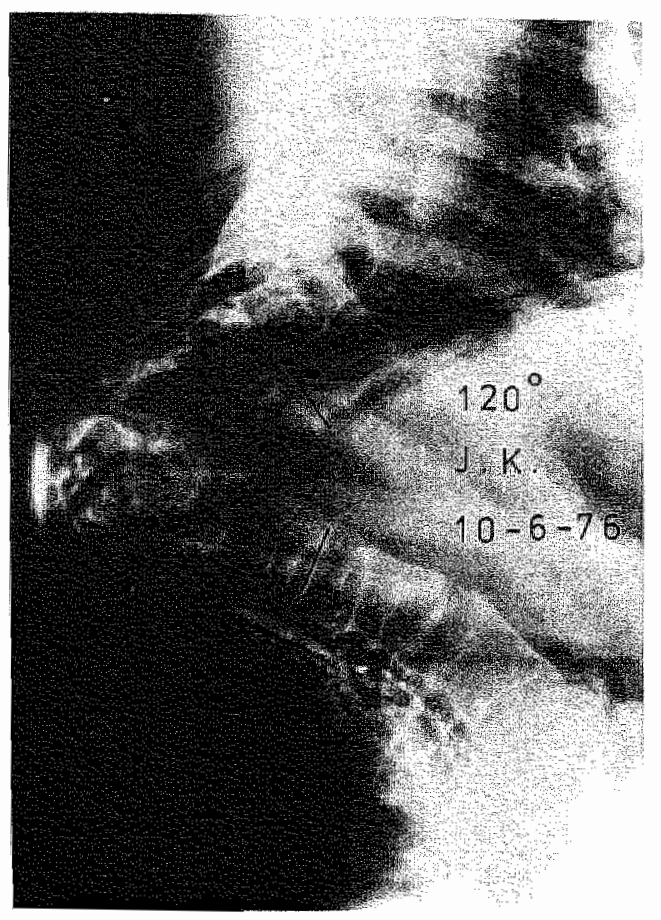

Kyfose préoperatief

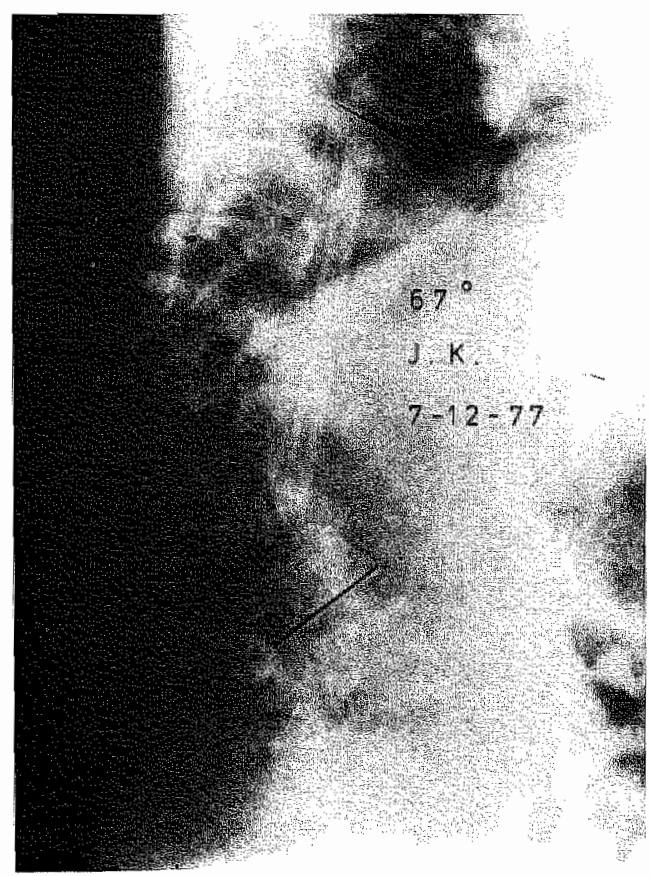

Situatie na 3e operatic

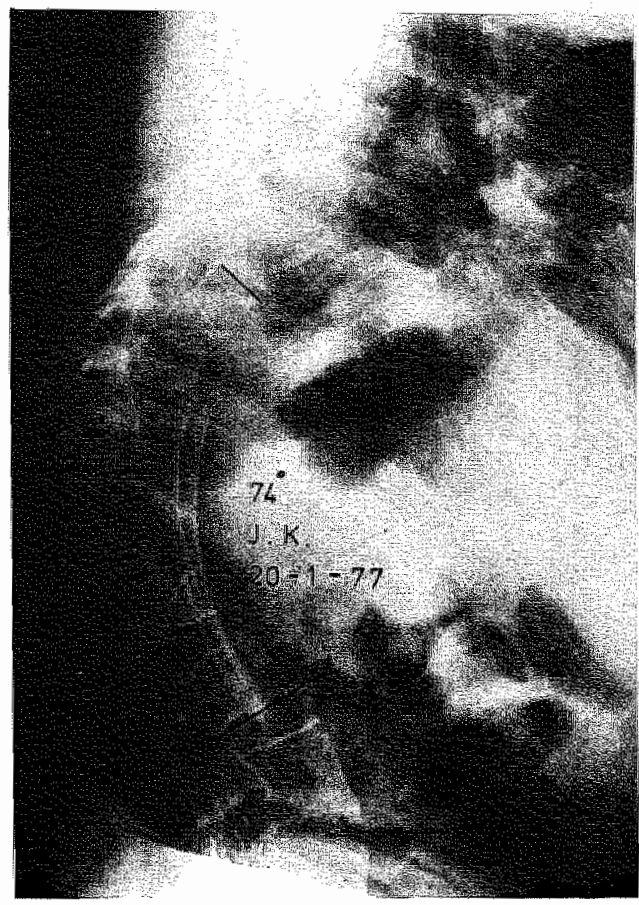

Situatie na 2e operatie

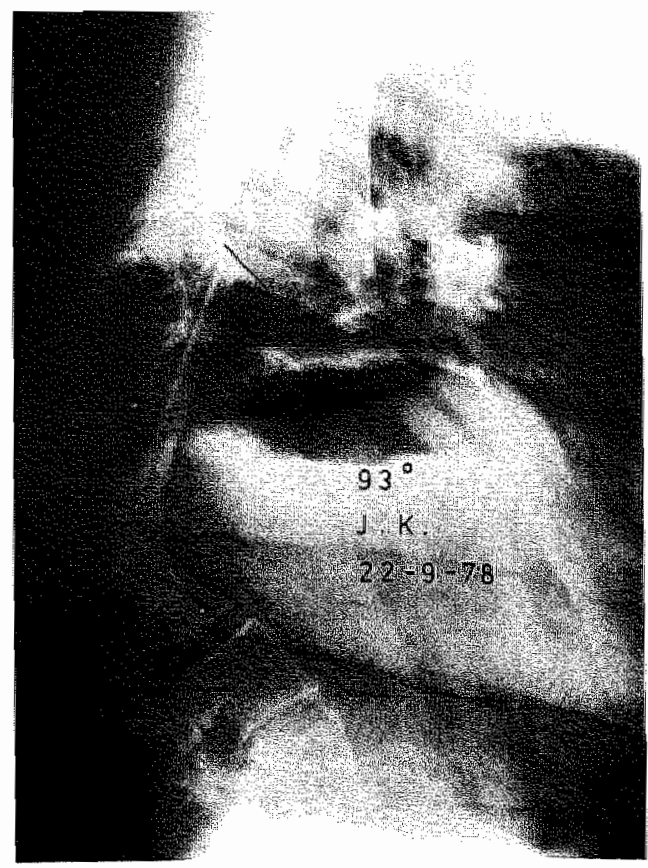

De fibulaspaan is ingegroeid en bouwt om 


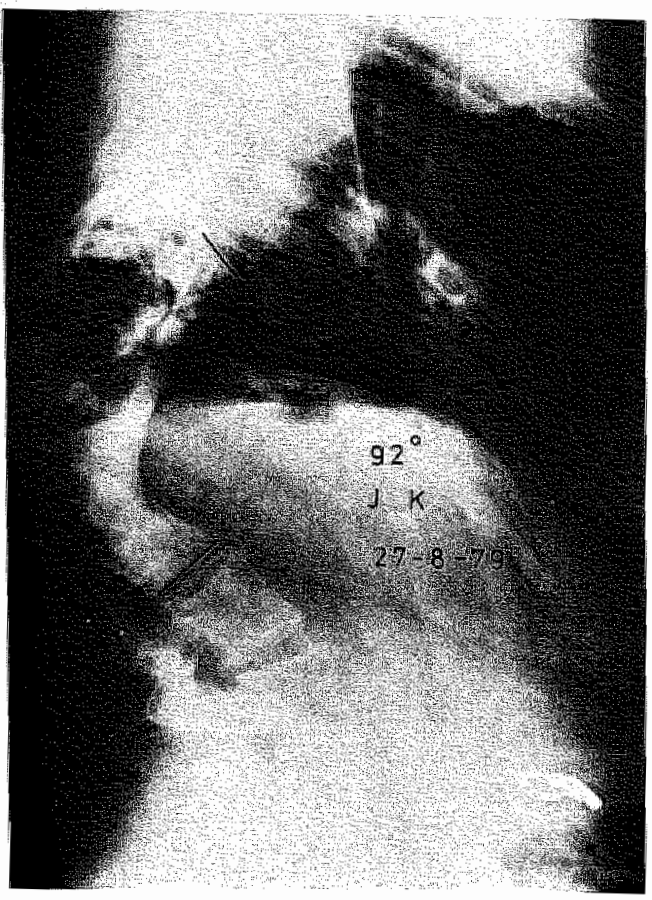

Fraaie ombouw van de fibulaspaan

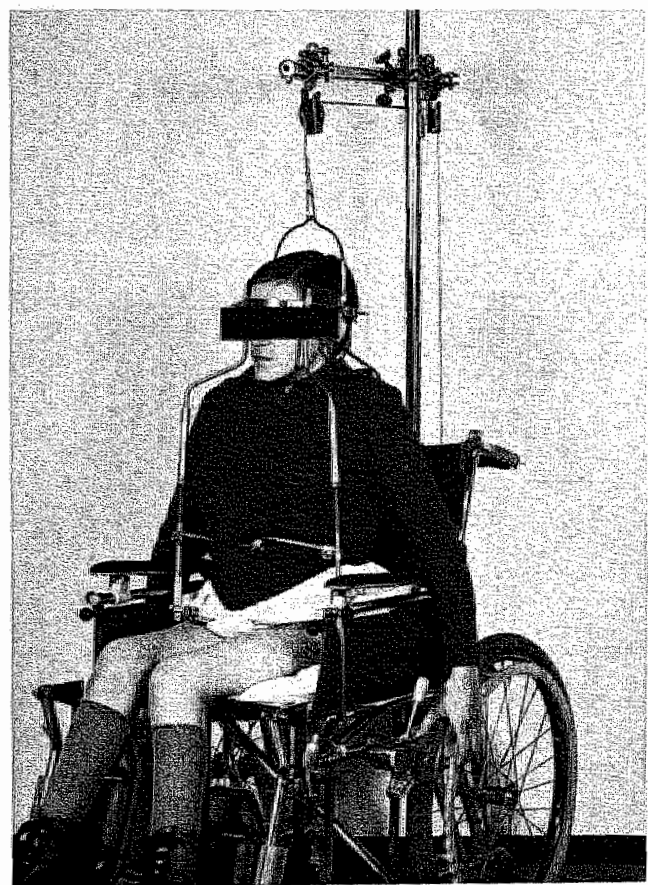

Patiënte in Halo-pelvicapparaat

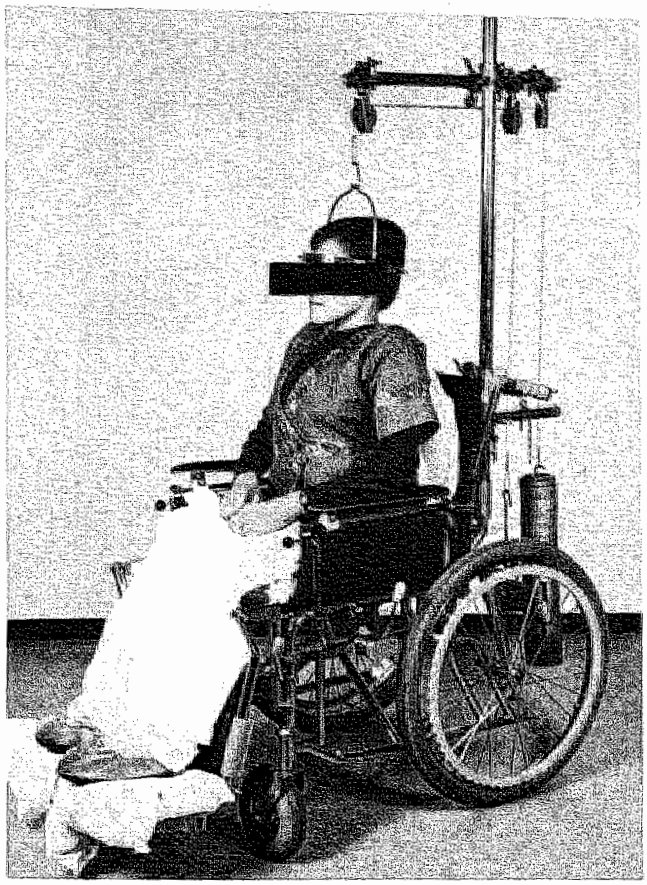

Patiënte in Halo-rolstoeltractie ( $18 \mathrm{~kg}$ )

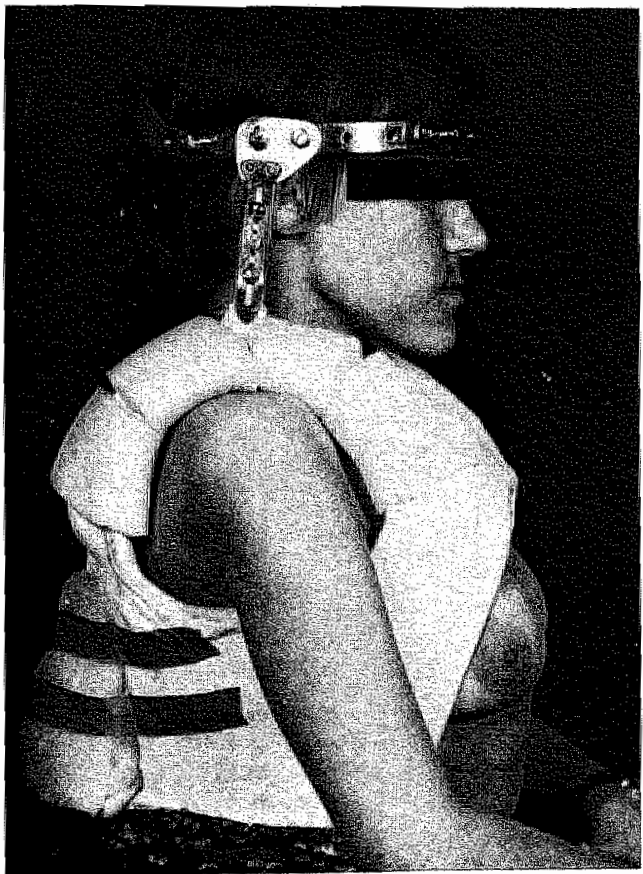

Patiente in Halo-rompgips 


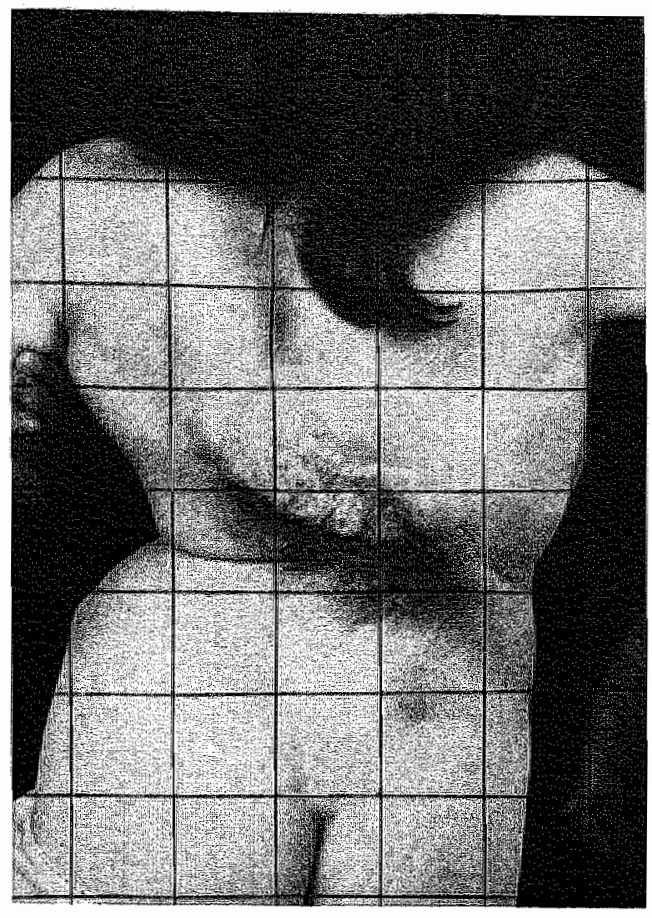

J. K. scoliose préoperatief

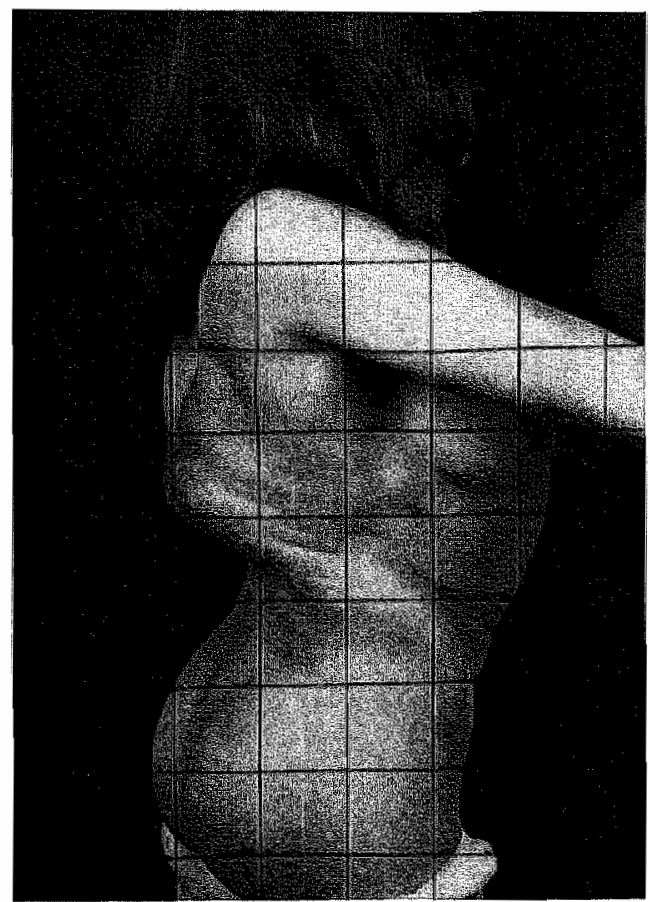

J. K. kyfose préoperatief

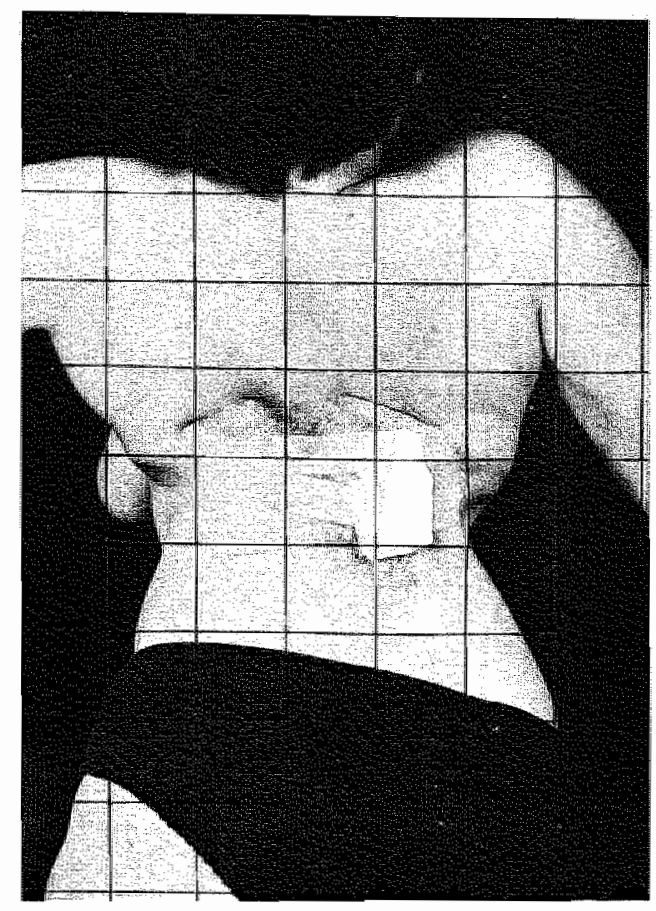

J. K. scoliose na 3 operaties

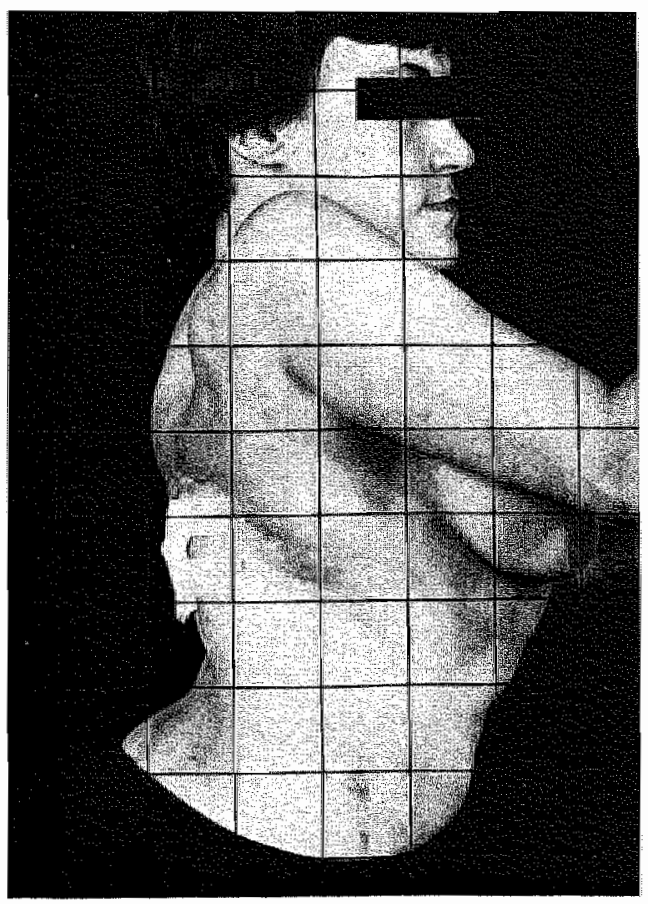

J. K. kyfose na 3 operaties 
Patiënt 43. E. K. vrouwelijk, geb. dat. 25-8-1948.

Aetiologie:

Vroegere behandeling:

Operatie:

Operatie:
Dislocatie van de wervelkolom met kyfosering ter plaatse van T12-LI op 24-jarige leeftijd na multipele laminectomieën wegens arachnoïditis.

Op 5 maanden oude leeftijd meningitis door haemophilus influenzae, behandeld met intrathecale injecties van antibiotica. Patiente ontwikkelt zich normaal tot 11-jarige leeftijd. Zij krijgt dan klachten over pijnlijke voeten, blaarvorming onder kopje metatarsale I beide voeten en een ronde rug. Er wordt $1 \mathrm{~cm}$ verkorting van het linker been gevonden en een geringe arcuaire kyfose van de wervelkolom. Behandeling door middel van heilgymnastiek en hakverhoging, later wordt een rechthouder gegeven. Op 13-jarige leeftijd ontwikkelen zich klachten van koude voeten en sneller vermoeid zijn van thet linker been, met onderbeensatrofie en blauwe verkleuring van tenen en koude voeten. Geen neurologische afwijkingen. Op 14-jarige leeftijd (januari 1963) wordt uitval van pijnzin van segment T11 $\mathrm{t} / \mathrm{m}$ S1 links gevonden, een Babinski reflex links, pathologische beenreflexen links en fasciculaties. Subocipitale punctie en myelografie toont een stop op T9. Van nu af vele operaties.

I. 31-1-1963. Laminectomie T9 t/m T12 met verwijderen van arachnoiditishaarden door de neurochirurg. Hierna weinig verandering van het klinisch beeld. Persisterend pijn in het linker been met een automatisme medullaire. Krijgt in 1965 toenemende dwarslinesie verschijnselen. Vooral in het linken been treedt een spastisch beeld op met clonicen en hoge reflexen. De diagnose wordt gesteld op een recidief arachnoïditis.

II. 6-5-1965. Relaminectomie, losmaken van arachnoïdale verklevingen, de dura wordt gesloten met een laagje periost.

Direkt postoperatief treedt er een verergering op van de neurologische situatie met totale verlamming van beide benen. Langzaam herstelt zich dit tot een spastisch beeld met grove sensibiliteitsuitval links meer dan rechts. De continentie blijft normaal. Patiënte kan moeizaam lopen met behulp wan krukken. Getracht wordt met phenolinjecties de spasticiteit te verminderen. In 1968 en 1969 toename van het spastisch beeld met krampen en moe, zwaar gevoel in de benen. 

arachnoiditis, verruming van de duraalzak met substituut. Partiële doorsnijding achterwortels L3-4-5. Postoperatief slappe paraparalyse, van het spastische beeld alleen nog een clonus van de voet over. Actief is er nawwelijks nog spierfunctie.

Anaesthesic onder niveau T9-TLO. Na enkele maanden terugkeer van de sterke spastische parese. In 1972 volgt opname wegens onaangename sensaties in de rug, met abnormale beweeglijkheid. Röntgenologisch bleek er een destructie van de wervellichamen T12 en L1 met afglijen van $T 12$ naar achteren en distaal ten opzichte van L. Gedacht wordt aan een infectieus proces.

Operatie:

IV. 22-3-1972. Open biopsie. Er wordt een holte zonder pus of tumorweefsel gevonden. Kweek negatief, ook P.A. onderzoek geen bijzonderheden. Situatie ter plekke zeer instabiel. Beleid na deze ingreep: conservatieve behandeling door middel van een orthopaedisch korset. Ondanks het korset progressieve afglijding.

Operatie:

V. 2-8-1972. Achterste spondylodese T11 t/m L2 in het spimale kanaal met behulp van $\mathrm{AO}$-plaat en cristachips. De myelumresten in het instabiele gebied worden gekliefd. Nabehandeling door middel van liggips en zitcorset. De spondylodese lijkt hierna goed geconsolideerd.

Operatie:

VI. 30-7-1973. Resectie tuber ischii rechts wegens decubitus. In 1975 blijkt er progressieve kyfosering te bestaan boven de spondylodese met breuk wan de bovenste schroef en mogelijk spontaanfractuur van de spondylodese.

Operatic:

VII. 5-9-1975. Uitbreiding van de achterste spondylodese T10 $\mathrm{t} / \mathrm{m} \mathbb{L} 2$ met behulp van het Dwyer instrumentarium.

Nabehandeling door lig- en zitgips gedurende 9 maanden. Echter ook nu weer progressieve kyfosering met pseudarthrose en breuk van de kabel ter plaatse van T11.

Operatie:

VTII. 10-8-1976. Respondylodese met behulp van nieuw Dwyer instrumentarium en 2 staples, aviveren van pseudarthrose ter plaatse van T11.

Nabehandeling zitgipscorset en ortholane corset. Consolidatie wordt nu wel bereikt. Resterende kyfose slechts $5^{\circ}$. 
Knagend gevoel in de rug. Zonder corset vermoeidheid. Irritatie van de rechter staple onder de huid. Deze wordt op 10-1-1980 onder locale anaesthesie verwijderd. Röntgenologische controlles tonen geen verandering.

Beschouwing en conclusie:

Arachnoïditis is een gevreesde afwijking, waarbij sterke fibrosering optreedt met uitval van zenuwfunctie. Deze afwijking treedt soms na operatie op, of na myelografie met oliehoudend contrast. In dit geval lijkt de vroegere meningitis met intrathecale injecties van antibiotica een oorzakelijke factor. Operatieve verwijdering van het arachnoiditisweefsel is berucht om zijn recidief, zoals bij deze patiënte het geval is. Het gevolg van de arachnoïditis, de multipele laminectomieën en denervatie ter plekke, ook van de musculatuur is een pseudo-arthrose van de wervelkolom ter plaatse van T12-L1, gelijkend op een Charcot gewricht bij neuropathie. Stabilisatie van de wervelkolom is aangewezen om de instabiliteit en progressie van de afglijding ondanks corset op te heffen. Het kost 3 operaties voordat de spondylodese solide is. De slechte botgenezing in neurotrofisch gestoorde gebieden is bekend. terwijl in dit geval de spondylodese aan de achterzijde van de wervellichamen mechanisch gezien vrij zwak is. Uiteindelijk is mede met behulp van eenvoudige instrumenten, zoals staples de spondylodese goed geslaagd met geringe resterende kyfose. Patiënte heeft echter om de snelle vermoeidheid van de rug tegen te gaan een corset nodig, waarmee zij een goede zitfunctie heeft en nagenoeg geen klachten. 


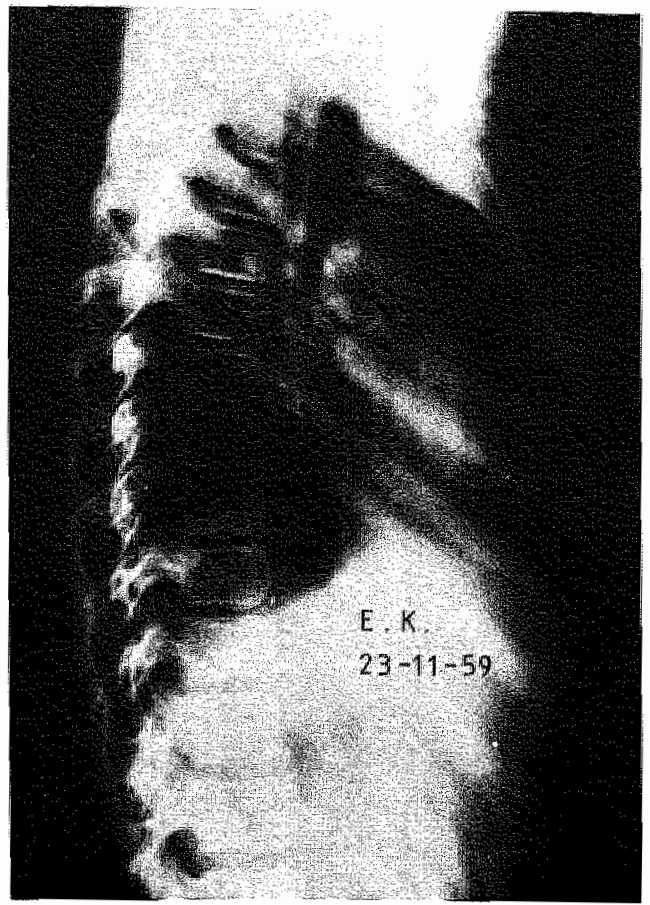

Normale wervelkolom in 1959

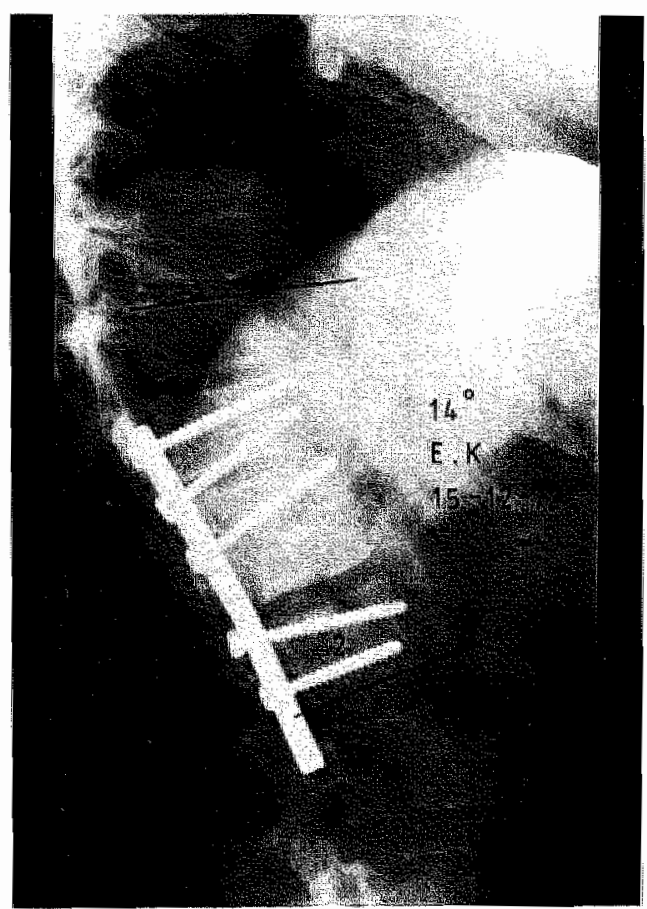

Na eerste spondylodese

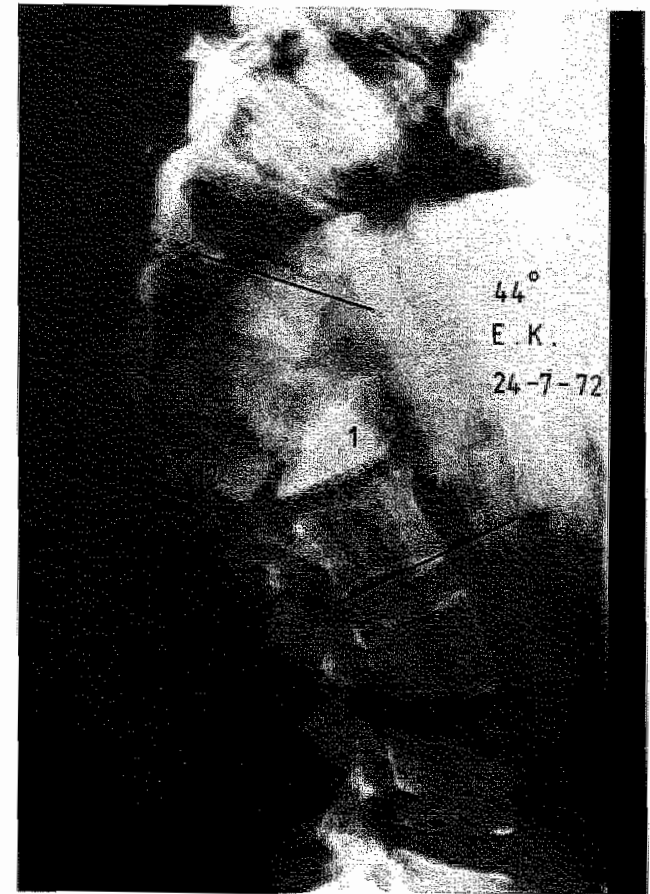

Situatie in 1972

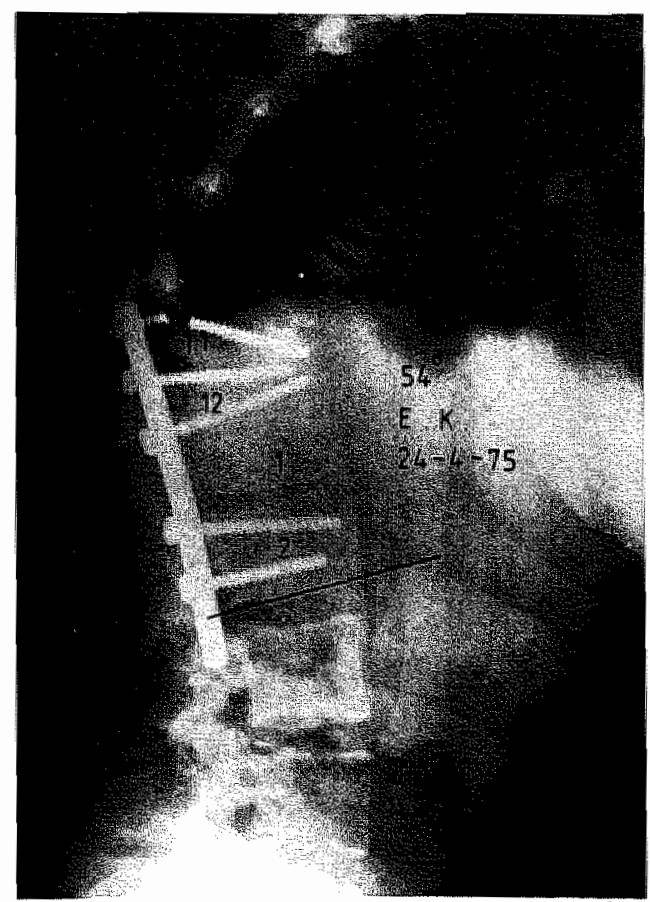

Rekyfosering in 1975 


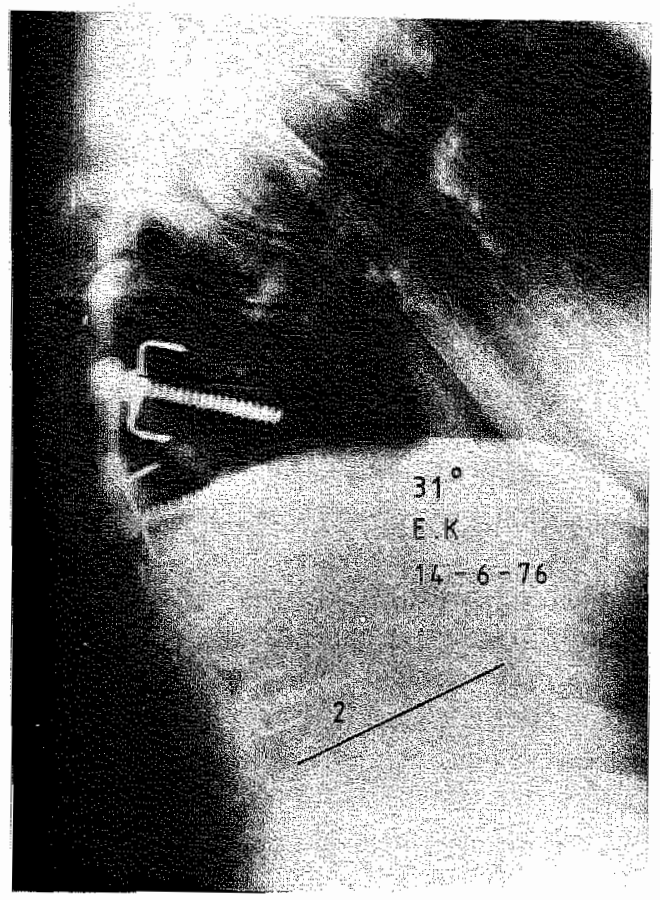

Pseudarthrose na operatie VII

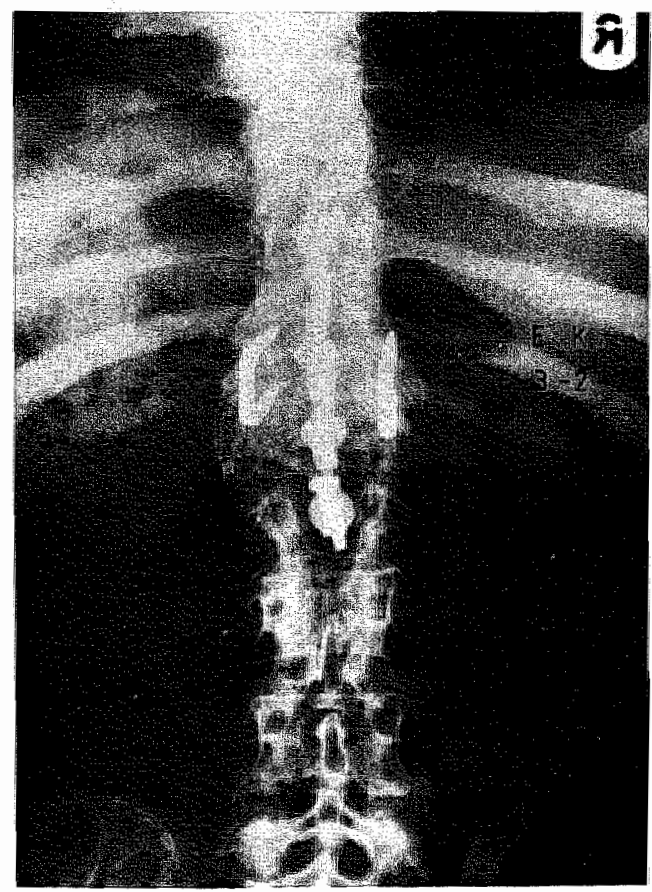

A.P. aanzicht van de geslaagde spondylodese

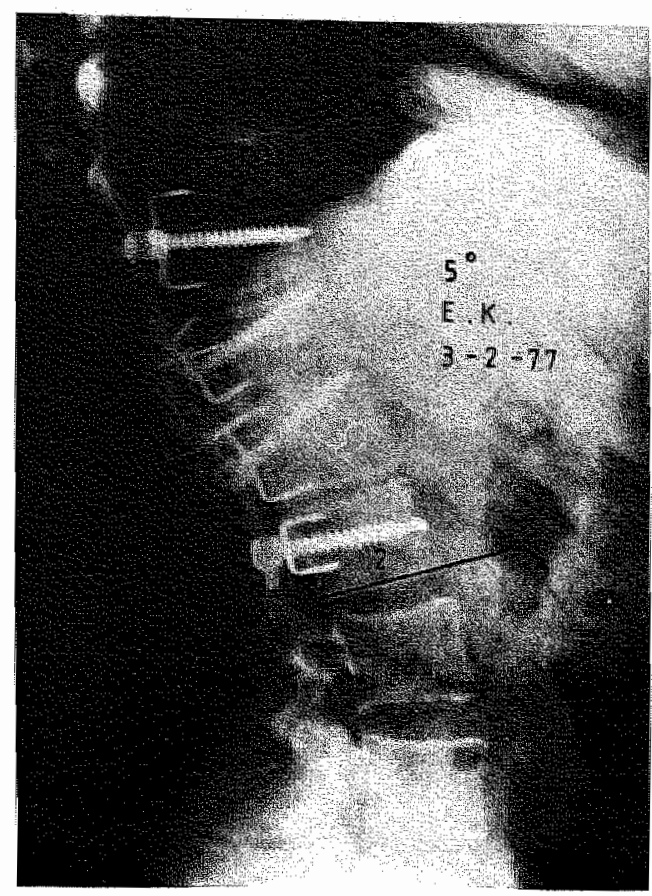

Uiteindelijke spondylodese in 1977 


\section{TRAUMATISCHE KYFOSEN}

\subsection{Inleiding}

Wervelfracturen krijgen de laatste jaren, ook in Nederland steeds meer aandacht. Er is een discussie gaande tussen de voorstanders van conservatieve en operatieve behandeling, waarbij beide groepen goedle resultaten claimen $(1,3,6,8,10,11,14-18,20,23$, $30,33,35,39,40,42,45,47,49)$.

Door de ontwikkeling van goed intern fixatiemateriaal kiezen steeds meer artsen voor een meer operatief gerichte aanpak, teneinde betere repositie van de fractuur, betere en snellere neurologische verbetering bij partiële dwarslaesie en snellere mobilisatie te verkrijgen. Het ligt niet in de bedoeling uitgebreid op de acute letsels in te gaan, maar omdat bij het beoordelen van de latere wervelkolomdeformiteit kennis van het acute gebeuren vereist is, zal deze inleiding toch voor een groot deel over de verse fracturen gaan. Belangrijke factoren bij wervelfracturen zijn:

1. Type fractuur, al of niet stabiel.

2. Neurologische uitval.

3. Localisatie van de fractuur.

4. Leeftijd van de patiënt.

ad. 1 .

De wervelkolom kan onderscheiden worden in 2 gedeeltes $(25,52)$.

De voorste pijler bestaat uit wervellichamen, disci, ligamentum longitudinale anterius en posterius.

De achterste pijler bestaat uit laminae, facetgewrichten, ligamentum flavum, processi spinosi met ligamentum interspinosum en supraspinosum.

Men onderscheidt ook wel afzonderlijk nog een middelste pijler, welke van cruciaal belang zou zijn voor de stabiliteit en ernst van de neurologische uitval. Deze middelste pijler bestaat uit de achterste gedeelten van de wervellichamen en disci en het ligamentum longitudinale posterius (34).

Het achterste complex heeft de meeste rigiditeit en is de belangrijkste factor voor het al of niet optreden van instabiliteit. Bij laesie van beide (of drie) complexen bestaat een acute instabiliteit, bij laesie van alleen het achterste complex kan chronische instabiliteit optreden, evenals door beschadiging van het voorste complex op meerdere niveaus (3). Instabiliteit is ook een begrip in tijd. Wat direct na het ongeval acuut instabiel is, kan na 3 maanden door bot en weke delen genezing volledig stabiel geworden zijn ( 1 . $11,15,39)$.

ad. 2 .

Neurologische schade kan volledig of partieel zijn. Volledige dwarslaesie, welke in 24 uur niet verandert, heeft een zeer slechte prognose en wordt niet beïnloed door chirurgische decompressie $(1,6,10,15,16,29,40,45,47,52)$. In eerste instantie moet het handelen bij volledige dwarslaesie gericht zijn op een zo spoedig mogelijk starten van de revalidatie van de patiënt, wat kan betekenen: spondylodese bij instabiele wervelfractuur met de mogelijkheid patiënt vroeg te verticaliseren. Bij partiële paraplegie bestaat een grote kans op spontaan herstel, met name geldt dit voor conus-cauda letsels.

Diverse auteurs melden een sneller en meer volledig herstel na operatieve decompres- 
sie en stabilisatie, waarbij het opnieuw herstellen van de contouren van het spinale kanaal voorop staat $(2,18,20,21,27,33,42,47,49)$. Vergelijken van neurologisch herstel tussen geopereerde en niet geopereerde patiëntengroepen is echter niet goed mogelijk, zodat hierover een duidelijk inzicht nog niet verkregen is.

ad. 3.

Het thoracale spinale kanaal is nauwer dan het lumbale kanaal. Bovendien is het myelum meer traumagevoelig dan de cauda equina, terwijl ook de bloedvoorziening naar het thoracale myelum minder rijk is dan op lagere localisatie. Conus-cauda laesies hebben dan ook een betere prognose dan thoracale of cervicale dwarslaesies (16.33). Maar ook als er geen enkele neurologische uitval is, speelt de localisatie een belangrijke rol. Hier geldt de volgende regel: Hoe lager de fractuur in de wervelkolom en hoe groter de kyfosehoek des te ongunstiger wordt de statiek beïnvloed.

and. 4 .

$\mathrm{Bij}$ kinderen hebben wervelfracturen zonder neurologische schade zelden ernstige deformiteit tot gevolg, mits er geen letsel van de groeikernen is (36). Met dwarslaesie treedt echter in een hoog percentage van de kinderen wervelkolondeformiteit op atls gevolg van paralyse van onder andere de lange rugspieren. Tijdig moet dan ook begonnen worden met brace therapie, dus als de deformiteit nog in een vroeg stadium is. Anaesthesie van de huid bemoeilijkt dit wel, maar maakt bracing niet onmogelijk. Vaak zal toch uiteindelijk operatie aangewezen zijn. Bij traumatische dwarslaesie op de kinderleeftijd, gevolgd door laminectomie zijn alle voorwaarden aanwezig voor het ontwikkelen van een wervelkolomdeformiteit, met name een progressieve kyfose $(32,36)$.

\section{Classificatie:}

Wervelfracturen kunnen op diverse manieren worden ingedeeld, zoals bijvoorbeeld naar aard van het inwerkend trauma. Een gemakkelijker te hanteren classificatie is de volgende:

1A. Stabiele fracturen zonder neurologische schade.

1B. Instabiele fracturen zonder neurologische schade.

2A. Stabiele fracturen met incomplete dwarslaesie.

2B. Instabiele fracturen met incomplete dwarslaesie.

3A. Stabiele fracturen met complete dwarslaesie.

3B. Instabiele fracturen met complete dwarslaesie.

Hierachter zou men dan het type fractuur kunnen vermelden, zoals flexie-compressiefractuur, flexie-distractie (Chance) fractuur $(5,48)$, axiale compressie (Burst) fractuur (33), flexie rotatie (Slice) fractuur (17).

\subsection{Behandeling}

Ad. 1A/1B.

Deze fracturen behoeven weinig tot geen behandeling. Meestal betreft het geringe compressiefracturen of burstfracturen zonder veel inzakking. Enige tijd bedrust mel of zonder corsettherapie hierna is voor genezing van dit soort fracturen voldoende $(4,7,9$, $22,30,39,43,50,51)$. Compressie van het wervellichaam meer dan $50 \%$ van de wervelhoogte duidt al op een zekere mate van instabiliteit, omdat het achterste ligament- 
complex hierbij geruptureerd zal zijn. Het ligamentum longitudinale anterius zal vrijwel altijd gespaard blijven, zodat met lordoserende gipsen of corsetten de gebroken wervel ontplooid kan worden. Teleurstellend is het vaak later weer inzakken van de aangedane wervel, terwijl door de lang aangehouden lordosering de aangrenzende facetgewrichten geschaad worden en verlies van beweeglijkheid niet zelden optreedt $(4,22,51)$. Afzien van fractuurrepositie betekent vaak een persisterende kyfose op een mechanisch gezien ongunstige plaats, meestal is dit thoraco-lumbaal. Hierdoor kan overbelasting van de musculatuur optreden, terwijl ook de kyfose zelf pijnlijk kan zijn (7). Of operatie voor deze groep fracturen de oplossing is, lijkt vooralsnog niet duidelijk.

\section{Ad. $2 \mathrm{~A} / 2 \mathrm{~B}$}

Incomplete dwarslaesiebeelden hebben een goede kans op verbetering als voldoende ruimte in het spinaalkanaal is overgebleven, dit zou meer dan $50 \%$ van de oorspronkelijke voor-achterwaartse diameter moeten zijn. Een CT-scan is een uitstekende methode om dit te visualiseren $(24,26,34,47)$. Minder overgebleven ruimte met compressie op het myelum of conus-cauda betekent een operatie indicatie, waarbij getracht moet worden de oorspronkelijke ruimte van het spinale kanaal te herstellen $(20,33,37,42$, 47). Dit kan gebeuren door met behulp van Harrington distractie staven de fractuur aan de achterzijde op te spannen, zodat een realignement wordt verkregen. Hierbij wordt de compressie, welke bijna altijd aan de voorzijde van de duraalzak is gelocaliseerd en veroorzaakt wordt door de ingestuikte achterkant van het wervellichaam opgeheven. Overcorrectie is onmogelijk als het ligamentum longitudinale anterius intact is. Dit is bij praktisch alle flexie en compressie fracturen het geval $(3,8,10,12,19,20,33,38$, $47,52)$. Bij distractie fracturen of dislocaties kan het compressiesysteem volgens Harrington gebruikt worden, terwijl de laatste jaren ook het segmentale instrumentatiesysteem volgens Luque furore maakt $(31,34)$. Een nadeel van dit laatste systeem is dat het geen distractie geeft en de fractuur langs de staaf weer kan inzakken. Zijn er losse fragmenten in het spinale kanaal dan kunnen deze via een kleine laminectomie verwijderd worden. In de toekomst zal waarschijnlijk steeds vaker een voorste oprichtingsspondylodese plaatsvinden met zonodig voorste decompressie of interne fixatie, omdat aan de voorzijde met minder segmenten kan worden volstaan ( 2 à 3 ten opzichte van 5 à 6 aan de achterzijde), terwijl het gevaar van rekyfosering minder is $(2,21,32,37)$. Lijkt de stabiliteit van de fractuur goed en is er voldoende ruimte in het spinale kanaal, dan is conservatieve aanpak gerechtvaardigd. Bij instabiele fracturen met kans op chronische instabiliteit (bijwoorbeeld fractuur-dislocaties of flexie-rotatie fracturen) lijkt operatieve decompressie en stabilisatie de betere keus, ondat bij latere progressie van de dislocatie of kyfose de neurologische symptomatologie kan verergeren (32).

\section{Ad. $3 \mathrm{~A} / 3 \mathrm{~B}$.}

Volledige dwarslaesiebeelden hebben een slechte prognose. Praktisch alle auteurs zijn het erover eens dat met welke therapie dan ook verbetering zelden of nooit optreedt. Elke fractuur of dislocatie welke een volledige dwarslaesie veroorzaakt moet ten tijde van het ongeval instabiel zijn geweest om het myelum zo ernstig te kunnen beschadigen. De mate van resterende instabiliteit moet nagegaan worden om te bezien of operatieve behandeling in de zin van een stabiliserende operatie zinvol is. Dit zal vooral het geval zijn bij meer ligamentaire letsels, terwijl bij uitgebreide ossale letsels door natuurlijke botgenezing na enkele maanden in het algemeen voldoende stabiliteit zal zijn bereikt om de patiënt te verticaliseren $(1,6,11,14,15)$. Laminectomie is gecontraïndiceerd omdat hiermee extra instabiliteit wordt gecreëerd, terwijl de prognose van de 
dwarslaesie er niet door verbetert $(1,9,15,25)$. Opstijgende paraplegie door een zich uitbreidend epiduraal haematoom vormt wel een indicatie voor operatieve exploratic (1).

\section{Verouderde traumatische $k y$ fose}

Progressieve kyfosering na wervelletsels kan optreden bij de volgende situaties:

1. De fractuur was instabiel en werd onvoldoende geredresseerd en/of geimmobiliseerd.

2. Er vond een laminectomie plaats.

3. Er trad een paraplegie op de kinderleeftijd op.

De kyfose in de eerste 2 situaties is over een kort traject gelocaliseerd en bijna altijd rigide van karakter. Een achterste spondylodese is hierbij wel mogelijk, maar zal geringe correctie geven omdat aan de voorzijde de rigiditeit gelocaliseerd is. Het is in het algemeen beter aan de voorzijde een oprichtingsspondylodese te verrichten zonodig met decompressie van de duraalzak. De ingebrachte botgratts staan aan de voorzijde onder compressie, terwijl zonodig interne fixatie met het Zielke materiaal of met ander instrumentarium verricht kan worden. Een toegevoegde achterste spondylodese is hierma zelden nodig $(2,21,32)$.

Bij de paraplegie op de kinderleeftijd treden langgerekte curves op, voor de bespreking van deze deformiteit verwijs ik naar het hoofdstuk over paralytische kyfose.

\subsection{Literatum hoofdstuk 9}

1. Bedbrook G. M. Use and disuse of surgery in lumbodorsal fractures. Journ. West Pacific Orthop. Association 6, 1969, 5-26.

2. Bohlman H. H. Eismont F. J. Surgical techniques of anterior decompression and fusion for spinal cord injuries. Clin. Orthop. 154, 1981, 57-67.

3. Bradford D. S. Akbarnia B. A. Winter R. B. Seljeskog E. L. Surgical stabilization of fracture and fracture-dislocations of the thoracic spine. Spine $2,1977,185-196$.

4. Bürkle de la Camp H. Funktionelle Wirbelbruchbehandiung oder Böhlersche Wirbelbruchaufrichtung. Archiv für Klinische Chirurgie 200, 1940, 32' -337.

5. Chance $G$. Q. Note on a type of flexion fracture of the spine. Brit. Journ. of Radiol. $21,1948,452-453$.

6. Davies W. E. Morris J. H. Hill V. An analysis of conservative (non-surgical) management of thoracolumbar fractures and fracture-dislocations with neural damage. Journ. of Bone and Joint Surg. 62A, 1980, 1324-1328.

7. Day B. Kokan P. Compression fractures of the thoracic and lumbar spine from compensable injuries. Clin. Orthop. 124, 1977, 173-176. 
8. Dickson J. H. Harrington P. R. Erwin W. D. Results of reduction and stabilization of the severelly fractured thoracic and lumbar spine. Journ. of Bone and Joint Surg. $60 \mathrm{~A}, 1978,799-805$

9. Dorr L. D. Harvey Jr. J. P. Nickel V. L. Clinical review of the early stability of spine injuries. Spine 7, 1982,545-550.

10. Flesch J. R. Leider L. L. Erickson D. L. Chou S. N. Bradford D. S. Harrington instrumentation and spine fusion for unstable fractures and fracture-dislocation of the thoracic and lumbar spine. Journ. of Bone and Joint Surg. 59A, 1977, 143-153.

11. Frankel H. L. Hancock D. O. Hyslop G. Melzak J. Michaelis L. S. Ungar G. H. Vernon J. D. S. Walsh J. J. The value of postural reduction in the initial management of closed injuries of the spine with paraplegia and tetraplegia. Paraplegia 7. $1969,179-192$.

12. Gertzbein S. D. MacMichael D. Tile M. Harrington instrumentation as a method of fixation in fractures of the spine. A Critical analysis of deficienties. Journ. of Bone and Joint Surg. 64B, 1982, 526-529.

13. Gumley G. Taylor T. K. F, Ryan M. D. Distraction fractures of the lumbar spine. Journ. of Bone and Joint Surg. 64B, 1982, 520-525.

14. Guttmann L. Management of spinal cord injuries. Chapter 12 in: Modern trends in diseases of the vertebral column. Butterworths Medical Publications. London 1959.

15. Guttmann L. Spinal deformities in traumatic paraplegics and tetraplegics following surgical procedures. Paraplegia 7, 1969, 38-49.

16. Hardy A. G. The treatment of paraplegia due to fracture-dislocations of the dorsolumbar spine. Paraplegia 3, 1965, 112-123.

17. Holdsworth F. W. Fractures, dislocations, and fracture-dislocations of the spine. Journ. of Bone and Joint Surg. 52A, 1970, 1534-1551.

18. Jacobs R. R. Asher M. A. Snider R. K. Dorso-lumbar spine fractures: recumbent vs. operative treatment. Paraplegia 18, 1980, 358-376.

19. Jacobs R. R. Nordwall A. Nachemson A. Reduction, stability, and strength provided by internal fixation systems for thoracolumbar spinal injuries. Clin. Orthop. $171,1982,300-308$.

20. Jelsma R. K. Kirsch P. T. Jelsma L. F. Ramsey W. C. Rice J. F. Surgical treatment of thoracolumbar fractures. Surg. Neurol. 18. 1982, 156-166.

21. Johnson J. R. Leatherman K. D. Holt R. T. Anterior decompression of the spinal cord for neurological deficit. Spine 8. 1983.396-405. 
22. Katthagen B.-D. Rehn J. Büchter M. Formveränderung von Wirbelkompressionsbrüchen unter funktioneller Therapie. Zeitschr. f. Orthop. 119, 1981,811812.

23. Kaufer H. Hayes J. T. Lumbar fracture-dislocation. Journ. of Bone and Joint Surg. 48A, 1966, 712-730.

24. Keene J. S. Goletz T. H. Lilleas F. Alter A. J. Sackett J. F. Diagnosis of vertebral fractures. A comparison of conventional radiography, conventional tomography and computed axial tomography. Journ. of Bone and Joint Surg. 64A. 1982, 586595.

25. Kelly R. P. Whitesides T. E. Treatment of lumbo-dorsal fracture-dislocations. Ann of Surg. 167, 1968, 705-717.

26. Kilcoyne R. F. Mack L. A. King H. A. Ratcliffe S. S. Loop J. W. Thoracolumbar spine injuries associated with vertical plunges: reappraisal with computed tomography. Radiology 146, 1983, 137-140.

27. Larson S. J. Holst R. A. Hemmy D. C. Sances A. Lateral extracavitary approach to traumatic lesions of the thoracic and lumbar spine. Journ. of Neurosurg. 45 , $1977.628-637$.

28. Leidholt J. D. Young J. J. Hahn H. R. Jackson R. E. Gamble W. E. Milis J. S. Evaluation of late spinal deformities with fracture-dislocations of the dorsal and lumbar spine in paraplegics. Paraglegia 7, 1969, 16.

29. Lewis J. McKibbin B. The treatment of unstable fracture-dislocations of the thoraco-lumbar spine accompanied by paraplegia. Journ. of Bone and Joint Surg. 56B, $1974,603-612$.

30. Ludolph E. Hierholzer G. Funktionelie Behandlung der Frakturen an der Brustund Wirbelsäule. Der Orthopäde 12, 1983, 1.36-142.

31. Luque E. R. Cassis N. Ramirez-Wiella G. Segmentat spinal instrumentation in the treatment of fractures of the thoracolumbar spine. Spine 7, 1982, 312-317.

32. Malcolm B. W. Bradford D. S. Winter R. B. Chou S. N. Posttraumatic kyphosis. A review of forty-eight surgically treated patients. Journ. of Bone and Joint Surg. $63 \mathrm{~A}, 1981,891-899$.

33. McAfee P. C. Yuan H. A. Lasda N. A. The unstable burst fracture. Spine 7, 1982. 365-373.

34. McAfee P. C. Yuan H. A. Frederickson B. E. Lubicky J. P. The value of computed tomography in thoracolumbar fractures. Journ. of Bone and Joint Surg. 65 A. 1983. 461-473. 
35. McKibbin B. Editorial: Internal fixation in fractures of the thoracolumbar spine. Journ, of Bone and Joint Surg. 64B, 1982, 517-518.

36. McPhee I. B. Spinal fractures and dislocations in children and adolescents. Spine 6 , $1981,533-537$.

37. Moon M. S. Kim 1. Woo Y-K. Lee J-J. Anterior interbody fusion in fractures and fracture-dislocations of the spine. Int. Orthop. 5, 1981, 143-149.

38. Nagel D. A. Koogle T. A. Piriali R. L. Perkash I. Stability of the upper lumbar spine following progressive disruptions and the application of individual internal and external fixation devices. Journ. of Bone and Joint Surg. 63A, 1981, 62-70.

39. Nicoll E. A. Fractures of the dorso-lumbar spine. Journ. of Bone and Joint Surg. 31B, 1949, 376-394.

40. Osebold W. R. Weinstein S. L. Sprague B. L. Thoracolumbar spine fractures. Results of treatment. Spine 6, 1981, 13-32.

41. Purcell G. A. Markolf K. L. Dawson E. G. Twelfth thoracic-first lumbar vertebral mechanical stability of fractures after Harrington-rod instrumentation. Journ. of Bone and Joint Surg. 63A, 1981, 71-78.

42. Riska $\mathbb{E}$. B. Antero-lateral decompression as a treatment of paraplegia following vertebral fracture in the thoracolumbar spine. Int. Orthop. 1, 1977, 22-32.

43. Roaf R. A study of the mechanics of spinal injuries. Journ. of Bone and Joint Surg. $42 \mathrm{~B}, 1960,810-823$.

44. Roaf R. International classification of spinal injuries. Paraplegia 10, 1972, 78-84.

45. Roberts P. H. Internal metallic splintage in the treatment of traumatic paraplegia. Injury 1, 1969, 4-11.

46. Roberts J. B. Curtiss P. H. Stability of the thoracic and lumbar spine in traumatic paraplegia following tracture or fracture dislocation.

47. Schmidek H. H. Gomes F. B. Seligson D. McSherry J. W. Management of acute unstable thoracolumbar (T11-L1) fractures with and without neurological deficit. Neurosurg. 7, 1980, 30-35.

48. Smith W. S. Kaufer H. Patterns and mechanisms of lumbar injuries associated with lap seat beits. Journ. of Bone and Joint Surg. 51 A, 1969, 239-254.

49. Soreff J. Axdorph G. Bylund P. Odéen 1. Olerud S. Treatment of patients with unstable fractures of the thoracic and lumbar spine. Acta Orthop. Scand. 53, 1982, 369-381. 
50. Veen H. F. van der Slikke W. Diagnostiek en behandeling van stabiele fracturen van de thoracolumbale wervelkolom. Ned. Tijdschr. Geneesk. 119, 1975, 19301937.

51. Weitzman G. Treatment of stable thoracolumbar spine compression fractures by early ambulation. Clin. Orthop. 76, 1971, 116-122.

52. Whitesides T. E. Jr. Traumatic kyphosis of the thoracolumbar spine. Clin. Orthop. $128,1977,78-92$. 


\subsection{Patientenbeschrijvingen bij traumarische kyfosen}

Patiënt 44. E. W.-K., vrouwelijk, geb. dat. 8-6-1947.

Aetiologie:

Vroegere behandeling:

Klachten:

Préoperatieve curves:

Voorbehandeling:

Longfunctie:

Neurologisch onderzoek:

Myelografie:

Operatie:

Complicaties:

Nabehandeling:

Postoperatieve curves:

Postoperatieve klachten:
Kyfose na wervelfractuur $T 7$.

Auto-ongeval in Saoedi-Arabië in januari 1977. Behandeld met tractie onder narcose, waarna 2 maanden gipsbed en 1 maand gipscorset.

Pijn ter hoogte van de $7 e$ thoracale wervel. Geen neurologische afwijkingen.

Kyfose $\mathrm{T} 6 \mathrm{t} / \mathrm{m} \mathrm{T} 834^{\circ}$. Fragmentatie wervellichaam T7.

1 week hato-rolstoeltractie

Niet verricht.

Geen afwijkingen, met name geen tekenen van myelumcompressie.

Niet verricht.

19-12-1977: Thoracotomie 5e rib rechts. Verwijderen restant wervel met disci erboven en eronder, opvullen holte T6-7-8 met ribspanen.

Passagère sympathische prikkeling linker hand met hyperhydrosis.

3 maanden gipscorset met kraag.

Kytose $32^{\circ}$, constant gebleven.

Geen, met name de pijnklachten waren verdwenen.

Beschouwing en conclusie:

Bij deze wervelfractuur werd het wervellichaam $T 7$ in voornamelijk 2 grote stukken uit elkaar gedrukt. Het contact hiertussen was minimat, zodat consolidatie uitbleef en een pijolijke niet genezen fractuur met kyfosering resteerde. Na conservatief behandelde wervelfracturen klagen patiënten regelmatig over pijnklachten. De genese van de pijn is onduidelijk. mogelijk dat geruptureerd discusweefsel of onder tractie staande ligamenten aan de achterzijde oorzaken van pijn kunnen zijn. Bij overbrugging van de fractuur met een ossale brug zijn de patiënten bijna altijd klachtenvrij. hetgeen er op wijst dat een ankylose ter plaatse de beste oplossing is. Een versterkte angulaire kyfose kan bovendien klachten geven door overbelasting van de rugmusculatuur. met name als 
een compensatoire lordose nodig is om de wervelkolom te balanceren. Bij deze pattiente bestond een duidelijke oorzaak voor de pijnklachten. Na spondylodese was zij dan ook klachtenvrij.

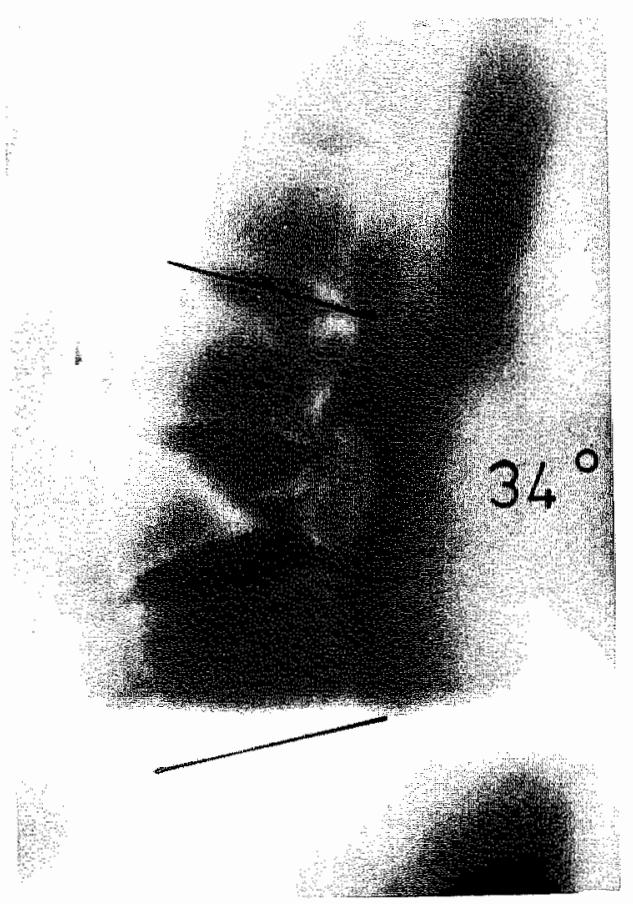

Fragmentatie corpus $\mathrm{T} 7$ met kyfose.

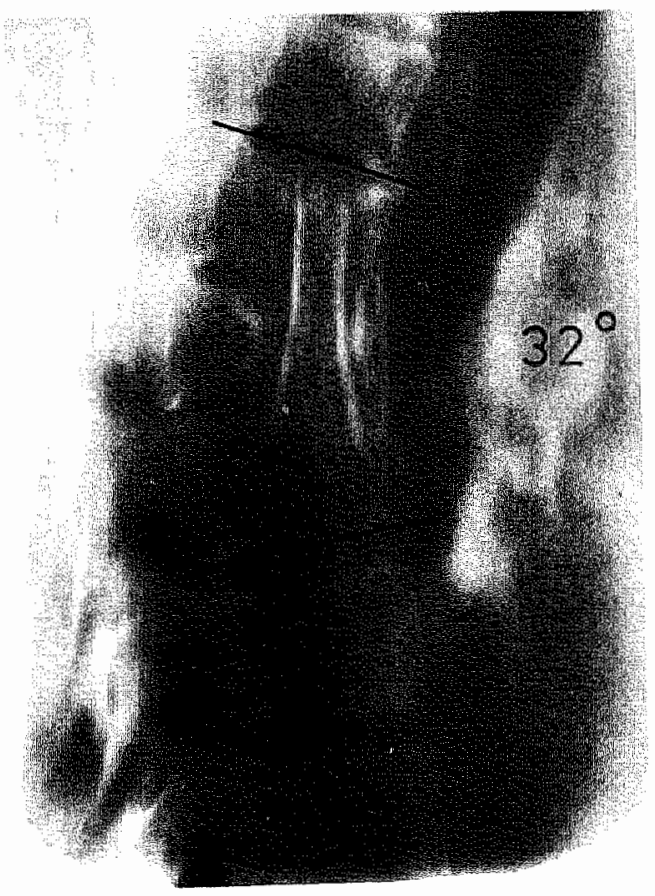

Spondylodese T6-7-8 met ribspanen. 
Patiẻnt 45. T. w. Z., vrouwelijk, geboren 21-4-1961.

Aetiologie:

Vroegere behandeling:

Klachten:

Préoperatieve curves:

Voorbehandeling:

Longfunctie:

Neurologisch onderzoek:

Myelografie:

Operatie:

Complicaties:

Nabehandeling:

Postoperatieve curves:

Postoperatieve klachten:

Kyfose door wervelfractuur Li.

Op 4-2-1979 als duopassagiere op bromfiets aangereden door een auto. Behandeling van de wervelfractuur met 4 weken klinische bedrust, waarna 2 weken bedrust thuis. Kreeg hierna wegens persisterende pijn orthopaedisch corset.

Ondanks corset rugpijn, uitstralend in rechter been. Ook paraesthesieën rechter been, geen verergering bij drukverhogende momenten, geen krachtsverlies of sensibiliteitsuitval.

Kyfose $\mathrm{T} 12 \mathrm{t} / \mathrm{m} \mathrm{L} 140^{\circ}$.

Geen.

Niet verricht.

Geen duidelijke afwijkingen. Paraesthesieën in dermatoom L5 en S1, niet overeenkomend met de localisatie van de fractuur.

Duidelijke knik ter plaatse van T12-L1 met indeuking van de contrastkolom.

14-11-1979. Intercorporele spondylodese T'12-L1 met behulp van cristabot en Zielke osteosynthese via bed 11 e rib links.

Geen, behalve peroperatoir klein pleuradefect, behandeld met 3 dagen thoraxdrainage.

3 maanden loopgipscorset.

Kyfose $\mathrm{T} 12 \mathrm{t} / \mathrm{m} \mathrm{L} 1$ postoperatoir $10^{\circ}$. Na 3 maanden $10^{\circ}$, na 8 maanden $12^{\circ}$.

Geen.

Beschouwing en conclusie:

Bij deze patiënte bestond een forse kyfosering op I niveau, met myelografisch een duidelijke indeuking van de contrastkolom. Duidelijke neurologische stoornissen waren niet aanwezig, toch kan men de vraag stellen of de geuite paraesthesieën hier niet mee te maken hadden. De pijnklachten kunnen het gevolg zijn geweest van een verscheurde discus T12-L1, terwijl er geen ankylose over dit niveau bestond. Ook de kyfosering op 
de thoracolumbale overgang kan klachten geven door musculaire overbelasting. Na de oprichtingsspondylodese waren niet alleen de pijnklachten, maar ook de paraesthesieën verdwenen. Dit laatste lijkt te komen door het opnieuw in lijn brengen van de achterzijde van de desbetreffende wervellichamen, waardoor de knik en daardoor de compressie op het myelum verdwijnt. 


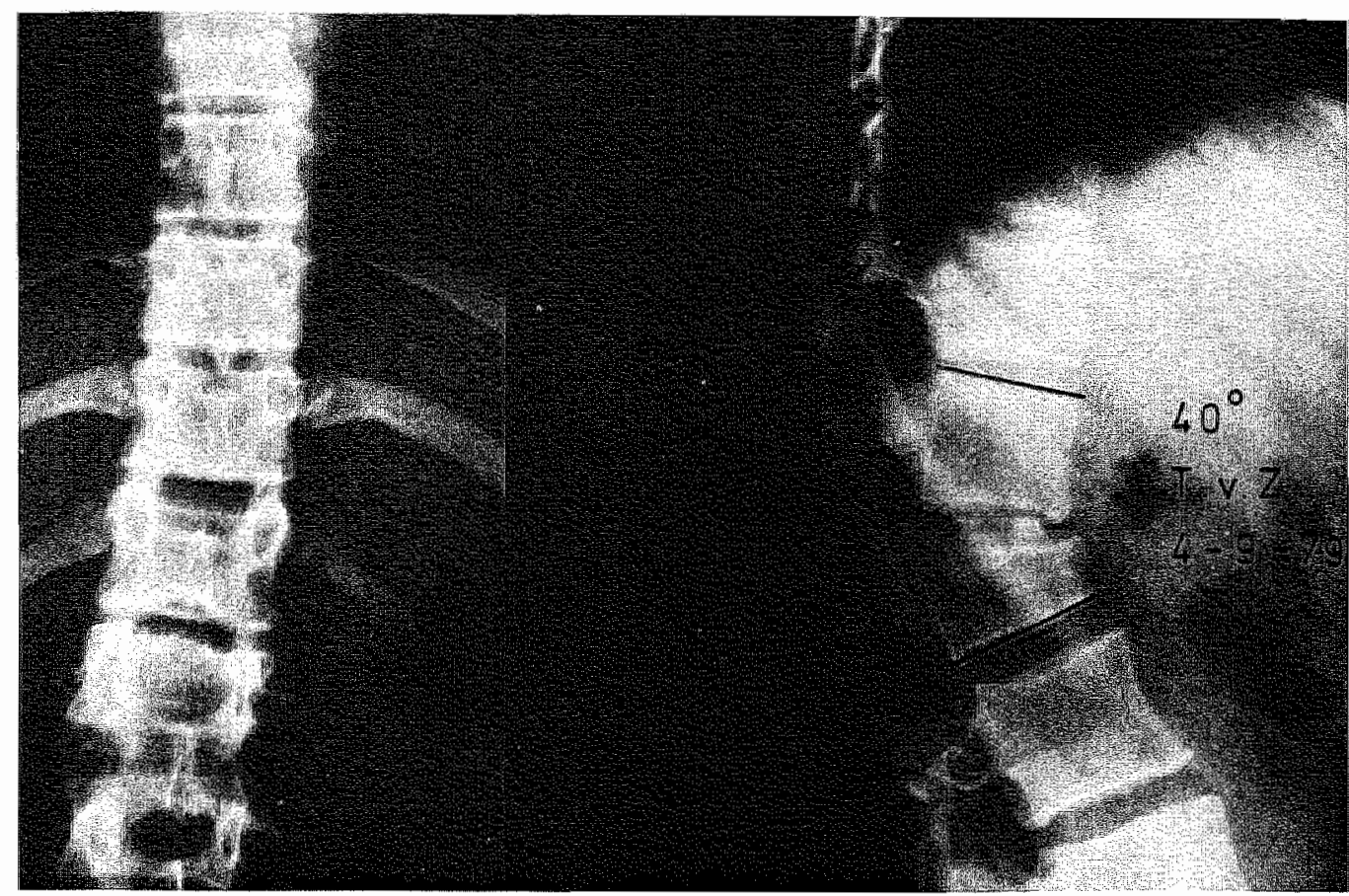

AP aanzicht fractuur $L$.

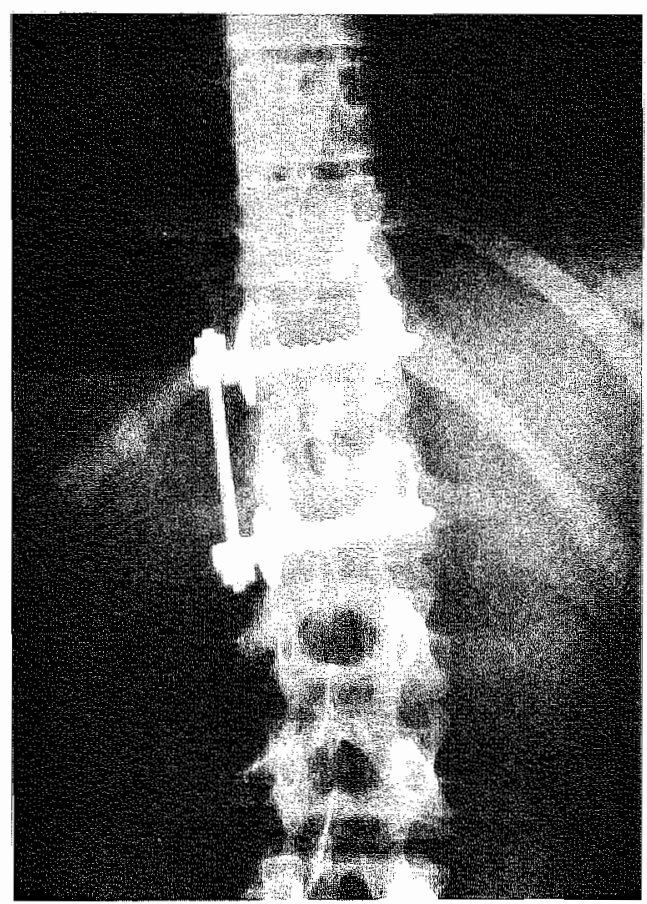

Ligging Zielke materiaal
Kyfose préoperatief.

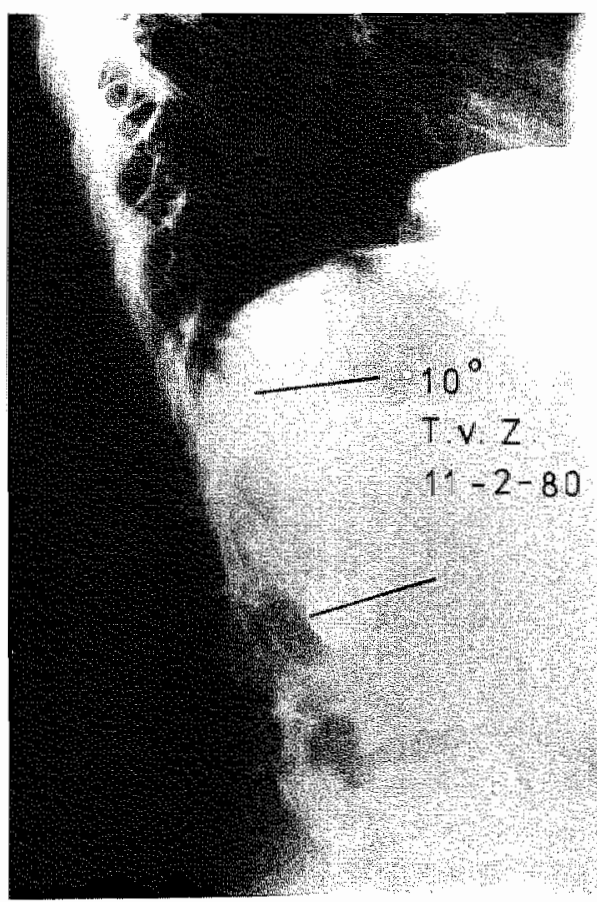

Kyfose postoperatief. 
Patiënt 46. H. v. A., mannelijk, geboren 11-6-1959.

Aetiologie:

Vroegere behandeling:

Klachten:

Préoperatieve curves:

Voorbehandeling:

Longfunctie:

Conclusie:

Neurologisch onderzoek:

Myelografie:

Operatie:

Complicaties:

Nabehandeling:

Postoperatieve curves:

Postoperatieve klachten:
Kyfose ten gevolge van wervelfractuur To met volledige dwarslaesie. Op 13-jarige leeftijd uit kabelbaan gevallen (5-7-1972). Paralyse beide benen. Anaesthesie vanaf de mammillae, mictie en defaecatiestoornis.

Uitgebreide laminectomie T4 t/m T8 op 6-7-1972.

Geen. Operatie-indicatic was de progressie van de kyfose.

17-11-1972 kyfose T4 t/m T8 $78^{\circ}$ met ernstige wigvorm T6. 16-4-1973 kyfose 94\%. 26-8-1974 kyfose $115^{\circ}$. Progressie mede door groei aan de achterzijde wan de wervellichamen.

Geen.

Vit. cap. $1875 \mathrm{cc}$ normaal $4750 \mathrm{cc}$. Tot. cap. $3100 \mathrm{cc}$ normaal $5975 \mathrm{cc}$.

Duidelijke restrictieve functiestoornis, ventilatoire reserves flink gedaald.

Volledige verlamming vanaf niveau $\mathrm{T} 6$.

Niet verricht.

4-9-1974. Intercorporele spondylodese T5 $\mathrm{t} / \mathrm{m}$ T8 met cristablok. T6 bleek praktisch geheel fibrotisch.

Geen.

3 maanden gipscorset.

Na 3 maanden $101^{\circ}$ kyfose. Na 18 maanden $123^{\circ} \mathrm{ky}-$ fose. Na 4 jaar $117^{\circ}$ kyfose. Na 5 jaar $108^{\circ} \mathrm{kylose}$.

Geen.

Beschouwing en conclusie:

Laminectomie op de kinderleeftijd bij wervelfracturen kan leiden tot ernstige kyfosering doordat bij verminderde stabiliteit aan de voorzijcle de stabiliteit aan de achterzijde tot een minimum wordt gereduceerd. Kyfoserende krachten worden dan niet meer geneutraliseerd en kunnen, mede door uitval van de lange rugspieren de wervelkolom in kyfose doen collaberen. Bij deze jongen ontstond tevens fusie aan de voorzijue van de wervellichamen T5-6-7, terwijl de resterende discusresten aan de achterzijde intact ble- 
ven en doorgroei vertoonden zoals bij een congenitale kyfose met stoornis in segmentatie. De voorste spondylodese heeft weinig correctie gegeven en waarschijnlijk is ook hierna doorgroei aan de achterzijde van de disci blijven bestaan met verdere, zij het geringe progressie tot gevolg. Het was achteraf gezien beter geweest na voorste osteotomie een strutgrafting te verrichten met eventueel interne fixatie na correctie, of gevolgd door achterste spondylodese, zodat progressie zoals nu na uitsluitend voorste fusie (de patiënt was toen 15 jaar) voorkomen had kunnen worden. 


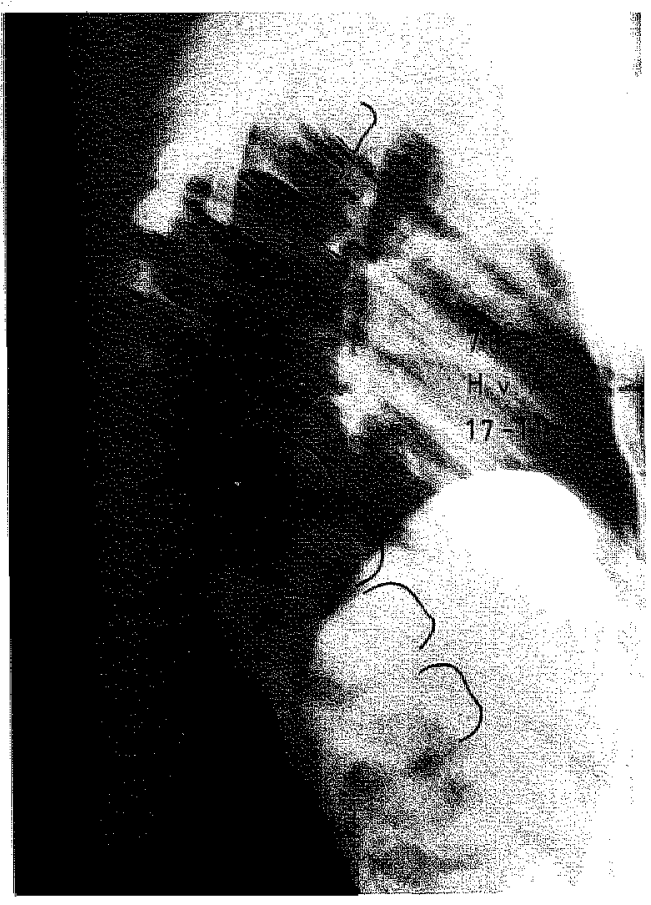

Kyfose 4 maanden na ongeval.

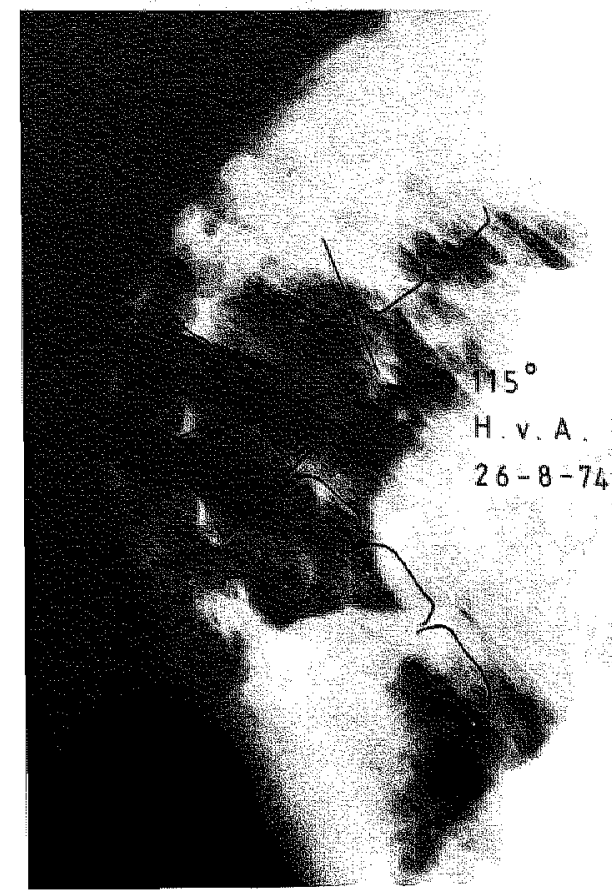

Progressie na 2 jaar.

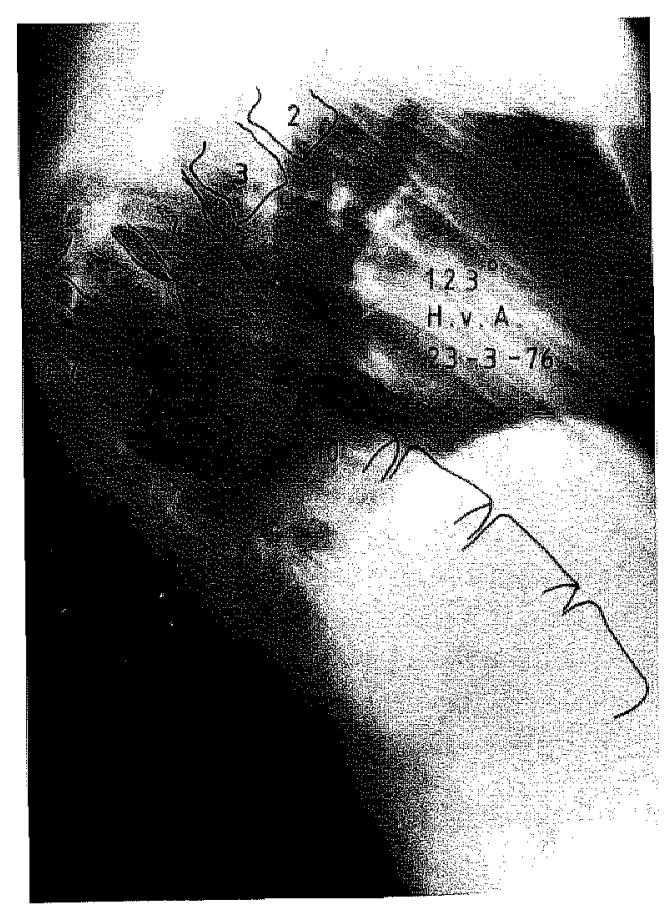

Kyfose $1 \frac{1}{2}$ jaar postoperatief. 


\section{KYFOSEN DOOR PRIMAIRE OF SECUNDAIRE TUMOREN}

\subsection{Bespreking}

Primaire bottumoren zijn zeldzaam in de wervelkolom. Meestal betreft het betrekkelijk goedaardige tumoren, die pas laat zoveel destructie geven, dat kyfose optreedt door collaps van het wervellichaam. Vaak is er een localisatie in de wervelboog. Bekende voorbeelden van goedaardige tumoren zijn aneurysmatische botcysten, haemangioom, eosinofiel granuloom, osteoid osteoom en osteoblastoom. De reusceltumor komt voor in de wervelkolom en kan diverse graderingen hebben, van goedaardig tot maligne. Osteo- en chondrosarcomen zijn zeldzaam in de wervelkolom, vaker voorkomende maligne tumoren zijn het Ewingsarcoom, chordoom (meestal in het sacrum), en het multiple myeloom $(1,9,12-14)$.

Locale resectie van de tumor behoort tegenwoordig tot de mogelijkheden, soms alleen van voren uit, soms alleen van achteren, soms gecombineerd. Reconstructie kan geschieden met behulp van bottransplantatie, interne fixatie, eventueel ook methylmetacrylaat en speciale wervelprotheses. Goede resultaten, ook bij de meer maligne tumoren zijn van deze procedures gemeld $(7,9,12-14)$.

Metastasen in de wervelkolom zullen slechts zelden geschikt zijn voor locale resectie en reconstructie. De patiënten zijn meestal ouder en door de tumorgroei in slechte conditie. Veelal zijn e metastasen multipel en heeft het weinig zin slechts één hiervan te verwijderen. Solitaire metastasen zijn bekend bij de Grawitztumor van de nier, die zich vaak als eerste uit door een metastase. Andere, langzaam groeiende metastasen die in aanmerking kunnen komen voor locale resectie zijn die van het mammacarcinoom en prostatcarcinoom. Belangrijk ten aanzien van de indicatiestelling is het al of niet aanwezig zijn van dwarslaesieverschijnselen. Snel optredende dwarslaesies zijn zelden reversibel, langzaam progressieve neurologische beelden hebben een betere prognose na decompressie, vooral als de dwarslaesie nog incompleet is. Zij moet dan worden gezien als een spoedgeval voor decompressie $(2,4,15)$.

Meijer (8) beschrijft in zijn proefschrift de teleurstellende resultaten van de laminectomie bij dwarslaesies ten gevolge van wervelmetastasen, vooral bij de acuut opgetreden beelden. Vaak is het zo dat de metastase primair in het wervellichaam gelocaliseerd is, terwijl de bogen later aangetast worden door doorgroei vanuit het corpus vertebrae. Het lijkt dan ook zinvoller, als er een operatieindicatie bestaat, de metastase van de voorzijde uit te benaderen en het myelum c.q. de cauda equina van voren uit te decomprimeren. Men kan op deze wijze de metastase completer verwijderen, terwijl een reconstructie kan worden toegevoegd. Door laminectomie alleen is men zelden compleet, terwijl de wervelkolomstabiliteit erdoor wordt verminderd. Meijer waarschuwt ook voor een laminectomie bij een al kyfotische deformiteit. In voorkomende gevallen zal een benadering van de metastase zowel van voren uit, als via een laminectomie nodig zijn $(1,3,5-7,1,11,16)$.

Het stellen van de indicatie blijft een moeilijke zaak. De volgende criteria zou men kunnen lhanteren.

1. De metastase moet bij voorkeur solitair zijn.

2. Dreigende dwarslaesie, indien al aanwezig kort bestaand en zonder acute ontstaanswijze. 
3. De lichamelijke en psychische conditie van de patiënt moet goed zijn.

4. Als er onvoldoende reactie te verwachten is of geweest is op bestraling en/of chemotherapie.

Het gaat erom met deze operaties het nog resterende leven van de patient te veraangenamen, slechts zelden zal immers een curatieve behandeling mogelijk blijken.

\subsection{Literatuur hoofdstuk 10}

1. Enneking W. F. Spine, chapter 10 in: Musculoskeletal tumor surgery. Churchill Livingstone New York, 1983.

2. Gilbert R. W. Kim J-H. Posner J. B. Epidural spinal cord compression from metastatic tumor: diagnosis and treatment. Ann. of Neurol. 3. 1978, 40-51.

3. Gunn D. R. Tupper J. W. Mullen M. P. Decompression and immediate stabilization of the spine in patients suffering from malignant disease. Journ. of Bone and Joint Surg. 56A, 1974, 1767-1768.

4. Hall A. J. Mackay N. N. S. The results of laminectomy for compression of the cord or cauda equina by extradural malignamt tumour. Journ. of Bone and Joint Surg. $55 \mathrm{~B}, 1973,497-505$.

5. Harrington $K$. D. The use of methylmethacrylate for vertebral-body replacement and anterior stabilization of pathological fracture-dislocations of the spine due 10 metastatic malignant disease. Journ. of Bone and Joint Surg. 63A. 1981, 36-46.

6. Kawabata M. Sugiyama M. Suzuki T. Kumano K. The role of metal and bone cement fixation in the management of malignant lesions of the vertebral column. Int. Orthop. 4, 1980, 177-181.

7. Martin N. S. Williamson J. The role of surgery in the treatment of malignant tumours of the spine. Journ. of Bone and Joint Surg. 52B. 1970. 227-237.

8. Meyer E. Compressio medullae ten gevolge van wervelmetastasen. Over de vratg naar het nut van decomprimerende laminectomieen. Proefschrift Nijmegen 1977.

9. Nicastro J. F. Leatherman K. D. Two-stage resection and spinal stabilization for aneurysmal bone cyst. A report of two cases. Clin. Orthop. 180, 1983, 173-178.

10. Onimus M. Bertin D. Stabilisation chirurgicale des fractures métastatiques du ratchis. Revue de Chir. Orthop. 68, 1982, 369-378.

11. Scoville W. B. Palmer A. H. Samra K. Chong G. The use of acrylic plastic for vertebral replacement or fixation in metastatic disease of the spine. Journ. of Neurosurg. $27,1967.274-279$.

12. Stener B. Johnsen O. E. Complete removal of three vertebrae for giant-cell tumour. Journ. of Bone and Joint Surg. 53B, 1971.278-287. 
13. Stener B. Total spondylectomy in chondrosarcoma arising from the seventh thoracic vertebra. Joum. of Bone and Joint Surg. 53B, 1971, 288-295.

14. Verbiest H. Giant-cell tumours and aneurysmal bone cysts of the spine. With special reference to the problems related to the removal of a vertebral body. Journ. of Bone and Joint Surg. 47B, 1965, 699-713.

15. White W. A. Patterson R. H. Jr. Bergland R. M. Role of surgery in the treatment of spinal cord compression by metastatic neoplasm. Cancer 27, 1971, 558-561.

16. Winter R. B. Anterior spinal cord decompression and spine stabilization for metastatic disease. A case report. Spine 7, 1982, 70-71. 
Patiënt 47. M.F.-K. vrouwelijk. geboren 8-4-1915.

Aetiologie:

Vroegere behandeling:

Klachten:

Préoperatieve curves:

Voorbehandeling:

Longfunctie:

Neurologisch onderzoek:

Myelografie:

Operatie:
Metastase T11 van mammacarcinoom met partiële dwarslaesie en kyfosering. Ook metastasen T2 en pedikel T9.

Mammaamputatie links in verband met carcinoom in 1964. In februari 1977 radiculaire pijn thoracolumbaal. Röntgenologisch metastasen T9 en T11. Ook discopathie L4-5-S1. Therapie: bestraling en decadronkuur. In augustus 1978 compressio medullae niveau T9-10. Myelografie: passagestoomis t.h.v. T3 en totale stop laag thoracaal. Botscan: metastasen T2, T9 en T11. Op 21-9-1978 werd laminectomie $\mathrm{T} 9 \mathrm{t} / \mathrm{m} 12$ en laminectomie $\mathrm{T} 2 \mathrm{t} / \mathrm{m}$ T4 verricht. Op beide plaatsen metastasen van een grootcellig. ongedifferentieerd carcinoom. Op T11 bestond infiltratie van de dura met tumor. In oktober 1979 ontstond een progressief conussyndroom met myelografisch een praktisch totale stop op T11. Als medicatie gebruikt patiënte nolvodex (oestrogeen) en decadron.

Krachtsverlies in de benen en paraesthesieën. Met bedrust weinig klachten.

Kyfose T10 t/m T12 $37^{\circ}$.

Interne screening, overleg met de neurochirurg. I.V.P. préoperatief een urineweginfect en een kleine longembolie links.

Niet verricht.

Myelumcompressie t.h.v. T11-12, zich vooral uitend als een Brown-Sequard syndroom. Hypaesthesie in de benen, mictietoornis.

Practisch totale stop op T11.

5-12-1979. Thoracotomie rechts via bed ge rib. Excisie "wervel" T11 met decompressie van het myelum. Spouwen van de kyfose met behulp van de kyfosedistractor. Opvullen van het defect met ribspanen en cristabot, platsen van dubbel Zielke systeem. 
Complicaties:

Nabehandeling:

Postoperatieve curves:

Postoperatiewe klachten:
Uitbreken van 1 staafje.

Gipscorset 21/2 maand. Hierna röntgenologische consolidatie. Patiënte kreeg hierna een Jewitt brace.

$15^{\circ}$ kyfose.

Na ontgipsing veel lumbale pijnklachten met uitstraling in het linker been. Na behandeling met anabole steroiden (primobolan) en bestraling zijn deze klachten en het algemene welbevinden sterk verbeterd. Op 13-1-81 was patiënte in goede conditie zonder rugklachten en met een neurologisch normale functie van de benen. Op 30-5-1982 is patiënte overleden ten gevolge van uitgebreide metastasen in het skelet en in cerebro.

Beschouwing en conclusie:

De operatieve uitruiming van wervelmetastasen zal slechts zelden geïndiceerd zijn en moet als palliatie gezien worden met het doel een dwarslaesie te voorkomen. Als er een solitaire metastase bestaat is er een kleine kans dat met volledige resectie en eventuele nabestraling of chemotherapie de patiënt ook daadwerkelijk genezen is. Bij langzaam groeiende metastasen, zoals van het mammacarcinoom kan een dreigende dwarslaesie, ook als er meerdere metastasen zijn op deze wijze behandeld worden, als de andere mogelijkheden (bestraling, hormonale of cytostatische therapie) geen verbetering te zien hebben gegeven. De patiënt moet dan nog wel in een goede algemene conditie verkeren om een dergelijke grote operatie te kunnen doorstaan. In dit geval kon patiënte nog geruime tijd na de operatie op de been blijven, terwijl zij voor de operatie aan bed gebonden was. 


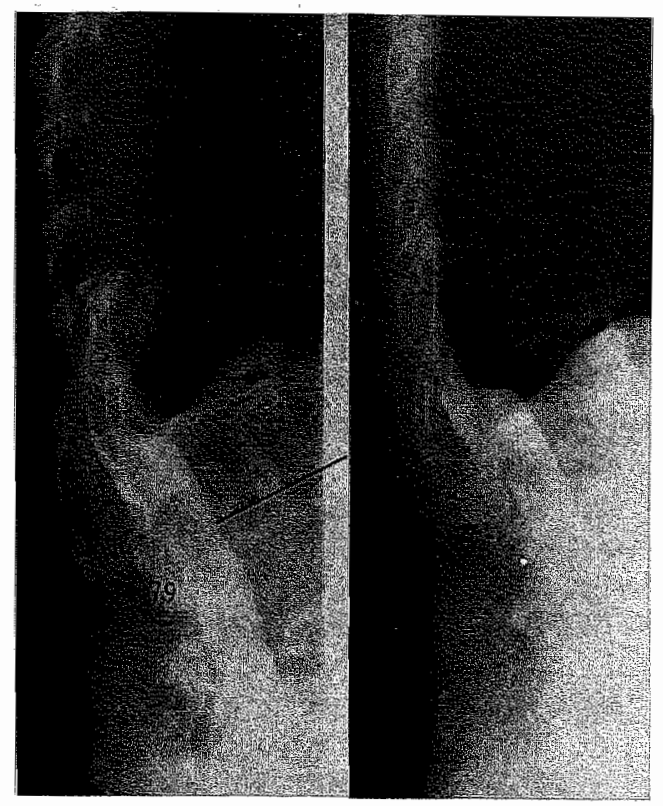

Compressio medullae t.h.v. T11

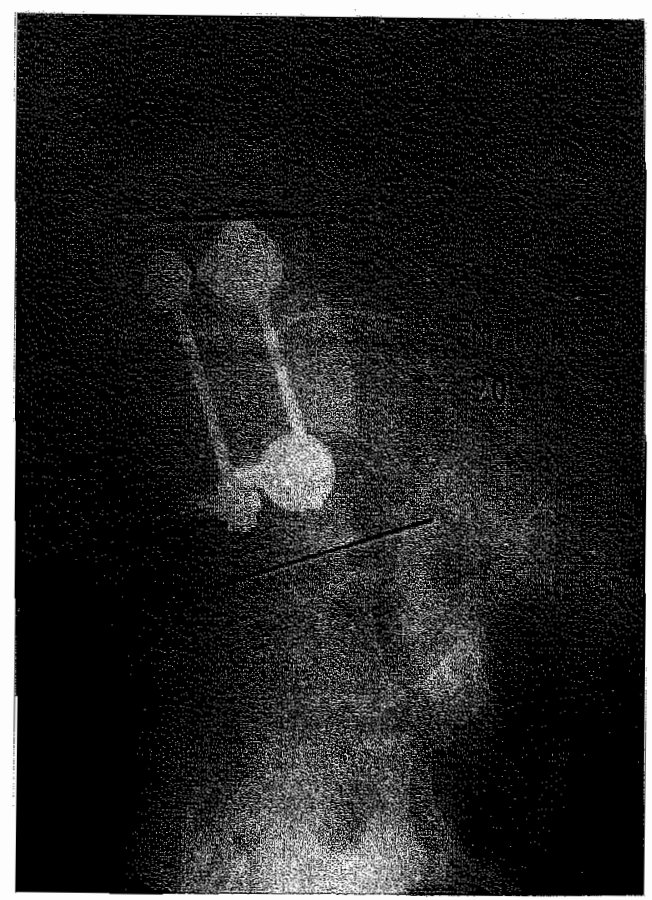

Postoperatieve situatie

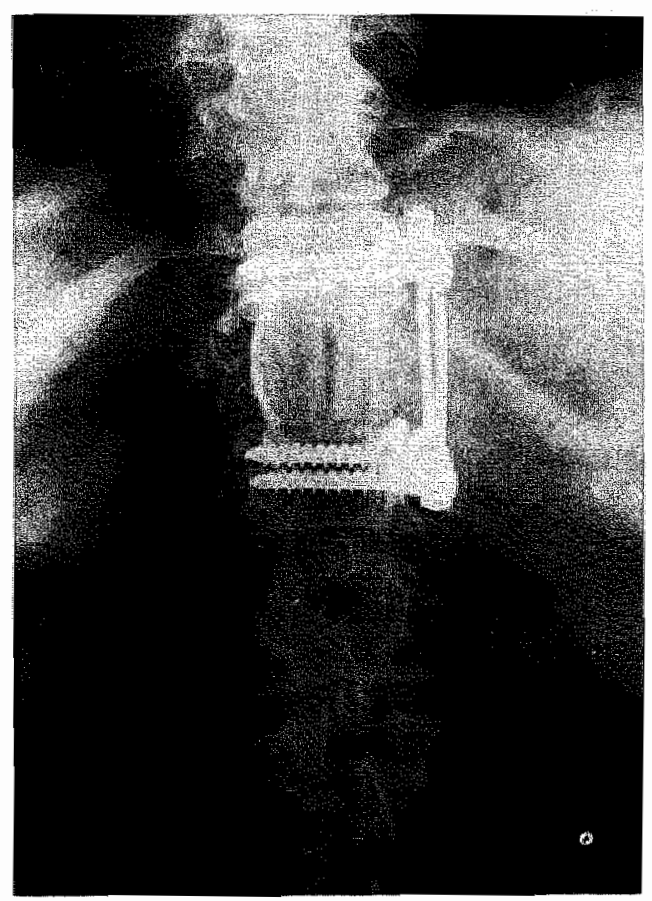

A.P. Aanzicht spondylodese 


\section{KYFOSEN DOOR ERNSTIGE ROTATIE BIJ IDIOPATHISCHE SCOLIOSEN} (TASSEMENT EN CYPHOSE)

\subsection{Inleiding}

Tassement en cyphose betekent wegzakken in kyfose $(17,18)$. De term duidt op de kyfosering van de wervelkolom ten gevolge van de rotatie behorende bij de scoliose. Een scoliose is een driedimensionaal gebeuren. Het gaat niet alleen om de curve in het frontale vlak, waar we via de A. P. röntgenfoto informatie over krijgen, praktisch even belangrijk is de rotatie van de wervels in het transversale vlak, terwijl de lordose of kyfose ook vaak afwijkend is (curve in het sagittale vlak) (13).

De gewone idiopathische thoracale adolescentenscoliose gaat in de regel gepaard met min of meer opgeheven kyfose van de thoracale wervelkolom (de term lordoscoliose is meestal onjuist). De rug krijgt hierdoor een zeer vlak karakter.

De infantiele idiopathische scoliose wordt in Nederland zelden gezien. Deze geeft onbehandeld aanleiding tot ernstige kyfoscoliosen $(2,13,17,18)$. De apicale wervels op het thoracale niveau roteren meer dan $90^{\circ}$, waardoor de intergewrichten van het frontale in het sagittale vlak komen. De curve kan dan in kyfose doorzakken: tassement en cyphose $(17,18)$. Sommige onderzoekers menen dat bij deze curves de term kyfose niet gebruikt mag worden, en dat de ribbengibbus een kyfose simuleert (2). Soms is dit waar, maar vaak bestaat er wel degelijk ook een versterkte kyfose van de wervels op de zijdelingse röntgenopname mede ontstaan door de vaak extreme draaiing.

Op het lumbale niveau vindt het z.g. „drehgleiten” plaats. De intergewrichten staan hier normaal meer in het sagittale vlak. Bij optreden van scoliose kunnen de wervels uit hun normale lordose roteren en komen de intergewrichten in het frontale vlak te liggen. De wervels kunnen dan van elkaar af gaan glijden in laterale richting. Kyfoserende krachten hebben op deze nu instabiele wervelkolom, waarbij de lordose verdwenen is en de zwaartelijn van het lichaam ten opzichte van de wervelkolom meer naar voren is verlegd, zoveel effect, dat een (meestal matige) kyfosering optreedt. Statisch gezien is dit een slechte situatie. Deze patiënten krijgen dan ook frequent lage rugklachten ten gevolge van discopathie of musculaire overbelasting. Ook na het beëindigen van de groei zijn deze lumbale curves vaak progressief. Bij vrouwen is dit vooral na de menopauze het geval en kunnen zelfs scolioses ,de novo" ontstaan $(12-14,16-18)$.

Een andere vorm van "tassement en cyphose" trad nogal eens op tussen 2 afzonderlijk gefuseerde gedeelten van de wervelkolom, meestal op de thoraco-lumbale overgang (17). Met het gebruik van interne fixatiematerialen wordt deze vorm praktisch niet meer gezien.

\subsection{Behandeling}

De thoracale vorm kan worden behandeld zoals aangegeven door Stagnara (16-19). In Lyon heeft hij veel patiënten met zeer ernstige kyfoscoliosen behandeld. Begonnen wordt met een periode tractie, of dit nu Halo-rolstoel, Halo-femoraal, Halo-tibia, HaloCotrel of elongatiegips is. Waarschijnlijk heeft langer dan 2 weken tractie weinig effect in de zin van extra correctie. Dan verricht Stagnara een achterste Harringtoninstrumentatie zonder fusie met dubbele staaf, indien nodig retropleuraal prévertebraal, waarbij enkele ribhalsjes worden verwijderd in de concaviteit. Dan volgt enkele weken tractie 
met verdere correctie (er is een release gebeurd van intergewrichten, spontane fusies in de concaviteit werden opgeheven), wararna in $2 \mathrm{e}$ tempo de definitieve instrumentatic met fusie wolgt. Uiteraard wordt hiema langdurig (ongeveer 1 jaar) geimmobiliseerd met gips, later met een $\mathrm{z.g}$. corset lyonmais tot ongeveer 2 jaar postoperatief. Omdat de staaf voor de wervelkolom komt te liggen behoeft geen voorste spondylodese te worden toegevoegd. Bovendien is de longfunctie vaak zodanig slecht dat liever geen thoracotow mie gedaan wordt. Deze gefaseerde methode vergt veel van patient en behandelaar. Meestal zal met één ingreep, waarbij zonder de ribhalsjes te verwijderen de staaf ook voor de kyfose geplaatst kan worden, kunnen worden volstaan, ook al zal de correctie vaak minder zijn dan bij de hierboven geschetste methode.

Voor de lumbale idiopathische kyfoscoliose is het V.D.S. (voorste derotatie systeem) volgens Zielke bij uitstek geschikt $(12,19,20)$. Hiermee kan goed gederoteend worden, zodat ook weer lordose, of in ieder geval minder kyfose gecreeerd kan worden. Het gevaar voor terugzakken in kyfose is door de betere fixatie bij het Zielkesysteem veel geringer dan bij het Dwyersysteem, waar de kabel de zwakke schakel is in het geheel $(12$, 15). Het hangt van het resultaat van de voorste derotatie-spondylodese af of men een achterste Harringtonspondylodese moet toevoegen. Met name is de scheefstand van de onderste lumbale wervels ten opzichte van elkaar van belang in verband met de kans op later optredende discopathieèn $(5,20)$. Is er tevens een thoracale scoliose aanwezig, dan moet men na de Zielke-operatie een achterste Harringtonspondylodese toevoegen als de spontane correctie van de thoracale curve na operatie onvoldoende is.

Een achterste spondylodese alléen bij lumbale scoliosen met drehgleiten en kyfose heeft een vrij slechte prognose. De derotatie en dekyfosering is met de Harringtonmethode matig, zodat kyfoserende krachten op de spondylodese blijven bestaan, met een grotere kans op pseudarthrosevorming en staafbreuk $(1,16,17)$. De voorste derotatie spondylodese volgens Zielke lijkt de volgende voordelen ten opzichte van de achterste Harringtonspondylodese te hebben $(1,4-7,12,15,18-20)$ :

1. Betere correctie, met name ook dekyfosering.

2. Goede fusie (meestal al na ongeveer $1 / 2$ jaar), minder kans op pseudarthrose.

3. Men kan met de voorste methode met minder segmenten volstaan.

4. De morbiditeit van de voorste scoliose correcties is bij gezonde patienten verrassend gering en minder dan men gezien de witgebreidheid van de operatie zou verwachten. Er is ook minder kans op neurologische complicaties omdat door het verwijderen van de disci en het op elkaar brengen van de wervellichamen het betreffende wervelkolomgedeelte in feite verkort wordt.

De ervaringen met de Zielke spondylodese zijn echter nog kort en kunnen pas na een langere follow-up vergeleken worden met de resultaten van de Harrington operatie. Ook het indicatiegebied voor de Dwyer- of Zielke spondylodese stat nog niet geheel vast. maar lijkt vooral te liggen op het gebied van de paralytische scoliose, in het bijzonder bij spina bifida en bij de thoracolumbale idiopathische scoliose. De rol van de Luque procedure, waarbij middels cerclages om de laminae, verbonden aan 2 voorgebogen metalen staven, een segmentale stabilisatie plaatsvindt, is nog niet volledig uitgekristalliseerd. Deze lijkt vooral op het terrein van de lange paralytische curves te liggen. Het gebruik hiervan bij idiopathische scoliosen wordt wegens de verhoogde kans op neurologische complicaties vooralsnog door velen afgewezen $(8,10,11)$. 


\subsection{Literatuar hoofdstuk 11}

1. Bradford D. S. Anterior spinal surgery in the management of scoliosis. IndicationsTechniques-Results. Orthop. Clinics of North America 10, 1979, 801-812.

2. Chapchal G. Operative treatment of scoliosis. 4th intern. symposium 1971, Nijmegen Netherlands. Thieme Publishers Stuttgart 1973.

3. Cotrel $Y$. Techniques nouvelles dans le traitement de la scoliose idiopathique. Int. Orthop. 1, 1978, 247-265.

4. Dwyer A. F. Experience of anterior correction of scoliosis. Clin. Orthop. 93, 1973, 191-206.

5. Griss P. Jentschura G. Erste Ergebnisse der Skoliosenbehandlung unter Verwendung des Instrumentariums der ventralen Derotationsspondylodese (VDS-Zielke). Zeitschr. für Orthop. 119, 1981, 115-122.

6. Harrington P. R. The history and development of Harrington instrumentation. 1973 Nicholas Andry Award Contribution. Clin. Orthop. 93, 1973, 110-112.

7. Harrington P. R. Dickson J. H. An eleven-year clinical investigation of Harrington instrumentation. 1973 Nicholas Andry Award Contribution. A preliminary report on 578 cases. Clin. Orthop. 93, 1973, 113-130.

8. Herring J. A. Wenger D. R. Segmental spinal instrumentation. A preliminary report of 40 consecutive cases. Spine 7, 1982, 285-298.

9. Kleinberg S. Kaplan, A. Scoliosis complicated by paraplegia. Journ. of Bone and Joint Surg. 34A, 1952, 162-167.

10. Luque E. L. The anatomic basis and development of segmental spinal instrumentation. Spine 7, 1982, 256-259.

11. Luque E. L. The correction of postural curves of the spine. Spine 7, 1982, 270-275.

12. Moe J. H. Purcell G. A. Bradford D. S. Zielke instrumentation (VDS) for the correction of spinal curvature. Analysis of results in 66 patients. Clin. Orthop. 180 , 1983. 133-153.

13. du Peloux J. Fauchet R. Faucon B. Stagnara P. Le plan d'élection pour l'examen radiologique des cypho-scolioses. Revue de Chir. Orthop. 51, 1965, 517-524.

14. Robin G. C. Span Y. Steinberg R. Makin M. Menczel J. Scoliosis in the elderly. Spine 7, 1982, 355-359.

15. Slot G. H. De spondylodese volgens Dwyer bij ernstige wervelkolomdeformaties. Een onderzoek van 50 geopereerde patiënten. Proefschrift Nijmegen 1980. 
16. Stagnara P. Fauchet R. Bouillat G. du Peloux J. Mazoyer D. Callay C. A propos de 17 observations de paraplégies par déformations vertébrales traitées par redressement partiel. Revue de Chir. Orthop. 54, 1968, 623-636.

17. Stagnara P. Mauroy J-C. de Gonon G. Campo-Paysaa A. Scolioses cyphosantes de l'adulte et greffes antérieures. Int. Orthop. 2, 1978, 149-165.

18. Zielke K. Pellin B. Die operative Behandlung der Erwachsenenskoliose. Zeitschr. für Orthop. 114, 1976, 598-604.

19. Zielke K. Pellin B. Ergebnisse operativer Skoliosen- und Kyphoskoliosenbehandlung beim Adoleszenten über 18 Jahre und beim Erwachsenen. Zeitschr. tür Orthop. 113, 1975, 157-174.

20. Zielke $\mathbb{K}$. Ventrale Derotationsspondylodese. Behandlungsergebnisse bei idiopathischen Lumbalskoliosen. Zeitschr. für Orthop. 120, 1982, 320-329. 


\subsection{Patientenbeschrijuingen bij rassement en cyphose}

Patiënt 48. C. D. mannelijk, geb dat. 11-4-1970.

Aetiologie:

Vroegere behandeling:

Klachten:

Préoperatieve curves:

Voorbehandeling:

Longfunctie:

Conclusie:

Neurologisch onderzoek:

Myelografie:

Operatie:

Complicaties:

Nabehandeling:

Postoperatieve curves:

Infantiele idiopathische kyfoscoliose.

Niet bekend, waarschijnlijk in Turkije geen behandeling gehad. Was slechts kort in Nederland.

Geen.

scoliose $\mathrm{T} 7 \mathrm{t} / \mathrm{m} \mathrm{L} 2$ rechts convex $95^{\circ}$, tractie $90^{\circ}$. kyfose $95^{\circ}$.

Van 24-2-1977 tot 10-6-1977 Cotreltractie en gipscorset vervolgens 3 maanden halo-rolstoeltractie, waarna 8 weken correctiegips, vervolgens 3 weken halo-rolstoeltractie tot aan de operatie. Correctie van de scoliose tot $64^{\circ}$, kyfose tot $53^{\circ}$.

Vit. cap. $600 \mathrm{cc}$. normaal $1175 \mathrm{cc}$. Tot cap. $1000 \mathrm{cc}$. normaal $1475 \mathrm{cc}$.

Duidelijke restrictie, echter slechte coöperatie door de taalbarrière, zodat niet teveel waarde aan het onderzoek moet worden gehecht.

Lichte pyramidale prikkeling rechts meer dan links, alleen aan de benen, vooral aandoening dorsale deel pyramidebaan.

Niet verricht.

30-11-1977. Harringtonspondylodese met dwarstractie T4 t/m L3 met cristabot.

Infectie pengaten van de Halo.

Halo-rompgips 3 weken, waarna tot 7 maanden gipscorset, vervolgens Milwaukee brace tot het einde van de groei.

$\begin{array}{lll} & \text { scoliose } & \text { kyfose } \\ \text { post. op. } & 42^{\circ} & \\ \text { na 2 maanden } & 40^{\circ} & 42^{\circ} \\ \text { na 3 maanden } & 43^{\circ} & 44^{\circ} \\ \text { na } 7 \text { maanden } & 51^{\circ} & 57^{\circ} \\ \text { na 1 } 1 / 2 \text { jaar } & 42^{\circ} & 50^{\circ} \\ \text { na 21/2 jaar } & 52^{\circ} & 55^{\circ} \\ \text { na 3 jaar } & 52^{\circ} & 55^{\circ}\end{array}$


Postoperatieve klachten:

Geen

Beschouwing en conclusie:

Aangenomen mag worden dat zonder behandeling de scoliose bij deze patiënt geresulteerd zou hebben in een extreme curve met mogelijk ernstige neurologische problematiek. Nu was er al een lichte pyramidale prikkeling. Conservatieve behandeling bij deze curves heeft geen zin, de kyfoscoliose was hiervoor al veel te groot. Operatieve correctie en stabilisatie was hier aangewezen, het resultaat is zeer goed te noemen. 


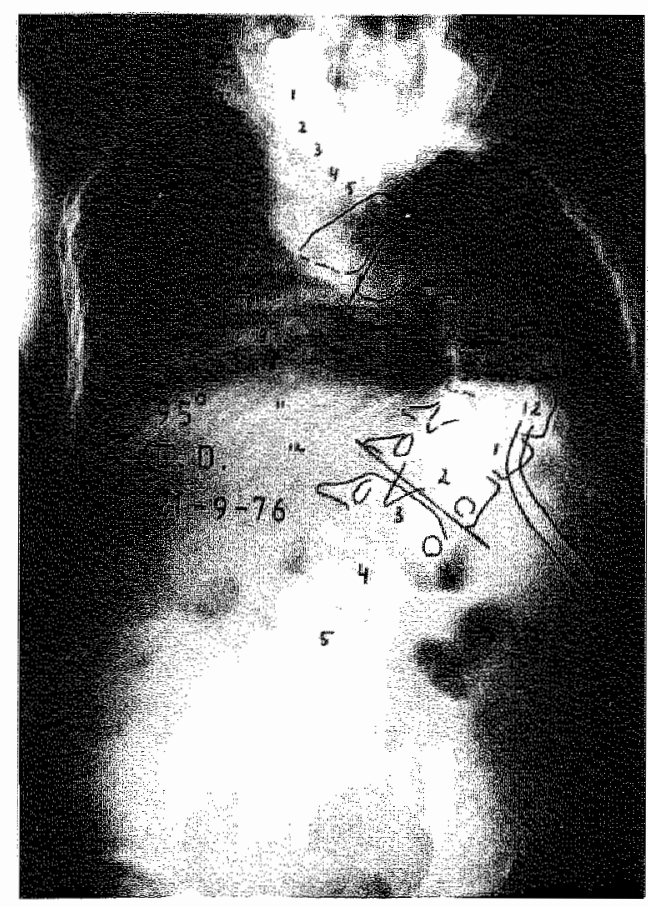

Scoliose préperatief

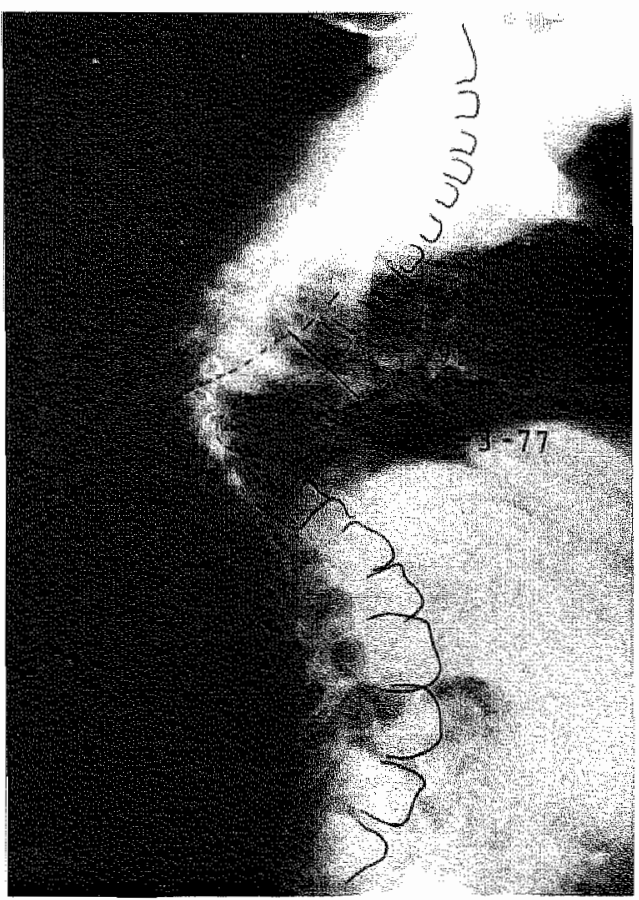

Kyfose préoperatief

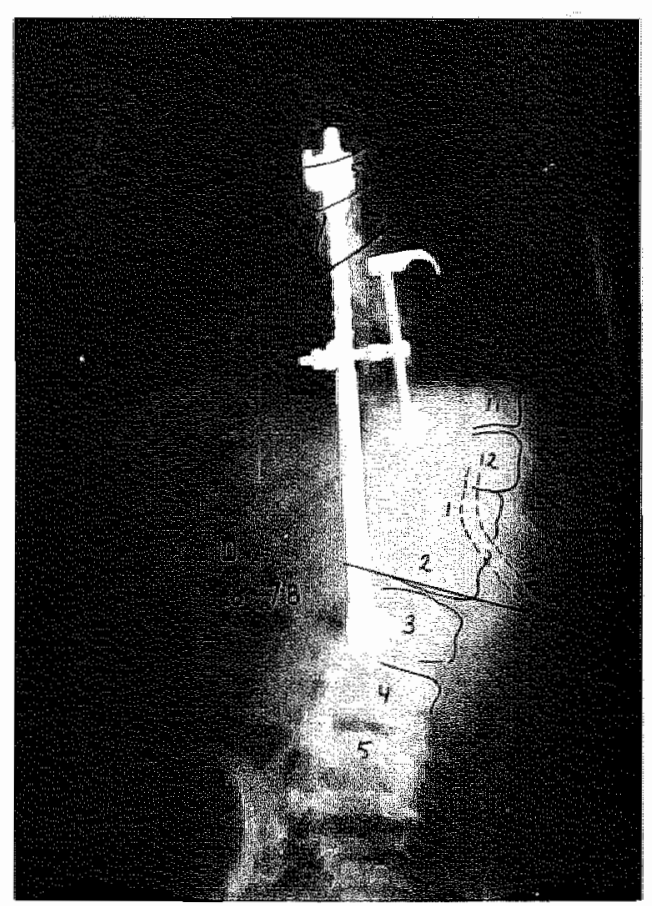

Scoliose postoperatief

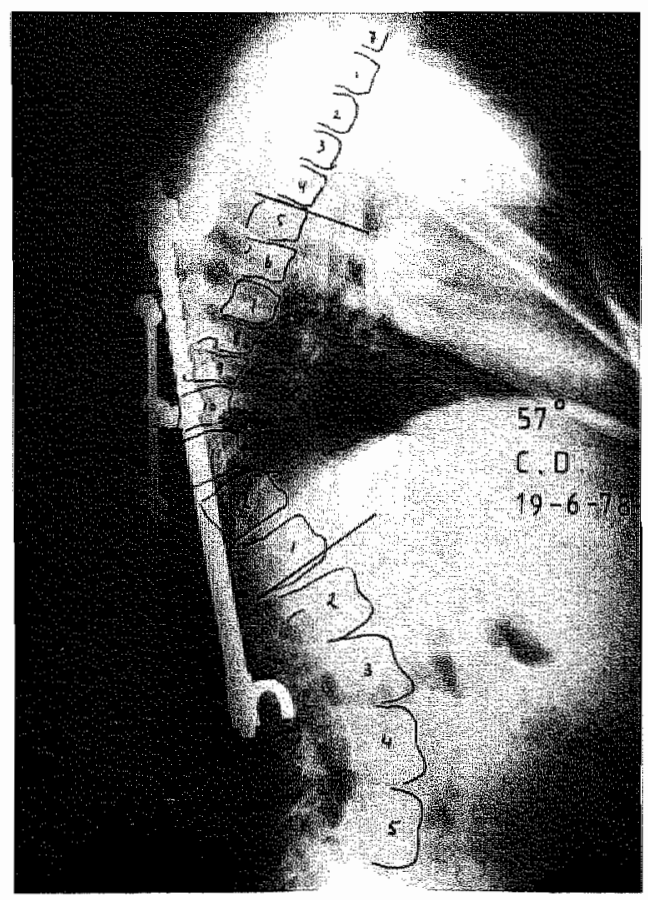

Kyfose postoperatief 


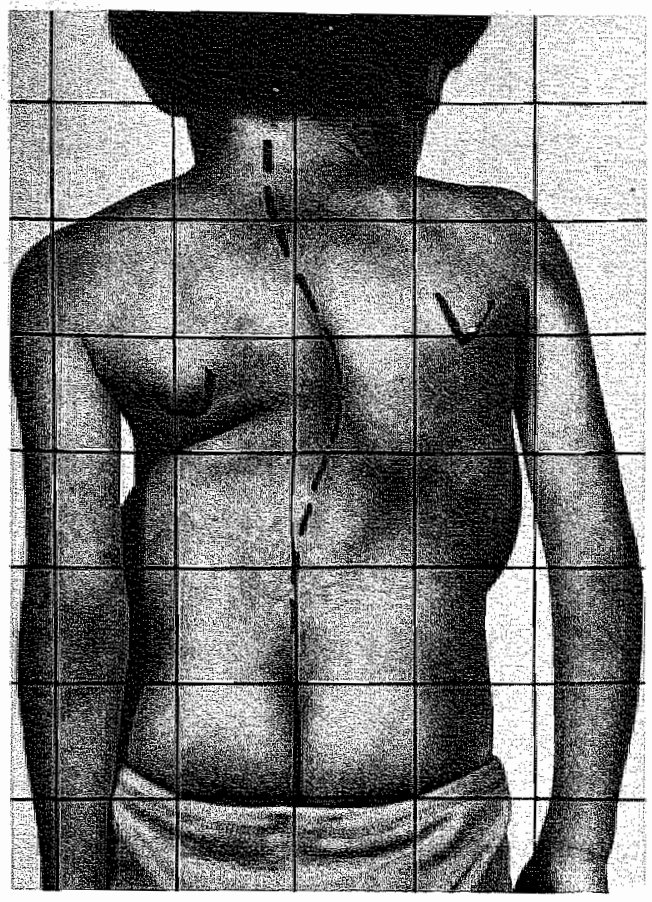

C. D. Scoliose préoperatief

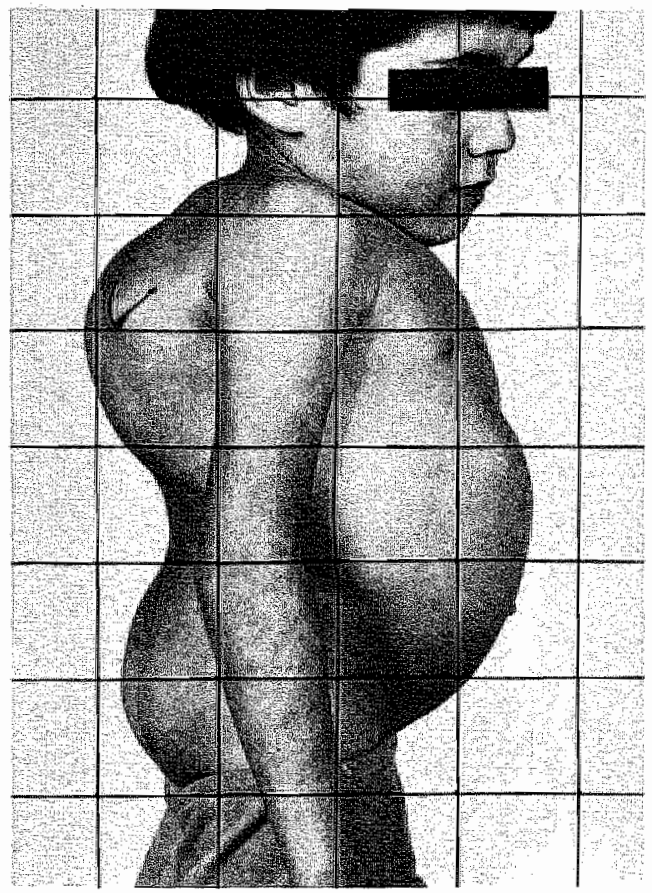

C. D. Kyfose préoperatief

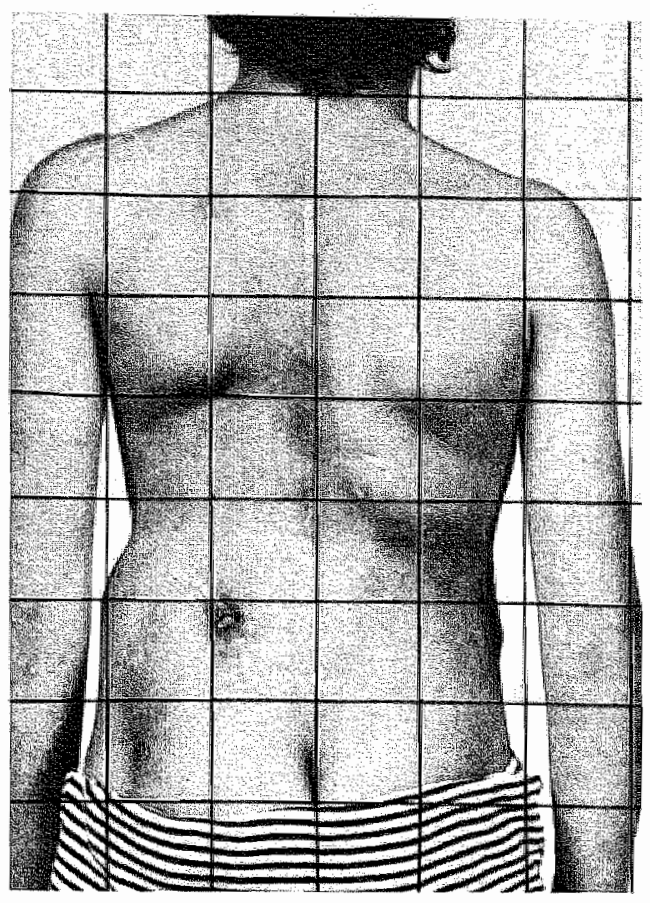

C. D. Scoliose postoperatief

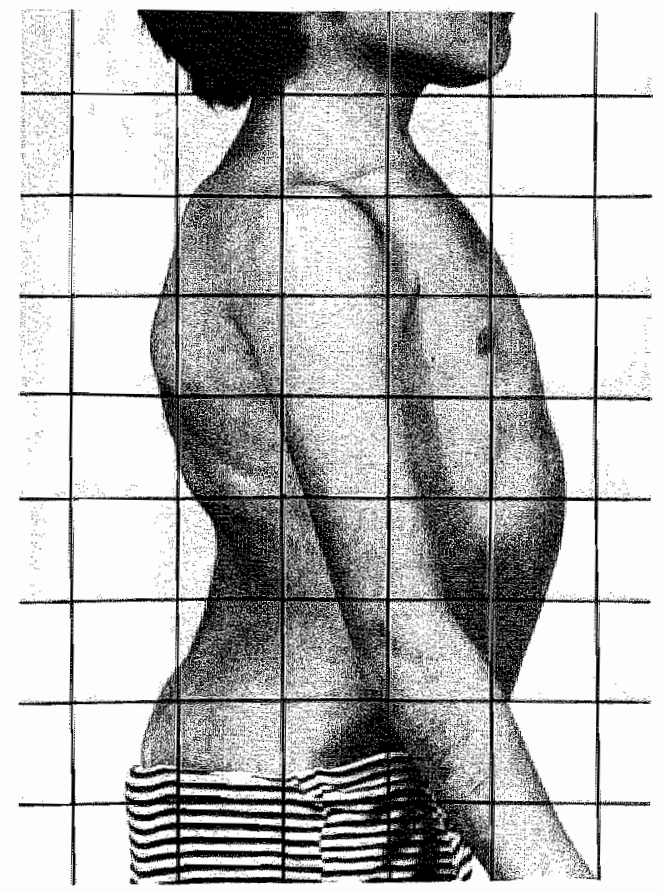

C. D. Kyfose $21 / 2$ jaar postoperatiel 


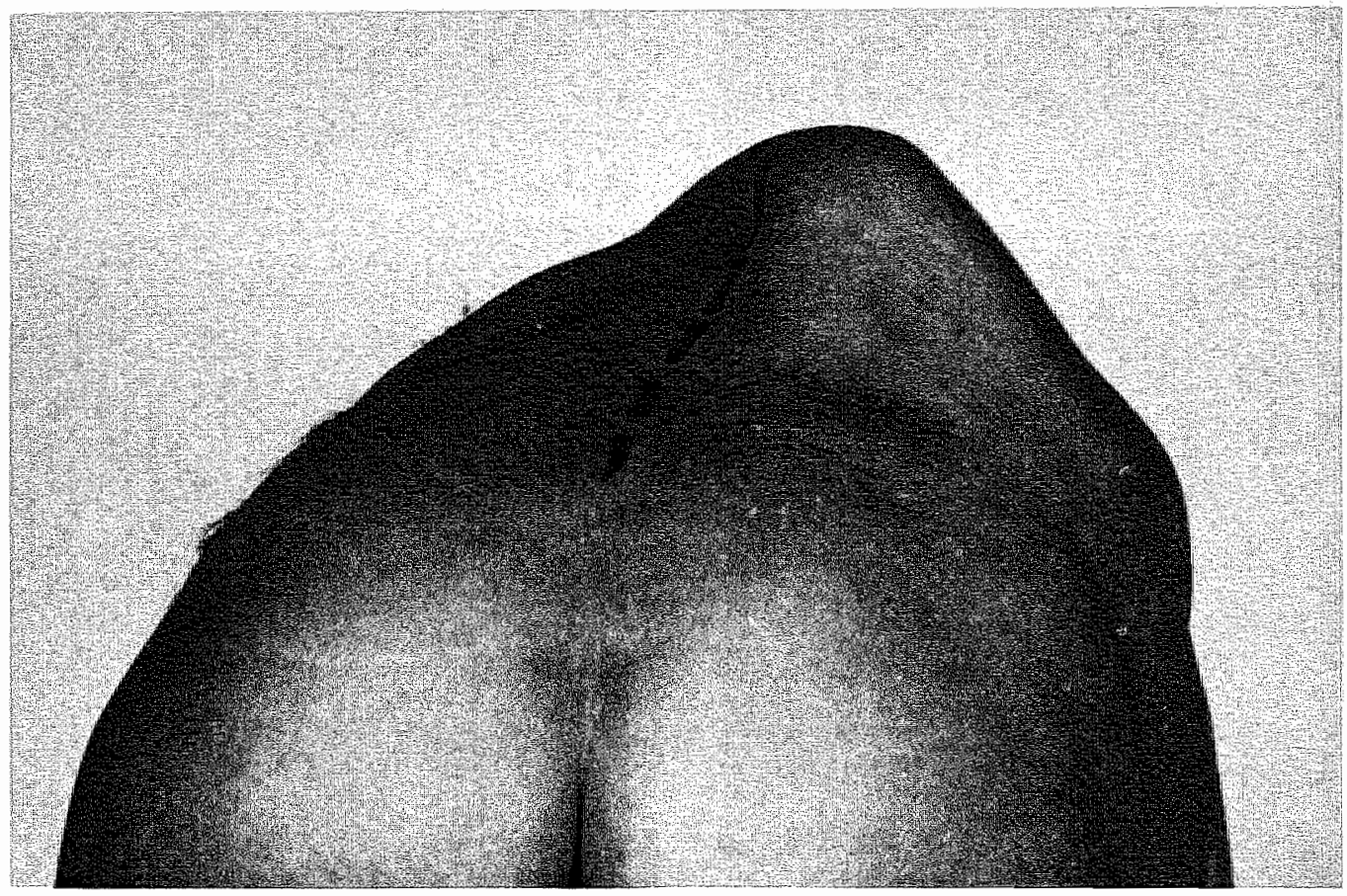

C. D. Gibbus costarum préoperatief

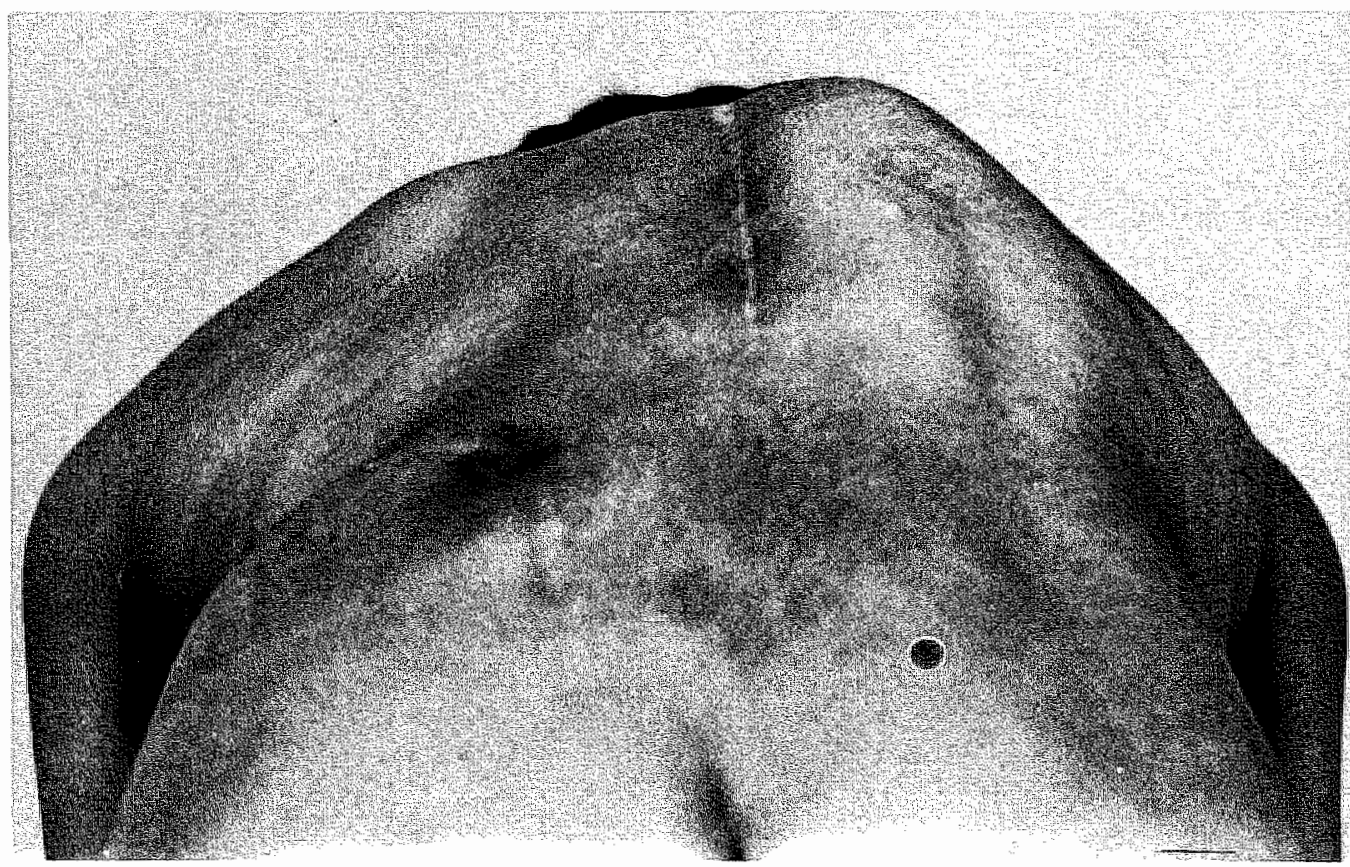

C. D. Lichte restgibbus $2 \frac{1 / 2}{\text { jaar post- }}$ operatief 
Patiënt 49. P. v. đ. L.-K. vrouwelijk, geb.dat. 17-9-1937

Aetiologie:

Vroegere behandeling:

Klachten:

Préoperatieve curves:

Voorbehandeling:

Longfunctie:

Conclusie:

Neurologisch onderzoek:

Myelografie:

Operatie:

Complicaties:

Nabehandeling:

Postoperatieve curves:

Postoperatieve klachten:

Beschouwing en conclusie:

Met de Dwyer-methode werd in eerste instantie een prima correctie bereikt van deze lumbale scoliose met kyfose door rotatie. De bereikte correctie bleef echter niet behouden. met name zakte de wervelkolom weer terug in kyfose. Met het Zielke-systeem zal dit niet of nauwelijks meer gebeuren. Overigens was het waarschijnlijk nuttig geweest een Harringtonspondylodese aan de achterzijde toe te voegen.
Idiopathische lumbale kyfoscoliose met „drehglei ten".

Op 20-jarige leeftijd scoliose vastgesteld. In 1971 rib-

resectie 11 en 12 rechts wegens druk op de crista iliaca. Dit gaf enige baat, fysiotherapie niet.

Lumbale pijnklachten, progressieve deformatie.

Scoliose $60^{\circ} \mathrm{T} 12 \mathrm{t} / \mathrm{m} \mathrm{L}$. Met tractie $50^{\circ}$. Kyfose $47^{\circ}$. T12 t/m L3.

Cotreltractie 2 weken. Correctie scoliose tot $48^{\circ}$.

Vit.cap. $3800 \mathrm{cc}$. normaal $4150 \mathrm{cc}$. Tot. cap. $4800 \mathrm{cc}$. normaal $5375 \mathrm{cc}$.

Mogelijk zeer geringe restrictie.

Lichte tekenen van een caudaal regressiesyndroom.

Niet verricht.

10-12-1976. Spondylodese volgens Dwyer T12 $\mathrm{d} / \mathrm{m}$ L4 via lumbotomie rechts.

Urineweginfecties.

Laag gipscorset 3 maanden.

Postoperatief scoliose kyfose

na 4 maanden

$11^{\circ}$

$23^{\circ}$

na 6 maanden

$15^{\circ}$

$27^{\circ}$

na 1 jaar

$15^{\circ}$

$11^{\circ}$

$24^{\circ}$

$31^{\circ}$

na $\mathbb{1} 1 / 2$ jaar

$39^{\circ}$

na 2 jaar

$32^{\circ}$

na 3 jaar

$23^{\circ}$

$27^{\circ}$

$42^{\circ}$

Soms pijn in de rechter flank, pijn hoog thoracaal en in de nek. 


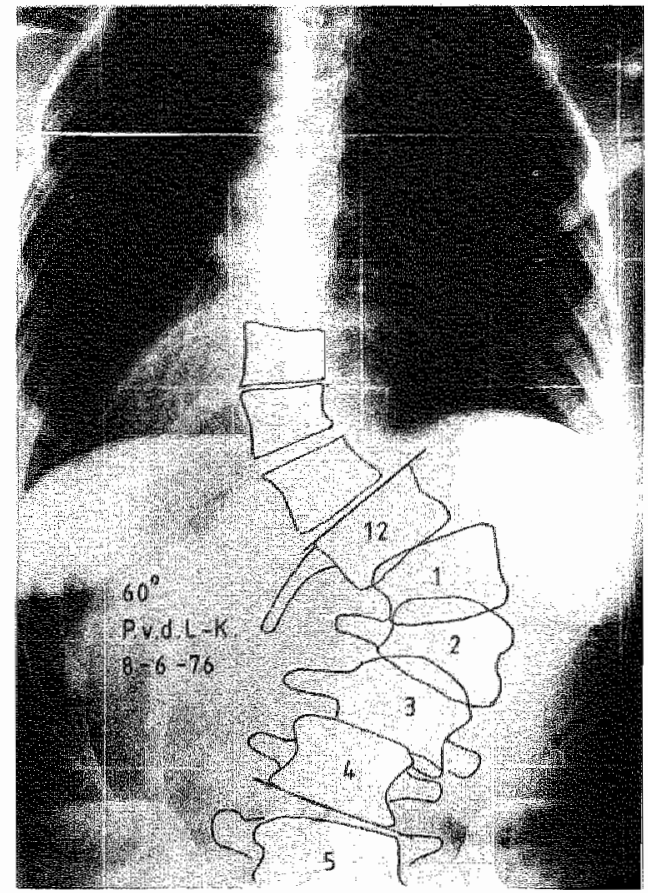

Préoperatieve scoliose

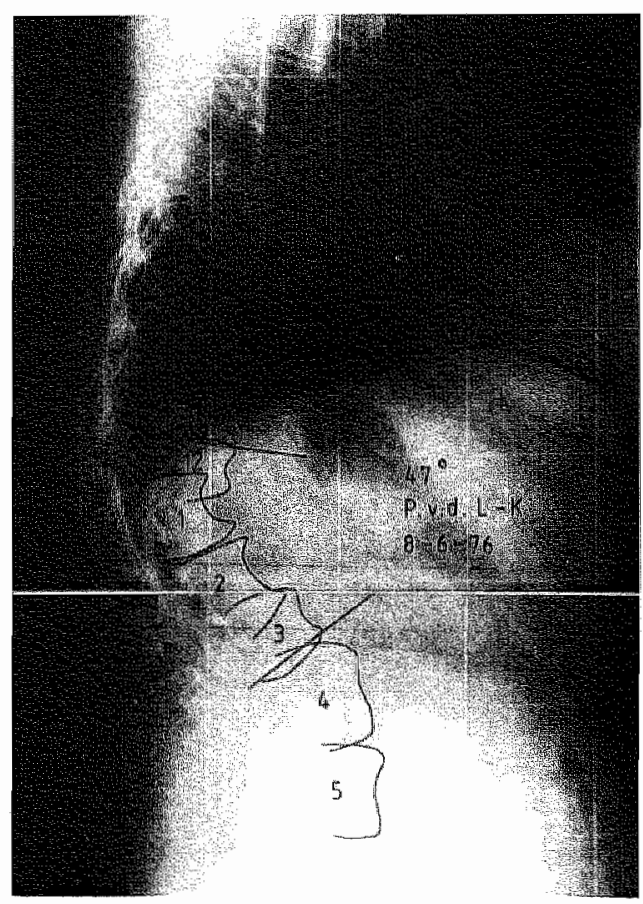

Kylose door drehgleiten préoperatief

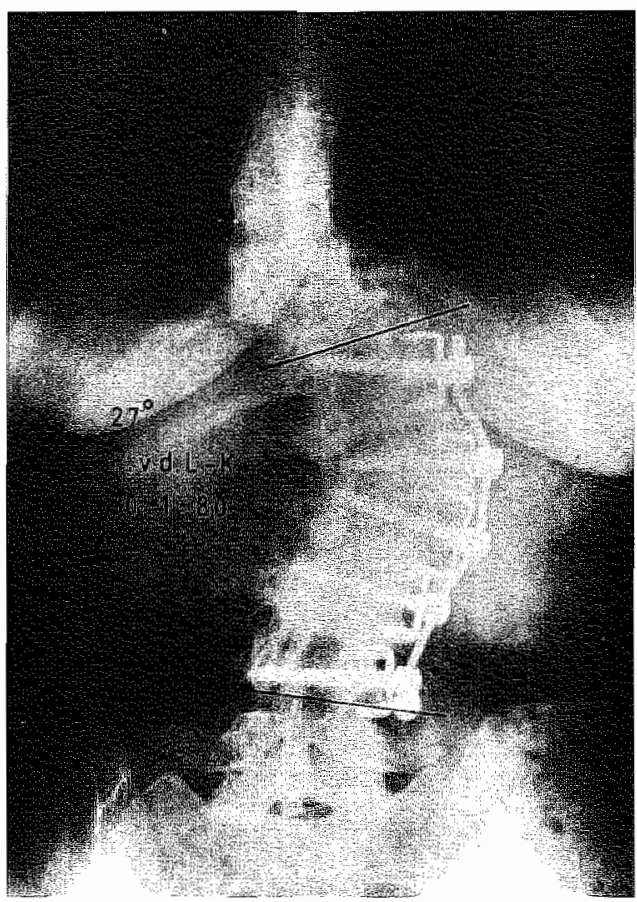

Scoliose na 3 jaar

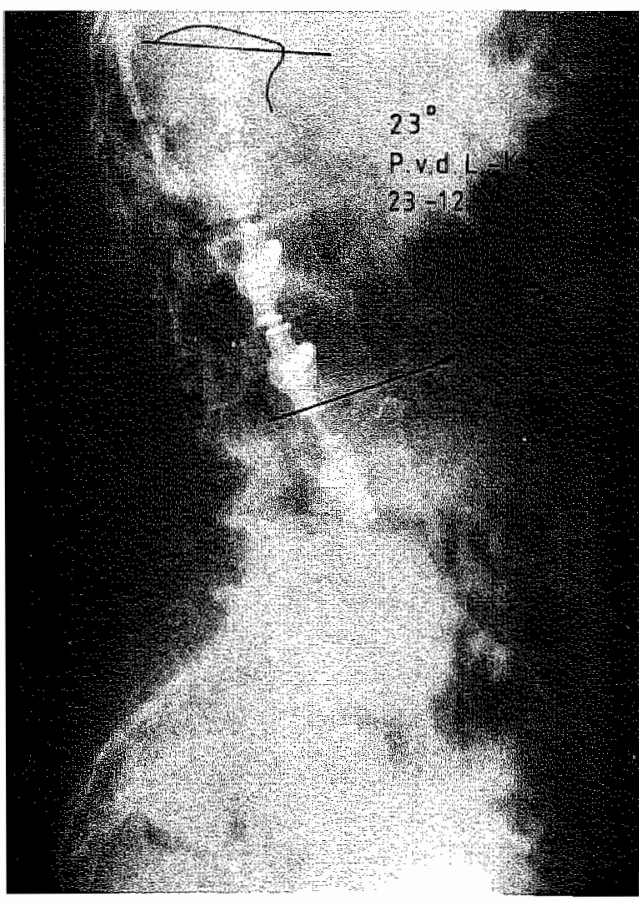

Kyfose postoperatief 


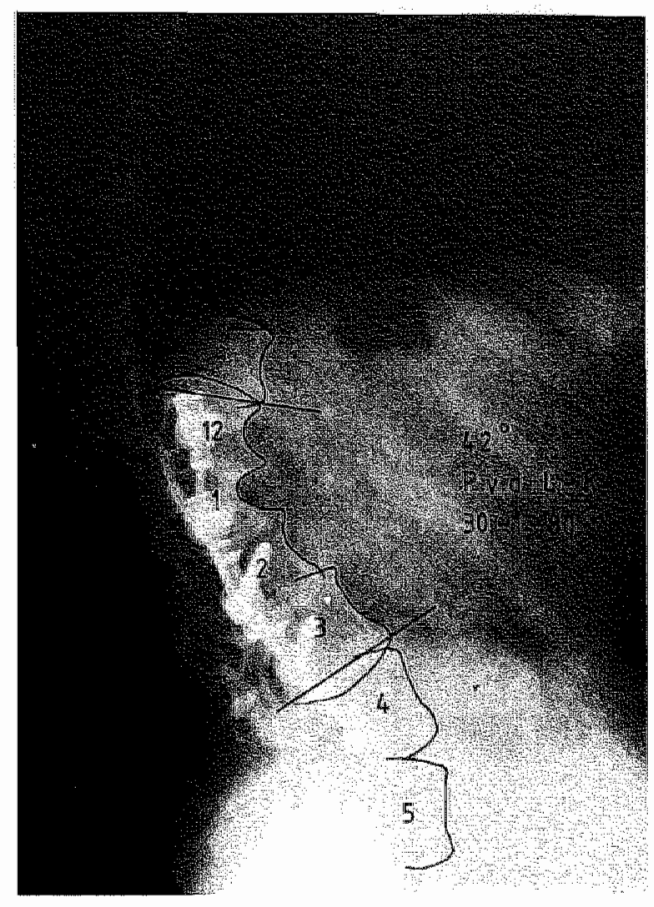

Kyfose na 3 jaar bijna terug op het oude niveau

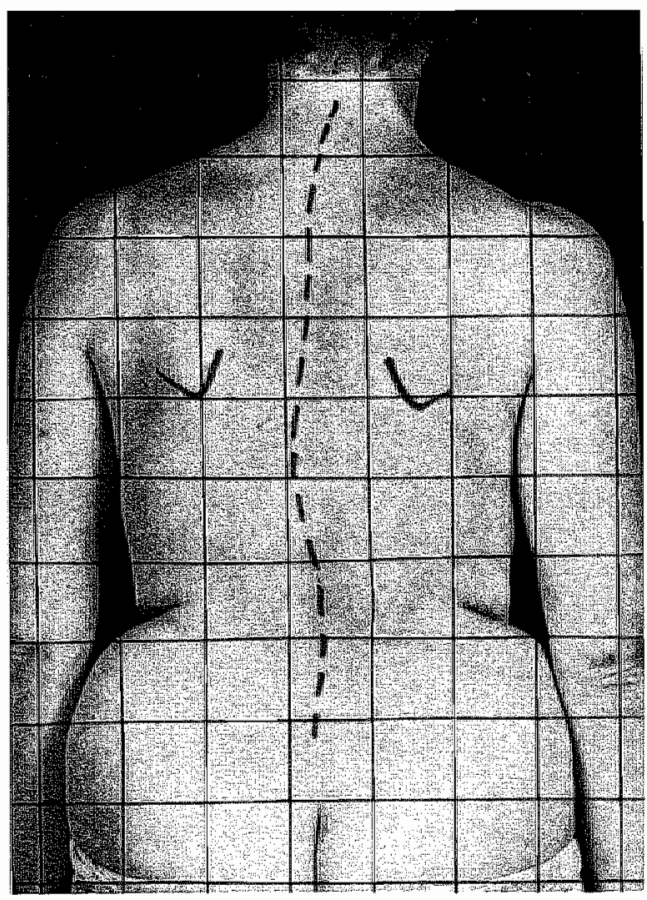

P. v. d. L.-K. Scoliose préoperatief

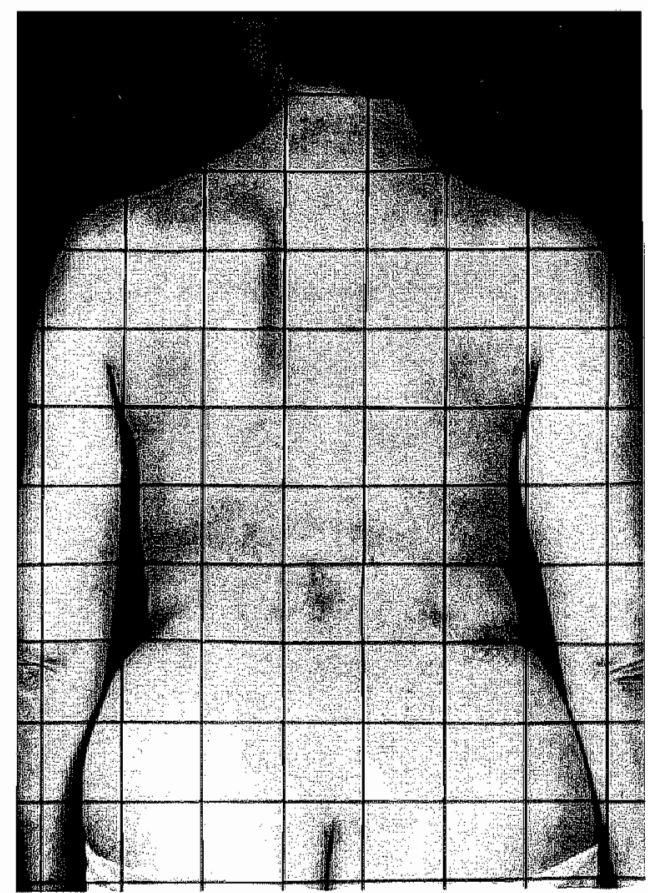

P. v. d. L.-K. Scoliose postoperatief 


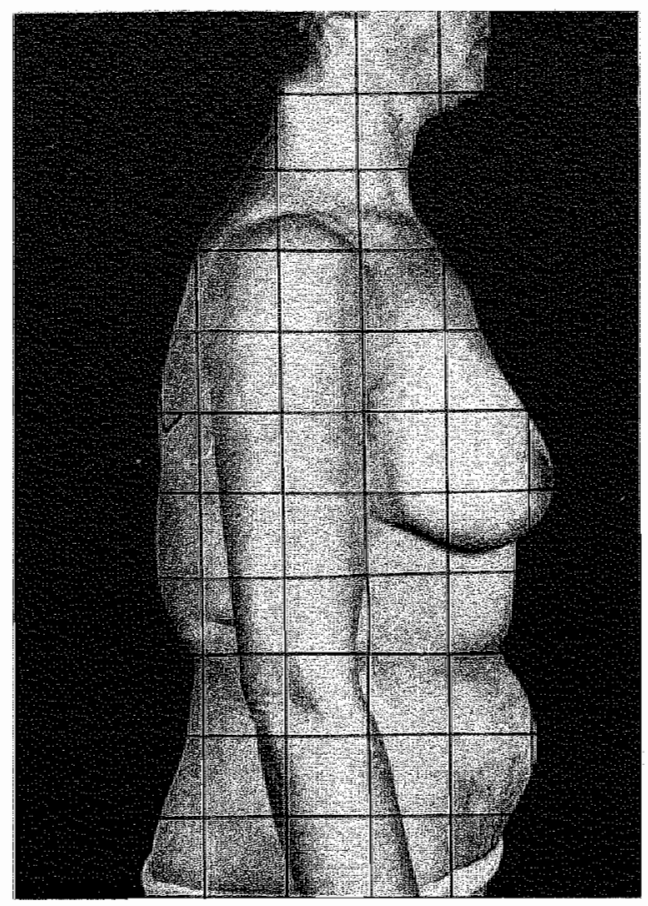

P. v. d. L.-K. Kyfose préoperatief

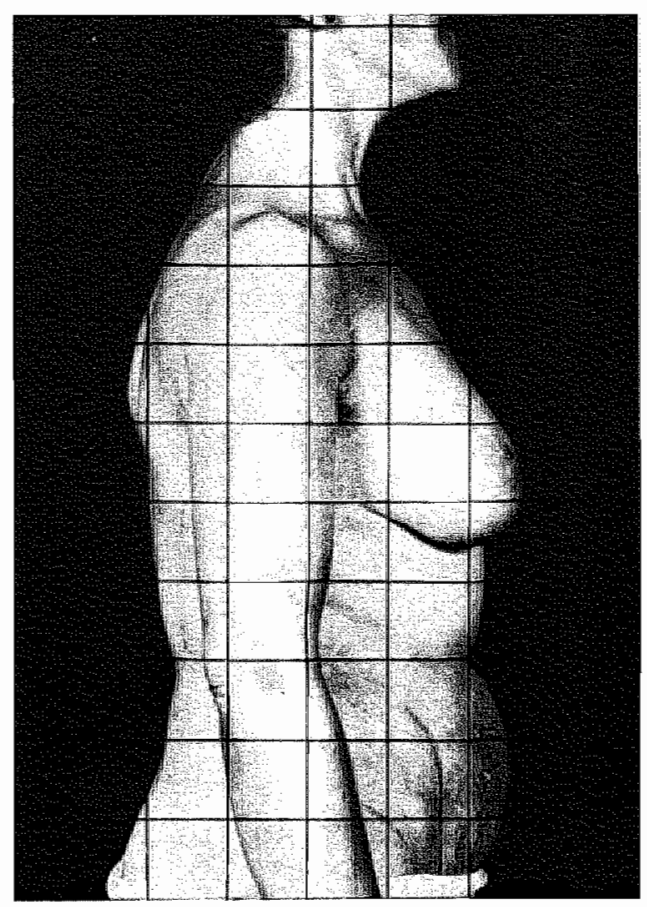

P. v. d. L.-K. Kyfose postoperatief 
Patiënt 50. H. K. B. mannelijk, geb.dat. 9-2-1946.

Aetiologie:

Vroegere behandeling:

Klachten:

Préoperatieve curves:

Voorbehandeling:

Longfunctie:

Conclusie:

Neurologisch onderzoek:

Myelografie:

Operatie 1 :

Operatie 2:

Operatie 3:

Complicaties:

Nabehandeling:
Idiopathische lumbale kyfoscoliose bij oude coxitis tuberculosa rechts op 8 maand oude leeftijd.

Diverse correctie-osteotomieèn aan de benen, epifysiodese linker knie. Voor de rug geen enkele behandeling gehad.

Pijnklachten in de lumbale rug en in de rechter heup.

Scoliose T10 t/m L3 $110^{\circ}$. Tractie $82^{\circ}$. Kyfose T10 $\mathrm{t} / \mathrm{m} \mathrm{L} 290^{\circ}$.

Halo-rolstoeltractie $2 \frac{1}{2}$ week.

Vit. cap. $4400 \mathrm{cc}$. normaal $6600 \mathrm{cc}$. Tot. cap. 5500 cc. normal $8600 \mathrm{cc}$.

Duidelijke restrictieve functiestoornis met nog ruime ventilatoire reserves.

Geen afwijkingen.

Niet verricht.

23-5-1978. Achterste release van de ligamenten en intergewrichten.

7-6-1978. Spondylodese volgens Dwyer T9 t/m L2.

23-6-1978. Spondylodese volgens Harrington $\mathrm{T} 7 \mathrm{t} / \mathrm{m}$ L5. De curve bleek zeer stug, tijdens de operaties weinig correctie mogelijk.

Geen.

9 maanden gipscorset 
Na 2e operatie

Na 3 e operatie

Na 2 weken

Na 4 maanden

Na 7 maanden

$\mathrm{Na} 9$ maanden

$\mathbb{N a} 14$ maander

$\mathrm{Na} 21$ maanden

Na 28 maanden

Na 34 maanden scoliose

$76^{\circ}$

$70^{\circ}$

$70^{\circ}$

$65^{\circ}$

$64^{\circ}$

$74^{\circ}$

$79^{\circ}$

$84^{\circ}$

$85^{\circ}$

$73^{\circ}$ kyfose

-

$-$

$50^{\circ}$

$54^{\circ}$

$53^{\circ}$

$64^{\circ}$

$53^{\circ}$

$52^{\circ}$

$60^{\circ}$

$64^{\circ}$

Postoperatieve klachten:

Regelmatig lumbale spierpijnen met een stijf en trekkend gevoel.

Beschouwing en conclusie:

Scoliosen op de volwassen leeftijd zijn vaak zeer rigide en moeilijk te corrigeren. Zelfs voorafgegaan door een operatieve release van de achterstructuren bleek met de Dwyerprocedure nauwelijks meer correctie te krijgen dan met de préoperatieve tractie bereikt was. Bovendien leent de kyfosecomponent van dit soort curves zich slecht voor de Dwyer-operatie. Het effect van operatie op pijnklachten is bij volwassenen moeilijk te voorspellen, soms zijn deze al zodanig gefixeerd dat ook na goede correctie klachten blijven bestaan. Bij deze patiënt zijn regelmatige rugklachten nog aanwezig, mogelijk doordat de correctie en daardoor het herstel van het musculaire evenwicht matig is geweest. 


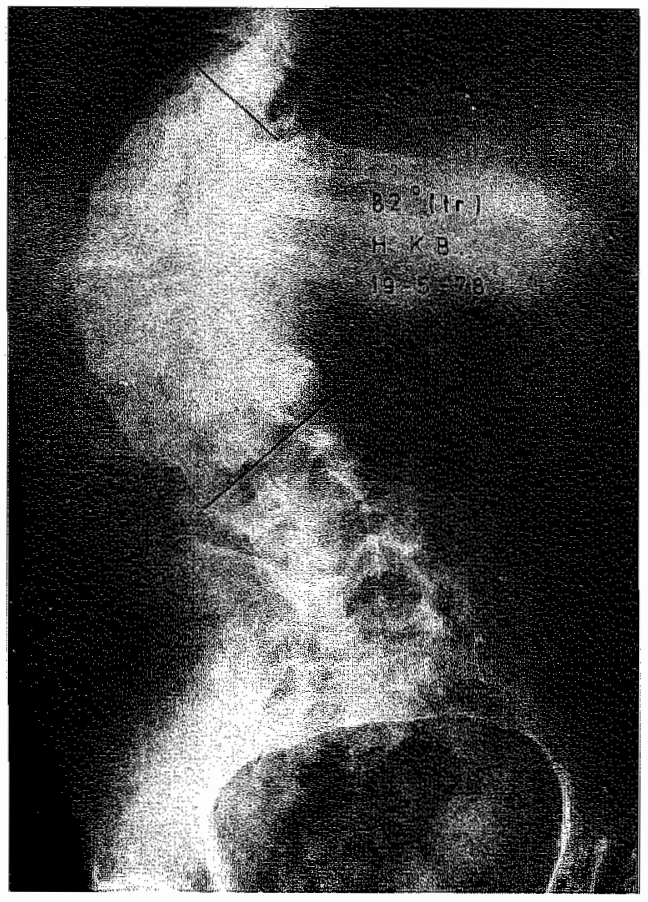

Scoliose in tractie préoperatief

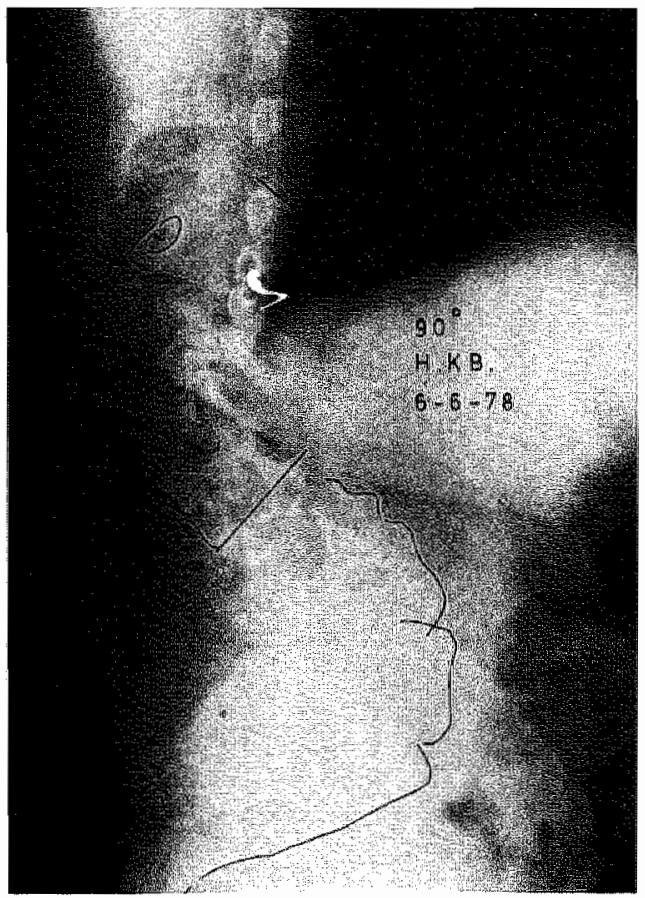

Kyfose door rotatie

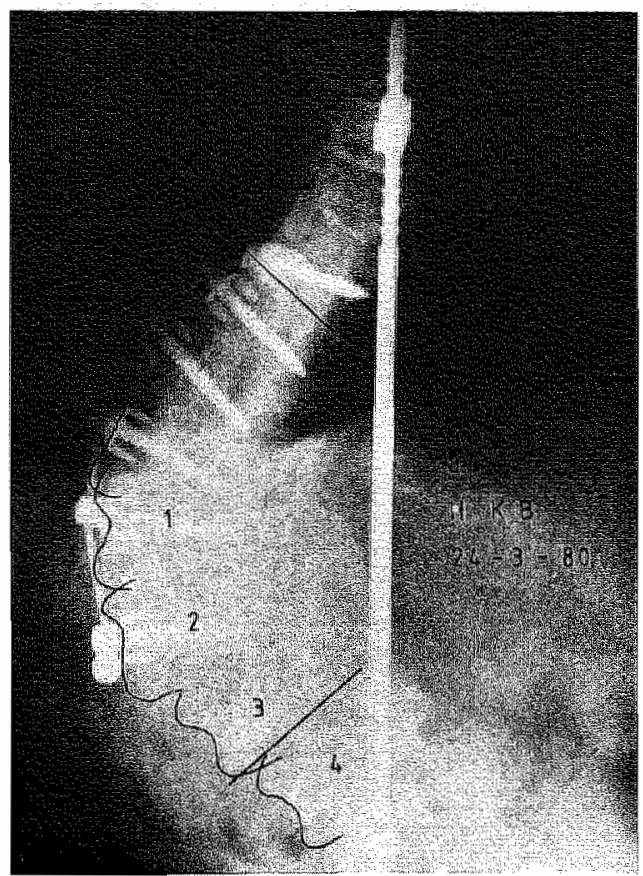

Scoliose postoperatief

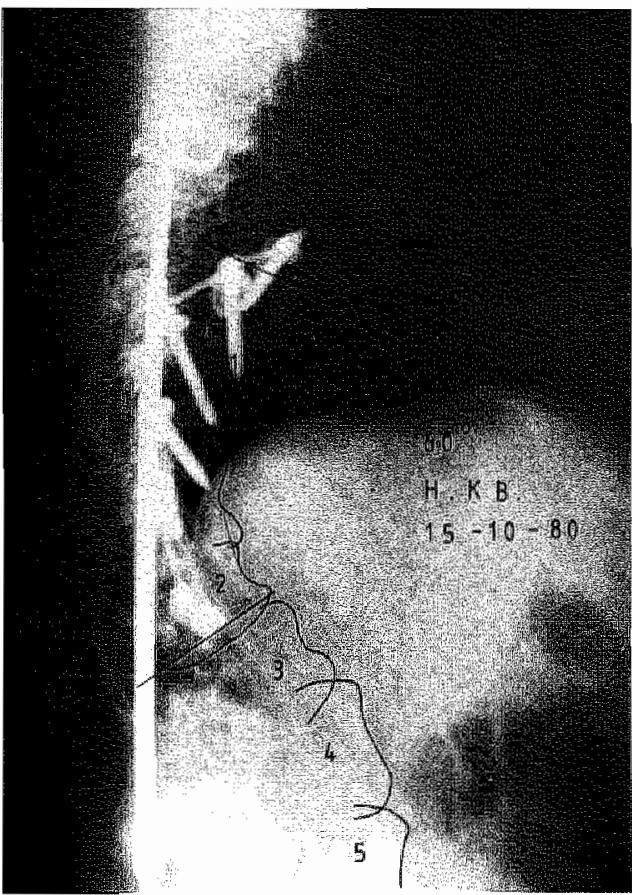

Kyfose postoperatief 


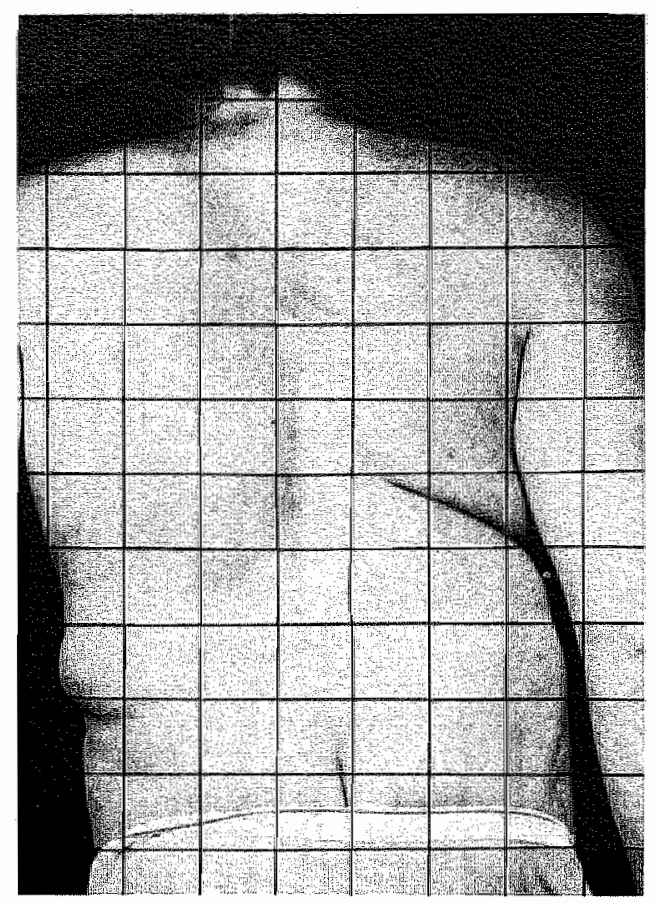

H. K. B. Scolliose préoperatief

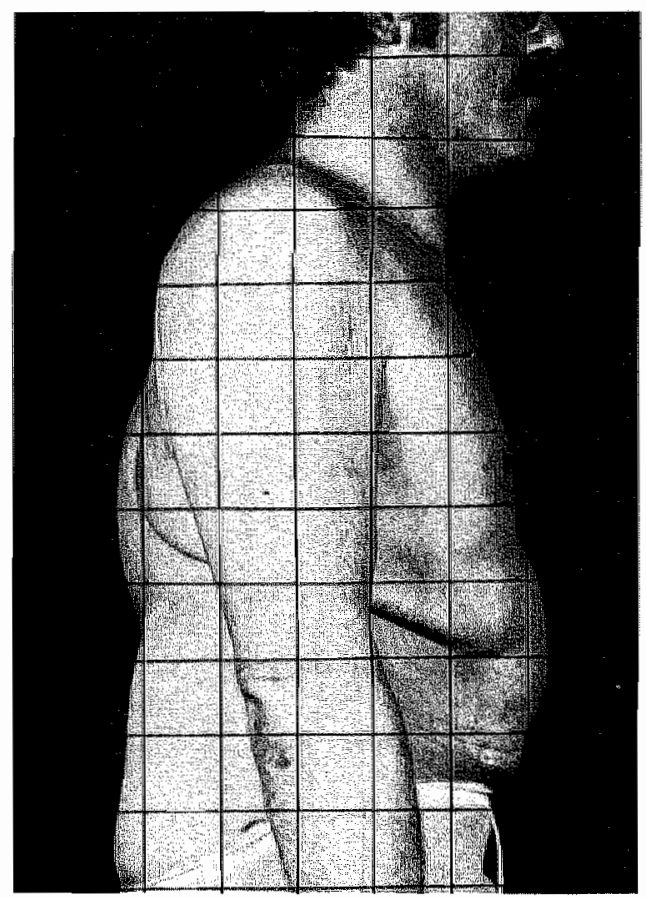

H. K. B. Kytose thoracolumbaal

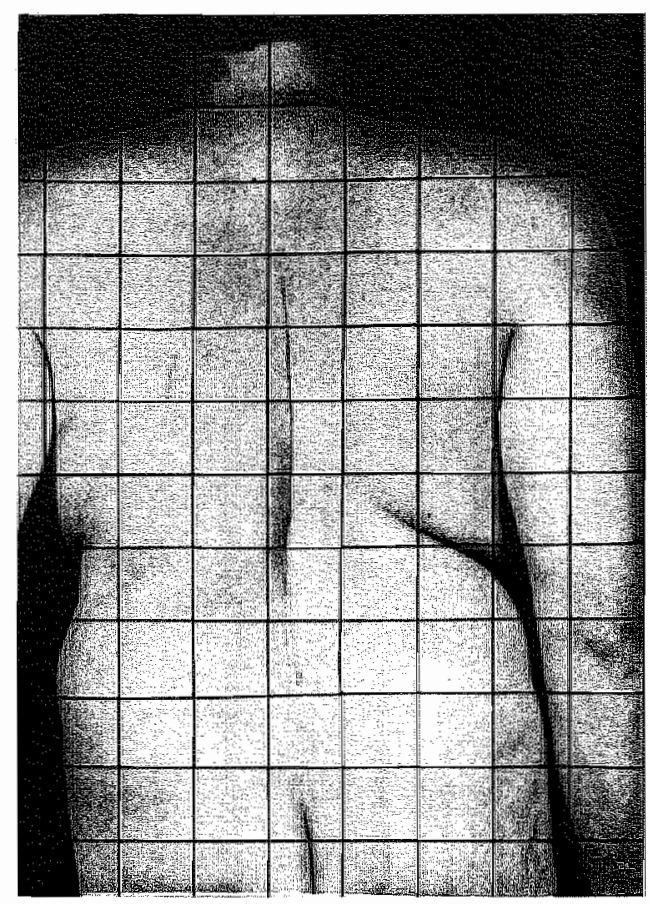

H. K. B. Scoliose postoperatief

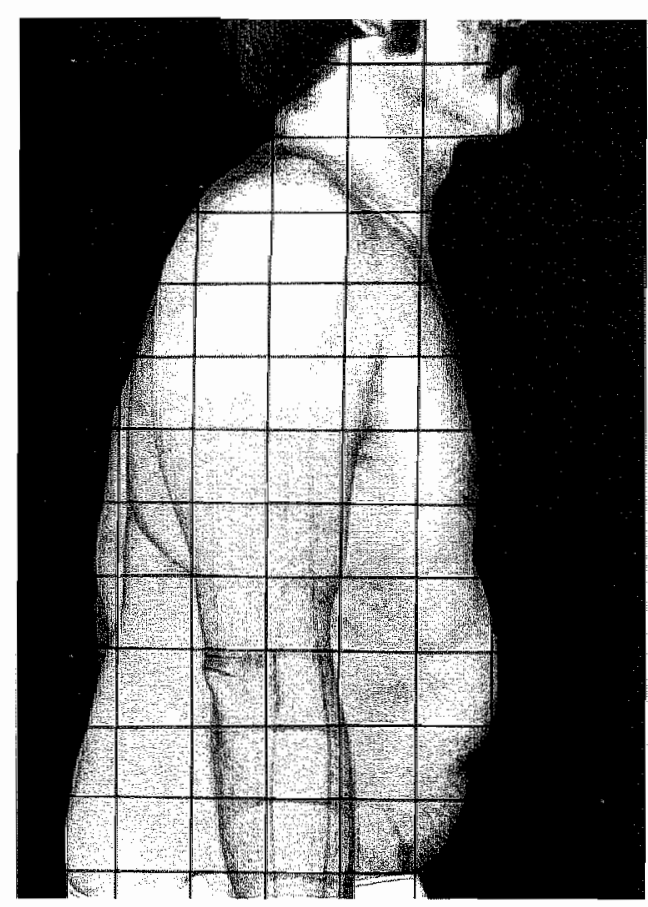

H. K. B. Kyfose postoperatief 
Patiënt 51. M. L.-v. O. vrouwelijk, geb.dat 11-10-1947.

Aetiologie:

Vroegere behandeling:

Klachten:

Préoperatieve curves:

Voorbehandeling:

Longfunctie:

Neurologisch onderzoek:

Operatie 1:

Operatie 2:

Complicaties:

Nabehandeling:

Postoperatieve curves:

Postoperatieve klachten:
Idiopathische scoliose met kyfosering door rotatie.

\section{Geen.}

Cosmetische bezwaren. Was dag en nacht met het ontsierende uiterlijk bezig. Bezocht de revalidatiearts om een opvulling van de scheve rug te krijgen. Volgens patiënte was er progressie. met name in de 2 recente zwangerschappen. Geen pijnklachten.

Scoliose T10 t/m L2 $74^{\circ}$. Kyfose $T 10 \mathrm{t} / \mathrm{m}$ L2 $39^{\circ}$. De scoliose was in $197567^{\circ}$.

Halo-rolstoeltractie 2 weken met gering resultaat (correctie van de scoliose tot $69^{\circ}$ ).

Vit. cap. $3300 \mathrm{cc}$. nomaal $3700 \mathrm{cc}$. Totaalcapaciteit niet gemeten.

Geen afwijkingen.

3-11-1982. Zielke spondylodese T9 t/m L.3. Zeer rigide curve, weinig correctie te verkrijgen.

17-11-1982. Harrington spondylodese met distractie en compressiesysteem T7 t/m L4.

Geen.

6 maanden gipscorset.

Na operatie 1

scoliose

kyfose

Na operatie 2

$55^{\circ}$

$32^{\bar{x}}$

$41^{\circ}$

$22^{\circ}$

$\mathrm{Na} 2$ maanden

$41^{\circ}$

$27^{\circ}$

Na 6 maanden

$43^{\circ}$

$48^{\circ}$

$15^{\circ}$

$19^{\circ}$

$\mathrm{Na} 9$ maanden

Geen. Patiënte is zeer tevreden over het cosmetische resultaat. Ze heeft haar vroegere werk als kapster weer hervat. 
Op de volwassen leeftijd is het moeilijk een goede correctie van scoliotische curves te verkrijgen, zelfs met de meest moderne technieken. De rigiditeit van de scoliose neemt meestal langzaam maar zeker toe, terwijl toch vaak langzame progressie aantoonbaar is. Bij deze patiënte was het begin van spontane verbening in de concaviteit van de curve mede oorzaak van de matige correctie. Het cosmetisch resultaat is desondanks zeer goed, waarover patiente zeer tevreden is. 


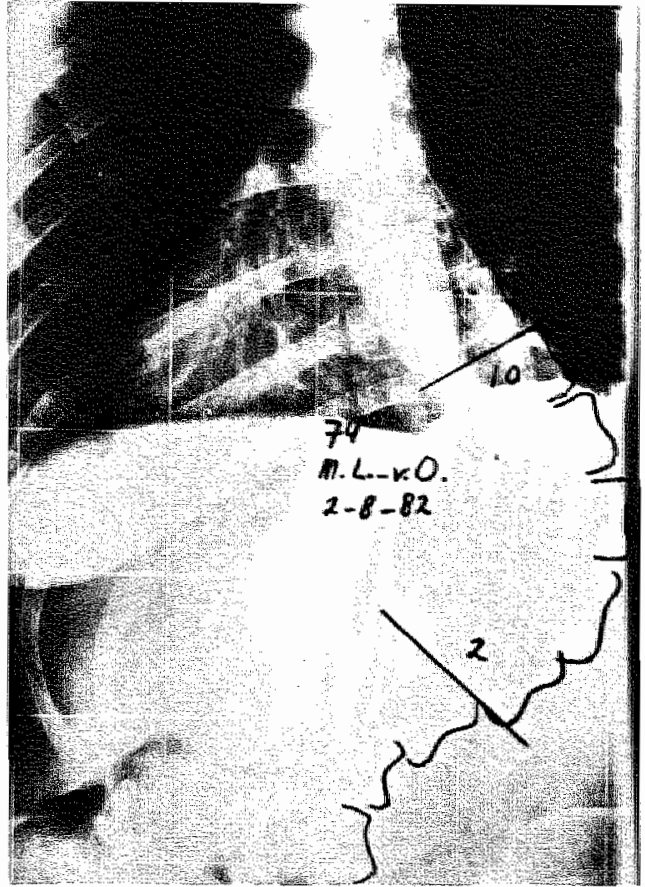

Préoperatieve scoliose

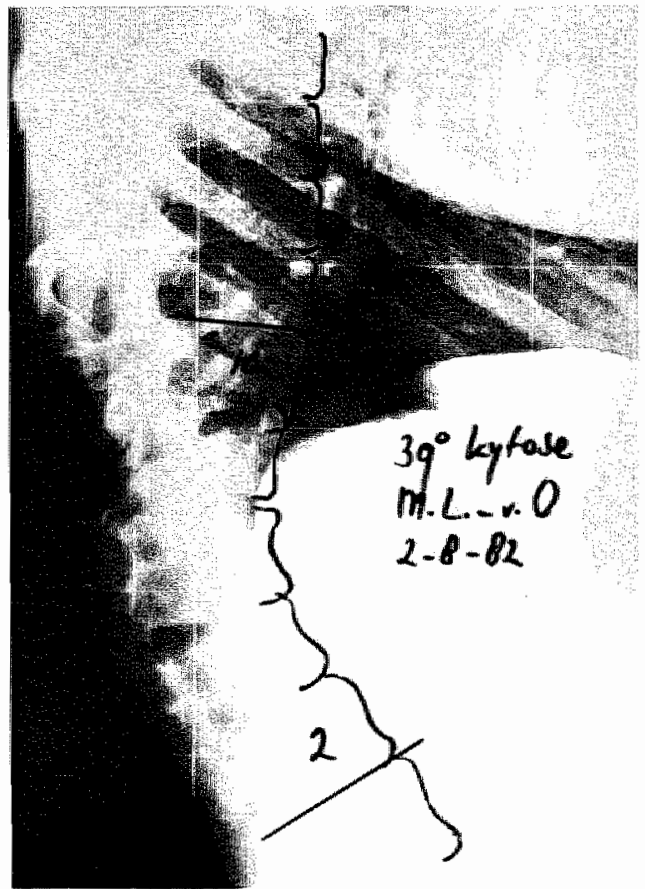

Préoperatieve kyfose

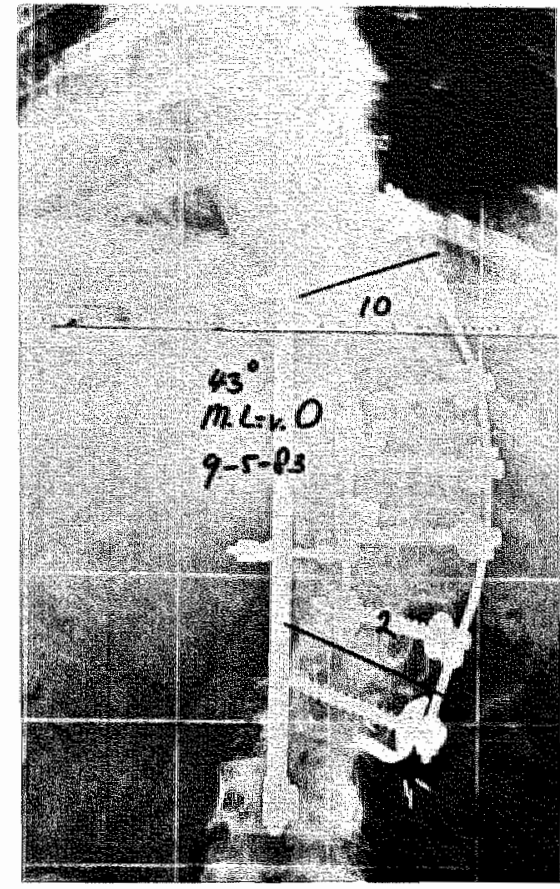

Postoperatieve scoliose

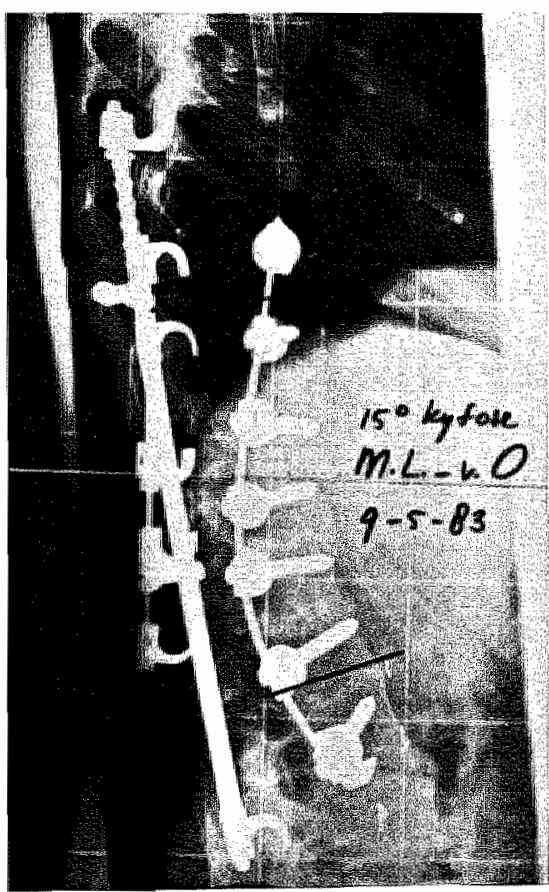

Postoperatieve kyfose 


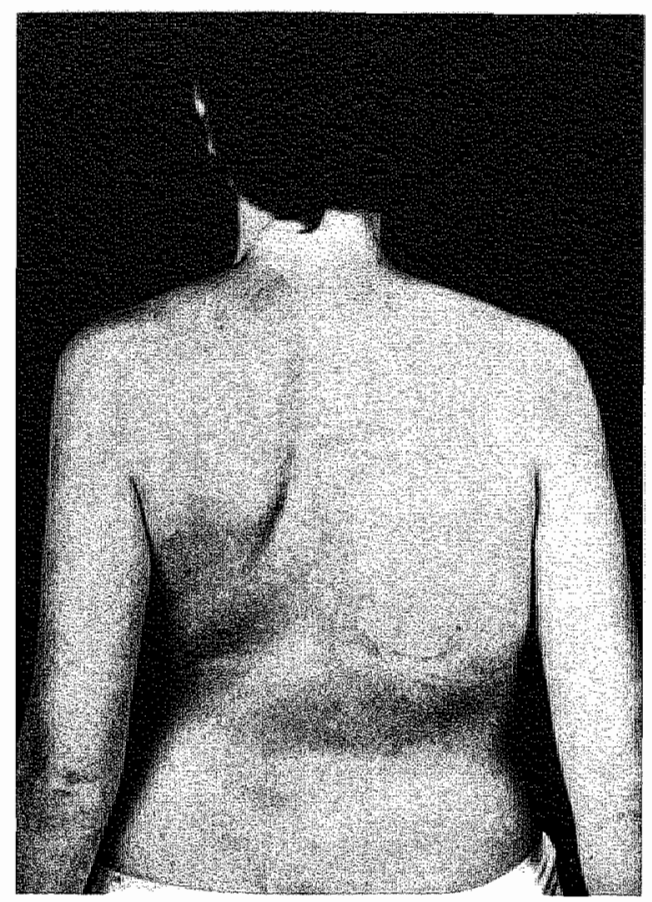

M. L.-v. O. Préoperatieve scoliose

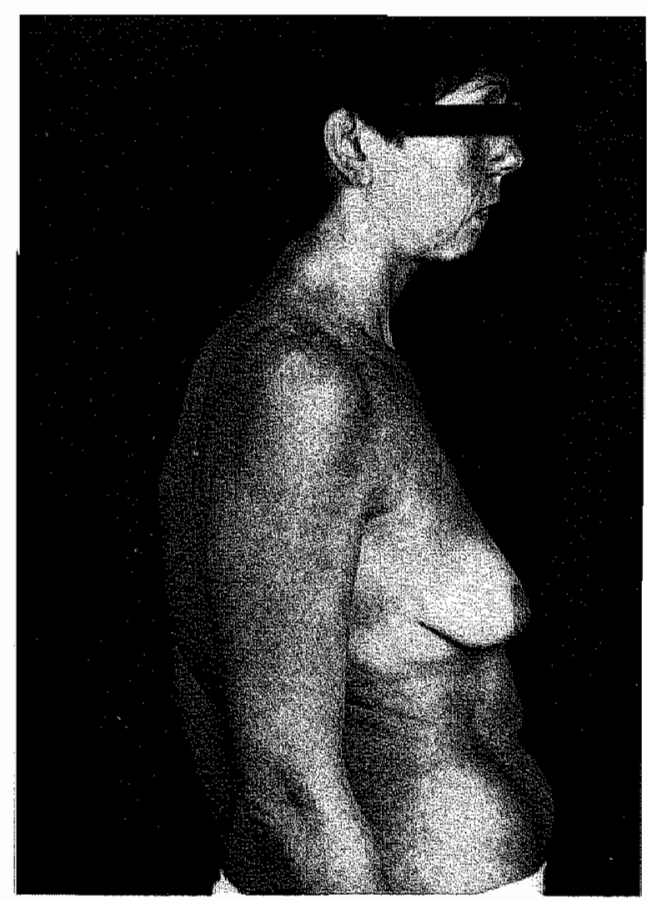

M. L.-v. O. Préoperatieve kyfose

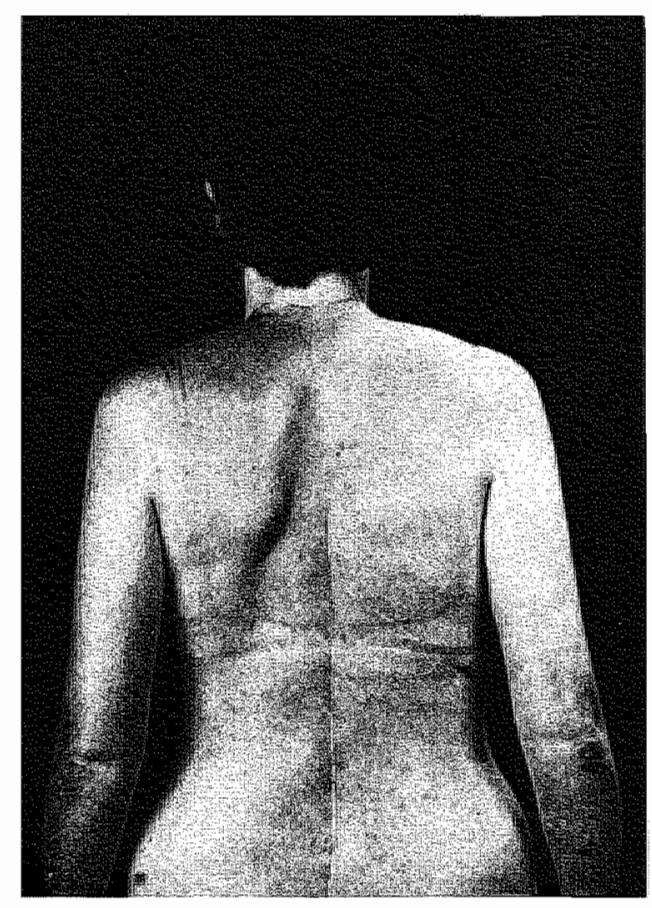

M. L.-v. O. Postoperatieve scoliose

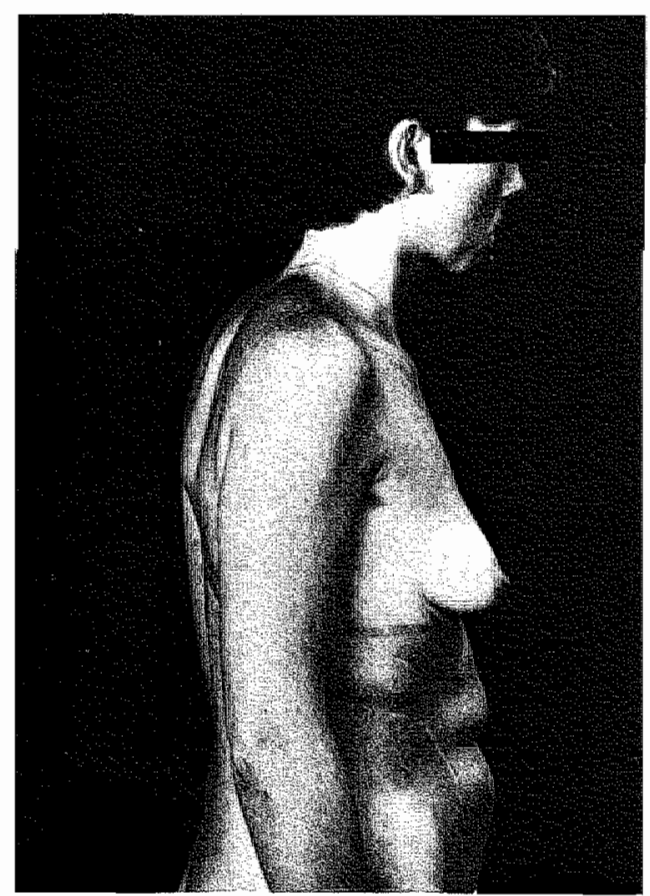

M. L.-v.O. Kyfose 


\section{CONCLUSIES}

De doelstelling van dit proefschrift is onder andere na te gaan welke indicaties er zijn voor operatieve correctie van kyfotische verkrommingen en welke resultaten bereikt worden. Na literatuurstudie en bewerking van het patiëntenmateriaal kunnen conclusies getrokken worden, welke ook in de voorafgaande hoofdstukken al besproken werden.

In het algemeen kan gezegd worden dat hyperkyfosen problemen kunnen geven door veranderde statiek, degeneratieve veranderingen, neurologische symptomen, long-hart afwijkingen, drukafwijkingen van de huid, cosmetische en psychologische veranderimgen. Al deze symptomen kunnen op zich een indicatie zijn voor behandeling, meestal zal een combinatie van symptomen aanwezig zijn, terwijl ook progressie van een hyperkyfose een indicatie tot behandeling kan zijn. Operatieve correctie komt meestal pas in aanmerking als conservatieve maatregelen, zoals fysiotherapie of corsettherapie gefaald hebben. Sommige soorten kyfosen, zoals de congenitale groep, zijn echter alleen door operatie reëel te behandelen. Kennis van het onbehandelde verloop van de verschillende kyfotische verkrommingen is voorwaarde om een goed advies te kunnen geven. In hoofdstuk 1 wordt hier nader op ingegaan.

In de diverse hierop volgende hoofdstukken worden de mogelijkheden tot operatieve correctie bij verschillende aetiologieën besproken. De belangrijkste conclusies kunnen als volgt worden geformuleerd:

- Bij Scheuermannkyfose is conservatief redresserende behandeling in het groeiende kind verre te verkiezen boven latere operatieve correctie. Deze is goed mogelijk via een voorste en achterste ingreep, maar het effect op het klachtenpatroon, met name de pijnklachten is onvoorspelbaar.

- Bij congenitale kyfosen dient bij aangetoonde progressie zo vroeg mogelijk een achterste fusie te geschieden. Op latere leeftijd kan correctie van een grote curve zeer moeilijk zijn, terwijl ook de kans op paraplegie, zo deze nog niet aanwezig was, bij de operatieve correctie niet gering is.

- Paralytische kyfosen zijn veelal langgerekt en geven vooral problemen in de statick. Corsetbehandeling is vaak teleurstellend, vroege operatieve correctic en fusic van meestal een groot gedeelte van de wervelkolom tot en met het sacrum is dan de enige manier om een goede zitfunctie te behouden.

- Bechterewkyfosen kunnen in vele gradaties aanwezig zijn, zelfs zeer bizarre lichaamsvormen kunnen ontstaan mede als gevolg van botstructuurveranderingen (casus 27). Meestal zal een hoog lumbale columnotomie een belangrijke verbetering van de statiek en het psychisch welbevinden tot gevolg hebben, soms is een goed resultaat echter uiterst moeizaam te verkrijgen door insufficiëntie van het bot zelf

- De neurofibromatose van von Recklinghausen is berucht om de zeer moeilijk te behandelen kyfoscoliose. Door dysplasie en zelfs verdwijnen van dragende structuren collabeert de wervelkolom. Achterste en voorste fusie is aangewezen, maar zelfs dan is resorptie van ingebracht bot en verlies van correctie of pseudarthrose mogelijk. Paraplegie door ernstige kyfosering moet echter tot elke prijs voorkomen worden.

- Tuberculose van de wervelkolom kan op vele manieren behandeld worden, de snelste genezing kan bereikt worden door tuberculostatica, voorste debridement en opvullen van het defekt met botgrafts. Verouderde kyfosen zijn zeer moeilijk te corri- 
geren door sterke rigiditeit. Bij dreigende of manifeste paraplegie is soms decompressie van het myelum door verwijdering van de interne gibbus nodig. meestal zal stabilisatie ter plaatse voldoende zijn.

- Door laminectomie en/of bestraling op de kinderleeftijd kunnen ernstige wervelkolomdeformiteiten ontstaan, vaak met kyfose. Dwarslaesieverschijnselen zijn vaak aanwezig, ook in verband staand met de primaire ziekte. Belangrijk is het in een vroeg stadium adequat conservatief of operatief behandelen "soms door tegelijk met de laminectomie een spondylodese toe te voegen.

- De behandeling van traumatische kyfosen lijkt steeds meer een operatieve richting op te gaan. Vooral door CT scan toepassing wordt bij wervelfracturen vaker een fragment van het wervellichaam in het spinaalkanaal aangetoond. Verwijdering of repositie van dit fragment ligt voor de hand als neurologische symptomatologie bestaat. Dit lijkt door de betere toegang het beste via de voorzijde te kunnen geschieden. Verouderde traumatische kyfosen kunnen alleen van de voorkant van de wervelkolom uit gecorrigeerd worden met decompressie indien nodig.

- Bij kyfosen ten gevolge van tumoren zal operatieve benadering overwogen worden als er een meestal solitaire localisatie bestaat met bedreiging van het ruggemerg, terwijl er onvoldoende reactie op bestraling en/of chemotherapie zal bestaan. Bij primaire bottumoren zal deze indicatie eerder gesteld worden dan bij metastasen. Bij localisatie in het wervellichaam is een voorste ingreep in principe zinvoller dan een achterste laminectomie.

- De kyfose welke kan ontstaan bij de idiopathische scoliose treedt op door sterke rotatie. Hierdoor draait de curve in het sagittale vlak. Correctie kan in het thoracolumbale en lumbale traject plaatsvinden met de Zielke derotatie procedure eventueel gevolgd door een achterste ingreep. Thoracaal kan een Harrington spondylodese goede resultaten geven.

Uit het patiëntenmateriaal van 51 gevallen blijkt dat meestal goede resultaten verwacht kunnen worden, al zall soms herhaalde operatie nodig zijn om een goed resultaat te verkrijgen. 


\section{SAMENVATTING}

In dit proefschrift wordt een overzicht gegeven van de operatieve mogelijkheden bij verschillende vormen van versterkte kyfosering van de wervelkolom. Tot op heden zijn deze mogelijkheden vrij onbekend gebleven. De voornaamste reden om dit proefschrift te schrijven is dan ook meer bekendheid te geven aan de chirurgische behandeling van kyfosen en het eigen materiaal kritisch te evalueren. De operaties zijn van een dusdanige omvañg dat een zörgvuldige indicatiestelling van het grootste belang is. Kennis van het onbehandelde beloop van deze deformiteiten is noodzaak en voorwaarde om de patiënt en zijn familie op verantwoorde wijze te kunnen voorlichten over de zirn van de operatie gesteld tegenover de risico"s hiervan.

In het eerste hoofdstuk wordt een indeling gegeven van de diverse vormen van kyfose. warna enkele algemene kenmerken worden besproken.

In het tweede hoofdstuk over Scheuermannkyfosen wordt de conservatieve therapie bij het kind met deze groeistoornis benadrukt. Indien deze behandeling adequaat gegeven wordt zal het zelden nodig zijn op volwassen leeftijd een kyfosecorrectie uit te voeren. Vier patiënten worden beschreven, bij 1 patiënt is met een achterste spondylodese volstaan, terwijl bij de 3 andere patiënten een gecombineerde voorste en achterste fusie is uitgevoerd. De correctie van de kyfose bedraagt meestal iets minder dan de helft van de préoperatieve kyfose. Afhankelijk van de ernst wordt dan ook niet altijd een normale kyfosehoek bereikt. Het effect van de correctie op het klachtenpatroon is moeilijk voorspelbaar. Vooral als de compensatoire lordose al gefixeerd is en klachten veroorzaakt, zal een correctie van de hyperkyfose hierboven weinig verbetering van de klachten geven.

In hoofdstuk 3 over congenitale kyfosen wordt de noodzaak van vroege operatie bij aangetoonde progressie van deze afwijking benadrukt. Conservatieve therapie zoals bracebehandeling of fysiotherapie heeft hier geen nut en kan in het gunstigste geval de compensatoire curves in bedwang houden. Op latere leeftijd bestaat grote kans dat uitgebreider ingrepen moeten plaatsvinden om een goed resultaat te bereiken, terwijl ook het gevaar voor paraplegie bij onbehandelde angulaire congenitale kyfosen niet gering is. Dit komt naar voren in de patiëntenbeschrijvingen. Bij de 10 beschreven patiënten is 3 maal een resectie van de dorsolaterale halfwervel verricht, waarmee een goede equilibratie van de wervelkolom is verkregen. Bij operatie op de kinderleeftijc zouden deze grote operaties echter onnodig zijn geweest.

Hoofdstuk 4 behandelt de paralytische kyfosen. Een grote verscheidenheid aan ziektebeelden kan oorzaak van kyfose zijn, vaak gecombineerd met scoliose. Het collaberen van de wervelkolom veroorzaakt een ernstige longfunctiestoornis en een verstoring van de zitbalans. Bij vroege progressie is het aan te bevelen met corsettherapie te starten. Als verdere progressie ondanks een brace optreedt komt vroege operatie in aanmerking. Hierbij is dan een groot gedeelte van de rug, meestal tot en met het sacrum, betrokken. Hoe ernstiger de deformiteit, des te groter de kans op complicaties, mede door het feit dat de patient in een slechtere conditie is komen te verkeren. Aan de hand van 6 patiënten worden diverse aspecten van de operatieve behandeling belicht en conclusies getrokken.

In hoofdstuk 5 komen de kyfosen bij de ziekte van Bechterew aan de orde. Belangrijk is hier het voorkómen van een ernstige deformiteit door gerichte oefentherapie en hou- 
dingsadviezen, ook tijdens de nachtrust. Deze conservatieve therapie dient in een vroeg stadium te worden ingesteld. Soms lijkt ook een metabole factor in thet spel, waardoor de kwaliteit van het botweefsel achteruitgaat. Hierdoor kan tijdens de ombouw van het botweefsel de werwelkolom als het ware meebuigen, hetgeen de versterkte kyfosering en vooral ook de vervlakking van de lendenlordose in de hand werkt. De kyfosering heeft een beperking van het gezichtsveld tot gevolg en verdere insufficiëntie van de door de starre thorax toch al bemoeilijkte ademhaling. Met de columnotomie wordt een hernieuwde equilibratie van de kyfose-lordose nagestreefd en kan het beste hoog lumbaal verricht worden, soms cervicaal of thoracaal. Het blikveld wordt hierdoor verruimd en door strekken van de buikspieren wordt de ademhaling verbeterd. Met interne fixatie kan de patiënt al na enkele weken gemobiliseerd worden, terwijl de kans op verlies van correctie veel geringer geworden is. De ziektegeschiedenissen van 7 patiënten geven aan dat de procedure niet geheel zonder risico is, en dat volledige correctie van een ernstig gekyfoseerde wervelkolom uiterst moeilijk is.

De kyfosering bij de neurofibromatose van Von Recklinghausen wordt in hoofdstuk 6 beschreven. Bij de typische vorm gaat het om uiterst agressieve curves met verlies aan botweefsel, dat vervangen wordt door bindweefsel. Hierdoor verliest de voorzijde van de wervelkolom zijn stabiliteit en treedt angulaire kyfose, in de meeste gevallen met enige scoliose op. Door de sterke knik bestaat kans op paraplegie. Door verwijding van het spinale kanaal treedt deze gewoonlijk pas bij een zeer ernstige curve op. Een andere kyfosevorm is die welke ontstaat door sterke rotatie van een meestal thoracolumbale scoliose. Belangrijk is bij de eerste vorm het creëren van een nieuwe voorste wervelkolompijler, waarvoor de fibula het meest geschikt is. Of interne fixatie aan de voorzijde wezenlijk bijdraagt tot ongestoorde ingroei van het transplantaat zal de ervaring ons moeten leren. Met resorptie van het transplantaat door het agressieve bindweefsel moet rekening worden gehouden. Dit voorkómen is tot op dit moment niet mogelijk. Zeven patiënten worden beschreven, waarbij de problemen die zich voordoen bij het verkrijgen van een goed stabiele wervelkolom duidelijk naar voren komen.

Hoofdstuk 7 behandelt de tuberculose van de wervelkolom. Genezing van de in ons land zelden voorkomende Pottse kyfose is een langdurige zaak. Met de nieuwe tuberculostatica lijkt genezing echter sneller te bereiken, terwijl strikte bedrust en gipscorsetten in grote vergelijkende onderzoeken weinig blijkt bij te dragen aan de genezing. De snelste genezing met de minste deformiteit wordt verkregen met de radicale operatie volgens Hodgson. Voldoende faciliteiten om deze operaties uit te voeren moeten aanwezig zijn om deze ingrepen te rechtvaardigen. Bij verouderde Pottse kyfosen is het zeer moeilijk correctie te verkrijgen door de sterke rigiditeit van de meestal angulaire kyfosen. Stabilisatie is vooral belangrijk als er dreigende of al manifeste paraplegie is door afknikking van het myelum over de kyfotische wervellichamen. Vijf patiènten worden beschreven om deze problematiek nader te illustreren.

De problemen, welke kunnen ontstaan na laminectomie en/of bestraling, worden besproken in hoofdstuk 8 . Met name op de kinderleeftijd treedt dan trequent een kyfose of kyfoscoliose op door vermindering van de stabiliteit van het achterste wervelcomplex of door groeischijfbeschadiging van de wervellichamen. Meer of minder dramatische wervelkolomdeformiteiten kunnen hiervan het gevolg zijn als niet tijdig wordt ingegrepen. Soms zal conservatieve behandeling met behulp van een brace mogelijk zijn, maar vaak zal operatieve stabilisatie geindiceerd zijn als de levenswerwachting goed is. Bij matige kyfotische deformiteiten zal een achterste spondylodese meestal nog mogelijk zijn; bij ernstige vormen zal een voorste spondylodese nodig zijn, mede door de vaak bestaande deficiëntie van de achterstructuren. De moeilijkheden, welke kunnen ont- 
staan bij de ernstiger vormen. komen vooral in de laatste 2 can de 4 beschreven patienten naar voren.

In hoofdstuk 9 komt de wellicht meest controversiele groep kyfosen aan de orde. De traumatische kyfose als acuut letsel moet onderscheiden worden van de verouderde traumatische kyfose. Bij de acute wervelfractuur met kytose met of zonder paraplegie kunnen vele behandelingsmethoden gevolgd worden, zowel conservatief als operatief. Een duidelijk superieure beleidslijn is nog niet naar voren gekomen. hoewel een trend bestaat naar een operatieve behandeling van meer ernstige fracturen. Dit houdt een 20 goed mogelijke correctie in van de kyfose en stabilisatie met behulp van inwendige fixatie en een locale spondylodese. Het herstel van de contouren van het spinale kanaal is hierbij het meest gewenst, met name als er een partiële paraplegie bestat. Operatie bij volledige dwarslaesie lijkt in het algemeen overbodig en heeft alleen nut bij ernstige instabiliteit. Verouderde traumatische kyfosen kunnen alleen na voorste telease gecorrigeerd worden, warbij zonodig een decompressie van het myelum of cauda equina kan worden toegevoegd. Een achterste spondylodese is hierna zelden nodig. Drie patiënten worden besproken, bij 2 van hen was de correctie relatief eenvoudig. Bij de $3 \mathrm{e}$ patiënt trad ten gevolge van de fractuur paraplegie op, zonder verbetering na laminectomie. Op de kinderleeftijd is progressieve kyfosering dan te verwachten en deze moet voorkomen worden door vroeg een spondylodese te verrichten. Bij deze patiënt gebeurde dit veel te laat met gering resultaat.

Hoofdstuk 10 behandelt kort de kyfose welke bij tumoren kan optreden. Meestal gaat het om metastasen en zal operatieve therapie niet geindiceerd zijn. Slechts als er een metastase is met directe bedreiging voor de ruggemergstunctie bij een in goede algehele conditie verkerende patiënt komt uitruiming wan de tumorhaard met vervanging wan het wervellichaam en inwendige stabilisatie in anmerking. Bij de zeldzamer primaire werveltumoren, welke onvoldoende op bestraling en/of chemotherapie reageren zal eerder chirurgische verwijdering met reconstructie in aanmerking komen. Eén patiënte wordt beschreven met wervelmetastase en dreigende paraplegie bij mammacarcinoom, warbij met voorste resectie en stabilisatie een goed resultat werd verk regen.

Tenslotte wordt in hoofdstuk 11 . de rotatiekyfose behandeld. Deze ontstaat door de sterke draaing van een scoliotische curve, waardoor deze in het sagittale vlak komt te liggen en er van een versterkte kyfose sprake is. Lumbaal wordt de lordose opgeheven en bij verdere rotatie kan zelfs kyfose ontstan met afglijding van de wervellichamen ten opzichte van elkaar, het zogenaamde drehgleiten. Thoracaal kan een zo sterke rotatie optreden dat de ribben aan de convexe zijde recht naar achteren wijzen. De facetgewrichten van de thoracale wervelkolom komen van het frontale vlak in het sagiftale vlak te liggen, waardoor kyfosering van de wervels onderling mogelijk wordt. Deze deformiteiten zijn ook op volwassen leeftijd vaak progressief, met name bij vrouwen rond en na de menopauze. Soms treedt spontane fusie in de concaviteit van de curve op, maar meestal zal operatie nodig zijn om de progressie te stoppen. Verschillende technieken kunnen hiervoor gebruikt worden, de voorste derotatiespondylodese volgens Zielke lijkt het meest geschikt om het beste resultaat bij thoracolumbale en lumbale curves te verkrijgen. Bij thoracale curves kan de techniek volgens Stagnara gebruikt worden, essentieel is het verkrijgen van een spondylodese in de belastingslijn. Vier patiënten met deze problematiek worden gedemonstreerd.

Uit dit exposé van kyfotische verkrommingen, gerangschikt naar aetiologie, blijkt dat het zeker aiet de eenvoudigste deformiteiten zijn om te behandelen. Mogelijk is dit proefschrift van nut bij het beoordelen van de mogelijkheden die aanwezig zijn bij de behandeling van deze patiëntencategorie. 
In this thesis a survey is given of the operative possibilities in different forms of hyperkyphosis of the spine. Until now these possibilities were relatively unknown. The most important reason for writing this thesis is the opportunity to acquaint more people with the surgical treatment of kyphosis and to evaluate our own material critically. The operations are of such magnitude that careful consideration of the indications is of the utmost importance. Knowledge of the natural history of these deformities is necessary and the first priority is to inform the patient and his family in a justifiable way of the benefit of the operation compared with the risk it carries.

The operative treatment of kyphosis is not possible without teamwork. Besides the orthopaedic surgeon the general surgeon, rehabilitation physician, anaesthesist, roentgenologist, rheumatologist, neurologist and neurosurgeon are sometimes closely involved in the treatment. The plastertechnician, fysiotherapist and nurse are indispensable collaborators in reaching an optimum result.

In the first chapter a survey is given of the different forms of kyphosis, whereafter some general characteristics are discussed.

In chapter 2 on Scheuermann kyphosis the conservative treatment in the growing child is stressed. When this treatment is adequately given it will be rarely necessary to perform a kyphosis correction in adulthood. Four patients are presented, 1 patient had a one-stage posterior correction and fusion, 3 patients had a two-stage anterior and posterior correction and fusion. In most patients correction is somewhat less than half the preoperative kyphosis. Depending on the preoperative severity a normal kyphosis angle is not always reached. The effect of the correction on the symptoms is difficult to predict. Especially when the lumbar lordosis is fixed and gives rise to symptoms a correction of the hyperkyphosis above it will not always improve the symptoms.

In chapter 3 on congenital kyphosis the necessity of early operation in cases of proved progression is underlined. Conservative treatment by brace therapy or fysiotherapy has no use and can at best stop the progression of the compensatory curves. At a later stage there is a chance that more extensive surgery becomes necessary to achieve a good result, whereas the danger of paraplegia in untreated angular kyphosis is not inconsiderable. This is illustrated by the case reports. Three times out of ten cases a resection of the postero-lateral hemivertebra was performed, whereafter a good realignement of the spine was obtained. If these patients had been operated during childhood this major surgery would not have been necessary.

Chapter 4 deals with the paralytic kyphosis and kyphoscoliosis. Many diseases can cause such a deformity. Collapsing of the spine creates a severe restriction of lung capacity and a loss of balance. In cases of early progression brace treatment is advised. If progression continues despite conservative treatment early operation is the best solution. In these cases a major part of the spine is involved, usually including the sacrum. The complication rate is greater in the more serious curve group, also depending on the fact that the patient is in a worse condition than before. Illustrated by 6 case reports various aspects of the operative treatment are presented.

In chapter 5 the kyphosis due to Bechterew's disease (ankylosing spondylitis) is discussed. An important consideration is the prevention of serious deformity by means of specific exercises and advice about the posture, especially during sleep. This conservative therapy must be instituted in an early phase of the disease. Sometimes it seems that a metabolic factor plays a role, through which a loss of quality of bone tissue arises. During the turnover of bone tissue the spine can gradually bend under the influence of 
the kyphosing forces, giving rise to a hyperkyphosis and especially a loss of lumbar lordosis. The hyperkyphosis gives a loss of the range of vision and a progressive insufficiency of respiration by shortening of the abdominal muscles, already hindered because of the ankylosed thorax. With a spinal osteotomy we try to achieve a renewed equilibrium of kyphosis-lordosis. It can best be done at the high lumbar level, sometimes a cervical or thoracic correction is the best solution. The visual field becomes enlarged and respiration is improved by stretching the abdominal muscles. With the adding of internal fixation the patient can be mobilized after a few weeks, whereas the chance of loss of correction is minimized. The case histories of 7 patients indicate that the procedure is not without danger and that full correction of a badly deformed spine can be extremely difficult.

The kyphosis caused by the neurofibromatosis of Von Recklinghausen is described in chapter 6. In the typical form a very agressive curve exists with loss of bony substance. that is replaced by fibrous tissue. The anterior part of the spine loses its stability and angular kyphosis appears, most of the time with some degree of scoliosis. On account of the strong bend there is a risk of paraplegia. Because of enlargement of the spinal canal this only happens in the very advanced curvatures. A different form of kyphosis arises as the effect of strong rotation of a usually thoracolumbar scoliosis. In the first type of kyphosis it is important to rebuild a new anterior spinal column, for which the fibula is best suited. Whether internal anterior fixation is really a help in undisturbed ingrowth of the transplant remains to be seen. One must bear in mind that the transplant can be reabsorbed by the agressive fibrous tissue. Preventing this seems at the moment not possible. Seven patients are described, in the course of which the problems of achieving a stable spine are stressed.

Chapter 7 deals with tuberculosis of the spine. Healing of (in our country rare) Pott's kyphosis is a long-term process. With the new anti-tuberculous drugs healing seems faster, whereas strict bedrest and plaster casts do not contribute to healing, as is shown by large randomized trials. The fastest cure with the least deformity is accomplished with the so-called radical operation described by Hodgson. Good facilities to perform these operations must be available to justify the surgery. In long-standing Pott's kyphosis it is very difficult to achieve correction due to the great rigidity of the mostly angular kyphosis. Stabilization is especially important when there is threatening or already manifest paraplegia due to compression of the spinal cord over the kyphotic vertebral bodies. Five patients are described to enlighten this issue.

The problems arising after laminectomy and/or radiation are described in chapter 8 . In the growing child kyphosis of kyphoscoliosis frequently develops as a result of destabilization of the posterior vertebral structures or dlamage to the vertebral growth centers. More or less dramatic deformations of the spine can be the result when adequate treatment is not given at the right time. Sometimes brace treatment is possible, but often operative stabilization will be indicated when the life expectation is good. A posterior arthrodesis of the spine is often possible in moderate curves, in severe curves an anterior arthrodesis will be necessary, also on account of the deficient posterior structures. The difficulties arising in the more serious curvatures are especially illustrated in the last 2 of the 4 patients described.

In chapter 9 the probably most controversial group of kyphotic deformities is under discussion. The traumatic kyphosis as an acute injury is distinguished from the old traumatic kyphosis. Many treatment regimens can be applied to the acute vertebral fracture with kyphosis with or without paraplegia, conservative as well as operative. A clearly superior management has till now not yet appeared, although there is a trend towards 
the operative treatment of the more serious fractures. This includes the best possible correction of the kyphosis and stabilization by using internal fixation and performing a local fusion. The recontouring of the spinal canal is the most important feature, especially when a partial paraplegia exists. In cases of total paraplegia operation is generally speaking unnecessary and is only useful in cases of serious instability. Old traumatic kyphosis can only be managed by anterior release and correction, to which a decompression of the spinal cord or cauda equina can be added. A supplementary posterior fusion is seldom necessary afterwards. Three patients are described, in 2 of them the correction was relatively simple, in the third patient a paraplegia existed after the fracture, without improvement after laminectomy. During childhood progressive kyphosis is than to be expected, this must be prevented by performing an early fusion. In this patient the fusion was done far too late and without much result.

Chapter 10 discusses briefly the kyphosis which can occur in tumor cases. Most of the time metastases are the cause and operative treatment is not indicated. Only if there is a metastasis directly threatening spinal cord function in patients in good general health a removal of the tumor with replacement of the vertebral body and internal fixation can be considered. In the rare cases of primary bone tumor, with insufficient response to radiation and-or chemotherapy, surgical removal of the tumor with reconstruction is indicated. One patient is described with a metastasis of carcinoma of the breast in a lumbar vertebral body, accompanied by threatening paraplegia. A good result was obtained with anterior resection and stabilization.

Finally in chapter 11 the rotational kyphosis is discussed. This kyphosis is caused by the strong rotation of a scoliotic curve, through which the curve is placed in the sagittal plane and one may speak of a hyperkyphosis. In the lumbar area the lordosis is suppressed and as rotation continues a kyphosis can develop with gliding of the vertebral bodies on each other, the so called ,drehgleiten". In the thoracic area the rotation can be so strong, that the ribs on the convex side of the curve point straight backwards. The facet joints of the thoracic spine rotate from the frontal plane into the sagittal plane causing kyphosis of the vertebrae on each other. These deformities are often progressive in adult age, especially in women around and after the menopause. Sometimes spontaneous fusion occurs in the concavity of the curve, but most of the time operation is needed to stop the progression. Various techniques can be used, the ventral derotation spondylodesis of Zielke seems to be the most suited for obtaining the best result in thoraco-lumbar and lumbar curves. In thoracic curves the technique of Stagnara can be used, essential is the position of the fusion in the line of gravity. Four patients illustrating these problems are demonstrated.

This exposure of kyphotic deformities, arranged according to etiology, shows that these are not the most simple deformities to handle. I hope this thesis can be of use in judging the possibilities available in the treatment of these patients. 


\section{TABELLEN}

Trabel 1. Algemeen overzicht

\begin{tabular}{|c|c|c|c|c|c|c|c|}
\hline \multicolumn{2}{|c|}{ Aeliologie } & Leeftijd & $\begin{array}{l}\text { Kyfose } \\
\text { preop. }\end{array}$ & $\begin{array}{l}\text { Scoliose } \\
\text { preop. }\end{array}$ & $\begin{array}{l}\text { Kytose } \\
\text { postop. }\end{array}$ & $\begin{array}{l}\text { Scoliose } \\
\text { postop. }\end{array}$ & Aard operaties \\
\hline \multicolumn{8}{|c|}{ Scheuermann } \\
\hline \multirow[t]{4}{*}{ adsus } & 1 & $17 \mathrm{jr}$. & $70^{\circ}$ & & $47^{\circ}$ & & Hart compr. \\
\hline & 2 & $32 j r$ & $101^{\circ}$ & & $65^{\circ}$ & & $\begin{array}{l}\text { I Ant. release } \\
2 \text { Harr. compr. }\end{array}$ \\
\hline & 3 & $33 \mathrm{jr}$. & $83^{\circ}$ & & $57^{\circ}$ & & $\begin{array}{l}1 \text { Ant. release } \\
2 \text { Harr compr. }\end{array}$ \\
\hline & 4 & $19 \mathrm{jr}$ & $87^{\circ}$ & & $46^{\circ}$ & & $\begin{array}{l}\text { I Ant release } \\
2 \text { Harr compr. }\end{array}$ \\
\hline
\end{tabular}

casts 5

6

7

8

9

10

11

12

$35 \mathrm{jr}$.

$139 \mathrm{jr}$.

$14 \quad 33 \mathrm{jr}$.

Paralytiseh atsus 15

16

17

18

19

20

$11 \mathrm{jr}$.

$15 \mathrm{jtr}$.

$8 \mathrm{jr}$

$8 \mathrm{jt}$.

$30 \mathrm{jr}$.

$10 \mathrm{jr}$.

$37 \mathrm{jr}$.

$31 \mathrm{jr}$. $100^{\circ}$

94

$53^{\circ}$

$145^{\circ}$

$80^{\circ}$

$148^{\circ}$

$170^{\circ}$ $71^{\circ}$

$17 \mathrm{jt}$ "

$44 \mathrm{jr}$.

$26 \mathrm{jt}$.

$16 \mathrm{jt}$.

$23 \mathrm{ju}^{\mathrm{r}}$

$68^{\circ}$ $83^{\circ} 77^{\circ}$

$21^{\circ}$

$117^{\circ}$

platel.

$102^{\circ}$

$73^{\circ}$

$37^{\circ} 54^{\circ}$

pled

1170

$148^{\circ}$

$136^{\circ}$

$105^{\circ}$ $52^{\circ}$

$50^{\circ}$

?

$32^{\circ}$

$37^{\circ}$

$35^{\circ}$

$38^{\circ}$

$55^{\circ}$

$26^{\circ}$

$36^{\circ}$

$42^{\circ}$

$?$

$90^{\circ}$

$43^{\circ}$

$9^{\circ}$

$22^{\circ}$

$24^{\circ}$

$45^{\circ}$

$55^{\circ}$

$\begin{array}{ll}52^{\circ} & 59^{\circ} \\ 98^{\circ} & 80^{\circ}\end{array}$

$140^{\circ} \quad 127^{\circ}$

$63^{\circ} \quad 80^{\circ}$

$40^{\circ} \quad 72^{\circ}$
Har compr.

I.Ant spond.

2 Harr distr /compr.

Harr. compr.

Post, resectie + Har.

compr.

1 Post. releas:

2 Ant.release

3 Harr. compr.

1 Ant. resectie

2. Post. resectie +

Harr distr./compr.

1 Ant resectio

2 Post. resectie + Harr.

distr.fompr.

3 Ant. spond.

Ant resectic

2 Post. resectie + Harr.

distr. compr.

Post. spond.

Ant. spond t

Slot systeem

$I$ Dwyer

2 Fistelexcisic

3 Harr distr.

4 Revisie Harr distr.

Harr distr.

Harr. dister.

Harr distr.

Harr distr.

I Postralease

2 Dwyer

3 Harr distr. 


\section{Geen}

Uitbreken ribspaan

$2 \times$ pneumothorax

Vertraagde ontplooiing Li. long

Thrombosebeen; passagère plexuslaesie

Geen

Geen

Geen

Geen

Geen

Geen

Dubieuze uretersteen

\section{Geen}

Geen

mogelijke

schroefbreuk

Fisteling na operatie 1.

Pseudarthrose en staafbreuk na operatie 3

Nabloeding

Art. mes. sup. synd.

Geen

Geen

Geen
Goed

Correctie goed, geringe

vermindering klachten

Correctie goed. weinig

verandering klachten

Goed

Goed

Goed

Goed

Goed

Goed. Rugklachten sterk

verminderd

Goed

Goed

Goed. Black-outs en pijn verdwenen

Goed

Matig. Weinig correctie

en wermindering klachten

Goed. Rugpijn verdwenen en

dyspnoe minder

Goed

Goed. Minder dyspnoe

Goed. Minder dyspnoe

Goed

Goed. Nog zelden pijn 
Tabel 1. Algemeen overzicht

\begin{tabular}{|c|c|c|c|c|}
\hline Acturologie & Leeftijo & $\begin{array}{l}\text { K.ylose } \\
\text { preop. }\end{array}$ & $\begin{array}{l}\text { Scoliose } \\
\text { preop. }\end{array}$ & $\begin{array}{l}\text { Kyfose } \\
\text { postop. }\end{array}$ \\
\hline \multicolumn{5}{|l|}{ Bhentherew } \\
\hline $\begin{array}{r}\text { Cistus } 21 \\
22\end{array}$ & $\begin{array}{l}5 s \mathrm{Jr} . \\
54 \mathrm{jr}\end{array}$ & $71^{\circ}$ & & $\begin{array}{l}40 \\
25^{\circ}\end{array}$ \\
\hline 23 & $30 \mathrm{jr}$ & $72^{\circ}$ & & $53^{\circ}$ \\
\hline 24 & $5 \pi \mathrm{jr}$. & $115^{\circ}$ & & $89^{\circ}$ \\
\hline 25 & $3 \| \mathrm{jr}$. & $\begin{array}{l}74^{\circ} \\
\text { ford } 23^{\circ}\end{array}$ & & $\begin{array}{l}74^{\circ} \\
\text { lord } 60^{\circ}\end{array}$ \\
\hline 26 & $42 \mathrm{jr}$. & $60^{\circ}$ & & $22^{\circ}$ \\
\hline 27 & $31 \mathrm{jr}$. & $108^{\circ}$ & & $73^{\circ}$ \\
\hline
\end{tabular}

Neurofibromatose

casus $28 \quad 16 \mathrm{jr}$

$93^{\circ}$

$62^{\circ}$

$87^{\circ}$

Scoliose

Aard operaties

postop.

\begin{tabular}{|c|c|c|c|c|c|}
\hline 29 & $14 \mathrm{jr}$ & $102^{\circ}$ & $82^{\circ}$ & $61^{\circ}$ & $50^{\circ}$ \\
\hline 30 & $13 \mathrm{jr}$. & $54^{\circ}$ & $47^{\circ}$ & $51^{\circ}$ & $58^{\circ}$ \\
\hline 31 & $27 \mathrm{jr}$ & $55^{\circ}$ & $95^{\circ}$ & $17^{\circ}$ & $20^{\circ}$ \\
\hline 32 & $37 \mathrm{jr}$ & $106^{\circ}$ & $125 / 96^{\circ}$ & $93^{\circ}$ & $74 / 56$ \\
\hline 33 & $6 \mathrm{jr}$. & $\begin{array}{l}\text { spondy- } \\
\text { lloprosis } \\
\text { C6-7 }\end{array}$ & & $90^{\circ}$ & $50^{\circ}$ \\
\hline $\begin{array}{l}34 \\
\text { spculose }\end{array}$ & $55 \mathrm{jr}$. & $>1.80^{\circ}$ & $>180^{\circ}$ & & \\
\hline 85 & $25 \mathrm{jr}$ & $45^{\circ}$ & & $32^{\circ}$ & \\
\hline 36 & $13 \mathrm{jr}$ & $52^{\circ}$ & & $40^{\circ}$ & \\
\hline 37 & $35 \mathrm{jr}$ & $112^{\circ}$ & & $79^{\circ}$ & \\
\hline 38 & $41 \mathrm{jr}$. & $108^{\circ}$ & & $99^{\circ}$ & \\
\hline 39 & $29 \mathrm{jr}$. & $96^{\circ}$ & & $81^{\circ}$ & \\
\hline
\end{tabular}

$45^{\circ}$

Columnotomie L.1-2

Collumnotomie $1-2-3$

Columnotomie $1.2-3$

Columnotomie $\mathrm{C} 7-\mathrm{T} 1$

Columnotomie

L3-4 + Harr. compr.

Columnotomie

L2-3 + Harr compr.

I Harr. compr. +

columnotomie L 1-2

2 Respondylodese + witbreiden Harr, compr. 3 Columnotomie L $4-5$ *

Harr compr.

1 Harr distr.

2 Harr distr wit

(pseudarthr.)

3 Harr compr.

4 Harr compr, uit

5 Ant. spond.

6 Ant spond. + Harr.

staal

1 Ant. spond.

2 Harr distr./compr.

1 Harr compr.

2 Ant. spond. + $5 l$ tot

syst.

1 Post relcase

2 Zielke spond.

1 Ant. spond.

+ Slot syst.

2 Harr. distr.

Ant spond. C6.7

Geen operatie

Ant. spond.

Ant. spond.

1 Release t ant spond.

2 Harr. compr.

Release + Ant spond.

Release t ant spond. +

Slot. syst. 
Recorrectie onder narcose

Decubitus. Urineweginfectic

Fors verlies van correctie

Passagère radialis uitva!

Tijdelijke

hypertensie

Geen

Wondrandnecrose na le operatie. Uitbreken haakje T10 + progressie kylose na $2 \mathrm{e}$ operatic. Na 3e operatie geen complicaties

Pseudarthrose tot en met operatie 5

Losraken Harrington materiat

Na le operatie progressieve kyfose

Irritatie Halo-pen

Verlies correctic, staalbreuk en migratie sacrumhaak

Geen

\section{Geen}

Geen

Longinfect

Cystitis. 1/2 jr. nal op. mors subitus

Geen
Goed. Geen dyspnoe meer

Goed. Geen dyspnoe of pijn

Matig. Correctie praktisch

verloren gegaan

Goed

Goed

Goed

In le instantie goed later fors terugzakken wan de correctie. Uiteindelijk goede equilibratie.

Uiteindelijk goed. Iets eerder vermoeid

Ondanks terugzakken van de correctie uiteindelijk goed

Uiteindelijk goed

Goed. Rugpijn verdwenen

Pseudarthrose of doorzakken van de spondylodese.

Inmiddels gereviseerd

Tot nu toe stabiele

ky foscoliose, behandeld mel

Milwakuee brace

Dwarslaesie vanaf de jeugd

Goed

Goed Echter nog pijn

Goed

Vour overlijden verbetering wan de neurologie

Goed 
Tabel 1. Algemenowerzich

\begin{tabular}{|c|c|c|c|c|c|c|}
\hline Aeriologie & Leemijd & $\begin{array}{l}\text { Kylose } \\
\text { preop. }\end{array}$ & $\begin{array}{l}\text { Scoliose } \\
\text { preop. }\end{array}$ & $\begin{array}{l}\text { Kyfose } \\
\text { postop. }\end{array}$ & $\begin{array}{l}\text { Scoliose } \\
\text { postop. }\end{array}$ & Aard operaties \\
\hline \multicolumn{7}{|c|}{ Laminechomie Bestraling } \\
\hline casus 40 & $14 \mathrm{jr}$ & $75^{\circ}$ & $50^{\circ}$ & $52^{\circ}$ & $37^{\circ}$ & $\begin{array}{l}\text { 1 Harr distr compr. } \\
2 \text { Compr. syst unt }\end{array}$ \\
\hline 41 & $14 \mathrm{jr}$ & 510 & $48^{\circ}$ & $37^{\circ}$ & $37^{\circ}$ & $\begin{array}{l}\text { I Harr distr. } \\
2 \text { Revisie haakje }\end{array}$ \\
\hline 42 & $24 \mathrm{jr}$. & $120^{a}$ & $113 / 124^{\circ}$ & $92^{\circ}$ & $76 / 62^{\circ}$ & $\begin{array}{l}\text { Ant. release + } \\
\text { myelumdecompressio } \\
2 \text { Ant. spond. } \\
3 \text { Ant. respond. }\end{array}$ \\
\hline 43 & $23 \mathrm{jr}$. & $44^{\circ}$ & & $5^{\circ}$ & & $\begin{array}{l}\text { P Post spond + AO } \\
\text { Plaal } \\
2 \text { Post. spond + Dwyer } \\
\text { spond. } \\
3 \text { Post. spond. + Dwyer } \\
\text { spond. + staples. }\end{array}$ \\
\hline \multicolumn{7}{|l|}{ Tratumatisch } \\
\hline 45 & $18 \mathrm{jr}$ & $40^{\circ}$ & & $12^{\circ}$ & & $\begin{array}{l}\text { Ant. spond. + Zielke } \\
\text { fixatie }\end{array}$ \\
\hline 46 & $19 \mathrm{jr}$. & $115^{\circ}$ & & $108^{\circ}$ & & Ant "spond. \\
\hline $\begin{array}{l}\text { Thmor } \\
\text { casus } 47\end{array}$ & $64 \mathrm{jr}$. & $37^{\circ}$ & & $15^{\circ}$ & & $\begin{array}{l}\text { Myelumdecompressie + } \\
\text { ant. spond. + dubbele } \\
\text { Zielke lixatie }\end{array}$ \\
\hline $\begin{array}{l}\text { Tassomen } \\
\text { casus } 48\end{array}$ & $7 \mathrm{jr}$. & $95^{\circ}$ & $95^{\circ}$ & $55^{\circ}$ & $52^{\circ}$ & Harr distr. \\
\hline 49 & $36 \mathrm{jr}$. & $47^{\circ}$ & $60^{\circ}$ & $42^{\circ}$ & $27^{\circ}$ & Dwyer spond. \\
\hline 50 & $32 \mathrm{jr}$. & $90^{\circ}$ & $110^{\circ}$ & $64^{\circ}$ & $73^{\circ}$ & $\begin{array}{l}\text { 1 Post release } \\
2 \text { Dwyer spond. } \\
3 \text { Harr. distr. }\end{array}$ \\
\hline 51 & $35 \mathrm{jr}$. & $39^{\circ}$ & $74^{\circ}$ & $19^{\circ}$ & $48^{\infty}$ & $\begin{array}{l}1 \text { Zielke spond. } \\
2 \text { Harr. distr./compr. }\end{array}$ \\
\hline
\end{tabular}


Fisteling na de operatie

Uibreken hataje

Verergering neurologische symptomen. Decubitus.

haematothorax, urinesepsis

Na le operatie spontanfractuur bowen spondylodese, na $2 e^{\mathrm{a}}$ operatic pseudarthrose t kabelbreuk

Symp. handprikkeling

Pleuradefectje

\section{Gean}

Uitbreken 1 starfje

Pengatinfectie Halo

Terugzakken kyfose

Geen

Geen

\section{Goed}

Goed

Redeligk goed ondanks alle complicaties

Goed gezien de onstandigheden. Snelle vermoeidheid wan de rug

Goed

Goed

Matig. Geringe correctie

Goed

Goed

Matig

Matig. Sterk rigide curve. Nog rugklachten

Goed 
Tabel 2. Owerzicht percentages correctic

\begin{tabular}{|c|c|c|c|}
\hline Aantal pat. & Gem preop. kylose & Gem postop kyfose & Gem $\%$ correctie \\
\hline \multicolumn{4}{|l|}{ Schewermann } \\
\hline 4 & $85^{\circ}$ & $54^{\circ}$ & $36 \%$ \\
\hline \multicolumn{4}{|l|}{ Congenitaal } \\
\hline 10 & $73^{\circ}$ & $45^{\circ}$ & $38 \%$ \\
\hline \multicolumn{4}{|l|}{ Paralytisch } \\
\hline 6 & $105^{\circ}$ & $73^{\circ}$ & $30 \%$ \\
\hline \multicolumn{4}{|l|}{ Bechterew } \\
\hline 7 & $78^{\circ}$ & $46^{\circ}$ & $41 \%$ \\
\hline \multicolumn{4}{|c|}{ Neurofibromatose } \\
\hline $5(\mathrm{excl} 2$ pat $)$ & $85^{\circ}$ & $62^{\circ}$ & $27 \%$ \\
\hline \multicolumn{4}{|l|}{ Tuberculose } \\
\hline 5 & $83^{\circ}$ & $66^{\circ}$ & $20 \%$ \\
\hline \multicolumn{4}{|l|}{ Lamin Bestr. } \\
\hline 4 & $73^{\circ}$ & $47^{\circ}$ & $36 \%$ \\
\hline \multicolumn{4}{|l|}{ Trauma } \\
\hline 3 & $63^{\circ}$ & $51^{\circ}$ & $19 \%$ \\
\hline \multicolumn{4}{|l|}{ Tumor } \\
\hline 1 & $37^{\circ}$ & $15^{\circ}$ & $59 \%$ \\
\hline \multicolumn{4}{|l|}{ Tassement } \\
\hline 4 & $68^{\circ}$ & $45^{\circ}$ & $34 \%$ \\
\hline Aantal pat. & Gem. preop. scol. & Gem postop. scol. & Gem. \% correctie \\
\hline \multicolumn{4}{|l|}{ Congenitaal } \\
\hline 7 & $67^{\circ}$ & $40^{\circ}$ & $40 \%$ \\
\hline \multicolumn{4}{|l|}{ Parallytisch } \\
\hline 6 & $114^{\circ}$ & $79^{\circ}$ & $31 \%$ \\
\hline \multicolumn{4}{|c|}{ Meurofibromatose } \\
\hline 5 & $86^{\circ}$ & $51^{\circ}$ & $41 \%$ \\
\hline \multicolumn{4}{|l|}{ Lamin. Bestr. } \\
\hline 3 & $84^{\circ}$ & $53^{\circ}$ & $37 \%$ \\
\hline \multicolumn{4}{|l|}{ Tassement } \\
\hline 4 & $85^{\circ}$ & $50^{\circ}$ & $41 \%$ \\
\hline
\end{tabular}


Operatiegroep 50 patiënten - 86

operatios

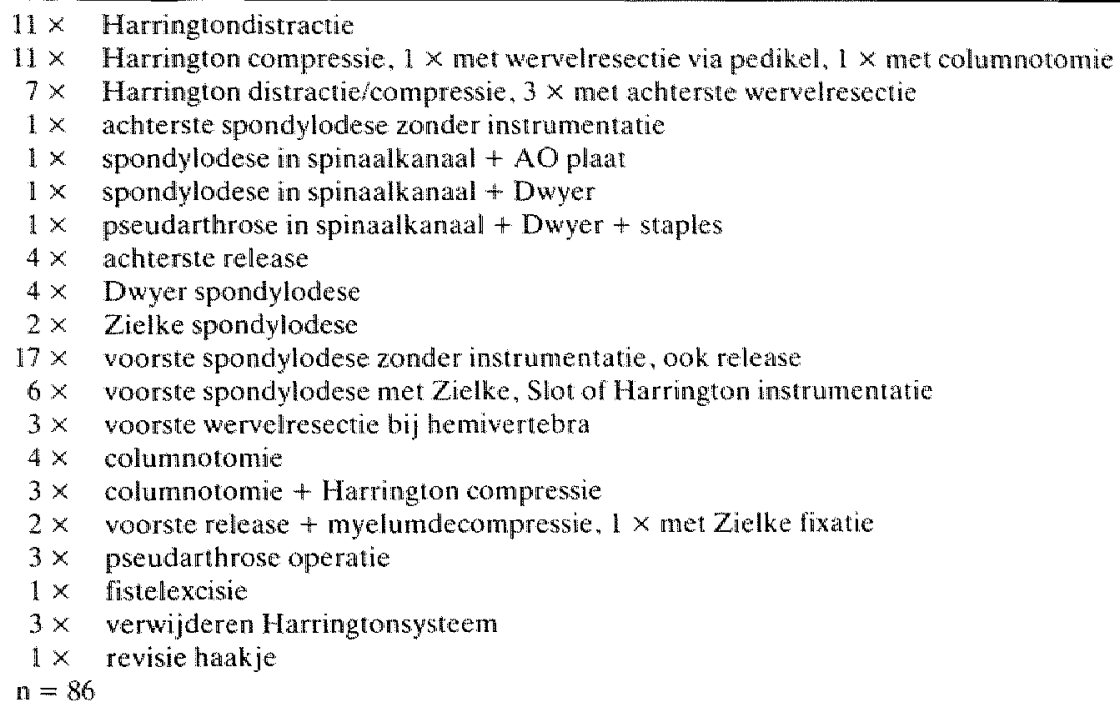

Complicaties bij 86 operaties

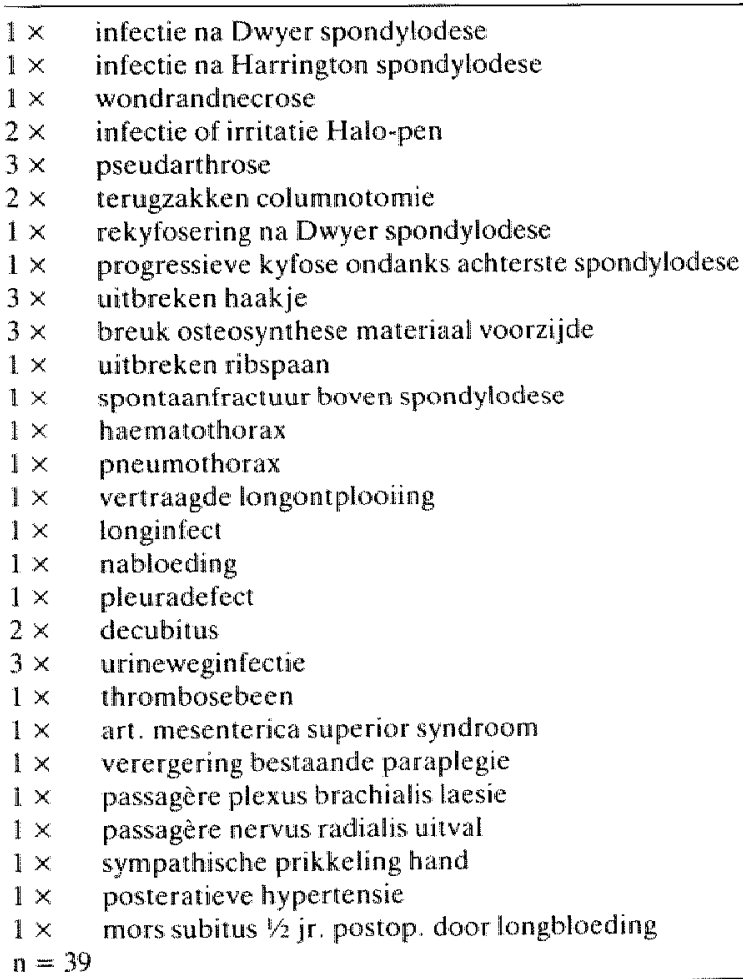

39 complicaties bij 50 patiënten in 86 operaties

un 20 patiënten geen complicaties $=40 \%$

Meeste complicaties van geringe importantie 
Tabel 4. Longfunctiemetingen

\begin{tabular}{|c|c|c|c|c|c|}
\hline Aetiologie & $\begin{array}{l}\text { \% Vit. } \\
\text { capic. }\end{array}$ & $\begin{array}{l}\text { Gem.\% } \\
\text { vit.cap. }\end{array}$ & $\begin{array}{l}\text { Kylose } \\
\text { hoek }\end{array}$ & $\begin{array}{l}\text { Scoliose } \\
\text { hoek }\end{array}$ & Plats deform \\
\hline \multicolumn{6}{|c|}{ Schewermann } \\
\hline \multirow[t]{2}{*}{ casuls } & $67 \%$ & $74 \%$ & $101^{\circ}$ & & thorac. \\
\hline & $80 \%$ & & $87^{\circ}$ & & thorac. \\
\hline \multicolumn{6}{|l|}{ Congeniraal } \\
\hline \multirow{4}{*}{$\begin{aligned} & \text { casuls } 5 \\
& 6 \\
& 7\end{aligned}$} & $68 \%$ & $70 \%$ & $38^{\infty}$ & $20^{\circ}$ & thorac. \\
\hline & $86 \%$ & & $67^{\circ}$ & $25^{\circ}$ & thorac. \\
\hline & $64 \%$ & & $43^{\circ}$ & & thorac. \\
\hline & (slechte coöperatie) & & & & \\
\hline 8 & $\begin{array}{l}46 \% \\
\text { (ook cor vitium) }\end{array}$ & & $73^{\circ}$ & $42^{\circ}$ & thorac lumb. \\
\hline 9 & $79 \%$ & & $83^{\circ}$ & & thorac.lumb. \\
\hline 1.1 & $83 \%$ & & $100^{\circ}$ & $78^{\circ}$ & thorac.lumb. \\
\hline 12 & $73 \%$ & & $94^{\circ}$ & $83 / 77^{\circ}$ & thorac lumb. \\
\hline 13 & $91 \%$ & & $53^{\circ}$ & $21^{\circ}$ & thorac. \\
\hline 14 & $43 \%$ & & $117^{\circ}$ & $115^{\circ}$ & thorac. \\
\hline
\end{tabular}

Paralyisch

Casus 1.5

16
17

18

19

20

\section{Becherew}

casus 21

$\begin{array}{ll}22 & 74 \% \\ 23 & 61 \% \\ 24 & 62 \% \\ 26 & 63 \% \\ 27 & 36 \%\end{array}$

Neurofibromatose

casus 28

29

31

32

\section{Tuberculose}

casus 36

37

38

39

Lamin./Besur.

casus 40

42
$75 \%$

$53 \%$

$27 \%$

2 jaar posiop

$32 \%$

$26 \%$

$52 \%$

$1,4 \mathrm{jr}$. postop.

toename vit cap.

$650 \mathrm{cc}=31 \%$

$83 \%$

$51 \%$

$60 \%$

$90 \%$

$92 \%$

$69 \%$

$71 \%$

$53 \%$

$50 \%$

$69 \%$

$34 \%$
$53 \%$

$\begin{array}{rr}80^{\circ} & 102^{\circ} \\ 93^{\circ} & 73^{\circ} \\ 1.48^{\circ} & 117^{\circ}\end{array}$

thorac lumb. thorac lumb. thorac.

$170^{\circ} \quad 148^{\circ}$ thorac.

$71^{\circ} \quad 136^{\circ}$ thorac.

$68^{\circ} \quad 105^{\circ}$ thorac.lumb.

$62 \%$

$70^{\circ}$

$71^{\circ}$

$72^{\circ}$

$1115^{\circ}$

$60^{\circ}$

$108^{\circ}$

$73 \%$

$93^{\circ}$

$102^{\circ}$

$55^{\circ}$

$106^{\circ}$

$62^{\circ}$

$82^{\circ}$

$80^{\circ}$

$125^{\circ}$

$61 \% \quad \begin{array}{r}52^{\circ} \\ 112^{\circ} \\ 108^{\circ} \\ 96^{\circ}\end{array}$

thorac.

thorac.lumb. thorac lumb. thorac lumb.

$\begin{array}{rrrl}52 \% & 75^{\circ} & 50^{\circ} & \text { thorac. } \\ 120^{\circ} & 113 / 124^{\circ} & \text { thorac.lumb. }\end{array}$




\begin{tabular}{|c|c|c|c|c|c|}
\hline Aetiologie & $\begin{array}{l}\text { ovit. } \\
\text { capac. }\end{array}$ & $\begin{array}{l}\text { Gem. of } \\
\text { vit.cap. }\end{array}$ & $\begin{array}{l}\text { Kyfose } \\
\text { hoek }\end{array}$ & $\begin{array}{l}\text { Scoliose } \\
\text { hoek }\end{array}$ & Plaats deformitcit \\
\hline $\begin{array}{l}\text { Traumh } \\
\text { casus } 46\end{array}$ & $39 \%$ & & $115^{\circ}$ & & thorac. \\
\hline $\begin{array}{l}\text { Tassement } \\
\text { casus } 48\end{array}$ & $\begin{array}{l}51 \% \\
\text { (slechte coopperatie) }\end{array}$ & $75 \%$ & $95^{\circ}$ & $95^{50}$ & thorat lumb. \\
\hline $\begin{array}{l}49 \\
50 \\
51\end{array}$ & $\begin{array}{l}92 \% \\
67 \% \\
89 \%\end{array}$ & & $\begin{array}{l}47^{\circ} \\
90^{\circ} \\
39^{\circ}\end{array}$ & $\begin{array}{r}60^{\circ} \\
110^{\circ} \\
74^{\circ}\end{array}$ & $\begin{array}{l}\text { thorac lumb. } \\
\text { thorac lumb. } \\
\text { thorac lumb. }\end{array}$ \\
\hline
\end{tabular}

Tabel 5. Einsit deformiteit en resultant

Ernst van de deformiteit:

\begin{tabular}{|c|c|c|c|c|c|c|c|}
\hline Graad 1: & \multirow{3}{*}{\multicolumn{7}{|c|}{ 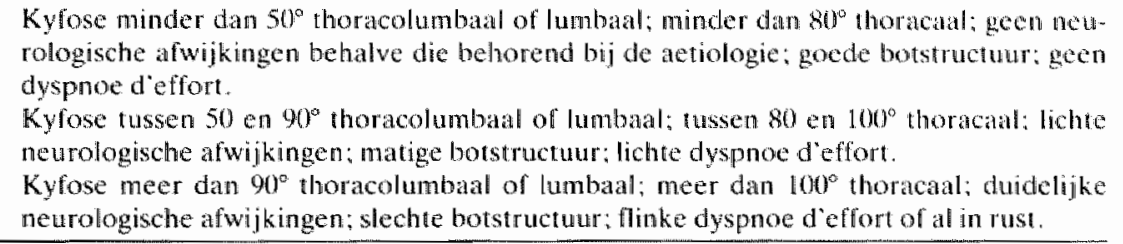 }} \\
\hline Graad 2: & & & & & & & \\
\hline Graad 3 & & & & & & & \\
\hline \multicolumn{8}{|l|}{ Indeling resultaat: } \\
\hline Goed resultaat: & \multirow{3}{*}{\multicolumn{7}{|c|}{$\begin{array}{l}\text { Goede spondylodese met goede correctie; geen klachten; geen neurologische afwijkin- } \\
\text { gen. } \\
\text { Goede spondylodese met geringe correctie; matige pijnklachten of lichte neurologische } \\
\text { afwijkingen. } \\
\text { Pseudarthrose, weinig correctie; veell pijnklachten; duidehijke neurologische afwijkin- } \\
\text { gen. }\end{array}$}} \\
\hline Matig resultaat: & & & & & & & \\
\hline Slecht resultaat: & & & & & & & \\
\hline \multirow[t]{2}{*}{ Aetiologie } & \multirow{2}{*}{$\begin{array}{l}\text { Aantal } \\
\text { pat. }\end{array}$} & \multicolumn{3}{|c|}{ Emst afwijking } & \multicolumn{3}{|c|}{ Resultaat } \\
\hline & & Graad 1 & Graad 2 & Graad 3 & Goed & Matigg & Slecht \\
\hline Schetermann & 4 & $1 x$ & $2 \times$ & $1 x$ & $2 \times$ & $2 x$ & \\
\hline Congenitaal & 10 & $4 x$ & $3 x$ & $3 x$ & $9 x$ & & $\| x$ \\
\hline Paralycisch & 6 & & $2 x$ & $4 x$ & $\| x$ & $5 x$ & \\
\hline Bechierew & 7 & & $5 x$ & $2 x$ & $5 x$ & $1 \times$ & $1 \times$ \\
\hline Nevrofibromatose & 6 & $1 x$ & $3 x$ & $2 x$ & $2 x$ & $4 x$ & \\
\hline Tuberculose & 5 & $2 x$ & & $3 x$ & $2 x$ & $3 x$ & \\
\hline Lamin/Bestr. & 4 & $1 x$ & $d x$ & $2 \times$ & $3 x$ & $1 x$ & \\
\hline Trauma & 3 & $2 x$ & & $1 x$ & $2 x$ & $1 x$ & \\
\hline Tirmor & 1 & & $1 \times$ & & $1 x$ & & \\
\hline Tassement & 4 & $2 x$ & $2 \times$ & & $2 x$ & $2 x$ & \\
\hline
\end{tabular}

Totaal 50 geopereerde patiènten met

$13 \times$ graad 1 deformiteit $(26 \%)$

$19 \times$ graad 2 deformiteit $(38 \%)$

$18 \times$ graad 3 deformiteil $(36 \%)$

Resultaat

$29 \times \operatorname{goed}(58 \%)$

$19 \times$ matig $(38 \%)$

$2 \times$ slechi ( $4 \%$ )

Gemiddelde follow up 28,6 maanden (spreiding 6-72 maanden) 
De auteur werd geboren te Leiden op 20 april 1948. Na het Thorbecke Lyceum te Utrecht te hebben doorlopen (HBS-B) werd de medische studie aangevangen aan de R.U. Utrecht in 1965. In het 7e jaar werd als assistent-arts een stage orthopaedie gevolgd bij prof. dr. L. J. L. Koekenberg, ziekenhuis Zonnestraal te Hilversum. De militaire diensttijd in 1973 heeft hij voor het grootste gedeelte doorgebracht op de afdeling orthopaedie van het militair hospitaal „Dr. A. Mathijsen” te Utrecht onder leiding van dr. Th. W. Beeker. De B-opleiding algemene heelkunde van 1974 tot 1976 heeft hij genoten in het Juliana ziekenhuis te Apeldoorn (hoofd. dr. J. Paré), terwijl de opleiding orthopaedie van 1976 tot 1980 plaatsvond in de Sint Maartenskliniek te Nijmegen (hoofd G. Th. M. Bossers) met een stage jaar in het Sint Franciscus ziekenhuis te Roosendaal bij dr. F. A. A. van de Weyer. Vanaf mei 1980 werkt de auteur als orthopaedisch chirurg in het Sint Annadal ziekenhuis te Maastricht in samenwerking met prof. dr. A. J. van der Linden, R. G. T. Geesink en dr. G. H. I. M. Walenkamp. 